Caracterização de determinantes genéticos envolvidos na qualidade industrial e nutricional do fruto de tomate

Luisa Fernanda Bermúdez Salazar

Tese apresentada ao Instituto de Biociências da Universidade de São Paulo para a obtenção de Titulo de Doutor em Ciências, na área de Botânica.

Orientadora: Profa. Dra. María Magdalena Rossi

Co-orientador: Prof. Dr. Fernando Carrari 


\section{FICHA CATALOGRÁFICA}

Bermúdez, Luisa Fernanda

Titulo da tese: Caracterização de determinantes genéticos envolvidos na qualidade industrial e nutricional do fruto de tomate.

Número de páginas: 222

Tese (Doutorado Direto) - Instituto de Biociências da Universidade de São Paulo.

Departamento de Botânica.

1. tomate. 2. Solanum lycopersicum. 3. qualidade de fruto. 4. metabolismo.

A comissão julgadora dos trabalhos de defesa da tese de doutorado, em sessão publica realizada a ....................., considerou

Aprovado ( ) Reprovado( )

COMISSÃO JULGADORA

Prof(a). Dr(a).

$\operatorname{Prof}(a) . \operatorname{Dr}(a)$.

$\operatorname{Prof}(a) . \operatorname{Dr}(a)$.

Prof(a). Dr(a).

Prof(a). Dr(a). María Magdalena Rossi 
A los amores de mi vida

Jaime, Gilma y Camila

Dedico 



\section{AGRADECIMENTOS}

Este doutorado além do crescimento profissional representou uma experiência de vida inigualável. Conheci países maravilhosos entre eles o Brasil e a Argentina que agora amo quase como a minha querida Colômbia. Levo comigo famílias, amigos e irmãos, além de muitas experiências que mudaram minha vida para sempre. É a vocês que agradeço por ter me acompanhado neste caminho e ter feito isto possivel!

NO BRASIL...

Ao Brasil por me receber e permitir continuar a minha formação acadêmica.

Ao Departamento de Botânica do Instituto de Biociências da Universidade de São Paulo pelo suporte acadêmico e estrutural.

A Magda... Son tantas cosas que quisiera agradecerte que no alcanzaría a plasmarlo aquí. Primero, gracias por la confianza brindada tantas veces, por oírme y empujarme a dar pasos que probablemente nunca los hubiera dado sola y que cambiaron mi vida. Mil gracias por haber sido mi orientadora, amiga y hasta mamá cuando fue necesario. Gracias por compartir conmigo tu familia, amigos, casa y viajes... Enloqueciste conmigo para intentar "entender" esto, acompañándome en este proceso científico, para al final darnos cuenta que cuanto más aprendemos percibimos que cada vez nos queda más por saber. Eres un ejemplo de mujer en la ciencia y esto se ve reflejado aquí y en el equipo de "chicas" científicas que vienes formando. En fin, se que este es solo uno de los tantos logros que tendremos juntas. Te adoro mi vieja de 42!!

À Profa. Dra. Marie-Anne Van Sluys por ter sempre as portas abertas.

Às meninas do GMP - Silvia, Dani, Junia, Juliana e Fabi, pelo apoio incondicional brindado, amizade e por ter feito este novo grupo de cientificas o melhor lugar para trabalhar. À Silvia pela imensa ajuda com os experimentos de última hora, compras e por fazer tudo mais fácil no lab. À Dani que esteve sempre disponível para nos ajudar. À Junia pelas dicas agronômicas. À Ju pela amizade, ajuda com as clonagens, discussões muito ricas, companhia na Argentina em momentos muito especiais e claro por todas as milhares de correções do meu portunhol.

À Fa, meu querido babelito de Godoy. Você sabe que esta tese é tanto minha quanto sua, você fez parte de tudo e sempre esteve ao meu lado (seja presencialmente, ou via skype/gmail) para me apoiar e acompanhar... pensamos y comemoramos juntas, mas também esteve ai quando as coisas não estavam tão certas. Agradeço à vida por ter me dado a melhor parceira cientifica que além de tudo é minha irmã. Foi muito lindo ter você ao meu lado nesta etapa tão importante na minha vida. Te amo!!

À Nati, você foi um suporte muito importante tanto no âmbito científico como pessoal. Fez com que a "evolução dos tomates" fosse digerível e até legal! Teve a paciência suficiente para me escutar sempre, seja falando de Schauer, chaperonas e tocoferois, até para conversar da vida. Obrigada pela sua amizade, por tantas conversas e 
"desconexões" e por me receber na tua casa sempre com os braços abertos e, mais ainda, nesta última etapa.

Ao pessoal do "antigo" e "novo" GaTE lab - Alessandro, Andrés, Breno, Bruno, Cushla, Dani Q, Dani Milstein, Douglas, Érika, Guilherme, Hana, Jonas, Juliana Nico, Juliane, Kleber, Leonor, Marcelo, Marisa, Mayra, Myna, Nathalia, Nilo, Robson, Tatiana, Úrsula, Vivian e Wanessa.

À Úrsula e Dani Milstein pelo treinamento científico e amizade que me brindaram no começo deste projeto, foram parte fundamental do mesmo.

Ao Robson, Alessandro, Marcelito, Gui e Andrés pelo suporte e por ter me acompanhado na minha entrada no mundo bioinformático. Fizeram tudo mais fácil e até divertido!!

Ao Douggy, Muchachito Marcelito, Andrés e Gui por fazer tantas tardes-noites mais divertidas e sempre me fazer sorrir. No final a minha cuca não ficou tão bagunçada assim!!!

À Maria Elisa pela sua amizade, conversas e cafecitos que tanto bem me fizeram.

Ao Gerson e o Santiago por me receber na sua casa e agüentar esses dias de loucura finais. Fizeram tudo melhor nesses momentos críticos!

À Pati, minha cunhis, que foi mais que uma irmã para mim, você fez parte de tudo isto, me trouxe até a USP e me acompanhou até o final. Obrigada pela companhia, amor e família que me deu, além da minha afilhadinha maravilhosa. Obrigada por tantos momentos lindos que me fez passar e por estar ao meu lado quando mais eu precisei, me cuidar, desde o meu dengue brasileiro até quando meu coração mais precisava de alguém. Você, o Marcio e as minhas hermosas princessas são a minha família brasileira que ficara para sempre no meu coração. Amo vocês!

Ao Renato por ter me permitido conhecer o Brasil, foi muito importante sua companhia e apoio no começo deste projeto.

Aos "Monticellis" e "Ferreiras" por me receber como uma integrante mais da família e me aconchegar quando mais batiam saudades de casa.

Especialmente ao Tio Luiz, Gê, Bê e Gaby, por me receber tantas vezes na sua casa, me dar todo o amor nesses abraços apertados, soupinhas e claro, cervejinhas! Obrigada mesmo.

Ao Marcio, Aline, Edu, Lu, Cristian e Pati, por comemorar comigo todas as festas do tomate e me brindar sua amizade ao longo destes anos. 
Al Instituto de Biotecnología del INTA- Castelar por el soporte brindado.

A Fer, gracias por todo el apoyo académico y personal que me ofreciste. Ha sido una experiencia gratificante tu orientación. Hiciste subir mi autoestima científica cuando ya no creía en nada y me enseñaste nuevas formas de hacer ciencia. Fue tanto tu apoyo que hasta recorriste conmigo 2,600 $\mathrm{Km}$ en auto en 3 dias! Pero bueno, hasta fue divertido! Espero que esto sea solo el comenzó de un largo camino científico a recorrer con el grupo y que vengan muchos éxitos más! Tu amistad y la de Trixi son muy importantes para mí, amé compartir y disfrutar con ustedes mi linda Colombia!

A Ramón, Santi y Vir por todo el apoyo brindado durante las maratonas de tocoferoles en Córdoba.

A Ceci Vasquez, Sebas, Mariana y Fabiana Bigi, por todas las discusiones y oír mis telenovelas de fugitiva colombiana.

A Oscar por su buena energía todos los días, es lindo comenzar el día con una sonrisa. Ya tengo casi un armario lleno de bolitas de papel!

A Cintia, Sandra y Perla por toda su ayuda y buena onda.

Muy especialmente a los chicos del Invernáculo - Agustín, Martin, Nacho y Mati, por su ayuda, siempre buena disposición y excelente trabajo que hicieron parte vital de todo esto.

A las chicas del TEM, GRACIAS!! Por las enseñanzas, cariño y apoyo que me brindaron durante los largos días de repiques y mas repiques, además de cuidarme mis plantiCas cuando estaba en algún lugar del mundo.

A los tomateros - Gabriel, Guada, Julia, Lau K., Lean, Mari Conte, Mari Lopez y Tomás, por las tantas discusiones enriquecedoras, ayuda y por toda la buena onda para hacer cada vez mejor este grupo.

A Lean por tantas conversaciones científicas y por las otras también, en aquellas tardes pelando tomates. Por su amistad y estar siempre ahí para oír y ayudarme con mis nudos cerebrales!

A Lau Ramos por todo el cariño que siempre me brindó y estar siempre con una sonrisa dispuesta a ayudar.

A los chicos del lab, Ceci, Mari C, Carlos, Guada, Gabi y Lean por las tantas terapias grupales, facturas, chocolates y hacer con que el día a día sea más fácil de llevar.

A Gabi Conti y Vanessita por su apoyo y amistad! Gracias por estar siempre dispuestas a oírme.

A Fede por siempre, sea como sea, sacarme una sonrisa! Alegraste hasta los días más oscuros "Intianos"... Gracias por tu cariño y apoyo!!! 
A Natalia, Diego, Guille, Vanessa, Gaby LLauger, Cori, Lucila por toda su ayuda!

A Guille por todas las" terapias de carro", por su compañía durante tantos días...

A Grace, por ser mi embajada Colombiana en Argentina y disfrutar conmigo los triunfos de los tomaticos! Te amo amiguita!

A Carli, por ser mi compañera durante tanto tiempo, oír todas mis telenovelas colombo-brasileras, fue muy lindo haber podido compartir este tiempo contigo y Alimañas!

A Carla, Lu y Caro por tantas noches locas y cuidarme al nene en mi ausencia! Y, obviamente, ser mis amigas y compartir conmigo esta etapa hermosa de mi vida! Las adoro!

A Pili y Willy por adoptarme como la nena de casa, oír todas mis descargas tomateras y consentirme siempre. Gracias por todo su apoyo, por brindarme su casa como la mía y sobre todo por "prestarme" su hijo maravilloso!

A ti "José" Ignacio... el mejor regalo que me pudo haber dejado la querida jefa tía en este doctorado. Muchas veces creo que la vida conspiro todo esto solo para que nos encontráramos. Gracias por llegar a mi vida y hacerme feliz, por acompañarme en los momentos más críticos de este proyecto, por intentar entender con todo el amor del mundo desde el ADN hasta las chaperonas y tocoferoles. Por apoyarme y darme ánimo en mis miles de crisis "becarias". Sé que esta es solo una de las metas que vamos a conquistar en nuestra vida juntos. Te amo chuic.

EN COLOMBIA

A mis papás y hermanita Camila, por ser mi ejemplo y motor de vida. Sin su apoyo y amor incondicional nada de esto hubiera sido posible. Por entender mi ausencia en estos cuatro años que espero poder recompensar, aunque sea en parte. Sabemos lo difícil que ha sido, pero también tenemos certeza que el amor supera todas las barreras de tiempo y espacio. Gracias por estar siempre ahí para darme todo el amor telefónicamente y hacerme sentir que estaban ahí a mi lado. Los amo requete... hasta el cielo infinito.

A mi hermanita, especialmente, por toda su ayuda de design por toda la paciencia con los tomates de todas las formas, tamaños y colores. Viste que lindos eran? Te amo!

A mi tio Mauricio, por ser mi angel de la guarda, guiarme y protegerme durante toda mi vida.

A mis amigas de vida - Mónica, Ana, Grace, Figue, Kolo, Sandy y Luisa, ni siquiera 10 años, miles de kilómetros de distancia y dos continentes nos han separado! Gracias por estar acompañándome vía skype y compartir conmigo todas las etapas de este proyecto! Las amo amigas. 


\section{ABREVIATURAS E NEOLOGISMOS}

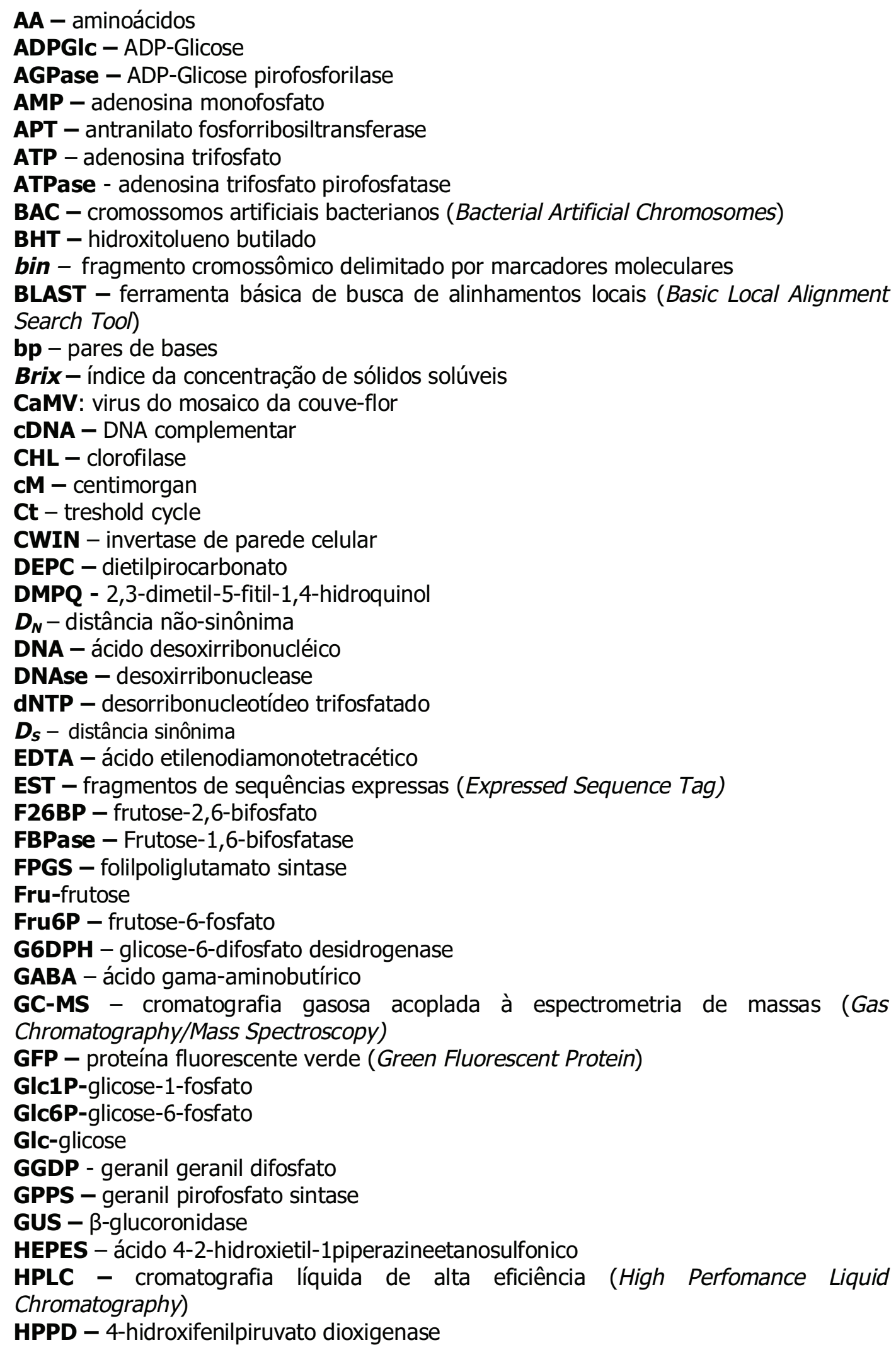


HPT/ VTE2 - homogentisato fitil transferase

IL - linhagem introgredida (introgressed line)

indels - inserções/deleções

IRGA - infrared gas analyser

$\mathbf{K b}$ - kilo pares de base

LB - meio de Luria-Bertani

LTRs - longas terminações repetidas (Long Terminal Repeats)

LYCB - licopeno $\beta$-ciclase

MAA: milhões de anos atrás

Mb - mega pares de base

MEP - metileritritol fosfato

MES - ácido 2-morfolinoetanosulfónico monohidratado

MPQ - 2-metil-6-fitil-1,4-hidroquinol

MSS - meio Murashige-Skoog com 20\% sacarose

NADP - nicotinamida adenina dinucleótido fosfato

NADPH - nicotinamida adenina dinucleótido fosfato reduzido

Nc - número efetivo de codons

nt - nucleotídeos

3-PGA - fosfo-gliceraldeido-trifosfato

PCR - reação em cadeia da polimerasa (Polymerase Chain Reaction)

PFD - densidade de fluxo de fótons (Photon Flux Density)

Pi - fosfato inôrganico

PPM - partes por milhão

PRAI - fosforribosilantranilato isomerase

PSI - fotossístema I

PSII- fotossístema II

QML - locos para carateres metabólicos quantitativos (Quantitative Metabolic Loci)

qPCR - reação em cadeia da polimerasa quantitativa (Quantitative Polymerase Chain Reaction)

QTL - locos para carateres quantitativos (Quantitative Trait Loci)

RNA - ácido ribonucléico

RNAi - RNA de interferência

RNAm - ácido ribonucléico mensageiro

RNAse - ribonuclease

ROS -espécies reativas de oxigênio (Reactive Oxygen Species)

rpm - revoluções por minuto

SK -rota do chiquimato

SnRK1 - proteínas quinases relacionadas a sacarose não-fermentativa

SPS- sacarose fosfato sintase

SuSy - sacarose sintase

TAE - tampão tris-acetato-EDTA

TAT - tirosina aminotransferase

TyrA - arogenato desidrogenase

Unigene - consenso de sequências de CDNA segundo a Solanaceae Genomics Network

UTR - região não traduzida (Untranslated Region)

VTE - vitamina E

VTE1 - tocoferol ciclase

VTE3 - dimetil-fitilquinol metil transferase

VTE4 $-\gamma$-tocoferol C-metil transferase

VTE5 - fitol quinase

YAL - locos para caratéres associados ao rendimento (Yield Associated Loci) 


\section{RESUMO}

A presente tese aborda o estudo do metabolismo dos frutos de tomate a partir de três estratégias complementares: i) a identificação de genes candidatos colocalizados com QTL, previamente descritos a partir do perfil metabólico de $S$. lycopersicum (cv. M82) e linhagens introgredidas de S. pennellii, associados ao conteúdo de metabólitos de interesse industrial e nutricional; ii) a análise estrutural das regiões genômicas portadoras desses genes; e iii) a análise funcional dos genes chaperona DnaJ e sec14 por meio de genética reversa mediante o silenciamento por RNAi. A análise de marcadores moleculares previamente mapeados nas regiões portadoras dos QTL permitiu identificar 127 genes candidatos cujos produtos foram mapeados nas rotas metabólicas correspondentes. Um subgrupo desses genes apresentou diferenças alélicas entre os progenitores da população utilizada para a identificação dos QTL. A análise de micrositenia revelou um alto grau de conservação na estrutura genômica, apresentando polimorfismos nas regiões codificantes e regulatórias, assim como no padrão de inserção de elementos de transposição. Baseado nessas diferenças, análises de expressão e funcionalidade putativa, dois genes foram escolhidos para a análise funcional utilizando a estratégia de RNA de interferência. Os resultados obtidos da avaliação fenotípica das plantas deficientes em chaperona DnaJ permitiram concluir que esta proteína, localizada nos cloroplastos, participa da regulação do metabolismo de açúcares, em particular na síntese de amido, controlando assim, a exportação de fotoassimilados. Já, a caracterização das linhagens silenciadas para o gene sec14, levou a postular que os conteúdos de tocoferol (VTE) nos frutos de tomate, não só dependem da regulação cinética das enzimas envolvidas na sua síntese, mas também da função da proteína do SEC14, não caracterizada em plantas até o momento. Essa proteína estaria envolvida no transporte de VTE entre os diferentes compartimentos do cloroplasto tendo impacto no equilíbrio oxidativo, na estrutura do plastídeo e, consequentemente, na biossíntese desta vitamina. Os resultados obtidos nesta tese reforçam a hipótese que o germoplasma selvagem constitue uma fonte de variabilidade a ser explorada para a identificação de determinantes genéticos que viabilizem novas estratégias de melhoramento de tomate por meio da manipulação do metabolismo central dos frutos. 



\begin{abstract}
This thesis addresses tomato fruit metabolism analysis by using three complementary approaches: i) the identification of candidate genes co-located with QTL previously described from metabolic profiles of $S$. lycopersicum (cv. M82) and $S$. pennellii introgressed lines, associated with industrial and nutritional quality traits; ii) the structural analyses of the genomic regions harboring the identified genes and ; iii) the functional analysis of the chaperone DnaJ and sec14 genes through reverse genetics mediated by iRNA silencing. The analysis of the molecular markers previously mapped onto the QTL-associated regions allowed the identification of 127 candidate genes whose products were mapped in the corresponding metabolic pathways. A subset of these genes showed allelic differences between the parental genotypes used for QTL identification. Based on these differences, together with the expression profile analysis and their putative function, two genes were selected for functional analysis using RNA interference approach. The phenotypic profile of the chaperone DnaJ deficient plants allowed to conclude that this protein, located in chloroplasts, participates in sugar metabolism, in particular, starch synthesis, controlling assimilates partitioning. The characterization of sec14-silenced transgenic lines leads to propose that fruit tocopherol (VTE) contents not only depend on the kinetic regulation of the biosynthesis-involved enzymes, but also on the SEC14 action, not yet characterized in plants. This protein might be involved in VTE transport between the different plastidial compartments thus, affecting oxidative balance, chloroplast structure and, consequently, VTE biosynthesis. All together these results support the hypothesis that wild germoplasm represents a remarkable source of variability to be explore aiming the identification of genetic determinants to develop new breeding approaches for tomato through metabolic engineering.
\end{abstract}





\section{SUMÁRIO}

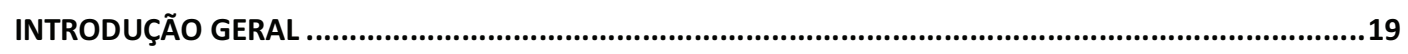

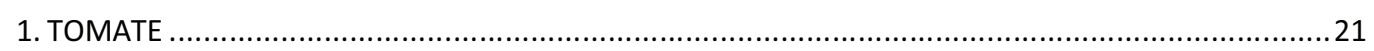

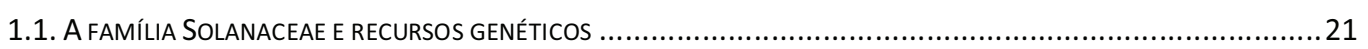

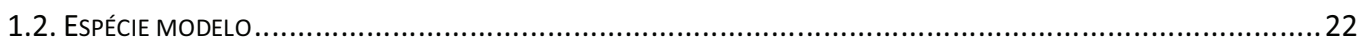

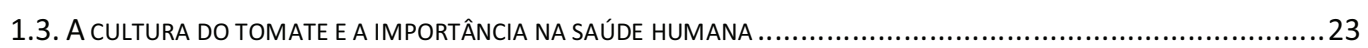

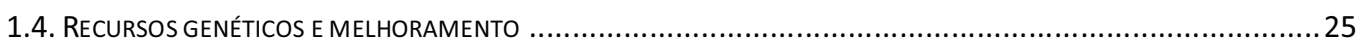

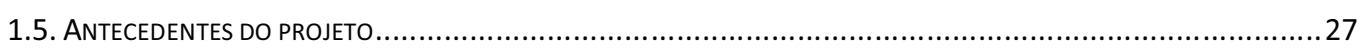

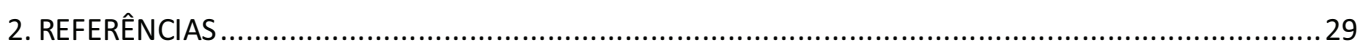

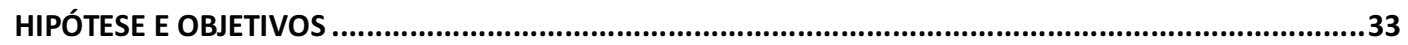

CAPÍTULO I: BUSCA DE GENES CANDIDATOS ASSOCIADOS AOS QTL QUE AFETAM A COMPOSIÇÃO

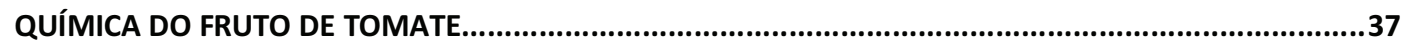

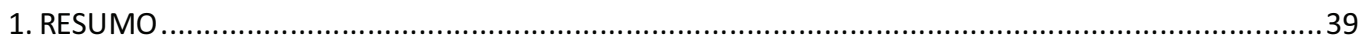

CAPÍTULO II: ANÁLISE DA DIVERSIDADE GENÔMICA ENTRE O TOMATE CULTIVADO, SOLANUM LYCOPERSICUM, E A ESPÉCIE SELVAGEM SOLANUM PENNELLII. ......................................................71

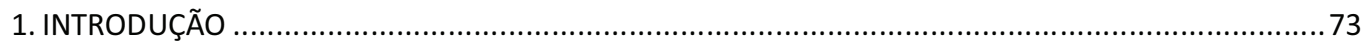

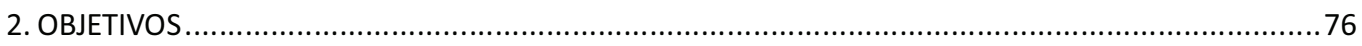

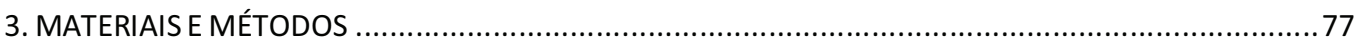

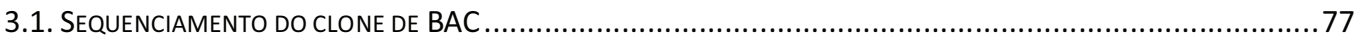

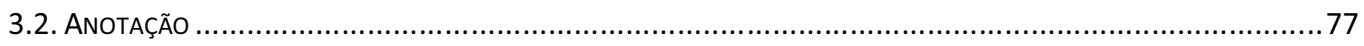

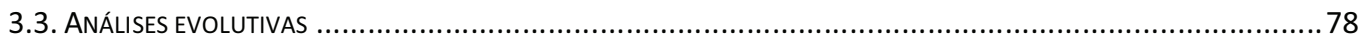

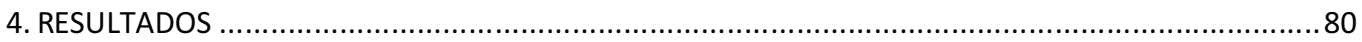

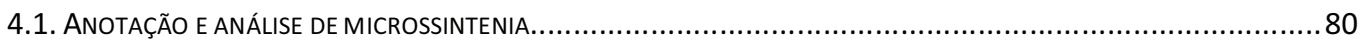

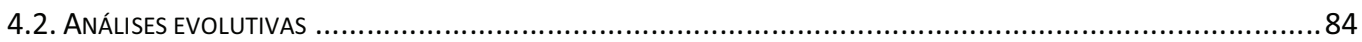

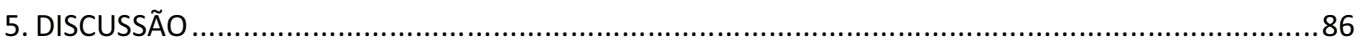

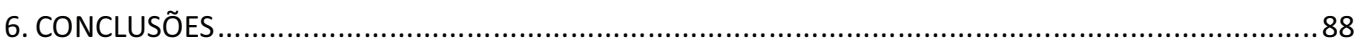

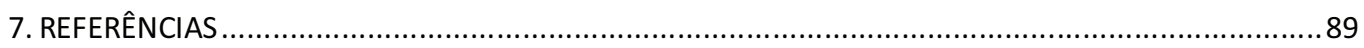

CAPÍTULO III: CARACTERIZAÇÃO E ESTUDO FUNCIONAL DO GENE CHAPERONA DNAJ..........................93

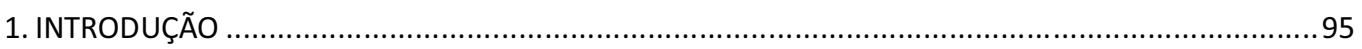

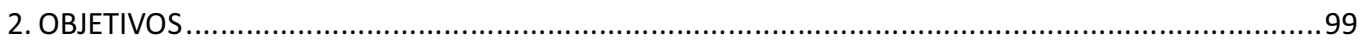

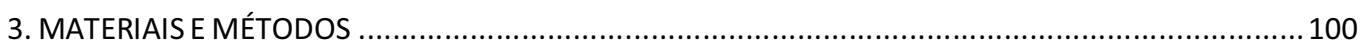

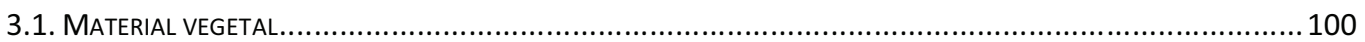

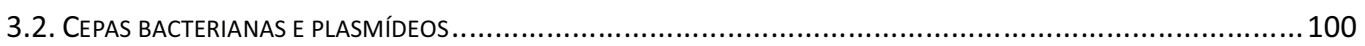

3.3. OBTENÇÃO DAS SEQUÊNCIAS DOS ALELOS DO GENE CHAPERONA DNAJ, ANÁLISE DA ESTRUTURA GÊNICA E FILOGENIA

3.4. OBTENÇÃO DAS CONSTRUÇÕES PARA O ESTUDO DA ATIVIDADE DAS REGIÕES PROMOTORAS DOS ALELOS DE $S$.

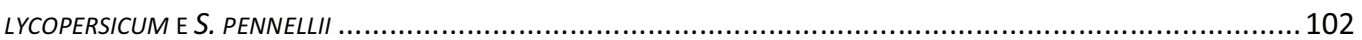

3.5. OBTENÇÃO DA CONSTRUÇÃO PARA ESTUdO DA LOCALIZAÇÃO SUBCELULAR DA PROTEÍNA CHAPERONA DNAJ .........103

3.6. OBTENÇÃO DA CONSTRUÇÃO PARA AVALIAÇÃO DO EFEITO DO SILENCIAMENTO GÊNICO POR RNA DE INTERFERÊNCIA

3.7. INFILTRAÇÃO E ENSAIO HISTOQUÍMICO DE FOLHAS DE N. BENTHAMIANA PARA O ESTUDO DA ATIVIDADE DAS REGIÕES

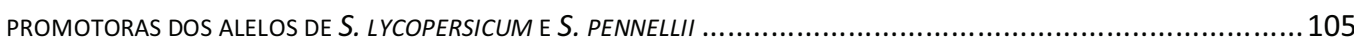

3.8. INFILTRAÇÃO DE FOLHAS DE N. BENTHAMIANA PARA O ESTUDO DA LOCALIZAÇÃO SUBCELULAR DA PROTEÍNA

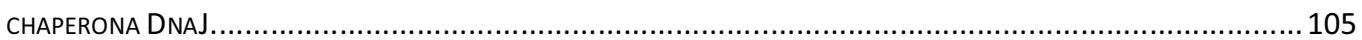

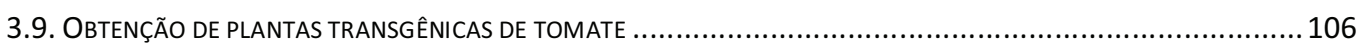




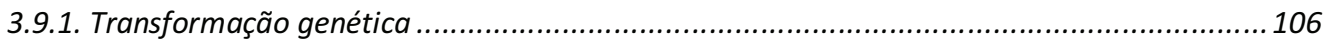

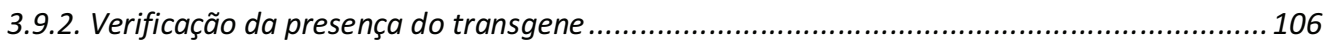

3.9.3. Análise de expressão do gene chaperona DnaJ nas linhagens transgênicas obtidas............107

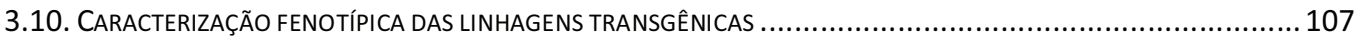

3.10.1. Cultivo e parâmetros de produção..................................................................... 107

3.10.2. Verificação do nível de silenciamento nas linhagens transgênicas.................................. 108

3.10.3. Medição dos parâmetros fotossintéticos ................................................................... 108

3.10.4. Extração e quantificação de pigmentos ....................................................................... 109

3.10.5. Extração e quantificação de aminoácidos, açúcares solúveis e amido .............................. 110

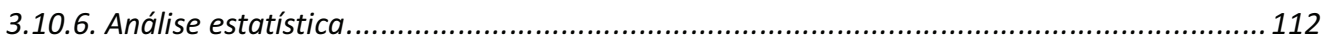

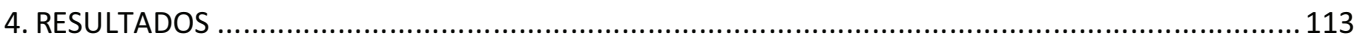

4.1. A ProteínA CHAPERONA DNAJ AgRUPA EM UM CLADO DIFERENTE DAS CHAPERONAS PREVIAMENTE DESCRITAS ... 113

4.2. OS PROMOTORES DOS ALELOS SELVAGEM E CULTIVADO APRESENTAM ATIVIDADE TRANSCRICIONAL DIFERENCIAL ...115

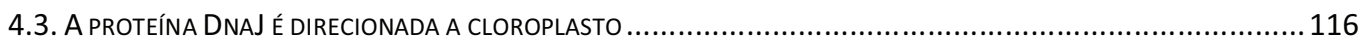

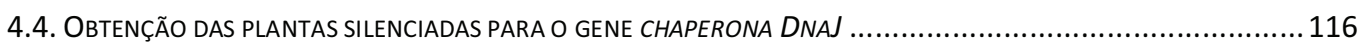

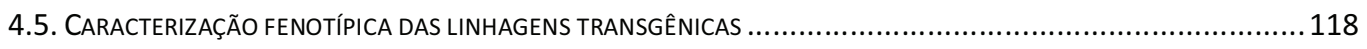

4.5.1. Verificação do nível de silenciamento nas linhagens transgênicas.....................................118

4.5.2. O silenciamento do gene chaperona DnaJ não impacta os parâmetros fotossintéticos ........119

4.5.3. O silenciamento do gene chaperona DnaJ altera os conteúdos de clorofilas e carotenóides em

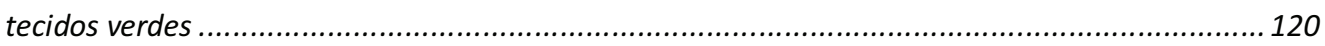

4.5.4. O silenciamento do gene chaperona DnaJ altera o conteúdo de açúcares e amido............. 121

4.5.5. O silenciamento do gene chaperona DnaJ não altera o conteúdo de aminoácidos totais.... 122

4.5.6. O silenciamento do gene DnaJ não altera os indicadores de produção das linhagens

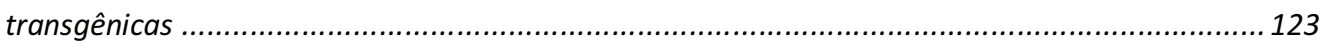

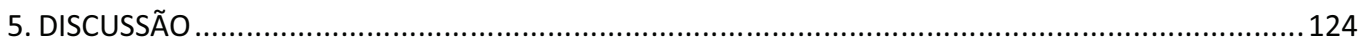

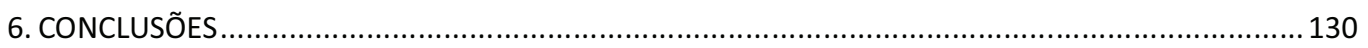

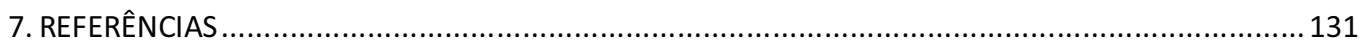

CAPÍTULO IV : CARACTERIZAÇÃO E ESTUDO FUNCIONAL DO GENE SEC14 .......................................135

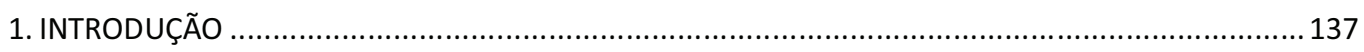

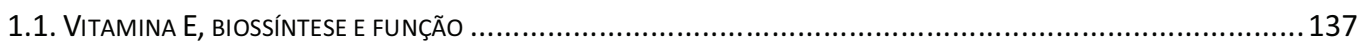

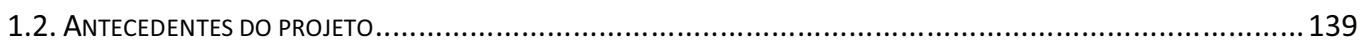

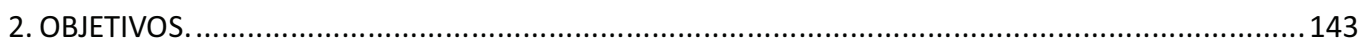

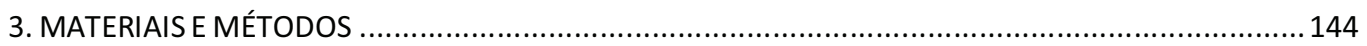

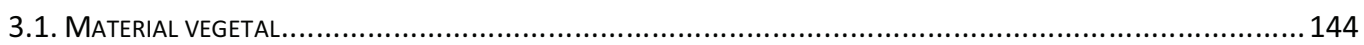

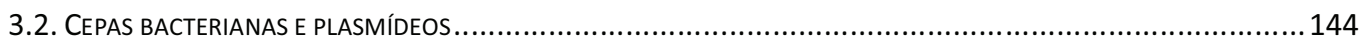

3.3. OBTENÇÃO DAS SEQUÊNCIAS DOS ALELOS DO GENE SEC14, ANÁLISE DA ESTRUTURA GÊNICA E FILOGENIA .............145

3.4. OBtenÇÃo dA CONSTRUÇÃO PARA ESTUdo DA LOCALIZAÇÃO SUBCELULAR DA PROTEÍNA SEC14 .....................146

3.5. OBTENÇÃO DA CONSTRUÇÃO PARA AVALIAÇÃO DO EFEITO DO SILENCIAMENTO GÊNICO POR RNA DE INTERFERÊNCIA

3.6. INFILTRAÇÃO DE FOLHAS DE N. BENTHAMIANA PARA ESTUDO DA LOCALIZAÇÃO SUBCELULAR DA PROTEÍNA SEC14 148

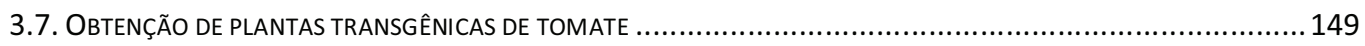

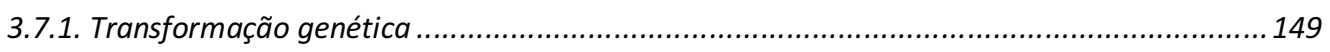

3.7.2. Verificação da presença do transgene ...................................................................... 149

3.7.3. Análise de expressão do gene sec14 nas linhagens transgênicas obtidas ......................... 149

3.8. CARACTERIZAÇÃO FENOTíPICA DAS LINHAGENS TRANSGÊNICAS ........................................................ 150

3.8.1. Cultivo e parâmetros de produção ........................................................................ 150

3.8.2. Verificação do nível de silenciamento nas linhagens transgênicas.................................... 151

3.8.3. Avaliação da expressão dos genes da rota central de biossíntese do tocoferol ................... 151

3.8.4. Medição dos parâmetros fotossintéticos ................................................................. 151 
3.8.5. Extração e quantificação de pigmentos.................................................................... 152

3.8.6. Extração e quantificação de aminoácidos, açúcares solúveis e amido ................................ 153

3.8.7. Extração e quantificação de tocoferóis ...................................................................... 155

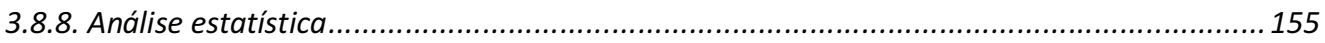

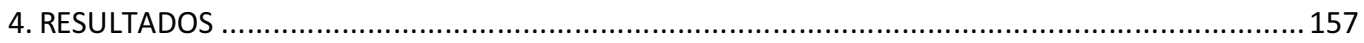

4.1. A PROTEÍNA SEC14 POSSUI O DOMÍNIO CRAL/TRIO E UM PEPTídEO DE DIRECIONAMENTO A CLOROPLASTOS..... 157

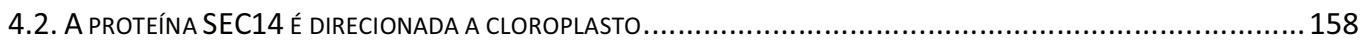

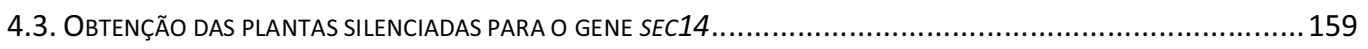

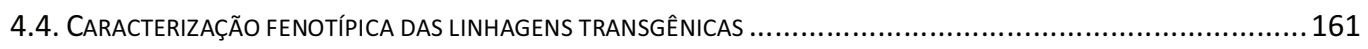

4.4.1. Verificação do nível de silenciamento nas linhagens transgênicas....................................161

4.4.2. O silenciamento do gene sec14 altera o funcionamento da maquinaria fotossintética ........162

4.4.3. O silenciamento do gene sec14 não altera o conteúdo de pigmentos................................ 164

4.4.4. O silenciamento do gene sec14 altera parcialmente o conteúdo de açúcares e amido.........164

4.4.5. O silenciamento do gene sec14 não altera o conteúdo de aminoácidos totais..................... 165

4.4.6. O silenciamento do gene sec14 altera os conteúdos de tocoferóis em folha fonte e fruto

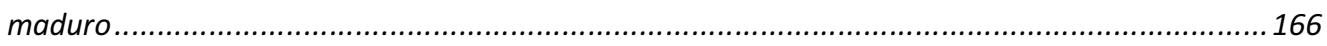

4.4.7. A expressão dos genes que codificam para as enzimas da rota central de VTE não foi alterada 168

4.4.8. O silenciamento do gene sec14 não altera os indicadores de produção das linhagens

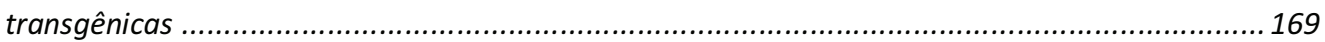

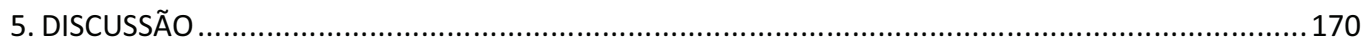

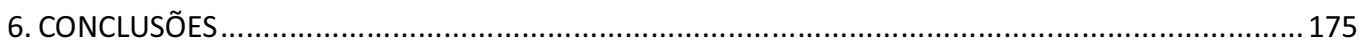

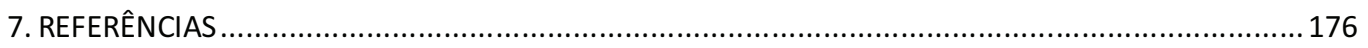

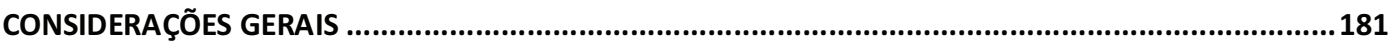

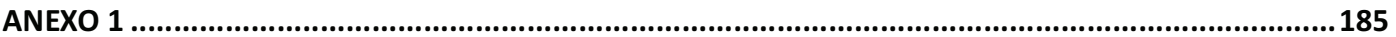

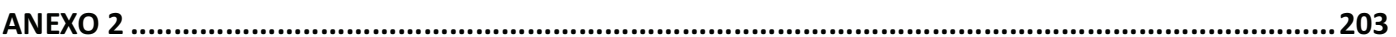



Introdução geral 



\section{TOMATE}

\subsection{A família Solanaceae e recursos genéticos}

O tomate cultivado (Solanum lycopersicum L.) pertence à família Solanaceae. A mesma compreende mais de 3.000 espécies adaptadas aos mais diversos ambientes em termos de temperatura, altitude e disponibilidade de água. Essa família se apresenta como a terceira em importância econômica e a mais cultivada para produção de hortaliças, tendo espécies de alta relevância como a batata, berinjela, tabaco e pimenta. Mais ainda, suas espécies se apresentam como plantas modelo para o estudo do desenvolvimento de tubérculos (Kolomiets et al., 2001, Fernie et al., 2001), da resposta de defesa em plantas (Martin et al., 1993, Rossi et al., 1998, Rathjen et al., 1999, Bogdanove e Martin, 2000; Gebhardt et al., 2001; Li et al.,2001; Hui et al., 2003; Pedley et al., 2003; Chung et al., 2011), do metabolismo de flavonóides e antocianinas (Olsen et al., 2010; Yamagishi et al., 2010) e do desenvolvimento de frutos carnosos (Alexander e Grierson, 2002; Tanksley, 2004; Giovanonni, 2004;Carrari et al., 2006a, 2006b).

Solanaceae divergiu há 40 milhões de anos de um ancestral diplóide com $\mathrm{x}=12$ cromossomos e, embora apresente ampla diversidade fenotípica, os estudos desenvolvidos até hoje indicam que a maioria das espécies mantém este número cromossômico, além de uma alta conservação da estrutura genômica. Desta forma, Solanaceae se consolida como um excelente modelo para estudar a diversidade subjacente à adaptação a ambientes diversos (Wikstrom et al., 2001; Wang et al., 2008; Wu e Tanksley, 2010).

As espécies de Solanum seção Lycopersicon, são nativas do oeste de América do Sul com uma distribuição ao longo dos Andes, desde a região central do Equador até o norte do Chile, incluindo as Ilhas Galápagos. Essa seção compreende treze espécies, algumas das quais estão apresentadas na Figura 1. Acredita-se que o tomate cultivado tenha sido domesticado a partir de Solanum lycopersicum var. cerasiforme, o qual apresenta uma maior distribuição desde o México até o sul do continente americano (Peralta e Spooner, 2007). 


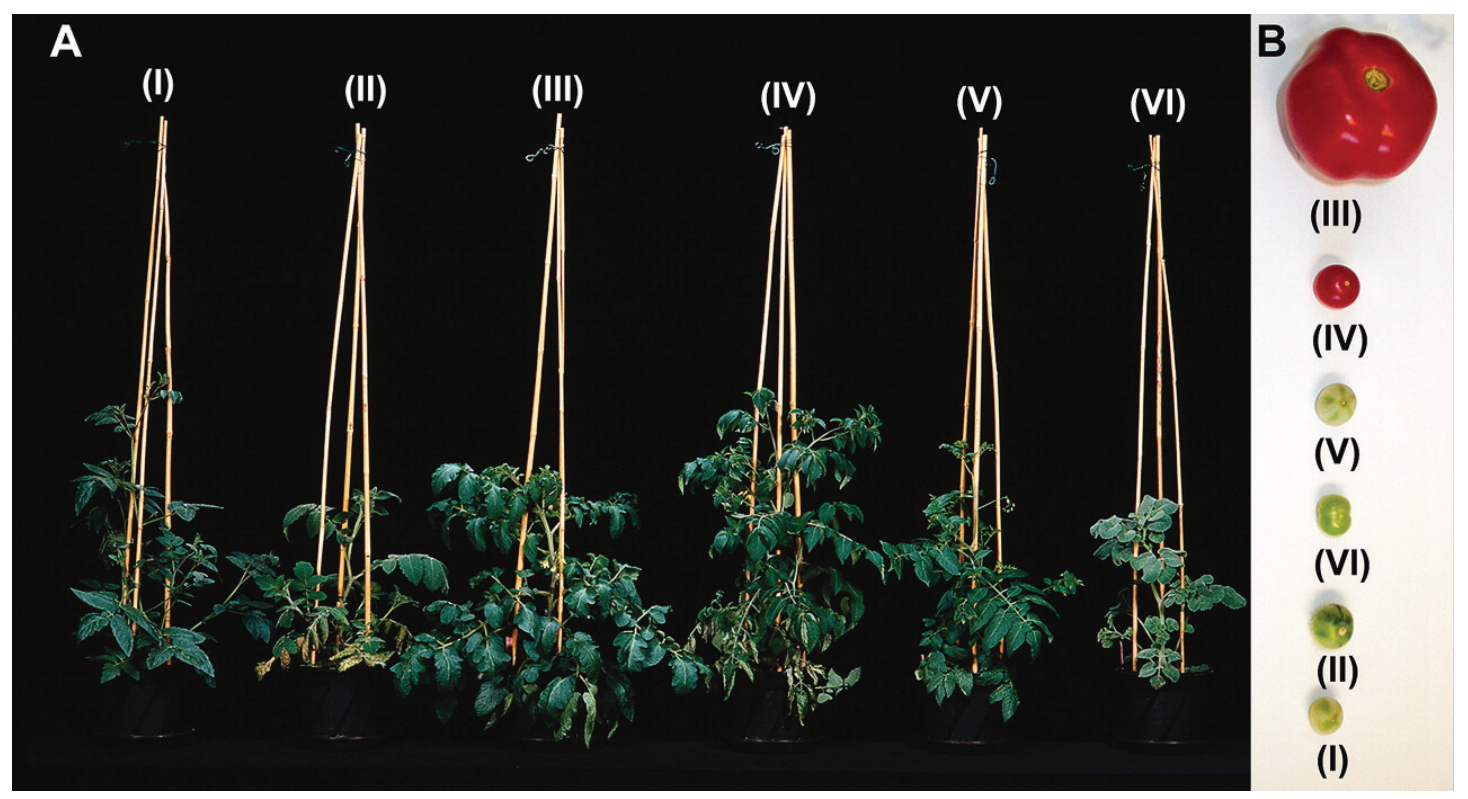

Figura 1. Fenótipo de folhas (A) e frutos (B) de espécies de tomate.

I: S. chmielewskii. II: S. habrochaites. III: S. lycopersicum. IV: S. pimpinellifolium. V: S. neorickii. VI: $S$. pennellii. Adaptado de Schauer et al. (2005).

\subsection{Espécie modelo}

O tomate possui genoma diplóide e relativamente pequeno (950 Mb), e representa um modelo de estudo alternativo a Arabidopsis thaliana, principalmente com relação aos processos de formação e amadurecimento de frutos carnosos e climatéricos (Giovannoni, 2004; Carrari et al., 2006a, 2006b). Dessa forma, diversos recursos genéticos e genômicos têm sido desenvolvidos para esta espécie: i) genoma totalmente sequenciado em fase final de anotação e montagem; ii) bibliotecas genômicas; iii) coleções de sequências de cDNA; iv) mapas genéticos de alta densidade e $v$ ) coleções de populações de mapeamento e mutantes. Adicionalmente, diversas abordagens tecnológicas foram bem estabelecidas e continuam sendo aplicadas com sucesso em tomate, como por exemplo, a transformação genética estável e o silenciamento gênico induzido por vírus (Barone et al., 2008; Quadrana et al., 2011).

O fruto de tomate é composto pela epiderme, um grosso pericarpo e a placenta, que recobre as sementes. O desenvolvimento do fruto pode ser dividido em quatro estágios esquematizados na Figura 2: i) início da floração até a antese (duas a três semanas); ii) intensa divisão celular (duas a três semanas a partir da fertilização); iii) expansão celular (duas a três semanas após o final do estágio de divisão) e finalmente, iv) amadurecimento que, pela sua importância na cadeia produtiva, especialmente na pós-colheita, tem sido exaustivamente estudado tanto ao nível 
genético como bioquímico (Alexander e Grierson, 2002; Alba et al., 2005; Barry et al., 2005; de Jong et al., 2009; Bapat et al., 2010). Este estágio final do desenvolvimento do fruto de tomate se inicia com a parada do crescimento, aumento da respiração e das concentrações de etileno, que por sua vez, desencadeiam uma complexa e rápida alteração no perfil metabólico (Figura 2). O amadurecimento está relacionado à modificação no acúmulo de carotenóides e clorofilas, concomitante à diferenciação de cloroplastos a cromoplastos (Bartley et al., 1994; Bramley, 2002; Waters et al., 2004), determinando assim a cor do fruto maduro. Por outro lado, a alteração no turgor celular e estrutura da parede modificam a textura. Neste sentido, a matriz péctica sofre uma série de alterações na composição e organização das pectinas, hemiceluloses e polissacarídeos celulósicos. Essas mudanças, que levam à perda da integridade do tecido, encontram-se mediadas pela ação de hidrolases específicas de parede (Rose et al., 2004; Duan et al., 2008; Meli et al., 2010, Almeida e Huber, 2011). Por fim, ocorrem mudanças no metabolismo de açúcares, ácidos e compostos voláteis que afetam a qualidade nutricional, aroma e sabor do fruto (Tieman et al., 2006; Carrari et al., 2006b). Porém, mesmo que os processos mencionados anteriormente tenham sido amplamente estudados, só recentemente estão sendo realizados trabalhos que estudam a sua integração e impacto no conteúdo de metabólitos primários e secundários relacionados com a qualidade do fruto (Carrari et al., 2006a, 2006b).

Um aspecto muito interessante que ainda abre questionamentos é o papel da fotossíntese do fruto durante os três primeiros estágios de desenvolvimento descritos anteriormente. Os poucos dados publicados a respeito indicam que os frutos verdes possuem cadeia de transporte de elétrons e ciclo de Calvin ativos, mas embora fixem carbono, a taxa respiratória é muito alta mascarando a fixação líquida. Assim o fruto apresentaria um metabolismo fotossintético, mas não autossuficiente, até o começo do amadurecimento e, então, sofreria uma transição ficando totalmente heterotrófico, dependente principalmente da respiração (Piechulla et al., 1987; Carrara et al., 2001).

\subsection{A cultura do tomate e a importância na saúde humana}

O tomateiro é cultivado nos cinco continentes, em regiões tropicais, subtropicais e temperadas. Sua produção anual alcança 152 milhões de toneladas (FAO Base de dados estatísticos, última atualização 2009; http://faostat.fao.org), sendo que a China e os Estados Unidos destacam-se como principais produtores. O Brasil ocupa a nona posição com uma produção de 4,3 milhões de toneladas por ano. $65 \%$ da 
produção mundial de tomate se destina para consumo fresco, e o restante é processado industrialmente com os seguintes fins: $40 \%$ para produção de extratos, $30 \%$ para molhos e purês, $15 \%$ para pasta e $15 \%$ para ketchup (USDA 2009).

Devido a sua facilidade e versatilidade na utilização, o tomate é a hortaliça mais consumida no mundo, tanto em forma fresca como processada. Adicionalmente é conhecido como um alimento nutracêutico, já que, além das bem conhecidas características organolépticas do fruto, o tomate é também valorizado pelo seu alto teor nutricional e a presença de diversos compostos com características antioxidantes que têm sido associadas à prevenção de doenças crônicas (Beecher, 1998; DemmigAdams e Adams, 2002; Giovannucci, 2005; Chang et al., 2006; Periago e Garcia, 2009) (Tabela 1).

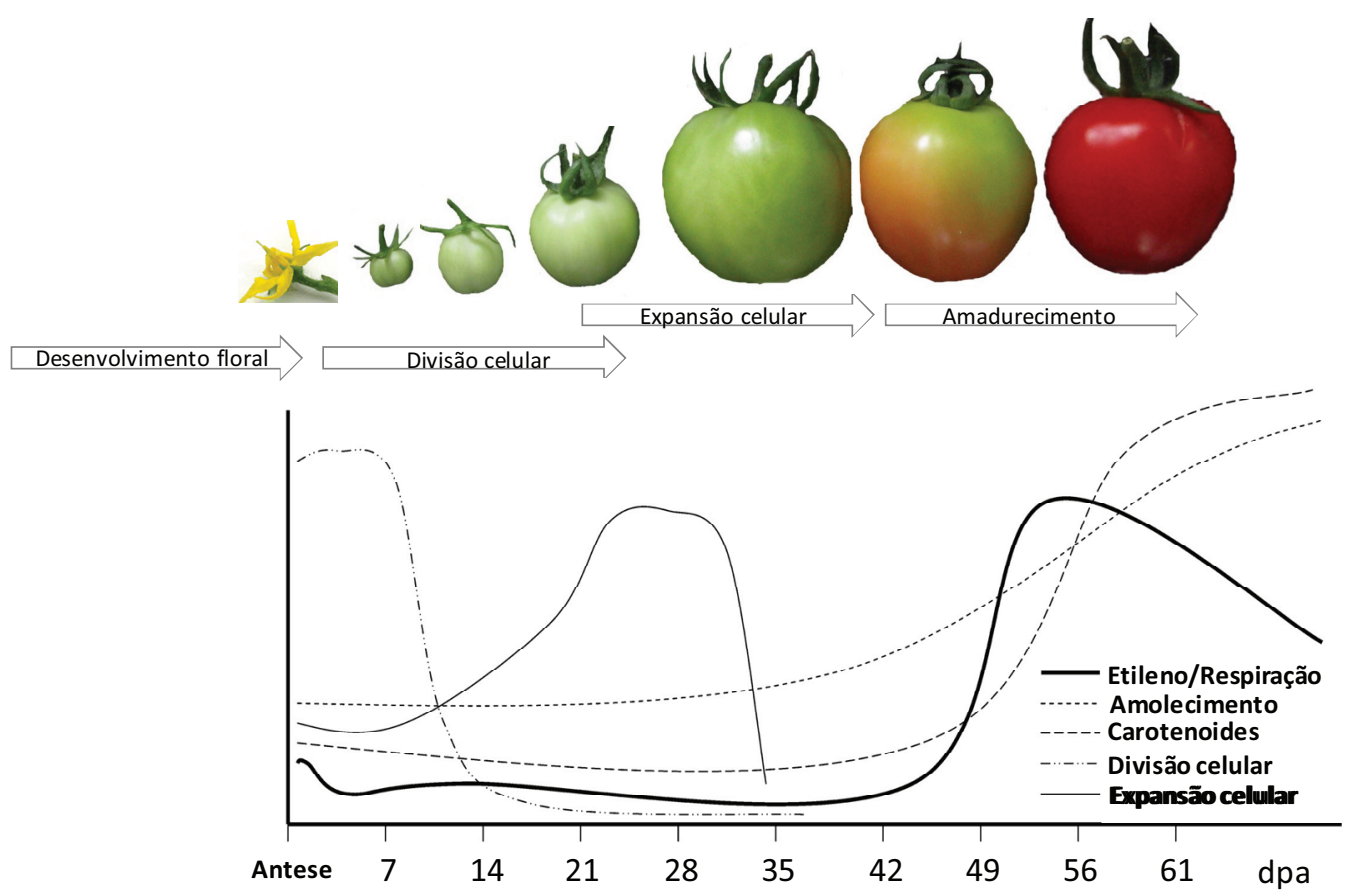

Figura 2. Esquema do desenvolvimento do fruto de tomate. dpa: dias pós-antese. Adaptado deTanksley (2004).

Tabela 1. Valor nutricional do tomate.

\begin{tabular}{|c|c|c|c|c|c|}
\hline \multirow[b]{2}{*}{ Nutriente } & \multicolumn{2}{|c|}{ TOMATE CRU } & \multicolumn{2}{|c|}{ TOMATE PROCESSADO } & \multirow{2}{*}{$\begin{array}{l}\text { Aporte do tomate } \\
\text { à dieta diária* }\end{array}$} \\
\hline & Quantidade/100 g & \% Valores Diários & Quantidade/100g & \% Valores Diários & \\
\hline Calorias & 18 (kcal) & $1 \%$ & 102 (kcal) & $5 \%$ & $4.5 \%$ \\
\hline Proteínas & $0.9 \mathrm{~g}$ & $2 \%$ & $3.2 \mathrm{~g}$ & $6 \%$ & $5.6 \%$ \\
\hline $\begin{array}{c}\text { Carboidratos } \\
\text { totais }\end{array}$ & $3.9 \mathrm{~g}$ & $1 \%$ & $21.3 \mathrm{~g}$ & $7 \%$ & 6.2 \\
\hline \multicolumn{6}{|l|}{ Vitaminas } \\
\hline Vitamina A & $833 \mathrm{IU}$ & $17 \%$ & $1298 \mathrm{IU}$ & $26 \%$ & $26 \%$ \\
\hline Vitamina C & $12.7 \mathrm{mg}$ & $21 \%$ & $32 \mathrm{mg}$ & $53 \%$ & $50 \%$ \\
\hline $\begin{array}{l}\text { Vitamina E (a- } \\
\text { tocoferol) }\end{array}$ & $0.5 \mathrm{mg}$ & $3 \%$ & $4.2 \mathrm{mg}$ & $21 \%$ & $19 \%$ \\
\hline
\end{tabular}




\subsection{Recursos genéticos e melhoramento}

Como em todas as espécies cultivadas, um dos objetivos mais importantes no melhoramento é aumentar o rendimento, além disso, busca-se a obtenção de variedades resistentes a fatores bióticos e abióticos limitantes dos cultivos. Porém, o melhoramento genético do tomate nos últimos anos ampliou sua atuação baseado nas demandas geradas pelo mercado de consumo. Para a indústria, busca-se aumentar o grau Brix, que representa o conteúdo de sólidos solúveis, especialmente açúcares e ácidos orgânicos. Para o mercado de consumo fresco, busca-se melhorar principalmente os metabólitos determinantes do aroma e sabor do fruto, assim como, da qualidade nutricional.

No entanto, para atingir estes desafios, os programas de melhoramento se deparam com a restrição da estreita base genética existente, devido à utilização histórica de espécies ou variedades filogeneticamente próximas. Atualmente só $2 \%$ da variabilidade observada no antigo gênero Lycopersicon se encontra na espécie cultivada Solanum lycopersicum (Fray e Grierson, 1993). Frente a esse panorama, fontes de germoplasma selvagens têm se apresentado muito úteis para a incorporação de novos caracteres no tomate. Neste sentido, existem vários exemplos da incorporação de genes de espécies selvagens no tomate cultivado que, por exemplo, conferem resistência a diferentes patógenos limitantes do cultivo (Seah et al., 2004; Martin et al., 1993; Rathjen et al., 1999).

Em 1995, Eshed e Zamir desenvolveram uma coleção de 76 linhagens introgredidas (ILs) nas quais segmentos definidos do genoma de Solanum pennellii (LA716) substituem regiões homólogas em um fundo genético de $S$. lycopersicum (cv. M82) (Figura 3A). Essas linhagens cobrem todo o genoma da espécie S. lycopersicum e os fragmentos estão bem delimitados por meio de marcadores moleculares (http://www.sgn.cornell.edu/maps/pe.pl), o qual permite que o genoma seja segmentado em 107 bins (Eshed e Zamir 1995; Pan et al., 2000) (Figura 3B).

Essa coleção de linhagens tem sido amplamente caracterizada com o intuito de identificar diferenças para caracteres de interesse, sendo mapeados mais de 2.000 QTL (Quantitative Trait Loci) (Lippman et al., 2007). Por exemplo, Rousseaux et al. (2005) estudaram metabólitos relacionados à qualidade nutricional e presença de antioxidantes no fruto das 76 ILs. Além desse estudo, Causse et al. (2002, 2004) mapearam 130 QTL para 38 caracteres relacionados à qualidade organoléptica e 81 QTL associados ao tamanho, conteúdo de ácidos orgânicos e açúcares de fruto. Devido 
à sua estrutura genômica, as ILs se apresentam como uma ferramenta muito interessante para desvendar os determinantes genéticos por trás dos caracteres quantitativos, já que todas as diferenças fenotípicas entre as linhagens e $S$. lycopersicum (cv. M82) estão determinadas apenas pelo fragmento de $S$. pennellii introgredido. Isto foi claramente demonstrado pelo estudo realizado por Fridman et al. (2000, 2004), no qual foi identificado que a IL 9-2-5 apresentava um incremento de $25 \%$ no Brix. Após o mapeamento genético e físico de alta resolução, um fragmento da região introgredida de $S$. pennellii foi sequenciada. Nela foi identificado um gene que codifica para uma invertase de parede celular, lin5. A comparação dos alelos selvagem e cultivado permitiu concluir que o QTL estava determinado pela mudança de um único nucleotídeo no terceiro éxon do gene, sendo que essa mudança modificava as propriedades cinéticas da enzima. Essa invertase é chave no carregamento de sacarose no floema, sendo esse o maior fator envolvido no incremento do conteúdo de açúcar no fruto (Baxter et al., 2005).

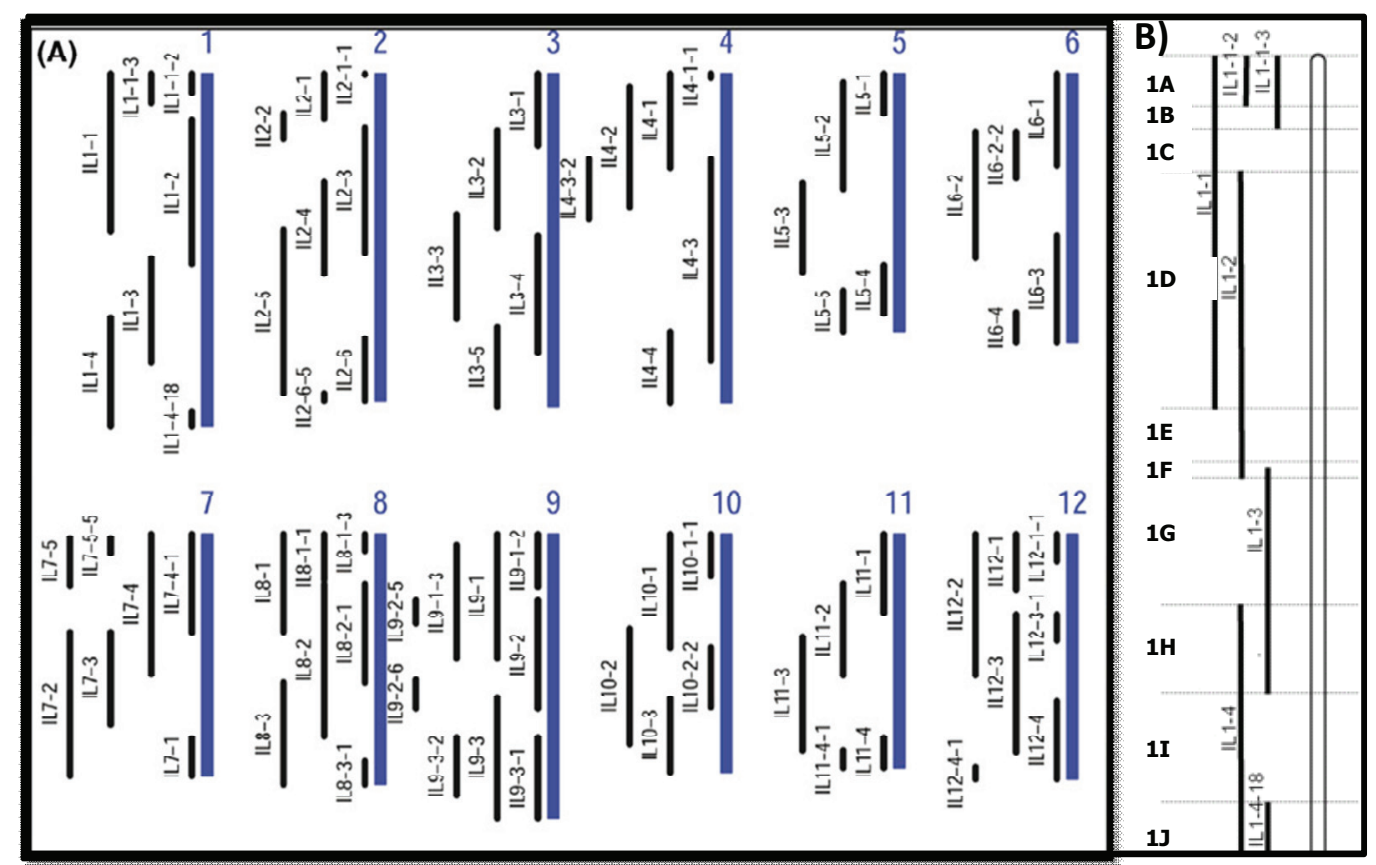

Figura 3. Representação esquemática da população das ILs de $S$. pennelli em fundo genético S. Iycopersicum, desenvolvidas por Eshed e Zamir (1995).

(A) esquema geral das ILs. As linhas pretas representam o fragmento de $S$. pennellii contido em cada linhagem. Junto aos fragmentos se indica o nome da linhagem. Fonte: Lippman et al. (2007). (B) ILs que abrangem o cromossomo 1 . As letras indicam os bins, nos quais é possível dividir o cromossomo 1 de acordo à sobreposição dos diferentes fragmentos introgredidos.

Historicamente, a caracterização de QTL, como o exemplo descrito acima, era realizada por meio de longos processos de mapeamento genético, seguidos de 
mapeamentos físicos para finalmente chegar à clonagem posicional. Com o aumento da quantidade de informação sobre sequências genômicas e expressas, assim como a disponibilidade de mapas de alta densidade, surgiu a estratégia de "genes candidatos" como uma alternativa à clonagem posicional. Essa abordagem consiste na identificação de genes que cossegregam com os caracteres de interesse e que, pela função dos seus produtos, podem contribuir ou determinar as variações observadas. A candidatura de um gene pode ser reforçada de diferentes maneiras, entre elas: i) se o gene é expresso nas mesmas condições temporais e espaciais que o QTL; ii) se os alelos presentes nos genitores da população de mapeamento apresentam padrões de expressão diferenciais ou; iii) se os alelos genitores apresentam polimorfismos não silenciosos. Finalmente, o envolvimento do gene candidato no carácter de interesse deve ser testado por meio de análises funcionais utilizando diversas ferramentas de genética reversa, muitas delas baseadas em mutagênese ou no silenciamento gênico específico por meio de tecnologias baseadas em RNAi (RNA de interferência) (Rothan e Causse, 2007).

\subsection{Antecedentes do projeto}

Recentemente, nas 76 linhagens introgredidas desenvolvidas por Eshed e Zamir (1995), Schauer et al. (2006) identificaram e quantificaram 74 metabólitos, entre eles, aminoácidos, ácidos orgânicos e graxos, açúcares e vitaminas E e C, assim como diversos caracteres morfológicos associados ao rendimento da planta, como peso e altura de planta, largura e peso de fruto, grau Brix e índice de colheita. Esse trabalho resultou na descrição de 889 QML (Quantitative Metabolic Loci) e 326 YAL (Yield Associated Loci). Tendo como base esse estudo e em colaboração com a equipe do Dr. Alisdair Fernie do Max-Planck-Institut (Gölm, Alemanha) e do Dr. Fernando Carrari do INTA (Castelar, Argentina), nosso grupo trabalha para identificar e caracterizar os determinantes genéticos responsáveis por essas mudanças.

Assim, partindo dos 1.215 QTL identificados por Schauer et al. (2006) na população de ILs de S. pennellii foram selecionados 106 QML e 20 YAL segundo os seguintes critérios: i) no mínimo uma variação significativa de $100 \%$ no conteúdo do metabólito quando comparado com o genitor $S$. lycopersicum e ii) uma posição cromossômica claramente definida dentro do contexto dos bins. Os QTL selecionados encontram-se localizados em 16 bins (1J, 2F, 4E, 4I, 5D, 5E, 5F, 7B, 7F, 7H, 9B, 9D, 
9E, 9J, 10B, 11C) distribuídos ao longo de 8 dos 12 cromossomos do tomate e compreendem 52 metabólitos diferentes e 9 caracteres associados ao rendimento.

Para identificar as possíveis diferenças entre $S$. lycopersicum e $S$. pennellii determinantes das mudanças observadas, foram utilizadas inicialmente duas abordagens: a de genes candidatos (para os bins 1J, 2F, 4E, 4I, 5D/5E/5F, 7B, 7F, 7H, 9B/9D/9E, 9J, 10B, 11C) com o intuito de identificar diferenças em produtos gênicos (ex. mudanças de aminoácidos) e o mapeamento físico (para os bins 4I, 7H, 11C) para avaliar a colinearidade e identificar diferenças em promotores, padrão de inserção de elementos de transposição ou possíveis rearranjos.

Neste contexto, a presente tese aborda a caracterização de genes candidatos nas regiões genômicas selecionadas, assim como uma análise da diversidade genômica entre as duas espécies para a região do bin 4I. Adicionalmente, foram realizados estudos funcionais para dois genes candidatos. A chaperona DnaJ localizada no bin 4I, associada a mudanças no conteúdo de açúcares a qual demonstrou alterar a relação fonte - dreno, modificando a distribuição de fotossintetizados na planta. Finalmente, o gene sec14 que co-localiza com um QTL para vitamina E (VTE), demonstrou participar do controle da biossíntese e acúmulo de tocoferol em tomate. 


\section{REFERÊNCIAS}

Alba R, Payton P, Fei Z, McQuinn R, Debbie P, Martin GB, Tanksley SD, Giovannoni JJ. 2005. Transcriptome and selected metabolite analyses reveal multiple points of ethylene control during tomato fruit development. Plant Cell 17, 2954-65.

Alexander L, Grierson D. 2002. Ethylene biosynthesis and action in tomato: a model for climacteric fruit ripening. Journal of Experimental Botany 53, 2039-2055.

Almeida DPF, Hube DJ. 2011. Autolysis of cell walls from polygalacturonase-antisense tomato fruit in simulated apoplastic solutions. Plant Physiology and Biochemistry 49, 617-622.

Bapat VA, Trivedi PK, Ghosh A, Sane VA, Ganapathi TR, Nath P. 2010. Ripening of fleshy fruit: molecular insight and the role of ethylene. Biotechnology Advances 28, 94-107.

Barone A, Chiusano ML, Ercolano MR, Giuliano G, Grandillo S, Frusciante L. 2008. Structural and functional genomics of tomato. International Journal of Plant Genomics 2008, 820274.

Barry CS, McQuinn RP, Thompson AJ, Seymour GB, Grierson D, Giovannoni JJ. 2005. Ethylene insensitivity conferred by the Green-ripe and Never-ripe 2 ripening mutants of tomato. Plant Physiology 138, 267-75.

Bartley GE, Scolnik PA. 1994. Molecular biology of carotenoid biosynthesis in plants. Annual Review of Plant Physiology and Plant Molecular Biology 45, 287-301.

Baxter C, Carrari F, Bauke A, Overy S, Hill S, Quick P, Fernie A, Sweetlove L. 2005. Fruit Carbohydrate Metabolism in an Introgression Line of Tomato with Increased Fruit Soluble Solids. Plant Cell Physiology 46, 425-437.

Bramley PM. 2002. Regulation of carotenoid formation during tomato fruit ripening and development. Journal of Experimental Botany 377, 2107-13.

Beecher GR. 1998. Nutrient content of tomatoes and tomato products. Proceedings of the Society for Experimental Biology and Medicine 218, 98-100.

Bogdanove AJ, Martin GB. 2000. AvrPto-dependent Pto interacting proteins and AvrPtointeracting proteins in tomato. Proceedings of the National Academy of Sciences of the United States of America 97, 8836-8840.

Carrara S, Pardossi A, Soldatini GF, Tognoni F, Guidi L. 2001. Photosynthetic Activity of Ripening Tomato Fruit. Photosynthetica 39, 75-78.

Carrari F, Fernie AR. 2006a. Metabolic regulation underlying tomato fruit development. Journal of Experimental Botany 57, 1883-97.

Carrari F, Baxter C, Usadel B, Urbanczyk-Wochniak E, Zanor MI, Nunes-Nesi A, Nikiforova V, Centero D, Ratzka A, Pauly M, Sweetlove L, Fernie AR. 2006b. Integrated analysis of metabolite and transcript levels reveals the metabolic shifts that underlie tomato fruit development and highlight regulatory aspects of metabolic network behavior. Plant Physiology 142, 1380-96.

Causse M, Saliba-Colombani V, Lecomte L, DuffeÂ P, Rousselle P, Buret M. 2002. QTL analysis of fruit quality in fresh market tomato: a few chromosome regions control the variation of sensory and instrumental traits. Journal of Experimental Botany 53, 2089-2098.

Causse M, Duffe P, Gómez M, Buret M, Damidaux R, Zamir D, Gur A, Chevalier C, Lemaire-Chamley M, Rothan C. 2004. A genetic map of candidate genes and QTLs involved in tomato fruit size and composition. Journal of Experimental Botany 55, 1671-1685.

Chang $\mathrm{CH}$, Lin HY, Chang CY, Liu YC. 2006. Comparisons on the antioxidant properties of fresh, freeze-dried and hot-air-dried tomatoes. Journal of Food Engineering $77,478-485$. 
Chung SH, Felton GW. 2011. Specificity of induced resistance in tomato against specialist lepidopteran and coleopteran species. Journal of Chemical Ecology 37, 378-86.

de Jong $\mathrm{M}$, Mariani $\mathrm{C}$, Vriezen $\mathrm{WH}$. 2009. The role of auxin and gibberellin in tomato fruit set. Journal of Experimental Botany 60, 1523-32.

Demmig-Adams B, Adams WWR. 2002. Antioxidants in photosynthesis and human nutrition. Science 298, 2149-2153.

Duan X, Chenga G, Yanga E, Yia C, Ruenroengklina N, Lub W, Luoc Y, Jiang Y. 2008. Modification of pectin polysaccharides during ripening of postharvest banana fruit. Food Chemistry 111, 144-149.

Eshed Y, Zamir D. 1995. An Introgression Line Population of Lycopersicon pennelli in the Cultivated Tomato Enables the Identification and Fine Mapping of YieldAssociated QTL. Genetics 141, 1147-1162.

Fernie AR e Willmitzer L. 2001. Molecular and Biochemical Triggers of Potato. Tuber Development. Plant Physiology 127, 1459-1465.

Fray RG, Grierson D. 1993. Identification and genetic analysis of normal and mutant phytoene synthase genes of tomato by sequencing, complementation and cosuppression. Plant Molecular Biology 22, 589-602.

Fridman E, Pleban T, Zamir D. 2000. A recombination hotspot delimits a wild-species quantitative trait locus for tomato sugar content to $484 \mathrm{bp}$ within an invertase gene. PNAS 97, 4718-4723.

Fridman E, Carrari F, Liu Y, Fernie A, Zamir D. 2004. Zooming In on a quantitative Trait for Tomato Yield Using Interspecific Introgressions. Science 305, 1786-9.

Gebhardt C, Valkonen JP. 2001. Organization of genes controlling disease resistance in the potato genome. Annual Review Phytopathology 39, 79-102.

Giovannoni JJ. 2004. Genetic regulation of fruit development and ripening. Plant Cell $16,170-18$.

Giovannucci E. 2005. Tomato products, lycopene, and prostate cancer: A review of the epidemiological literature. Journal of Nutrition 135, 2030S-2031S.

Hui D, Iqbal J, Lehmann K, Gase K, Saluz HP, Baldwin IT. 2003. Molecular interactions between the specialist herbivore Manduca sexta (Lepidoptera, Sphingidae) and its natural host Nicotiana attenuata: V. microarray analysis and further characterization of large-scale changes in herbivore-induced RNAms. Plant Physiology 131, 1877-1893.

Kolomiets MV, Hannapel DJ, Chen H, Tymeson M, Gladon RJ. 2001. Lipoxygenase Is Involved in the Control of Potato Tuber Development. Plant Cell 13, 613-626.

Li L, Li C, Howe GA. 2001. Genetic analysis of wound signaling in tomato. Evidence for a dual role of jasmonic acid in defense and female fertility. Plant Physiology 127, 1414-1417.

Lippman ZB, Semel Y, Zamir D. 2007. An integrated view of quantitative trait variation using tomato interspecific introgression lines. Current Opinion in Genetics $e$ Development 17, 545-552.

Martin GB, Brommonschenkel SH, Chunwongse J, Frary A, Ganal MW, Spivey R, Wu T, Earle ED, Tanksley SD. 1993. Map-based cloning of a protein kinase gene conferring disease resistance in tomato. Science 262, 1432-1436.

Meli VS, Ghosh S, Prabha TN, Chakraborty N, Chakraborty S, Datta A. 2010. Enhancement of fruit shelf life by suppressing $\mathrm{N}$-glycan processing enzymes. Proceedings of the National Academy of Sciences of the United States of America 107, 2413-8.

Olsen KM, Hehn A, Jugdé H, Slimestad R, Larbat R, Bourgaud F, Lillo C. 2010. Identification and characterisation of CYP75A31, a new flavonoid 3'5'hydroxylase, isolated from Solanum lycopersicum. BMC plant biology 3, 10-21. 
Pan Q, Liu Y-S, Budai-Hadrian O, Sela M, Carmel-Goren L, Zamir D, Fluhr R. 2000. Comparative genetics of nucleotide binding site-leucine rich repeat resistance gene homologues in the genomes of two dicotyledons: Tomato and Arabidopsis. Genetics 155, 309-322.

Peralta IE e Spooner DM. 2007. History, origin and early cultivation of tomato (Solanaceae). Em Genetic improvement of Solanaceaus crops. Razdan MK e Mattoo AK. Science publishers Enfield, New Hampshire, EUA.

Periago MJ e Garcia-Alonso J. 2009. Bioactive compounds, folates and antioxidant properties of tomatoes (Lycopersicum esculentum) during vine ripening, International Journal of Food Sciences and Nutrition 60, 694-708.

Pedley KF, Martin GB. 2003. Molecular basis of Pto-mediated resistance to bacterial speck disease in tomato. Annual Review Phytopathology 41, 215-243.

Piechulla B, Glick R, Bahl H, Gruissem W. 1987. Changes in Photosynthetic Capacity and Photosynthetic Protein Pattern during Tomato Fruit Ripening. Plant Physiology 84, 911-917.

Quadrana L, Rodriguez C, López M, Bermudez L, Nunes-Nesi A, Fernie AR, Descalzo A, Asis R, Rossi M, Asurmendi S, Carrari F. 2011. Coupling virus induced gene silencing to the exogenous green fluorescence protein expression provides an efficient system for functional genomics which exhibits negligible effects on plant metabolism. Plant Physiology, 111-177345.

Rathjen JP, Chang JH, Staskawicz BJ, Michelmore RW. 1999. Constitutively active Pto induces a Prf-dependent hypersensitive response in the absence of AvrPto. The EMBO journal 18, 3232-3240.

Rose JKC, Saladie M, Catala C. 2004. The plot thickens: new perspectives of primary cell wall modification. Current Opinion in Plant Biology 7, 296-301.

Rothan C, Causse M. 2007. Natural and artificially induced genetic variability in crop and model plant species for plant systems biology. Experientia Supplementum 97, 21-53.

Rousseaux M, Jones C, Adams D, Chetelat R, Bennett A, Powell A. 2005. QTL analysis of fruit antioxidants in tomato using Lycopersicon pennelli introgression lines. Theoretical and Applied Genetics 111, 5740-5752.

Rossi M, Goggin FL, Milligan SB, Kaloshian I, Ullman DE, Williamson VM. 1998. The nematode resistance gene $\mathrm{Mi}$ of tomato confers resistance against the potato aphid. Proceedings of the National Academy of Sciences of the United States of America 95, 9750-4.

Schauer N, Semel Y, Roessner U, Gur A, Balbo I, Carrari F, Pleban T, Perez-Melis A, Bruedigam C, Kopka J, Willmitzer L, Zamir D, Fernie A. 2006. Comprehensive metabolic profiling and phenotyping of interspecific introgression lines for tomato improvement. Nature Biotechnology 24, 447-454.

Seah S, Yaghoobi J, Rossi M, Gleason CA, Williamson VM. 2004. The nematoderesistance gene, $\mathrm{Mi}-1$, is associated with an inverted chromosomal segment in susceptible compared to resistant tomato. Theoretical and Applied Genetics $108,1635-1642$.

Tanksley SD. 2004. The genetic, developmental, and molecular bases of fruit size and shape variation in tomato. Plant Cell 16, 181-189.

Tieman DM, Zeigler M, Schmelz EA, Taylor MG, Bliss P, Kirst M, Klee HJ. 2006. Identification of loci affecting flavour volatile emissions in tomato fruits. Journal of Experimental Botany 57, 887-896.

Wang Y, Diehl A, Wu F, Vrebalov J, Giovannoni J, Siepel A, Tanksley SD. 2008. Sequencing and comparative analysis of a conserved syntenic segment in the Solanaceae. Genetics 180, 391-408. 
Wu F, Tanksley SD. 2010. Chromosomal evolution in the plant family Solanaceae. BMC genomics 17, 11-182.

Waters MT, Fray RG, Pyke KA. 2004. Stromule formation is dependent upon plastid size, plastid differentiation status and the density of plastids within the cell. Plant Journal 39, 655-667.

Wikström N, Savolainen V, Chase MW. 2001. Evolution of the angiosperms: calibrating the family tree. Proceedings of the Royal Society - Biological Sciences 268, 2211-20.

Yamagishi M, Shimoyamada Y, Nakatsuka T, Masuda K. 2010. Two R2R3-MYB genes, homologs of Petunia AN2, regulate anthocyanin biosyntheses in flower Tepals, tepal spots and leaves of asiatic hybrid lily. Plant Cell Physiology 51, 463-74. 
Hipótese e objetivos 

Tendo como ponto de partida os QTL descritos por Schauer et al. (2006) a partir do perfil metabólico da população de ILs (Eshed e Zamir, 1995), o objetivo geral desta tese foi aprofundar o conhecimento sobre os determinantes genéticos dos caracteres envolvidos na qualidade industrial e nutricional de frutos. As abordagens experimentais propostas se sustentam pela hipótese das variantes alélicas introduzidas pelo genitor selvagem da população (Solanum pennellii) e, as interações destas com o fundo genético do genitor recurrente (Solanum lycopersicum) ser os principais fatores causadores das variações fenotípicas observadas.

Para atingir este objetivo foram, inicialmente, propostas duas diferentes abordagens:

i) Busca de genes candidatos associados aos QTL selecionados (Capítulo I).

ii) Análise da diversidade genômica entre o tomate cultivado, S. Iycopersicum, e a espécie selvagem, S. pennellii (Capítulo II).

A partir dos resultados obtidos foram propostos os dois seguintes objetivos:

iii) Caracterização e estudo funcional do gene chaperona DnaJ (Capítulo III).

iv) Caracterização e estudo funcional do gene sec14 (Capítulo IV). 



\section{Capitulo I: Busca de genes}

candidatos associados aos QTL que afetam a composição química do

fruto de tomate 



\section{RESUMO}

Em tomateiro diversos estudos têm demonstrado que as espécies selvagens apresentam uma abundante fonte de variabilidade genética para diversos fatores, como genes de resistência a patógenos e caracteres relacionados à qualidade industrial e nutricional, entre outros. A partir de uma coleção de linhagens introgredidas de $S$. pennellii, em um fundo genético de $S$. lycopersicum, foram identificados previamente 889 QML e 326 YAL, distribuídos ao longo do genoma do tomate (Schauer et al., 2006).

O objetivo geral deste capítulo foi identificar e caracterizar genes candidatos que co-localizam com um subgrupo de QTL descritos por Schauer et al. (2006), que compreendem 106 QML e 20 YAL associados a importantes características nutricionais e agronômicas localizados em 16 regiões do genoma do tomate.

Para atingir este objetivo, foram desenvolvidas as seguintes atividades:

a) Levantamento dos marcadores moleculares localizados nas 16 regiões genômicas sob estudo.

b) Análise das sequências dos marcadores para identificação e anotação dos genes a partir da sua comparação com sequências genômicas e expressas disponíveis em banco de dados públicos.

c) Seleção dos genes candidatos a partir da reconstrução das vias metabólicas nas quais os produtos protéicos dos genes identificados atuam.

d) Amplificação e clonagem dos alelos de S. lycopersicum e S. pennellii de 127 genes candidatos.

e) Sequenciamento e identificação de diferenças alélicas.

f) Análise das correlações entre as variações na expressão dos genes e as mudanças nos níveis de metabólitos durante o desenvolvimento e amadurecimento dos frutos de $S$. lycopersicum

Desta maneira foi possível identificar 127 genes candidatos, dos quais 85 foram clonados e sequenciados parcialmente, sendo geradas 45.816 e 45.787 bases para $S$. lycopersicum e $S$. pennellii, respectivamente.

A comparação dos alelos revelou que 37 destes genes apresentaram variação nas sequências protéicas entre ambas as espécies. Adicionalmente, para 56 deles foi observada a correlação do perfil transcricional com a variação metabólica. Os resultados obtidos representam o passo inicial para a compreensão dos mecanismos 
que determinam a composição metabólica no fruto de tomate e foram publicados na íntegra no periódico Journal of Experimental Botany em 2008 que se anexa a seguir.

A partir deste ponto, os capítulos seguintes propuseram: i) análise da diversidade genômica entre o tomate cultivado, S. lycopersicum, e a espécie selvagem S. pennellii; ii) o estudo funcional do gene chaperona DnaJ, localizada no cromossomo 4 e associada a mudanças no conteúdo de açúcares solúveis, e; iii) o estudo funcional do gene sec14 identificado no cromossomo 9 que co-localiza com um QTL para o conteúdo de vitamina $\mathrm{E}$. 


\title{
A candidate gene survey of quantitative trait loci affecting chemical composition in tomato fruit
}

\author{
L. Bermúdez ${ }^{1, \star}$, U. Urias ${ }^{1,2, \star}$, D. Milstein ${ }^{1}$, L. Kamenetzky², R. Asis ${ }^{3}$, A. R. Fernie ${ }^{4}$, M. A. Van Sluys ${ }^{1}$, \\ F. Carrari ${ }^{2, \dagger}$ and M. Rossi ${ }^{1, \dagger}$ \\ ${ }^{1}$ GaTE Lab, Departamento de Botânica-IB-USP, Brasil. Rua do Matão, 277, 05508-900, São Paulo, SP, Brazil \\ 2 Instituto de Biotecnología, Instituto Nacional de Tecnología Agrícola (IB-INTA), PO Box 25, B1712WAA Castelar, \\ Argentina (partner group of the Max Planck Institute for Molecular Plant Physiology, Potsdam-Golm, Germany) \\ ${ }^{3}$ Facultad de Ciencias Químicas Universidad Nacional de Córdoba, CC 5000, Haya de la Torre y Medina Allende, \\ Córdoba, Argentina \\ ${ }^{4}$ Max Planck Institute for Molecular Plant Physiology, Wissenschaftspark Golm, Am Mühlenberg 1, Potsdam-Golm, \\ D-14 476, Germany
}

Received 18 February 2008; Revised 3 April 2008; Accepted 29 April 2008

\begin{abstract}
In tomato, numerous wild-related species have been demonstrated to be untapped sources of valuable genetic variability, including pathogen-resistance genes, nutritional, and industrial quality traits. From a collection of $S$. pennellii introgressed lines, 889 fruit metabolic loci (QML) and 326 yield-associated loci (YAL), distributed across the tomato genome, had been identified previously. By using a combination of molecular marker sequence analysis, PCR amplification and sequencing, analysis of allelic variation, and evaluation of co-response between gene expression and metabolite composition traits, the present report, provides a comprehensive list of candidate genes colocalizing with a subset of $106 \mathrm{QML}$ and $20 \mathrm{YAL}$ associated either with important agronomic or nutritional characteristics. This combined strategy allowed the identification and analysis of 127 candidate genes located in 16 regions of the tomato genome. Eightyfive genes were cloned and partially sequenced, totalling 45816 and 45787 bases from S. Iycopersicum and $S$. pennellii, respectively. Allelic variation at the amino acid level was confirmed for 37 of these candidates. Furthermore, out of the 127 gene-metabolite co-locations, some 56 were recovered following correlation of parallel transcript and metabolite profiling. Results obtained here represent the initial steps in the
\end{abstract}

integration of genetic, genomic, and expressional patterns of genes co-localizing with chemical compositional traits of the tomato fruit.

Key words: Candidate genes, introgressed lines, metabolite content, quantitative trait loci, Solanum lycopersicum, Solanum pennelli, tomato.

\section{Introduction}

Tomato (Solanum lycopersicum $=$ Lycopersicum esculentum) is a horticultural crop of major economic importance, displaying several characteristics which have established it as a model system for dissection of genetic determinants of quantitative trait loci. In tomato, numerous wild-related species have been demonstrated to be untapped sources of valuable genetic variability, including pathogen-resistance genes, and nutritional and industrial quality traits (Fernie et al., 2006). Despite the fact that the tomato genome sequence is not yet complete, there is an extensive amount of genetic data on this species comprising relatively comprehensive genetic maps, expressed sequence tag (EST) collections, as well as precious germoplasm collections and mapping populations (including recombinant inbred and introgression lines), from which many quantitative trait loci (QTL) have already been reported

\footnotetext{
* These authors contributed equally to this work.

To whom correspondence should be addressed. E-mail: magda1708@yahoo.com. Correspondence may also be addressed to F. Carrari. Email: fcarrari@cnia.inta.gov.ar
} 
(Van der Hoeven et al., 2002; Mueller et al., 2005a; Lippman et al., 2007; Paran and Van der Knaap, 2007).

Historically in plant genetics, traits of interest have been genetically dissected through physical mapping followed by positional cloning (Salvi and Tuberosa, 2005). The advent of genomics and the increase of gene expression and mapping information that became available on its application have, however, recently facilitated the candidate gene approach. Following this approach the colocation of course map positions of genes with genomic regions conferring a trait of interest are regarded as 'candidates' that contribute, if not determine, changes in the trait (Tabor et al., 2002). Given that relatively few tomato QTL have been cloned or accurately tagged (see, for example, Frary et al., 2000; Fridman et al., 2004; Galpaz et al., 2006; Chen et al., 2007), and this is currently a laborious and slow process, requiring many generations of crossings and the screening of thousands of segregants, the candidate gene approach represents an attractive alternative as a way to start QTL characterization (Causse et al., 2004; Price, 2006). When studying populations resulting from inter-specific crosses the first step of this process is to identify co-location of course map position with trait variation associated with genomic regions harbouring QTL of interest. However, several further steps can be taken to support the candidacy of the genes in question. It is important to determine whether the genes are expressed in a spatial-temporal pattern that is consistent to that under which the QTL is detected. In addition, it is now relatively easy to determine whether the parental alleles differ in sequence identity or their level of expression.

In a recent study, Schauer et al. (2006) identified 889 fruit metabolic loci (QML) and 326 yield-associated loci (YAL) distributed across the tomato genome. These QTL were identified using the $S$. pennelli introgression line (ILs) population (Eshed and Zamir, 1995), that had previously been utilized by several groups to identify a further 1000 QTL (Lippman et al., 2007). However, despite producing an enormous amount of QTL data, the level of genetic resolution of these traits is currently somewhat limited since each IL harbours hundreds to thousands of genes, and, despite the availability of dense genetic maps for tomato, the number of metabolismassociated genes currently mapped is relatively low (in the region of 200-300). In a previous study by Causse et al. (2004), some 100 genes associated with primary metabolism were mapped and associations with fruit weight, and sugar and organic acid contents in fruits were examined. More recently, a map-based approach revealed few colocations between candidate genes and QTL involved in the metabolism of ascorbic acid. Remarkable are the cases of the monodehydroascorbate reductase and the GDPmannose epimerase genes that co-locate with two distinct QTL for ascorbic acid on chromosome 9 (Stevens et al., 2007). However, these studies not withstanding and the analysis of all genes associated with metabolism currently mapped failed to yield candidate genes for the vast majority of QML identified by Schauer et al. (2006).

In the current study, the aim was to provide a more comprehensive list of candidate genes following a slightly different strategy. Rather than taking the top-down approach of pre-selecting genes of interest and mapping their positions by means of multi-parallel Southern hybridizations, it was decided to identify all candidates within specific genomic regions of interest. The focus was on a subset of 106 QML and 20 YAL reported by Schauer et al. (2006), specifically those associated either with important agronomic or nutritional characteristics. It was possible to identify a total of 88 metabolism-associated and 39 non-metabolism (transport, signalling, protein processing or degradation, and DNA/RNA-protein metabolism) -associated candidate genes for these QTL. To validate these further, two additional experiments were performed: (i) sequence analysis of allelic variation between $S$. lycopersicum and $S$. pennellii; and (ii) evaluation of the correlation between the expression of these genes and the trait of interest within a dataset obtained from the assessment of tomato fruit development (Carrari et al., 2006). The combined results are discussed with respect both to the use of multiple association approaches and select sequencing for the cross-validation of candidate genes, and the ultimate utility of IL breeding in crop compositional improvement.

\section{Materials and methods}

\section{QML selection and identification of candidate genes}

All the molecular markers mapped onto the selected genomic regions (BINs: 1J, 2F, 4E, 4I, 5D/E/F, 7B, 7F, 7H, 9B/D/E, 9J, $10 \mathrm{~B}, 11 \mathrm{C})$, selected on the basis of the data presented in Schauer et al. (2006), were obtained from the Solanaceae Genomic Network (http://www.sgn.cornell.edu/). Marker sequences were compared by WU-BLAST algorithm (http://blast.wustl.edu) to the NCBI protein database (http://www.ncbi.nlm.nih.gov/). The pipeline designed for selection and analysis of candidate genes is shown in Fig. 1. The functions of selected gene products within metabolic pathways were predicted by mapping them using the KEGG database (http:// www.genome.jp/kegg/; Kanehisa et al., 2008).

\section{Plant material and DNA extraction}

Seeds from 75 independent ILs, were kindly provided by CM Rick, Tomato Genetics Resource Center (TGRC). This resource is composed of a tomato variety, Solanum lycopersicum (inbred variety M82, Acc LA3475), which includes single introgressed genomic regions from the wild green-fruited species Solanum pennellii (LA716). Amongst the ILs there is a complete coverage of the wildspecies genome. The ILs have been produced through successive introgression backcrossing and marker-assisted selection to generate a set of recurrent parent lines with single introgressed segments (Eshed and Zamir, 1995). Plants were grown in a greenhouse and DNA extraction was performed from fresh leaf material following the method described by Hoisington et al. (1994). 


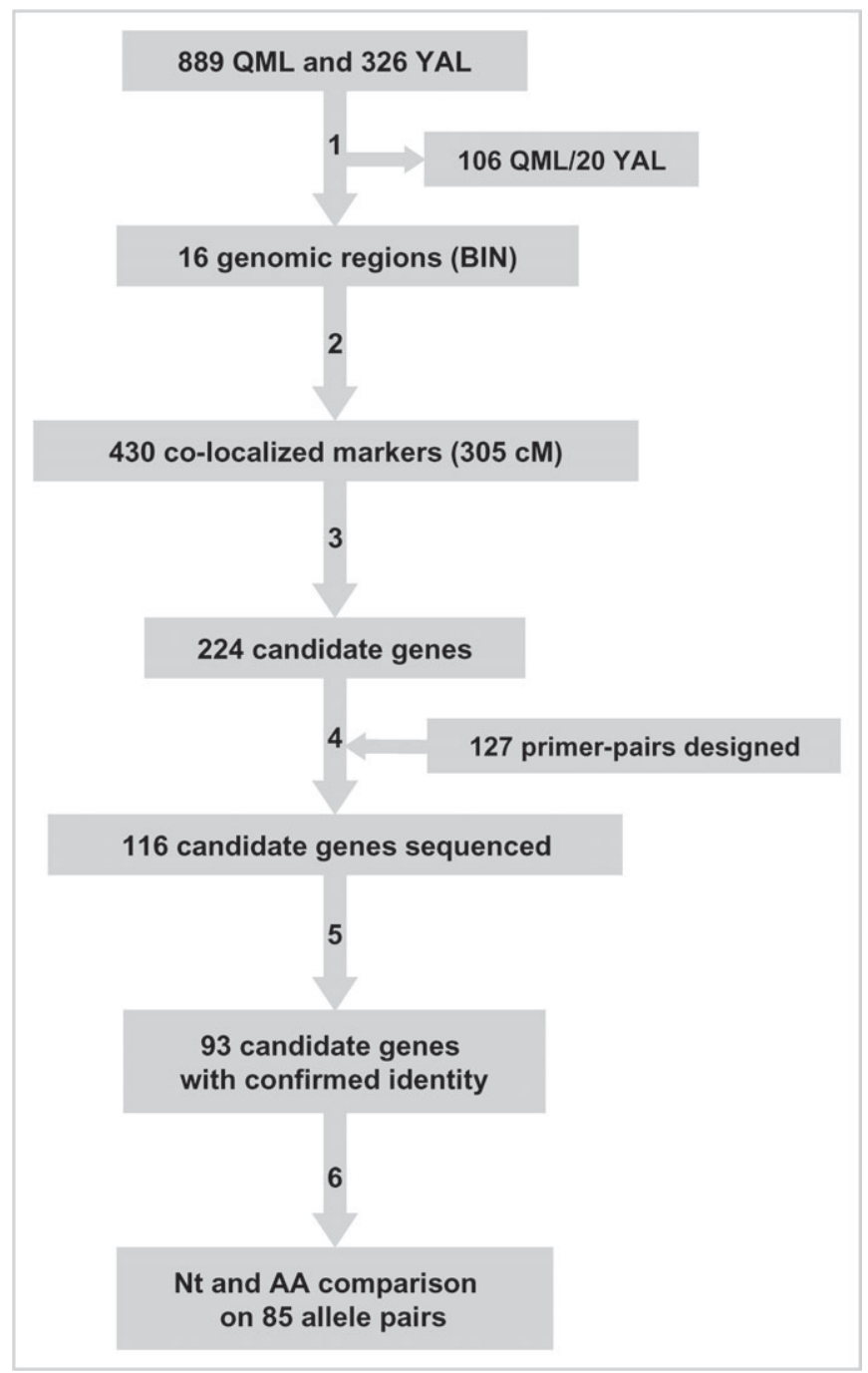

Fig. 1. QML selection and candidate genes identification pipeline. Schematic representation of the process designed to identify candidate genes co-localizing with previously detected QML onto tomato genomic regions. (1) At least 2-fold variation in metabolite content relative to $S$. lycopersicum and precise genome localization by at least two overlapped introgressed regions. (2) Retrieval of all mapped markers onto the selected genomic regions from the comparison between the Tomato-EXPEN2000, the Tomato-EXPEN1992, and the Tomato IL map by using the comparative map web interface from SGN (Mueller et al., 2008). (3) Sequence analysis by comparison with NCBI protein data base by using the Blastx algorithm. (4) Selection of complete Solanum cDNA sequences deposited onto SGN data repository or NCBI for primer design. PCR amplification and cloning from S. lycopersicum (M82 cultivar) and from the corresponding IL. End-sequencing of three independent clones from each genotype. (5) Sequence quality trimming and identity evaluation against the sequence used for primer design. (6) Identification of exons and introns by alignment with the corresponding sequence used for primer design. Allele comparison by identification of nucleotide and amino-acid polymorphisms. Output results from these analyses can be downloaded from URL: http://gracilaria.ib.usp.br/services/tomato/index.html.

\section{Candidate gene amplification and cloning}

Primers were designed with the Vector NTI 10.0 software package (Invitrogen) based on the unigene sequences available at the SGN (www.sgn.cornell.edu) or NCBI cDNA accessions (http://www. ncbi.nlm.nih.gov/) (Table S2 in Supplementary data available at $J X B$ online). Candidate genes were amplified by PCR using Elongase $^{\circledR}$ DNA polymerase (Invitrogen). The PCR reactions were performed using $0.2 \mathrm{mM}$ of each dNTPs, $0.2 \mathrm{mM}$ of each primer, $1.5 \mathrm{mM}$ of $\mathrm{MgSO}_{4}, 100 \mathrm{ng}$ of genomic DNA, and 2 units of enzyme. The PCR programme was $94{ }^{\circ} \mathrm{C}$ for $3 \mathrm{~min} ; 35$ cycles of $94{ }^{\circ} \mathrm{C}$ for $30 \mathrm{~s}$, primer-specific annealing temperature for $30 \mathrm{~s}$, $68{ }^{\circ} \mathrm{C}$ for $4 \mathrm{~min}$; and a final period of $68{ }^{\circ} \mathrm{C}$ for $10 \mathrm{~min}$. Amplification products were purified with GFX purification Kit (Amersham Biosciences) and cloned using the pMOSBlue blunt-ended cloning kit (Amersham Biosciences), following the manufacturer's instructions. Clones were end sequenced using vector universal primers, and reactions were read either with an ABI3700 or ABI3100 (Applied Biosystems).

\section{Sequence and co-expression analyses}

Vector sequences were trimmed using the VecScreen (www.ncbi.nlm.nih.gov/VecScreen/VecScreen.htm) software at the NCBI (www.ncbi.nlm.nih.gov). After quality trimming, all accepted sequences reached a Phred value $\geqslant 20$ (Gordon et al., 1998). Intron/ exon prediction was performed by comparing the $S$. pennelli or $S$. lycopersicum sequences obtained with the corresponding unigene or marker sequence from SGN (www.sgn.cornell.edu), or NCBI cDNA accessions (http://www.ncbi.nlm.nih.gov/) using the Blast2 Sequences algorithm (Tatusova and Madden, 1999). Polymorphisms were detected at nucleotide and amino acid levels aligning $S$. pennellii and $S$. lycopersicum sequenced alleles (excluding primer regions) using the MULTALIN program (http://wwwarchbac.u-psud.fr/genomics/multalin.html; Corpet, 1988). The nucleotide diversity, which estimates the average number of substitutions between any two sequences, was determined using the software DNAsp version 4.10.9 (Rozas et al., 2003). The rate of synonymous and non-synonymous substitutions was determined using Nei and Gojobori's method (Nei and Gojobori, 1986) with the Jukes-Cantor correction, calculated using the MEGA 2.1 software (Kumar et al., 2001). Codon-based tests of selection (Fisher's exact test) were performed using the same software.

Developmental microarray expression data and metabolite data had been previously described in Carrari et al. (2006). In that study a combined analysis of metabolite and gene expression profiles from tomato fruits harvested through development and ripening stages $(10,15,20,21,35,49,56$, and $70 \mathrm{~d}$ after anthesis) was carried out. Although, the previous study reported extensive correlation analysis, this was performed in a targeted manner and did not include the candidate genes identified in the current study. For this reason, the expression data from 56 candidate genes, out of the 127 selected, which were spotted on the TOM1 microarray were correlated against the metabolite data of 66 metabolites determined in the ILs, using the Spearman algorithm (Urbanczyk-Wockniak et al., 2003).

\section{Results and discussion}

\section{QML selection and identification of candidate genes}

As a starting point for this study, we relied on the recent identification of 889 fruit metabolic loci (QML) and 326 yield-associated loci (YAL) in the $S$. pennellii IL population (Schauer et al., 2006). In order to select QML and identify candidate genes putatively responsible for those metabolite variations, a pipeline was established (Fig. 1). Out of those QML, 106 were selected based on the following criteria: they exhibited (i) at least 2-fold 
variation in metabolite content relative to M82 variety of S. lycopersicum and (ii) a clear chromosomal position using the BIN mapping method. The selected QML were localized on 16 BINs $(1 \mathrm{~J}, 2 \mathrm{~F}, 4 \mathrm{E}, 4 \mathrm{I}, 5 \mathrm{D}, 5 \mathrm{E}, 5 \mathrm{~F}, 7 \mathrm{~B}, 7 \mathrm{~F}$, $7 \mathrm{H}, 9 \mathrm{~B}, 9 \mathrm{D}, 9 \mathrm{E}, 9 \mathrm{~J}, 10 \mathrm{~B}, 11 \mathrm{C}$ ) across 8 of the 12 tomato chromosomes and comprised 52 different metabolites and nine different yield-associated traits. In addition, some QML for a range of traits were selected despite the fact that they did not fulfil the second criterion. Specifically, citrate, palmitate, stearate, fructose, GABA ( $\gamma$-aminobutyric acid), glycine, tyrosine, and threonate QML (mapped onto chromosome 5), and phosphate and dehydroascorbate QML (mapped onto chromosome 9) could not be unambiguously defined to any of the BINs of these chromosomes. In these instances, candidate genes were grouped within BINs $5 \mathrm{D} / \mathrm{E} / \mathrm{F}$ and $9 \mathrm{~B} / \mathrm{D} / \mathrm{E}$ for chromosomes 5 and 9, respectively (see Figs 3 and 4 and Table S1 in Supplementary data available at $J X B$ online).

The selected regions carry a total of 430 mapped molecular markers present on the Tomato-EXPEN 2000 and Tomato-EXPEN 1992 maps (S. lycopersicum LA925 $\times$ S. pennellii LA716) (http://www.sgn.cornell.edu/) spanning $305 \mathrm{cM}$. Sequences of the 430 available molecular markers, as well as previously described genes and cDNAs (Ganal et al., 1998; Causse et al., 2004; Zou et al., 2006), mapping onto the 16 selected genome regions were compared with the NCBI protein database. This survey resulted in a catalogue of 224 candidate genes (not shown) that presented sequence homology to pre- viously characterized expressed sequences (reference proteins), whose functions have been experimentally demonstrated and could be involved in the observed metabolic changes. Out of these 224 putative genes, for 127 genes, it was possible to identify complete Solanum cDNA sequences (unigenes or markers from the Solanaceae Genome Network, or NCBI accessions) and to design primers that facilitated genomic-based PCR of a significant portion of the coding regions. Detailed information of these 127 candidates as well as the entire dataset of all 16 genomic regions studied is provided in Table $\mathrm{S} 1$ in Supplementary data available at $J X B$ online. Identity between the Solanum cDNA sequences and the reference proteins varied between $32 \%$ and $100 \%$.

The 127 candidate genes were positioned with respect to metabolic pathways (using the KEGG database) where their products are predicted to be involved, to visualize better their putative contributions to the described QML. Figures 2-5 provide an overview of the central metabolic pathways where each colour represents a selected genomic region, or BIN, with its corresponding QML and the candidate genes. For each gene, results of the amplification, cloning, and allele mining are also indicated. These genes were grouped, according to putative function, into six categories: carbon and nitrogen metabolism, transport, photosynthesis and oxidative phosphorylation, protein processing and degradation, DNA/RNA-protein metabolism, and signalling and regulation. The most abundant gene category was carbon and nitrogen metabolism (59\%). This observation is
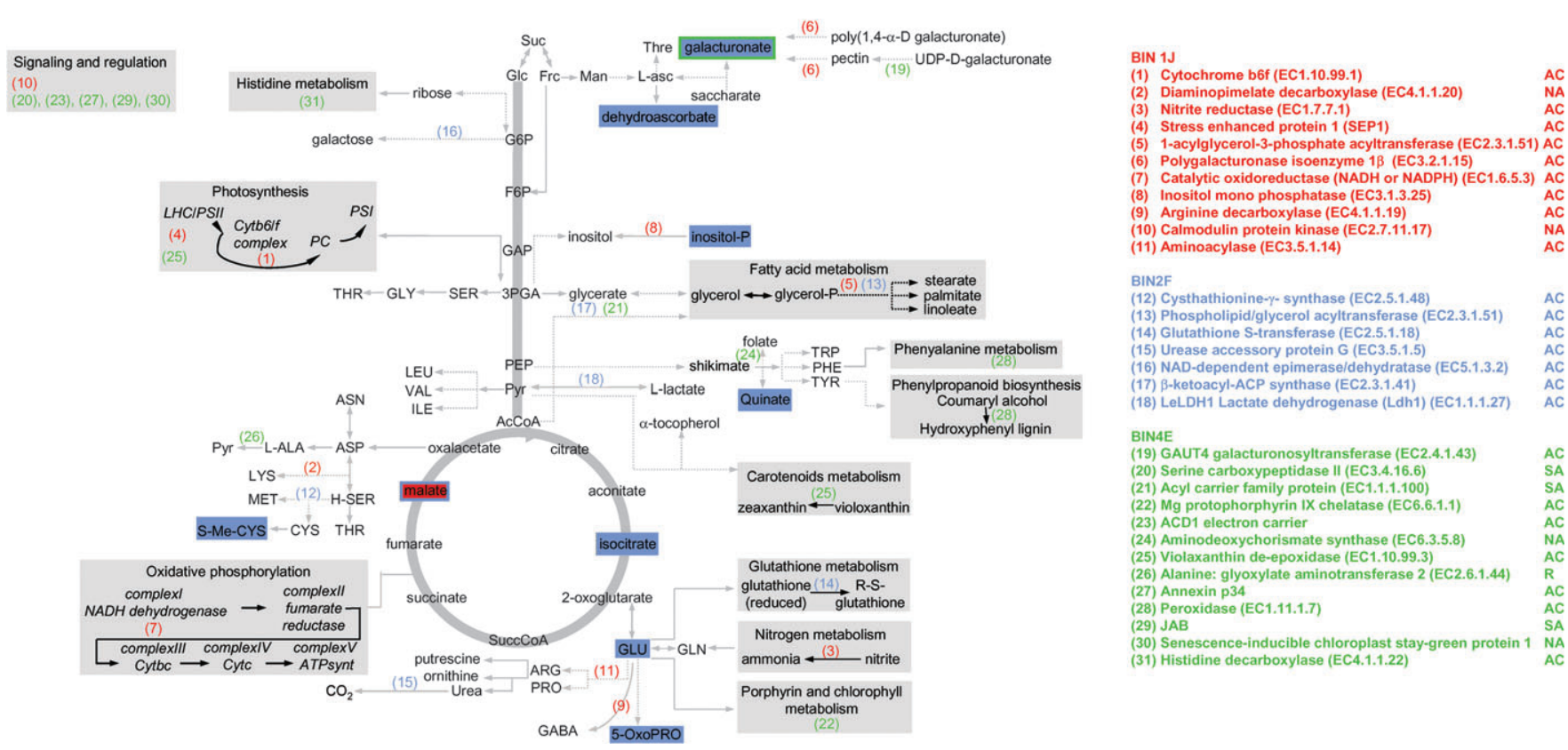

Fig. 2. Metabolic role of candidate genes in BINs 1J, 2F, and 4E. BINs are identified by colours. Candidate genes are identified by numbers and both metabolites and genes are highlighted in the corresponding BIN colour. The KEGG Accession Map Code and the results of the amplification, cloning, and allele mining are also indicated. NA, No amplification product; SA, spurious amplification product; R, sequence rearrangements; AC, alleles comparison (Table 1). 

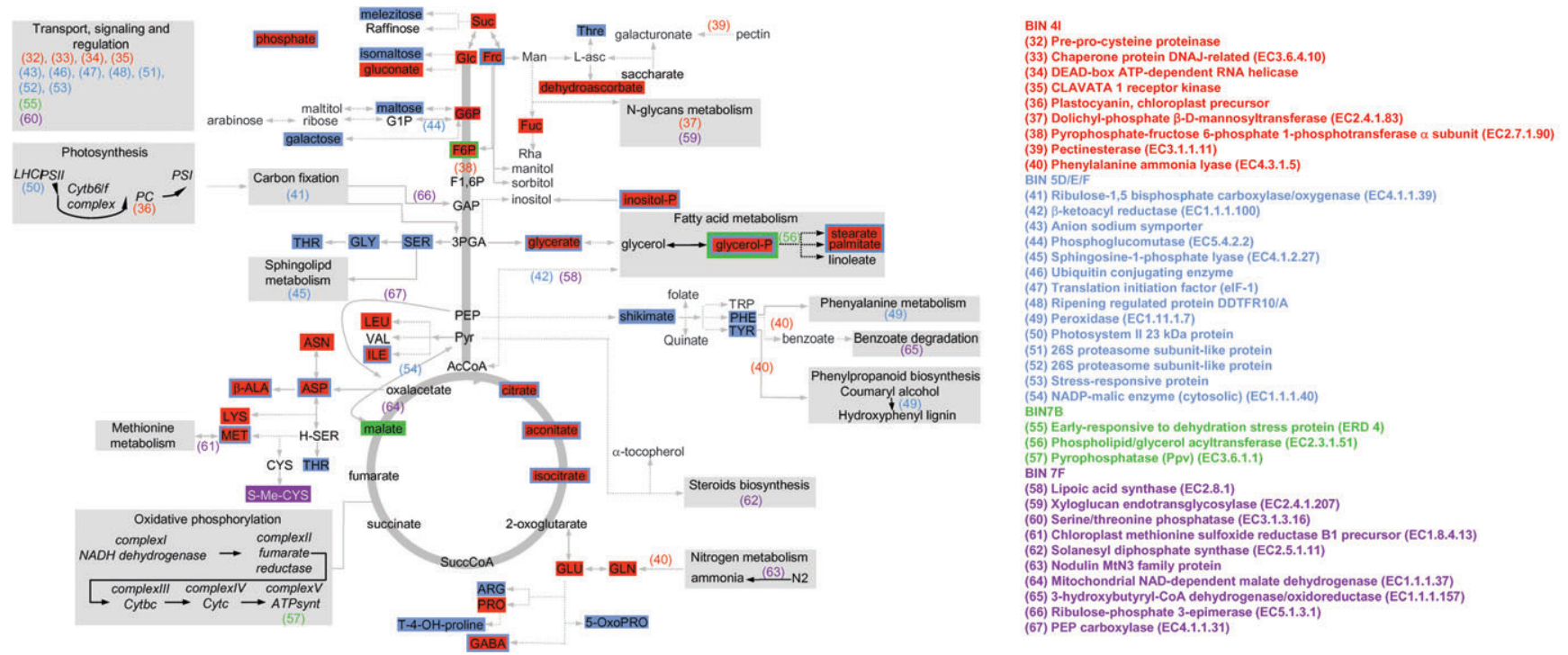

Fig. 3. Metabolic role of candidate genes in BINs 4I, 5D/E/F, 7B, and 7F. BINs are identified by colours. Candidate genes are identified by numbers and both metabolites and genes are highlighted in the corresponding BIN colour. The KEGG Accession Map Code and the results of the amplification, cloning, and allele mining are also indicated. NA, No amplification product; SA, spurious amplification product; R, sequence rearrangements; $\mathrm{AC}$, alleles comparison (Table 1).

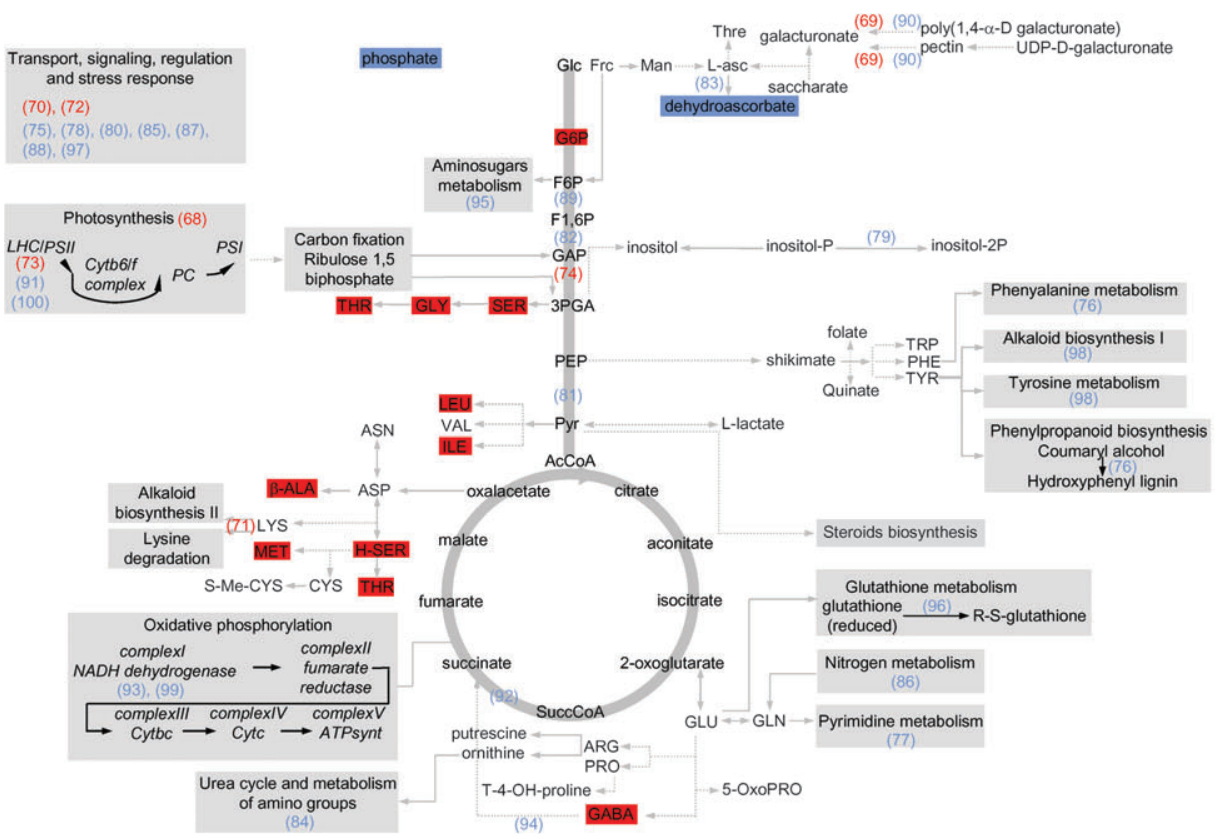

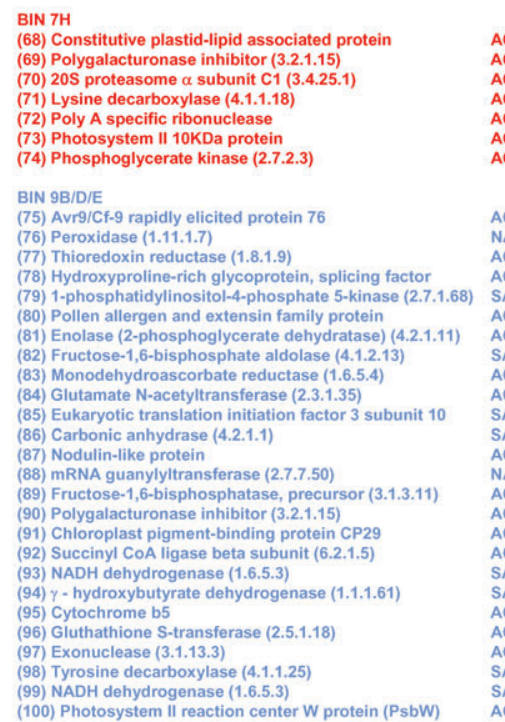

(100) Photosystem II reaction center W protein (PsbW)

Fig. 4. Metabolic role of candidate genes in BINs $7 \mathrm{H}$ and $9 \mathrm{~B} / \mathrm{D} / \mathrm{E}$. BINs are identified by colours. Candidate genes are identified by numbers and both metabolites and genes are highlighted in the corresponding BIN colour. The KEGG Accession Map Code and the results of the amplification, cloning, and allele mining are also indicated. NA, No amplification product; SA, spurious amplification product; AC, alleles comparison (Table 1).

somehow predictable since regulatory factors control entire carbon and nitrogen metabolic networks. In the same way, transport effectors re-distribute products of those metabolic pathways. Within carbon and nitrogen metabolism, 23\% corresponds to genes involved in amino acid metabolism and $24 \%$ to those implicated on central carbon metabolism. Only three candidates are genes related to nitrogen metabolism and the rest, 49\%, distributed along different secondary pathways.

\section{Candidate gene cloning and allele mining}

Even though the candidature of some of the 127 identified genes is questionable in terms of the control they exert on the selected QML, given that metabolic variation within 

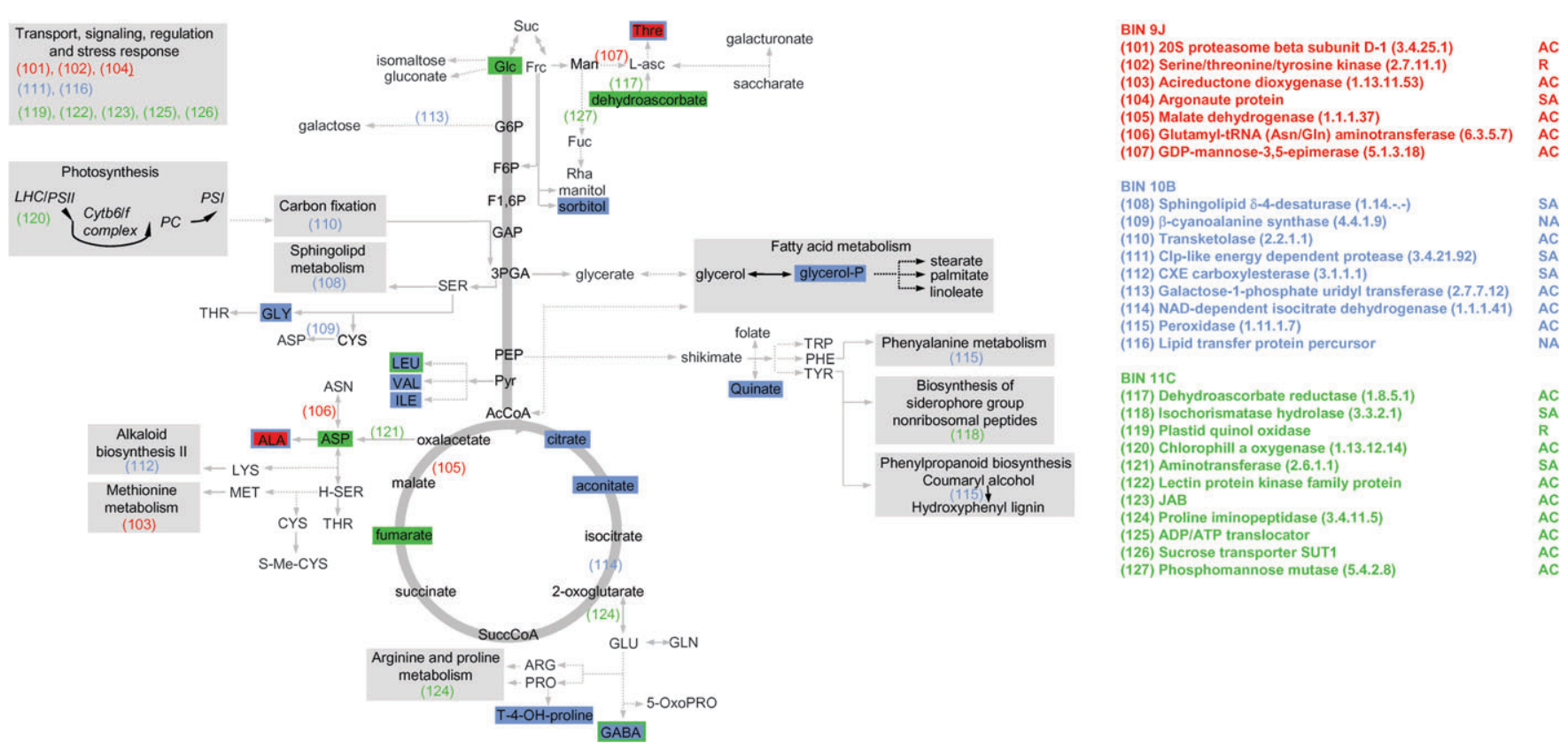

Fig. 5. Metabolic role of candidate genes in BINs 9J, 10B, and 11C. BINs are identified by colours. Candidate genes are identified by numbers and both metabolites and genes are highlighted in the corresponding BIN colour. The KEGG Accession Map Code and the results of the amplification, cloning and allele mining are also indicated. NA, No amplification product; SA, spurious amplification product; R, sequence rearrangements; AC, alleles comparison (Table 1).

the ILs is likely to arise from the $S$. pennellii introgressed genomic fragments, the comparative analysis of both alleles adds valuable information about polymorphisms between S. lycopersicum and S. pennellii. For this reason, a pair of primers was designed for each of the 127 candidate genes to amplify the alleles from the M82 variety and the corresponding IL (Table S2 in Supplementary data available at $J X B$ online). PCR products were obtained for 116 pairs of alleles, with the remaining 11 genes being recalcitrant for amplification (Fig. 1). It is conceivable that the absence of amplification products of these alleles might be indicative of allele polymorphism, resulting in dominant molecular markers; however, this conclusion cannot be drawn from the present study alone. Larger genomic rearrangements also need to be considered in the chromosomal region encompassing the allele position.

The cloning and end-sequencing of three independent clones of each allele, enabled the confirmation of the identities of 93 pairs, while for 23 either one or both alleles did not present detectable homology to the sequence used for primer design and were considered as spurious amplification. Out of these 93 pairs, eight pairs were considered as possible rearrangements because, even when both alleles presented homology to the corresponding reference sequence, they did not overlap each other. After quality trimming, 85 pairs of genes were in silico spliced and translated, and the nucleotide and amino acid sequences of both alleles were compared (Table 1).
In order to provide the full information of these sequences together with the derived analyses, a database was created that can be accessed via a web interface (http://gracilaria.ib.usp.br/services/tomato/ILs.html). This resource allows both sequences and raw chromatograms, as well as the analyses of the results discussed in this paper, to be downloaded.

A total of 17857 intron and 27959 exon bases from S. lycopersicum and 17974 intron and 27813 exon bases from $S$. pennellii were sequenced. In silico translation of these sequences resulted in 9229 and 8994 protein amino acids from S. lycopersicum and S. pennellii, respectively. Out of those numbers, 15261 intron bases, 23716 exon bases, and 8007 protein amino acids overlap between both genotypes. The comparison between these overlapping regions revealed some interesting observations. The overall nucleotide polymorphism frequency was $4 \%$, with an expected statistically significant greater variation in introns (7\%) than in exons (1\%) (Fisher's exact test $P<0.05)$. Most of the detected modifications corresponded to single nucleotide polymorphisms. INDELs (insertion/deletion) were found in 27 of the genes fragments analysed and almost all were located within intron regions (25 out of 27). Exon fragments were obtained and analysed for 81 out of the 85 genes amplified. From those, 56 contained nucleotide polymorphisms and 37 of these resulted in an amino acid change. Within each pair of alleles, a comparison between the ratio of non-synonymous $\left(K_{\mathrm{a}}\right)$ and synonymous $\left(K_{\mathrm{s}}\right)$ substitutions showed 
Table 1. Allele analysis of candidate genes from S. lycopersicum (Lyc) and S. pennellii (Pen)

\begin{tabular}{|c|c|c|c|c|c|c|}
\hline $\begin{array}{l}\text { Marker } \\
\text { (unigene) }^{a}\end{array}$ & $\begin{array}{l}\text { Size (b) } \\
\text { exon/intron }\end{array}$ & $\begin{array}{l}\text { Nucleotide } \\
\text { polymorphism } \\
\text { (exon) }^{c}\end{array}$ & $\begin{array}{l}\text { Nucleotide } \\
\text { polymorphism } \\
\text { (intron) }^{d}\end{array}$ & $\begin{array}{l}\text { Amino } \\
\text { acid } \\
\text { coverage }^{e}\end{array}$ & $\begin{array}{l}\text { Analysed } \\
\text { fragment }^{f}\end{array}$ & $\begin{array}{l}\text { Amino } \\
\text { acid } \\
\text { polymorphism }^{g}\end{array}$ \\
\hline $\begin{array}{l}\text { (1) T0646 } \\
\text { (U316058) }\end{array}$ & $\begin{array}{l}\text { Lyc: } 356 /- \\
\text { Pen: } 356 /-\end{array}$ & $4 / 313$ & - & $118 / 123$ & $5-122$ & $\begin{array}{l}\mathrm{T}_{17} \rightarrow \mathrm{I} \\
\mathrm{T}_{29} \rightarrow \mathrm{P} \\
\mathrm{K}_{70} \rightarrow \mathrm{R}\end{array}$ \\
\hline $\begin{array}{l}\text { (3) } \mathrm{T} 1006 \\
(\mathrm{U} 317524)\end{array}$ & Lyc: 626/- & $5 / 605$ & - & $208 / 584$ & $376-583$ & $\mathrm{E}_{531} \rightarrow \mathrm{G}$ \\
\hline $\begin{array}{l}\text { (U317524) } \\
\text { (4) C2_At4g34190 } \\
\text { (U216629) }\end{array}$ & $\begin{array}{l}\text { Pen: } 734 /- \\
\text { Lyc: } 136 / 172 \\
\text { Pen: } 93 / 467\end{array}$ & $1 / 93$ & $6 / 128$ & $31 / 141$ & $16-46$ & $\begin{array}{l}\mathrm{V}_{569} \rightarrow \mathrm{I} \\
\mathrm{T}_{32} \rightarrow \mathrm{P}\end{array}$ \\
\hline $\begin{array}{l}\text { (5) CLET-1-A11 } \\
\text { (U324336) }\end{array}$ & $\begin{array}{l}\text { Lyc: } 512 /- \\
\text { Pen: } 512 /-\end{array}$ & $1 / 469$ & - & $170 / 186$ & $12-181$ & $\mathrm{I}_{24} \rightarrow \mathrm{M}$ \\
\hline $\begin{array}{l}\text { (6) T1782 } \\
\text { (U319301) }\end{array}$ & $\begin{array}{l}\text { Lyc: } 714 / 47 \\
\text { Pen: } 585 / 68\end{array}$ & $9 / 585$ & $2 / 47$ & $194 / 405$ & 16-209 & $\begin{array}{l}\mathrm{L}_{92} \rightarrow \mathrm{H} \\
\mathrm{S}_{133} \rightarrow \mathrm{N} \\
\mathrm{E}_{151} \rightarrow \mathrm{G} \\
\mathrm{Q}_{157} \rightarrow \mathrm{R} \\
\mathrm{A}_{161} \rightarrow \mathrm{E} \\
\mathrm{N}_{185} \rightarrow \mathrm{D}\end{array}$ \\
\hline $\begin{array}{l}\text { (7) C2_At4g34700 } \\
\text { (U216646) }\end{array}$ & $\begin{array}{l}\text { Lyc: } 196 / 355 \\
\text { Pen: } 264 / 315\end{array}$ & $1 / 196$ & $20 / 320$ & $58 / 119$ & $1-58$ & - \\
\hline $\begin{array}{l}\text { (8) T1749 } \\
\text { (U326864) }\end{array}$ & $\begin{array}{l}\text { Lyc: } 72 / 448 \\
\text { Pen: } 72 / 278\end{array}$ & $0 / 49$ & $0 / 278$ & $24 / 180$ & $3-26$ & \\
\hline $\begin{array}{l}\text { (9) T1368 } \\
\text { (U312881) }\end{array}$ & $\begin{array}{l}\text { Lyc:459/- } \\
\text { Pen:742/- }\end{array}$ & $5 / 437$ & - & $153 / 707$ & $1-153$ & - \\
\hline $\begin{array}{l}\text { (11) T1306 } \\
\text { (U319133) }\end{array}$ & $\begin{array}{l}\text { Lyc: } 749 /- \\
\text { Pen: } 614 /-\end{array}$ & $3 / 609$ & - & $202 / 448$ & $36-237$ & $\mathrm{~F}_{186} \rightarrow \mathrm{L}$ \\
\hline $\begin{array}{l}\text { (12) T0869 } \\
(\text { AY508112 }\end{array}$ & $\begin{array}{l}\text { Lyc: } 335 / 300 \\
\text { Pen: } 335 / 293\end{array}$ & $8 / 311$ & $27 / 294$ & $111 / 540$ & $429-539$ & $\mathrm{P}_{483} \rightarrow \mathrm{S}$ \\
\hline $\begin{array}{l}\text { (13) T1768 } \\
\text { (U321585) }\end{array}$ & $\begin{array}{l}\text { Lyc: } 291 / 234 \\
\text { Pen: } 291 / 352\end{array}$ & $0 / 267$ & $7 / 234$ & $96 / 189$ & $93-188$ & - \\
\hline $\begin{array}{l}\text { (14) T1698 } \\
\text { (U315881) }\end{array}$ & $\begin{array}{l}\text { Lyc: 560/173 } \\
\text { Pen: } 523 / 173\end{array}$ & $4 / 504$ & $7 / 173$ & $174 / 367$ & $32-217$ & $\begin{array}{l}\mathrm{A}_{50} \rightarrow \mathrm{S} \\
\mathrm{V}_{107} \rightarrow \mathrm{I} \\
\end{array}$ \\
\hline $\begin{array}{l}\text { (15) C2_At2g34470 } \\
\text { (U219076) }\end{array}$ & $\begin{array}{l}\text { Lyc: } 190 /- \\
\text { Pen: } 179 /-\end{array}$ & $1 / 179$ & - & $59 / 277$ & $25-83$ & $\mathrm{I}_{118} \rightarrow \mathrm{M}$ \\
\hline $\begin{array}{l}\text { (16) T1516 } \\
\text { (U317147) }\end{array}$ & $\begin{array}{l}\text { Lyc: } 149 / 581 \\
\text { Pen: } 150 / 549\end{array}$ & $0 / 149$ & $19 / 550$ & $49 / 252$ & $20-68$ & - \\
\hline (17) cTOB-9-H18U315474 & $\begin{array}{l}\text { Lyc:349/276 } \\
\text { Pen:441/137 }\end{array}$ & $0 / 349$ & $0 / 137$ & $116 / 469$ & $36-151$ & - \\
\hline (18) TC128325U326680 & $\begin{array}{l}\text { Lyc: } 459 /- \\
\text { Pen: } 534 / 39\end{array}$ & $0 / 459$ & - & $153 / 350$ & $35-187$ & - \\
\hline $\begin{array}{l}\text { (19) T0891 } \\
\text { (U320717) }\end{array}$ & $\begin{array}{l}\text { Lyc:290/35 } \\
\text { Pen:303/267 }\end{array}$ & $0 / 278$ & $1 / 35$ & $95 / 679$ & $585-679$ & - \\
\hline $\begin{array}{l}\text { (22) T0635 } \\
\text { (U313864) }\end{array}$ & $\begin{array}{l}\text { Lyc: 618/- } \\
\text { Pen: } 746 /-\end{array}$ & $4 / 532$ & - & $177 / 722$ & $31-207$ & - \\
\hline $\begin{array}{l}\text { (23) T1054 } \\
\text { (U319327) }\end{array}$ & $\begin{array}{l}\text { Lyc: } 512 / 75 \\
\text { Pen: } 409 / 109\end{array}$ & $1 / 409$ & $0 / 75$ & $135 / 222$ & $41-175$ & $\mathrm{H}_{85} \rightarrow \mathrm{Y}$ \\
\hline $\begin{array}{l}\text { (25) T1317 } \\
\left(\mathrm{AK} 247081^{h}\right)\end{array}$ & $\begin{array}{l}\text { Lyc: } 465 / 131 \\
\text { Pen: } 465 / 131\end{array}$ & $5 / 445$ & $2 / 131$ & $149 / 478$ & $1-149$ & $\begin{array}{l}\mathrm{H}_{27} \rightarrow \mathrm{Q} \\
\mathrm{F}_{30} \rightarrow \mathrm{Y}\end{array}$ \\
\hline $\begin{array}{l}\text { (27) C2_At1g35720 } \\
\text { (U314161) }\end{array}$ & $\begin{array}{l}\text { Lyc: } 465 / 142 \\
\text { Pen: } 505 / 248\end{array}$ & $5 / 465$ & $143 / 248$ & $154 / 316$ & $148-301$ & $\begin{array}{l}\mathrm{K}_{256} \rightarrow^{h} \\
\mathrm{~N}_{288} \rightarrow \mathrm{S}\end{array}$ \\
\hline $\begin{array}{l}(28) \mathrm{T} 1719 \mathrm{~A} \\
\left(\mathrm{~L} 1365^{h}\right)\end{array}$ & $\begin{array}{l}\text { Lyc: } 567 / 152 \\
\text { Pen: } 561 / 158\end{array}$ & $24 / 537$ & $47 / 169$ & $187 / 329$ & 5-191 & $\begin{array}{l}\mathrm{C}_{14} \rightarrow \mathrm{Y} \\
\mathrm{V}_{17} \rightarrow \mathrm{L} \\
\mathrm{A}_{20} \rightarrow \mathrm{V} \\
\mathrm{I}_{51} \rightarrow \mathrm{V} \\
\mathrm{N}_{53} \rightarrow \mathrm{K} \\
\mathrm{A}_{59} \rightarrow \mathrm{P} \\
\mathrm{S}_{85} \rightarrow \mathrm{R} \\
\mathrm{V}_{113} \rightarrow \mathrm{L}\end{array}$ \\
\hline \multirow{2}{*}{$\begin{array}{l}\text { (31) T0883 } \\
\text { (U313818) }\end{array}$} & Lyc: $540 / 70$ & $31 / 540$ & $0 / 27$ & $179 / 413$ & $228-406$ & $\mathrm{~S}_{249} \rightarrow \mathrm{P}$ \\
\hline & Pen: 556/27 & & & & & $\begin{array}{l}\mathrm{G}_{251} \rightarrow \mathrm{D} \\
\mathrm{V}_{252} \rightarrow \mathrm{I} \\
\mathrm{R}_{257} \rightarrow \mathrm{K} \\
\mathrm{S}_{258} \rightarrow \mathrm{T} \\
\mathrm{L}_{263} \rightarrow \mathrm{H} \\
\mathrm{A}_{272} \rightarrow \mathrm{T} \\
\mathrm{L}_{292} \rightarrow \mathrm{I} \\
\mathrm{T}_{333} \rightarrow \mathrm{S}\end{array}$ \\
\hline
\end{tabular}


Table 1. Continued

\begin{tabular}{|c|c|c|c|c|c|c|}
\hline $\begin{array}{l}\text { Marker } \\
\text { (unigene) }^{a}\end{array}$ & $\begin{array}{l}\text { Size (b) } \\
\text { exon/intron }\end{array}$ & $\begin{array}{l}\text { Nucleotide } \\
\text { polymorphism } \\
\left(\text { exon) }{ }^{c}\right.\end{array}$ & $\begin{array}{l}\text { Nucleotide } \\
\text { polymorphism } \\
\text { (intron) }^{d}\end{array}$ & $\begin{array}{l}\text { Amino } \\
\text { acid } \\
\text { coverage }^{e}\end{array}$ & $\begin{array}{l}\text { Analysed } \\
\text { fragment }^{f}\end{array}$ & $\begin{array}{l}\text { Amino } \\
\text { acid } \\
\text { polymorphism }^{g}\end{array}$ \\
\hline & & & & & & $\begin{array}{l}\mathrm{R}_{346} \rightarrow \mathrm{H} \\
\mathrm{I}_{361} \rightarrow \mathrm{V} \\
\mathrm{N}_{382} \rightarrow \mathrm{K} \\
\mathrm{Y}_{383} \rightarrow- \\
\mathrm{K}_{384} \rightarrow \mathrm{R} \\
\mathrm{Y}_{386} \rightarrow \mathrm{F} \\
\mathrm{D}_{388} \rightarrow \mathrm{Y} \\
\mathrm{V}_{389} \rightarrow \mathrm{G} \\
\mathrm{A}_{391} \rightarrow \mathrm{T} \\
\mathrm{L}_{392} \rightarrow \mathrm{Q}\end{array}$ \\
\hline $\begin{array}{l}\text { (33) T0739 } \\
\text { (U321142) }\end{array}$ & $\begin{array}{l}\text { Lyc: } 140 / 393 \\
\text { Pen:140/424 }\end{array}$ & $1 / 118$ & $27 / 403$ & $44 / 146$ & $4-47$ & $\mathrm{~K}_{11} \rightarrow \mathrm{R}$ \\
\hline $\begin{array}{l}\text { (35) cLEW-8-J19 } \\
\text { (U324703) }\end{array}$ & $\begin{array}{l}\text { Lyc: } 431 / 170 \\
\text { Pen: } 431 / 140\end{array}$ & $4 / 412$ & $13 / 151$ & $121 / 285$ & $165-285$ & $\mathrm{~V}_{241} \rightarrow \mathrm{I}$ \\
\hline $\begin{array}{l}\text { (36) cLET-5-D13 } \\
\text { (U312690) }\end{array}$ & $\begin{array}{l}\text { Lyc:427/- } \\
\text { Pen: } 379 /-\end{array}$ & $3 / 379$ & - & $124 / 170$ & $35-158$ & - \\
\hline $\begin{array}{l}\text { (40) LED50 } \\
\left(\operatorname{LED} 50^{h}\right)\end{array}$ & $\begin{array}{l}\text { Lyc: 728/- } \\
\text { Pen: 632/- }\end{array}$ & $0 / 611$ & - & $210 / 704$ & $485-694$ & - \\
\hline $\begin{array}{l}\text { (41) T0778 } \\
\text { (U317221) }\end{array}$ & $\begin{array}{l}\text { Lyc: } 411 / 209 \\
\text { Pen: } 467 / 54\end{array}$ & $0 / 383$ & $0 / 54$ & $127 / 488$ & $33-159$ & - \\
\hline $\begin{array}{l}\text { (42) T1174 } \\
\text { (U321882) }\end{array}$ & $\begin{array}{l}\text { Lyc: } 536 / 18 \\
\text { Pen: 208/- }\end{array}$ & $0 / 208$ & - & $69 / 234$ & $12-80$ & - \\
\hline $\begin{array}{l}\text { (43) T0328 } \\
\text { (U315874) }\end{array}$ & $\begin{array}{l}\text { Lyc: } 118 / 6 \\
\text { Pen: } 241 / 157\end{array}$ & $0 / 93$ & $0 / 6$ & $39 / 407$ & $2-40$ & - \\
\hline $\begin{array}{l}\text { (44) T1601 } \\
\text { (U333333) }\end{array}$ & $\begin{array}{l}\text { Lyc: } 473 / 25 \\
\text { Pen: } 473 / 41\end{array}$ & $4 / 451$ & $0 / 25$ & $157 / 191$ & $17-173$ & $\begin{array}{l}\mathrm{S}_{50} \rightarrow \mathrm{G} \\
\mathrm{T}_{96} \rightarrow \mathrm{A}\end{array}$ \\
\hline (47) cTOS-7-03 & Lyc: $175 / 446$ & $3 / 148$ & $90 / 354$ & $58 / 145$ & $85-142$ & $\begin{array}{l}\mathrm{R}_{108} \rightarrow \mathrm{G} \\
\mathrm{V}_{124} \rightarrow \mathrm{D}\end{array}$ \\
\hline (U314198) & Pen: $175 / 300$ & & & & & \\
\hline $\begin{array}{l}\text { (48) cLEX-13-G5 } \\
\text { (U315595) }\end{array}$ & $\begin{array}{l}\text { Lyc: } 588 /- \\
\text { Pen: } 710 /-\end{array}$ & $1 / 316$ & - & $105 / 314$ & 104-208 & $\mathrm{M}_{194} \rightarrow \mathrm{V}$ \\
\hline $\begin{array}{l}\text { (50) T0837 } \\
\text { (U312572) }\end{array}$ & $\begin{array}{l}\text { Lyc: } 404 / 134 \\
\text { Pen: } 124 / 39\end{array}$ & $0 / 124$ & $0 / 39$ & $41 / 258$ & $37-77$ & - \\
\hline $\begin{array}{l}\text { (53) C2_At3g17210 } \\
\text { (U214933) }\end{array}$ & $\begin{array}{l}\text { Lyc: } 142 / 294 \\
\text { Pen: } 142 / 410\end{array}$ & $6 / 122$ & $18 / 302$ & $47 / 106$ & $2-48$ & $\mathrm{E}_{18} \rightarrow \mathrm{K}$ \\
\hline (54) cLES-1-A11 & Lyc: $459 / 350$ & $4 / 432$ & $13 / 352$ & $141 / 579$ & $438-578$ & $\mathrm{~V}_{503} \rightarrow \mathrm{M}$ \\
\hline $\begin{array}{l}\text { (U312789) } \\
\text { (55) T1355 }\end{array}$ & Pen: $432 / 352$ & & & & & \\
\hline $\begin{array}{l}\text { (55) T1355 } \\
\text { (U323609) }\end{array}$ & $\begin{array}{l}\text { Lyc: } 300 / 239 \\
\text { Pen: } 272 / 131\end{array}$ & $0 / 272$ & $0 / 131$ & $73 / 312$ & $28-100$ & - \\
\hline $\begin{array}{l}\text { (56) C2_At4g30580 } \\
\text { (U229764) }\end{array}$ & $\begin{array}{l}\text { Lyc: } 25 / 514 \\
\text { Pen: }-/ 557\end{array}$ & - & $68 / 514$ & $-/ 284$ & - & - \\
\hline $\begin{array}{l}\text { (57) cLER-17P11 } \\
\text { (U313426) }\end{array}$ & Lyc: $390 / 383$ & $5 / 390$ & $10 / 239$ & $129 / 765$ & $83-211$ & - \\
\hline $\begin{array}{l}\text { (U313426) } \\
\text { (59) C2_At4g03210 }\end{array}$ & Pen: 467/239 & & & & & \\
\hline$\left(\mathrm{DQ} 098654^{h}\right)$ & $\begin{array}{l}\text { Lyc: } 169 / 228 \\
\text { Pen: } 102 / 316\end{array}$ & $1 / 102$ & $4 / 162$ & $34 / 266$ & $24-57$ & - \\
\hline $\begin{array}{l}\text { (61) C2_At1g53670 } \\
\text { (U216219) }\end{array}$ & $\begin{array}{l}\text { Lyc: } 169 / 231 \\
\text { Pen: } 75 / 317\end{array}$ & $1 / 75$ & $6 / 231$ & $24 / 189$ & $33-56$ & $\mathrm{~S}_{34} \rightarrow \mathrm{R}$ \\
\hline $\begin{array}{l}\text { (62) T1624 } \\
\left(\mathrm{T} 1624^{h}\right)\end{array}$ & $\begin{array}{l}\text { Lyc: } 285 / 136 \\
\text { Pen: } 285 / 274\end{array}$ & $2 / 262$ & $4 / 138$ & $94 / 398$ & $3-96$ & - \\
\hline $\begin{array}{l}\text { (63) C2_At3g } 14770 \\
\text { (U231080) }\end{array}$ & $\begin{array}{l}\text { Lyc: } 363 / 222 \\
\text { Pen:240/209 }\end{array}$ & $9 / 217$ & $5 / 209$ & $37 / 235$ & 199-235 & - \\
\hline $\begin{array}{l}\text { (64) T1171 } \\
\text { (U313128) }\end{array}$ & $\begin{array}{l}\text { Lyc: } 247 / 338 \\
\text { Pen:247/345 }\end{array}$ & $1 / 226$ & $13 / 338$ & $82 / 345$ & $5-86$ & - \\
\hline $\begin{array}{l}\text { (66) cLET-14-A10 } \\
\text { (U313308) }\end{array}$ & $\begin{array}{l}\text { Lyc: } 148 / 419 \\
\text { Pen: } 148 / 306\end{array}$ & $0 / 127$ & $0 / 306$ & $39 / 282$ & 244-282 & - \\
\hline $\begin{array}{l}\text { (68) T0966 } \\
\text { (U313029) }\end{array}$ & $\begin{array}{l}\text { Lyc: } 249 / 437 \\
\text { Pen: } 191 / 411\end{array}$ & 0/191 & $1 / 411$ & $63 / 192$ & $25-87$ & - \\
\hline $\begin{array}{l}\text { (70) cLEX-13-I15 } \\
\text { (U316193) }\end{array}$ & $\begin{array}{l}\text { Lyc:597/- } \\
\text { Pen:543/- }\end{array}$ & $0 / 528$ & - & $175 / 224$ & $41-215$ & - \\
\hline $\begin{array}{l}\text { (71) C2_At1g50575 } \\
\text { (U222777) }\end{array}$ & $\begin{array}{l}\text { Lyc:218/220 } \\
\text { Pen:241/473 }\end{array}$ & $1 / 218$ & $8 / 220$ & $62 / 202$ & $115-176$ & - \\
\hline
\end{tabular}


Table 1. Continued

\begin{tabular}{|c|c|c|c|c|c|c|}
\hline $\begin{array}{l}\text { Marker } \\
\text { (unigene) }\end{array}$ & $\begin{array}{l}\text { Size (b) } \\
\text { exon/intron }\end{array}$ & $\begin{array}{l}\text { Nucleotide } \\
\text { polymorphism } \\
\text { (exon) })^{c}\end{array}$ & $\begin{array}{l}\text { Nucleotide } \\
\text { polymorphism } \\
\text { (intron) }^{d}\end{array}$ & $\begin{array}{l}\text { Amino } \\
\text { acid } \\
\text { coverage }^{e}\end{array}$ & $\begin{array}{l}\text { Analysed } \\
\text { fragment }^{f}\end{array}$ & $\begin{array}{l}\text { Amino } \\
\text { acid } \\
\text { polymorphism }\end{array}$ \\
\hline $\begin{array}{l}\text { (72) C2_At1g55870 } \\
\text { (U228097) }\end{array}$ & $\begin{array}{l}\text { Lyc: } 481 /- \\
\text { Pen: } 312 /-\end{array}$ & $23 / 291$ & - & $104 / 355$ & $255-354$ & $\begin{array}{l}\mathrm{H}_{267} \rightarrow \mathrm{Y} \\
\mathrm{R}_{309} \rightarrow \mathrm{G} \\
-315 \rightarrow \mathrm{V} \\
-315 \rightarrow \mathrm{C} \\
-315 \rightarrow \mathrm{V} \\
-315 \rightarrow \mathrm{E} \\
\mathrm{R}_{320} \rightarrow \mathrm{S} \\
\mathrm{N}_{323} \rightarrow \mathrm{D} \\
\mathrm{I}_{330} \rightarrow \mathrm{M}\end{array}$ \\
\hline $\begin{array}{l}\text { (73) CT223 } \\
\text { (U143214) }\end{array}$ & $\begin{array}{l}\text { Lyc:100/326 } \\
\text { Pen:153/340 }\end{array}$ & $1 / 100$ & $44 / 311$ & $32 / 138$ & $20-51$ & - \\
\hline $\begin{array}{l}\text { (74) cLEB-3-N22 } \\
\text { (U313176) }\end{array}$ & $\begin{array}{l}\text { Lyc: } 415 / 45 \\
\text { Pen: } 415 / 160\end{array}$ & $3 / 394$ & $0 / 45$ & $138 / 482$ & $2-140$ & $\begin{array}{l}\mathrm{T}_{47} \rightarrow \mathrm{A} \\
\mathrm{V}_{64} \rightarrow \mathrm{L}\end{array}$ \\
\hline $\begin{array}{l}\text { (75) cLEX-3-N24 } \\
\text { (U3208109) }\end{array}$ & $\begin{array}{l}\text { Lyc: } 660 /- \\
\text { Pen: } 415 /-\end{array}$ & $11 / 415$ & - & $138 / 251$ & $11-148$ & $\begin{array}{l}\mathrm{K}_{20} \rightarrow \mathrm{N} \\
\mathrm{C}_{74} \rightarrow \mathrm{F} \\
\mathrm{L}_{83} \rightarrow \mathrm{F} \\
\mathrm{V}_{100} \rightarrow \mathrm{L} \\
\mathrm{D}_{115} \rightarrow \mathrm{E} \\
\mathrm{N}_{120} \rightarrow \mathrm{Y}\end{array}$ \\
\hline $\begin{array}{l}\text { (77) C2_At2g41680 } \\
\text { (U221908) }\end{array}$ & $\begin{array}{l}\text { Lyc: } 248 / 362 \\
\text { Pen: } 248 / 362\end{array}$ & $0 / 248$ & $0 / 362$ & $82 / 256$ & $12-93$ & - \\
\hline $\begin{array}{l}\text { (78) C2_At2g32600 } \\
\text { (U218453) }\end{array}$ & $\begin{array}{l}\text { Lyc: } 266 / 207 \\
\text { Pen: } 332 / 371\end{array}$ & $3 / 245$ & $15 / 214$ & $87 / 252$ & $155-241$ & $\mathrm{~T}_{217} \rightarrow \mathrm{I}$ \\
\hline $\begin{array}{l}(80) \mathrm{T} 1673 \\
\text { (U327399) }\end{array}$ & $\begin{array}{l}\text { Lyc: } 109 / 319 \\
\text { Pen: } 82 / 60\end{array}$ & $0 / 82$ & $25 / 84$ & $27 / 173$ & $27-53$ & - \\
\hline $\begin{array}{l}\text { (81) T0532 } \\
\text { (U312379) }\end{array}$ & $\begin{array}{l}\text { Lyc: } 255 / 289 \\
\text { Pen: } 254 / 287\end{array}$ & $1 / 232$ & $14 / 290$ & $82 / 444$ & $353-434$ & - \\
\hline $\begin{array}{l}\text { (83) cLET-3-C15 } \\
\text { (U315877) }\end{array}$ & $\begin{array}{l}\text { Lyc: } 299 / 182 \\
\text { Pen: } 299 / 80\end{array}$ & $1 / 299$ & $2 / 81$ & $99 / 433$ & $328-426$ & $\mathrm{P}_{416} \rightarrow \mathrm{A}$ \\
\hline $\begin{array}{l}\text { (84) C2_At2g37500 } \\
\text { (U231168) }\end{array}$ & $\begin{array}{l}\text { Lyc: } 134 / 363 \\
\text { Pen: } 134 / 454\end{array}$ & $0 / 112$ & $1 / 361$ & $44 / 234$ & $217-233$ & - \\
\hline $\begin{array}{l}\text { (87) } \mathrm{T} 1617 \\
\text { (U321884) }\end{array}$ & $\begin{array}{l}\text { Lyc: } 334 / 358 \\
\text { Pen: } 348 / 340\end{array}$ & $6 / 328$ & $14 / 345$ & $110 / 388$ & $273-382$ & $\begin{array}{l}\mathrm{V}_{309} \rightarrow \mathrm{I} \\
\mathrm{P}_{366} \rightarrow \mathrm{L} \\
\mathrm{S}_{377} \rightarrow \mathrm{L}\end{array}$ \\
\hline $\begin{array}{l}\text { (89) T1212 } \\
\text { (U316424) }\end{array}$ & $\begin{array}{l}\text { Lyc: } 282 / 295 \\
\text { Pen: } 380 / 232\end{array}$ & $0 / 282$ & $0 / 231$ & $93 / 403$ & $45-137$ & - \\
\hline $\begin{array}{l}\text { (90) cLET-2-D4 } \\
\text { (U315727) }\end{array}$ & $\begin{array}{l}\text { Lyc: } 556 /- \\
\text { Pen: } 442 /-\end{array}$ & $2 / 322$ & - & $106 / 327$ & 96-201 & $\mathrm{A}_{101} \rightarrow \mathrm{T}$ \\
\hline $\begin{array}{l}\text { (91) cLET-7-N21 } \\
\text { (U312661) }\end{array}$ & $\begin{array}{l}\text { Lyc: } 241 /- \\
\text { Pen: } 384 / 144\end{array}$ & $2 / 241$ & - & $80 / 285$ & $38-117$ & - \\
\hline $\begin{array}{l}\text { (92) T0443 } \\
\text { (U315467) }\end{array}$ & $\begin{array}{l}\text { Lyc: } 105 / 9 \\
\text { Pen: } 229 / 339\end{array}$ & $1 / 105$ & $0 / 9$ & $34 / 421$ & $76-109$ & - \\
\hline $\begin{array}{l}\text { (95) T1785 } \\
\text { (U318473) }\end{array}$ & $\begin{array}{l}\text { Lyc: } 199 / 328 \\
\text { Pen: } 180 / 303\end{array}$ & $29 / 179$ & $186 / 328$ & $59 / 137$ & 49-107 & $\begin{array}{l}\mathrm{D}_{76} \rightarrow \mathrm{E} \\
\mathrm{A}_{80} \rightarrow \mathrm{S} \\
\mathrm{K}_{85} \rightarrow \mathrm{S} \\
\mathrm{T}_{86} \rightarrow \mathrm{V} \\
\mathrm{Q}_{95} \rightarrow \mathrm{H} \\
\mathrm{S}_{102} \rightarrow \mathrm{T} \\
\mathrm{V}_{105} \rightarrow \mathrm{I} \\
\mathrm{V}_{106} \rightarrow \mathrm{I}\end{array}$ \\
\hline $\begin{array}{l}\text { (96) cLEX-13-I3 } \\
\text { (U324385) }\end{array}$ & $\begin{array}{l}\text { Lyc: } 318 / 246 \\
\text { Pen: } 322 / 243\end{array}$ & $0 / 236$ & $0 / 243$ & $65 / 229$ & $42-106$ & - \\
\hline $\begin{array}{l}\text { (97) cTOA-30-C21 } \\
\text { (U327971) }\end{array}$ & $\begin{array}{l}\text { Lyc: } 22 / 425 \\
\text { Pen: } 22 / 374\end{array}$ & - & $109 / 374$ & - & - & - \\
\hline $\begin{array}{l}\text { (100) T0556 } \\
\text { (U314531) }\end{array}$ & $\begin{array}{l}\text { Lyc: } 269 / 496 \\
\text { Pen: } 269 / 381\end{array}$ & $1 / 246$ & $1 / 381$ & $89 / 132$ & $32-120$ & $\mathrm{R}_{51} \rightarrow \mathrm{K}$ \\
\hline $\begin{array}{l}\text { (101) cLET-7-D17 } \\
\text { (U316001) }\end{array}$ & $\begin{array}{l}\text { Lyc: } 312 / 284 \\
\text { Pen: } 312 / 351\end{array}$ & $0 / 291$ & $1 / 284$ & $102 / 198$ & 89-191 & - \\
\hline $\begin{array}{l}\text { (103) cLET-42-02 } \\
\text { (U313367) }\end{array}$ & $\begin{array}{l}\text { Lyc: } 263 / 240 \\
\text { Pen: } 182 / 239\end{array}$ & $1 / 160$ & $17 / 240$ & $59 / 200$ & $142-200$ & - \\
\hline $\begin{array}{l}(105) \mathrm{T} 1190 \\
\text { (U312385) }\end{array}$ & $\begin{array}{l}\text { Lyc: } 192 / 602 \\
\text { Pen: } 190 / 463\end{array}$ & $0 / 97$ & $21 / 448$ & $32 / 583$ & $271-302$ & - \\
\hline $\begin{array}{l}(106) \mathrm{T} 1519 \\
\text { (U332457) }\end{array}$ & $\begin{array}{l}\text { Lyc: } 455 / 131 \\
\text { Pen: } 505 /-\end{array}$ & $5 / 230$ & - & $76 / 219$ & $50-125$ & $\mathrm{G}_{79} \rightarrow \mathrm{V}$ \\
\hline
\end{tabular}


Table 1. Continued

\begin{tabular}{|c|c|c|c|c|c|c|}
\hline $\begin{array}{l}\text { Marker } \\
\text { (unigene) })^{a}\end{array}$ & $\begin{array}{l}\text { Size (b) } \\
\text { exon/intron }\end{array}$ & $\begin{array}{l}\text { Nucleotide } \\
\text { polymorphism } \\
\text { (exon) }^{c}\end{array}$ & $\begin{array}{l}\text { Nucleotide } \\
\text { polymorphism } \\
\text { (intron) }^{d}\end{array}$ & $\begin{array}{l}\text { Amino } \\
\text { acid } \\
\text { coverage }^{e}\end{array}$ & $\begin{array}{l}\text { Analysed } \\
\text { fragment }^{f}\end{array}$ & $\begin{array}{l}\text { Amino } \\
\text { acid } \\
\text { polymorphism }^{g}\end{array}$ \\
\hline $\begin{array}{l}\text { (107) cTOF-18-B12 } \\
\left(\mathrm{BG} 128005^{h}\right)\end{array}$ & $\begin{array}{l}\text { Lyc: } 262 / 439 \\
\text { Pen: } 254 / 315\end{array}$ & $1 / 254$ & $9 / 316$ & $84 / 219$ & 54-137 & $\mathrm{V}_{77} \rightarrow \mathrm{A}$ \\
\hline $\begin{array}{l}\text { (110) cLES-2-K4 } \\
\text { (U312319) }\end{array}$ & $\begin{array}{l}\text { Lyc: } 312 / 16 \\
\text { Pen: 258/- }\end{array}$ & $0 / 258$ & - & $85 / 760$ & $77-161$ & - \\
\hline $\begin{array}{l}(113) \mathrm{T} 1164 \\
\text { (U320574) }\end{array}$ & $\begin{array}{l}\text { Lyc: } 397 / 344 \\
\text { Pen: } 223 / 344\end{array}$ & $1 / 222$ & $13 / 344$ & $73 / 340$ & $237-309$ & $\mathrm{Y}_{284} \rightarrow \mathrm{F}$ \\
\hline $\begin{array}{l}\text { (114) T0308 } \\
\text { (U316154) }\end{array}$ & $\begin{array}{l}\text { Lyc: } 230 / 138 \\
\text { Pen: } 350 / 138\end{array}$ & $1 / 218$ & $0 / 138$ & $76 / 373$ & $257-332$ & - \\
\hline $\begin{array}{l}\text { (115) cLEY-13-H6 } \\
\text { (U315415) }\end{array}$ & $\begin{array}{l}\text { Lyc: } 585 / 150 \\
\text { Pen: } 603 / 150\end{array}$ & $4 / 565$ & $4 / 150$ & $200 / 300$ & $21-220$ & $\mathrm{~N}_{164} \rightarrow \mathrm{D}$ \\
\hline $\begin{array}{l}\text { (117) C2_At5g } 16710 \\
\text { (U214041) }\end{array}$ & $\begin{array}{l}\text { Lyc: } 89 / 452 \\
\text { Pen: } 89 / 263\end{array}$ & $1 / 68$ & $20 / 267$ & $28 / 268$ & $241-268$ & $\mathrm{E}_{246} \rightarrow \mathrm{D}$ \\
\hline $\begin{array}{l}\text { (120) C2_At1g44446 } \\
\text { (U220686) }\end{array}$ & $\begin{array}{l}\text { Lyc: } 29 / 560 \\
\text { Pen: } 29 / 562\end{array}$ & - & $32 / 562$ & $9 / 461$ & $8-16$ & - \\
\hline $\begin{array}{l}\text { (122) cLEX-4-G10 } \\
\text { (U346954) }\end{array}$ & $\begin{array}{l}\text { Lyc: 681/- } \\
\text { Pen: 658/- }\end{array}$ & $11 / 634$ & - & $219 / 233$ & 14-233 & $\begin{array}{l}\mathrm{A}_{75} \rightarrow \mathrm{V} \\
\mathrm{N}_{82} \rightarrow \mathrm{D} \\
\mathrm{P}_{87} \rightarrow \mathrm{Q} \\
\mathrm{Y}_{119} \rightarrow \mathrm{C}\end{array}$ \\
\hline $\begin{array}{l}\text { (123) cTOE-7-B4 } \\
\text { (U315480) }\end{array}$ & $\begin{array}{l}\text { Lyc: } 171 / 488 \\
\text { Pen: } 171 / 354\end{array}$ & $0 / 151$ & $13 / 354$ & $54 / 367$ & $313-366$ & - \\
\hline $\begin{array}{l}\text { (124) C2_At2g14260 } \\
\text { (U220663) }\end{array}$ & $\begin{array}{l}\text { Lyc: } 24 / 613 \\
\text { Pen: } 24 / 634\end{array}$ & - & $0 / 613$ & $7 / 380$ & $1-7$ & - \\
\hline $\begin{array}{l}(125) \text { CT55 } \\
\text { (U143394) }\end{array}$ & $\begin{array}{l}\text { Lyc: } 561 / 110 \\
\text { Pen: } 303 /-\end{array}$ & $1 / 303$ & - & $101 / 386$ & $36-136$ & $\mathrm{H}_{55} \rightarrow \mathrm{Q}$ \\
\hline $\begin{array}{l}\text { (126) cLED-7-H11 } \\
\text { (U315661) }\end{array}$ & $\begin{array}{l}\text { Lyc: } 147 / 252 \\
\text { Pen: } 147 / 381\end{array}$ & $1 / 126$ & $42 / 269$ & $48 / 511$ & $455-502$ & - \\
\hline $\begin{array}{l}\text { (127) cLEC-68-J21 } \\
\left(\mathrm{BI} 421979^{h}\right)\end{array}$ & $\begin{array}{l}\text { Lyc: } 182 / 185 \\
\text { Pen: } 209 / 204\end{array}$ & $0 / 182$ & $0 / 185$ & $60 / 241$ & $171-230$ & - \\
\hline
\end{tabular}

\footnotetext{
${ }^{a}$ Marker and unigene according to the Sol Genomics Network (www.sgn.cornell.edu). Genes are numbered according to Figs 2-5 and Table S1 (in Supplementary data available at $J X B$ online).

${ }^{b}$ Total number of trimmed bases for each genotype, exon/intron.

${ }^{c}$ Number of nucleotides along the exon showing polymorphisms between genotypes/total of exon bases compared (primer sequences were not considered, a dash means no exon fragment sequenced).

${ }^{d}$ Number of nucleotides along the intron showing polymorphisms between genotypes/total of intron bases compared (a dash means no intron fragment compared).

${ }^{e}$ Number of compared amino acids between alleles/total number of amino acids of the corresponding unigene translated protein.

${ }^{f}$ Analysed amino acid interval of the corresponding translated unigene.

${ }^{g}$ Polymorphic amino acids between amplified alleles. The numbers indicate the position of changes corresponding to the translated unigene. When there is no number it means that there is a frame shift between the predicted proteins for Lyc and Pen and the unigene protein. A dash means insertion or deletion.

${ }^{h}$ When there was no unigene, or the unigene was uncompleted, the sequence used for the analysis was taken from the GenBank (NCBI accession number) or the marker sequence according to Sol Genomic Network (www.sgn.cornell.edu).
}

values lower than 1 for 51 out of the 56 polymorphic genes. For only the eight following genes, out of the 51, the ratio was statistically significant $(P<0.05)$ : arginine decarboxylase (gene 9) on BIN 1J; cystathionine- $\gamma$ synthase (gene 12) on BIN 2F; Mg-protophorphyrin IX chelatase (gene 22) and peroxidase (gene 28) both located on BIN 4E; pyrophosphatase (Ppv) (gene 57) on BIN 7B; poly(A)-specific ribonuclease (gene 72 ) on $\mathrm{BIN} 7 \mathrm{H}$; cytochrome $b_{5}$ (gene 95) on $\mathrm{BINs} 9 \mathrm{~B} / \mathrm{D} / \mathrm{E}$; and lectin protein kinase family protein (gene 122) on BIN 11C. Although caution should be taken in order not to overinterpret these results, it is tempting to speculate the occurrence of purifying selection against non-synonymous substitutions in these genes indicative of a functional requirement for their products.

The analysis of the sequence divergence between S. pennellii and S. lycopersicum alleles across different candidate categories (Table 2) showed that the largest number of genes with polymorphisms resulting in changes at amino acid level were those belonging to signalling and regulation (seven out of nine), DNA/RNA-protein metabolism (three out of three), and transport (three out of five) categories. By contrast, those related to central carbon metabolism (3 out of 14), protein processing and degradation (one out of four), and photosynthesis and oxidative phosphorylation ( 3 out of 10 ) displayed only a few genes with amino acid changes. The rest of the categories presented intermediate numbers of polymorphism at the level of a protein amino acid sequence. Whilst it is important to point out that amino acid position, which is an important component, was not considered here. The observed trends are largely in accordance with results reported by Schauer et al. (2006). In this study, it had been noted that a large proportion 
Table 2. Distribution of candidate genes between metabolic categories

$n$, Total number of genes in each category according to the 127 candidates identified.

$p / n p$, Number of genes that presented amino acid polymorphisms on the analysed fragment sequence/number of genes that did not present amino acid polymorphisms on the fragment sequence analysed. In this case, the total is the 81 genes for which amino acid sequences were analysed.

\begin{tabular}{|c|c|c|c|c|c|c|c|c|c|c|c|}
\hline \multirow{3}{*}{$\begin{array}{l}\text { BIN } \\
\text { (total } \\
\text { candidates) }\end{array}$} & \multicolumn{5}{|c|}{ Carbon and nitrogen metabolism } & \multirow{3}{*}{$\begin{array}{l}\text { Transport } \\
n(\%) \\
p / n p\end{array}$} & \multirow{3}{*}{$\begin{array}{l}\begin{array}{l}\text { Photosynthesis } \\
\text { and oxidative } \\
\text { phosphorylation }\end{array} \\
\begin{array}{l}n(\%) \\
p / n p\end{array}\end{array}$} & \multirow{3}{*}{ 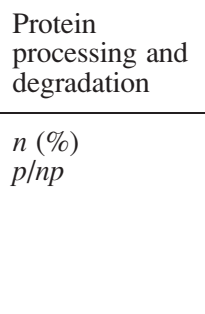 } & \multirow{3}{*}{$\begin{array}{l}\begin{array}{l}\text { DNA/RNA/ } \\
\text { protein } \\
\text { metabolism }\end{array} \\
\begin{array}{l}n(\%) \\
p / n p\end{array}\end{array}$} & \multirow{3}{*}{$\begin{array}{l}\begin{array}{l}\text { Signalling } \\
\text { and } \\
\text { regulation }\end{array} \\
n(\%) \\
p / n p\end{array}$} & \multirow{3}{*}{$\begin{array}{l}\text { Total } \\
\\
n \\
p / n p\end{array}$} \\
\hline & \multicolumn{5}{|l|}{$\begin{array}{l}n \\
p / n p\end{array}$} & & & & & & \\
\hline & $\begin{array}{l}\text { Amino } \\
\text { acids }\end{array}$ & $\begin{array}{l}\text { Central } \\
\text { carbon }\end{array}$ & Nitrogen & $\begin{array}{l}\text { Others } \\
\text { (secondary } \\
\text { metabolism) }\end{array}$ & $\begin{array}{l}\text { Total } \\
(\%)\end{array}$ & & & & & & \\
\hline $1 \mathrm{~J}(11)$ & $\begin{array}{l}3 \\
1 / 1\end{array}$ & - & $\begin{array}{l}1 \\
1 /-\end{array}$ & $\begin{array}{l}3 \\
2 / 1\end{array}$ & $\begin{array}{l}7(64) \\
4 / 2\end{array}$ & - & $\begin{array}{l}2(18) \\
1 / 1\end{array}$ & - & - & $\begin{array}{l}2(18) \\
1 /-\end{array}$ & $\begin{array}{l}11 \\
6 / 3\end{array}$ \\
\hline $2 \mathrm{~F}(7)$ & $\begin{array}{l}2 \\
1 / 1\end{array}$ & $\begin{array}{l}1 \\
-/ 1\end{array}$ & - & $\begin{array}{l}4 \\
1 / 3\end{array}$ & $\begin{array}{l}7(100) \\
2 / 5\end{array}$ & - & - & - & - & - & $\begin{array}{l}7 \\
2 / 5\end{array}$ \\
\hline $4 \mathrm{E}(13)$ & $\begin{array}{l}2 \\
1 /-\end{array}$ & - & - & $\begin{array}{l}5 \\
1 / 2\end{array}$ & $\begin{array}{l}7(54) \\
2 / 2\end{array}$ & $\begin{array}{l}1(8) \\
1 /-\end{array}$ & $\begin{array}{l}1(8) \\
1 /-\end{array}$ & $2(15)$ & - & $\begin{array}{l}2(15) \\
1 /-\end{array}$ & $\begin{array}{l}13 \\
5 / 2\end{array}$ \\
\hline 4I (9) & $\begin{array}{l}1 \\
-/ 1\end{array}$ & 1 & - & 2 & $\begin{array}{l}4(44) \\
-/ 1\end{array}$ & - & $\begin{array}{l}1(11) \\
-/ 1\end{array}$ & $\begin{array}{l}2(22) \\
1 /-\end{array}$ & $1(11)$ & $\begin{array}{l}1(11) \\
1 /-\end{array}$ & $\begin{array}{l}9 \\
2 / 2\end{array}$ \\
\hline 5D/5E/5F (14) & - & $\begin{array}{l}3 \\
2 / 1\end{array}$ & - & $\begin{array}{l}3 \\
-/ 1\end{array}$ & $\begin{array}{l}6(43) \\
2 / 2\end{array}$ & $\begin{array}{l}1(7) \\
-/ 1\end{array}$ & $\begin{array}{l}1(7) \\
-/ 1\end{array}$ & $3(21)$ & $\begin{array}{l}1(7) \\
1 /-\end{array}$ & $\begin{array}{l}2(14) \\
2 /-\end{array}$ & $\begin{array}{l}14 \\
5 / 4\end{array}$ \\
\hline 7B (3) & - & - & - & 1 & $1(33)$ & - & $\begin{array}{l}1(33) \\
-/ 1\end{array}$ & - & - & $\begin{array}{l}1(33) \\
-/ 1\end{array}$ & $\begin{array}{l}3 \\
-/ 2\end{array}$ \\
\hline 7F (10) & $\begin{array}{l}1 \\
1 /-\end{array}$ & $\begin{array}{l}3 \\
-12\end{array}$ & $\begin{array}{l}1 \\
-/ 1\end{array}$ & $\begin{array}{l}4 \\
-/ 2\end{array}$ & $\begin{array}{l}9(90) \\
1 / 5\end{array}$ & - & - & - & - & $1(10)$ & $\begin{array}{l}10 \\
1 / 5\end{array}$ \\
\hline $7 \mathrm{H}(7)$ & $\begin{array}{l}1 \\
-/ 1\end{array}$ & $\begin{array}{l}1 \\
1 /-\end{array}$ & - & $\begin{array}{l}1 \\
-/ 1\end{array}$ & $\begin{array}{l}3(43) \\
1 / 2\end{array}$ & - & $\begin{array}{l}2(29) \\
-/ 2\end{array}$ & $\begin{array}{l}1(14) \\
-/ 1\end{array}$ & $\begin{array}{l}1(14) \\
1 /-\end{array}$ & - & $\begin{array}{l}7 \\
2 / 5\end{array}$ \\
\hline 9B/9D/9E (26) & $\begin{array}{l}2 \\
-/ 1\end{array}$ & $\begin{array}{l}5 \\
-/ 3\end{array}$ & 1 & $\begin{array}{l}7 \\
3 / 2\end{array}$ & $\begin{array}{l}15(58) \\
3 / 6\end{array}$ & $\begin{array}{l}1(4) \\
1 /-\end{array}$ & $\begin{array}{l}4(15) \\
1 / 1\end{array}$ & - & $\begin{array}{l}4(15) \\
1 /-\end{array}$ & $\begin{array}{l}2(8) \\
1 / 1\end{array}$ & $\begin{array}{l}26 \\
7 / 8\end{array}$ \\
\hline 9J (7) & $\begin{array}{l}2 \\
1 / 1\end{array}$ & $\begin{array}{l}1 \\
-/ 1\end{array}$ & - & $\begin{array}{l}1 \\
1 /-\end{array}$ & $\begin{array}{l}4(57) \\
2 / 2\end{array}$ & - & - & $\begin{array}{l}1(14) \\
-/ 1\end{array}$ & - & $2(29)$ & $\begin{array}{l}7 \\
2 / 3\end{array}$ \\
\hline 10B (9) & 1 & $\begin{array}{l}2 \\
-/ 2\end{array}$ & - & $\begin{array}{l}4 \\
1 / 1\end{array}$ & $\begin{array}{l}7(78) \\
1 / 3\end{array}$ & $1(11)$ & - & $1(11)$ & - & - & $\begin{array}{l}9 \\
1 / 3\end{array}$ \\
\hline $11 \mathrm{C}(11)$ & 2 & $\begin{array}{l}1 \\
-/ 1\end{array}$ & - & $\begin{array}{l}2 \\
1 /-\end{array}$ & $\begin{array}{l}5(45) \\
1 / 1\end{array}$ & $\begin{array}{l}2(18) \\
1 / 1\end{array}$ & $1(9)$ & $\begin{array}{l}1(9) \\
-/ 1\end{array}$ & - & $\begin{array}{l}2(18) \\
1 /-\end{array}$ & $\begin{array}{l}11 \\
3 / 3\end{array}$ \\
\hline $\begin{array}{l}\text { Total } \\
\text { n } \\
\mathrm{p} / \mathrm{np}\end{array}$ & $\begin{array}{l}17 \\
5 / 6\end{array}$ & $\begin{array}{l}18 \\
3 / 11\end{array}$ & $\begin{array}{l}3 \\
1 / 1\end{array}$ & $\begin{array}{l}37 \\
10 / 13\end{array}$ & $\begin{array}{l}75 \\
19 / 31\end{array}$ & $\begin{array}{l}6 \\
3 / 2\end{array}$ & $\begin{array}{l}12 \\
3 / 7\end{array}$ & $\begin{array}{l}12 \\
1 / 3\end{array}$ & $\begin{array}{l}7 \\
3 /-\end{array}$ & $\begin{array}{l}15 \\
7 / 2\end{array}$ & $\begin{array}{l}127 \\
81\end{array}$ \\
\hline
\end{tabular}

of the fruit QML were strongly associated with variation in yield-associated traits (Table S1in Supplementary data available at $J X B$ online), in particular with the harvest index which is obviously closely related to assimilate partitioning. Thus, one could rationalize that allelic variations on genes of the first groups (signalling and regulation, DNA/RNA-protein metabolism, and transport) may well play a more major role affecting the final fruit metabolite content than those of the second group (central carbon metabolism, protein processing and degradation, photosynthesis, and oxidative phosphorylation). It should be borne in mind, however, that the failure in the present study to detect polymorphism between $S$. pennellii and $S$. lycopersicum alleles does not preclude the candidacy of the genes for two reasons: (i) since only partial sequences were analysed it cannot be excluded that the alleles were polymorphic in the non-sequenced regions of their reading frames; and (ii) because regulatory sequences, upstream of the amplified coding region, could be responsible for differential expression levels or pattern of the alleles.

\section{Co-response and integrative analyses}

The evaluation of the co-response pattern of transcription in relation to the variations in metabolite contents of interest supports the candidacy of the selected genes and may provide hints about epistatic interactions of the candidates identified with QML localized in other BINs. Then, a correlation analysis was performed between the expression profile of the candidates and the metabolite variations along fruit development and ripening in $S$. lycopersicum. Expression data of 56 of the selected candidate genes that were present on the TOM1 microarray were correlated against the content variation of 66 metabolites quantified across a fruit development and 


\section{Bermúdez et al.}

ripening time course (Carrari et al., 2006). Out of the 3696 pairs analysed, 724 positive (blue) and 307 negative (red) significant correlations were observed (Fig. 6). This number of correlations is well above of that expected merely by chance $(185$ at $P<0.05)$.

In the following section, only those candidate genes, which it was possible to provide supporting evidence from metabolic mapping, sequence analysis, and their correlative behaviour from the developmental time series experiment, will be dealt with in detail.

The gene encoding cystathionine- $\gamma$-synthase (gene 12), localized on BIN 2F, correlated with the contents of many metabolites including several for which QML mapped to this BIN (correlating positively with malate, quinate, and inositol-P; and negatively with galacturonate and dehy- droascobate). Allelic variation, at amino acid level, between $S$. lycopersicum and the corresponding $S$. pennellii introgressed line was also found (Table 1). This enzyme participates in the conversion of homo-Ser to Met (Fig. 2) and could be involved in the variation of S-MeCys found in this BIN. A role for this pathway during tomato fruit ripening has been assessed recently by Katz et al. (2006). The massive production of ethylene during ripening requires an increase in the de novo Met synthesis through up-regulation of this enzyme. In the present correlation analysis, mRNA levels of this gene correlate negatively with Cys, a precursor in the biosynthesis of S-Me-Cys (Fig. 6). In addition, a glutathione $S$-transferase encoding gene (gene 14) was found co-locating with variations in Glu and 5-OxoPro QML onto this BIN (Fig. 2). Together with the amino acid

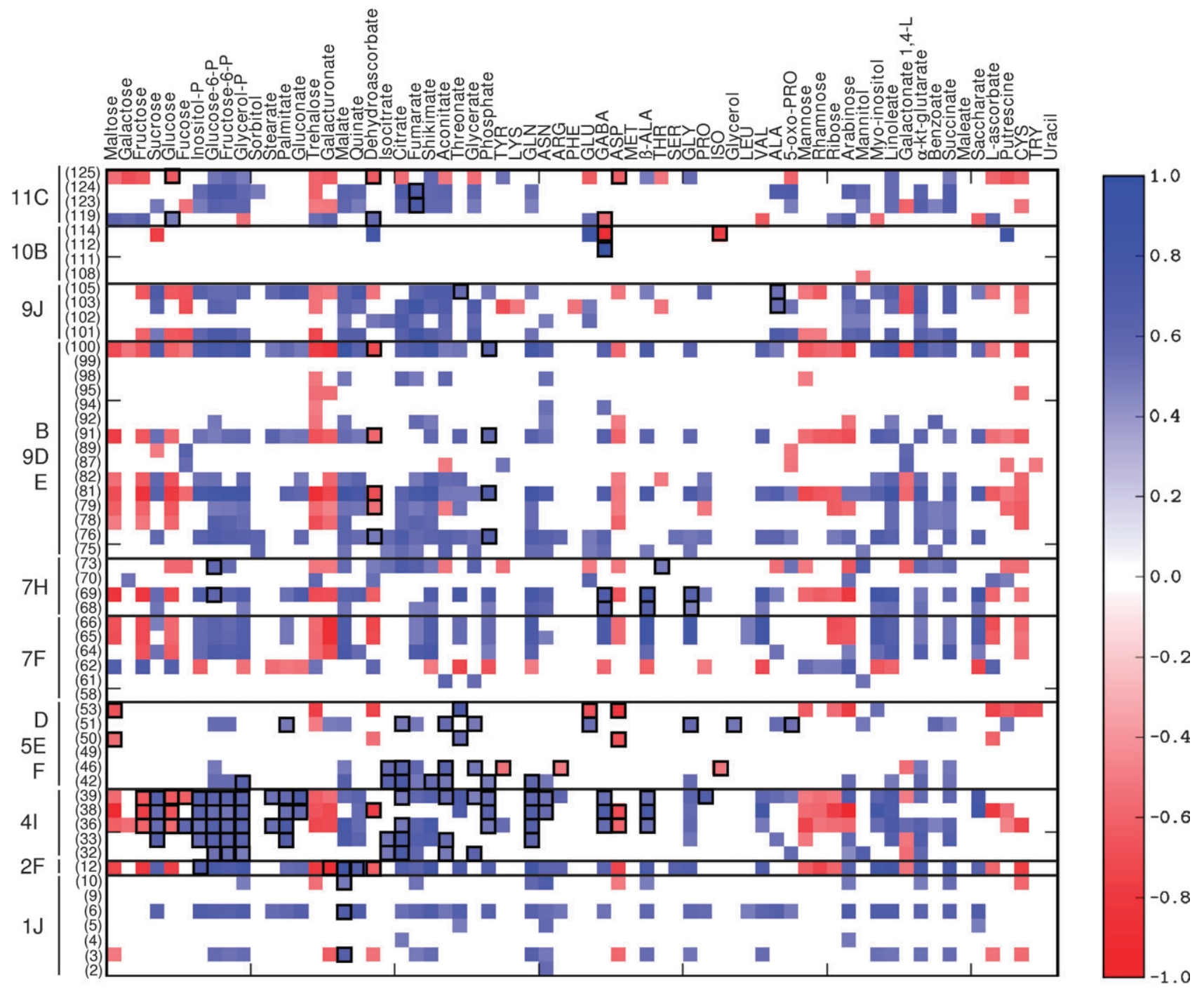

Fig. 6. Correlations between candidate gene transcription profile and metabolite contents through $S$. lycopersicum fruit development. Correlation coefficients (two tailed) and significances $(P<0.05)$ were calculated by applying Spearman algorithm using SSPS software. Each dot indicates a given $r$-value, resulting from a Spearman correlation analysis, in a false colour scale. Blue and red represent significant positive and negative correlations, respectively; white indicates a lack of significant correlation. The genes are indicated with the same number order as in Figs $2-5$. Dots demarcated by a bold border indicate those that exhibit significant correlations between a given gene and the metabolite corresponding to the QML to which it co-localizes. 
changes found in the coding region of this gene (Table 2), results mentioned above make it a good candidate to test using functional approaches.

The most supported candidate gene mapped on BIN 4E is GAUT4 galacturonosyltransferase (gene 19, Fig. 2), which co-localized with galacturonate QML, since this enzyme participates in pectin biosynthesis from galacturonate (Sterling et al., 2006). However, no polymorphisms at the amino acid level were detected on the protein fragment analysed.

The introgressed region delineated as BIN 4I harbours QML for elevated sugars, as well as elevations in the metabolites belonging to the pathway linking citrate to glutamate, and was, therefore, defined as a pathway QTL (Schauer and Fernie, 2006). Moreover, about $60 \%$ of all QML mapped onto this BIN have been defined as morphology-dependent QML as they could be associated with phenotypic traits by correlation analyses (Table S1 in Supplementary data available at $J X B$ online). In fact, this pathway QTL showed significant association with plant weight, Brix levels, fruit width, and harvest index.

Genes mapped onto this BIN for which it would be possible to evaluate transcriptional behaviour (gene 32, pre-pro-cysteine proteinase; gene 33, chaperone protein DnaJrelated; gene 36, plastocyanin chloroplast precursor; gene 38, pyrophosphate-fructose 6-phosphate 1-phosphotransferase $\alpha$-subunit; and gene 39, pectinesterase) displayed a wide range of significant correlations with most of the colocalizing QML including sugars, phosphates, and amino acids. Their co-localization, together with the similar patterns of correlation they showed, might be indicative of a coordinated mechanism of regulation operating at this same position on the genome. Phenylalanine ammonia lyase (gene 40) is involved in a wide range of metabolic pathways (Fig. 3) including nitrogen releases of $\mathrm{NH}_{4}^{+}$for $\mathrm{Gln}$ and Glu biosynthesis. Thus, this enzyme, previously mapped by Causse et al. (2004) onto the same BIN, may be involved in the variations of these two amino acids observed in S. pennellii IL. However, no amino acid polymorphisms were detected in the gene fragment analysed here (Table 1) and further investigations are needed to evaluate the candidature of this gene. When looking for the genetic determinants for these pathway QTL there are two alternatives: either (i) is not controlled by variation at a single genetic locus or (ii), more likely, the gene responsible for the entire pathway variation encodes not an enzyme activity protein but a regulatory one. In this direction, a chaperone protein DnaJ-related (gene 33) mapped onto this BIN and classified within regulatory categories emerged as an interesting candidate. DnaJ-chaperone proteins constitute a wide family both in prokaryote and eukaryote organisms and participate in protein folding, assembly, disassembly, and translocation into organelles through a mechanism involving interaction with Hsp70 chaperones (Qiu et al.,
2006). It has been demonstrated recently that a mutation on a cauliflower locus encoding a member of this family (Or locus) leads to chromoplast differentiation and consequently a deposit of $\beta$-carotene in the affected tissues ( $\mathrm{Lu}$ et al., 2006). Moreover, transgenic potato plants overexpressing this allele in a tuber-specific manner result in the production of orange-yellow tubers associated with high levels of carotenoids (Lu et al., 2006). The chaperone protein DnaJ-related described here also possesses the Cysrich zinc finger domains characteristics of DnaJ chaperones (not shown) and an amino acid polymorphism in the coding region $\left(\mathrm{K}_{11} \rightarrow \mathrm{R}\right)$. Additionally, the levels of $\beta$-carotene in the fruit correlated positively $(r=0.76 ; P<0.0001)$ with the expression of this gene during the developmental time-series experiment. These results, when taken together, make this gene a good candidate to be tested functionally for its putative role in the control of fruit metabolism.

The other BINs exhibiting patterns of metabolite and whole-plant phenotypic variations similar to those described for $4 \mathrm{I}$ are 5D, E, and F (Fig. 3). For reasons explained above, these last three BINs are here considered as a single entity. Except for the case of the peroxidase (gene 49), the other five candidates mapped on BIN 5D/E/ $\mathrm{F}$ for which a transcriptional pattern was analysed, correlate with three to seven QML localized onto these BINs. $\beta$-Ketoacyl reductase (gene 42) plays a key role in fatty acid biosynthesis and positively correlates with glycerol-P, rendering it indirectly linked to stearate and palmitate QML. Phosphoglucomutase (gene 44) has long been considered a key enzyme in starch biosynthesis of potato tubers. Although the role of this enzyme has not been directly assessed in tomato fruits, it has been demonstrated that its activity declines during early developmental stages in accordance with the expression level of its cytosolic isoform (Kortstee et al., 2007). The colocalization of this gene with a YAL for Brix variation, and QML for maltose and galactose, renders it a good candidate to follow-up. Whilst, starch in its own right is not a highly important quality trait in tomato, its accumulation is only transient and there is increasing evidence that the biosynthesis and degradation of starch plays an important role in determining Brix at harvest time (Baxter et al., 2005).

Sphingosine-1-phosphate lyase (gene 45) catalyses one of the first steps of sphingolipid biosynthesis. Interestingly, this enzyme co-maps with one of the precursors, Ser, and the metabolically related Gly and Thr QML (Fig. 3).

On BIN 7B, the phospholipid/glycerol acyltransferase gene (gene 56, Fig. 3) could be related to the decrease in glycerol-P levels, a QML localized into this BIN. Glycerol$\mathrm{P}$ is an important intermediate metabolite in the fatty acids biosynthesis pathway in which this enzyme is involved.

The QML mapped onto BIN 7F was a variation in $S$-methyl-Cys content; since this metabolite was not measured through a developmental time-series experiment, it was not possible to analyse any correlation 
between candidate gene expression and the QML (Fig. 6). However, three candidates deserve to be highlighted in view of their positions within the metabolic pathways (Fig. 3). First, a methionine sulphoxide reductase (gene 61 ), thought to participate in the protection of chloroplasts against oxidative damage (Vieira Dos Santos et al., 2005), may be involved in the alterations found in the levels of $S$-methyl-Cys increasing the free Met pool by reducing Met-S-oxide in the reverse reaction. The amino acid variation found at residue $34\left(\mathrm{~S}_{\mathrm{lyc}} \rightarrow \mathrm{R}_{\mathrm{pen}}\right)$ of the sequence analysed lies within the signal peptide that directs this protein into the chloroplast (Vieira Dos Santos et al., 2005). Secondly, a mitochondrial malate dehydrogenase (mMDH) also mapped onto this BIN (gene 64). This protein has been implicated in modifying photosynthetic activity and aerial growth in tomato under ambient growth conditions (Nunes-Nesi et al., 2005). mMDH-silenced tomato plants were characterized by a decreased partitioning into organic and amino acids, an altered redox state and dramatic alterations in foliar ascorbic acid levels (Nunes-Nesi et al., 2005). No allelic variations were observed between $S$. lycopersicum and S. pennellii. Thirdly, phosphoenolpyruvate carboxylase (gene 67), which also mapped to this BIN, is involved in malate assimilation and at post-transcriptional level it is regulated by this compound which could eventually lead to the modification of the fluxes from the TCA cycle (through oxalacetate) to amino acid biosynthesis.

The expression of a constitutive plastid lipid-associated protein (gene 68), a polygalacturonase inhibitor gene (gene 69), and a photosystem II $10 \mathrm{kDa}$ protein (gene 73), all mapped on BIN $7 \mathrm{H}$ presented a co-response with 3,4 , and 2 of the co-located QML observed in S. pennellii ILs, respectively (Fig. 6). Interestingly, the polygalacturonase inhibitor expression displays a positive correlation with the QML for glucose-6-P, mapped onto this region, as well as with the sucrose content; and a negative correlation with fructose and glucose contents. A gene encoding a lysine decarboxylase protein (gene 71) could possibly be involved in the variation in $\beta$-Ala, Met, H-Ser, and Thr co-localizing to this BIN. Another gene with the potential to be directly involved with variations of $\mathrm{Thr}$, Gly, Ser, and glucose-6-P is the phosphoglycerate kinase (gene 74), linked to these QML, which showed two amino acid polymorphisms in the fragment analysed (Table 1). This observation is in line with the finding of two other linked genes related with photosynthesis: a chloroplastassociated (gene 68) and the photosystem II $10 \mathrm{kDa}$ proteins (gene 73) that could play in the mentioned variations. A poly(A)-specific ribonuclease (gene 72) also mapped onto this region showed a high level of amino acid polymorphisms (Table 1). As an alternative to the involvement of the other candidates mentioned above, it is conceivable that this gene has a regulatory role that contributes to, or indeed even causes, the observed metabolic variations.
Out of the 15 genes profiled from BIN 9B/D/E only five (gene 76, peroxidase; gene 79, 1-phosphatidylinositol-4phosphate 5-kinase; gene 81, enolase; gene 91, chloroplast pigment-binding protein; and gene 100, photosystem II reaction centreW protein) displayed a co-response with dehydroascorbate and phosphate, both co-located QML (Fig. 6). An obvious candidate associated with the increment observed in the levels of dehydroascorbate was the gene encoding monodehydroascorbate reductase (gene 83; Fig. 4), wherein three single nucleotide polymorphisms were found; two in an intron and one that resulted in an amino acid change in the coding region analysed.

On BIN 9J, an acireductone dioxygenase (gene 103), involved in Met metabolism, and a malate dehydrogenase (gene 105; Fig. 5), positively correlated with a co-located QML observed for Ala (Fig. 6). Another gene that could putatively be involved in the variation of this amino acid was a glutamyl-tRNA aminotransferase (gene 106). Despite the fact that the correlative behaviour of this gene could not be assessed, an amino acid polymorphism was found in its coding region (Table 1), so its candidature cannot be discarded. Similarly, variation in threonate levels mapped on this BIN could be linked to the presence of a GDP-mannose-3,5-epimerase gene (107), where polymorphisms between the two alleles were observed.

In BIN 10B, a CXE carboxylesterase (gene 112) presents a positive correlation with a GABA-co-localized QML, while an NAD-dependent isocitrate dehydrogenase (gene 114) negatively correlates with both GABA and Ile QML. It is conceivable that an increment in NADdependent isocitrate dehydrogenase mRNA levels negatively affects the GABA and T-4-OH-Pro contents by diverting the flux of 2-oxoglutarate towards Glu metabolism. In addition, $\beta$-cyanoalanine synthase (gene 109), a key enzyme involved in the detoxification of $\mathrm{HCN}$, co-localizes with QML for Ala and Gly. This enzyme has previously been characterized as playing an important role in the detoxification of $\mathrm{HCN}$, a side product of ethylene biosynthesis during climateric fruit ripening (Han et al., 2007).

Four genes which mapped to BIN 11C (gene 119, plastid quinol oxidase; gene 123, JAB; gene 124, proline iminopeptidase; and gene 125, ADP/ATP translocator), displayed correlation with several of the metabolites whose QTL co-localized to glucose, dehydroascorbate, fumarate, GABA, and Asp. Intriguingly, the dehydroascorbate QML co-localizes to a dehydroascorbate reductase (gene 117). Whilst no expression data are available for this gene from the previous developmental series experiment, allelic variation was found at the amino acid level, highlighting this as an interesting candidate for further study. Since ascorbic acid-associated genes have been deeply surveyed in tomato, it is unlikely that the gene identified in this work localized into BIN $11 \mathrm{C}$ is different from that previously mapped by Zou et al. (2006) onto BIN 11D, being an inaccurate localization. Another 
obvious candidate for the dehydroascorbate QML mapped into this BIN is the phosphomannose mutase (gene 127) that was also mapped by Zou et al. (2006). Finally, the co-localization of the sucrose transporter SUT1 gene with glucose QML is highly interesting, particularly in light of the fact that antisense inhibition of this gene resulted in modification of this metabolite content, as well as dramatic morphological changes (Hackel et al., 2006).

\section{Conclusions}

In this article, a combination of molecular marker sequence analysis, PCR amplification and sequencing, analysis of allelic variation, and evaluation of co-responses between gene expression and metabolite composition traits was used in order to identify candidate genes responsible for a sub-set of the previously reported metabolic QTL (Schauer et al., 2006). Using this combined strategy, 127 candidate genes located in 16 regions of the tomato genome were identified, 85 genes were cloned and partially sequenced from both $S$. lycopersicum and $S$. pennellii, and allelic variation at the amino acid level was confirmed in 37 of these candidates. Furthermore, of the 127 gene-metabolite co-locations, some 56 were recovered following correlation of parallel transcript and metabolite profiling. It is likely that the combined approaches taken here would allow the detection of both expression QTL (wherein the mechanism underlying the metabolic change is an alteration in transcript and by implication in protein amount), as well as change in function mutations in which the level of expression is unaltered (for example, the modified enzymatic activity of the $S$. pennellii LIN5 isoform invertase; Fridman et al., 2004). The candidate genes discussed here fit into both categories.

The work presented here represents the initial steps in the integration of genetic, genomic, and expressional patterns of genes co-localizing with chemical compositional traits of the fruit. Whilst, in the present study were mapped a similar number of genes as by Causse et al. (2004), due to the nature of the present approach it was possible to map a higher density of candidate genes. Depending on the gene nature, different strategies are being used for functional analyses in order to gather information about the role of these candidates. Moreover, a physical map of some of the genomic regions studied is under construction using $S$. pennellii $\mathrm{BAC}$ and $\mathrm{COS}$ libraries in order to facilitate future sequencing initiatives. Once complete it is likely that this work will allow the identification of novel candidate genes but will also be useful for BAC sorting and sequence assembly in the nascent tomato genome sequencing programme (Mueller et al., 2005b).

\section{Supplementary data}

The complete candidate genes information is detailed in Table S1. The primer sequences used to amplify all selected candidate genes are provided in Table S2. Supplementary data may be found at $J X B$ online.

\section{Acknowledgements}

This work was partially supported with grants from FAPESP (Brazil), CNPq (Brazil), Max Planck Society (Germany), INTA (Argentina), CONICET (Argentina), and under the auspices of the EU SOL Integrated Project FOOD-CT-2006-016214. UU was the recipient of PIBIC (Brazil) and CONICET (Argentina) fellowships. LB was the recipient of a FAPESP (Brazil) fellowship. RA, FC, and LK are members CONICET. This work was carried out in compliance with current laws governing genetic experimentation in Brazil and in Argentina.

\section{References}

Baxter CJ, Carrari F, Bauke A, Overy S, Hill SA, Quick PW, Fernie AR, Sweetlove LJ. 2005. Fruit carbohydrate metabolism in an introgression line of tomato with increased fruit soluble solids. Plant Cell Physiology 46, 425-437.

Carrari F, Baxter C, Usadel B, et al. 2006. Integrated analysis of metabolite and transcript levels reveals the metabolic shifts that underlie tomato fruit development and highlight regulatory aspects of metabolic network behaviour. Plant Physiology 142, 1380-1396.

Causse M, Duffe P, Gomez MC, Buret M, Damidaux R, Zamir D, Gur A, Chevalier C, Lemaire-Chamley M, Rothan C. 2004. A genetic map of candidate genes and QTLs involved in tomato fruit size and composition. Journal of Experimental Botany 55, 1671-1685.

Chen KY, Cong B, Wing R, Vrebalov J, Tanksley SD. 2007. Changes in regulation of a transcription factor lead to autogamy in cultivated tomatoes. Science 318, 643-645.

Corpet T. 1988. Multiple sequence alignment with hierarchical clustering. Nucleic Acids Research 16, 10881-10890.

Eshed Y, Zamir D. 1995. An introgression line population of Lycopersicon pennellii in the cultivated tomato enables the identification and fine mapping of yield-associated QTL. Genetics 141, 1147-1162.

Fernie AR, Tadmor Y, Zamir D. 2006. Natural genetic variation for improving crop quality. Current Opinion in Plant Biology 9, 196-202.

Frary A, Nesbitt TC, Grandillo S, Knaap E, Cong B, Liu J, Meller J, Elber R, Alpert KB, Tanksley SD. 2000. fw2.2: a quantitative trait locus key to the evolution of tomato fruit size. Science 289, 85-88.

Fridman E, Carrari F, Liu YS, Fernie A, Zamir D. 2004. Zooming in on a quantitative trait for tomato yield using interspecific introgressions. Science 305, 1786-1789.

Galpaz N, Ronen G, Khalfa Z, Zamir D, Hirschberg J. 2006. A chromoplast-specific carotenoid biosynthesis pathway is revealed by cloning of the tomato white-flower locus. The Plant Cell 18, 1947-1960.

Ganal MW, Czihal R, Hannappel U, Kloos DU, Polley A, Ling HQ. 1998. Sequencing of cDNA clones from the genetic map of tomato (Lycopersicon esculentum). Genome Research $\mathbf{8}$, 842-847.

Gordon D, Abajian C, Green P. 1998. Consed: a graphical tool for sequence finishing. Genome Research 8, 195-202.

Hackel A, Schauer N, Carrari F, Fernie AR, Grimm B, Kühn C. 2006. Sucrose transporter LeSUT1 and LeSUT2 
inhibition affects tomato fruit development in different ways. The Plant Journal 45, 180-192.

Han S, Seo YS, Kim D, Sung S-K, Kim WT. 2007. Expression of MdCAS1 and MdCAS2, encoding apple $\beta$-cyanoalanine synthase homologs, is concomitantly induced during ripening and implicates MdCASs in the possible role of the cyanide detoxification in Fuji apple (Malus domestica Borkh.) fruits. Plant Cell Reports 26, 1321-1331.

Hoisington D, Khairallah M, Gonzalez de Leon D. 1994. Laboratory protocols. El Baton, Mexico: CIMMYT Applied Molecular Genetics Laboratory.

Kanehisa M, Araki M, Goto S, et al. 2008. KEGG for linking genomes to life and the environment. Nucleic Acids Research 36, $480-484$.

Katz YS, Galili G, Amir R. 2006. Regulatory role of cystathionine$\gamma$-synthase and de novo synthesis of methionine in the ethylene production during tomato fruit ripening. Plant Molecular Biology 61, 255-268.

Kortstee AJ, Appeldoorn NJ, Oortwijn ME, Visser RG. 2007. Differences in regulation of carbohydrate metabolism during early fruit development between domesticated tomato and two wild relatives. Planta 226, 929-939.

Kumar S, Tamura K, Jakobsen IB, Nei M. 2001. MEGA2: molecular evolutionary genetics analysis software. Bioinformatics 17, 1244-1245.

Lippman ZB, Semel Y, Zamir D. 2007. An integrated view of quantitative trait variation using tomato interspecific introgression lines. Current Opinion in Genetics \& Development 17, 1-8.

Lu S, Van Eck J, Zhou X, et al. 2006. The cauliflower Or gene encodes a Dnaj cysteine-rich domain-containing protein that mediates high levels of $\beta$-carotene accumulation. The Plant Cell 18, 3594-3605.

Mueller L, Mills A, Skwarecki B, Buels R, Menda N, Tanksley S. 2008. The SGN comparative map viewer. Bioinformatics 24, 422-423.

Mueller LA, Solow TH, Taylor N, et al. 2005a. The SOL genomics network: a comparative resource for Solanaceae biology and beyond. Plant Physiology 138, 1310-1317.

Mueller LA, Tanksley SD, Giovannoni JJ, et al. 2005b. The Tomato Sequencing Project, the first cornerstone of the International Solanaceae Project (SOL). Comparative and Functional Genomics 6, 153-158.

Nei M, Gojobori T. 1986. Simple methods for estimating the numbers of synonymous and nonsynonymous nucleotide substitutions. Molecular Biology and Evolution 5, 418-426.

Nunes-Nesi A, Carrari F, Lytovchenko A, Smith AMO, Loureiro ME, Ratcliffe RG, Sweetlove LJ, Fernie AR. 2005. Enhanced photosynthetic performance and growth as a consequence of decreasing mitochondrial malate dehydrogenase activity in transgenic tomato plants. Plant Physiology 137, 611622.
Paran I, Van der Knaap E. 2007. Genetic and molecular regulation of fruit and plant domestication traits in tomato and pepper. Journal of Experimental Botany 58, 3841-3852.

Price A. 2006. Believe it or not, QTLs are accurate! Trends in Plant Science 11, 213-216.

Qiu XB, Shao YM, Miao S, Wang L. 2006. The diversity of the DnaJ/Hsp40 family, the crucial partners for Hsp70 chaperones. Cell and Molecular Life Science 63, 2560-2570.

Rozas J, Sánchez-DelBarrio JC, Messeguer X, Rozas R. 2003. DnaSP, DNA polymorphism analyses by the coalescent and other methods. Bioinformatics 19, 2496-2497.

Salvi S, Tuberosa R. 2005. To clone or not to clone plant QTLs: present and future challenges. Trends in Plant Science 10, 297-304.

Schauer N, Fernie A. 2006. Plant metabolomics: towards biological functions and mechanism. Trends in Plant Science 11, 508-516.

Schauer N, Semel Y, Roessner U, et al. 2006. Comprehensive metabolic profiling and phenotyping of interspecific introgression lines for tomato improvement. Nature Biotechnology 24, 447-454.

Sterling JD, Atmodjo MA, Inwood SE, Kumar Kolli VS, Quigley HF, Hahn MG, Mohnen D. 2006. Functional identification of an Arabidopsis pectin biosynthetic homogalacturonan galacturonosyltransferase. Proceedings of National Academy of Science, USA 103, 5639-5640.

Stevens R, Buret M, Duffé P, Garchery C, Baldet P, Rothan C, Causse M. 2007. Candidate genes and QTLs affecting fruit ascorbic acid content in three tomato populations. Plant Physiology 143, 1943-1953.

Tabor HK, Risch NJ, Myers RM. 2002. Candidate-gene approaches for studying complex genetic traits: practical considerations. Nature Reviews Genetics 3, 1-7.

Tatusova TA, Madden TL. 1999. BLAST 2 Sequences, a new tool for comparing protein and nucleotide sequences. FEMS Microbiology Letters 174, 247-250.

Urbanczyk-Wochniak E, Luedemann A, Kopka J, Selbig J, Roessner-Tunali U, Willmitzer L, Fernie AR. 2003. Parallel analysis of transcript and metabolic profiles: a new approach in systems biology. EMBO Reports 4, 989-93.

Van der Hoeven R, Ronning C, Giovannoni J, Martin G, Tanksley S. 2002. Deductions about the number, organization, and evolution of genes in the tomato genome based on analysis of a large expressed sequence tag collection and selective genomic sequencing. The Plant Cell 14, 1441-1456.

Vieira Dos Santos C, Cuiné S, Rouhier N, Rey P. 2005. The Arabidopsis plastidic methionine sulfoxide reductase B proteins: sequence and activity characteristics, comparison of the expression with plastidic methionine sulfoxide reductase $\mathrm{A}$, and induction by photooxidative stress. Plant Physiology 138, 909-922.

Zou L, Li H, Ouyang B, Zhang J, Ye Z. 2006. Cloning and mapping of genes involved in tomato ascorbic acid biosynthesis and metabolism. Plant Science 170, 120-127. 


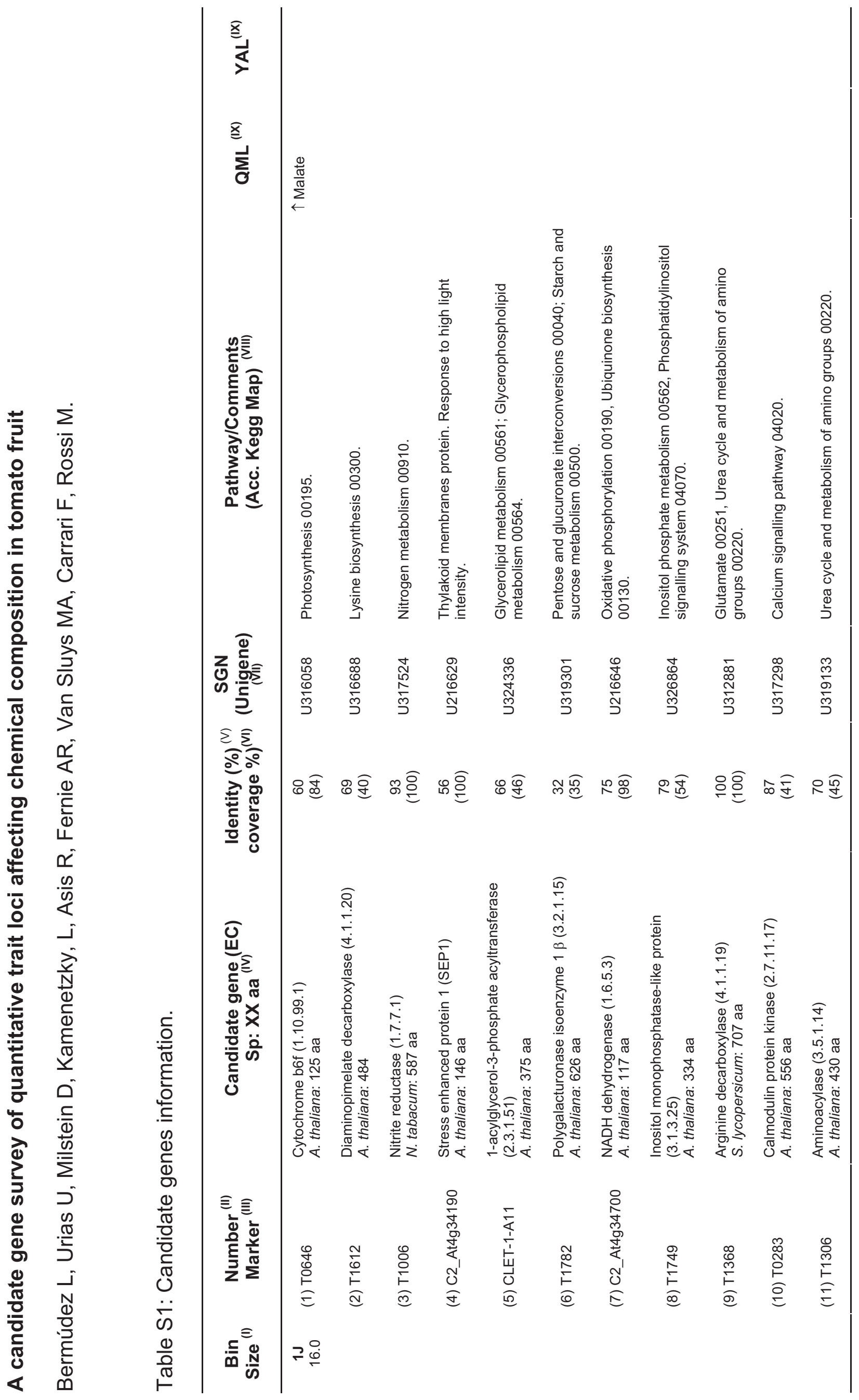




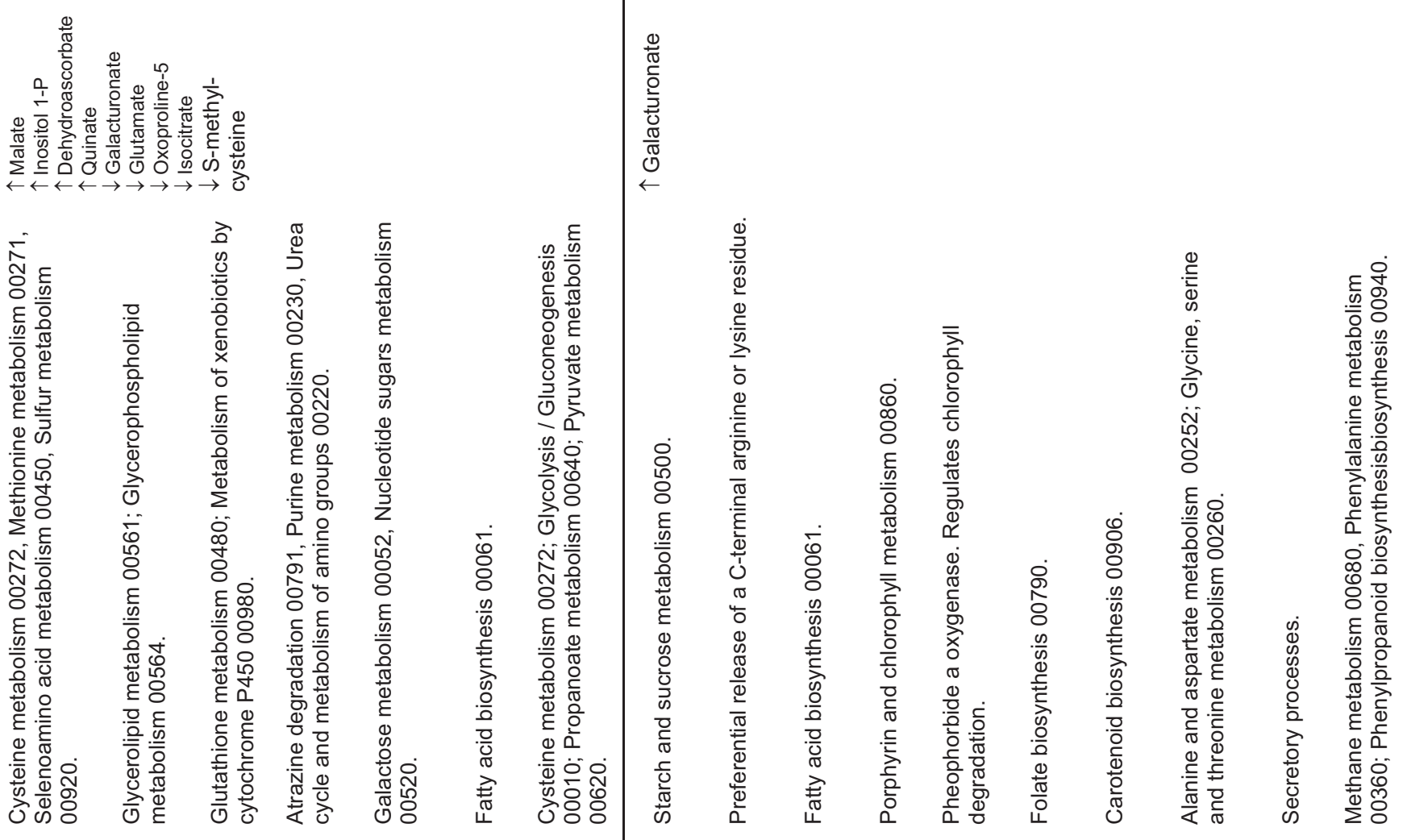

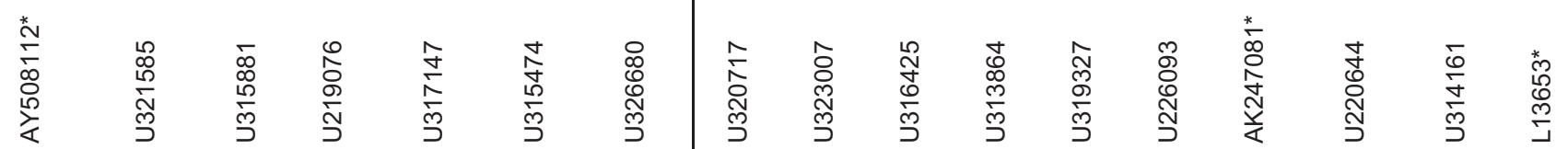

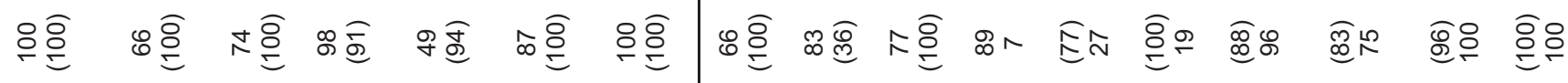

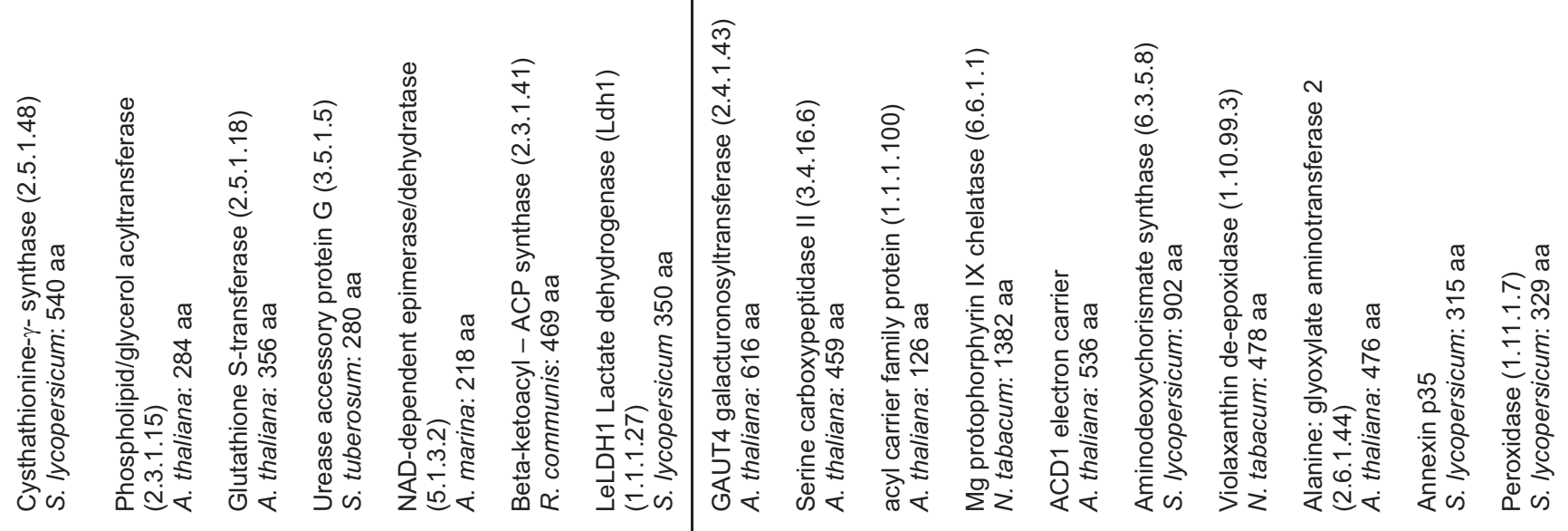

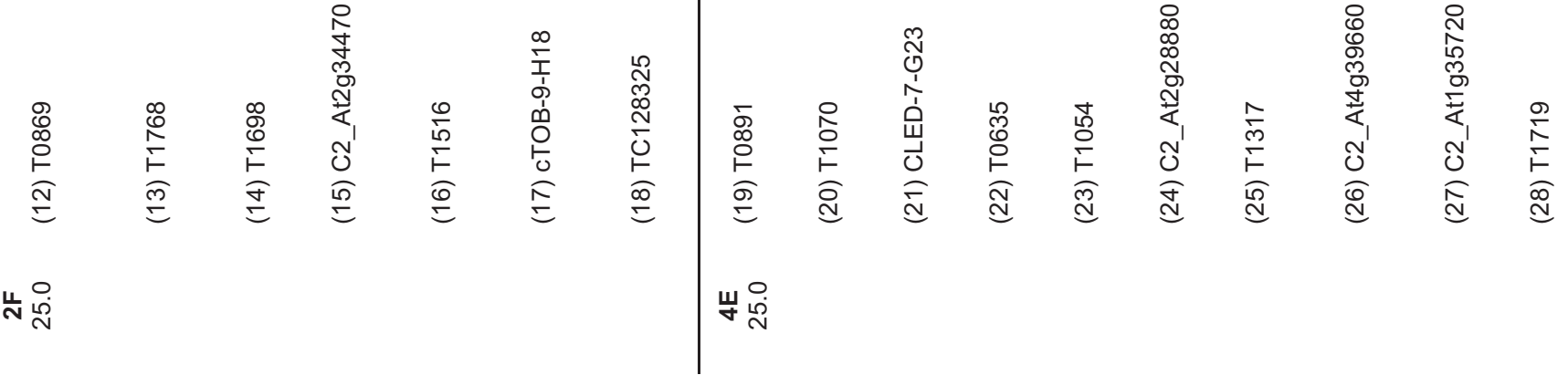




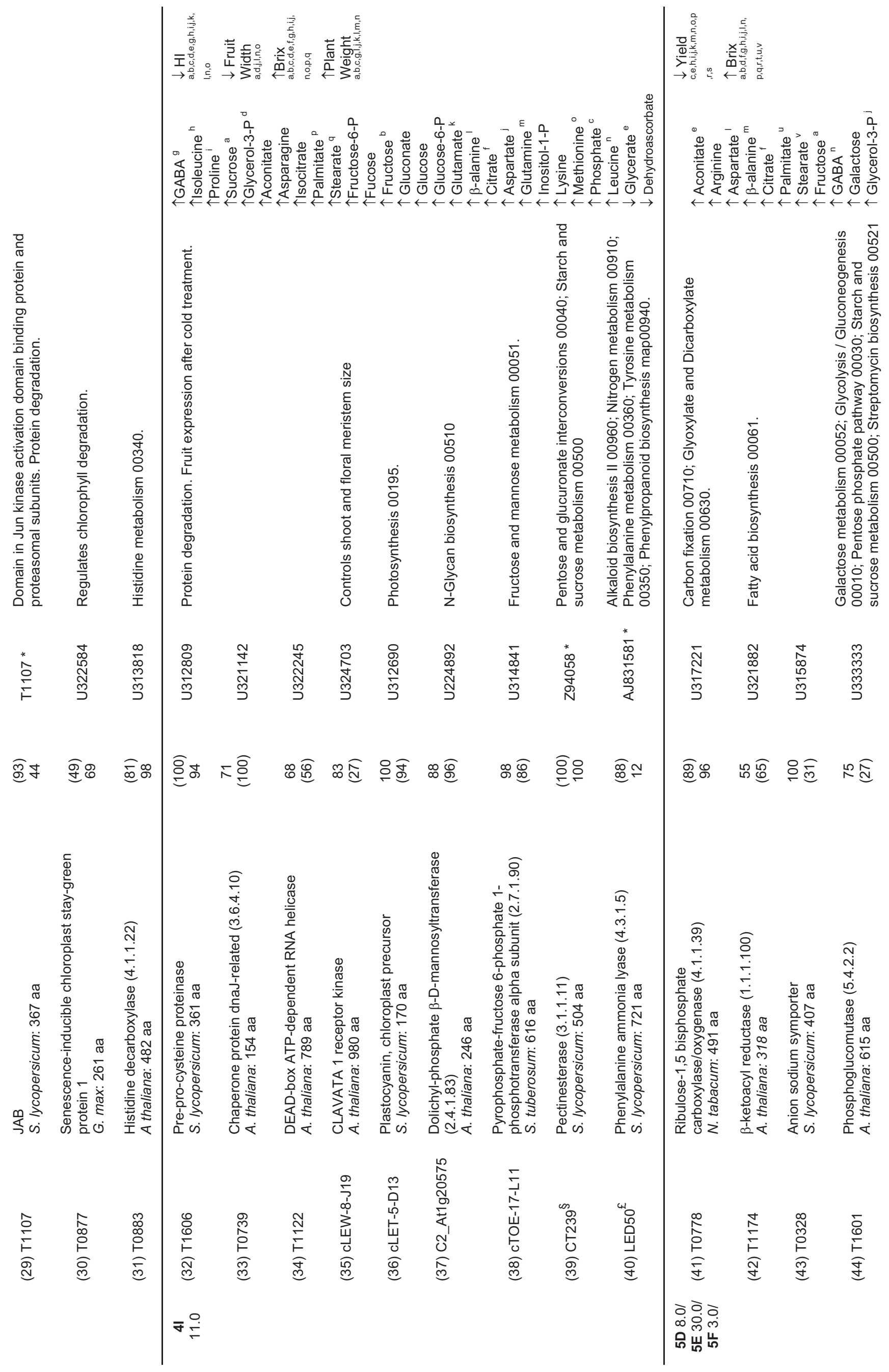



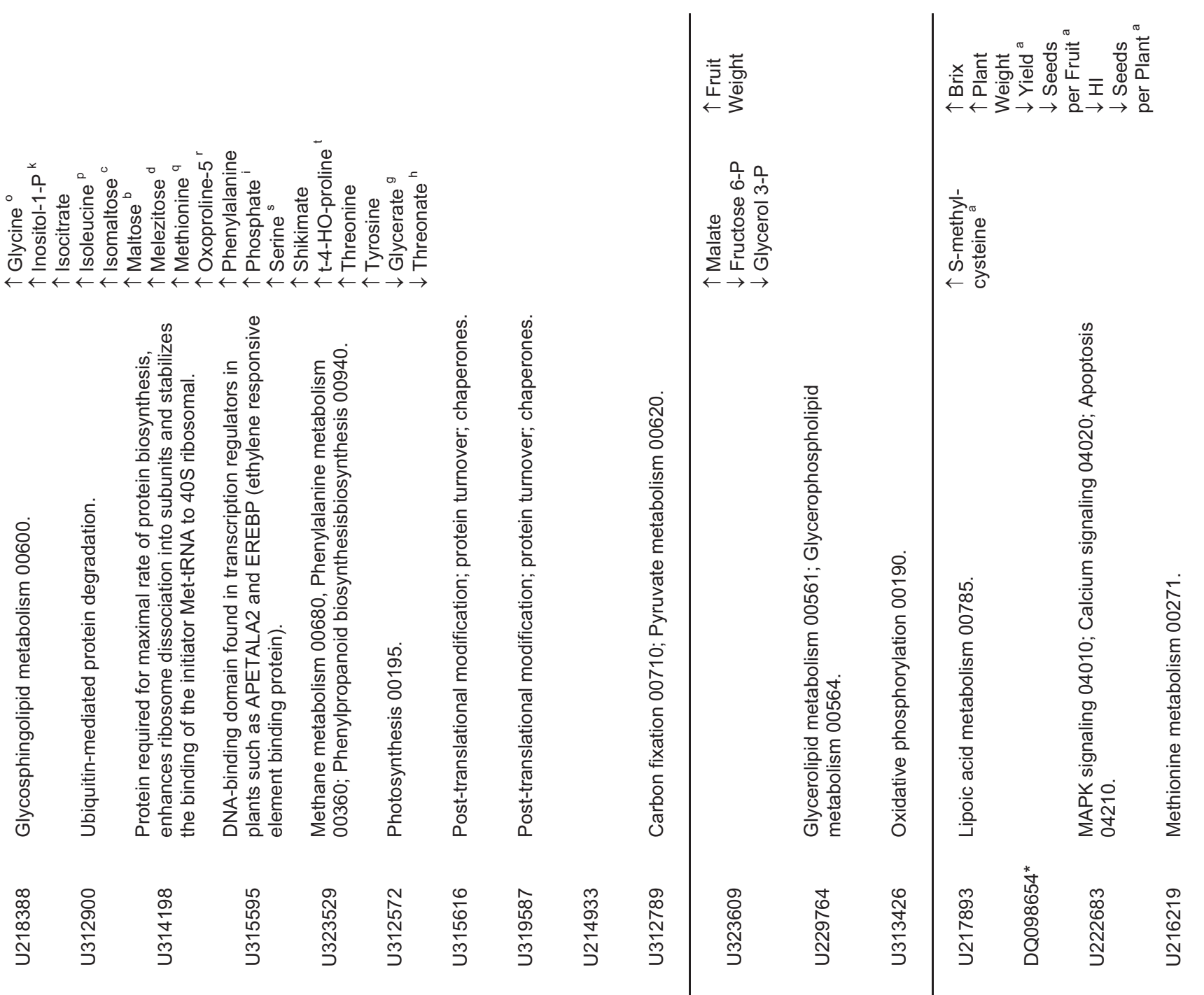

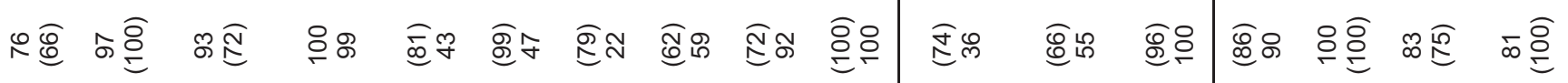

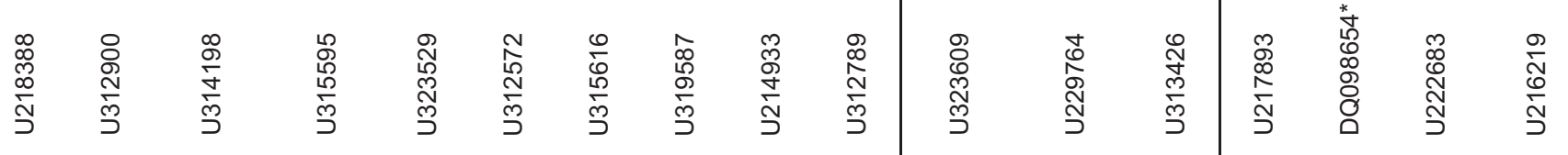

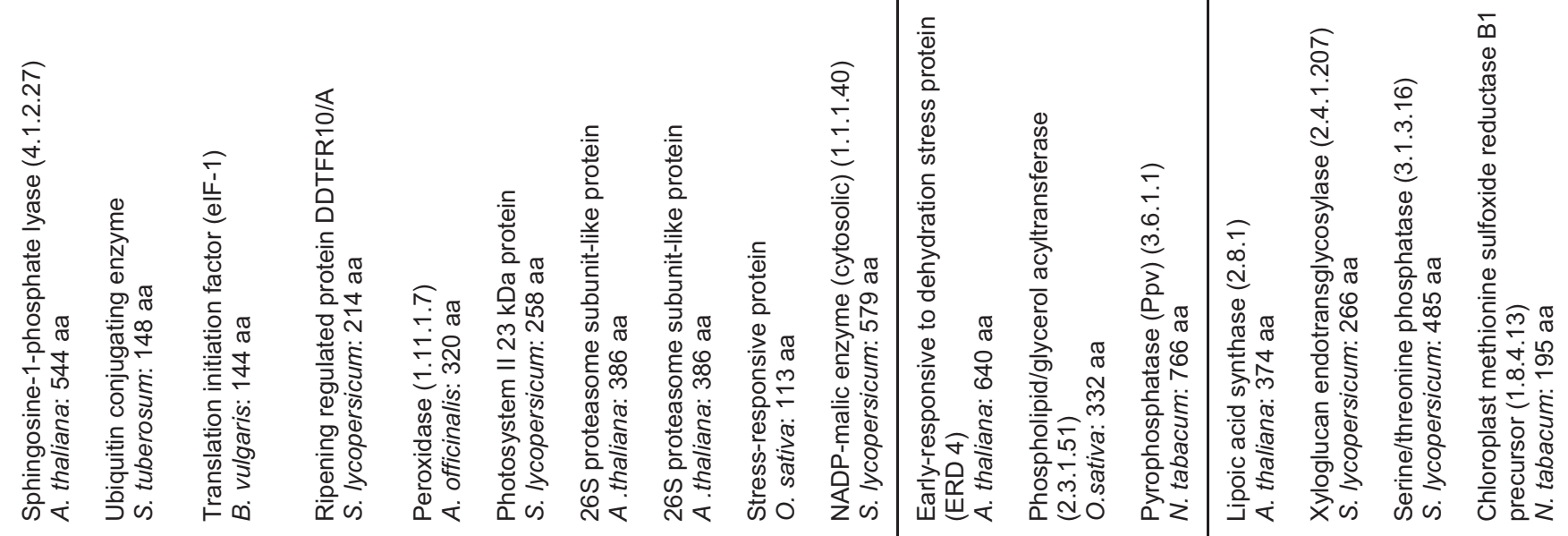

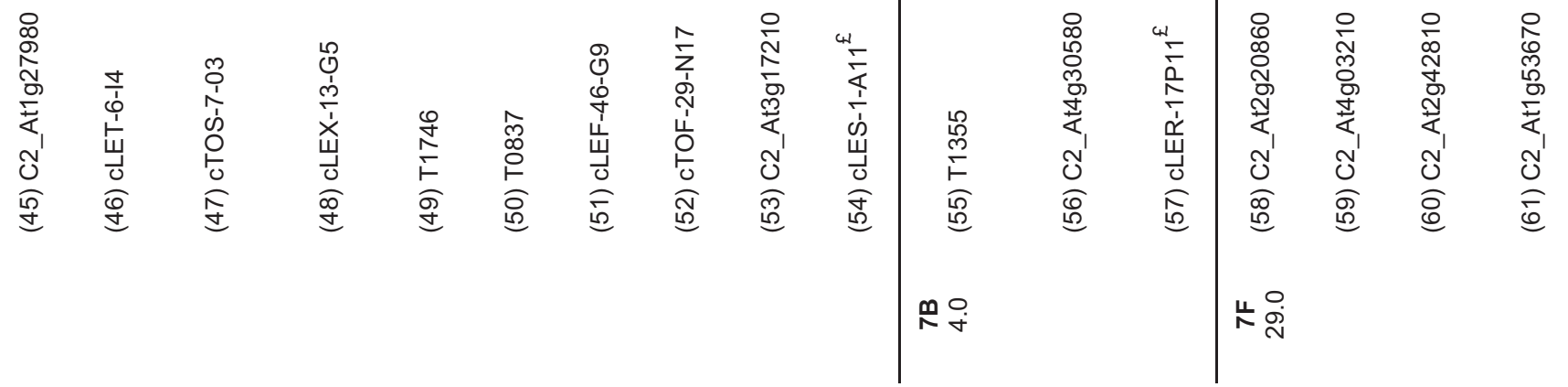




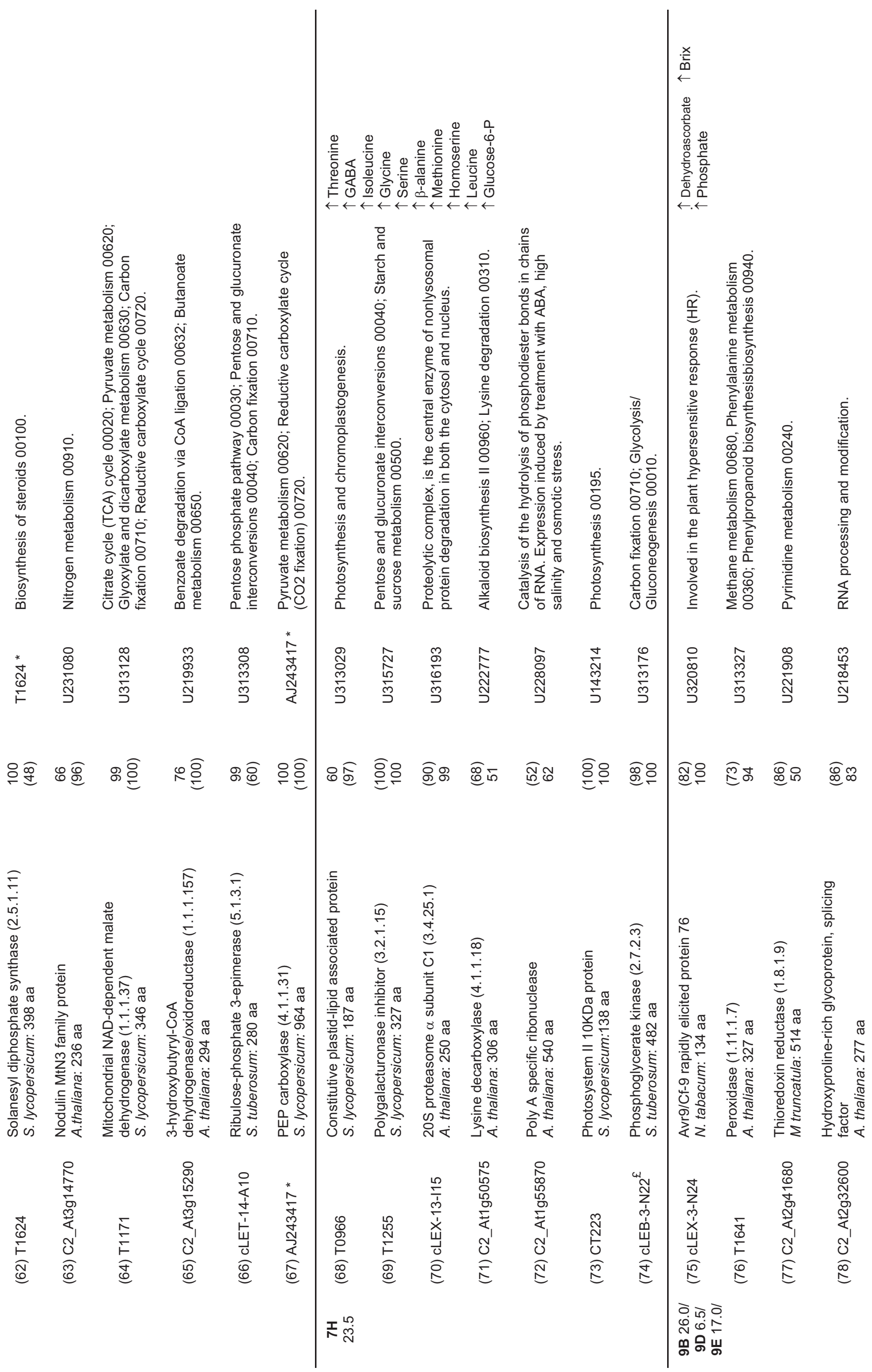




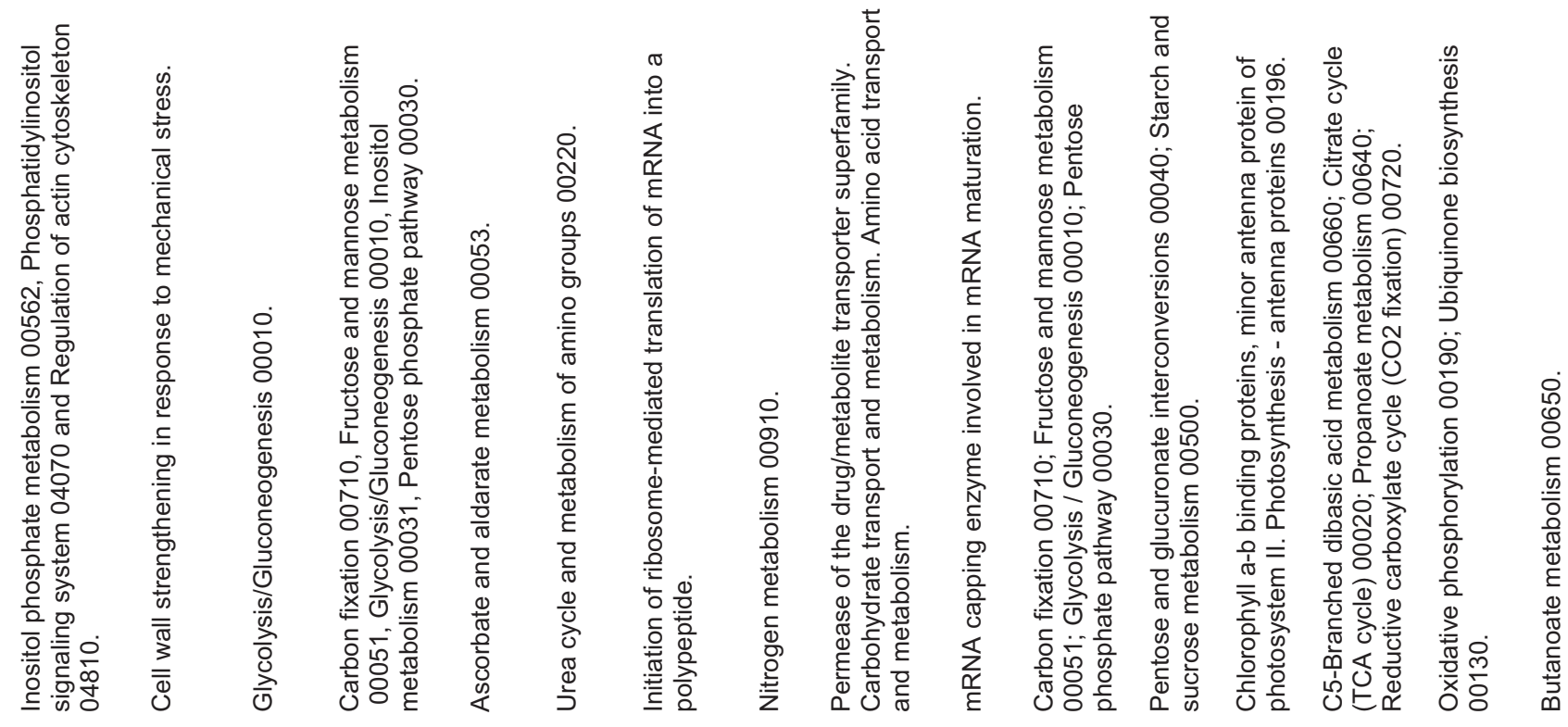

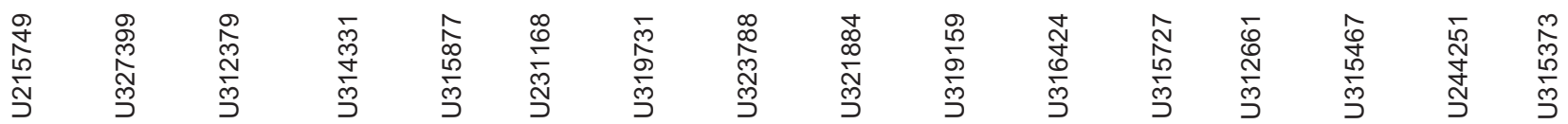

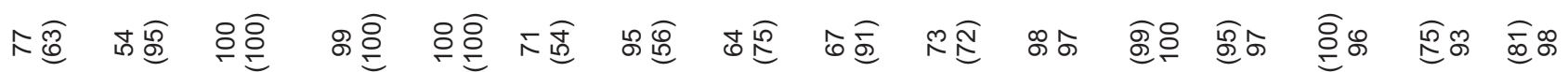

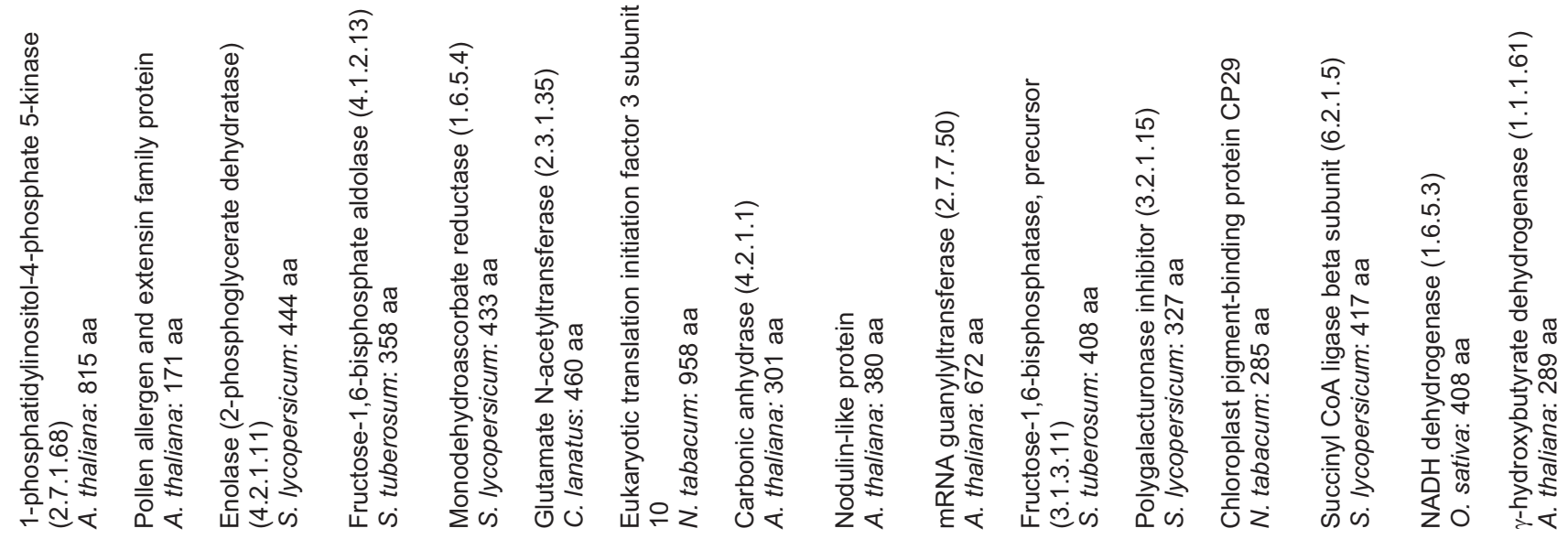

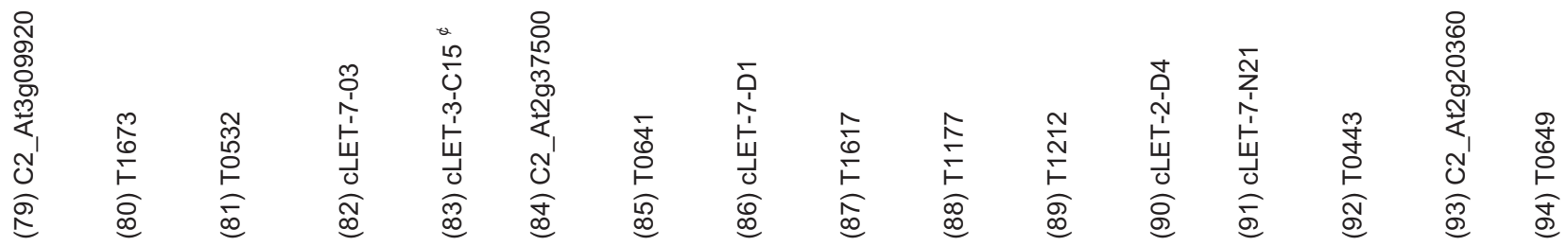




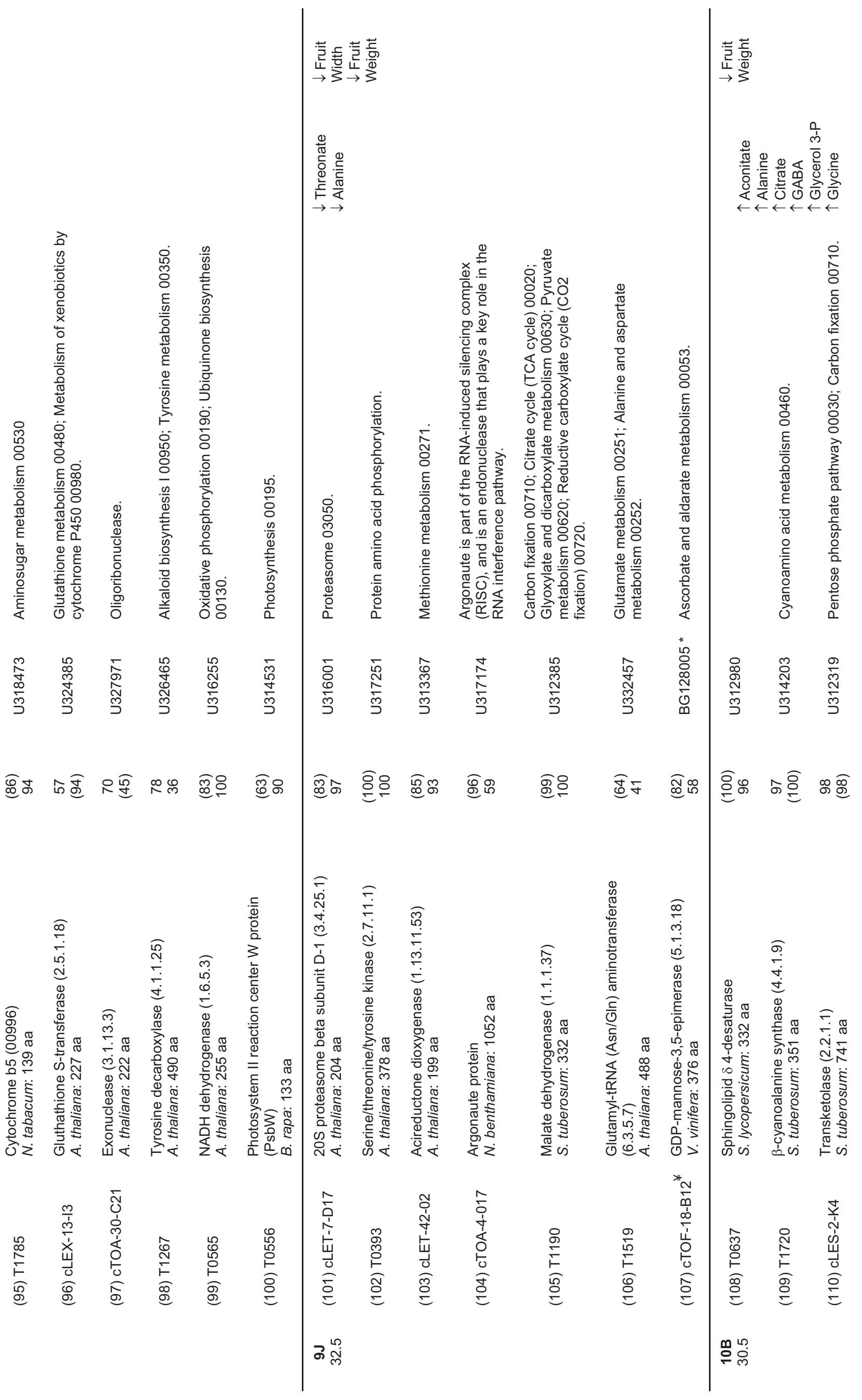




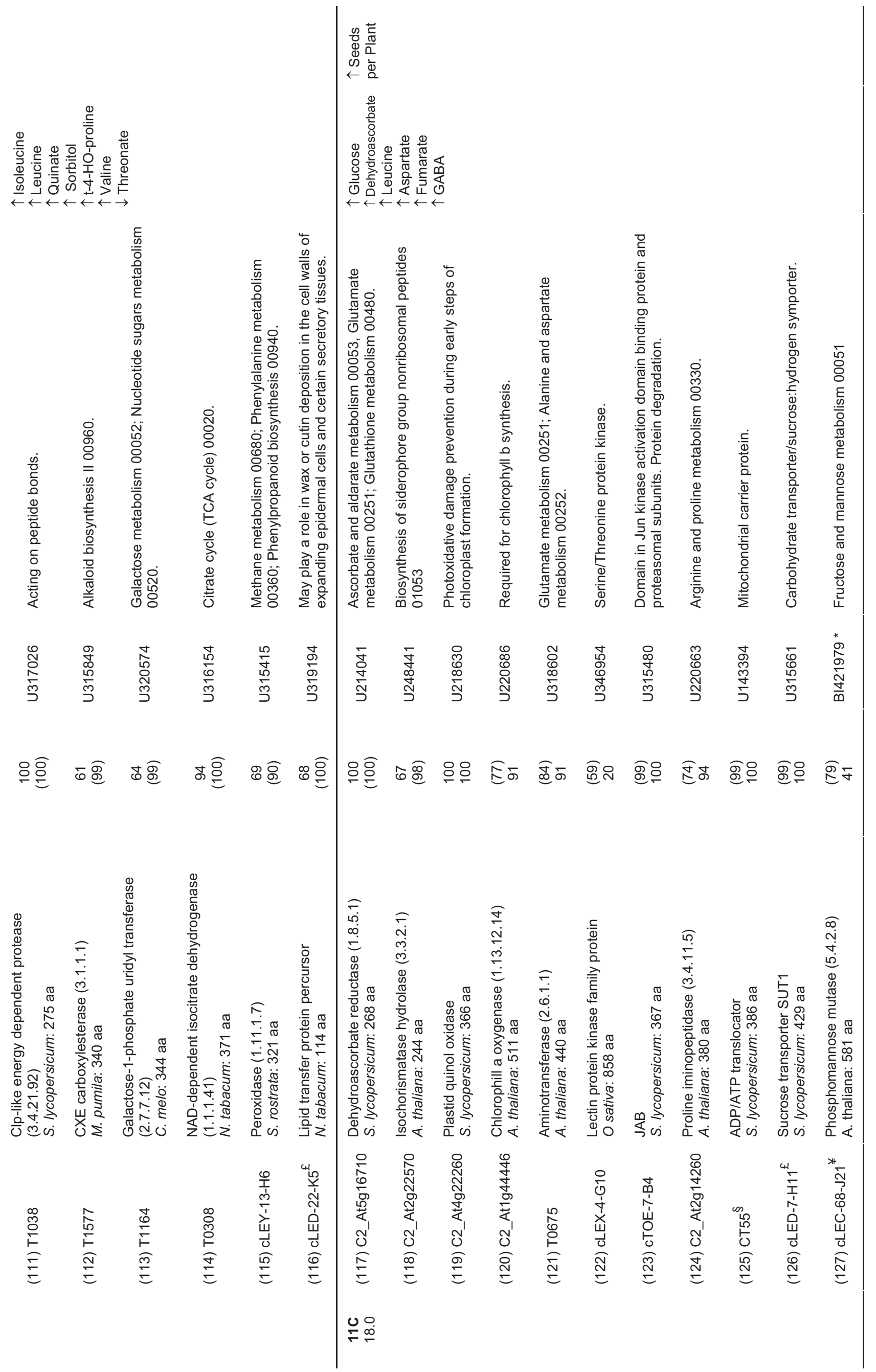




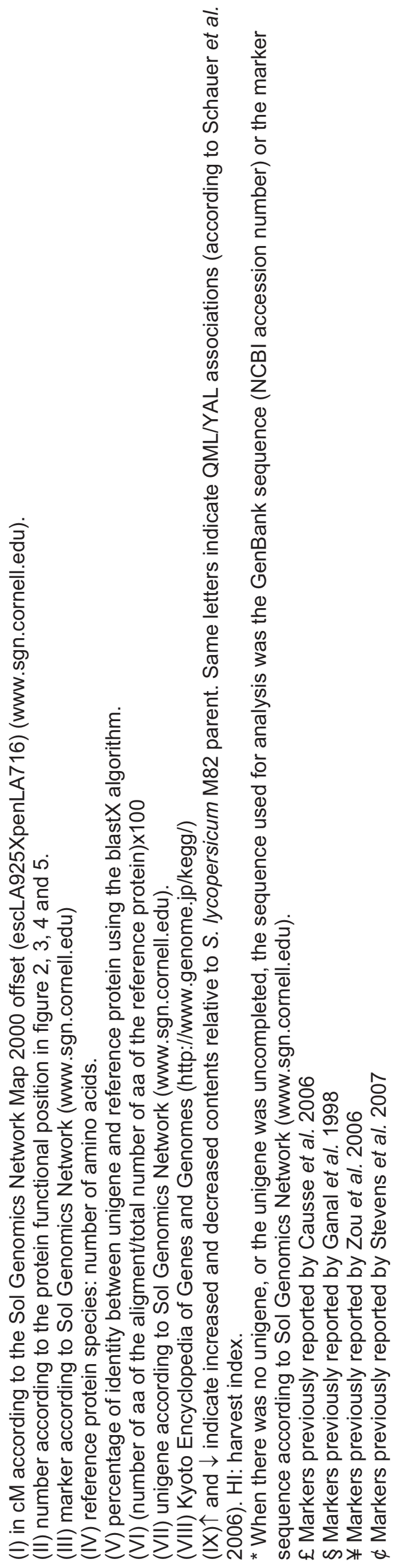


Table S2. Primer sequences used to amplify all selected candidate genes.

\begin{tabular}{|c|c|c|c|}
\hline Size $^{(l)}$ & $\begin{array}{l}\text { Number } \\
\text { Marker }\end{array}$ & $\begin{array}{c}\text { SGN } \\
\text { (Unigene) }^{(I V)}\end{array}$ & \\
\hline \multirow[t]{11}{*}{$\begin{array}{c}1 \mathrm{~J} \\
16.0\end{array}$} & (1) T0646 & U316058 & $\begin{array}{l}\text { GACAACATTCTCTGCAGCAAC } \\
\text { CAGATTCCTCTACAGCAGTTTC }\end{array}$ \\
\hline & (2) T1612 & U316688 & $\begin{array}{l}\text { TAAGCCCCAAATTACTAGGAACGTTG } \\
\text { GGTCTTCGAATGTCTCCCCATGAC }\end{array}$ \\
\hline & (3) T1006 & U317524 & $\begin{array}{l}\text { CAGCTACTTCACTTCCAAATTC } \\
\text { CСTCTGTTTCTTCTCTTTCTC }\end{array}$ \\
\hline & (4) C2_At4g34190 & U216629 & $\begin{array}{l}\text { GCTGTTGTTCAAATTTCCAGTTCTCTC } \\
\text { GACAGCGGTCAAAACGCCCACC }\end{array}$ \\
\hline & (5) CLET-1-A11 & U324336 & $\begin{array}{c}\text { GCAACCAAGGCACCGTAATC } \\
\text { CAAGCCACAGTGGATCTTCAGGA }\end{array}$ \\
\hline & (6) T1782 & U319301 & $\begin{array}{l}\text { GCTTGGTTTTTGTGTTCTCTCCC } \\
\text { GGCGATTTTTGGAACCCACAC }\end{array}$ \\
\hline & (7) C2_At4g34700 & U216646 & $\begin{array}{l}\text { CGACGTCGTAGGAAGTAGTTCTG } \\
\text { CAGCCTCTTCCTTGCCATAGTC }\end{array}$ \\
\hline & (8) T1749 & U326864 & $\begin{array}{l}\text { GGTACTAAGAGTTTCATCACAGGG } \\
\text { GAGACTCAGCGGCAAAGTAATC }\end{array}$ \\
\hline & (9) T1368 & U312881 & $\begin{array}{l}\text { ATGCCGGCCTTAGGTTGTTGTG } \\
\text { CTTCAAGCAACGCAGTATGGCC }\end{array}$ \\
\hline & (10) T0283 & U317298 & $\begin{array}{l}\text { CTTATCCGGAAGATGTTGTGC } \\
\text { CTCATCCTCTTCTAGCAAACTC }\end{array}$ \\
\hline & (11) T1306 & U319133 & $\begin{array}{l}\text { CGGCTATTATCTTGATTTGCGTGT } \\
\text { CCTCTCTCGAAGCATCATCTCTTT }\end{array}$ \\
\hline \multirow[t]{7}{*}{$\begin{array}{c}\mathbf{2 F} \\
25.0\end{array}$} & (12) T0869 & AY508112* & $\begin{array}{c}\text { GCCGTCTCTAGTTACGCTAG } \\
\text { GGAATCCAAAGCCTGAAGAACATC }\end{array}$ \\
\hline & (13) T1768 & U321585 & $\begin{array}{c}\text { GTTTTGCCGCCGGACTTTGAC } \\
\text { GCTCTGCCTTGGCATAAGATTTAC }\end{array}$ \\
\hline & (14) T1698 & U315881 & $\begin{array}{l}\text { ATGGCTCGTTCCGCTCTGG } \\
\text { GATTGAGGCAGCATCAGTAC }\end{array}$ \\
\hline & (15) C2_At2g34470 & U219076 & $\begin{array}{l}\text { CAGACCACCATATGAATGACCACC } \\
\text { CTTATTGCCTGTTGCAACTTCCCAG }\end{array}$ \\
\hline & (16) T1516 & U317147 & $\begin{array}{l}\text { GAAAAAGAAGCAGGTATTGGTC } \\
\text { GAACCAAAGAGTTCCTCGAATG }\end{array}$ \\
\hline & (17) сTOB-9-H18 & U315474 & $\begin{array}{c}\text { CAATCTCTATCATTTCGTCCGTCTC } \\
\text { CGACAGAGTTGTGACCACC }\end{array}$ \\
\hline & (18) TC128325 & U326680 & $\begin{array}{l}\text { CAGTAGTTCATCTTCATCACTCGG } \\
\text { CCCAACTGACTCTGCACTTCC }\end{array}$ \\
\hline \multirow[t]{8}{*}{$\begin{array}{c}4 \mathrm{4E} \\
25.0\end{array}$} & (19) T0891 & U320717 & $\begin{array}{l}\text { GAGGAAGCCGGTTTTGTTCTTGTTG } \\
\text { GTGCAGAGAACACTTCATGAACCAC }\end{array}$ \\
\hline & (20) T1070 & U323007 & $\begin{array}{l}\text { GCACTTCACCGCAACCTAAGG } \\
\text { CTCTGGTCCTTTGACAACATG }\end{array}$ \\
\hline & (21) CLED-7-G23 & U316425 & $\begin{array}{l}\text { CTCCAGAACCTTTGAGAAAGC } \\
\text { GCCTGAGGGTGAGATGCAATG }\end{array}$ \\
\hline & (22) T0635 & U313864 & $\begin{array}{l}\text { GCAGTTCTCCACTTTGGTACTC } \\
\text { GAAGTATCCCAGTATCCACGCC }\end{array}$ \\
\hline & (23) T1054 & U319327 & $\begin{array}{l}\text { GCTTCTTCCTTTTCACCATTTCACC } \\
\text { CAAGTTCAGGTATATAGGGAGCCC }\end{array}$ \\
\hline & (24) C2_At2g28880 & U226093 & $\begin{array}{c}\text { CTGCCATGTCTTCGTCATC } \\
\text { CTGATGAGAAGATGCTGCTCTG }\end{array}$ \\
\hline & (25) T1317 & AK247081* & $\begin{array}{c}\text { ATGGCGCTTGCCCCTCATTC } \\
\text { CAGTTGCTTCCATTTTAAGTCCATCC }\end{array}$ \\
\hline & (26) C2_At4g39660 & U220644 & $\begin{array}{l}\text { CCGGAATTACCAAGTTAAGGTGGTTC } \\
\text { GAGAATAATCCAGTGCATCAACTAGG }\end{array}$ \\
\hline
\end{tabular}




\begin{tabular}{|c|c|c|c|}
\hline & (27) C2_At1g35720 & U314161 & $\begin{array}{l}\text { GTTCCAGCATCAGTTCCAGATCC } \\
\text { CTCCGTGCCCAATCAGAGCCAG }\end{array}$ \\
\hline & (28) T1719 & L13653* & $\begin{array}{l}\text { GGTGATTTGAGTAACTTTCTAGTG } \\
\text { CTATTCACAGCTGCACAGTG }\end{array}$ \\
\hline & (29) T1107 & T1107 * & $\begin{array}{l}\text { ATGGACGCTCTGAATTCTTACGC } \\
\text { GCGTAAGAATTCAGAGCGTCCAT }\end{array}$ \\
\hline & (30) T0877 & U322584 & $\begin{array}{l}\text { GGGAACTTTGACTACTTCTCTAGTGG } \\
\text { CTTGCAAGCCTTGTTGGATGGTC }\end{array}$ \\
\hline & (31) T0883 & U313818 & $\begin{array}{l}\text { ATGGTAGGAACAAGTGCAGTAATC } \\
\text { GTGCTGAGGGCAGCAACAG }\end{array}$ \\
\hline \multirow[t]{9}{*}{$\begin{array}{c}4 I \\
11.0\end{array}$} & (32) T1606 & U312809 & $\begin{array}{l}\text { CGTCGGCGATTGCTTTCTCCG } \\
\text { GTGTGGCAGTCACAGTAGAGACC }\end{array}$ \\
\hline & (33) T0739 & U321142 & $\begin{array}{l}\text { CGTGGCGAAATTCGTACCCATG } \\
\text { CAGGTCAAAATGACAGGTCTTCTAG }\end{array}$ \\
\hline & (34) T1122 & U322245 & $\begin{array}{l}\text { CAGTGCTGAAATTCGTGAGCTGG } \\
\text { GCTACAAGCTCAATATCAGCAACAC }\end{array}$ \\
\hline & (35) cLEW-8-J19 & U324703 & $\begin{array}{l}\text { GGAGCTGGTGTTGTGTACCG } \\
\text { GACTCGTGCTCCCGGCCTC }\end{array}$ \\
\hline & (36) cLET-5-D13 & U312690 & $\begin{array}{l}\text { CTGTTACCTCTGCTGCTGTTGC } \\
\text { CTTTGCCAACCATTCCAGCTCC }\end{array}$ \\
\hline & (37) C2_At1g20575 & U224892 & $\begin{array}{l}\text { GGGGGAGAAGAACAAGTACAG } \\
\text { GGTTGCAAAACAACTCAAGTCTTC }\end{array}$ \\
\hline & (38) cTOE-17-L11 & U314841 & $\begin{array}{l}\text { CAGATTACGGCATAGCTCGAG } \\
\text { GGATGCAAAGCAGGTACCCC }\end{array}$ \\
\hline & (39) СТ239 & Z94058 * & $\begin{array}{l}\text { CCTCTCGGAGTTCCTCAACAG } \\
\text { GTTGACCGAGGTACTGTCGTG }\end{array}$ \\
\hline & (40) LED50 & AJ831581 * & $\begin{array}{l}\text { GGCTGCTGATTCTTTAAGAGGC } \\
\text { CTTCAGACACTCCAACAATGG }\end{array}$ \\
\hline \multirow{14}{*}{$\begin{array}{c}\text { 5D } 8.0 / \\
5 \mathrm{E} 30.0 / \\
5 \mathrm{~F} 3.0\end{array}$} & (41) T0778 & U317221 & $\begin{array}{l}\text { TCTCTTTACCCTCTTCATCTTTCC } \\
\text { GCTATCTGAAGCCTTGAACTGAGGTT }\end{array}$ \\
\hline & (42) T1174 & U321882 & $\begin{array}{l}\text { GGGATAAGCACTTTGTGAAACATTC } \\
\text { GGAGAAAAGAGGATGAGAAGGTAC }\end{array}$ \\
\hline & (43) T0328 & U315874 & $\begin{array}{l}\text { GGCTTCTCTGTCCAGATTTATTGGG } \\
\text { CTCCTTAAAATCATCCTTGTCATCAAC }\end{array}$ \\
\hline & (44) T1601 & U333333 & $\begin{array}{l}\text { CCAACTTCCCTTGTGTTCCAAT } \\
\text { CCATTTCGAGTGTAGGGTAAGTG }\end{array}$ \\
\hline & (45) C2_At1g27980 & U218388 & $\begin{array}{l}\text { ATCAGTTCAGAGCTTCAGCAAATTCC } \\
\text { CACGATTTCGGTACAGAACTACAC }\end{array}$ \\
\hline & (46) cLET-6-14 & U312900 & $\begin{array}{l}\text { CGAAACGAATATTGAAGGAGC } \\
\text { GGACCCAGAAGTATGCCATG }\end{array}$ \\
\hline & (47) cTOS-7-03 & U314198 & $\begin{array}{l}\text { GCCGAAGAACAAGGGTAAGGGAG } \\
\text { CAATGTCTTCATCCTCAAACTCAATGT }\end{array}$ \\
\hline & (48) cLEX-13-G5 & U315595 & $\begin{array}{l}\text { CACTAGAAATGATAAGACAAC } \\
\text { GATCGTGATGGCAGTAAGTTC }\end{array}$ \\
\hline & (49) T1746 & U323529 & $\begin{array}{l}\text { GTTCATCAGCACAGCTTTCTAC } \\
\text { CGACAGTTCTTCCTAATTTCACC }\end{array}$ \\
\hline & (50) T0837 & U312572 & $\begin{array}{l}\text { GCTTCCACACAATGTTTCTTGCACC } \\
\text { GCACCCTTAAACCATCTCTTGTC }\end{array}$ \\
\hline & (51) cLEF-46-G9 & U315616 & $\begin{array}{l}\text { CACACCCACGTACTCGCTTCG } \\
\text { CTAGATCAGGAGTTTCAGCC }\end{array}$ \\
\hline & (52) cTOF-29-N17 & U319587 & $\begin{array}{l}\text { CGGCTCTACAGTATTTGGAATCGC } \\
\text { CCAAATCAGGAGTTTCAGCTTCC }\end{array}$ \\
\hline & (53) C2_At3g17210 & U214933 & $\begin{array}{l}\text { GGAGGGTGGCAAAGGAGGAG } \\
\text { CAATTTGAGAATTCAGTTTAGGG }\end{array}$ \\
\hline & (54) cLES-1-A11 & U312789 & $\begin{array}{l}\text { GAGAGCGCATTGAAGGATCTGTC } \\
\text { CTGTAGCTTCGGTAGTTAGGAG }\end{array}$ \\
\hline
\end{tabular}




\begin{tabular}{|c|c|c|c|}
\hline \multirow[t]{3}{*}{$\begin{array}{l}7 \mathrm{~B} \\
4.0\end{array}$} & (55) T1355 & U323609 & $\begin{array}{l}\text { GACAGTGCTAGAAGCGTATTTAC } \\
\text { CTGAAGAAGACCCTGTTTTGG }\end{array}$ \\
\hline & (56) C2_At4g30580 & U229764 & $\begin{array}{l}\text { CTCCGACGAGGATTCCGAC } \\
\text { CCATGCAACGCTTGAGACATTC }\end{array}$ \\
\hline & (57) cLER-17P11 & U313426 & $\begin{array}{l}\text { GTAGTCTGCCTGTCGGAGTTTATT } \\
\text { CTTGAAGAGAAGACCACCGTG }\end{array}$ \\
\hline \multirow[t]{10}{*}{$\begin{array}{c}7 \mathrm{~F} \\
29.0\end{array}$} & (58) C2_At2g20860 & U217893 & $\begin{array}{c}\text { CACCGCTACACCAGCATCTCC } \\
\text { CAAAAGCATCTCAAAACCAGAAGC }\end{array}$ \\
\hline & (59) C2_At4g03210 & DQ098654* & $\begin{array}{l}\text { CAGTTGGGCTTTTTGACCATTTG } \\
\text { TGGTGGTGCTGGCACTCAAC }\end{array}$ \\
\hline & (60) C2_At2g42810 & U222683 & $\begin{array}{l}\text { CGGTATGGAAGCTGAGAACTC } \\
\text { CATGCGAAGGAAGTTGGC }\end{array}$ \\
\hline & (61) C2_At1g53670 & U216219 & $\begin{array}{l}\text { CTCGAACCATACAAATCTCCTC } \\
\text { CTTTAGAAGCAACATTATTCGTGC }\end{array}$ \\
\hline & (62) T1624 & T1624 * & $\begin{array}{l}\text { GTCTGTGACTTGCCATAATCTTG } \\
\text { CAATTCTCTCCAGATTATACTTC }\end{array}$ \\
\hline & (63) C2_At3g14770 & U231080 & $\begin{array}{l}\text { GATGCAGCTGGAATCGCCGGG } \\
\text { GAACTGCCATCACCTTGAGCTTGG }\end{array}$ \\
\hline & (64) T1171 & U313128 & $\begin{array}{l}\text { ATGTTGAAATCCATCGTCCGC } \\
\text { GAGGAGAGCAGCTCTGGC }\end{array}$ \\
\hline & (65) C2_At3g15290 & U219933 & $\begin{array}{l}\text { GGATCGGAGTTGTTGGCGCC } \\
\text { CGGTAATCATATACCCCAACCCC }\end{array}$ \\
\hline & (66) cLET-14-A10 & U313308 & $\begin{array}{l}\text { CTTTGGGTTCATCAACTCTGTTAC } \\
\text { TACTTGAACCAAGTAGGCCGG }\end{array}$ \\
\hline & (67) AJ243417 * & AJ243417 * & $\begin{array}{l}\text { GGCTACTCGTAATTTGGAGAAAT } \\
\text { CAATACCTTTCATGGTCAAGATG }\end{array}$ \\
\hline \multirow[t]{7}{*}{$\begin{array}{c}7 \mathrm{H} \\
23.5\end{array}$} & (68) T0966 & U313029 & $\begin{array}{l}\text { GTCGCACCGGGAAGCTTTTG } \\
\text { CATAGCTGCCATGGAAGTTGAAGAC }\end{array}$ \\
\hline & (69) T1255 & U315727 & $\begin{array}{l}\text { CCTTACCATTTAGCTTCATGG } \\
\text { TCCTCGACCTCCATACCTAC }\end{array}$ \\
\hline & (70) cLEX-13-I15 & U316193 & $\begin{array}{l}\text { GGAGGCTATTGGAAATGCAGG } \\
\text { GTAGGTTGAGTCAGTCCAGCAC }\end{array}$ \\
\hline & (71) C2_At1g50575 & U222777 & $\begin{array}{l}\text { GGGGTCTTGTATGAGAAAGGAAAC } \\
\text { ACATCTCACAACAGCATCCACCA }\end{array}$ \\
\hline & (72) C2_At1g55870 & U228097 & $\begin{array}{l}\text { TAAATTCATTGGTCCACTACCTTC } \\
\text { GCTTGCCAGAACTTCATCTAG }\end{array}$ \\
\hline & (73) СТ223 & U143214 & $\begin{array}{l}\text { GGCAAGCACAGTAATGAGCTC } \\
\text { GCGCCAAAGCACTTGTGTTG }\end{array}$ \\
\hline & (74) cLEB-3-N22 & U313176 & $\begin{array}{l}\text { GCATCAGCTACTGCTTCCCCAC } \\
\text { CTGCAACAGGGGCGTCAGCC }\end{array}$ \\
\hline \multirow{8}{*}{$\begin{array}{c}\text { 9B } 26.0 / \\
\text { 9D } 6.5 / \\
\text { 9E } 17.0\end{array}$} & (75) cLEX-3-N24 & U320810 & $\begin{array}{l}\text { GGCTGATCGCGTACATCCTCG } \\
\text { CCTTAACGGTGATTTCCCACG }\end{array}$ \\
\hline & (76) T1641 & U313327 & $\begin{array}{l}\text { CTCTTATTGTTATTACCTCTACTTC } \\
\text { CATCTTTTCTAATTTCACCTTGATC }\end{array}$ \\
\hline & (77) C2_At2g41680 & U221908 & $\begin{array}{l}\text { CAACACTGAGACTGTGGATGTCG } \\
\text { CATTTTAACACCTGATACCGTCC }\end{array}$ \\
\hline & (78) C2_At2g32600 & U218453 & $\begin{array}{l}\text { GACAGAGAATGGGGTTCGAAG } \\
\text { GTGGAGGTAGAGGCCTGGATG }\end{array}$ \\
\hline & (79) C2_At3g09920 & U215749 & $\begin{array}{l}\text { CGATGGAGTCTTGAAGGAGCC } \\
\text { GGTCTTCCTCCTGGAGCTCC }\end{array}$ \\
\hline & (80) T1673 & U327399 & $\begin{array}{l}\text { GAAGCCTCAGATGGAATGGATGTTATG } \\
\text { GGAGTTGTGTAGTAGAAAGGGCTAAG }\end{array}$ \\
\hline & (81) T0532 & U312379 & $\begin{array}{l}\text { GATCTTTGACAGCCGTGGTAAC } \\
\text { GCTCCTGCATAAACAGCCTCTG }\end{array}$ \\
\hline & (82) cLET-7-03 & U314331 & $\begin{array}{l}\text { CAAGGGAAAGTATGCTGATGAGC } \\
\text { GTAACTTTGTCCATTGCCTCACC }\end{array}$ \\
\hline
\end{tabular}




\begin{tabular}{|c|c|c|c|}
\hline & (83) cLET-3-C15 & U315877 & $\begin{array}{l}\text { GTATGTGATCGTCGGTGGCG } \\
\text { GCCCTCCTGTGCCAATTG }\end{array}$ \\
\hline & (84) C2_At2g37500 & U231168 & $\begin{array}{l}\text { CAGAACTCTTTAGCTGACCAAC } \\
\text { GTTAGGATGAATCATCCCAGAA }\end{array}$ \\
\hline & (85) T0641 & U319731 & $\begin{array}{l}\text { GAGAAGGAGATTGCGGCACCC } \\
\text { GTTTGCCAAAGAAGACAGCACCC }\end{array}$ \\
\hline & (86) cLET-7-D1 & U323788 & $\begin{array}{l}\text { GCTACAACAAGGATCTTGAGGACC } \\
\text { CCCGGTTCTTGATGGAGACTTGAT }\end{array}$ \\
\hline & (87) T1617 & U321884 & $\begin{array}{l}\text { GTTGAAAGTACACAATGGAGGCAG } \\
\text { GCCTTCATCTTCGGTAGCAG }\end{array}$ \\
\hline & (88) T1177 & U319159 & $\begin{array}{l}\text { GGGCATAATCGCACTGGGTTT } \\
\text { CAGTGTGCCAACTGGATCCATA }\end{array}$ \\
\hline & (89) T1212 & U316424 & $\begin{array}{l}\text { AAGTGCTCTAGACAAAAAGACTCC } \\
\text { CCAATGTACAATGGAACTCGTTGATG }\end{array}$ \\
\hline & (90) cLET-2-D4 & U315727 & $\begin{array}{l}\text { CTTCACTATCAGTAAGATGCAATC } \\
\text { CAAGGGAGAGCCACAAAGGCAT }\end{array}$ \\
\hline & (91) cLET-7-N21 & U312661 & $\begin{array}{l}\text { GCTACATCCTCGTTCATCGGAACAC } \\
\text { GTGTGAAGCGGGTCACTCAAG }\end{array}$ \\
\hline & (92) T0443 & U315467 & $\begin{array}{c}\text { GAGGAATGCTGCGTAAACTTGCCAATC } \\
\text { GGCCTTGACTGCCTTTTCAGCTG }\end{array}$ \\
\hline & (93) C2_At2g20360 & U244251 & $\begin{array}{l}\text { TGAGGTTCACCCAATTACTAG } \\
\text { GTACCGATCATCACTGCTGG }\end{array}$ \\
\hline & (94) T0649 & U315373 & $\begin{array}{l}\text { GGGTTTCTAGGGATTGGTATTATGGG } \\
\text { AAAGTCATGGTCTCCCAAGCCCAAG }\end{array}$ \\
\hline & (95) T1785 & U318473 & $\begin{array}{l}\text { CTGAGGTCTCCCAGCACAAC } \\
\text { GTAGAAGCGGAGGCCAACAGC }\end{array}$ \\
\hline & (96) cLEX-13-I3 & U324385 & $\begin{array}{c}\text { GGCATGCCCGTATGTGTATCG } \\
\text { CTCGACATACTTGTGATAAATTCCCAC }\end{array}$ \\
\hline & (97) сTOA-30-C21 & U327971 & $\begin{array}{l}\text { GGGGTGGATTGTGTTATGTTGC } \\
\text { GTGTCCCTTGTAGTATTTGAG }\end{array}$ \\
\hline & (98) T1267 & U326465 & $\begin{array}{l}\text { GTGATACAGGGAACAGCAAG } \\
\text { GATACTCAGGATTTGTTGACAGT }\end{array}$ \\
\hline & (99) T0565 & U316255 & $\begin{array}{l}\text { CCCGGGCTGCAGGAATCGG } \\
\text { CTGGATCCGGTAAGAGTTAAAC }\end{array}$ \\
\hline & (100) T0556 & U314531 & $\begin{array}{l}\text { CATCACTGCTTGCACCACAACTTC } \\
\text { CCAGAAGTGTAAACAGTGTAGAG }\end{array}$ \\
\hline \multirow[t]{7}{*}{$\begin{array}{c}9 \mathrm{~J} \\
32.5\end{array}$} & (101) cLET-7-D17 & U316001 & $\begin{array}{l}\text { GTCGGTAACGGTTTCTCACTGG } \\
\text { CTTTGACAGACTCGCGCCAAG }\end{array}$ \\
\hline & (102) T0393 & U317251 & $\begin{array}{l}\text { CTTTGCGTCTGTAAATGTTAAATGC } \\
\text { GGACCCTTACTACGAACAATGC }\end{array}$ \\
\hline & (103) cLET-42-02 & U313367 & $\begin{array}{l}\text { GCAAAGGATCCAAGAGAGGATGTC } \\
\text { GCAGCAGCATTAACAGCACGAC }\end{array}$ \\
\hline & (104) cTOA-4-017 & U317174 & $\begin{array}{l}\text { CGCAGATGGGATTATCCCTG } \\
\text { GACAGAACGAGTACACCTAGCA }\end{array}$ \\
\hline & (105) T1190 & U312385 & $\begin{array}{l}\text { ATAGGGCAAAAGATCCAGTTCGC } \\
\text { GCAAGGCAGGAGTAAGCCAATG }\end{array}$ \\
\hline & (106) T1519 & U332457 & $\begin{array}{l}\text { CATACTCCATAGAAACTGCTAAAC } \\
\text { GCACCCTGGTAATGCCAAAC }\end{array}$ \\
\hline & (107) cTOF-18-B12 & BG128005 * & $\begin{array}{l}\text { GGGAGCCCTACTGGCCTTCAG } \\
\text { CTGCTGTGCTTTCTCACGTCCG }\end{array}$ \\
\hline \multirow[t]{3}{*}{$\begin{array}{l}10 \mathrm{~B} \\
30.5\end{array}$} & (108) T0637 & U312980 & $\begin{array}{l}\text { GGGATTTGAAGGGGAAAAGAG } \\
\text { AACAACTTGAGTATAATGTCCCAC }\end{array}$ \\
\hline & (109) T1720 & U314203 & $\begin{array}{l}\text { CGTTGGTGAGGAGAAGATTTTATTCG } \\
\text { GCATGTTTTGTGCCTCTTTCCTGAGA }\end{array}$ \\
\hline & (110) cLES-2-K4 & U312319 & $\begin{array}{l}\text { CCCTCGCCATGGCTCATCTTC } \\
\text { CTCATTCAGTAGAGTAGACCAGC }\end{array}$ \\
\hline
\end{tabular}




\begin{tabular}{|c|c|c|c|}
\hline & (111) T1038 & U317026 & $\begin{array}{c}\text { CGTCTGCAATTGCTGGAACGTC } \\
\text { GATCAACAGCAGTTTTTTCATCTCTTG }\end{array}$ \\
\hline & (112) T1577 & U315849 & $\begin{array}{l}\text { CCGGGAATTCCTTGGAGGACAC } \\
\text { CCTCAAGAATAAGTTGTGTAGCTTC }\end{array}$ \\
\hline & (113) T1164 & U320574 & $\begin{array}{l}\text { GGCAGAAACGCCAAATCGGAG } \\
\text { GTTATTGGAGATTCTCACATCCC }\end{array}$ \\
\hline & (114) T0308 & U316154 & $\begin{array}{l}\text { GCTAAGCGAACCCTACCCATCC } \\
\text { CCAGATTTGCAATGACAGCATC }\end{array}$ \\
\hline & (115) cLEY-13-H6 & U315415 & $\begin{array}{l}\text { GCCAGCCATAAAACGAGTCG } \\
\text { CGTTCACCTTCCTGCAGTTTACG }\end{array}$ \\
\hline & (116) cLED-22-K5 & U319194 & $\begin{array}{l}\text { GCATGCTTTGTGGTTTTGTGC } \\
\text { GCATCTTATTCTTTGCCACCATG }\end{array}$ \\
\hline \multirow[t]{11}{*}{$\begin{array}{l}11 C \\
18.0\end{array}$} & (117) C2_At5g16710 & U214041 & $\begin{array}{l}\text { TCGACCGCAAAGATAACACCGTC } \\
\text { CTAACCCATGACTTTTGGTCG }\end{array}$ \\
\hline & (118) C2_At2g22570 & U248441 & $\begin{array}{l}\text { GAACGGTGGCGCAAGAGG } \\
\text { GACTAAGCAAGCTAAGAAGGTC }\end{array}$ \\
\hline & (119) C2_At4g22260 & U218630 & $\begin{array}{c}\text { GCGATTTCGATTTCTGCTATGAG } \\
\text { GTGACTGACTTCTTTATACAATCCACG }\end{array}$ \\
\hline & (120) C2_At1g44446 & U220686 & $\begin{array}{l}\text { GCCGCTCTAACAAGTCTTGTAC } \\
\text { GATGTGTTTCAGCAGGGGAGC }\end{array}$ \\
\hline & (121) T0675 & U318602 & $\begin{array}{l}\text { CCAGTCAAATGCTTCAGCAGC } \\
\text { CCTTCATCCTCTGCACTGC }\end{array}$ \\
\hline & (122) cLEX-4-G10 & U346954 & $\begin{array}{l}\text { CTTGACTTATCCTCCAGAATTATC } \\
\text { GAACTCATAGACCAGTACCCTGTG }\end{array}$ \\
\hline & (123) cTOE-7-B4 & U315480 & $\begin{array}{l}\text { GGACGCTCTGAATTCTTACGC } \\
\text { GTTTCGACCATCGGCTCTGG }\end{array}$ \\
\hline & (124) C2_At2g14260 & U220663 & $\begin{array}{c}\text { GATGAGATTACCCATGAAGTTGGC } \\
\text { GAGAAACTGAAAAATGTCCTTGAAGGAG }\end{array}$ \\
\hline & (125) CT55 & U143394 & $\begin{array}{l}\text { GCAGACATGAATCAGCATCCAAC } \\
\text { GCACCACCAGATCCGTATTTC }\end{array}$ \\
\hline & (126) cLED-7-H11 & U315661 & $\begin{array}{l}\text { GGTACAAAAGGGAAACTTACAG } \\
\text { GTTTAGCATCAGCAGGTGGTG }\end{array}$ \\
\hline & (127) cLEC-68-J21 & $\mathrm{B} \mid 421979$ * & $\begin{array}{l}\text { CTCCGTCGGTCATGACTCAC } \\
\text { CACGACCACTCGAATCCACAG }\end{array}$ \\
\hline \multicolumn{4}{|c|}{$\begin{array}{l}\text { (I) in cM according to the Sol Genomics Network Map } 2000 \text { offset (escLA925XpenLA716) } \\
\text { (www.sgn.cornell.edu). } \\
\text { (II) number according to the protein functional position in figure } 2 \text {. } \\
\text { (III) marker according to Sol Genomics Network (www.sgn.cornell.edu) } \\
\text { (IV) unigene according to Sol Genomics Network (www.sgn.cornell.edu). } \\
\text { *When there was no unigene, the sequence used for primer design was the GenBank sequence } \\
\text { (NCBI accession number) or the marker sequence according to Sol Genomics Network } \\
\text { (www.sgn.cornell.edu). }\end{array}$} \\
\hline
\end{tabular}


Capítulo II: Análise da diversidade genômica entre o tomate cultivado, Solanum lycopersicum, e a espécie selvagem Solanum pennellii. 



\section{INTRODUÇÃO}

A genômica comparativa é uma abordagem muito útil para a obtenção de informação biológica proveniente de sequências de DNA, permitindo a transferência de dados obtidos do estudo de uma espécie para outra, inclusive quando distantes filogeneticamente. Um caso extremo é o uso dos genomas de Escherichia coli, Homo sapiens, A. thaliana e Oryza sativa no entendimento do genoma do trigo (HeslopHarrison, 2000). A análise da diversidade alélica, ou entre genes ortólogos, permite identificar a origem da variação funcional e estrutural dos sistemas biológicos. Adicionalmente, converte-se em uma ferramenta determinante para estudos evolutivos e de biodiversidade.

A comparação de genomas filogeneticamente próximos tem permitido o descobrimento de variantes alélicas e novos genes, RNAs não-codificantes, elementos regulatórios e diversas sequências conservadas com função até hoje desconhecida (Guigó et al., 2003; Kellis et al., 2003; Siepel et al., 2007; Stark et al., 2007; Katzman et al., 2007; Zheng e Zhang, 2008; Clepet et al., 2011; Reineke et al., 2011). Porém, devido ao reduzido número de espécies de plantas vasculares com o genoma completamente sequenciado, não existem muitas sequências disponíveis de espécies filogeneticamente próximas, com exceção do grupo das gramíneas. Desta forma, as análises comparativas são restritas, sendo que os dados disponíveis estão limitados às regiões codificantes e elementos de transposição (Ku et al., 2000; Quiros et al., 2001; Ilic et al., 2003; Barakat et al., 2011; Sanchez et al., 2011; Liu et al., 2011).

Apesar da importância econômica de várias das espécies que compõem Solanaceae, a existência de uma ampla base de dados genéticos e de sequências genômicas e expressas, uma sólida plataforma bioinformática (Mueller et al., 2005, http://www.sgn.cornell.edu) e o genoma de tomate sequenciado, poucos são os trabalhos de genômica comparativa de grande escala (Rensink et al., 2005; Kamentezky et al., 2010; Song e Wang, 2010; Bossolini et al., 2011). Um destes trabalhos desenvolvido pelo nosso grupo (Kamentezky et al., 2010, vide anexo 1) comparou os genomas de um tomate silvestre, $S$. pennellii e do cultivado, $S$. lycopersicum, ao longo de cinco regiões genômicas que compreendem mais de 100 QTL associados com o metabolismo primário (Schauer et al., 2006, 2008). Para isso, foi construído um mapa físico ancorando 374 clones de BACs (Bacterial Artificial Chromosomes) e cosmídeos, provenientes de bibliotecas genômicas de $S$. pennellii, ao mapa genético de $S$. lycopersicum. A topologia do mapa mostrou que os genomas 
podem ser considerados, de forma geral, colineares (Figura 1A). No entanto, algumas regiões apresentaram evidências de rearranjos como inversões ou indels (Inserções/Deleções) (Figura 1B). Outra observação interessante foi a convergência de amplas distâncias genéticas de S. pennelli em intervalos menores em S. lycopersicum, como pode ser claramente evidenciado para o fragmento do cromossomo 4 analisado (Figura 1A). Esse resultado sugere expansões locais do genoma da espécie selvagem as quais se refletem na diferença de tamanho dos genomas, $1.200 \mathrm{Mb}$ e $950 \mathrm{Mb}$ para S. pennellii e S. lycopersicum, respectivamente (Kamentezky et al., 2010).

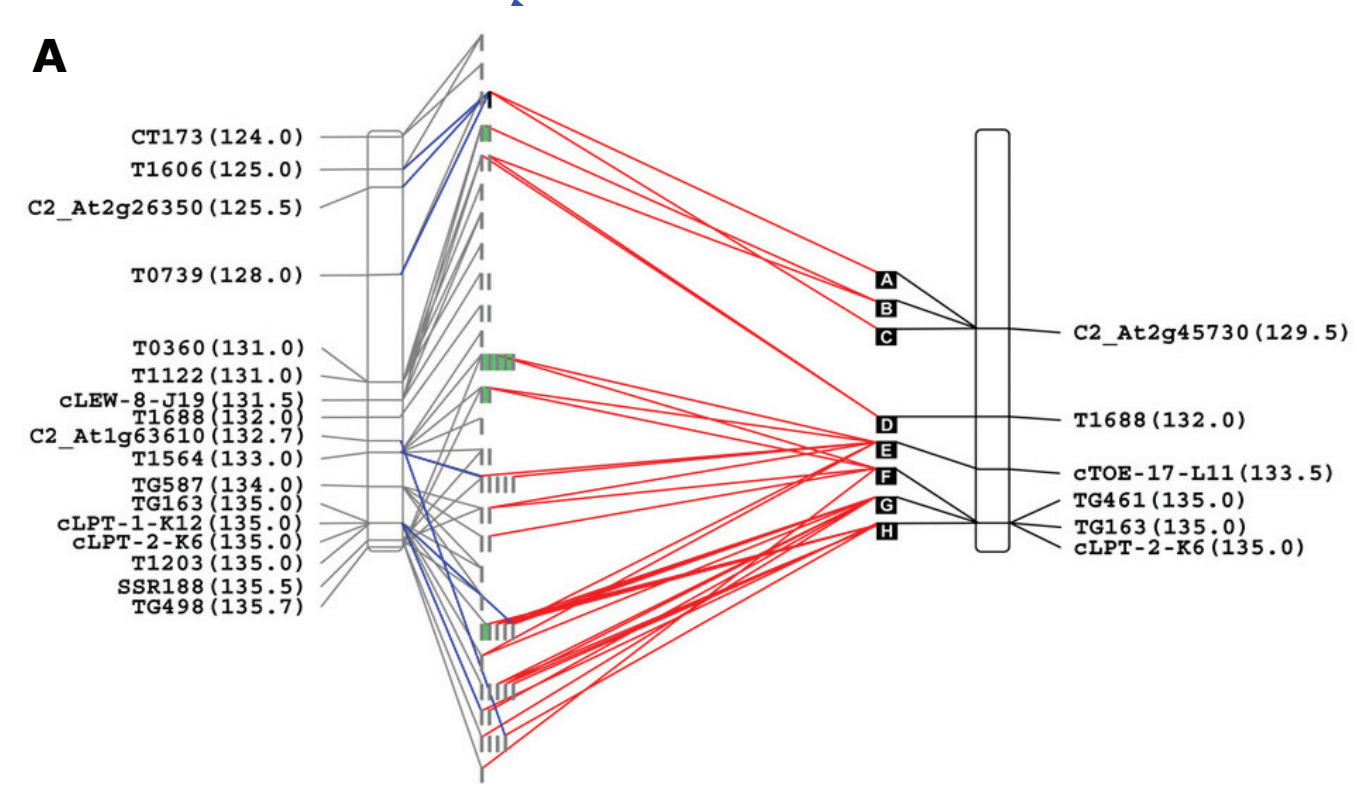

Figura 1. Mapas físicos e genéticos integrados de S. pennellii e S. lycopersicum.

Os marcadores genéticos e suas posições em cM de acordo ao mapa Tomato EXPEN 2000 estão indicados à esquerda e à direita dos fragmentos cromossômicos de $S$. pennellii e $S$. lycopersicum, respectivamente. Os clones ancorados de $S$. pennellii estão indicados com barras cinza. Os clones pertencentes ao mesmo contig estão agrupados em verde. Os clones de BAC de $S$. lycopersicum estão indicados com quadrados pretos. As linhas cinza unem clones de $S$. pennellii com os marcadores com os quais hibridam. As linhas azuis indicam os clones de $S$. pennellii que possuem a sequência do markers na sua sequência terminal. As linhas vermelhas unem os clones de ambas as espécies que possuem sequências ortólogas. As linhas pretas unem os clones de $S$. lycopersicum com seus correspondentes marcadores. (A) Fragmento do cromossomo 4, o clone indicado com uma seta azul foi totalmente sequenciado nesta tese e contém 0 gene candidato chaperona DnaJ. (B) Fragmento do cromossomo 7. Adaptado de Kamenetzky et al. (2010). 


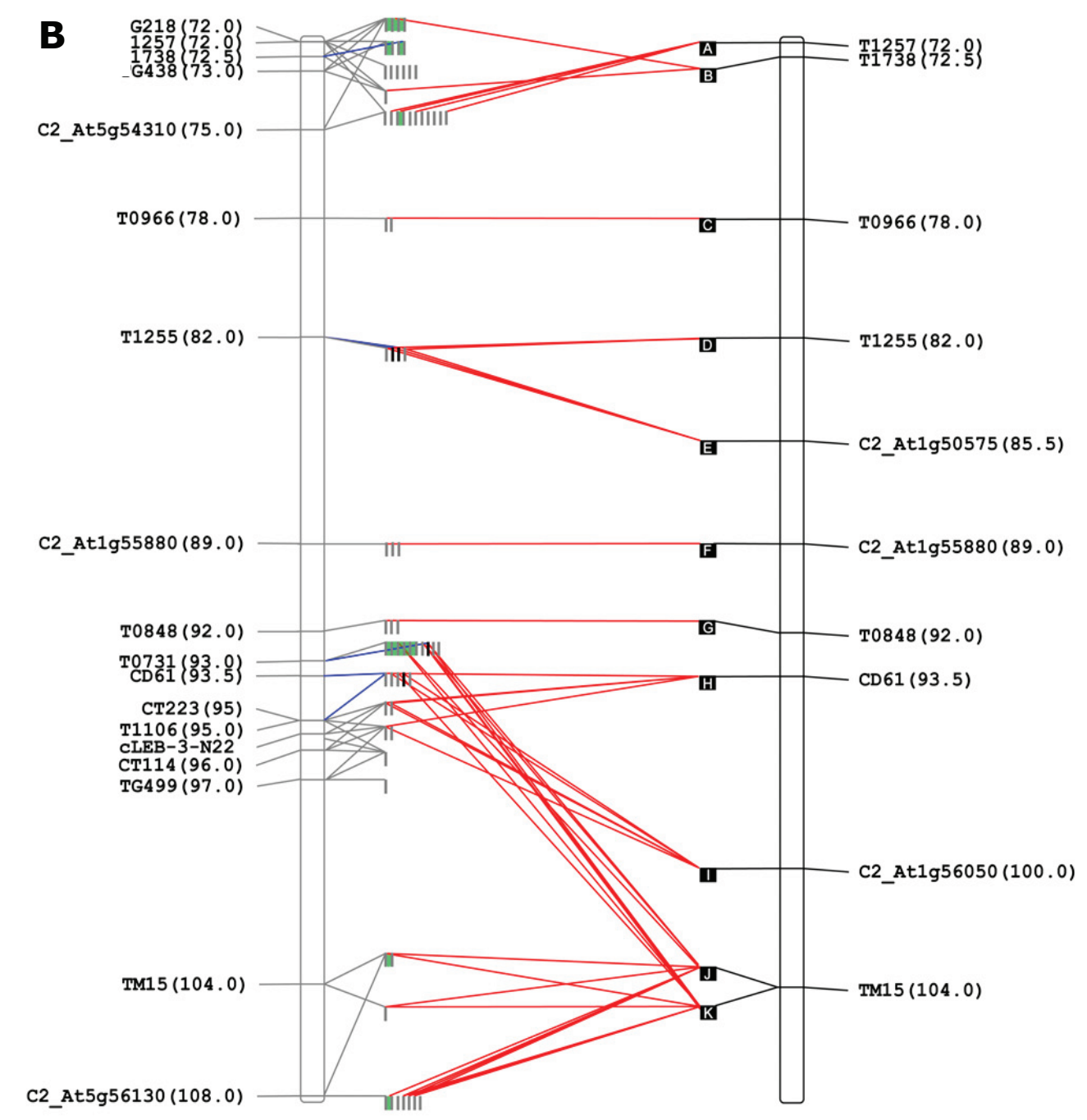

A fim de avaliar a diversidade genômica entre S. pennellii e S. lycopersicum por meio de outra abordagem, este trabalho realizou o sequenciamento, anotação e análise de um fragmento genômico do cromossomo 4, região na qual esta contido o gene candidato chaperona DnaJ identificado no capítulo I (Bermúdez et al., 2008). A escolha dessa região foi motivada pelo grande número de QTL descrito por Schauer et al. (2006) -37 QML e 10 YAL- associados a caracteres que determinam a qualidade do fruto. Além disso, as evidências funcionais descritas para a chaperona DnaJ discutidas no capitulo anterior revelam esse gene como um possível regulador metabólico. Desta forma, o sequenciamento da região é altamente desejável para revelar as diferenças genômicas que as determinam, já que as variações no conteúdo de metabólitos descritas nas ILs proveem do fragmento introgredido. Os resultados obtidos formam parte do mesmo artigo que descreve o mapa físico, publicado pelo grupo em 2010 (Kamenetzky et al., 2010). 


\section{OBJETIVOS}

Após ter sido descritos diversos genes candidatos associados a um vasto número de caracteres de interesse agronômico do fruto de tomate, o segundo objetivo desta Tese foi avaliar a diversidade genômica entre S. pennellii e S. Iycopersicum para melhor entender as diferenças que determinam as mudanças fenotípicas. Considerando as justificativas expostas na introdução deste capítulo, foi escolhido para a análise um fragmento genômico do cromossoma 4 que contém o gene candidato chaperona DnaJ.

Desta forma foram propostos os seguintes objetivos específicos:

1) Sequenciar e anotar um clone de BAC da espécie selvagem $S$. pennellii que contém o gene candidato chaperona DnaJ;

2) Analisar a microsintenia com a região ortóloga da espécie cultivada $S$. lycopersicum; e

3) Analisar o padrão de evolução dos genes identificados e estimar o tempo de divergência entre as duas espécies. 


\section{MATERIAIS E MÉTODOS}

\subsection{Sequenciamento do clone de BAC}

O BAC de S. pennellii C04SpBP093E005.P4C04 foi identificado a partir da triagem de uma biblioteca genômica da espécie selvagem (Chen et al., 2007) utilizando o marcador molecular T0739 (Kamenetzky et al., 2010). O DNA foi purificado usando o kit R.E.A.L Prep 96 Plasmid Kit (Qiagen) segundo recomendações do fabricante e sequenciado, por pirosequenciamento (plataforma 454 Roche) por meio de uma colaboração realizada com a empresa. 0 processo de montagem foi realizado usando 0 programa Phred+Phrap+Consed (Ewing e Green, 1998; Gordon et al., 1998).

\subsection{Anotação}

A sequência obtida do BAC de $S$. pennellii, assim como a correspondente ao clone ortólogo de S. Iycopersicum (C04HBa0331L22) obtido da Solanaceae Genomics Network (SGN, http://solgenomics.net/), foi anotado usando dois programas de predição gênica FGENESH (Salamov e Solovyev, 2000) e Augustus (Stanke et al., 2004). Cada clone foi comparado independentemente contra a base de dados de unigenes da SGN (versão de Setembro 2009, com 123.550 sequências e 92.327.235 bp) usando o programa de alinhamento global cross-match (www.phrap.org). As sequências dos genes preditos foram verificadas manualmente por comparação por BLAST (Altschul et al., 1990) com o unigene correspondente identificado. Quando não foi possível identificar um unigene associado na SGN, foi usada a base de dados do TIGR (Plant Transcript Assemblies) (http://plantta.tigr.org/). Apenas os genes preditos pelos dois programas e que apresentaram homologia com uma sequência de RNAm de S. Iycopersicum e/ou A. thaliana foram anotados. Quando os RNAm homólogos eram provenientes de $S$. Iycopersicum, foram utilizados parâmetros de corte de $95 \%$ de identidade e $90 \%$ de cobertura. Quando os RNAm eram provenientes de $A$. thaliana, os critérios considerados foram menos estringentes, com $70 \%$ de identidade e $85 \%$ de coberturaRNAm. A identificação das sequências repetitivas foi realizada usando o software RepeatMasker (http://www.repeatmasker.org), e só foram considerados elementos que cobriram no mínimo $70 \%$ da sequência do elemento de referência. Os retrotransposons com LTRs (repetições terminais longas, Long Terminal Repeats) foram identificados usando 0 programa LTR finder 
(http://tlife.fudan.edu.cn/ltr_finder/). Os genes encontrados no BAC de S. pennellii foram nomeados com a seguinte nomenclatura: Sp04gBP4C04.\#, em que Sp pertence a $S$. pennellii, os dois dígitos (04) indicam o número do cromossomo, g representa a sequência genômica, B que identifica o clone de BAC, os cinco dígitos (P4C04) indicam as coordenadas do clone na biblioteca, e o \# corresponde a números consecutivos que indicam a ordem dos genes dentro do clone. Para realizar a análise comparativa da região genômica ortóloga entre $S$. lycopersicum e $S$. pennellii, foi escolhido o clone de BAC C04HBa0331L22 de $S$. lycopersicum que foi o que apresentou a maior cobertura da sequência de S. pennellii. A identificação de indels e SNPs foi calculada usando o algoritmo Needleman-Wunsch global alignment disponível em http://www.ebi.ac.uk/Tools/emboss/align.

\subsection{Análises evolutivas}

As sequências codificantes dos genes foram alinhadas usando o software ClustalW multiple alignment (versão 1.5; Thompson et al., 1994). O alinhamento foi manualmente ajustado usando como referência o alinhamento da sequência protéica. As distâncias sinônimas $\left(d_{S}\right)$ e não-sinônimas $\left(d_{N}\right)$ foram estimadas usando o programa MEGA 3.1 (Kumar et al., 2004) e o método Nei-Gojobori (Jukes-Cantor). O desvio no uso de códons foi determinado pelo índice Nc (número efetivo de códons) usando o software DNAsp versão 4.10 .99 (Rozas et al., 2003). O teste de seleção foi realizado com o programa MEGA 3.1 (Kumar et al., 2004) usando o método Nei-Gojobori (JukesCantor). Para rejeitar a hipótese nula de evolução neutra $\left(d_{S}=d_{N}\right)$ foi considerado um $P<0,05$ no teste $Z$. $O$ teste da taxa relativa foi realizado usando o programa HYPHY (http://www.hyphy.org) e o modelo de códons proposto por Muse e Gaut (1994). Para rejeitar a hipótese nula de homogeneidade foi considerado um $P<0,05$ no teste de $\chi^{2}$. As taxas de substituição específicas da região genômica ( $r$ ) e o tempo de divergência entre as espécies foram estimados usando a equação $r=d_{S} / 2 \mathrm{~T}$, onde: $d_{S}$ é o número estimado da substituições sinônimas por sítio entre as sequências homólogas (distância sinônima) e T é o tempo de divergência. $r$ foi estimado usando o dado de tempo de divergência entre arabidopsis/Solanaceae baseado em dados fósseis de 120 MAA (milhões de anos atrás) (Bell et al., 2005; Magallon e Sanderson, 2005). Para o cálculo de $d_{S}$ foram utilizadas as regiões codificantes concatenadas dos genes. A estimativa do tempo de inserção do retrotransposon foi calculado utilizando o alinhamento das duas LTRs (ClustalW multiple alignment, version 1.5, Thompson et al., 1994). A distância 
genética (D) entre elas foi estimada com o programa MEGA 3.1 (Kumar et al., 2004) usando o modelo Kimura 2-parâmetros, o qual corrige a homoplasia e as diferenças nas taxas de transição e transversão. A data de inserção do retrotransposon foi estimada usando $T=D / 2 r$, onde: $r$ corresponde a $1,3 \times 10^{-8}$ substituições por sítio por ano como foi proposto por Ma e Bennetzen (2004). Os intervalos de confiança foram calculados usando o erro padrão da distância média (D) estimado com o programa MEGA 3.1. 


\section{RESULTADOS}

\subsection{Anotação e análise de microssintenia}

No capítulo I foram identificados 127 genes candidatos que co-localizavam com 106 QTL associados a caracteres de rendimento e qualidade nutricional do fruto de tomate ao longo de 16 regiões cromossômicas. Em particular, localizado a 128 cM do cromossomo 4, existe um gene codificante para uma chaperona DnaJ que se apresentou como possível candidato para explicar as diferenças do conteúdo de aminoácidos, ácidos orgânicos e açúcares observadas entre a linhagem introgredida 44 e o controle S. Iycopersicum (M82) (Schauer et al., 2006). Este gene foi identificado a partir da sequência do marcador T0739 (Figura 1) o qual foi utilizado para triar bibliotecas genômicas de S. pennellii (Kamenetzy et al., 2010). Desta forma, foi selecionado o clone de BAC C04SpBP093E005.P4C04 que foi sequenciado com o intuito de realizar um estudo de microsintenia entre $S$. pennellii e $S$. lycopersicum, avaliando: i) ordem gênica, ii) diferenças alélicas e iii) existência de elementos regulatórios ou padrão de inserção de elementos de transposição diferenciais entre ambas as espécies.

Após o sequenciamento do clone C04SpBP093E005.P4C04, cujo tamanho revelado perfaz 83.193 pb, a anotação realizada revelou uma densidade gênica de 0,2 genes/Kb. Para as outras regiões do genoma foi observada uma densidade de 0,1 genes/Kb (Kamenetzky et al., 2010), e uma menor densidade de elementos de transposição. A anotação do clone ortólogo de $S$. lycopersicum e a comparação de ambas as espécies permitiu a identificação de 14 genes ao longo dos 77.972 pb do genoma. Os genes apresentaram alta conservação na ordem, orientação e estrutura gênica (éxons/íntrons) (Tabela 1, Figura 2). Só foram observadas alterações da colinearidade do tamanho das regiões intergênicas e no padrão de inserção de elementos de transposição, já que foi encontrado um retroelemento presente unicamente na sequência de $S$. pennellii (Figura 2). Adicionalmente, analisando a distribuição dos polimorfismos, foi encontrada, como esperado, uma maior porcentagem de indels nas regiões intergênicas do que nas gênicas (Figura 2), e em íntrons do que nos éxons (Tabela 1). 


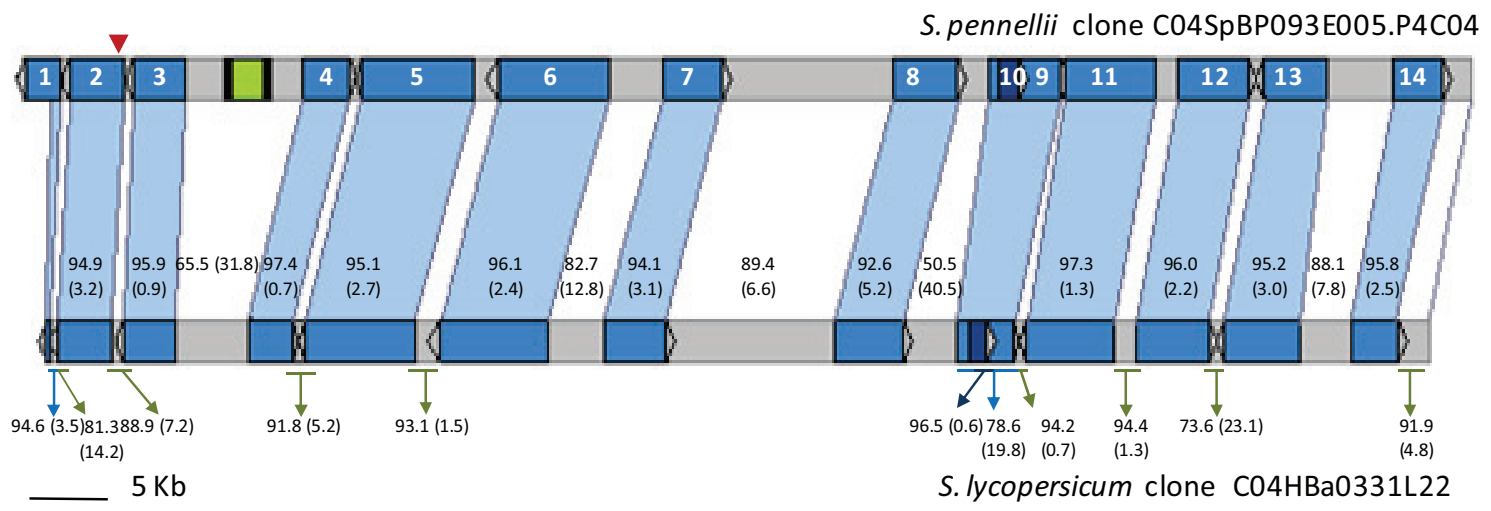

Figura 2. Microsintenia entre S. Iycopersicum e S. pennellii da região genômica que contêm o gene chaperona DnaJ. Os genes encontram-se indicados como setas azuis e nomeados de acordo com a Tabela 1. O gene chaperona DnaJ encontra-se indicado com a seta vermelha. $O$ retângulo verde representa o retroelemento identificado na sequência de $S$. pennellii, e as suas LTRs encontram-se indicadas como linhas pretas nos extremos do elemento. A porcentagem de identidade e de indels entre os genótipos, ao longo das regiões gênicas, incluindo as regiões não traduzidas, e intergênicas, encontram-se indicadas.

Analisando os genes identificados, dois novos candidatos surgem particularmente interessantes como possíveis envolvidos nas alterações no conteúdo de açúcares solúveis observadas. O Sp04gBP4C04.8, que corresponde a uma hexoquinase plastidial e o Sp04gBP4C04.13 que codifica uma B-frutofuranosidase (invertase). Ambos os genes são expressos no fruto e apresentam polimorfismos de aminoácidos (Tabela 1). Interessantemente, foi observada também, em menor escala, uma colinearidade com um fragmento do cromossomo 1 do genoma de arabidopsis (Tabela 1). 


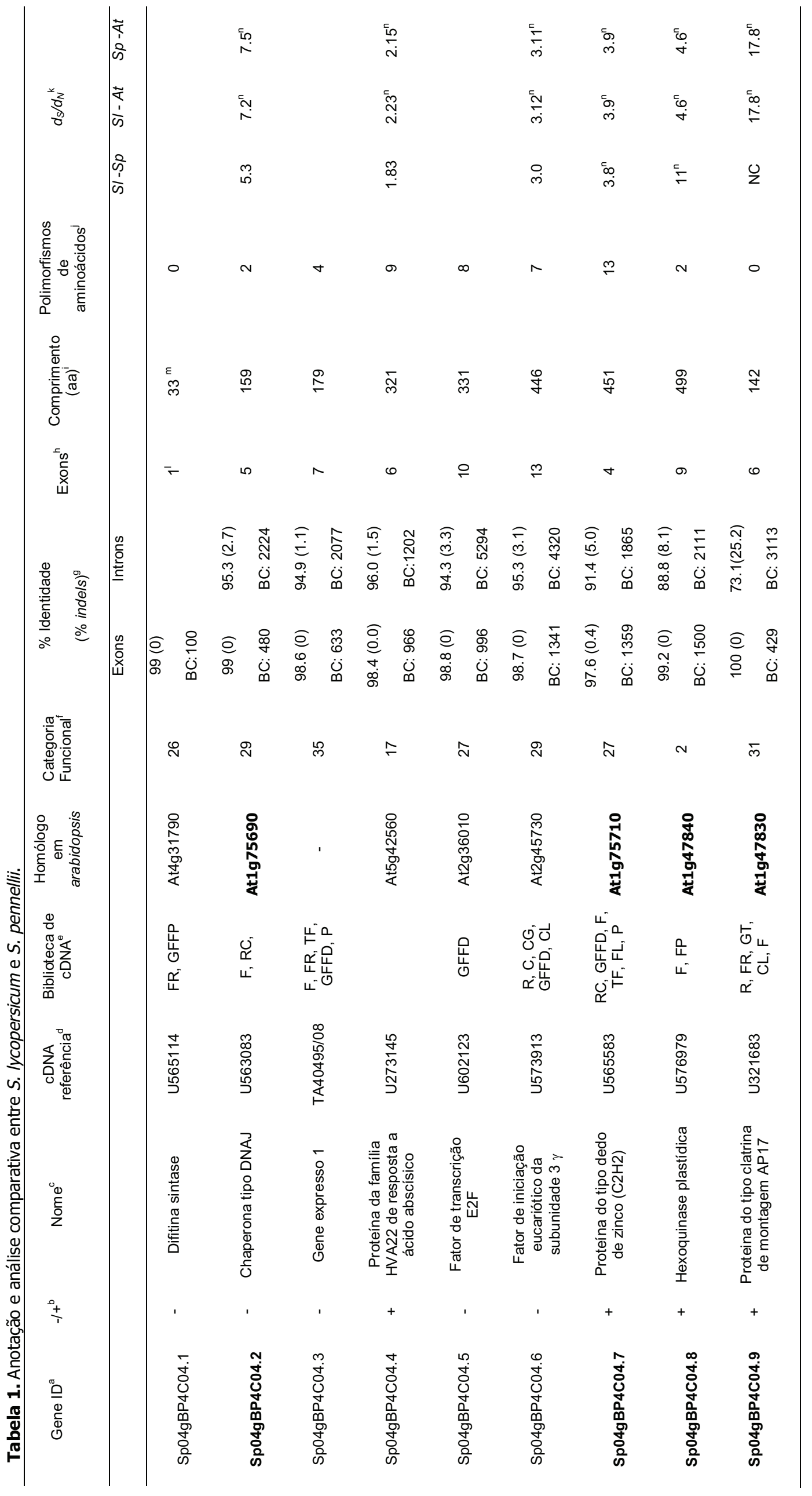




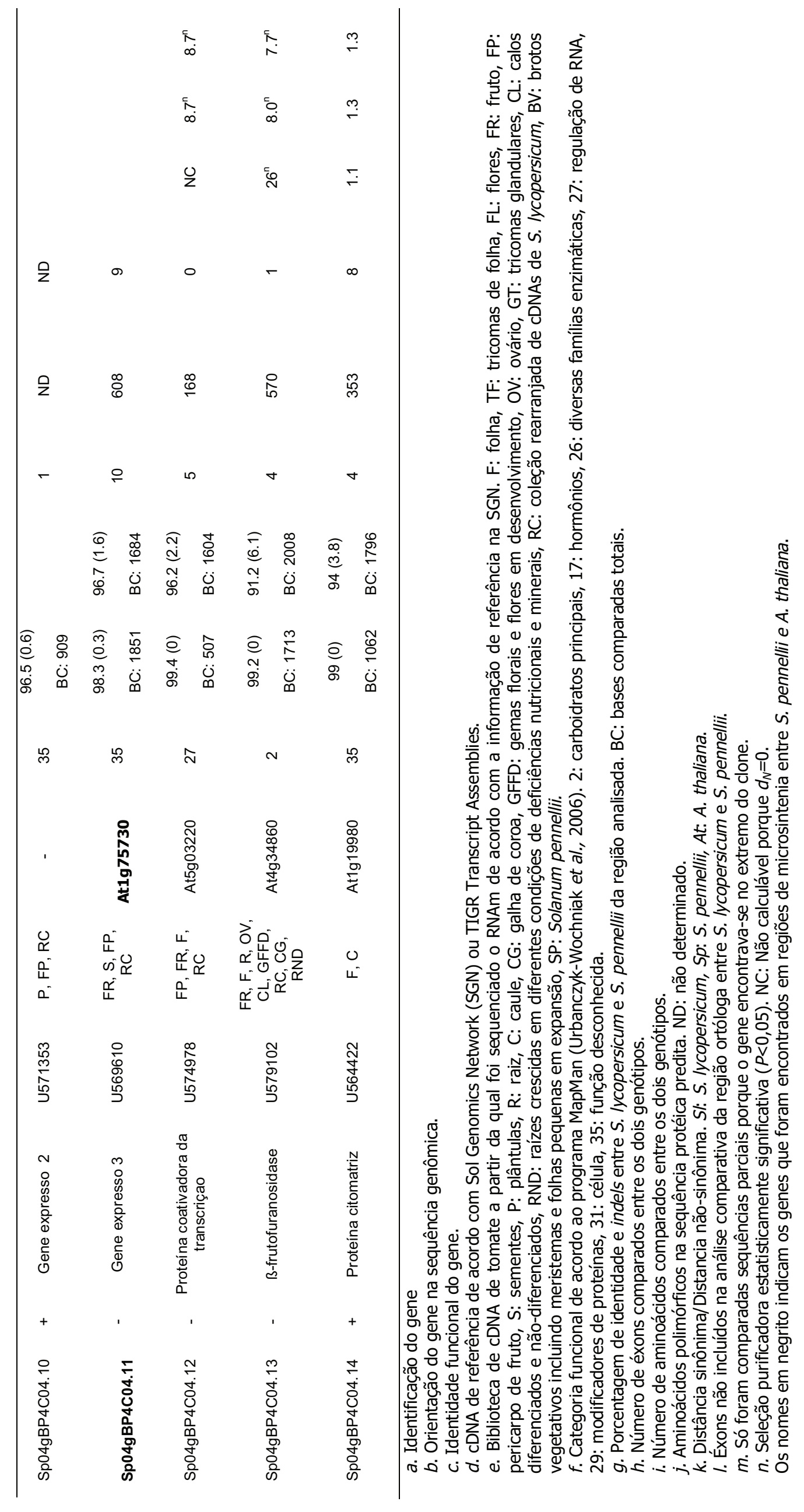




\subsection{Análises evolutivas}

Para avaliar o grau de conservação de cada gene, foi estimada a razão entre as distâncias sinônimas e não-sinônimas $\left(d_{S} / d_{N}\right)$. A escolha dos genes a serem avaliados foi baseado nos seguintes critérios: i) apresentar a sequência codificante completa (assim o gene Sp04gBP4C04.1 foi descartado); ii) apresentar ortólogos de $A$. thaliana, e; iii) mostrar taxas de substituição relativa homogênea entre $S$. lycopersicum e $S$. pennellii, considerando $A$. thaliana como o grupo externo. Para os treze genes analisados, a taxa $d_{S} / d_{N}$ foi maior que 1 , indicando a ausência de seleção positiva (Tabela 1). Foi realizado um teste de seleção sendo identificados genes sob evolução neutra $\left(d_{S}=d_{N}\right)$ e seleção purificadora $\left(d_{S}>d_{N}\right)$ (Tabela 1$)$. Todos os genes que apresentaram seleção purificadora não-significativa entre $S$. lycopersicum e $S$. pennellii também demonstraram ter polimorfismos na sequência de aminoácidos. É importante ressaltar que a taxa $d_{S} / d_{N}$ pode ser mal interpretada quando o desvio no uso de códons é alto, porém, para os dados usados neste trabalho, não foi observado qualquer viés de códons para nenhum gene nas três espécies analisadas.

Os dados obtidos do sequenciamento, anotação e comparação das regiões ortólogas entre $S$. pennellii e $S$. lycopersicum apresentadas neste trabalho constituem uma informação muito valiosa para estimar a data de divergência entre essas duas espécies de tomate. Usando a estimativa de 120 milhões de anos como data de divergência entre $A$. thaliana e Solanaceae (Bell et al., 2005, Magallon e Sanderson, 2005), foram estimadas as taxas de substituição específica para a região genômica analisada e o tempo de divergência entre as espécies. Assim, foi obtida uma taxa de substituição de $4,26 \times 10^{-09}$ por sítio por ano e uma data de divergência estimada de $2,9( \pm 690,736)$ milhões de anos (Figura 3). A identificação do retrotransposon do tipo Copia, SHACOP_I_MT com ambas as LTRs, no genoma de S. pennelli unicamente, permitiu estimar a data de inserção do mesmo baseado no relógio molecular. O cálculo resultou em 150 mil anos o qual esta de acordo com a data estimada de divergência entre as duas espécies mencionadas acima (Figura 3). 


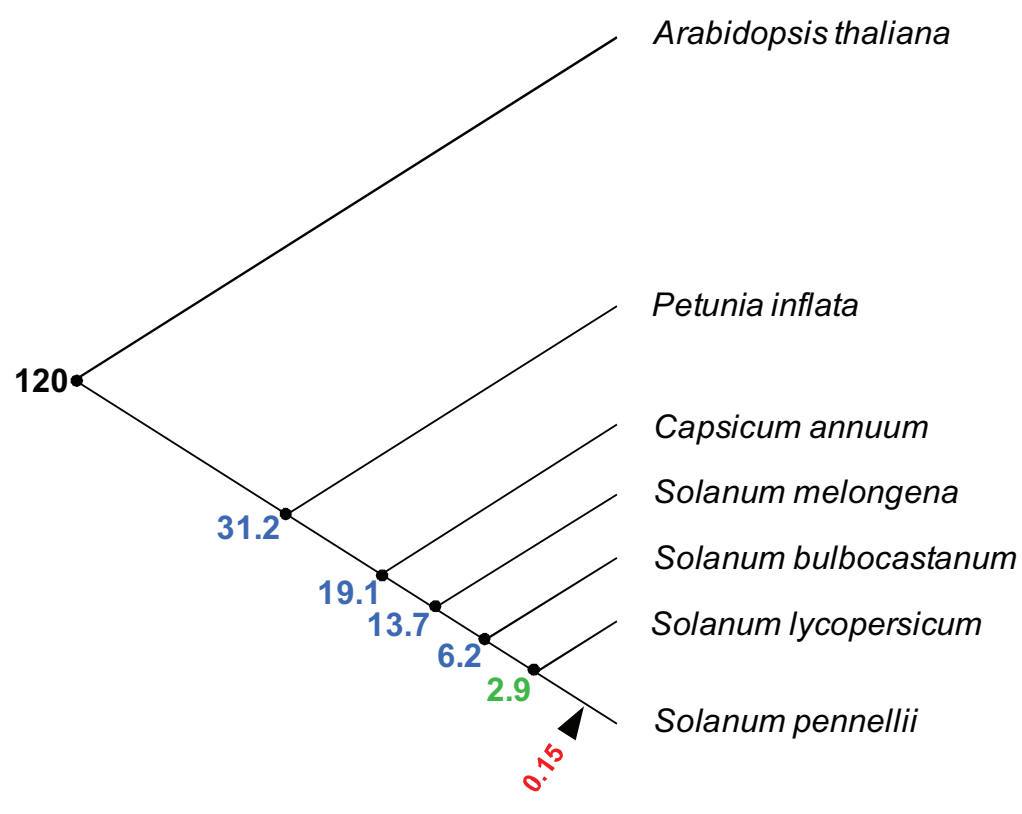

Figura 3. Estimativa do tempo de divergência das espécies.

As datas estimadas por Bell et al. (2005) e Magallon e Anderson (2005) estão em preto. As datas estimadas por Wang et al. (2008) estão em azul. A divergência entre S. pennellii e S. lycopersicum, estimada segundo o relógio molecular, está indicada em verde. A inserção do retrotransposon SHACOP_I_MT está indicada com uma seta em vermelho. 


\section{DISCUSSÃO}

A domesticação das plantas cultivadas é um dos eventos mais recentes que influem drasticamente na evolução das plantas. Existem evidências que as mudanças anatômicas selecionadas durante a domesticação são determinadas pela modificação dos padrões de expressão gênica de poucos locos regulatórios (Doebley et al., 1997). Por exemplo, demonstrou-se que os alelos determinantes do tamanho do fruto não apresentam diferenças na sequência protéica, mas sim nos níveis de transcrição devido a polimorfismos na região promotora (Nesbitt e Tanksley, 2002). Porém, neste trabalho foi observado um padrão diferente identificando-se polimorfismos nas sequências protéicas. Nas 77.972 bases comparadas entre os dois genótipos foram identificados 14 genes dos quais 10 apresentaram polimorfismos na sequência protéica. Ainda mais, dentre os sete genes para os quais foi possível estimar a taxa $d_{S} / d_{N}$, quatro não apresentaram seleção purificadora entre $S$. pennellii e $S$. lycopersicum. Inclusive os três genes que mostraram seleção purificadora também apresentaram polimorfismos de aminoácidos. Estes resultados indicam que as regiões codificantes analisadas estão divergindo com diferentes graus de pressão seletiva desde a divergência entre as duas espécies. Todos os genes analisados, exceto pela proteína codificante para citomatriz (Sp04gBP4C04.14), apresentaram seleção purificadora entre tomate e arabidopsis, indicando que os genes analisados teriam uma função conservada evolutivamente. Em trabalhos prévios, Nesbitt e Tanksley (2002) reportaram uma data de divergência entre $S$. pennellii e $S$. lycopersicum de sete milhões de anos, usando uma taxa de substituição de $6,03 \times 10^{-9}$ e quatro locos. Por outro lado, Wang et al. (2008) reportaram a análise de sequências de um segmento sintênico conservado nos genomas de cinco espécies de Solanaceas (petunia [Petunia hybrida], pimenta [Capsicum annuum], berinjela [Solanum melongena], batata [Solanum tuberosum] e tomate). Esses resultados indicam que o último ancestral comum entre as espécies viveu há aproximadamente 31,2 milhões de anos e que a divergência entre a batata e o tomate ocorreu há aproximadamente 6,2 milhões de anos atrás, data incompatível com a de Nesbitt e Tanksley (2002). Os nossos dados, baseados em 14 locos, nos permitiram estimar a data de divergência entre $S$. pennellii e $S$. Iycopersicum em 2,7 milhões de anos. Estes dados, aliado ao fato de $S$. pennellii ser uma das espécies selvagens mais distantes de $S$. lycopersicum, indicariam que as espécies do gênero Solanum divergiram mais recentemente do que tinha sido reportado previamente. $O$ retransposon do tipo Copia identificado na sequência de $S$. 
pennellii apresenta uma data de inserção estimada de 150 mil anos, como esperado, após a divergência entre as duas espécies. Recentemente, em diversos trabalhos têm sido demonstrado o impacto dos elementos de transposição em caracteres de interesse agronômico. Como alguns exemplos, podemos citar o efeito da inserção de um retrotransposon no acúmulo de $\beta$-caroteno nos plastídios de diferentes órgãos em couve-flor (Brassica oleracea) (Lu et al., 2006) e também na duplicação de um gene causando variações morfológicas no fruto de tomate (Xiao et al., 2008). Desta maneira, esse elemento de transposição diferencial identificado poderia ser estudado para avaliar o seu possível efeito em padrões diferenciais de expressão entre $S$. pennellii e $S$. lycopersicum.

Finalmente, estudos funcionais deverão ser desenvolvidos com o intuito de verificar o envolvimento dos novos genes candidatos identificados, uma hexoquinase plastidial e uma ß-frutofuranosidase, no metabolismo de açúcares no fruto do tomate.

Não foram encontrados rearranjos na região estudada, no entanto, a existência de polimorfismos tanto nas regiões codificantes como nas não-codificantes, permitem postular que sejam essas as responsáveis pelas mudanças fenotípicas observadas. Desta forma, havendo obtido a sequência genômica do alelo de $S$. pennellii do gene chaperona DnaJ, que apresenta polimorfismos tanto na região regulatória quanto na sua sequência protéica, esta tese propôs um estudo funcional deste gene que se desenvolve no capítulo III. 


\section{CONCLUSÕES}

A partir do sequenciamento de uma região genômica de $83,42 \mathrm{~Kb}$ da espécie selvagem $S$. pennellii e da análise comparativa com a região ortóloga de $S$. lycopersicum, os resultados obtidos permitiram estabelecer as seguintes conclusões:

1) A região cromossômica analisada apresenta um ordenamento genômico semelhante entre as espécies, tanto a respeito do conteúdo gênico quanto à orientação dos mesmos assim como das regiões intergênicas. A microsintenia foi interrompida unicamente pela inserção de um retrotransposon do tipo Copia, SHACOP_I_MT, no genoma de S. pennellii;

2) A identificação de genes e a sua comparação com outros segmentos cromossômicos analisados ao longo deste trabalho (Kamenetzky et al., 2010) permitem concluir que se trata de uma região com densidade gênica maior à média $(0,2$ versus 0,1 genes/Kb); o qual está de acordo com o número de QML e YAL associados a ela, e;

3) Os dados obtidos permitiram estimar a taxa de divergência entre estas duas espécies do gênero Solanum em 2,9 milhões de anos que, pela abordagem adotada, representa o valor mais robusto calculado até o momento. 


\section{REFERÊNCIAS}

Altschul SF, Gish W, Miller W, Myers EW, Lipman DJ. 1990. Basic local alignment search tool. Journal of Molecular Biology 215, 403-410.

Barakat A, Choi A, Yassin NB, Park JS, Sun Z, Carlson JE. 2011. Comparative genomics and evolutionary analyses of the O-methyltransferase gene family in Populus. Gene 47, 37-46.

Bell CD, Soltis DE, Soltis PE. 2005. The age of the angiosperms: a molecular timescale without a clock. Evolution 59, 1245-1258.

Bermúdez L, Urias U, Milstein D, Kamenetzky L, Asis R, Fernie AR, Van Sluys MA, Carrari F, Rossi M. 2008. A candidate gene survey of quantitative trait loci affecting chemical composition in tomato fruit. Journal of Experimental Botany 59, 2875-2890.

Bossolini E, Klahre U, Brandenburg A, Reinhardt D, Kuhlemeier C. 2011. High resolution linkage maps of the model organism Petunia reveal substantial synteny decay with the related genome of tomato. Genome 54, 327-40.

Chen KY, Cong B, Wing R, Vrebalov J, Tanksley SD. 2007. Changes in regulation of a transcription factor lead to autogamy in cultivated tomatoes. Science 318, 643645.

Clepet C, Joobeur T, Zheng Y, Jublot D, Huang M, Truniger V, Boualem A, HernandezGonzalez ME, Dolcet-Sanjuan R, Portnoy V, Mascarell-Creus A, Cano-Delgado AI, Katzir N, Bendahmane A, Giovannoni JJ, Aranda MA, Garcia-Mas J, Fei Z. 2011. Analysis of expressed sequence tags generated from full-length enriched cDNA libraries of melon. BMC Genomics 12, 252.

Doebley J, Stec A, Hubbard L. 1997. The evolution of apical dominance in maize. Nature 386, 485-488.

Ewing B, Green P. 1998. Basecalling of automated sequencer traces using phred II: error probabilities. Genome Research 8, 186-194.

Gordon D, Abajian C, Green P. 1998. Consed: a graphical tool for sequence finishing. Genome Research 8, 195-202.

Guigo RET, Dermitzakis P, Agarwal CP, Ponting G, Parra G, Reymond A, Abril J, Keibler E, Lyle R, Ucla C, Antonarakis SE, Brent MR. 2003. Comparison of mouse and human genomes followed by experimental verification yields an estimated 1,019 additional genes. Proceedings of the National Academy of Sciences of the United States of America 100, 1140-1145.

Heslop-Harrison, J.S. 2000. Comparative Genome Organization in Plants: From Sequence and Markers to Chromatin and Chromosomes. The Plant Cell 12, 617-635.

Ilic, K, SanMiguel PJ, Bennetzen JL. 2003. A complex history of rearrangement in an orthologous region of the maize, sorghum, and rice genomes. Proceedings of the National Academy of Sciences of the United States of America 100, 1226512270.

Kamenetzky L, Asís R, Bassi S, de Godoy F, Bermúdez L, Fernie AR, Van Sluys MA, Vrebalov J, Giovannoni JJ, Rossi M, Carrari F. 2010. Genomic analysis of wild tomato introgressions determining metabolism- and yield-associated traits. Plant Physiology 152, 1772-86.

Katzman S, Kern AD, Bejerano G, Fewell G, Fulton L, Wilson RK, Salama SR, Haussler D. 2007. Human genome ultraconserved elements are ultraselected. Science $317,5840-5915$. 
Kellis M, Patterson N, Endrizzi M, Birren B, Lander ES. 2003. Sequencing and comparison of yeast species to identify genes and regulatory elements. Nature 423, 241-254.

Ku HM, T Vision, J Liu and SD Tanksley. 2000. Comparing sequenced segments of the tomato and Arabidopsis genomes: large-scale duplication followed by selective gene loss creates a network of synteny. Proceedings of the National Academy of Sciences of the United States of America 97, 9121-9126.

Kumar S,Tamura K, Nei M. 2004. MEGA3: integrated software for molecular evolutionary genetics analysis and sequence alignment. Briefing in Bioinformatics 5, 50-163.

Liu W, Huang D, Liu K, Hu S, Yu J, Gao G, Song S. 2010. Discovery, identification and comparative analysis of non-specific lipid transfer protein (nsLtp) family in Solanaceae. Genomics Proteomics Bioinformatics 8, 229-237.

Lu S, Van Eck J, Zhou X, Lopez AB, O'Halloran DM, Cosman KM, Conlin BJ, Paolillo DJ, Garvin DF, Vrebalov J, Kochian LV, Kupeer H, Earle ED, Cao J, Li L. 2006. The cauliflower or gene encodes a dnaj cysteine-rich domain-containing protein that mediates high levels of $\beta$-Carotene accumulation. The Plant Cell 18, 3594-3605.

Ma J, Bennetzen JL. 2004. Rapid recent growth and divergence of rice nuclear genomes. Proceedings of the National Academy of Sciences of the United States of America 101, 12404-12410.

Magallon SA, Sanderson MJ. 2005. Angiosperm divergence times: the effect of genes, codon positions, and time constraints. Evolution 59, 1653-1670.

Mueller LA, Solow TH, Taylor N, Skwarecki B, Buels R, Binns J, Lin C, Wright MH,Ahrens R, Wang Y. 2005. The SOL Genomics Network: a comparative resource for Solanaceae biology and beyond. Plant Physiology 138, 1310-1317.

Muse SV, Gaut BS. 1994. A likelihood approach for comparing synonymous and nonsynonymous nucleotide substitution rates, with application to the chloroplast genome. Molecular Biology and Evolution 11, 715-724.

Nesbitt TC, Tanksley SD. 2002. Comparative sequencing in the genus Lycopersicon: implications for the evolution of fruit size in the domestication of cultivated tomatoes. Genetics 162, 365-379.

Quiros CF, Grellet F, Sadowski J, Suzuki T, Li G, Wroblewski T. 2001. Arabidopsis and Brassica comparative genomics: sequence, structure and gene content in the ABI-Rps2-Ck1 chromosomal segment and related regions. Genetics 157, 13211330.

Reineke AR, Bornberg-Bauer E, Gu J. 2011. Evolutionary divergence and limits of conserved non-coding sequence detection in plant genomes. Nucleic Acids Research [Epub ahead of print].

Rensink W, Lee Y, Liu J, Iobst S, Ouyang S, Buell CR. 2005. Comparative analyses of six solanaceous transcriptomes reveal a highdegree of sequence conservation and species-specific transcripts. BMC genomics 6, 124.

Rozas J, Sánchez-DelBarrio JC,Messeguer X, Rozas R. 2003. DnaSP, DNA polymorphism analyses by the coalescent and other methods. Bioinformatics 19, 2496-2497.

Salamov AA, Solovyev VV. 2000. Ab initio gene finding in Drosophila genomic DNA. Genome Research 10, 516-522.

Sanchez DH, Pieckenstain FL, Szymanski J, Erban A, Bromke M, Hannah MA, Kraemer U, Kopka J, Udvardi MK. 2011. Comparative functional genomics of salt stress in related model and cultivated plants identifies and overcomes limitations to translational genomics. Public Library of Science one 6, e17094. 
Schauer N, Semel Y, Balbo I, Steinfath M, Repsilber D, Selbig J, Pleban T, Zamir D, Fernie AR. 2008. Mode of inheritance of primary metabolic traits in tomato. Plant Cell 20, 509-523.

Schauer N, Semel Y, Roessner U, Gur A, Balbo I, Carrari F, Pleban T, Perez-Melis A, Bruedigam C, Kopka J, Willmitzer L, Zamir D, Fernie A. 2006. Comprehensive metabolic profiling and phenotyping of interspecific introgression lines for tomato improvement. Nature Biotechnology 24, 447-454.

Siepel A, Diekhans M, Brejov B, Langton L, Stevens M, Comstock CLG, Davis C, Ewing B, Oommen S, Lau C, Yu HC, Li J, Roe BA, Green P, Gerhard DS, Temple G, Haussler D, Brent MR. 2007. Targeted discovery of novel human exons by comparative genomics. Genome Research 17, 1763-1773.

Song C, Wang Y. 2010. Microsynteny analysis of tomato and peach genome. Yi Chuan 32, 966-73.

Stanke M, Steinkamp R, Waack S, Morgenstern B. 2004. AUGUSTUS: a Web server for gene finding in eukaryotes. Nucleic Acids Research 32, 309-312.

Stark A, Lin M, Kheradpour P, Pedersen J, Parts L, et al. 2007. Discovery of functional elements in 12 Drosophila genomes using evolutionary signatures. Nature 450, 219-232.

Thompson J, Higgins D, Gibson T. 1994. CLUSTAL W: improving the sensitivity of progressive multiple sequence alignment through sequence weighting, positionspecific gap penalties and weight matrix choice. Nucleic Acids Research 22, 4673-4680.

Urbanczyk-Wochniak E, Usadel B, Thimm O, Nunes-Nesi A, Carrari F, Davy M, Bläsing O, Kowalczyk M, Weicht D, Polinceusz A, Meyer S, Stitt M, Fernie AR. 2006. Conversion of MapMan to allow the analysis of transcript data from Solanaceous species: effects of genetic and environmental alterations in energy metabolism in the leaf. Plant Molecular Biology 60, 773-792.

Wang Y, Diehl A, Wu F, Vrebalov J, Giovannoni J, Siepel A, Tanksley SD. 2008. Sequencing and comparative analysis of a conserved syntenic segment in the Solanaceae. Genetics 180, 391-408.

Xiao H, Jiang N, Schaffner E, Stockinger EJ, Van der Knaap E. 2008. A retrotransposonmediated gene duplication underlies morphological variation of tomato fruit. Science 319, 1527-1530.

Zheng WX, Zhang CT. 2008. Ultraconserved elements between the genomes of the plants Arabidopsis thaliana and rice. Journal of biomolecular structure \& dynamics 26, 1-8 

Capítulo III: Caracterização e estudo funcional do gene chaperona DnaJ 



\section{INTRODUÇÃO}

A introgressão de um segmento cromossômico proveniente de $S$. pennellii, no bin I do cromossomo 4 de $S$. lycopersicum, resultou em uma alteração massiva nos conteúdos de diversos metabólitos em fruto maduro (Schauer et al., 2006, Figura 1). Uma tendência interessante foi que a maioria dos compostos que apresentaram mudanças pertencem a mesma categoria metabólica, principalmente açúcares e aminoácidos. Também foram evidenciadas alterações em vias completas como na que liga o citrato à glutamina e GABA (ácido gama-aminobutírico) e da rota de glicerato a ácidos graxos. Devido à mudança drástica no metabolismo do fruto, essa região foi definida como um QTL "de rota" por Schauer e Fernie (2006). Por outro lado, foi evidenciada uma correlação significativa entre as variações nos níveis de transcrito de alguns dos genes candidatos identificados neste bin, e o conteúdo de alguns dos metabólitos identificados ao longo do desenvolvimento do fruto (Figura 2).

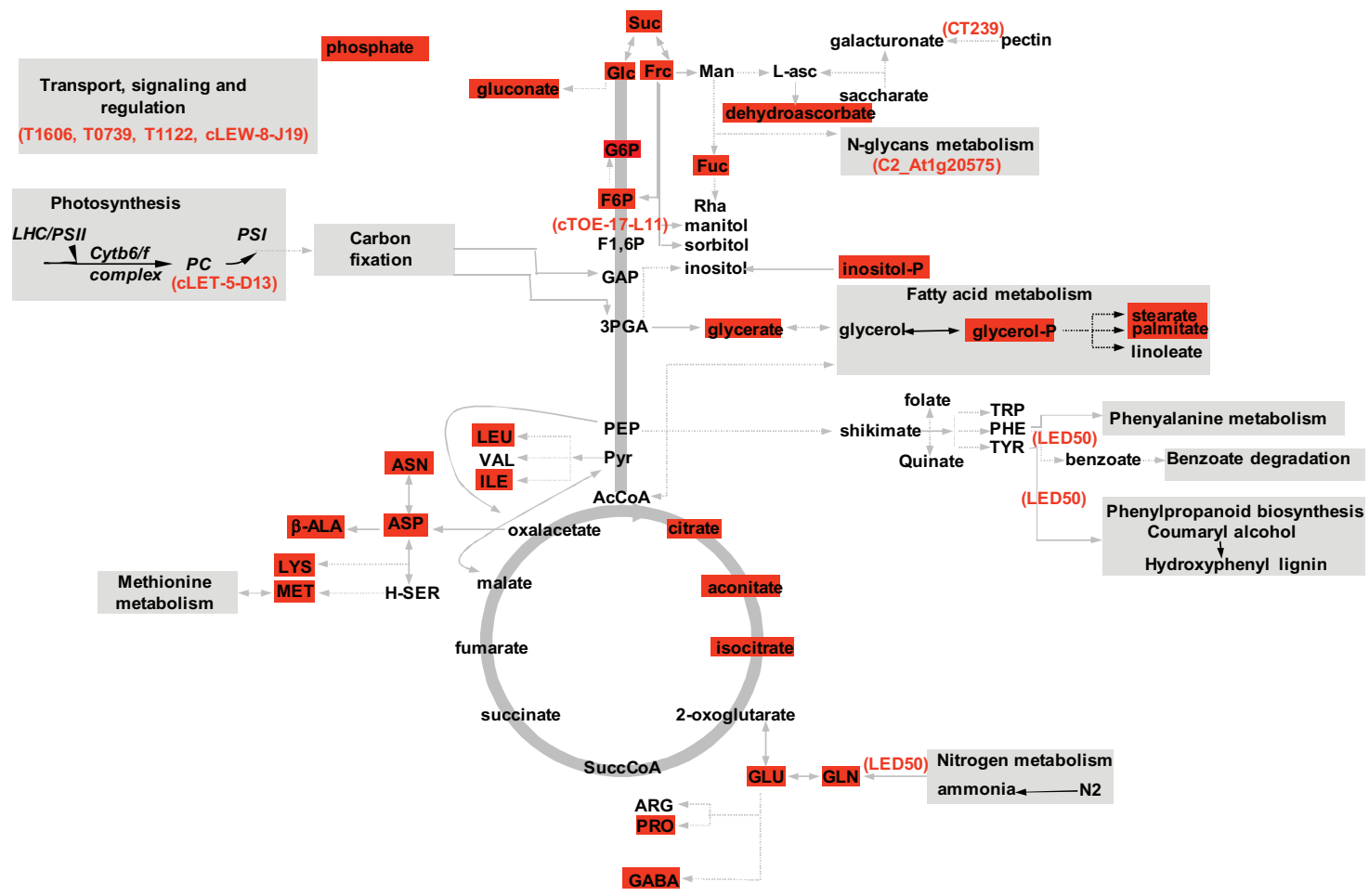

Figura 1. Alterações no conteúdo de metabólitos no fruto da IL 4-4.

Em vermelho encontram-se identificados os metabólitos alterados significativamente. Os genes candidatos encontram-se indicados pelo marcador molecular correspondente e localizados na rota metabólica associada. (T1606) proteinasa pre-pro-cisteína. (T0739) chaperona DnaJ. (T1122) RNA helicase ATP dependente DEAD-box. (cLEW-8-J19) receptor quinase CLAVATA 1. (cLET-5-D13) precursor plastidial de plastocianina. (C2_At1g20575) Dolichil-fosfato $\beta$-D-manosiltransferase. (cTOE-17-L11) subunidade da pirofosfato frutose 6 -fosfato 1 -fosfotransferase. (CT239) pectinesterase. (LED50) fenilalanine amônio liase. Adaptado de Bermudez et al. (2008). 


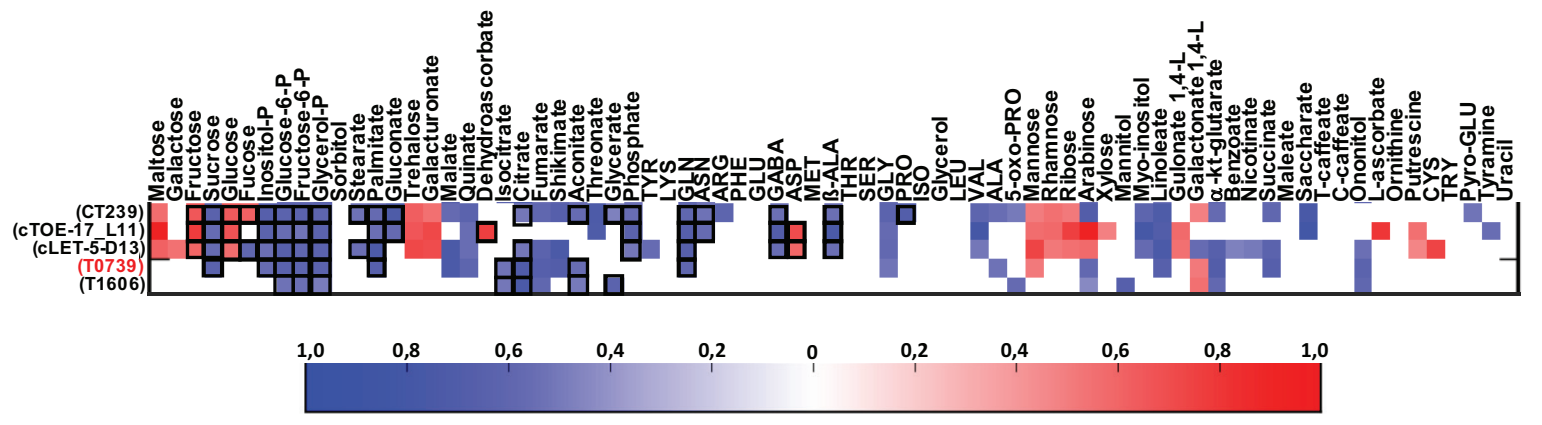

Figura 2. Correlação entre o perfil transcricional dos genes candidatos e o conteúdo dos metabólitos ao longo do desenvolvimento do fruto em S. Iycopersicum.

Cada quadrado representa o valor $r$ da análise de correlação numa escala de cor, onde azul, vermelho e branco representam correlações positivas, negativas e não-significância, respectivamente. Os genes encontram-se indicados com os respectivos marcadores moleculares segundo a Figura 1 . Os quadros delineados em preto indicam uma correlação significativa entre o gene candidato e o metabolito correspondente ao QML com o qual co-localiza. Em vermelho encontra-se ressaltado o gene candidato chaperona DnaJ.

A mudança massiva no perfil metabólico da IL 4-4 levanta duas hipóteses acerca de quais mecanismos genéticos estariam envolvidos: i) vários genes cujos produtos possuem uma função enzimática direta ou indireta nas rotas alteradas modificam as diferentes etapas metabólicas, ou ii) um ou poucos genes regulatórios provocam a mudança massiva. Para os genes de função enzimática nesta região não foram detectados polimorfismos de aminoácidos nas sequências analisadas (vide Tabela 2 do Capítulo I). Por sua vez, exceto pela fenilalanina amônio liase, marcador LED50, que poderia unicamente explicar os aumentos de prolina, GABA, glutamina e glutamato, nenhum dos genes com função enzimática estava diretamente envolvido nas rotas metabólicas alteradas (Figura 1).

Considerando as hipóteses levantadas, sabe-se que diferente das proteínas com função enzimática ou estrutural, as regulatórias (ex. chaperonas, quinases, fosfatases e proteases) são expressas em determinados estágios do desenvolvimento, condições fisiológicas, ou frente a estímulos ambientais, geralmente em baixas quantidades. Embora apresentem um padrão de expressão temporal/espacial restrito, elas regulam rotas metabólicas inteiras. Várias destas proteínas regulatórias são de vital importância para o funcionamento adequado da maquinaria fotossintética, atuando na biogênese, manutenção e estabilidade das membranas do tilacóide, assim como, na regulação das reações fotossintéticas em função dos estímulos ambientais (Chen et al., 2011). Assim, já que vários dos QML localizados no bin $4 \mathrm{I}$ estão relacionados ao metabolismo plastidial, o gene que codifica para uma proteína chaperona do tipo DnaJ pode ter uma função no metabolismo plastidial e se apresenta como um candidato a ser estudado funcionalmente 
As chaperonas são proteínas que interagem fisicamente com outros peptídeos, seja auxiliando-os a atingir a sua correta estrutura terciária, prevenindo o agrupamento destes com outras proteínas, ou alterando a sua atividade (Li e Chui, 2010). As chaperonas do tipo DnaJ constituem uma super-família gênica, encontrada tanto em organismos procariontes como eucariontes e compostas por três domínios protéicos (Kampinga e Craig, 2010; Rajan e D'Silva, 2009). O domínio J consiste em uma região de 70 aminoácidos com estrutura secundária a-hélice que interage com proteínas do tipo Hsp70 estimulando a sua atividade ATPase. O domínio G/F é uma região de 30 a 40 aminoácidos, rica em glicina e fenilalanina que confere a especificidade de interação com a proteína alvo (Miernyk, 2001). Finalmente, o domínio dedo de zinco ou DnaJ, rico em cisteína, consiste em quatro repetições do motivo CXXCXGXG. Este domínio é altamente conservado desde bactérias a humanos (Lu et al., 2006) e media a interação proteína-proteína (Banecki et al., 1996; Szabo et al., 1996; Linke et al., 2003). As chaperonas do tipo DnaJ se classificam em três grandes grupos de acordo com a combinatória de domínios na sua estrutura primária (Figura 3).

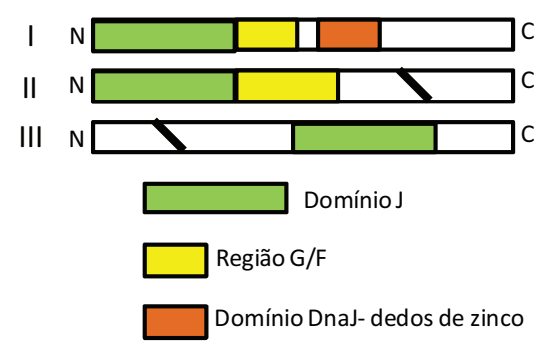

Figura 3. Representação esquemática dos tipos de proteínas chaperonas DnaJ.

I. Proteínas que conservam a estrutura protéica de E. coli com os três domínios. II. Proteínas sem domínio de dedo de zinco. III. Proteínas só com domínio J. Modificado de Cheetman e Caplan (1998).

Em plantas, as chaperonas DnaJ têm sido identificadas em diversos compartimentos celulares: no citosol (Thomas e Baneyx, 1996), na mitocôndria (Kroczynska et al., 1996; Voos e Rotgers, 2002), no retículo endoplasmático (Nicoll et al., 2006) e nos cloroplastos (Orme et al., 2001). Devido a sua função em processos fundamentais como na diferenciação e funcionamento dos plastídeos, as chaperonas DnaJ que atuam nesta organela têm sido objeto de diversos estudos nos últimos anos. Em 2003, Vitha et al. identificaram a proteína ARC6 (Accumulation and Replication of Chloroplasts 6) localizada no envelope do cloroplasto e com função na divisão dos plastídeos. A proteína CYO1 (Cotyledon-Specific Chloroplast Biogenesis Factor), caracterizada por Shimada et al. (2007), encontra-se localizada nas membranas dos tilacóides e atua na diferenciação dos cloroplastos (Shimada et al., 2007). Em 
arabidopsis, as proteínas At] têm sido relacionadas com a eficiência fotossintética, dada pela estabilidade do fotossístema II e, mais ainda, análises funcionais revelaram que essas proteínas interagem com fatores de transcrição relacionados a estresse (Chen et al., 2010, 2011).

Genes da superfamília DnaJ que possuem unicamente o domínio de dedos de zinco apresentaram também papel chave no metabolismo plastidial. Lu et al. (2006) demonstraram que o alelo mutante do gene Or determina a diferenciação de proplastídeos em cromoplastos, com o consequente acumulo de carotenóides, em tecidos como a inflorescência e talos jovens em couve-flor (Figura 4). Por outro lado, em tabaco, Ham et al. (2006) identificaram a chaperona TSIP1 (Tobacco StressInduced1-Interacting Protein) associada à membrana do cloroplasto, a qual é recrutada pelo fator de transcrição TSI1 ativando a transcrição de genes relacionados a estresse mediado por ácido salicílico.

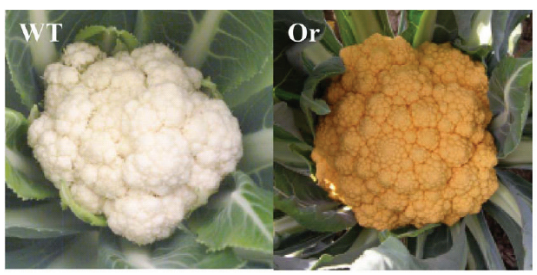

Figura 4. Fenótipo da B. oleracea mutante Or que apresenta acúmulo de carotenóides comparada com o fenótipo selvagem (Li et al., 2006).

Desta maneira, pelas evidências discutidas, a presença do alelo selvagem do gene chaperona DnaJ poderia, ao menos parcialmente, explicar as mudanças fenotípicas observadas no perfil metabólico da IL 4-4 quando comparado ao de $S$. lycopersicum. Adicionalmente, o estudo do perfil transcricional deste gene realizado pelo grupo (de Godoy, comunicação pessoal) revelou diferenças nos níveis de expressão entre os alelos de $S$. pennellii e $S$. lycopersicum, em diferentes tecidos da planta (Figura 5). Com estes antecedentes, espera-se que com a caracterização e estudo funcional do gene possam ser somadas evidências que reforcem o seu envolvimento nas alterações metabólicas observadas.

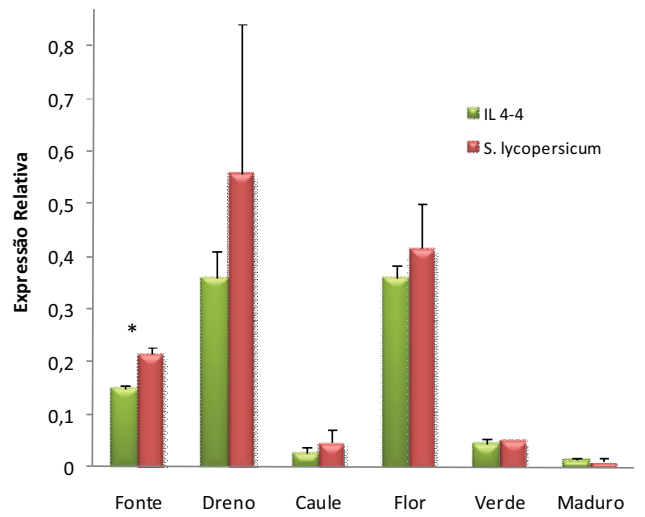

Figura 5. Padrão de expressão do gene chaperona DnaJ.

A expressão relativa está calculada como quantidade de RNAm do gene chaperona DnaJ/ quantidade de RNAm do gene de refêrencia EF1 $\alpha$. * Diferença estatística $P<0,05$. 


\section{OBJETIVOS}

Devido ao impacto no fenótipo que possui o bin I do cromossomo 4, demonstrado pela presença 37 QML e 10 YAL e, havendo descrito a região genômica que compreende o gene chaperona DnaJ (Kamenetzy et al., 2010) foi proposto realizar a caracterização e estudo funcional deste gene.

Para atingir este objetivo geral foram propostos os seguintes objetivos específicos:

- Analisar a estrutura gênica e realizar um estudo filogenético;

- Estudar a atividade transcricional dos promotores dos alelos de $S$. pennellii e $S$. lycopersicum;

- Estudar a localização subcelular da proteína; e

- Estudar o efeito sobre o metabolismo central de carbono do silenciamento gênico por RNA de interferência. 


\section{MATERIAIS E MÉTODOS}

\subsection{Material vegetal}

As sementes de tomate de S. lycopersicum (cv M82 e Moneymaker) foram gentilmente cedidas pelo Tomato Genetic Resource Center (http://tgrc.ucdavis.edu). As sementes de Nicotiana benthamiana foram obtidas do Instituto de Biotecnología do INTA - Argentina. As plantas de tomate e $N$. benthamiana foram crescidas em casa de vegetação, em potes de 20 e $1 \mathrm{~L}$, respectivamente, contendo terra vegetal e vermiculita (1:1). As condições da casa vegetação foram: fotoperíodo de $16 / 8 \mathrm{~h}$, temperatura de $24 \pm 3{ }^{\circ} \mathrm{C}, 60 \%$ umidade e fotoirradiância de $140 \pm 40 \mu \mathrm{mol} \mathrm{m}{ }^{-2} \mathrm{~s}^{-1}$.

\subsection{Cepas bacterianas e plasmídeos}

Escherichia coli: foram utilizadas as cepas $\mathrm{DH} 5 \alpha$, DH10 $\beta$ e DB3.1. Todos os cultivos foram realizados em meio LB (meio de Luria-Bertani). A temperatura de crescimento foi de $37^{\circ} \mathrm{C}$ e nos casos de cultivo líquido a agitação foi de $200 \mathrm{rpm}$. Quando as cepas bacterianas foram transformadas com um vetor plasmidial, foi adicionado o antibiótico de seleção correspondente ao meio de cultivo.

Agrobacterium tumefaciens: foram utilizaram as cepas GV3101 e GV2260. GV3101 possui resistência a rifampicina $(25 \mathrm{mg} / \mathrm{l})$ e gentamicina $(50 \mathrm{mg} / \mathrm{l})$ e foi utilizada para experimentos de expressão transitória. GV2260 é resistente a rifampicina ( $25 \mathrm{mg} / \mathrm{l}$ ) (Hoeckema et al., 1983) e foi utilizada para a transformação estável. As bactérias foram cultivadas em meio LB a uma temperatura de $28^{\circ} \mathrm{C}$ e nos casos de cultivo líquido a agitação foi de 200 rpm.

Plasmídeos: os vetores utilizados para os diferentes métodos experimentais estão listados na Tabela 1. 
Tabela 1. Vetores utilizados neste trabalho.

\begin{tabular}{|c|c|c|c|c|}
\hline Vetores & $\begin{array}{l}\text { Resistência } \\
\text { em bactéria }\end{array}$ & $\begin{array}{l}\text { Resistência } \\
\text { em plantas }\end{array}$ & Características & Origem \\
\hline $\begin{array}{c}\text { pENTR/D- } \\
\text { TOPO }\end{array}$ & canamicina & & 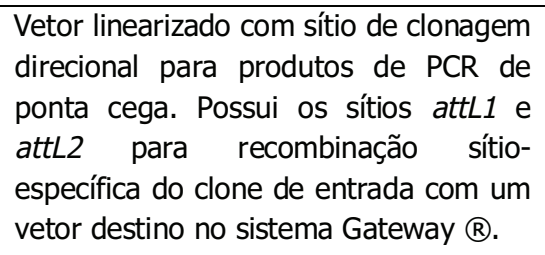 & Invitrogen \\
\hline pK7FWG2 & $\begin{array}{l}\text { spectinomicina } \\
\text { streptomicina }\end{array}$ & canamicina & $\begin{array}{l}\text { Vetor binário que possui o promotor } \\
35 \mathrm{~s} \text {, sítios attR1 e attR2, para } \\
\text { recombinação sítio-específica no } \\
\text { sistema Gateway }{ }^{\circledR} \text {, para fusão da } \\
\text { proteína de interesse a GFP (Green } \\
\text { Fluorescent Protein) e terminador } 35 \mathrm{~s} \text {. }\end{array}$ & $\begin{array}{c}\text { Karimi et al. } \\
\quad(2002)\end{array}$ \\
\hline pHGWFS7 & $\begin{array}{l}\text { spectinomicina } \\
\text { streptomicina }\end{array}$ & higromicina & $\begin{array}{l}\text { Vetor binário que possui sítios attR1 e } \\
\text { attR2 para recombinação sitio- } \\
\text { especifica no sistema Gateway® para } \\
\text { região promotora putativa seguida } \\
\text { pelos genes repórteres gfp (green } \\
\text { fluorescent protein ) e gus ( } \beta \text { - } \\
\text { glucoronidase) e terminador } 35 \text { s. }\end{array}$ & $\begin{array}{c}\text { Karimi et al. } \\
\quad(2002)\end{array}$ \\
\hline p7GWIWG2(I) & $\begin{array}{l}\text { spectinomicina } \\
\text { streptomicina }\end{array}$ & canamicina & $\begin{array}{l}\text { Vetor binário que possui o promotor } \\
35 \mathrm{~s} \text {, um íntron flanqueado por sítios } \\
\text { attR1 e attR2, para recombinação sítio- } \\
\text { específica no sistema Gateway } R \text {, e } \\
\text { terminador } 35 \text { s. Contém um fragmento } \\
\text { gênico em ambas as orientações } \\
\text { separados por um íntron permitindo a } \\
\text { formação de uma estrutura de alça. }\end{array}$ & $\begin{array}{c}\text { Karimi et al. } \\
\quad(2002)\end{array}$ \\
\hline pHGWFS735S & $\begin{array}{l}\text { spectinomicina } \\
\text { streptomicina }\end{array}$ & canamicina & pHGWFS7 contendo o promotor $35 S$. & $\begin{array}{c}\text { Karimi et al. } \\
\quad(2002)\end{array}$ \\
\hline
\end{tabular}

\subsection{Obtenção das sequências dos alelos do gene chaperona DnaJ, análise da estrutura gênica e filogenia}

A sequência completa do alelo de $S$. lycopersicum foi obtida do clone de BAC C04HBa0331L22 (Projeto de Sequenciamento Internacional de Tomate, SGN) disponível na página da Sol Genomics Network (Mueller et al., 2005, 2008, 2009). O alelo de $S$. pennellii foi clonado e sequenciado pelo nosso grupo, clone C04SpBP093E005.P4C04 (Kamenetzky et al., 2010) como descrito no capitulo 2. As UTRs foram determinadas de acordo com o unigene de referência (U563083) disponível na página da SGN. A comparação das sequências foi realizada com o auxílio 
do programa MULTALIN (http://www-archbac.u-psud.fr/genomics/multalin.html; Corpet, 1988).

Foi realizada uma busca no NCBI (http://www.ncbi.nlm.nih.gov/) e na literatura para identificar proteínas com domínio DnaJ com função experimentalmente demonstrada. Utilizando as sequências identificadas e a proteína chaperona DnaJ de tomate como referência, foram obtidas da base de proteínas não-redundantes (nr) do NCBI sequências ortólogas de arabidopsis e tomate por meio do algoritmo BLASTX (Altschul et al., 1990). O critério estabelecido para a escolha das sequências foi identidade de aminoácidos $\geq 40 \%$ e cobertura $\geq 65 \%$. Para todas as sequências protéicas foi predita a localização subcelular utilizando o programa TargetP 1.1 (http://www.cbs.dtu.dk/services/TargetP/). A estrutura secundária e terciária da proteína DnaJ foi analisada utilizando o programa TMHMM (http://www.cbs.dtu.dk/services/TMHMM/). Para a construção da árvore filogenética, as sequências de aminoácidos foram alinhadas utilizando o programa ClustalW (Thompson et al., 1994). A matriz de distância foi construída utilizando o método de Neighbor-joining (Saito e Nei, 1987) com o programa MEGA (Tamura et al., 2007). Os valores de bootstrap foram determinados a partir de 1000 réplicas.

\subsection{Obtenção das construções para o estudo da atividade das regiões promotoras dos alelos de S. Iycopersicum e S. pennellii}

Segundo o protocolo do CIMMYT (2005), foi extraído DNA genômico da IL 4-4 e da variedade M82 para a amplificação das regiões promotoras dos alelos de $S$. pennellii e S. Iycopersicum, respectivamente. A reação de PCR foi realizada utilizando $100 \mathrm{ng}$ de DNA molde, 0,2 mM de cada dNTPs, 0,2 mM de cada iniciador [PROM-Dna]-F (5'CACCCGCTGATCTGCCTATGGTTAAAAG-3') e PROM- DnaJ -R (5'GCCTTTGGATTGTGTGGGGAC-3')], 1,5 mM de $\mathrm{Mg}_{2} \mathrm{SO}_{4}$, e 2,5 unidades de enzima TAQ polymerase ${ }^{\circledR}$ (Invitrogen, 10342-020). O ciclo de amplificação utilizado foi de $94{ }^{\circ} \mathrm{C}$ por $3 \mathrm{~min} ; 35$ ciclos de $94{ }^{\circ} \mathrm{C}$ por $30 \mathrm{seg}, 52{ }^{\circ} \mathrm{C}$ por $30 \mathrm{seg}, 72{ }^{\circ} \mathrm{C}$ por $1 \mathrm{~min}$; e uma extensão final a $72{ }^{\circ} \mathrm{C}$ por $5 \mathrm{~min}$. Os fragmentos amplificados foram purificados utilizando o Kit GFX (Amersham Biosciences 27-9602-01), de acordo com especificações do fabricante.

Os fragmentos foram clonados no vetor de entrada pENTR/D-TOPO (Invitrogen, K240020) e posteriormente foram recombinados utilizando a enzima LR clonase (Invitrogen 11791-020) no vetor binário de pHGWFS7 (Tabela 1). Os clones obtidos 
pHGWFS7DnaJPromLyc e pKGWFS7DnaJPromPen foram analisados por restrição com endonucleases e confirmados por sequenciamento. Após confirmação da identidade dos clones, os mesmos foram incorporados em $A$. tumefaciens cepa GV3101 segundo protocolo de Wen-Jun e Forde (1989).

\subsection{Obtenção da construção para estudo da localização subcelular da proteína chaperona DnaJ}

Tecido de folha fonte (segundo e terceiro folíolos da terceira folha totalmente expandida) de S. lycopersicum (cv. M82), foi processado em nitrogênio líquido e uma alíquota de $200 \mathrm{mg}$ foi submetida a extração de RNA total empregando-se o reagente Trizol (Invitrogen, 15596018), segundo o protocolo recomendado pelo fabricante. A extração foi realizada utilizando clorofórmio $(0,2 \mathrm{~V} / \mathrm{V}$ de TRIZOL) e o ácido nucléico precipitado com isopropanol (0,6 V/V de solução). O RNA foi ressuspendido em $20 \mu \mathrm{l}$ de água $0,1 \%$ DEPC (livre de RNase) e a amostra estocada a $-80{ }^{\circ} \mathrm{C}$. A concentração foi avaliada por absorbância a $260 \mathrm{~nm}$ em espectrofotômetro. Para estimar a pureza da preparação, foi levada em consideração a relação entre as absorbâncias obtidas a 260 $\mathrm{nm}$ e $280 \mathrm{~nm}$, sendo que as amostras com razões acima de 1,8 foram consideradas puras. Quando necessário, uma nova precipitação com 1 volume de $\mathrm{LiCl}$ (5M) foi realizada. Aproximadamente $1 \mu \mathrm{g}$ de RNA foi tratado com $1 \mu \mathrm{l}$ de DNase (Invitrogen 18068-015), e posteriormente foi realizada a síntese de cDNA utilizando a enzima SuperScript III Reverse Transcriptase (Invitrogen 18080-044), segundo instruções do fabricante. Cada reação conteve: $11 \mu \mathrm{l}$ do RNA tratado com DNase (aproximadamente $1 \mu \mathrm{g}), 1 \mu \mathrm{l}$ de iniciadores OligoDT (Invitrogen 18418-012) $(150 \mu \mathrm{g} / \mathrm{ml})$ e 0,2 mM dNTPs. Após incubação a $65{ }^{\circ} \mathrm{C}$ por 5 minutos foi adicionado $1 \mathrm{x}$ tampão da enzima, 5

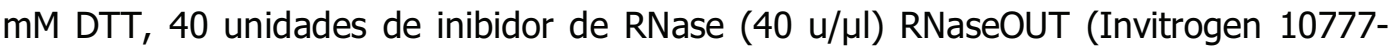

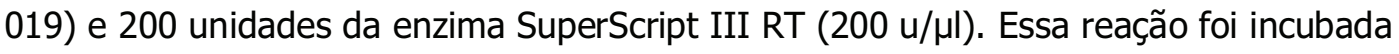
por 5 minutos a $25^{\circ} \mathrm{C}, 50^{\circ} \mathrm{C}$ por 1 hora e, finalmente, $70^{\circ} \mathrm{C}$ por 15 min. Para testar a pureza do cDNA (livre de DNA genômico), foi realizada uma PCR usando 0,2 mM de cada dNTPs, 0,2 mM de cada iniciador ActinaUp (5'- TGGCATCATACCTTTTACAA -3') e ActinaLow (5'- TCCGGGCATCTGAACCTCT -3'), 1,5 mM de $\mathrm{Mg}_{2} \mathrm{SO}_{4}$ e 2,5 unidades de enzima TAQ polymerase $\circledR$ (Invitrogen, 10342-020). O ciclo de amplificação utilizado foi de $94{ }^{\circ} \mathrm{C}$ por $3 \mathrm{~min}$; 35 ciclos de $94^{\circ} \mathrm{C}$ por $30 \mathrm{seg}, 55^{\circ} \mathrm{C}$ por $1 \mathrm{~min}, 72{ }^{\circ} \mathrm{C}$ por $2 \mathrm{~min}$; e uma extensão final a $72{ }^{\circ} \mathrm{C}$ por $10 \mathrm{~min}$. Os produtos da amplificação foram visualizados por eletroforese em gel de agarose $0,8 \%$ TAE $1 x$. 
A amplificação do cDNA completo do gene foi realizada por PCR utilizando 50 ng de cDNA, 0,2 mM de cada dNTPs, 0,2 mM de cada iniciador [FUS-Dna]-F (5'CACCATGTTGACGGCACCTTCAC-3') e FUS-DnaJ-R (5'- ATCATCGTCCTTGAATTCCCTG$\left.\left.3^{\prime}\right)\right], 1,5 \mathrm{mM}$ de $\mathrm{Mg}_{2} \mathrm{SO}_{4}$ e 2 unidades de enzima Elongase ${ }^{\circledR}$ DNA polimerase (Invitrogen, 10480-010). O ciclo de amplificação utilizado foi de $94{ }^{\circ} \mathrm{C}$ por $3 \mathrm{~min} ; 35$ ciclos de $94{ }^{\circ} \mathrm{C}$ por $30 \mathrm{seg}, 50^{\circ} \mathrm{C}$ por $30 \mathrm{seg}, 68^{\circ} \mathrm{C}$ por $2 \mathrm{~min}$, e; uma extensão final a $68{ }^{\circ} \mathrm{C}$ por $10 \mathrm{~min}$. O fragmento amplificado foi purificado utilizando o Kit GFX (Amersham Biosciences 27-9602-01), de acordo com especificações do fabricante e clonado no vetor de entrada pENTR/D-TOPO (Invitrogen, K240020). Posteriormente, foi recombinado utilizando a enzima LR clonase II (Invitrogen 11791-020) no vetor binário de pK7FWG2 (Tabela 1). O clone obtido pK7FWG2DnaJLyc foi analisado por restrição com endonucleases e confirmado por sequenciamento. Após confirmação da identidade, o clone foi inserido em $A$. tumefaciens cepa GV3101 segundo protocolo de Wen-Jun e Forde (1989).

\subsection{Obtenção da construção para avaliação do efeito do silenciamento gênico por RNA de interferência}

DNA plasmidial do clone contendo o alelo de $S$. lycopersicum do gene chaperona DnaJ obtido no capitulo 1 (Bermúdez et al., 2008) foi purificado segundo Sambrook et al. (1989). Para a amplificação do fragmento para RNAi, foram usados 10 ng de DNA molde, 0,2 mM de cada dNTPs, 0,2 mM de cada iniciador [DnaJRNAi-F (5'CACCTTGCATGGGTACTGGCAG-3') e DnaJRNAi-R (5'-CGAGGTTGAATGCCACTGCC-3')], $1,5 \mathrm{mM}$ de $\mathrm{Mg}_{2} \mathrm{SO}_{4}$ e 2,5 unidades de enzima TAQ polymerase ${ }^{\circledR}$ (Invitrogen, 10342020). O ciclo de amplificação utilizado foi de $94^{\circ} \mathrm{C}$ por $3 \mathrm{~min} ; 35$ ciclos de $94^{\circ} \mathrm{C}$ por $30 \mathrm{seg}, 52^{\circ} \mathrm{C}$ por $30 \mathrm{seg}, 72{ }^{\circ} \mathrm{C}$ por $1 \mathrm{~min}$; e uma extensão final a $72{ }^{\circ} \mathrm{C}$ por $10 \mathrm{~min}$.

O fragmento amplificado correspondente a 129 pb do éxon 5 foi purificado utilizando o Kit GFX (Amersham Biosciences 27-9602-01), de acordo com especificações do fabricante. $O$ fragmento foi clonado no vetor de entrada pENTR/DTOPO (Invitrogen, K240020) e posteriormente recombinado utilizando a enzima LR clonase (Invitrogen 11791-020) no vetor binário de p7GWIWG2(I) (Tabela 1). O clone obtido pK7GWIWG2(I)DnaJ foi analisado por restrição com endonucleases e confirmado por sequenciamento. Após confirmação da identidade, o clone foi inserido em A. tumefaciens cepa GV2260 segundo protocolo de Wen-Jun e Forde (1989). 


\subsection{Infiltração e ensaio histoquímico de folhas de $\boldsymbol{N}$. benthamiana para 0 estudo da atividade das regiões promotoras dos alelos de S. Iycopersicum e}

S. pennellii

As células de $A$. tumefaciens cepa GV3101 contendo os plasmídeos pHGWFS7DnaJPromPen e pHGWFS7DnaJPromLyc foram cultivadas a $28{ }^{\circ} \mathrm{C}$ durante 16 horas em $20 \mathrm{ml}$ de meio LB com rifampicina $(25 \mu \mathrm{g} / \mathrm{ml})$, spectinomicina $(50 \mu \mathrm{g} / \mathrm{ml})$ e gentamicina $(50 \mu \mathrm{g} / \mathrm{ml})$, até se obter uma densidade óptica (OD) a $600 \mathrm{~nm}$ de 0,5. Posteriormente, as células foram coletadas a $4000 \mathrm{rpm}$ por $10 \mathrm{~min}$ a temperatura ambiente e ressuspendidas em MES 10 mM com acetosiringona (100 mM). A suspensão foi incubada por quatro horas a temperatura ambiente e a infiltração foi realizada em plantas de seis semanas na superfície abaxial da folhas intermediarias com uma seringa de $1 \mathrm{ml}$ sem agulha.

Três dias após a infiltração, as folhas foram retiradas e a atividade da $\beta$ glucoronidase identificada por meio de um ensaio histoquímico utilizando X-Glu (5bromo-4-chloro-3-indolyl-ß-D-glucurónido) como substrato (McCabe et al., 1988). As folhas infiltradas foram incubadas em placas de Petri com um volume suficiente para cobrir o tecido com tampão de reação GUS [X-Glu $(0,5 \mathrm{mg} / \mathrm{ml}), \mathrm{Na}_{2} \mathrm{PO}_{4} \mathrm{H}_{2}(100 \mathrm{mM})$, EDTA $(10 \mathrm{mM}), \mathrm{K}_{4} \mathrm{Fe}(\mathrm{CN})_{6} \cdot 3 \mathrm{H}_{2} \mathrm{O}(5 \mathrm{mM})$, Triton $\mathrm{X}-100(0,1 \%), \mathrm{pH}$ 7]. Posteriormente, foram incubadas a $37{ }^{\circ} \mathrm{C}$ por $18 \mathrm{~h}$, tempo no qual foi detectada a presença de um precipitado azul no tecido. Para a melhor visualização e fixação do tecido, foram realizadas várias lavagens com etanol 70\%.

\subsection{Infiltração de folhas de $\boldsymbol{N}$. benthamiana para o estudo da localização subcelular da proteína chaperona DnaJ}

As células de $A$. tumefaciens cepa GV3101 contendo o plasmídeo pK7FWG2DnaJlyc foram cultivadas a $28{ }^{\circ} \mathrm{C}$ durante 16 horas em $20 \mathrm{ml}$ de meio LB com rifampicina $(25 \mu \mathrm{g} / \mathrm{ml})$, spectinomicina $(50 \mu \mathrm{g} / \mathrm{ml})$ e gentamicina $(50 \mu \mathrm{g} / \mathrm{ml})$, até se obter uma densidade óptica (OD) de 0,5 a $600 \mathrm{~nm}$. Posteriormente, as células foram coletadas a $4.000 \mathrm{rpm}$ por $10 \mathrm{~min}$ a temperatura ambiente e ressuspendidas em MES $10 \mathrm{mM}$ com acetosiringona (100 mM). A suspensão foi incubada por 4 horas a temperatura ambiente e a infiltração realizada em plantas de aproximadamente seis semanas na superfície abaxial da folha com uma seringa de $1 \mathrm{ml}$ sem agulha. 
Após $48 \mathrm{~h}$, as folhas infiltradas foram analisadas e fotografadas no microscópio de laser confocal espectral Leica TCS-SP5, usando o objetiva de 63x (HCX PL APO CS 63.0x1.20 WATER UV). A linha de $488 \mathrm{~nm}$ do laser de Argon foi usada para excitar as partículas de GFP e da clorofila. A emissão da fluorescência foi detectada a 525-600 $\mathrm{nm}$ para GFP e a $700-800 \mathrm{~nm}$ para a clorofila. As imagens de cada plano foram tomadas em modo sequencial para evitar o cruzamento de espectros de ambos os fluoróforos. A configuração geral do microscópio foi ajustada para otimizar o contraste e a resolução de cada imagem individualmente.

\subsection{Obtenção de plantas transgênicas de tomate}

\subsubsection{Transformação genética}

A obtenção de linhagens transgênicas de S. lycopersicum (cv. Moneymaker), via Agrobacterium, foi realizada segundo o protocolo utilizado pelo Instituto de

Biotecnologia do INTA Castelar, Argentina (http://www.inta.gov.ar/biotec/actividad/transformaciondeplantas.htm).

A micropropagação das linhagens transgênicas selecionadas foi realizada assepticamente em fluxo laminar horizontal (Nuaire, EUA) a partir de ápices de plantas cultivadas in vitro. Foram mantidas em tubos de vidro de $2,5 \mathrm{~cm}$ de diâmetro e $10 \mathrm{~cm}$ de altura com meio de cultura MSS (sais Murashige-Skoog com 20\% sacarose), em câmaras de cultura a $22^{\circ} \mathrm{C}$, e fotoperíodo de $16 \mathrm{~h}$ claro (5000 lux) - $8 \mathrm{~h}$ escuro.

\subsubsection{Verificação da presença do transgene}

Para conferir a presença do transgene, DNA genômico das linhagens foi extraído segundo CIMMYT (2005) e foi realizada uma PCR usando $50 \mathrm{ng}$ de DNA molde, 0,2 mM de cada dNTPs, 0,2 mM de cada iniciador [35S-right (5'CCCACTATCCTTCGCAAG-3') e 35S-left (5'- GCAGGTCACTGGATTTTGG-3')], 1,5 mM de $\mathrm{Mg}_{2} \mathrm{SO}_{4}$ e 2,5 unidades de enzima TAQ polymerase $\AA$ (Invitrogen, 10342-020). O ciclo de amplificação utilizado foi de $94{ }^{\circ} \mathrm{C}$ por $3 \mathrm{~min}$; 35 ciclos de $94{ }^{\circ} \mathrm{C}$ por $30 \mathrm{seg}, 55^{\circ} \mathrm{C}$ por $1 \mathrm{~min}, 72{ }^{\circ} \mathrm{C}$ por $2 \mathrm{~min}$, e; uma extensão final a $72{ }^{\circ} \mathrm{C}$ por $10 \mathrm{~min}$. Os produtos amplificados foram verificados por eletroforese em gel de agarose $0,8 \%$ TAE $1 x$. 
3.9.3. Análise de expressão do gene chaperona DnaJ nas linhagens transgênicas obtidas

As linhagens crescidas in vitro em meio seletivo com antibiótico, para as quais foi confirmada a presença do transgene por PCR, foram levadas a casa de vegetação. Após quatro semanas, foram retiradas gemas vegetativas para sincronização das plantas com o respectivo controle. Uma vez que as plantas apresentavam oito folhas completamente expandidas, foi coletado o terceiro folíolo da quarta folha totalmente expandida para a análise do silenciamento por reação em cadeia da polimerase quantitativa em tempo real (qPCR). A extração de RNA e posterior síntese de cDNA foi realizado como descrito no item 3.5. A reação de qPCR foi realizada com $1 \mu$ de uma diluição de CDNA 1:5, 0,2 mM de cada iniciador [RNAitrans-Dna]-F (5'CAGCACCTTCACTTTCCCGC-3') e RNAitrans-DnaJ-R (5'CGTGTTTTGATCAAGATCCACAGC-3') para o gene alvo, e EF-1a-up (5'ATTGGAAACGGATATGCTCCA-3') e EF-1a-Low (5'- TCCTTACCTGAACGCCTGTCA -3'), para o gene de referência] e 2x SYBR Green Master Mix (Qiagen, 204054). Foi utilizado um termociclador 7300 PCR Real Time (Applied Biosystems) e o ciclo de amplificação foi de $95{ }^{\circ} \mathrm{C}$ por $10 \mathrm{~min}$ e 40 ciclos de: $95^{\circ} \mathrm{C}$ por $15 \mathrm{seg}, 55^{\circ} \mathrm{C}$ por 1 min e $72{ }^{\circ} \mathrm{C}$ por $30 \mathrm{seg}$ (momento no qual ocorre a leitura do sinal emitido pelo SYBR Green). Os dados obtidos foram analisados com o software LinRegPCR (Ruijter et al., 2009) para calcular os valores de $\mathrm{Ct}$ (cycle threshold) e a eficiência da reação. A expressão relativa foi calculada segundo fórmula abaixo (Pfaffl et al., 2002) com o software fgStatistics (Di Rienzo, 2009). O mesmo software foi utilizado para as análises estatísticas.

Onde:

$$
\mathrm{ER}=\frac{\mathrm{Ef}_{\text {alvo }} \wedge \text { (média de } \mathrm{Ct} \text { do controle }- \text { média de } \mathrm{Ct} \text { da linhagem) }}{\mathrm{Ef}_{\text {ref }} \wedge \text { (média de } \mathrm{Ct} \text { do controle - média de } \mathrm{Ct} \text { da linhagem) }}
$$

ER: expressão relativa

Ef: eficiência da qPCR para cada par de iniciadores

alvo: gene alvo (DnaJ)

Ct do controle: média dos Cts das réplicas biológicas do controle

Ct da linhagem: média dos Cts das réplicas biológicas de cada linhagem

ref: gene de referência ( $E F 1 a)$

\subsection{Caracterização fenotípica das linhagens transgênicas}

\subsubsection{Cultivo e parâmetros de produção}

As cinco linhagens que apresentaram a maior redução dos níveis de RNAm do gene chaperona DnaJ foram selecionadas para caracterização fenotípica: RNAi:DnaJ-7, RNAi:DnaJ-12, RNAi:DnaJ-39, RNAi:DnaJ-40, RNAi:DnaJ-43. Foram estabelecidas seis 
réplicas de cada linhagem por meio de propagação por estaquia, em setembro de 2010. Foram feitas duas coletas no período das $10 \mathrm{~h}$ às $14 \mathrm{~h}$ : uma após cinco semanas e outra aos quatro meses, quando todas as plantas já apresentavam frutos maduros. Na primeira foi coletado o segundo e terceiro folíolo da terceira folha totalmente expandida e na coleta final foram amostrados pericarpos de fruto verde e maduro, de 37 e 52 dias após antese, respectivamente. Foram separados, contados e pesados todos os frutos restantes e, finalmente, a parte aérea da planta foi cortada no colo da raiz e pesada como parâmetro de biomassa. Para calcular o índice de colheita foi usada a seguinte fórmula:

Índice de colheita=(peso total de frutos verdes e maduros)*100/peso fresco da parte aérea.

\subsubsection{Verificação do nível de silenciamento nas linhagens transgênicas}

Uma nova verificação do nível de silenciamento do gene chaperona DnaJ foi realizada para as seis réplicas de cada linhagem selecionada. Foram testadas por qPCR amostras de folhas fonte e fruto maduro, segundo descrito no item 3.9.3.

\subsubsection{Medição dos parâmetros fotossintéticos}

As medidas de trocas gasosas e fluorescência da clorofila foram realizadas com o sistema portátil Licor-6400 (Li-Cor; www.licor.com) que consiste em um sistema aberto contendo um analisador de gases por infravermelho (IRGA) e uma câmara fluorométrica acoplada (Modelo 6400-40, Li-Cor).

As medidas foram realizadas no segundo folíolo da terceira folha totalmente expandida de plantas em estado vegetativo de quatro semanas, no período das $10 \mathrm{~h}$ às $14 \mathrm{~h}$. Antes de realizar as medições, as folhas a serem analisadas passaram por um processo de adaptação a escuridão durante no mínimo 30 min. Foram realizadas curvas de resposta à luz com uma câmara que possui uma área de exposição foliar de $2 \mathrm{~cm}^{2}$, as condições padrão para as medições foram de $400 \mathrm{PPM}$ de $\mathrm{CO}_{2}$ e temperatura foliar de $25^{\circ} \mathrm{C}$.

Os parâmetros fotossintéticos foram determinados segundo Maxwell e Johnson (2000). Foram calculadas as fluorescências mínimas de folhas adaptadas à escuridão (F0) e adaptadas à luz (F0'). Após um pulso de luz saturante branca (3.000 $\mu$ moles $\mathrm{E}$ $\mathrm{m}^{-2} \mathrm{~s}^{-1}$ ) foi determinada a fluorescência máxima da clorofila nas folhas adaptadas ao escuro $(F m)$ e à luz $\left(F m^{\prime}\right)$. A fluorescência variável foi determinada pelo cálculo de $\mathrm{Fv}=\mathrm{Fm}-\mathrm{F0}$ em folhas adaptadas à escuridão, ou $\mathrm{Fv}^{\prime}=\mathrm{Fm}^{\prime}-\mathrm{FO}^{\prime}$ em folhas adaptadas à luz variando a densidade de fluxo de fótons (PFD) entre 200 e $1200 \mu$ moles $\mathrm{E} \mathrm{m}^{-2} \mathrm{~s}^{-1}$. A 
relação entre a eficiência variável e a eficiência máxima Fv/Fm, a eficiência do fotossístema II $\left(\mathrm{Fm}^{\prime}-\mathrm{Fs}\right) / \mathrm{Fm}^{\prime}$, o quenching fotoquímico $\mathrm{qP}=\left(\mathrm{Fm}^{\prime}-\mathrm{Fs}\right) /\left(\mathrm{Fm}^{\prime}-\mathrm{FO}^{\prime}\right)$, o quenching não-fotoquímico $\mathrm{NPQ}=\left(\mathrm{Fm}-\mathrm{Fm}^{\prime}\right) / \mathrm{Fm}^{\prime}$ e a acumulação de quinonas reduzidas $1-\mathrm{pQ}=\left(F s-F 0^{\prime}\right) /\left(\mathrm{Fm}^{\prime}-\mathrm{FO}^{\prime}\right)$ também foram calculados. Finalmente, foi avaliada a taxa de transferência de elétrons:

$$
\mathrm{ETR}=\left[\left(\mathrm{Fm}^{\prime}-\mathrm{Fs}\right) / \mathrm{Fm}^{\prime}\right]^{*} f I \mathrm{a}_{\mathrm{folha}}
$$

onde Fs é o estado estável de fluorescência, $f$ é a fração de quanta absorvido que é usado pelo fotossístema II o qual se assume ser de 0,5 para plantas C3, I é a densidade de fluxo de fótons incidente e $a_{\text {folha }}$ é a absorbância da folha que se assume ser 0,85 (Sienkiewicz-Porzucek et al., 2010).

\subsubsection{Extração e quantificação de pigmentos}

Para a quantificação de pigmentos, foram coletados um disco foliar de área $0,38 \mathrm{~cm}^{2}$ do segundo folíolo da terceira folha totalmente expandida, $400 \mathrm{mg}$ de pericarpo de fruto verde e $400 \mathrm{mg}$ de pericarpo de fruto maduro para cada uma das réplicas das cinco linhagens transgênicas selecionadas, na coleta final. As amostras foram trituradas em nitrogênio líquido.

A extração de pigmentos para o tecido foliar e fruto verde foi realizada como descrito por Lichtenthaler (1987). As amostras foram maceradas em um tubo contendo $1 \mathrm{ml}$ de acetona $80 \%(\mathrm{~V} / \mathrm{V})$ por 2 horas em escuridão até observar a descoloração total do material e, posteriormente, centrifugadas por $10 \mathrm{~min}$ a $10.000 \mathrm{rpm}$. A absorbância do sobrenadante foi lida em espectrofotômetro a 663, 645 e 470 nm. Baseada nas absorbâncias obtidas foi calculada a concentração dos pigmentos pelas equações a seguir e o conteúdo total foi normalizado pela massa (fruto verde) ou área (folha fonte) de tecido.

Clorofila $\mathbf{a}=12,25 *$ Abs $663-2,79 *$ Abs 645

Clorofila $\boldsymbol{b}=21,50 *$ Abs $645-5,10 *$ Abs 663

Carotenóides totais $=(1000 *$ Abs $470-1,82 *$ Clorofila $a-85,02 *$ Clorofila $b) / 198$

Para a quantificação dos pigmentos de fruto maduro foi utilizado o protocolo descrito por Heredia et al. (2009). $400 \mathrm{mg}$ de tecido foram macerados em $4 \mathrm{ml}$ de etanol absoluto e $3 \mathrm{ml}$ de hexano (99\%) por $1 \mathrm{~h}$ no escuro com agitação de $150 \mathrm{rpm}$. Posteriormente, foi acrescentado $1 \mathrm{ml}$ de água MilliQ deionizada para permitir a separação das duas fases. A absorbância de $500 \mu \mathrm{l}$ da fase superior (hexano) foi lida 
em espectrofotômetro a 503 e 478 nm. Baseada nas absorbâncias obtidas foi calculada a concentração dos pigmentos pelas equações a seguir e o conteúdo total foi normalizado pela massa de tecido.

$$
\begin{gathered}
\frac{\mathrm{mg} \mathrm{\beta} \text {-caroteno }}{100 \mathrm{~g}}=\frac{\left[\mathrm{A}_{478}-\left(\mathrm{A}_{503} * 0,9285\right)\right] * M_{\beta \text {-car }} * \mathrm{~V} * 100}{\mathrm{~m} * E_{\beta \text {-car }}} \\
\frac{\mathrm{mg} \text { licopeno }}{100 \mathrm{~g}}=\frac{\mathrm{A}_{503} * M_{\mathrm{LIC}} * \mathrm{~V} * 100}{\mathrm{~m} * E_{\mathrm{LIC}}}
\end{gathered}
$$

onde A é a absorbância; $M_{\text {LIc }}$ e $M_{\beta \text {-car são os pesos moleculares do licopeno (537 }}$ $\mathrm{g} / \mathrm{mol}$ ) e $\beta$-caroteno $(533,85 \mathrm{~g} / \mathrm{mol})$, respectivamente; $V$ é o volume da fase de hexano

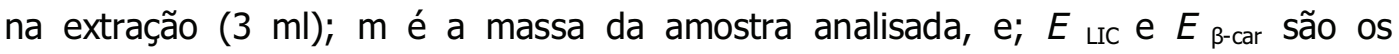
coeficientes de extinção do licopeno $\left(172 \mathrm{M}^{-1} \mathrm{~cm}^{-1}\right)$ e do $\beta$-caroteno $\left(139 \mathrm{M}^{-1} \mathrm{~cm}^{-1}\right)$, respectivamente (Zscheille e Porter, 1947).

\subsubsection{Extração e quantificação de aminoácidos, açúcares solúveis e amido}

As extrações de açúcares solúveis, aminoácidos totais e amido para folhas fonte e frutos maduros foram realizados usando protocolos estabelecidos pelo nosso grupo (Fernie et al., 2001).

\section{Extração}

Foram adicionados $250 \mu \mathrm{l}$ de etanol $80 \%$ a $10 \mathrm{mg}$ de tecido triturado, seguido de agitação por $20 \mathrm{~min}$ a $80{ }^{\circ} \mathrm{C}$. Após centrifugação por $5 \mathrm{~min}$ a $14.000 \mathrm{rpm}$, o sobrenadante foi recuperado e o pellet submetido a duas novas extrações, com $150 \mu \mathrm{l}$ de etanol $80 \%$ e $250 \mu \mathrm{l}$ de etanol $50 \%$, respectivamente. Os três sobrenadantes foram reunidos para posterior quantificação de açúcares e aminoácidos.

Ao pellet obtido foram adicionados $500 \mu \mathrm{l}$ de etanol $40 \%$ e centrifugado por 10 min a $14.000 \mathrm{rpm}$. O sobrenadante foi descartado e o pellet ressuspendido em $400 \mu \mathrm{l}$ de $\mathrm{KOH} \mathrm{0,2} \mathrm{M.} \mathrm{A} \mathrm{suspensão} \mathrm{foi} \mathrm{incubada} \mathrm{durante} 1 \mathrm{~h}$ a $95^{\circ} \mathrm{C}$ e, posteriormente, foram adicionados $70 \mu \mathrm{l}$ de ácido acético $1 \mathrm{M}$ seguido de uma centrifugação por $10 \mathrm{~min}$ a $14.000 \mathrm{rpm}$. O sobrenadante foi recuperado, e as amostras diluídas 1:3.

\section{Determinação de açúcares}

Para uma placa de 96 poços foi preparada uma mistura com 15,5 ml de tampão (HEPES/KOH 1 M, MgCl 30 mM pH 7,0) 0,1x, $480 \mu \mathrm{l}$ de ATP [60 mg/ml], $480 \mu \mathrm{l}$ de 
NADP [36 mg/ml] e $80 \mu \mathrm{l}$ de glicose-6-fosfato desidrogenase (G6PDH) [5 mg/ml]. Em cada poço, foram adicionados $50 \mu \mathrm{l}$ do extrato etanólico e $160 \mu \mathrm{l}$ da mistura descrita anteriormente. A leitura foi feita em espectrofotômetro a $340 \mathrm{~nm}$ com medições a cada minuto. Uma vez que a OD se estabilizou foram adicionadas sucessivamente $1 \mu \mathrm{l}$ de hexoquinase $[1500 \mathrm{U} / \mathrm{ml}], 1 \mu \mathrm{l}$ de fosfoglicose isomerase $[2 \mathrm{mg} / \mathrm{ml}$ ] e finalmente $1 \mu \mathrm{l}$ de invertase $0,1 \mathrm{M}$. Para fazer os cálculos da concentração dos respectivos açúcares, foi usada a seguinte equação:

$$
\mu \mathrm{mol} \mathrm{NADPH}=\Delta \mathrm{OD} /(2.85 * 6.22)
$$

Os valores foram normalizados pelo volume utilizado na medição e a massa de tecido.

\section{Determinação de aminoácidos}

Em um tubo de 1,5 ml foram adicionados $50 \mu$ de tampão citrato/ $\mathrm{NaOH} 1 \mathrm{M} \mathrm{pH}$ 5,2 com ácido ascórbico $0,2 \%, 50 \mu \mathrm{l}$ de extrato etanólico, obtido como descrito anteriormente e $100 \mu \mathrm{l}$ de solução de ninhidrina $1 \%$ (P/V em etanol 70\%). Os tubos foram selados e incubados por 20 min a $95{ }^{\circ} \mathrm{C}$, centrifugados por $10 \mathrm{seg}$ a $10.000 \mathrm{rpm}$ e finalmente as amostras foram dispostas em placa de 96 poços e lidas em espectrofotômetro a $570 \mathrm{~nm}$.

Para realizar a estimativa do conteúdo total de aminoácidos, foi realizada uma curva padrão de Leucina substituindo os $50 \mu \mathrm{l}$ da amostra por 0-2-5-10-20-50 $\mu \mathrm{l}$ de padrão de leucina completado com 50-48-45-40-30-0 $\mu$ le etanol 70\%, respectivamente. Os valores foram normalizados pelo volume utilizado na medição e a massa de tecido.

\section{Determinação de amido}

A determinação enzimática foi realizada com o kit Starch (GO/P) Assay da empresa SIGMA (STA20), segundo instruções do fabricante. A produção de NADH foi medida em espectrofotômetro a $340 \mathrm{~nm}$. Foi realizada uma curva padrão com glicose e o cálculo do conteúdo de amido foi realizado segundo a seguinte fórmula:

$\mu \mathrm{g} / \mathrm{g}$ peso fresco de amido $=\mu \mathrm{mol}$ de glicose $* 162$ (massa da anidroglicose)

Os valores foram normalizados pelo volume utilizado na medição e a massa de tecido. 


\subsubsection{Análise estatística}

Os diferentes parâmetros analisados nas linhagens transgênicas foram avaliados estatisticamente de acordo com Sokal e Rohlf (1981). Quando o conjunto de dados obedeceu ao critério de homoscedasticidade, com ou sem transformação logarítmica ou de raiz quadrada, os dados foram analisados por ANOVA seguido pelo teste de Duncan e/ou Tukey $(P<0,05)$ para comparação dos parâmetros entre as linhagens transgênicas silenciadas e o controle. $\mathrm{Na}$ falta de homoscedasticidade, uma comparação não-paramétrica foi feita por meio do teste Kruskal Wallis $(P<0,05$ e 0,1$)$. Os testes estatísticos foram realizados utilizando o programa InfoStat v. 2009 (www.infostat.com, Grupo InfoStat, FCA, Universidad Nacional de Córdoba, Argentina). 


\section{RESULTADOS}

\subsection{A proteína chaperona DnaJ agrupa em um clado diferente das chaperonas previamente descritas}

A partir da sequência do BAC de S. pennellii (C04SpBP093E005.P4C04), descrita no capítulo II, e do clone ortólogo de S. lycopersicum (C04HBa0331L22) foram obtidas as sequências completas de ambos os alelos do gene chaperona DnaJ. As regiões intergênicas amontante do sítio de inicio da transcrição, até o começo do cDNA do gene vizinho, foram consideradas como as respectivas regiões promotoras. As regiões transcritas apresentaram um tamanho de 3.019 e $3.063 \mathrm{nt}$ para S. lycopersicum e S. pennellii, respectivamente. A estrutura gênica dos alelos foi similar variando apenas no tamanho dos íntrons e pela presença de um intron adicional na região $3^{\prime}$ não-traduzida de $S$. pennellii (Figura 6). Para ambas as sequências foi identificado o domínio DnaJ, contendo os motivos ricos em cisteínas (CXXCXGXG), característico desta família protéica. Adicionalmente, foram preditos peptídeos de direcionamento ao cloroplasto, sendo que o do alelo de $S$. lycopersicum apresentou 65 aa e o de $S$. pennellii 47 aa. Finalmente, uma análise da estrutura protéica in silico permitiu identificar um domínio transmembrana entre os aminoácidos 54 e 76 para ambos os alelos, sendo que o domínio de interação proteína-proteína (DnaJ) ficaría exposto no citoplasma. Ao todo foram detectados dois polimorfismos de aminoácidos ambos sobre o peptídeo sinal (Figura 7).

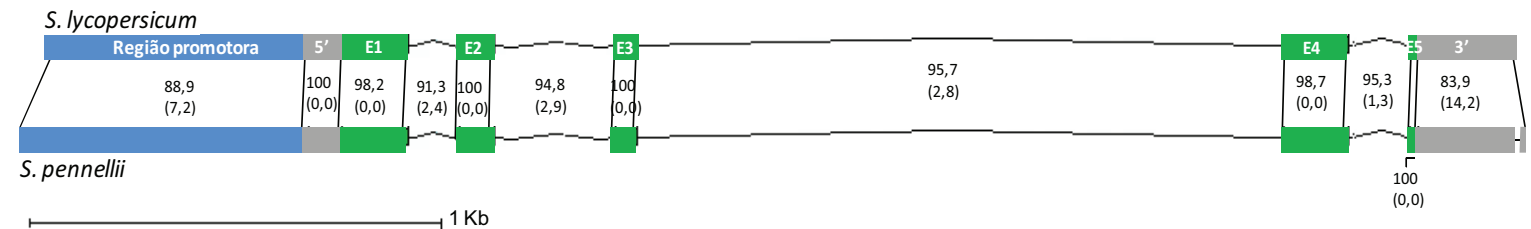

Figura 6. Análise comparativa da estrutura gênica entre os alelos de $\boldsymbol{S}$. lycopersicum e $\boldsymbol{S}$. pennellii para o gene chaperona DnaJ.

E: éxon, I: íntron, UTR: região transcrita não-traduzida. As setas verdes e vermelhas indicam os códons de inicio e fim da tradução, respectivamente. A porcentagem de identidade e indels (XX) entre ambos os genótipos encontra-se indicada para cada região individualmente. 


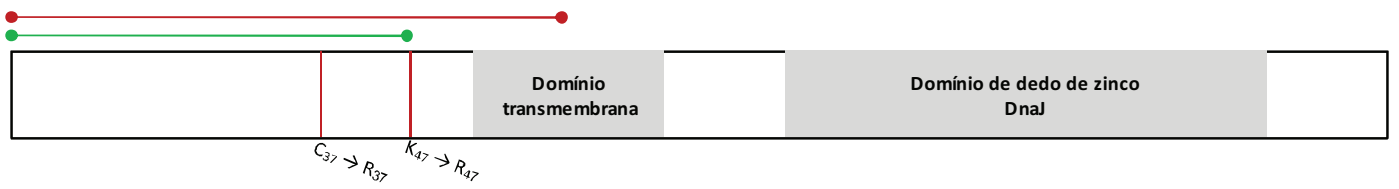

Figura 7. Análise comparativa da sequência protéica entre os alelos de $S$. lycopersicum e $S$. pennellii para a proteína chaperona DnaJ.

Os polimorfismos de aminoácidos entre os genótipos encontram-se indicados com linhas vermelas. Os peptídeos de direcionamento a cloroplasto estão indicados com uma linha vermelha e verde para $S$. lycopersicum e S. pennellii, respectivamenteOs domínios protéicos identificados estão demarcados com blocos cinza.

Para ganhar evidências sobre a função da chaperona DnaJ de tomate foi analisada a sua seqüência protéica no contexto das chaperonas funcionalmente caracterizadas em plantas por meio de uma análise filogenética. A topologia da árvore permitiu identificar quatro clados, os quais podem ser diferenciados claramente segundo a sua estrutura proteíca. As proteínas de $S$. lycopersicum e $S$. pennellii estudadas neste trabalho agrupam junto à ortóloga de arabidopsis e possuem 0 domínio transmenbrana que as diferencia das descritas por Lu et al. (2006) e Ham et al. (2006) (Figura 8).

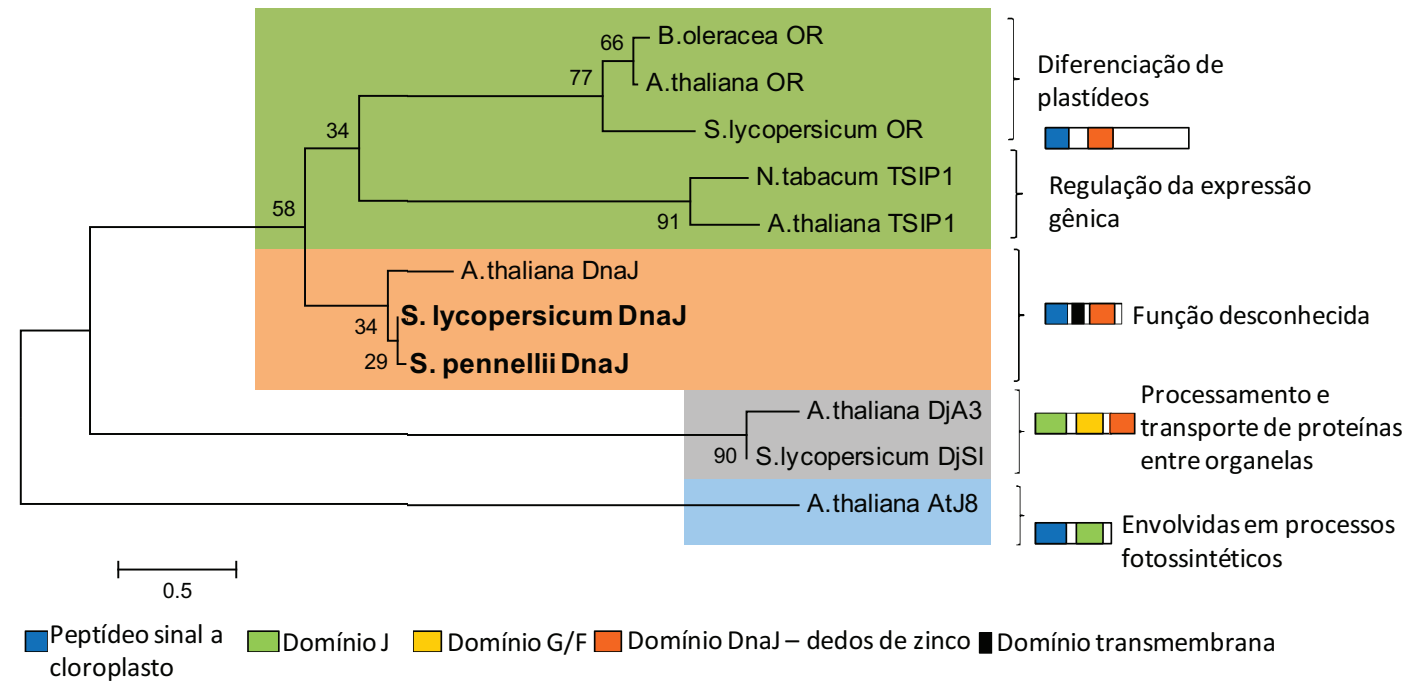

Figura 8. Análise da diversidade das chaperonas DnaJ.

Os quatro clados estão marcados em verde, laranja, cinza e azul. Na direita da árvore estão indicadas as estruturas protéicas de cada clado, assim como as funções demonstradas para cada grupo. Os genes envolvidos na determinação da eficiência fotossintética foram descritos por Chen et al. (2010). As seqüências relacionadas ao processamento de proteínas foram caracterizadas funcionalmente por Kroczynska et al. (1996). As sequências associadas à diferenciação de plastídeos e regulação da expressão gênica foram relatadas por Lu et al. (2006) e Ham et al. (2006), respectivamente. As sequências descritas neste trabalho estão ressaltadas em negrita. 


\subsection{Os promotores dos alelos selvagem e cultivado apresentam atividade transcricional diferencial}

Para avaliar a atividade transcricional dos promotores dos alelos de $S$. pennellii e S. lycopersicum do gene chaperona DnaJ foram obtidas construções fusionando os respectivos promotores às regiões codificantes dos genes repórteres gfp (green fluorescent protein) e gus ( $\beta$-glucoronidase). Folhas de $N$. benthamiana foram infiltradas com cultivos de $A$. tumefaciens contendo as construções pHGWFS7DnaJPromLyc (promotor de S. lycopersicum::gus), pHGWFS7DnaJPromPen (promotor de $S$. pennellii::gus), pHGWFS735s (controle positivo com promotor 35S:gus) e pHGWFS7 (controle negativo sem promotor) de acordo à distribuição apresentada na Figura 9. Três dias após a infiltração, foi realizado o ensaio histoquímico para detecção da atividade da proteína repórter GUS. A Figura 9 apresenta uma folha representativa do experimento, confirmando que o fragmento clonado de $S$. lycopersicum corresponde ao promotor do gene, e apresenta maior atividade transcricional que o promotor de $S$. pennellii, o qual apresentou um nível de atividade não detectável pela metodologia aplicada.

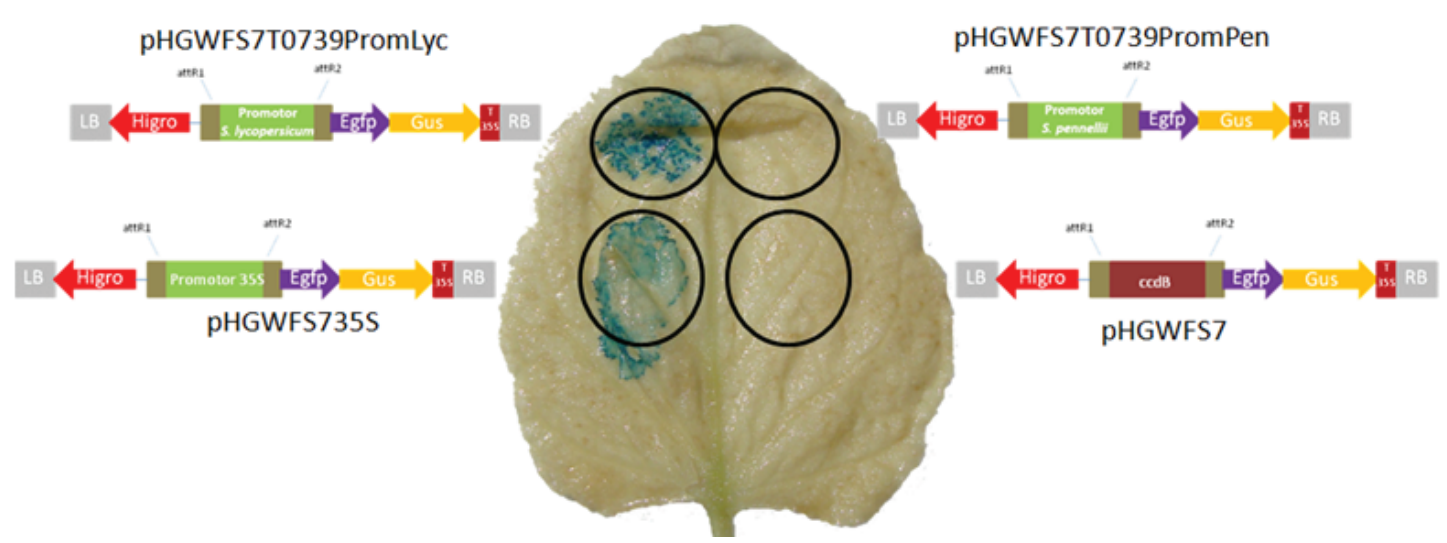

Figura 9. Estudo da atividade dos promotores por meio de ensaios de expressão transitória em folhas de $N$. benthamiana.

O precipitado azul revela a presença de atividade da proteína GUS. pHGWFS7DnaJPromLyc: promotor de $S$. lycopersicum fusionado a gus. pHGWFS7DnaJPromPen: promotor de $S$. pennellii fusionado a gus. pHGWFS735S: controle positivo com promotor 35S fusionado a gus. pHGWFS7: controle negativo sem promotor. LB: borda esquerda. Higro: cassete de resistência a higromicina. p35S: promotor $35 \mathrm{~s}$ do CaMV. Egfp: green fluorescent protein. Gus: $\beta$-glucuronidase. T35s: terminador 35S do CaMV. RB: borda direita. 


\subsection{A proteína DnaJ é direcionada a cloroplasto}

Para somar evidências sobre a função da chaperona DnaJ foi desenhado um experimento de localização com o intuito de identificar o compartimento celular onde essa proteína atua. Para isso, foi obtida a construção pK7FWG2DnaJLyc contendo o cDNA completo do gene chaperona DnaJ de 480 pb, de S. lycopersicum, abrangendo desde o ATG até o códon anterior ao de fim da tradução, fusionado à sequência codificante da proteína GFP. Um cultivo de $A$. tumefaciens contendo a construção supramencionada foi infiltrado em folhas de $N$. benthamiana. Após $48 \mathrm{~h}$, foram montadas lâminas com discos de folhas infiltradas e visualizadas ao microscópio confocal. A proteína de fusão foi localizada no cloroplasto das células, evidenciada pela sobreposição da emissão da proteína GFP e da clorofila (Figura 10).
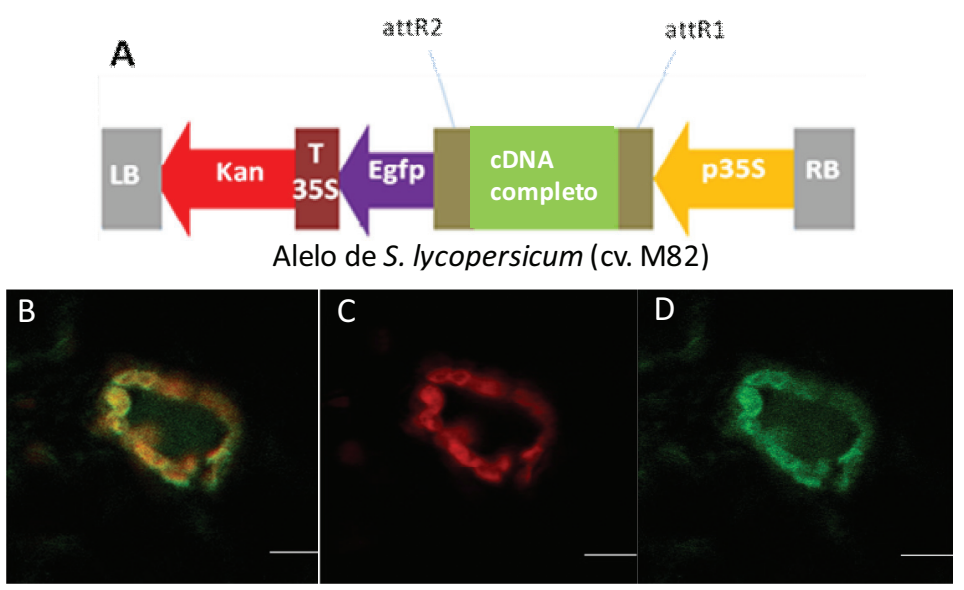

Figura 10. Localização subcelular da proteína de fusão chaperona DnaJ::GFP.

Esquema da construção pK7FWG2-DnaJLyc (A). Células de mesófilo de folhas de $N$. benthamiana agroinfiltrada com $A$. tumefasciens (GV3101) contendo a construção pK7FWG2DnaJLyc (B, C, D). Sobreposição das imagens de fluorescência da clorofila e GFP (B). Imagem da fluorescência da clorofila (C). Imagem da fluorescência de GFP (D). A barra da escala corresponde a $10 \mu \mathrm{m}$. LB: borda esquerda. Kan: cassete de resistência a canamicina. T35s terminador 35S: do CaMV. eGFP: green fluorescent protein. CDNA completo: cDNA do alelo de S. lycopersicum. p35S: promotor 35 s do CaMV. RB: borda direita.

\subsection{Obtenção das plantas silenciadas para o gene chaperona DnaJ}

Para demonstrar o envolvimento do gene chaperona DnaJ na determinação das diferenças observadas entre S. lycopersicum (cv. M82) e a IL 4-4 no conteúdo de metabólitos dos frutos, foi adotada a estratégia de silenciamento gênico por RNA de interferência. Desta forma, foi obtida a construção pK7GWIWG2(I)DnaJ contendo um fragmento de 129 pb do quarto éxon do gene (Figura 11). A escolha desse fragmento foi determinada a partir do alinhamento utilizado para a análise filogenética, realizada 
no item 4.1 deste capítulo, de maneira que o silenciamento fosse específico para o gene de interesse evitando interferir na expressão de outros genes parálogos. Por meio da transformação genética mediada por A. tumefaciens, foram obtidas 36 linhagens independentes de tomate que enraizaram em presença do agente seletivo.

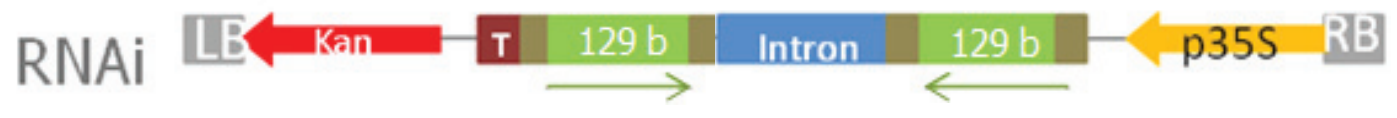

Figura 11. Representação esquemática do vetor pK7GWIWG2(I)DnaJ.

Construção utilizada para a obtenção das plantas transgênicas de tomate $S$. lycopersicum (cv. Moneymaker) RNAi:DnaJ. LB: borda esquerda. Kan: cassete de resistência a canamicina. T: terminador 35s do CaMV. 129b: fragmento da sequência codificante do gene chaperona DnaJ. p35s: promotor 35s do CaMV. RB: borda direita.

A presença do transgene nas linhagens obtidas foi verificada por meio de PCR utilizando iniciadores específicos para o promotor 35S. Dessa forma, foram identificados seis escapes e determinada uma eficiência de transformação de $75 \%$ (Tabela 2). Posteriormente, 15 das linhagens positivas foram sincronizadas por meio de estaquia junto aos respectivos controles, e foi avaliado o silenciamento do gene alvo utilizando qPCR. A Figura 12 apresenta os dados de expressão relativa do gene chaperona DnaJ demonstrando que 13 das linhagens transgênicas possuem níveis de RNAm mais baixos que o controle selvagem, resultando em uma eficiência de silenciamento do $86,6 \%$ (Tabela 2).

Tabela 2. Eficiência da transformação de tomate com a construção para silenciamento do gene chaperona DnaJ.

\begin{tabular}{|c|c|c|c|c|c|c|}
\hline Gene & $\begin{array}{l}\text { Linhagens } \\
\text { regeneradas }\end{array}$ & $\begin{array}{c}\text { Linhagens } \\
\text { positivas por PCR }\end{array}$ & $\begin{array}{c}\text { Eficiência de } \\
\text { transformação } \\
\%\end{array}$ & $\begin{array}{l}\text { Linhagens } \\
\text { avaliadas } \\
\text { por qPCR }\end{array}$ & $\begin{array}{l}\text { Linhagens } \\
\text { silenciadas }\end{array}$ & $\begin{array}{l}\% \text { Plantas } \\
\text { silenciadas }\end{array}$ \\
\hline $\begin{array}{c}\text { Chaperona } \\
\text { DnaJ }\end{array}$ & 36 & 27 & 75 & 14 & 13 & 92,8 \\
\hline
\end{tabular}




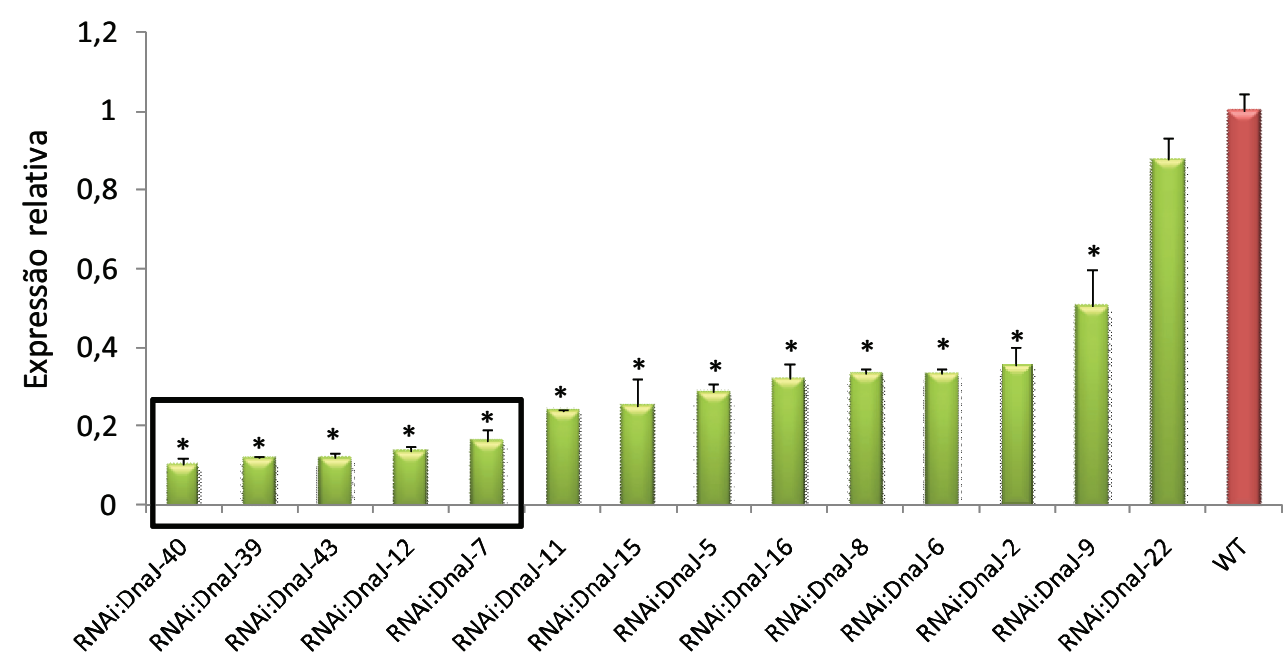

Figura 12. Análise de expressão do gene chaperona DnaJ nas linhagens transgênicas.

Os resultados representam a média de três réplicas técnicas. Os valores estão expressos como a abundância relativa do RNAm comparado ao controle $S$. lycopersicum (cv. Moneymaker). Na caixa preta destacam-se as linhagens selecionadas para avaliação fenotípica. *Diferenças estatisticamente significativas pelo teste de Kruskal-Wallis $(P<0,005)$.

\subsection{Caracterização fenotípica das linhagens transgênicas}

Para a avaliação fenotípica, foram selecionadas as cinco linhagens (RNAi:DnaJ7, RNAi:DnaJ-12, RNAi:DnaJ-39, RNAi:DnaJ-40, RNAi:DnaJ-43) que apresentaram a maior redução dos níveis de RNAm do gene chaperona DnaJ (Figura 12). As plantas escolhidas foram propagadas vegetativamente por meio de estaquia gerando seis réplicas para caracterização fenotípica.

\subsubsection{Verificação do nível de silenciamento nas linhagens transgênicas}

Com o intuito de confirmar o silenciamento nas réplicas biológicas, os níveis de RNAm do gene chaperona DnaJ foram novamente verificados em folhas e frutos por qPCR. De forma geral, os dados de expressão relativa confirmaram o silenciamento previamente observado para ambos os tecidos (Figura 13). No caso da linhagem RNAi:DnaJ-40 a redução não foi significativa, mas devido à verificação de outras alterações fenotípicas, esta linhagem não foi descartada. 


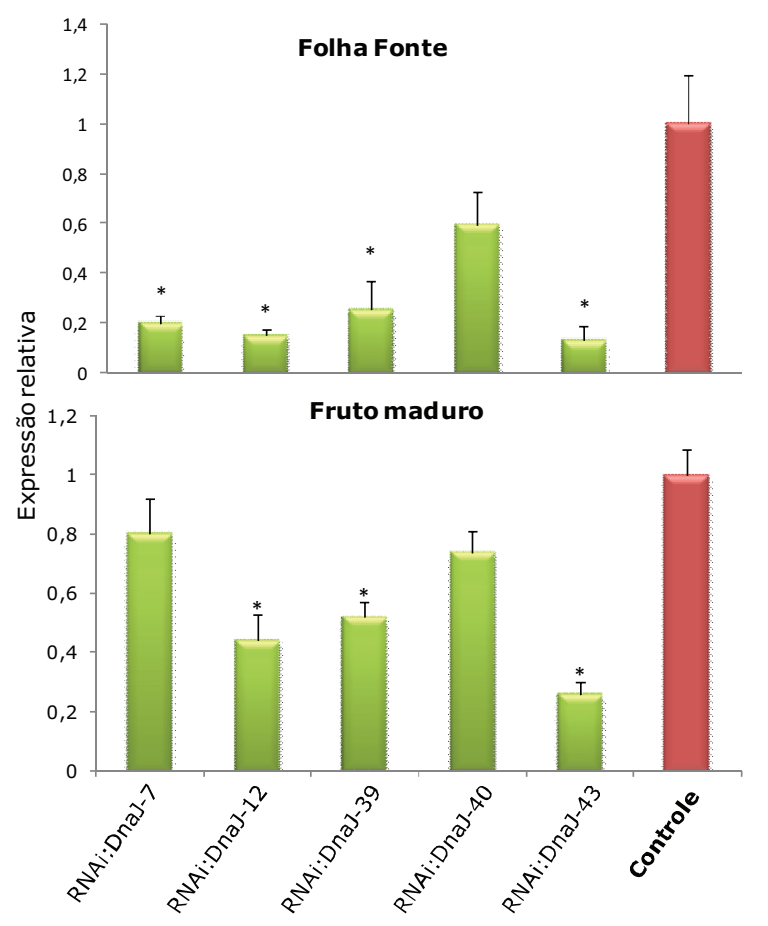

Figura 13. Análise de expressão do gene chaperona DnaJ nas linhagens transgênicas selecionadas.

Os resultados representam a média de seis réplicas biológicas com três réplicas técnicas cada. Os valores estão expressos como a abundância relativa do RNAm comparado ao controle S. lycopersicum (cv. Moneymaker). *Diferenças estatisticamente significativas $(P<0,005)$.

4.5.2. O silenciamento do gene chaperona DnaJ não impacta os parâmetros fotossintéticos

Para avaliar o possível efeito do silenciamento do gene chaperona DnaJ na fotossíntese foram realizadas medições de intercâmbio gasoso e fluorescência da clorofila a diferentes densidades de fluxo de fótons. Embora tenha sido observada uma tendência de maior taxa de assimilação de $\mathrm{CO}_{2}$ para as linhagens Rnai:DnaJ-7, RNAi:DnaJ-12, RNAi:DnaJ-39, as diferenças não apresentaram significância estatística (Figura 14). O mesmo padrão foi observado para a condutância estomática e consequentemente para a transpiração. Pelo contrário, não foram observadas alterações em nenhum dos parâmetros avaliados da fluorescência de clorofila (Tabela 3). 


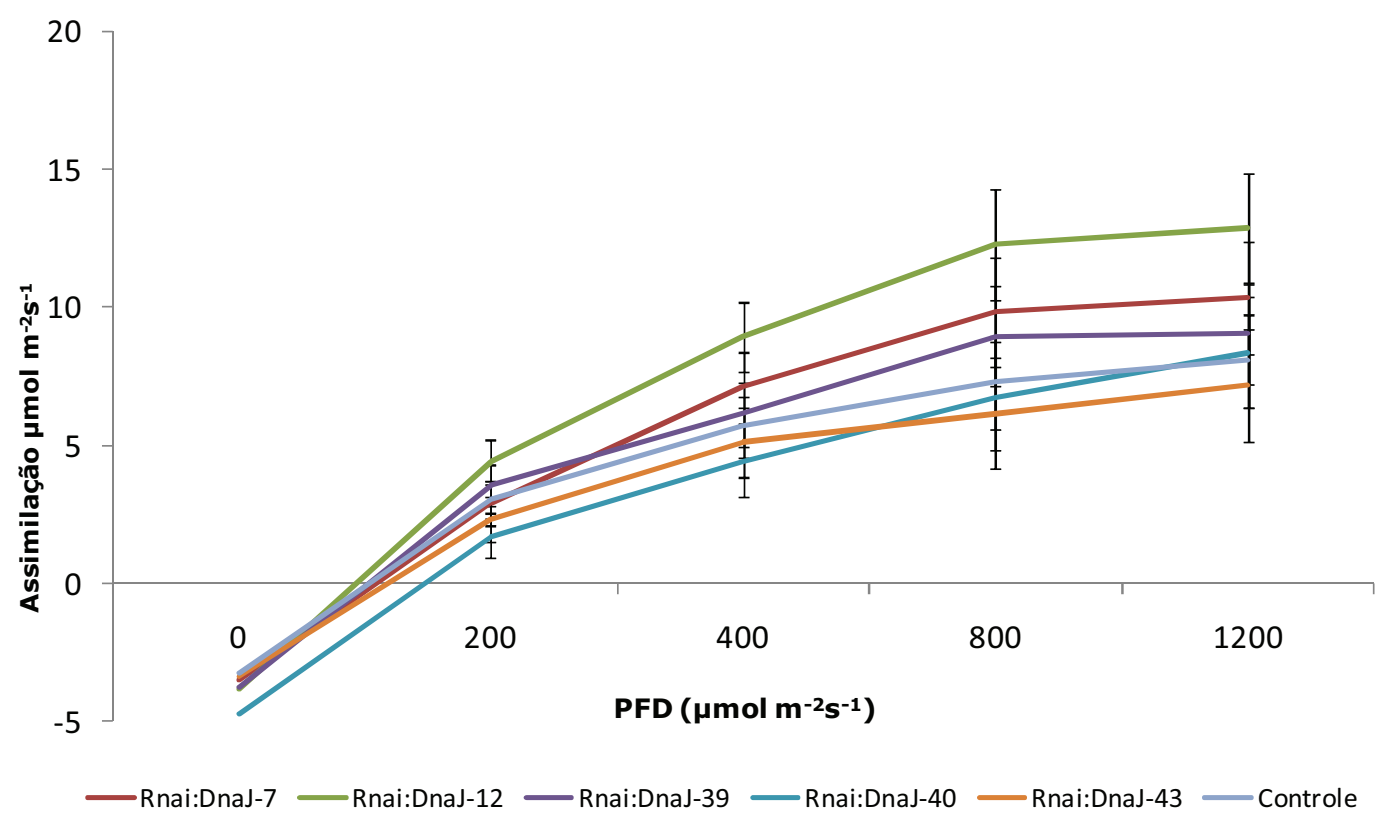

Figura 14. Taxa de assimilação de $\mathrm{CO}_{2}$ nas linhagens transgênicas.

Os valores apresentam a média obtida entre seis réplicas biológicas. Não foram encontradas diferenças significativas $(P<0,05)$. PFD: Densidade de fluxo de fótons.

Tabela 3. Parâmetros fotossintéticos e de trocas gasosas nas linhagens transgênicas.

\begin{tabular}{|c|c|c|c|c|c|c|c|}
\hline & $\begin{array}{l}\text { Condutância } \\
\text { estomática }\end{array}$ & Tran spiração ${ }^{2}$ & $\mathrm{ETR}^{3}$ & $\begin{array}{c}\text { Quenching } \\
\text { fotoquímico }\end{array}$ & $\begin{array}{c}\text { Quenching não } \\
\text { fotoquím ico }\end{array}$ & $1-p Q^{4}$ & $\begin{array}{l}\text { Eficiên cia do } \\
\text { fotossístema II }\end{array}$ \\
\hline RNAi:DnaJ-7 & $0,09 \pm 0,02$ & $2,36 \pm 0,41$ & $156,37 \pm 7,17$ & $0,6 \pm 0,03$ & $1,48 \pm 0,14$ & $0,4 \pm 0,03$ & $0,3 \pm 0,01$ \\
\hline RNAi:DnaJ-12 & $0,12 \pm 0,01$ & $2,46 \pm 0,41$ & $164,29 \pm 7,17$ & $0,6 \pm 0,03$ & $1,2 \pm 0,14$ & $0,4 \pm 0,03$ & $0,32 \pm 0,01$ \\
\hline RNAi:DnaJ-39 & $0,07 \pm 0,01$ & $1,83 \pm 0,38$ & $118,91 \pm 6,42$ & $0,5 \pm 0,02$ & $1,54 \pm 0,13$ & $0,5 \pm 0,02$ & $0,23 \pm 0,01$ \\
\hline RNAi:DnaJ-40 & $0,07 \pm 0,02$ & $1,9 \pm 0,41$ & $126,77 \pm 6,42$ & $0,52 \pm 0,02$ & $1,73 \pm 0,13$ & $0,48 \pm 0,02$ & $0,25 \pm 0,01$ \\
\hline RNAi:DnaJ-43 & $0,05 \pm 0,01$ & $1,64 \pm 0,41$ & $122,66 \pm 7,17$ & $0,48 \pm 0,03$ & $1,68 \pm 0,14$ & $0,52 \pm 0,03$ & $0,23 \pm 0,01$ \\
\hline Con trole & $0,06 \pm 0,01$ & $1,7 \pm 0,35$ & $148,72 \pm 6,42$ & $0,57 \pm 0,02$ & $1,47 \pm 0,13$ & $0,43 \pm 0,02$ & $0,29 \pm 0,01$ \\
\hline
\end{tabular}

1. $\left(\mathrm{mol} / \mathrm{m}^{2} / \mathrm{s}\right)$

2. $\left(\mathrm{mmol} / \mathrm{m}^{2} / \mathrm{s}\right)$

3. Taxa relativa de transporte de elétrons.

4. Acumulação de quinonas reduzidas.

Valores medidos a uma densidade de fluxo de fótons de $1200 \mu \mathrm{mol} \mathrm{m} \mathrm{m}^{-2} \mathrm{~s}^{-1}$. Não foram encontradas diferenças significativas $(P<0,05)$.

4.5.3. O silenciamento do gene chaperona Dnaj altera os conteúdos de clorofilas e carotenóides em tecidos verdes

A quantificação dos pigmentos revelou, de forma geral, que todas as linhagens transgênicas apresentaram um aumento significativo no conteúdo de pigmentos fotossintéticos em ambos tecidos verdes avaliados: folhas fonte e frutos verdes (Figura 15). Já no fruto maduro não houve alteração no conteúdo de licopeno e $\beta$-caroteno. 


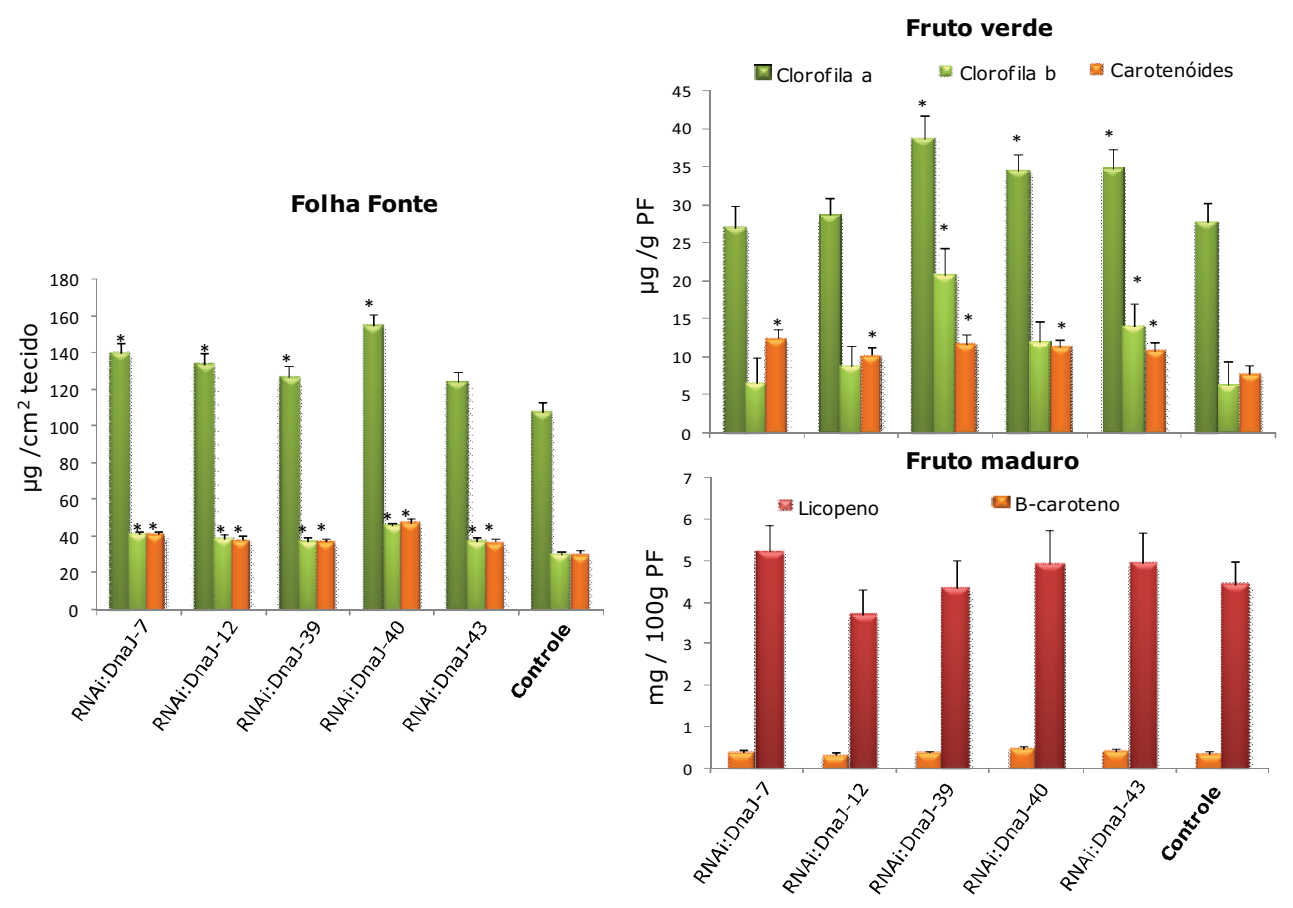

Figura 15. Conteúdo de pigmentos nos diferentes tecidos nas linhagens transgênicas.

As barras indicam a média obtida em no mínimo três ou quatro réplicas biológicas para frutos e folha fonte, respectivamente. *Diferenças estatisticamente significativas $(P<0,05)$. PF: peso fresco.

\subsubsection{O silenciamento do gene chaperona DnaJ altera o conteúdo de açúcares e amido}

A determinação do conteúdo de açúcares solúveis e amido, demonstrou que o metabolismo de carbono das linhagens silenciadas para o gene chaperona DnaJ foi alterado dramaticamente. Enquanto na folha fonte há uma queda tanto de hexoses e sacarose, quanto de reservas na forma de amido, no tecido dreno há um acúmulo deste último polímero (Figura 16). 


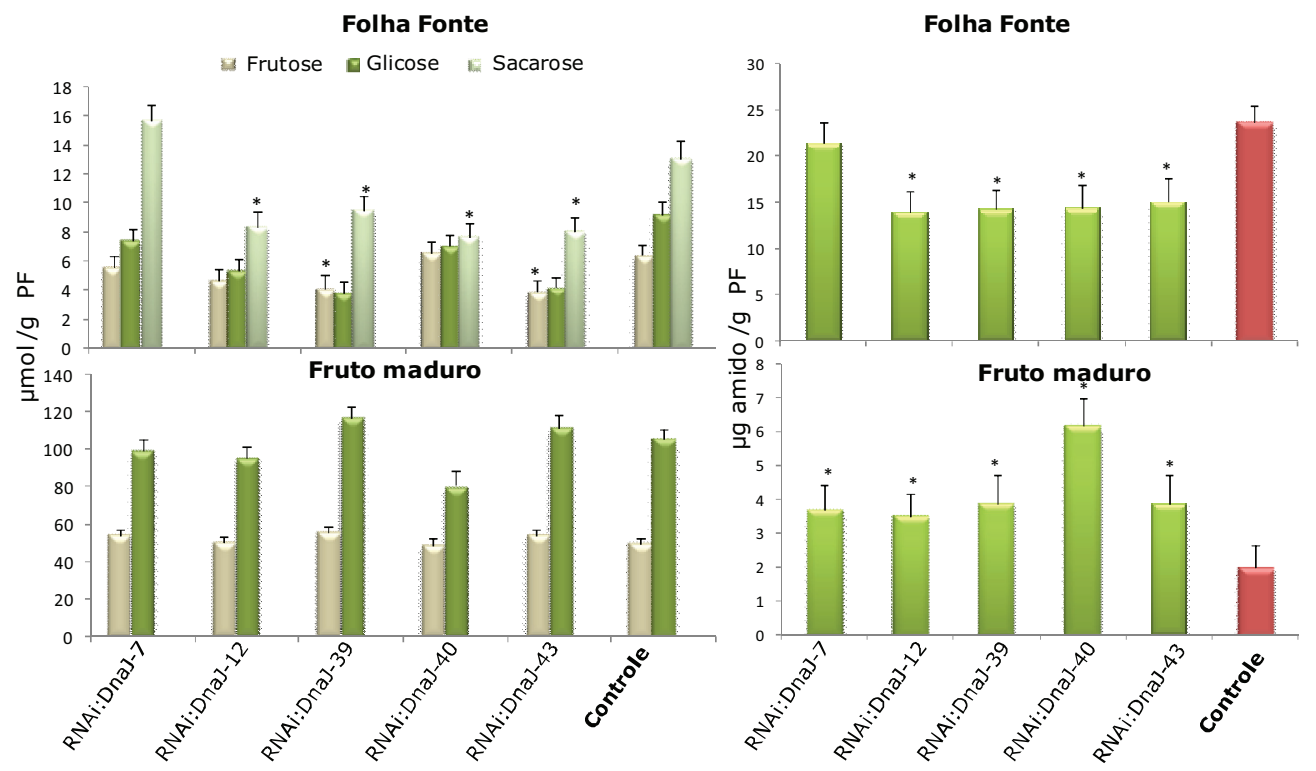

Figura 16. Conteúdo de açúcares e amido nas linhagens transgênicas.

As barras indicam a média obtida em no mínimo três ou cinco réplicas biológicas para fruto maduro e folha fonte, respectivamente. *Diferenças estatisticamente significativas $(P<0,05)$. PF: Peso fresco.

\subsubsection{O silenciamento do gene chaperona DnaJ não altera o conteúdo de aminoácidos totais}

Com o intuito de avaliar o efeito do silenciamento do gene no metabolismo de aminoácidos, foram feitas quantificações para os tecidos de folha fonte e fruto maduro. Como pode ser observado na Figura 17 não foi possível detectar, pela técnica utilizada, nenhum padrão determinado no conteúdo de aminoácidos totais para as linhagens transgênicas.

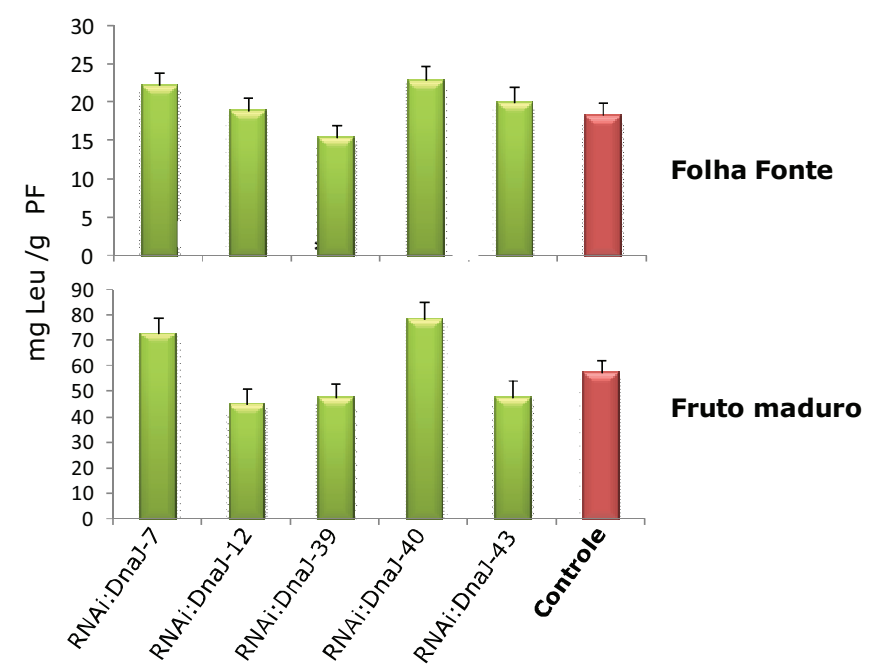

Figura 17. Conteúdo de aminoácidos totais nas linhagens transgênicas.

As barras indicam a média obtida em no mínimo três ou cinco réplicas biológicas para fruto maduro e folha fonte, respectivamente. Não foram encontradas diferenças estatisticamente significativas $(P<0,05)$. 
4.5.6. O silenciamento do gene DnaJ não altera os indicadores de produção das linhagens transgênicas

Para corroborar se o silenciamento do gene chaperona DnaJ impacta os parâmetros de produção, foi medido o peso médio de frutos verdes e maduros, a biomassa fresca da planta e o índice de colheita. Para nenhum dos parâmetros foram encontradas diferenças significativas (Tabela 4). Estes resultados indicam que as alterações observadas no metabolismo de hidratos de carbono não afetam a produção da planta.

Tabela 4. Indicadores de produção das linhagens transgênicas.

\begin{tabular}{c|cccc}
\hline Lin hagem & $\begin{array}{c}\text { FRUTO VERDE } \\
\text { (g/fruto) }\end{array}$ & $\begin{array}{c}\text { FRUTO MADURO } \\
\text { (g/fruto) }\end{array}$ & $\begin{array}{c}\text { BIOMASSA (g/ planta } \\
\text { sem raiz) }\end{array}$ & $\begin{array}{c}\text { ÍNDICE DE } \\
\text { COLHEITA }\end{array}$ \\
\hline RNAi:DnaJ -7 & $14,56 \pm 4,77$ & $41,98 \pm 2,76$ & $892 \pm 83,38$ & $36,15 \pm 10,28$ \\
RNAi: DnaJ -12 & $22,48 \pm 4,35$ & $34,24 \pm 2,52$ & $968,17 \pm 76,11$ & $40,06 \pm 9,38$ \\
RNAi: DnaJ -39 & $17,37 \pm 4,35$ & $35,66 \pm 2,52$ & $873,17 \pm 76,11$ & $35,7 \pm 9,38$ \\
RNAi: DnaJ -40 & $18,83 \pm 5,33$ & $30,3 \pm 3,09$ & $1095,75 \pm 93,22$ & $25,98 \pm 11,49$ \\
RNAi: DnaJ -43 & $20,75 \pm 4,35$ & $30,88 \pm 2,52$ & $793 \pm 76,11$ & $54,98 \pm 9,38$ \\
& & & & \\
Controle & $\mathbf{2 0 , 6 3} \pm \mathbf{3 , 3 3}$ & $\mathbf{3 8 , 2 8} \pm \mathbf{1 , 6 0}$ & $\mathbf{8 4 3 , 3 8} \pm \mathbf{9 7 , 4 9}$ & $\mathbf{4 2 , 1} \pm \mathbf{1 1 , 5 5}$ \\
\hline
\end{tabular}

Dados correspondentes á colheita das plantas após quatro meses. Não foram encontradas diferenças estatisticamente significativas $(P<0,05)$. 


\section{DISCUSSÃO}

As proteínas de $S$. lycopersicum e $S$. pennellii estudadas neste trabalho possuem domínio DnaJ e peptídeo sinal para cloroplasto. Chaperonas com essa mesma estrutura foram descritas por Lu et al. (2006) e por Ham et al. (2006) como proteínas que atuam na diferenciação de plastídeos e reguladoras da expressão gênica, respectivamente. Porém, $S$. lycopersicum DnaJ e $S$. pennellii DnaJ apresentam um domínio transmembrana que ancoraria essas proteínas no envelope plastídial deixando o domínio de interação proteína-proteína voltado para o citoplasma (Figura 7). A presença desse domínio diferencial permite o agrupamento dessas sequências de tomate em um clado separado, juntamente com o gene ortólogo de arabidopsis identificado, reforçando a provável diferenciação funcional dessas proteínas em relação as demais chaperonas descritas (Figura 8). A caracterização estrutural in silico foi em parte confirmada pelo experimento de direcionamento subcelular, demonstrando que S. lycopersicum DnaJ se encontra de fato localizada no cloroplasto (Figura 10). Assim, a localização demonstrada experimentalmente sugere a participação desta proteína no controle do metabolismo plastidial, o qual está de acordo com as alterações nos conteúdos de aminoácidos, açúcares solúveis e ácidos orgânicos observadas por Schauer et al. (2006) na IL 4-4 que levaram à identificação dos QTL mapeados no bin 4I (Figura 1).

É oportuno mencionar que os alelos apresentaram duas substituições nãosinônimas que determinam a alteração do tamanho do peptídeo sinal. Enquanto a sequência de direcionamento na proteína selvagem é menor, na espécie cultivada, ela se sobrepõe ao domínio transmembrana. Desta forma, é possível levantar três hipóteses: i) o polimorfismo de aminoácidos não altera a distribuição subcelular das proteínas, ii) a proteína selvagem é menos eficientemente direcionada à membrana plastidial e iii) a excisão do peptídeo sinal da proteína do alelo cultivado compromete o ancoramento da mesma. Nesses dois últimos casos, haveria menos proteína ativa no cloroplasto. Para esclarecer este ponto, já está em andamento o estudo da localização subcelular do alelo de $S$. pennellii.

Um estudo do perfil transcricional S. lycopersicum DnaJ e $S$. pennellii DnaJ realizado pelo nosso grupo revelou que há expressão em folhas fonte e dreno, caule, flor e frutos verdes e maduros, sendo que apenas níveis mínimos de expressão foram observados em caule e frutos, verdes e maduros. Comparativamente, o alelo cultivado possui maior expressão em folhas fonte que o selvagem (de Godoy et al., comunicação 
pessoal). Os resultados da análise funcional de ambos os promotores permitem concluir que a diferença nos níveis de expressão é ocasionada pela maior atividade transcricional do alelo de $S$. lycopersicum, não podendo descartar, de qualquer maneira, a participação de algum outro mecanismo de regulação trancricional ou póstranscricional (Figura 9).

Para avaliar o envolvimento da chaperona DnaJ no metabolismo plastidial foi adotada a estratégia de silenciamento estável por RNAi. Foram obtidas plantas transgências de tomate expressando uma molécula dupla fita de RNA correspondente a um fragmento da região codificante do gene, das quais foram selecionadas cinco linhagens que apresentaram uma redução aproximada de $80 \%$ nos níveis de RNAm em folhas. Já em frutos foram observados níveis de silenciamento menores, provavelmente pelo baixo nível de expressão nesse tecido.

As folhas fonte das linhagens silenciadas apresentam uma queda no conteúdo de açúcares solúveis e no acúmulo de amido. De alguma maneira, esses carboidratos são desviados para o fruto onde se evidencia maior nível desse polímero sem alteração no conteúdo de hexoses (Figura 16). Por outro lado, as plantas apresentam um discreto aumento na taxa de assimilação de $\mathrm{CO}_{2}$ coincidente com a conductância estomática e a transpiração (Tabela 3).

Uma análise conjunta da estrutura e localização protéica, análise de expressão e efeito fenotípico das transgênicas nos permite propor que o silenciamento da chaperona DnaJ mimetize em parte o alelo selvagem e, desta maneira, a hipótese da menor eficiência de ancoramento da proteína de $S$. lycopersicum seria descartada.

As folhas fonte mantêm altas taxas de fotossíntese em diversas condições fisiológicas que não dependem exclusivamente da coordenação entre as reações que acontecem nos tilacóides e no estroma, mas também, do intercâmbio de metabólitos com o citoplasma e organelas, assim como da necessidade de outros órgãos (Paul e Foyer, 2001). Desta maneira, diversos mecanismos garantem a manutenção do estado redox (para evitar a saturação da cadeia de transporte de elétrons), da relação ATP/ADP e do potencial redutor (NADPH, NADH e ferredoxina). No entanto, mudanças nas demandas metabólicas, sejam por alterações ambientais ou da relação fontedreno, podem levar os mecanismos homeostáticos ao seu limite. Por este motivo, os níveis de adenilato e o estado redox são permanentemente controlados. Embora alguns trabalhos apontem a existência de um mecanismo de percepção de ATP em condições de estresse ambiental, só recentemente foram realizados estudos que apresentam evidências de um sistema de transdução de sinal via adenilatos 
(Geigenberger et al., 2010). Em contrapartida, a regulação da fotossíntese por feedback exercida pelo estado redox e pelas trioses fosfato (triosesP) é bem conhecida em plantas (Smith e Stitt, 2007). A taxa de utilização dos produtos finais da fotossíntese (sacarose, aminoácidos e amido) determina a taxa de reciclagem do fosfato inorgânico (Pi), de forma que qualquer condição que restrinja o uso de triosesP poderia limitar a fotossíntese. Nesta linha de pensamento, tem sido demonstrado que altas taxas de fosfogliceraldeído 3-fosfato/Pi, 3-PGA/Pi, ativam a ADP-glicose pirofosforilase (AGPase) e, consequentemente, a síntese de amido (Preiss, 1988; Preiss e Romeo, 1994). Nestas condições, a sacarose fosfato sintase (SPS) é inativada por fosforilação pela ação das quinases relacionadas à sacarose não-fermentativa, (SnRKs), aumentando os níveis de frutose 2,6-bifosfato (F26BP) que, por sua vez, como demonstrado em fumo, reduz o fluxo de açúcares solúveis aumentando ainda mais o acúmulo de amido em folhas (Scott et al., 1995).

Frente aos resultados obtidos, propõe-se que a chaperona DnaJ medeie a percepção do balanço triosesP/Pi e a ativação/inativação da SPS, participando assim, na regulação da relação fonte-dreno. Na sua presença, ocorreria a inibição da fotossíntese pelo acúmulo de amido como conseqüência da queda na produção de sacarose para exportação e ativação da AGPase. Silenciando a chaperona, a SPS não seria inibida aumentando assim o consumo de triosasP para a produção de sacarose a qual seria exportada ao fruto. Assim, não haveria acúmulo de amido na folha nem queda na atividade fotossintética, justificando também a tendência no aumento de trocas gasosas garantindo o suprimento de carbono. Já nos frutos a sacarose seria degradada pela invertase de parede (Fridman et al., 2004) ou pela sacarose sintase (SuSy) e as hexoses incorporadas seriam desviadas para o acúmulo de amido (Figura 18) (Wang et al., 1993; D 'Aoust et al., 1999).

Para corroborar essa hipótese, a quantificação dos níveis de expressão e atividade de algumas das enzimas chave do metabolismo de açúcares, como a SPS, SuSy e a AGPase, nas linhagens silenciadas seria muito esclarecedor.

Recentemente, Centeno et al. (2011) reportaram que o silenciamento da fumarase em frutos de tomate leva à diminuição no conteúdo de malato que altera o estado redox mitocondrial. Esta alteração é transmitida para o cloroplasto onde é ativada a AGPase, provocando o acúmulo de amido nos frutos maduros. Isto possui um forte impacto no amadurecimento e na fisiologia pós-colheita, já que o incremento da osmolariedade diminui a perda de água prolongando assim a vida de prateleira do fruto. 
De acordo com os resultados obtidos é provável que o aumento nos níveis de amido no fruto seja devido à ativação da AGPase nas plantas silenciadas, o qual está de acordo com a observação de Schauer et al. (2005) que mostraram que os frutos de S. pennellii acumulam mais do dobro de amido que $S$. lycopersicum. Da mesma maneira, em um trabalho publicado recentemente foi observado que os níveis da enzima AGPase são significativamente maiores em frutos do tomate selvagem no começo do amadurecimento, 42 dias após antese (Steinhauser et al. 2010)

O silenciamento da chaperona DnaJ não modificou o conteúdo de aminoácidos totais em folhas nem em frutos. A respeito deste ponto, vale a pena mencionar que as plantas foram sistematicamente adubadas de forma de eliminar a falta de nitrogênio como um possível fator limitante. De qualquer forma, a determinação da relação $\mathrm{C} / \mathrm{N}$, assim como, uma quantificação por cromatografía de aminoácidos é altamente desejável.

Embora o silenciamento da chaperona DnaJ sugira uma alteração na relação fonte-dreno, não foram evidenciadas diferenças na massa de frutos ou parte aérea, nem no índice de colheita. Mesmo que esta observação possa parecer a priori contraditória, as casas de vegetação para as plantas transgênicas usadas neste trabalho requerem condições que podem mascarar diferenças na distribuição de fotoassimilados. Outra possibilidade é que o aumento da exportação da fonte para 0 dreno leve à aceleração fenológica, parâmetro que não foi avaliado neste estudo.

A relação entre chaperonas e regulação da fotossíntese tem sido muito pouco estudada. Recentemente, em 2010, Chen et al. descreveram três chaperonas cloroplásticas que atuam na estabilização do fotossintema II (PSII). Os genes que codificam estas proteínas são transcritos e traduzidos no escuro e o tratamento com alta intensidade de luz $\left(500 \mu \mathrm{mol}\right.$ de fótons $\left.\mathrm{m}^{-1} \mathrm{~s}^{-1}\right)$ resultou na completa depleção destas proteínas em folhas. Embora esta proteína possua um papel diferente ao proposto para a DnaJ de tomate, esses resultados demonstram também a participação das chaperonas no controle da maquinaria fotossintética.

O incremento da produtividade de culturas de interesse agronômico por meio da redistribuição de fotoassimilados sem alterar a biomassa parece ter atingido o limite. Para melhorar o rendimento e sustentar uma população crescente cuja estimativa atinge 10 bilhões em 2050, além de cobrir as necessidades de sequestro de carbono no contexto das mudanças climáticas globais, será necessário aumentar a biomassa incrementando a fixação de carbono por meio da manipulação da fotossíntese. Porém, devido ao fato que a comunicação entre fotossíntese e 
crescimento é uma relação de ida e volta, é altamente provável que a falta de demanda do dreno frustre a manipulação genética direta da fotossíntese (Paul e Foyer, 2001). Por este motivo, o entendimento da natureza do controle dos mecanismos que regem o balanço fonte-dreno surge como uma necessidade fundamental para 0 melhoramento das culturas no curto prazo e este trabalho abre uma porta neste sentido. 


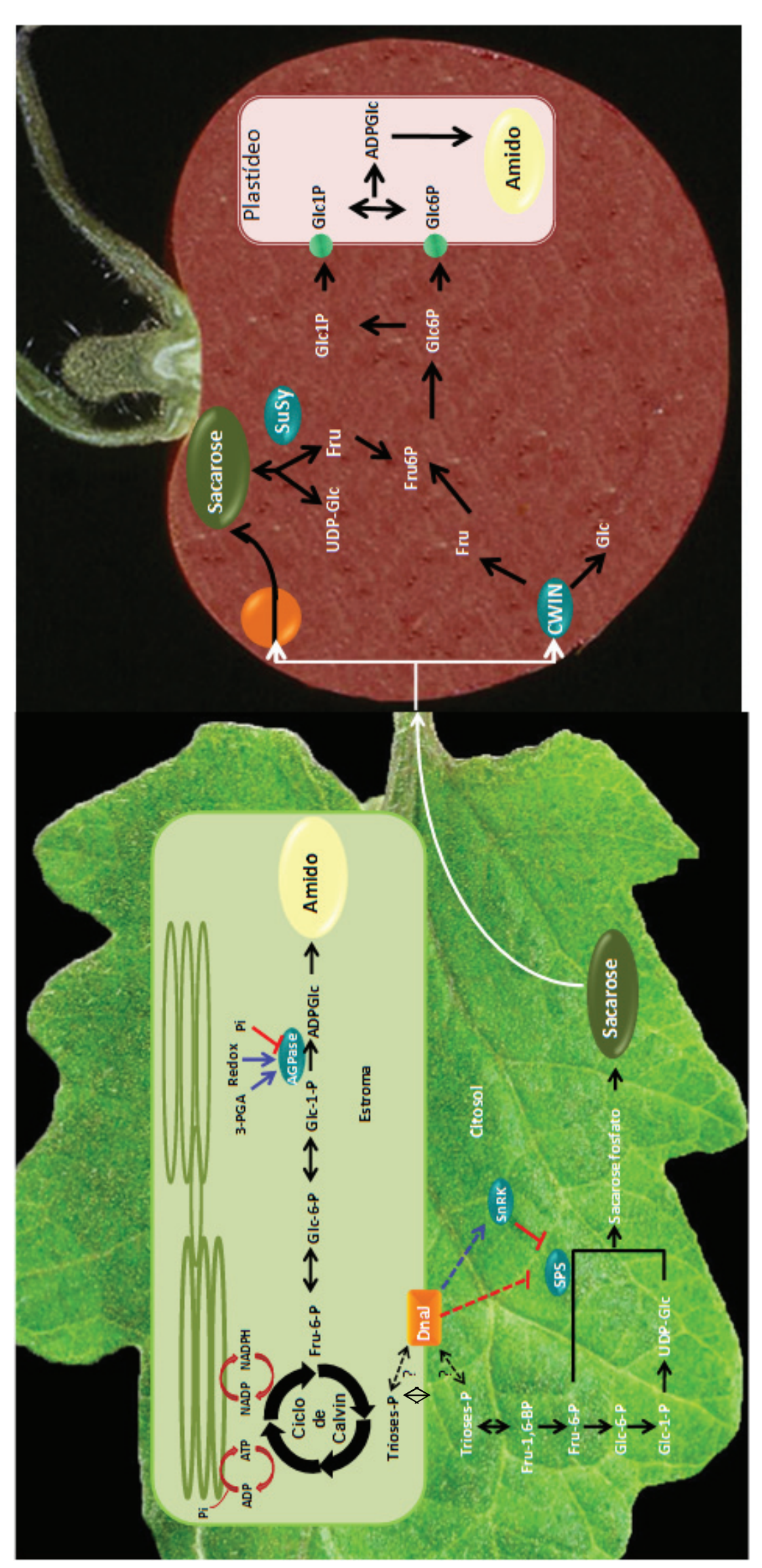

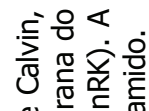

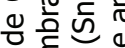

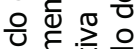

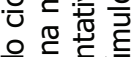

ए

(4)

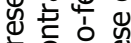

원

证

든

잉

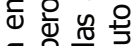

증 은 문혼

중

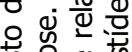

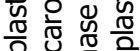

온 㤐言은

웜

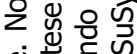

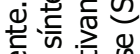

的芜塄

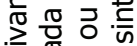

讨会采

ते के है

는

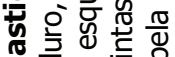

즌 议

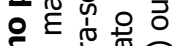

的语贾

인웅

웡

는잉

는 谂

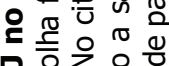

은 융

ธ。

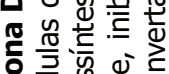

过 0

는융 웅

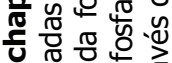

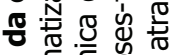

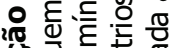

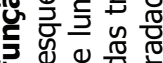

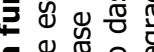

중

0 퉁

पे 는

응 娄

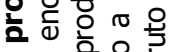

응ㅎㅁ원은

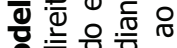

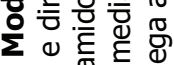

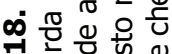

존

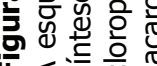




\section{CONCLUSÕES}

Com os dados gerados da análise da estrutura gênica e protéica, atividade promotora, determinação da localização subcelular e, análise fenotípica de plantas silenciadas para o gene chaperona DnaJ é possivel formular as seguintes conclusões:

1) A localização plastidial assim como o padrão de expressão diferencial levaría a uma maior quantidade de proteína em S. lycopersicum;

2) A deficiência nesta proteína leva a um aumento do armazenamento de amido no fruto maduro;

3) As mudanças no conteúdo de açúcares e pigmentos identificadas demonstram o envolvimento dessa proteína no metabolismo plastidial, e;

4) A proteína DnaJ atua no controle da relação fonte-dreno limitando a exportação de sacarose ao fruto. 


\section{REFERÊNCIAS}

Altschul SF, Gish W, Miller W, Myers EW, Lipman DJ. 1990. Basic local alignment search tool. Journal of Molecular Biology 215, 403-410.

Banecki B, Liberek K, Wall D, Wawrzynow A, Georgopoulos C, Bertoli E, Tanfani F, Zylicz M. 1996. Structure-function analysis of the zinc finger region of the DnaJ molecular chaperone. The Journal of Biological Chemistry 271, 14840-14848.

Bermúdez L, Urias U, Milstein D, Kamenetzky L, Asis R, Fernie AR, Van Sluys MA, Carrari F, Rossi M. 2008. A candidate gene survey of quantitative trait loci affecting chemical composition in tomato fruit. Journal of Experimental Botany 59, 2875-90.

Caplan AJ, Cyr DM, Douglas MG. 1993. Eukaryotic homologues of Escherichia coli dnaJ: a diverse protein family that functions with hsp70 stress proteins. Molecular Biology of the Cell 6, 555-63.

Centeno DC, Osorio S, Nunes-Nesi A, Bertolo AL, Carneiro RT, Araújo WL, Steinhauser MC, Michalska J, Rohrmann J, Geigenberger P, Oliver SN, Stitt M, Carrari F, Rose JK, Fernie AR. 2011. Malate plays a crucial role in starch metabolism, ripening, and soluble solid content of tomato fruit and affects postharvest softening. The Plant Cell 23, 162-184.

Cheetham ME, Caplan AJ. 1998. Structure, function and evolution of DnaJ: conservation and adaptation of chaperone function. Cell Stress and Chaperones 3, 28-36.

Chen KM, Holmström M, Raksajit W, Suorsa M, Piippo M, Aro EM. 2010. Small chloroplast-targeted DnaJ proteins are involved in optimization of photosynthetic reactions in Arabidopsis thaliana. BMC Plant Biology 7, 10-43.

Chen KM, Piippo M, Holmström M, Nurmi M, Pakula E, Suorsa M, Aro EM. 2011. A chloroplast-targeted DnaJ protein At]8 is negatively regulated by light and has rapid turnover in darkness. Journal of Plant Physiology. [Epub ahead of print].

CIMMYT. 2005. Laboratory Protocols: CIMMYT Applied Molecular Genetics Laboratory. Third Edition. México D.F.

Corpet T. 1988. Multiple sequence alignment with hierarchical clustering. Nucleic Acids Research 16, 10881-10890.

D'Aoust MA, Yelle S, Nguyen-Quoc B. 1999. Antisense inhibition of tomato fruit sucrose synthase decreases fruit setting and the sucrose unloading capacity of young fruit. The Plant Cell 11, 2407-2418.

Di Rienzo JA. 2009. Statistical software for the analysis of experiments of functional genomics. RDNDA. Argentina. 756587.http://sites.google.com/site/fgStatistics/.

Fernie AR, Roscher A, Ratcliffe G, Kruger NJ. 2001. Fructose 2,6-biphosphate actiates pyrophosphate: fructose-6-phosphate 1-phosphotransferase and increases triose phosphate to hexose phosphate cycling in heterotrophic cells. Plantta 212, 250-263.

Fridman E, Carrari F, Liu Y, Fernie A, Zamir D. 2004. Zooming In on a quantitative Trait for Tomato Yield Using Interspecific Introgressions. Science 305, 1786-1789.

Geigenbenger P, Riewe D, Fernie AR. 2010. The central regulation of plant physiology by adenylates. Trends in Plant Science 15, 98-105.

Ham BK, Park JM, Lee SB, Kim MJ, Lee IJ, Kim KJ, Kwon CS, Paek KH. 2006. Tobacco Tsip1, a DnaJ-type $\mathrm{Zn}$ finger protein, is recruited to and potentiates Tsi1mediated transcriptional activation. Plant Cell 18, 2005-2020.

Heredia A, Peinado I, Barrera C, Grau AA. 2009. Influence of process variables on colour changes, carotenoids retention and cellular tissue alteration of cherry 
tomato during osmotic dehydration. Journal of Food Composition and Analysis $22,285-294$.

Hoeckema A, Hirsch PR, Hooykas PJ, Schilperoot RA. 1983. A binay plant vector strategy based on separation of vir and T-region of the Agrobacterium tumefaciens Ti-plasmid. Nature 303, 179-180.

Kamenetzky L, Asís R, Bassi S, de Godoy F, Bermúdez L, Fernie AR, Van Sluys MA, Vrebalov J, Giovannoni J], Rossi M, Carrari F. 2010. Genomic analysis of wild tomato introgressions determining metabolism- and yield-associated traits. Plant Physiology 152, 1772-86.

Kampinga HH, Craig EA. 2010. The HSP70 chaperone machinery: J proteins as drivers of functional specificity. Nature Reviews Molecular Cell Biology 11, 579-92.

Karimi M, Inzé D, Depicker A. 2002. GATEWAY ${ }^{\mathrm{TM}}$ vectors for Agrobacterium-mediated plant transformation. Trends in Plant Science 7, 193-195.

Kroczynska B, Zhou R, Wood C, Miernyk JA. 1996. AtJ1, a mitochondrial homologue of the Escherichia coli DnaJ protein. Plant Molecular Biology 31, 619-629.

Lichtenthaler HK. 1987. Chlorophylls and carotenoids: Pigments of photosynthetic biomembranes. Methods in Enzymology 148, 350-382.

Linke K, Wolfram T, Bussemer J, Jakob U. 2003. The roles of the two zinc binding sites in DnaJ. The Journal of Biological Chemistry 278, 44457-66.

Li L, Lu S, Cosman KM, Earle ED, Garvin DF, O'Neill J (2006). $\beta$-Carotene accumulation induced by the cauliflower Or gene is not due to an increased capacity of biosynthesis. Phytochemistry 67, 1177-1184.

Li HM, Chiu CC. 2010. Protein transport into chloroplasts. Annual Review of Plant Biology 61, 157-80.

Lu S, Van Eck J, Zhou X, Lopez AB, O'Halloran DM, Cosman KM, Conlin BJ, Paolillo DJ, Garvin DF, Vrebalov J, Kochian LV, Kupeer H, Earle ED, Cao J, Li L. 2006. The cauliflower or gene encodes a dnaj cysteine-rich domain-containing protein that mediates high levels of $\beta$-Carotene accumulation. The Plant Cell 18, 3594-3605.

Maxwell K e Jonson G. 2000. Chlorophyll fluorescence a practical guide. Journal of Experimental Botany 345, 659-668.

Miernyk JA. 2001. The J-domain proteins of Arabidopsis thaliana: an unexpectedly large and diverse family of chaperones. Cell Stress Chaperones 6, 209-218.

Mueller LA, Solow TH, Taylor N, Skwarecki B, Buels R, Bins J, Lin C, Wright MH, Ahrens R, Wang Y, Herbst EV, Keyder ER, Menda N, Zamir D, Tanksley SD. 2005. The SOL Genomics Network. A Comparative Resource for Solanaceae Biology and Beyond. Plant Physiology 138, 1310-1317.

Mueller L, Mills A, Skwarecki B, Buels R, Menda N, Tanksley S. 2008. The SGN comparative map viewer. Bioinformatics 24, 422-423.

Mueller, L. et al. 2009. A snapshot of the emerging tomato genome sequence. The Plant Genome 2, 78-92.

Nicoll WS, Boshoff A, Ludewig MH, Hennessy F, Jung M, Blatck GL. 2006. Approaches to the isolation and characterization of molecular chaperones. Protein Expression and Purification 46, 1-15.

Orme W, Walker AR, Gupta R, Gray JC. 2001. A novel plastid-targeted J-domain protein in Arabidopsis thaliana. Plant Molecular Biology 46, 615-626.

Paul MJ, Foyer CH. 2001. Sink regulation of photosynthesis. Journal of Experimental Botany 52, 1383-1400.

Preiss J. 1988. Biosynthesis of starch and its degradation. Em: Preiss J, ed. Biochemistry of plants, Vol. 13. San Diego: Academic Press, 181-254.

Preiss J, Romeo T. 1994. Molecular biology and regulatory aspects of glycogen synthesis in bacteria. Em: Cohen WE, Moldane KE, eds. Progress in nucleic acid research and molecular biology, Vol. 47. San Diego: Academic Press, 112-138. 
Pfaffl MW, Horgan GW, Dempfle L. 2002. Relative expression software tool (RESTC) for group-wise comparison and statistical analysis of relative expression results in real-time PCR. Nucleic Acids Research 39, 9 -36.

Rajan VB, D'Silva P. 2009. Arabidopsis thaliana J-class heat shock proteins: cellular stress sensors. Functional e Integrative Genomics 9, 433-46.

Ruijter JM, Ramakers C, Hoogaars WM, Karlen Y, Bakker O, van den Hoff MJ, Moorman AF. 2009. Amplification efficiency: linking baseline and bias in the analysis of quantitative PCR data. Nucleic Acids Research 37, 45.

Sambrook J, Fritsch EF, Maniatis T. 1989. Molecular Cloning, a laboratory manual. Second Edition, Cold Spring Harbor Laboratory Press.

Saitou N e Nei M. 1987. The neighbor-joining method: A new method for reconstructing phylogenetic trees. Molecular Biology and Evolution 4, 406-425.

Shimada H, Mochizuki M, Ogura K, Froehlich JE, Osteryoung KW, Shirano Y, Shibata D, Masuda S, Mori K, Takamiya K. 2007. Arabidopsis cotyledon-specific chloroplast biogenesis factor CYO1 is a protein disulfide isomerase. Plant Cell 19, 3157-69.

Schauer N, Fernie AR. 2006. Plant metabolomics: towards biological function and mechanism. Trends Plant Science 10, 508-16.

Schauer N, Semel Y, Roessner U, Gur A, Balbo I, Carrari F, Pleban T, Perez-Melis A, Bruedigam C, Kopka J, Willmitzer L, Zamir D, Fernie A. 2006. Comprehensive metabolic profiling and phenotyping of interspecific introgression lines for tomato improvement. Nature Biotechnology 24, 447-454.

Scott P, Lange AJ, Pilkis SJ, Kruger NJ. 1995. Carbon metabolism in leaves of transgenic tobacco (Nicotiana tabacum L.) containing elevated fructose- 2,6- bisphosphate levels. The Plant Journal 7, 461-469.

Sienkiewicz-Porzuceka A, Sulpice R, Osorio S, Krahnert I, Leisse A, UrbanczykWochniak E, Hodges. M, Fernie AR, Nunes-Nesi A. 2010. Mild reductions in mitochondrial NAD-dependent isocitrate dehydrogenase activity result in altered nitrate assimilation and pigmentation but do not impact growth. Molecular Plant Biology 3, 156-173.

Smith AM, Stitt M. 2007. Coordination of carbon supply and plant growth. Plant Cell and Environment 30, 1126-1149.

Sokal RR, Rohlf JF. 1995. Biometry: the principles and practice of statistics in biological research. 3rd ed. W.H. Freeman, New York, 887p.

Steinhauser MC, Steinhauser D, Koehl K, Carrari F, Gibon Y, Fernie AR, Stitt M. 2010. Enzyme activity profiles during fruit development in tomato cultivars and Solanum pennellii. Plant Physiology 153, 80-98.

Szabo A, Korszun R, Hartl FU, Flanagan J. 1996. A zinc finger-like domain of the molecular chaperone DnaJ is involved in binding to denatured protein substrates. EMBO Journal 15, 408-417.

Tamura K, Dudley J, Nei M, Kumar S. 2007. MEGA4: Molecular Evolutionary Genetics Analysis (MEGA) software version 4.0. Molecular Biology and Evolution 24, 1596-1599.

Thomas JG, Baneyx F.1996. Protein folding in the cytoplasm of Escherichia coli: requirements for the DnaK-DnaJ-GrpE and GroEL-GroES molecular chaperone machines. Molecular Microbiology 21, 1185-1196.

Thompson J, Higgins D, Gibson T. 1994. CLUSTAL W: improving the sensitivity of progressive multiple sequence alignment through sequence weighting positionspecific gap penalties and weight matrix choice. Nucleic Acids Research 22, 4673-4680.

Vitha S, Froehlich JE, Koksharova O, Pyke KA, van Erp H, Osteryoung KW. 2003. ARC6 is a J-domain plastid division protein and an evolutionary descendant of the cyanobacterial cell division protein Ftn2. Plant Cell 15, 1918-33. 
Voos W, Rottgers K. 2002. Molecular chaperones as essential mediators of mitochondria biogenesis. Biochimica et Biophysica Acta 1592, 52-62.

Wang F, Sanz A, Brenner ML, Smith A. 1993. Sucrose synthase, starch accumulation, and tomato fruit sink strength. Plant Physiology 101, 321-327.

Wen-Jun S e Forde B. 1989. Efficient transformation of Agrobacterium spp. by high electroporation. Nucleic Acids Research 17, 8385.

Zscheille F e Porter J. 1947. Analytical methods for carotenes of Lycopersicon species and strains. Analytical Chemistry 19, 47-51 
Capítulo IV : Caracterização e estudo funcional do gene sec14 



\section{INTRODUÇÃO}

\subsection{Vitamina $E$, biossíntese e função}

Como mencionado na introdução geral, o tomate constitui uma fonte notável de antioxidantes na dieta humana devido ao alto teor desses compostos. Os principais antioxidantes não-enzimáticos encontrados nos frutos de tomate são o ácido ascórbico (VTC), licopeno e carotenóides, compostos fenólicos e vitamina E (VTE) (Frusciante et al., 2007; Abushita et al., 1997).

Os compostos com atividade VTE são moléculas anfipáticas e lipossolúveis sintetizadas exclusivamente nos organismos fotossintéticos. A estrutura molecular consiste em um anel hidroxicromanol polar, derivado do homogentisato, e uma cadeia lateral lipofílica, produtos da via do chiquimato (SK) e metil-eritritrolfosfato (MEP), respectivamente (Figura 2). São coletivamente chamados de tococromanóis, e podem ser classificados em dois grupos de acordo ao grau de saturação da cadeia lipofílica, tocoferóis e tocotrienóis. Os tocoferóis, mais abundantes em plantas, têm cadeia lateral saturada derivada do fitil-2P, e os tocotrienóis, possuem a cauda derivada de GGDP (geranil geranil difosfato) com instaurações nas posiçoes 3', 7' e 11' (MunnéBosch e Alegre, 2002; Figura 1). Existem quatro isômeros de tocoferóis e tocotrienóis $a, \beta, \gamma$ e $\delta$ - que variam quanto ao número e posição dos grupos metil junto ao anel cromanol (Kamal-Eldin e Appelqvist, 1996).
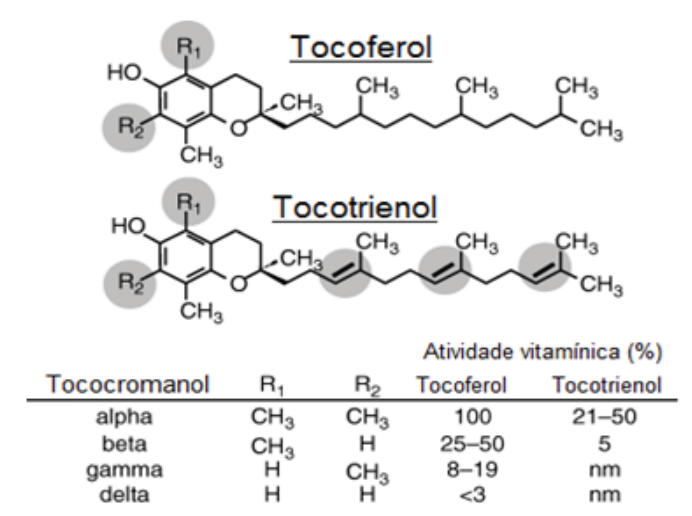

Figura 1. Estrutura química dos tococromanóis. A tabela indica 0 número/posição do radical metil no anel em $a, \beta, y$ e $\delta$-tocoferol e tocotrienol. A atividade vitamínica de cada composto é relativa ao a-tocoferol $(100 \%)$. nm, não-mensurável. As diferenças estruturais estão destacadas por círculos cinza. Adaptado de Dellapenna e Last (2006).

Mesmo apresentando uma estrutura química similar, os tococromanóis possuem propriedades bioquímicas que dependem da sua cadeia lateral. Os tocoferóis encontram-se presentes em todos os organismos fotossintéticos, enquanto que os 
tocotrienóis são encontrados unicamente em grupos específicos de plantas. Adicionalmente, nos casos em que ambos os compostos encontram-se presentes na mesma espécie, esses não necessariamente compartilham o mesmo tecido, indicando assim, possíveis diferenças funcionais na planta (Falk e Munné-Bosch, 2010). O atocoferol é o composto que apresenta maior atividade de VTE, a forma predominante encontrada nos tecidos verdes das plantas e em sementes de algumas espécies oleaginosas (Munné-Bosch e Alegre, 2002; DellaPenna e Last, 2006).

Pelas propriedades antioxidantes destes compostos, diversos trabalhos têm estudado as suas características químicas, localização e função nas membranas biológicas (Wang e Quinn, 2000); benefícios na saúde humana (Pryor, 2000; Ricciarelli et al., 2001; Bell e Grochoski, 2008; Ros 2009; Zhang et al., 2009; Das et al., 2009); aplicações biotecnológicas para sua produção (Ogbonna, 2009) e; biossíntese (DellaPenna, 2005 a, 2005b; DellaPenna e Pogson, 2006) e função em plantas (Munné-Bosch e Alegre, 2002;. Kruk et al., 2005; Abassi et al., 2007, 2009; MunnéBosh et al., 2005; Falk e Munné-Bosh, 2010; Zbierzak et al., 2010).

Nos vegetais, a VTE está associada à proteção de pigmentos, proteínas e ácidos graxos poliinsaturados da maquinária fotossintética contra espécies reativas de oxigênio (ROS) geradas durante a fotossíntese (Semchuk et al., 2009). Além disso, tem sido proposto que a VTE interage com outros sistemas antioxidantes com o intuito de manter a homeostase redox intracelular (Kruk et al., 2005; Foyer e Noctor, 2005; Zbierzak et al., 2010). A biossíntese dos tococromanóis foi descrita nos plastídeos e, até o momento, não foi demonstrada a possibilidade de transporte para nenhum dos isômeros de VTE dentro do corpo da planta (Sun et al., 2009).

A rota biossintética de tocoferol foi elucidada em 1979 (Soll e Schultz, 1979), porém, a identificação dos genes nela envolvidos ocorreu apenas recentemente. Por meio de diversas abordagens genéticas e genômicas, assim como com caracterização de mutantes, os genes que codificam para as enzimas da rota central da VTE foram identificados e clonados para algumas espécies vegetais (Li et al., 2008; Mène-Saffrané e DellaPenna, 2009; Falk e Munné-Bosch, 2010; Mène-Saffrané e DellaPenna, 2009). Esses estudos sugerem que a VTE desempenha um papel além de sua função antioxidante, que incluiria participação em diversos processos fisiológicos como germinação, senescência foliar, resposta ao stress abiótico, crescimento e particionamento de fotoassimilados (Falk e Munné-Bosch, 2010). Em concordância com a diversidade de processos nos quais está envolvida, vários trabalhos evidenciam uma estreita interação entre VTE e outras vias metabólicas, como síntese de carotenóides, 
glutationa e ascorbato (outros sistemas antioxidantes de defesa), além da degradação da clorofila.

Assim, devido à sua importância na fisiologia da planta e para a nutrição humana, muitos esforços têm sido empreendidos para entender os mecanismos responsáveis pela síntese, transporte e acúmulo de VTE em plantas, especialmente nas espécies cultivadas, com o objetivo de melhorar a produtividade e os níveis desses micronutrientes. Porém, apesar de muitos avanços terem sido alcançados nos últimos anos, aspectos relacionados à rota biossintética e sua regulação precisam ser melhor compreendidos. Só assim, será possível a manipulação do metabolismo a fim de aumentar os conteúdos de tocoferol nas espécies de interesse agronômico.

\subsection{Antecedentes do projeto}

Recentemente, o nosso grupo identificou todos os genes envolvidos na rota biossintética da VTE de tomate desde os seus precursores do metabolismo primário (Almeida et al., 2011, vide anexo 2). As 28 atividades enzimáticas compreendidas nas rotas do MEP, SK e central de tocoferol são catalisadas por 27 enzimas codificadas por 41 locos (Figura 2). Baseando-se na ligação física entre as sequências expressas, genômicas e de marcadores moleculares foi possível estabelecer a localização genômica de cada um dos genes identificados (Figura 3). Os mesmos se encontram distribuídos ao longo do genoma, no entanto, constatou-se que os locos que codificam para seis das sete enzimas da rota central de tocoferol se encontram agrupados nos cromossomos 7, 8 e 9. Em estudo anterior, Schauer et al. (2006), por meio da análise dos perfis metabólicos das ILs por GC-MS (Gas Chromatography - Mass Spectometry), descreveram dois QTL para o conteúdo de a-tocoferol em fruto maduro localizados no cromossomo 6 e 9. Notavelmente, os quatro genes mapeados no cromossomo 9, vte3(1), vte5, tyra(2), e ggps(4) co-localizam com um dos QTL identificados por Schauer et al. (2006). Nesse sentido, a fim de investigar a presença de outros possíveis QTL para os diferentes isômeros de tocoferol, foi determinado o conteúdo desses compostos por HPLC (High Performance Liquid Chromatography). As buscas por QTL concentraram-se nas ILs, cujos fragmentos introgredidos abrangem os genes da rota central da VTE e os QTL descritos por Schauer et al. (2006). Dessa forma, foram obtidos perfis completos dos quatro isômeros $\left(\alpha^{-}, \beta^{-}, \gamma^{-}\right.$e $\left.\delta^{-}\right)$de tocoferol em fruto das ILs 6-1, 6-2, 7-4, 7-4-1, 7-5, 8-2, 8-2-1, 9-1, 9-2-6 e nos frutos controle correspondentes de $S$. lycopersicum (cv M82), além de tocoferol total. 


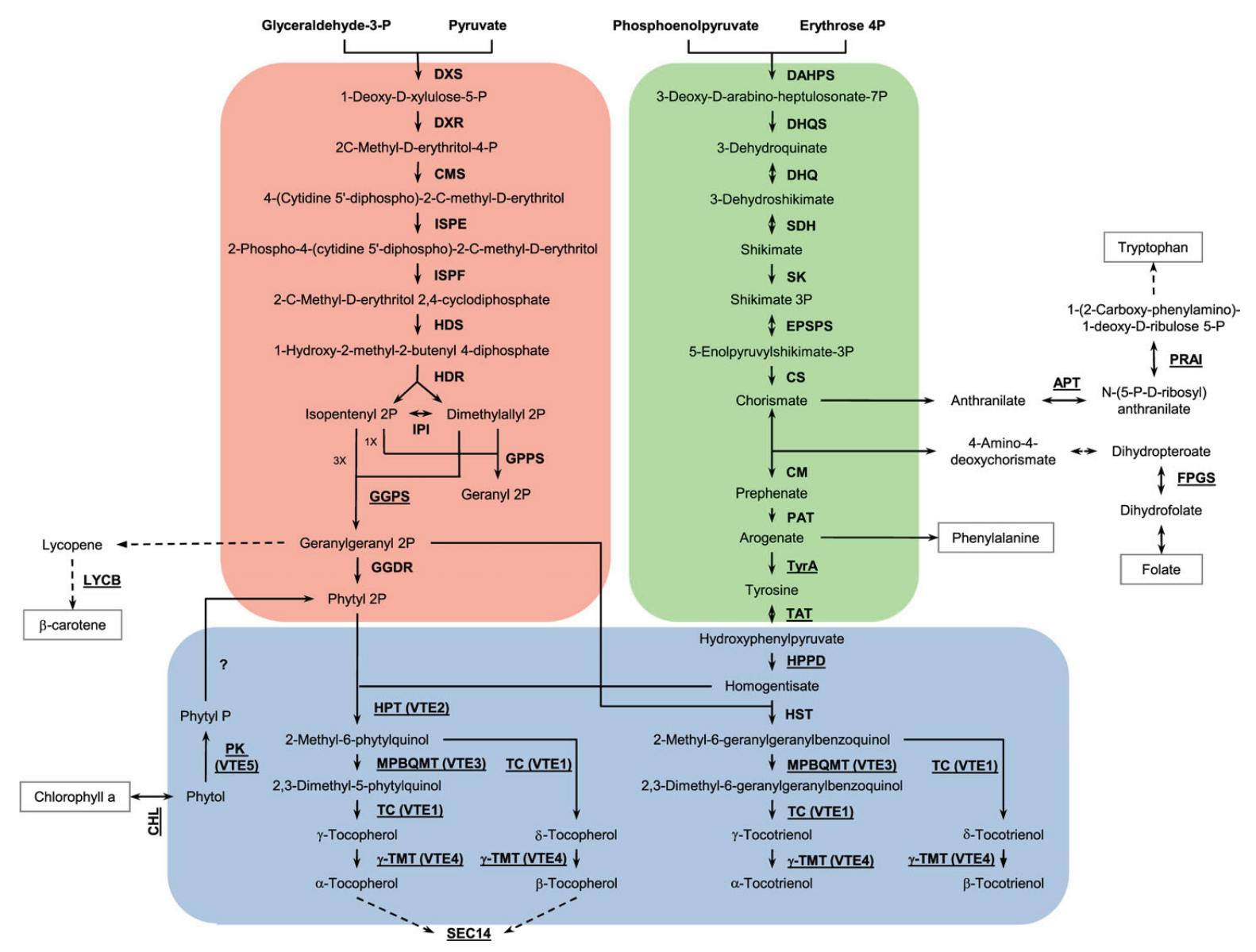

Figura 2. Rota de biossíntese do tocoferol.

As rotas de metileritritol fosfato, chiquimato e central de tocoferol estão destacadas em vermelho, verde e azul, respectivamente. Os nomes das enzimas estão abreviados conforme tabela de abreviaturas. As enzimas sublinhadas são genes candidatos que co-localizam com os QTL descritos por Almeida et al. (2011). Esquema adaptado de Almeida et al. (2011).

Foram, então, identificados QTL nos cromossomos 6, 7, 8 e 9; e após uma busca exaustiva nas regiões genômicas portadoras desses QTL, foi proposta a existência de 16 genes candidatos que codificam para enzimas envolvidas tanto diretamente no metabolismo de tocoferol como em rotas que provêm precursores para sua síntese: prai, fpgs, chl, apt e lycb no cromossomo 6; tyra (1), vte2, hppd (1) e tat (2) no cromossomo 7; vte1 e vte4 no cromossomo 8; ggps (4), tyra (2), vte5, sec14 e vte3 (1) no cromossomo 9 (Figura 3). A clonagem e a comparação dos alelos de $S$. pennellii e $S$. lycopersicum permitiu revelar a presença de polimorfismos de nucleotídeos e aminoácidos para todos os genes, fato que reforça suas candidaturas. Mais ainda, análises evolutivas revelaram que alguns desses candidatos apresentaram seleção positiva. 


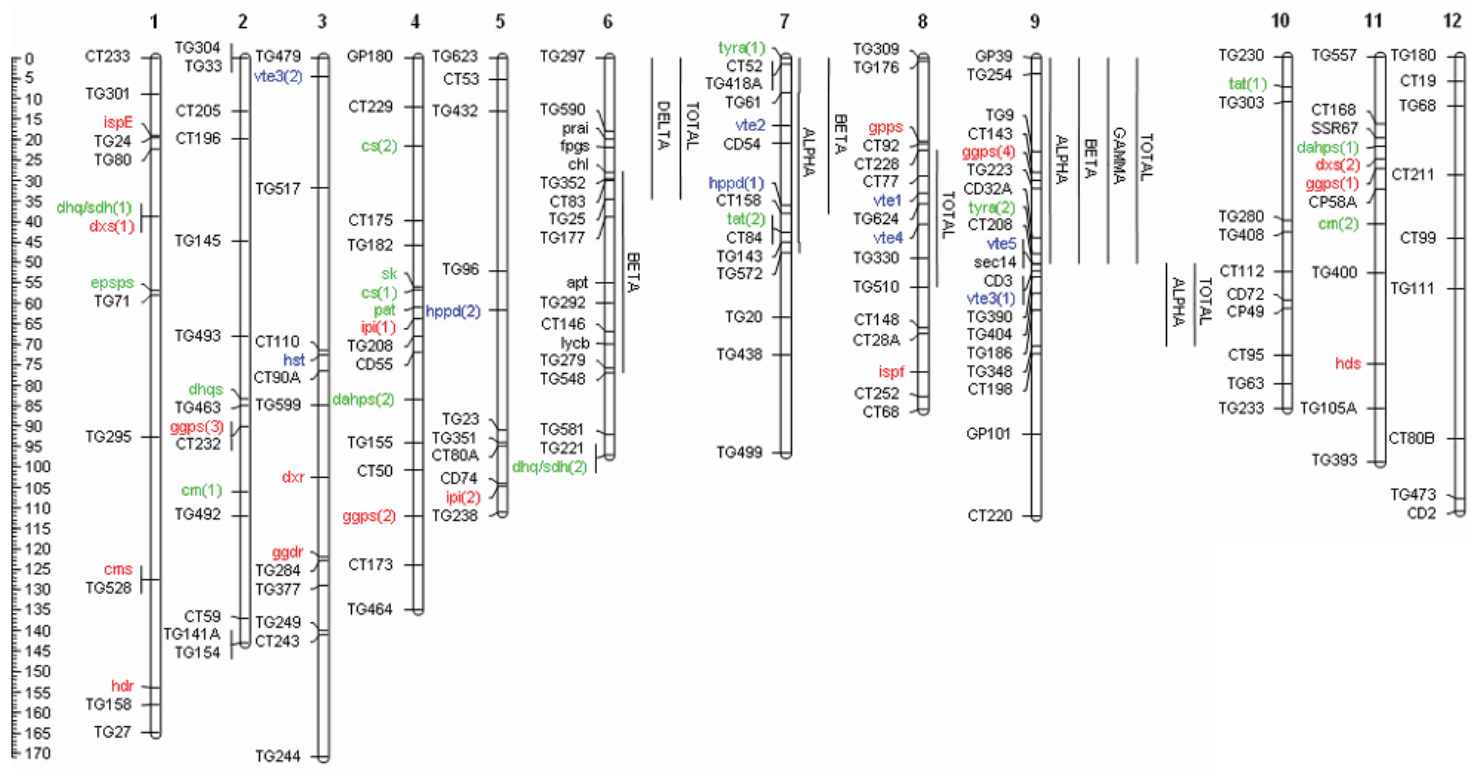

Figura 3. Localização genômica dos genes que codificam para as enzimas da rota biossíntetica de VTE, QTL identificados e genes candidatos associados.

Todos os genes foram localizados no mapa genético Tomato EXPEN 2000, disponível em Solanaceae Genomics Network (http://solgenomics.net/index.pl). Marcadores e genes estão indicados do lado esquerdo dos cromossomos. Os QTL para tocoferol estão indicados do lado direito dos cromossomos. $\mathrm{O}$ código de cores dos genes está em acordo com as rotas da Figura 2. Adaptado de Almeida et al. (2011).

Além dos genes que codificam para as enzimas da biossíntese e seus precursores, co-localizando com os QTL descritos no cromossomo 9, foi identificado um gene candidato cujo produto apresenta identidade de sequência com uma proteína do tipo SEC14. Tem sido reportado, que esse tipo de proteínas possuem domínios de ligação a lipídeos e atividade transportadora desses compostos. Esse domínio, chamado SEC14, foi inicialmente identificado em Saccharomyces cerevisiae, em uma proteína associada com a formação das vesículas secretoras no aparelho de Golgi e o transporte entre elas (Bankaitis et al., 1989, 1990). Na base de dados do NCBI (www.ncbi.nlm.nih.gov), encontram-se anotados 1.550 proteínas que possuem o domínio SEC14. Organismos eucariontes simples podem expressar várias proteínas pertecentes à família Sec14, por exemplo, S. cerevisiae expressa cinco genes com esse domínio (Li et al., 2000). Outras espécies onde essas proteínas têm sido identificadas incluem Homo sapiens, Mus musculus, Drosophila melanogaster, Caernorhabditis elegans e $A$. thaliana; em cada uma das quais podem ser encontrados pelo menos vinte membros dessa família multigênica (Bankaitis et al., 2010).

Todas as proteínas do tipo SEC14, cuja ligação a moléculas hidrofóbicas foi experimentalmente demonstrada, apresentam o motivo conservado $L_{L R F L}{ }^{R} / K A R$. Este motivo foi descrito em proteínas pertenecentes a grupos tão diversos como leveduras, 
plantas e animais, o qual sugere uma origem evolutiva ancestral e uma função conservada (Joaunicc et al., 1998). Além da ligação a moléculas hidrofóbicas, as proteínas Sec14 têm sido associadas a funções ainda mais complexas como transdução de sinal para a integração do metabolismo de lipídeos com outros processos bioquímicos (Saito et al., 2007, Bankaitis et al., 2009). Devido a essas proteínas não possuirem uma função enzimática, acredita-se que atuem principalmente como sensores de lipídeos controlando espaço-temporalmente a atividade de enzimas específicas (Bankaitis et al., 2010).

Em mamíferos, proteínas SEC14 têm demonstrado atuar como transportadoras de a-tocoferol (Stocker e Baumann, 2003; Stocker et al., 1999; Bankaitis et al., 2010). Já em plantas, os estudos são limitados e restritos a poucas espécies. Em soja, foram identificados dois genes homólogos, Ssh1p e Ssh2p (soybean homolog-1 e -2), cujos produtos protéicos apresentam propriedades de ligação e transferência de fosfolipídeos, e encontram-se associadas à resposta da planta a estresse ambiental de diversos tipos, especialmente, condições de elevada osmolaridade (Kearns et al., 1998). Em Arabidopsis, Jouannic et al. (1998) reportaram uma proteína SEC14 envolvida com secreção protéica e na transferéncia de fosfatidilinositol. Na mesma espécie, Vincent et al. (2005) descreveram a proteína AtSfh1p que regula a sinalização por $\mathrm{Ca}^{+2}$ e a função do citoesqueleto, determinando o crescimento polarizado das raízes. Em Lotus japonicus, tem sido reportada uma proteína SEC14 que atua na síntese e função de proteínas de transferência de fosfolipídeos em nódulos de fixação de nitrogênio (Kapranov et al., 2001). Finalmente, Peterman et al. (2004 e 2006) caracterizaram a proteína PATL1 (patellin 1) que liga fofoinositídeos e está associada a tráfego de membrana durante a biogênese da placa celular em arabidopsis.

Os antecedentes supramencionados permitem postular a hipótese que o gene sec14 identificado em tomate seja, pelo menos em parte, responsável pelo QTL de $\alpha$ tocoferol localizado no cromossomo 9 e, desta forma, o presente capítulo propõe a caractarização funcional deste gene. 


\section{OBJETIVOS.}

Devido ao interesse nutricional da VTE e ao seu papel na regulação do equilíbrio oxidativo foi proposto realizar a caracterização e estudo funcional do gene sec14 para melhor compreender os mecanismos que regulam a biossíntese e acúmulo desta vitamina na planta de tomate.

Para atingir este objetivo foram propostos os seguintes objetivos específicos:

1) Analisar a estrutura gênica e realizar um estudo filogenético;

2) Estudar a localização subcelular da proteína, e;

3) Estudar o efeito sobre o metabolismo do silenciamento gênico por RNA de interferência. 


\section{MATERIAIS E MÉTODOS}

\subsection{Material vegetal}

As sementes de tomate de S. lycopersicum L. (cv M82 e Moneymaker) e da linhagem introgredida IL 9-2 de $S$. pennellii foram gentilmente cedidas pelo Tomato Genetic Resource Center (http://tgrc.ucdavis.edu). As sementes de Nicotiana benthamiana foram obtidas do Instituto de Biotecnología do INTA - Argentina. As plantas de tomate e $N$. benthamiana foram crescidas em casa de vegetação, em potes de 20 e $1 \mathrm{~L}$, respectivamente, contendo terra vegetal e vermiculita (1:1). As condições da casa vegetação foram: fotoperíodo de $16 / 8 \mathrm{~h}$, temperatura de $24 \pm 3{ }^{\circ} \mathrm{C}, 60 \%$ umidade e fotoirradiância de $140 \pm 40 \mu \mathrm{mol} \mathrm{m} \mathrm{m}^{-2} \mathrm{~s}^{-1}$.

\subsection{Cepas bacterianas e plasmídeos}

Escherichia coli: foram utilizadas as cepas DH5 $\alpha$, DH10 $\beta$ e DB 3.1. Todos os cultivos foram realizados em meio LB (meio de Luria-Bertani). A temperatura de crescimento foi de $37^{\circ} \mathrm{C}$ e nos casos de cultivo liquido a agitação foi de $200 \mathrm{rpm}$. Quando as cepas bacterianas foram transformadas com um vetor plasmidial, foi adicionado o antibiótico de seleção correspondente ao meio de cultivo.

Agrobacterium tumefaciens: foram utilizaram as cepas GV3101 e GV2260. GV3101 possui resistência a rifampicina $(25 \mathrm{mg} / \mathrm{l})$ e gentamicina $(50 \mathrm{mg} / \mathrm{l})$ e foi utilizada para experimentos de expressão transitória. GV2260 é resistente a rifampicina ( $25 \mathrm{mg} / \mathrm{l}$ ) (Hoeckema et al., 1983) e foi utilizada para a transformação estável. As bactérias foram cultivadas em meio LB a uma temperatura de $28^{\circ} \mathrm{C}$ e nos casos de cultivo líquido a agitação foi de 200 rpm.

Plasmídeos: os vetores utilizados para os diferentes métodos experimentais estão listados na Tabela 1. 
Tabela 1. Descrição dos vetores utilizados neste trabalho.

\begin{tabular}{|c|c|c|c|c|}
\hline Vetores & $\begin{array}{c}\text { Resistência em } \\
\text { bactéria }\end{array}$ & $\begin{array}{l}\text { Resistência } \\
\text { em plantas }\end{array}$ & Características & Origem \\
\hline pENTR/D-TOPO & canamicina & & $\begin{array}{l}\text { Vetor linearizado com sitio de } \\
\text { clonagem direcional para } \\
\text { produtos de PCR de ponta } \\
\text { cega. Possui os sítios attL1 e } \\
\text { attL2 para recombinação sítio- } \\
\text { específica do clone de entrada } \\
\text { com um vetor destino no } \\
\text { sistema Gateway } \circledast \text {. }\end{array}$ & Invitrogen \\
\hline pK7FWG2 & $\begin{array}{l}\text { spectinomicina/ } \\
\text { streptomicina }\end{array}$ & canamicina & 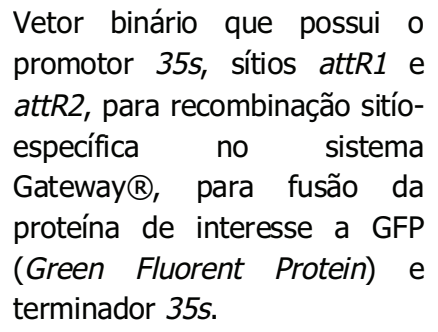 & Karimi et al. (2002) \\
\hline p7GWIWG2(I) & $\begin{array}{l}\text { spectinomicina/ } \\
\text { streptomicina }\end{array}$ & canamicina & $\begin{array}{l}\text { Vetor binário que possui o } \\
\text { promotor 35s, um íntron } \\
\text { flanqueado por sítios attR1 e } \\
\text { attR2, para recombinação sítio- } \\
\text { específica no sistema } \\
\text { Gateway } ₫ \text {, e terminador } 35 s \text {. } \\
\text { Contém um fragmento gênico } \\
\text { em ambas as orientações } \\
\text { separados por um íntron } \\
\text { permitindo a formação de uma } \\
\text { estrutura de alça. }\end{array}$ & Karimi et al. (2002) \\
\hline
\end{tabular}

3.3. Obtenção das sequências dos alelos do gene sec14, análise da estrutura gênica e filogenia

A sequência completa do alelo de $S$. lycopersicum foi obtida do contig SL2.31ct07099 (Projeto de sequenciamento internacional de Tomate, SGN) disponível na página da Sol Genomics Network (Mueller et al., 2005, 2008, 2009). O alelo correspondente a $S$. pennellii foi clonado e sequenciado pelo nosso grupo (Almeida et al., 2011). As UTRs foram determinadas de acordo com o unigene de referência (U583419) disponível na página da SGN. A comparação das sequências foi realizada com o auxilio do programa MULTALIN (Corpet, 1988).

Foi realizada uma busca no NCBI (http://www.ncbi.nlm.nih.gov/) e na literatura para identificar proteínas com domínio SEC14 com função experimentalmente 
demonstrada. Utilizando as sequências identificadas e a proteína SEC14 de tomate como referência, foram obtidas da base de proteínas não redundantes (nr) do NCBI, sequências ortólogas de outras espécies vegetais por meio do algoritmo BLASTX (Altschul et al., 1990). O critério estabelecido para a escolha das sequências foi identidade de aminoácidos $\geq 40 \%$ e cobertura $\geq 65 \%$. Para todas as sequências protéicas foi predita a localização subcelular utilizando o programa TargetP 1.1 (http://www.cbs.dtu.dk/services/TargetP/). A estrutura secundaria e terciária da proteína DnaJ foi analisada utilizando o programa TMHMM (http://www.cbs.dtu.dk/services/TMHMM/). Para a construção da árvore filogenética, as sequências de aminoácidos foram alinhadas utilizando o programa ClustalW (Thompson et al., 1994). A matriz de distância foi construída utilizando o método de Neighbor-joining (Saito e Nei, 1987) com o programa MEGA (Tamura et al., 2007). Os valores de bootstrap foram determinados a partir de 1000 réplicas.

\subsection{Obtenção da construção para estudo da localização subcelular da proteína SEC14}

Tecidos de folha fonte (segundo e terceiro folíolos da terceira folha totalmente expandida), da IL 9-2 e de S. Iycopersicum (cv. M82), foram processados em nitrogênio líquido e alíquotas de $200 \mathrm{mg}$ de tecido triturado foram submetidas à extração de RNA total empregando-se o reagente Trizol (Invitrogen, 15596018), segundo o protocolo recomendado pelo fabricante. A extração foi realizada utilizando clorofórmio (0,2 V/V de Trizol) e a precipitação do acido nucléico com isopropanol (0,6 V/V de solução). O RNA foi ressuspendido em $20 \mu \mathrm{l}$ de água 0,1\% DEPC (livre de RNase) e as amostras estocadas a $-80{ }^{\circ} \mathrm{C}$. As amostras foram quantificadas por absorbância a $260 \mathrm{~nm}$ em espectrofotômetro. Para estimar a pureza da preparação, foi levada em consideração a relação entre as absorbâncias obtidas a 260 nm e 280 nm, sendo que as amostras com rações acima de 1,8 foram consideradas puras. Quando necessário, uma nova precipitação com 1 volume de LiCl (5M) foi realizada. Aproximadamente $1 \mu \mathrm{g}$ de RNA foi tratado com $1 \mu \mathrm{l}$ de DNase (Invitrogen 18068-015), e posteriormente foi realizada a síntese de cDNA utilizando a enzima SuperScript III Reverse Transcriptase (Invitrogen 18080-044), segundo instruções do fabricante. Cada reação conteve: $11 \mu \mathrm{l}$ do RNA tratado com DNase (aproximadamente $1 \mu \mathrm{g}$ ), $1 \mu \mathrm{l}$ de iniciadores OligoDT (Invitrogen 18418-012) $(150 \mu \mathrm{g} / \mathrm{ml})$ e 0,2 mM dNTPs. Após incubação a $65^{\circ} \mathrm{C}$ por 5 minutos foi adicionado $1 x$ tampão da enzima, 5 mM DTT, 40 


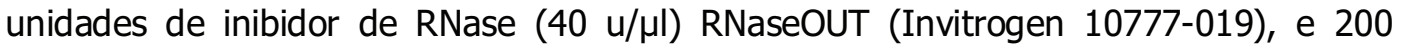
unidades da enzima SuperScript III RT (200 u/ $\mu$ l). Essa reação foi incubada por 5 minutos a $25^{\circ} \mathrm{C}, 50^{\circ} \mathrm{C}$ por 1 hora e, finalmente, $70{ }^{\circ} \mathrm{C}$ por 15 min. Para testar a pureza do cDNA (livre de DNA genômico), foi realizada uma PCR usando 0,2 mM de cada dNTPs, 0,2 mM de cada iniciador ActinaUp (5'- TGGCATCATACCTTTTACAA -3') e ActinaLow (5'- TCCGGGCATCTGAACCTCT -3'), 1,5 mM de $\mathrm{Mg}_{2} \mathrm{SO}_{4}$, e 2,5 unidades de enzima TAQ polymerase ${ }^{\circledR}$ (Invitrogen, 10342-020). O ciclo de amplificação utilizado foi de $94{ }^{\circ} \mathrm{C}$ por $3 \mathrm{~min}$; 35 ciclos de $94{ }^{\circ} \mathrm{C}$ por $30 \mathrm{seg}, 55^{\circ} \mathrm{C}$ por $1 \mathrm{~min}, 72^{\circ} \mathrm{C}$ por $2 \mathrm{~min}$; e uma extensão final a $72{ }^{\circ} \mathrm{C}$ por $10 \mathrm{~min}$. Os produtos da amplificação foram visualizados por eletroforese em gel de agarose $0,8 \%$ TAE $1 x$.

A amplificação do cDNA completo do gene para ambos os alelos foi realizada por PCR utilizando a $50 \mathrm{ng}$ de cDNA de cada um dos genótipos, 0,2 mM de cada dNTPs, 0,2 mM de cada iniciador [FUS-SEC14-F (5'- CACCATGGATTCTTCATCCCCC-3') e FUS-SEC14-R (5'- GGCTGAAATAGTTGCAGATTTGC -3')], 1,5 mM de $\mathrm{Mg}_{2} \mathrm{SO}_{4}$, e 2 unidades de enzima Elongase ${ }^{\circledR}$ DNA polimerase (Invitrogen, 10480-010). O ciclo de amplificação utilizado foi de $94^{\circ} \mathrm{C}$ por $3 \mathrm{~min}$; 35 ciclos de $94^{\circ} \mathrm{C}$ por $30 \mathrm{seg}, 50^{\circ} \mathrm{C}$ por $30 \mathrm{seg}, 68^{\circ} \mathrm{C}$ por $2 \mathrm{~min}$; e uma extensão final a $68{ }^{\circ} \mathrm{C}$ por $10 \mathrm{~min}$. Os fragmentos amplificados foram purificados utilizando o Kit GFX (Amersham Biosciences 27-960201), de acordo com especificações do fabricante e clonados no vetor de entrada pENTR/D-TOPO (Invitrogen, K240020). Posteriormente, foram recombinados utilizando a enzima LR clonase II (Invitrogen 11791-020) no vetor binário de pK7FWG2 (Tabela 1). Os clones obtidos pK7FWG2-SEC14Lyc e pK7FWG2-SEC14Pen foram analisados por restrição com endonucleases e confirmados por sequenciamento. Após confirmação da identidade, os clones foram inseridos $A$. tumefaciens cepa GV3101 segundo protocolo de Wen-Jun e Forde (1989).

\subsection{Obtenção da construção para avaliação do efeito do silenciamento gênico por RNA de interferência}

DNA plasmidial do clone contendo o alelo de $S$. lycopersicum do gene sec14 obtido pelo nosso grupo foi purificado segundo Sambrook et al. (1989). Para a amplificação do fragmento para RNAi, foram usados $10 \mathrm{ng}$ de DNA molde, 0,2 mM de

cada dNTPs, 0,2 $\mathrm{mM}$ de cada iniciador [RNAI-sec14-F (5'CACCGTAGTAGGAGGATGGGACTTGG-3') e RNAI-sec14-R (5'GCAGATTTGCGGACAATGTATCGATAG-3'), 1,5 mM de $\mathrm{Mg}_{2} \mathrm{SO}_{4}$, e 2,5 unidades de 
enzima TAQ polymerase $\circledR$ (Invitrogen, 10342-020). O ciclo de amplificação utilizado foi de $94{ }^{\circ} \mathrm{C}$ por $3 \mathrm{~min} ; 35$ ciclos de $94{ }^{\circ} \mathrm{C}$ por $30 \mathrm{seg}, 52{ }^{\circ} \mathrm{C}$ por $30 \mathrm{seg}, 72{ }^{\circ} \mathrm{C}$ por $1 \mathrm{~min}$; e uma extensão final a $72{ }^{\circ} \mathrm{C}$ por $10 \mathrm{~min}$.

O fragmento amplificado foi purificado utilizando o Kit GFX (Amersham Biosciences 27-9602-01), de acordo com especificações do fabricante. O fragmento foi clonado no vetor de entrada pENTR/D-TOPO (Invitrogen, K240020) e posteriormente recombinado utilizando a enzima LR clonase II (Invitrogen 11791-020) no vetor binário de p7GWIWG2(I) (Tabela 1). O clone obtido pK7GWIWG2(I)sec14 foi analisado por restrição com endonucleases e confirmado por sequenciamento. Após confirmação da identidade, o clone foi inserido em A. tumefaciens cepa GV2260 segundo protocolo de Wen-Jun e Forde (1989).

\subsection{Infiltração de folhas de $\boldsymbol{N}$. benthamiana para estudo da localização subcelular da proteína SEC14}

As células de $A$. tumefaciens cepa GV3101 contendo os plasmídeos pK7FWG2SEC14Lyc e pK7FWG2-SEC14Pen foram cultivadas a $28^{\circ} \mathrm{C}$ durante 16 horas em $20 \mathrm{ml}$ de meio LB com rifampicina $(25 \mu \mathrm{g} / \mathrm{ml})$, spectinomicina $(50 \mu \mathrm{g} / \mathrm{ml})$ e gentamicina (50 $\mu \mathrm{g} / \mathrm{ml}$ ), até obter uma densidade óptica (OD) de 0,5 a $600 \mathrm{~nm}$. Posteriormente, as células foram coletadas a $4.000 \mathrm{rpm}$ por $10 \mathrm{~min}$ a temperatura ambiente e ressuspendidas em MES 10 mM com acetosiringona (100 mM). A suspensão foi incubada por 4 horas a temperatura ambiente e a infiltração realizada em plantas de aproximadamente seis semanas na superfície abaxial da folha com uma seringa de $1 \mathrm{ml}$ sem agulha.

Após 48h, as folhas infiltradas foram analisadas e fotografadas no microscópio de laser confocal espectral Leica TCS-SP5, usando o objetivo 63x (HCX PL APO CS 63.0x1.20 WATER UV). A linha de $488 \mathrm{~nm}$ do laser de Argon foi usada para excitar as partículas de GFP e da clorofila. A emissão da fluorescência foi detectada a 525-600 $\mathrm{nm}$ para GFP e a $700-800 \mathrm{~nm}$ para a clorofila. As imagens de cada plano foram tomadas em modo sequencial para evitar o cruzamento de espectros de ambos os fluoróforos. A configuração geral do microscópio foi ajustada para otimizar o contraste e a resolução de cada imagem individualmente. 


\subsection{Obtenção de plantas transgênicas de tomate}

\subsubsection{Transformação genética}

A obtenção de linhagens transgênicas de S. lycopersicum (cv. Moneymaker), via Agrobacterium, foi realizada segundo o protocolo utilizado pelo Instituto de Biotecnologia do INTA Castelar, Argentina (http://www.inta.gov.ar/biotec/actividad/transformaciondeplantas.htm).

A micropropagação das linhagens transgênicas selecionadas foi realizada assepticamente em fluxo laminar horizontal (Nuaire, EUA) a partir de ápices de plantas cultivadas in vitro. Foram mantidas em tubos de vidro de $2,5 \mathrm{~cm}$ de diâmetro e $10 \mathrm{~cm}$ de alto com meio de cultura MSS (Sais de Murashige-Skoog comercial com 20\% sacarose), em câmaras de cultura a $22^{\circ} \mathrm{C}$, e um fotoperíodo de $16 \mathrm{~h}$ claro (5.000 lux) $8 \mathrm{~h}$ escuro.

\subsubsection{Verificação da presença do transgene}

Para conferir a presença do transgene, DNA genômico das linhagens foi extraído segundo CIMMYT (2005) e foi realizada uma PCR usando 50 ng de DNA molde, 0,2 mM de cada dNTPs, 0,2 mM de cada iniciador [35S-right (5'CCCACTATCCTTCGCAAG-3') e 35S-left (5'- GCAGGTCACTGGATTTTGG-3')], 1,5 mM de $\mathrm{Mg}_{2} \mathrm{SO}_{4}$, e 2,5 unidades de enzima TAQ polymerase $\AA$ (Invitrogen, 10342-020). O ciclo de amplificação utilizado foi de $94{ }^{\circ} \mathrm{C}$ por $3 \mathrm{~min}$; 35 ciclos de $94{ }^{\circ} \mathrm{C}$ por $30 \mathrm{seg}, 55^{\circ} \mathrm{C}$ por $1 \mathrm{~min}, 72{ }^{\circ} \mathrm{C}$ por $2 \mathrm{~min}$; e uma extensão final a $72{ }^{\circ} \mathrm{C}$ por $10 \mathrm{~min}$. Os produtos amplificados foram verificados por eletroforese em gel de agarose $0,8 \%$ TAE $1 x$.

\subsubsection{Análise de expressão do gene sec14 nas linhagens transgênicas obtidas}

As linhagens crescidas in vitro em meio seletivo com antibiótico, para as quais foi confirmada a presença do transgene por PCR, foram levadas a estufa. Após quatro semanas, foram retiradas gemas vegetativas para sincronização das plantas com o respectivo controle. Uma vez que as plantas apresentavam 8 folhas completamente expandidas, foi coletado o terceiro folíolo da quarta folha totalmente expandida para a análise do silenciamento por reação em cadeia da polimerase quantitativa em tempo real (qPCR). A extração de RNA e posterior síntese de cDNA foi realizado como descrito no item 3.4. A reação de qPCR foi realizada com $1 \mu$ de uma diluição de CDNA 1:5, 0,2 mM de cada iniciador [Rnaitrans-SEC14-F (5'-CATCCCCCATTACTGTTCAAAAAGCTC-3') e Rnaitrans-SEC14-R (5'-GGTTTAAGGTGAGAAGTGAAG-3') para o gene alvo, e EF-1 a-up 
(5'- ATTGGAAACGGATATGCTCCA-3') e EF-1 a-Low (5'- TCCTTACCTGAACGCCTGTCA 3'), para o gene de refêrencia] e 2x SYBR Green Master Mix (Qiagen, 204054). Foi utilizado um termociclador 7300 PCR Real Time (Applied Biosystems), e o ciclo de amplificação foi de $95^{\circ} \mathrm{C}$ por 10 min e 40 ciclos de: $95^{\circ} \mathrm{C}$ por $15 \mathrm{seg}, 55^{\circ} \mathrm{C}$ por $1 \mathrm{~min}$ e $72{ }^{\circ} \mathrm{C}$ por $30 \mathrm{seg}$ (momento no qual ocorre a leitura do sinal emitido pelo SYBR Green). Os dados obtidos foram analisados com o software LinRegPCR (Ruijter et al., 2009) para calcular os valores de Ct (cycle threshold) e a eficiência da reação. A expressão relativa foi calculada segundo fórmula abaixo (Pfaffl et al., 2002) com o software fgStatistics (Di Rienzo, 2009). O mesmo software foi utilizado para as análises estatísticas.

Onde: $\quad \mathrm{ER}=\frac{\mathrm{Ef}_{\text {alvo }} \wedge \text { (média de } \mathrm{Ct} \text { do controle }- \text { média de } \mathrm{Ct} \text { da linhagem) }}{\mathrm{Ef}_{\text {ref }} \wedge \text { (média de } \mathrm{Ct} \text { do controle - média de } \mathrm{Ct} \text { da linhagem) }}$

ER: expressão relativa

Ef: eficiência da qPCR para cada par de iniciadores alvo: gene alvo $(\sec 14)$

Ct do controle: média dos Cts das réplicas biológicas do controle Ct da linhagem: média dos Cts das réplicas biológicas de cada linhagem ref: gene de referência $(E F 1 a)$

\subsection{Caracterização fenotípica das linhagens transgênicas}

\subsubsection{Cultivo e parâmetros de produção}

As cinco linhagens que apresentaram a maior redução dos níveis de RNAm do gene sec14 foram selecionadas para caracterização fenotípica: RNAi:sec142, RNAi:sec1415, RNAi:sec1418, RNAi:sec1419 e RNAi:sec1424. Foram estabelecidas seis réplicas de cada linhagem por meio de propagação por estaquia, em setembro de 2010. Foram feitas duas coletas no período das 10h às 14h: uma após cinco semanas e outra aos quatro meses, quando todas as plantas já apresentavam frutos maduros. $\mathrm{Na}$ primeira foi coletado o segundo e terceiro folíolo da terceira folha totalmente expandida e na coleta final foram amostrados pericarpos de fruto verde e maduro, de 37 e 52 dias após antese, respectivamente. Foram separados, contados e pesados todos os frutos restantes e, finalmente, a parte aérea da planta foi cortada no colo da raiz e pesada como parâmetro de biomassa. Para calcular o índice de colheita foi usada a seguinte fórmula:

Índice de colheita=(peso total de frutos verdes e maduros)*100/peso fresco da parte aérea. 


\subsubsection{Verificação do nível de silenciamento nas linhagens transgênicas}

Uma nova verificação do nível de silenciamento do gene sec14 foi realizada para as seis réplicas de cada linhagem selecionada. Foram testadas por qPCR amostras de folhas fonte e fruto maduro, segundo descrito no item 3.7.3.

\subsubsection{Avaliação da expressão dos genes da rota central de biossíntese do tocoferol}

Para avaliar possíveis alterações na expressão dos genes relacionados à rota central de biossíntese de tocoferol, foram desenhados iniciadores específicos para cada um dos genes (Tabela 2), e avaliadas amostras de folhas fonte e fruto maduro por qPCR, segundo descrito no item 3.7.3.

Tabela 2. Iniciadores usados para análise de expressão por qPCR dos genes da rota central da biossíntese de tocoferol.

\begin{tabular}{|c|c|c|}
\hline Gene & Nome do iniciador & Sequência 5' - 3' \\
\hline \multirow[t]{2}{*}{ Tocoferol ciclase, VTE1 } & RT-VTE1-F & CGAACTCCTCATAGCGGGTATC \\
\hline & RT-VTE1-R & CACGCCAGTAAACCGAGGC \\
\hline \multirow[t]{2}{*}{ Homogentisato fitil transferase, VTE2 } & RT-VTE2-F & CAATTCCAGTTCCTGCTGAG \\
\hline & RT-VTE2-R & CCTCCAACATGCTCTTGCGTG \\
\hline \multirow[t]{2}{*}{ Dimetil-fitilquinol metil transferase, VTE3 (1) } & VTE3-RT-F & GAGGGTGATGCTGAGGATC \\
\hline & VTE3-RT-R & CGAGACAACCAAAAGGTAGGG \\
\hline \multirow{2}{*}{ Y-tocoferol C-metil transferase, VTE4 } & RT-VTE4-F & CAGATCATCGTGCTGCTCAG \\
\hline & RT-VTE4-R & ССTCTCTGCTTGTACAGGAC \\
\hline \multirow[t]{2}{*}{ 4-hidroxifenilpiruvato dioxigenase, HPPD (1) } & HPPD-RT-F & CAGGGCAGGGGATATACTGA \\
\hline & HPPD-RT-R & СТССАСАТССАСССТТСТG \\
\hline
\end{tabular}

\subsubsection{Medição dos parâmetros fotossintéticos}

As medidas de trocas gasosas e fluorescência da clorofila foram realizadas com o sistema portátil Licor-6400 (Li-Cor; www.licor.com) que consiste em um sistema aberto contendo um analisador de gases por infravermelho (IRGA) e uma câmara fluorométrica acoplada (Modelo 6400-40, Li-Cor).

As medidas foram realizadas no segundo folíolo da terceira folha totalmente expandida de plantas em estado vegetativo de quatro semanas, no período das $10 \mathrm{~h}$ às $14 \mathrm{~h}$. Antes de realizar as medições, as folhas a serem analisadas passaram por um processo de adaptação a escuridão durante no mínimo 30 min. Foram realizadas curvas de resposta à luz com uma câmara que possui uma área de exposição foliar de $2 \mathrm{~cm}^{2}$, as condições padrão para as medições foram de $400 \mathrm{PPM}$ de $\mathrm{CO}_{2}$ e temperatura foliar de $25^{\circ} \mathrm{C}$. 
Os parâmetros fotossintéticos foram determinados segundo Maxwell e Johnson (2000). Foram calculadas as fluorescências mínimas de folhas adaptadas à escuridão (F0) e adaptadas à luz (F0'). Após um pulso de luz saturante branca (3.000 $\mu$ moles $E$ $\mathrm{m}^{-2} \mathrm{~s}^{-1}$ ) foi determinada a fluorescência máxima da clorofila quando todos os centros do fotossístema II encontram-se na escuridão ( $F m)$ ou adaptados à luz (Fm'). A fluorescência variável foi determinada pelo cálculo de $\mathrm{Fv}=\mathrm{Fm}-\mathrm{F} 0$ em folhas adaptadas à escuridão, ou $\mathrm{Fv}^{\prime}=\mathrm{Fm}^{\prime}$-FO' em folhas adaptadas à luz variando a densidade de fluxo de fótons (PFD) entre 200 e $1200 \mu$ moles $\mathrm{E} \mathrm{m}^{-2} \mathrm{~s}^{-1}$. A relação entre a eficiência variável e a eficiência máxima Fv/Fm; a eficiência do fotossístema II (Fm'-Fs)/Fm'; o quenching fotoquímico qP=(Fm'-Fs)/(Fm'-F0'); o quenching não fotoquímico $\mathrm{NPQ}=\left(\mathrm{Fm}-\mathrm{Fm}^{\prime}\right) / \mathrm{Fm}^{\prime}$; e a acumulação de quinonas reduzidas $1-\mathrm{pQ}=\left(\mathrm{Fs}_{\mathrm{s}}-\mathrm{FO} 0^{\prime}\right) /\left(\mathrm{Fm}^{\prime}-\mathrm{FO}^{\prime}\right)$ também foram calculados. Finalmente, foi avaliada a taxa de transferência de elétrons:

$$
\mathrm{ETR}=\left[\left(\mathrm{Fm}^{\prime}-\mathrm{Fs}\right) / \mathrm{Fm}^{\prime}\right]^{*} f I \text { a folha }
$$

onde Fs é o estado estável de fluorescência; $f$ é a fração de quanta absorvido que é usado pelo fotossístema II o qual se assume ser de 0,5 para plantas C3; I é a densidade de fluxo de fótons incidente; e a folha é a absorbância da folha que se assume ser 0,85 (Sienkiewicz-Porzucek et al., 2010).

\subsubsection{Extração e quantificação de pigmentos}

Para a quantificação de pigmentos, no momento da coleta final das plantas foi coletado um disco foliar de área $0,38 \mathrm{~cm}^{2}$ do segundo folíolo da terceira folha totalmente expandida, $400 \mathrm{mg}$ de pericarpo de fruto verde, e $400 \mathrm{mg}$ de pericarpo de fruto maduro para cada uma das réplicas das 5 linhagens transgênicas selecionadas. As amostras foram trituradas em nitrogênio líquido.

A extração de pigmentos para o tecido foliar e fruto verde foi realizada como descrito por Lichtenthaler (1987). As amostras foram maceradas em um tubo contendo $1 \mathrm{ml}$ de acetona 80\% (V/V) por 2 horas em escuridão até observar a descoloração total do material e, posteriormente, centrifugadas por $10 \mathrm{~min}$ a $10.000 \mathrm{rpm}$. A absorbância do sobrenadante foi lida em espectrofotômetro a 663, 645 e 470 nm. Baseada nas absorbâncias obtidas foi calculada a concentração dos pigmentos pelas equações a seguir e o conteúdo total foi normalizado pela massa (fruto verde) ou área (folha fonte) de tecido.

Clorofila $\boldsymbol{a}=12,25 *$ Abs $663-2,79 *$ Abs 645

Clorofila $\boldsymbol{b}=21,50 *$ Abs $645-5,10 *$ Abs 663

Carotenóides totais $=(1000 *$ Abs $470-1,82 *$ Clorofila $a-85,02 *$ Clorofila $b) / 198$ 
Para a quantificação dos pigmentos de fruto maduro foi utilizado o protocolo descrito por Heredia et al. (2009). $400 \mathrm{mg}$ de tecido foram macerados em $4 \mathrm{ml}$ de etanol absoluto e $3 \mathrm{ml}$ de hexano (99\%) por $1 \mathrm{~h}$ no escuro com agitação de $150 \mathrm{rpm}$. Posteriormente, foi acrescentado $1 \mathrm{ml}$ de água MilliQ deionizada para permitir a separação das duas fases. A absorbância de $500 \mu$ da fase superior (hexano) foi lida em espectrofotômetro a 503 e 478 nm. Baseada nas absorbâncias obtidas foi calculada a concentração dos pigmentos pelas equações a seguir e o conteúdo total foi normalizado pela massa de tecido.

$$
\begin{gathered}
\frac{\mathrm{mg} \beta \text {-caroteno }}{100 \mathrm{~g}}=\frac{\left[\mathrm{A}_{478}-\left(\mathrm{A}_{503} * 0,9285\right)\right] * M_{\beta \text {-car }} * \mathrm{~V} * 100}{\mathrm{~m} * E_{\beta \text {-car }}} \\
\frac{\mathrm{mg} \text { licopeno }}{100 \mathrm{~g}}=\frac{\mathrm{A}_{503} * M_{\mathrm{LIC}} * \mathrm{~V} * 100}{\mathrm{~m} * E_{\mathrm{LIC}}}
\end{gathered}
$$

onde A é a absorbância; $M_{\text {LIC }}$ e $M_{\beta \text {-car }}$ são os pesos moleculares do licopeno (537 $\mathrm{g} / \mathrm{mol}$ ) e $\beta$-caroteno $(533,85 \mathrm{~g} / \mathrm{mol})$, respectivamente; $V$ é o volume da fase de hexano na extração ( $3 \mathrm{ml}) ; \mathrm{m}$ é a massa da amostra analisada, e; $E_{\text {Lic }}$ e $E_{\beta \text {-car }}$ são os coeficientes de extinção do licopeno $\left(172 \mathrm{M}^{-1} \mathrm{~cm}^{-1}\right)$ e do $\beta$-caroteno $\left(139 \mathrm{M}^{-1} \mathrm{~cm}^{-1}\right)$, respectivamente (Zscheille e Porter, 1947).

\subsubsection{Extração e quantificação de aminoácidos, açúcares solúveis e amido}

A extração de açúcares solúveis, aminoácidos totais e amido para folhas fonte e frutos maduros foram realizadas usando protocolos estabelecidos pelo nosso grupo (Fernie et al., 2001).

\section{Extração}

A $10 \mathrm{mg}$ de tecido triturado foram adicionados $250 \mu \mathrm{l}$ de etanol $80 \%$ seguido de agitação por $20 \mathrm{~min}$ a $80{ }^{\circ} \mathrm{C}$. Após centrifugação por 5 min a $14.000 \mathrm{rpm}$, o sobrenadante foi recuperado e o pellet submetido a duas novas extrações, com $150 \mu \mathrm{l}$ de etanol $80 \%$ e $250 \mu \mathrm{l}$ de etanol $50 \%$, respectivamente. Os três sobrenadantes foram reunidos para posterior quantificação de açúcares e aminoácidos.

Ao pellet obtido foram adicionados $500 \mu \mathrm{l}$ de etanol $40 \%$ e centrifugado por 10 min a $14.000 \mathrm{rpm}$. O sobrenadante foi descartado e o pellet ressuspendido em $400 \mu \mathrm{l}$ de $\mathrm{KOH} \mathrm{0,2} \mathrm{M.} \mathrm{A} \mathrm{suspensão} \mathrm{foi} \mathrm{incubada} \mathrm{durante} 1 \mathrm{~h}$ a $95^{\circ} \mathrm{C}$ e, posteriormente, foram adicionados $70 \mu \mathrm{l}$ de ácido acético $1 \mathrm{M}$ seguido de uma centrifugação por $10 \mathrm{~min}$ a $14.000 \mathrm{rpm}$. O sobrenadante foi recuperado, e as amostras diluídas 1:3. 


\section{Determinação de açúcares}

Para uma placa de 96 poços foi preparada uma mistura com 15,5 ml de tampão (HEPES/KOH 1 M, MgCl 30 mM pH 7,0) 0,1x, $480 \mu \mathrm{l}$ de ATP $[60 \mathrm{mg} / \mathrm{ml}], 480 \mu \mathrm{l}$ de NADP [36 mg/ml] e $80 \mu l$ de glicose-6-fosfato desidrogenase (G6PDH) [5 mg/ml]. Em cada poço, foram adicionados $50 \mu \mathrm{l}$ do extrato etanólico e $160 \mu \mathrm{l}$ da mistura descrita anteriormente. A leitura foi feita em espectrofotômetro a 340 nm com medições a cada minuto. Uma vez que a OD se estabilizou foram adicionadas sucessivamente $1 \mu \mathrm{l}$ de hexoquinase $[1500 \mathrm{U} / \mathrm{ml}], 1 \mu \mathrm{l}$ de fosfoglicose isomerase $[2 \mathrm{mg} / \mathrm{ml}$ ] e finalmente $1 \mu \mathrm{l}$ de invertase 0,1 M. Para fazer os cálculos da concentração dos respectivos açúcares, foi usada a seguinte equação:

$$
\mu \mathrm{mol} \mathrm{NADPH}=\Delta \mathrm{OD} /(2.85 * 6.22)
$$

Os valores foram normalizados pelo volume utilizado na medição e a massa de tecido.

\section{Determinação de aminoácidos}

Em um tubo de 1,5 ml foram adicionados $50 \mu \mathrm{l}$ de tampão citrato/NaOH $1 \mathrm{M} \mathrm{pH}$ 5,2 com ácido ascórbico 0,2\%, $50 \mu \mathrm{l}$ de extrato etanólico, obtido como descrito anteriormente e $100 \mu \mathrm{l}$ de solução de ninhidrina 1\% (P/V em etanol 70\%). Os tubos foram selados e incubados por $20 \mathrm{~min}$ a $95^{\circ} \mathrm{C}$, centrifugados por 10 seg a $10.000 \mathrm{rpm}$ e finalmente as amostras foram dispostas em placa de 96 poços e lidas em espectrofotômetro a $570 \mathrm{~nm}$.

Para realizar a estimativa do conteúdo total de aminoácidos, foi realizada uma curva padrão de Leucina substituindo os $50 \mu \mathrm{l}$ da amostra por 0-2-5-10-20-50 $\mu \mathrm{l}$ de padrão de leucina completado com 50-48-45-40-30-0 $\mu \mathrm{l}$ de etanol $70 \%$, respectivamente. Os valores foram normalizados pelo volume utilizado na medição e a massa de tecido.

\section{Determinação de amido}

A determinação enzimática foi realizada com o kit Starch (GO/P) Assay da empresa SIGMA (STA20), segundo instruções do fabricante. A produção de NADH foi medida em espectrofotômetro a $340 \mathrm{~nm}$. Foi realizada uma curva padrão com glicose e o cálculo do conteúdo de amido foi realizado segundo a seguinte fórmula:

$\mu \mathrm{g} / \mathrm{g}$ peso fresco de amido $=\mu \mathrm{mol}$ de glicose $* 162$ (massa da anidroglicose)

Os valores foram normalizados pelo volume utilizado na medição e a massa de tecido. 


\subsubsection{Extração e quantificação de tocoferóis}

A extração dos tocoferóis foi realizada como descrito por Fraser et al. (2000) com algumas modificações. Os tecidos analisados foram moídos em nitrogênio liquido e $400 \mathrm{mg}$ do material extraídos com 1,5 ml de metanol puro. Após agitação por $1 \mathrm{~min}$ foi adicionado $1 \mathrm{ml}$ de clorofórmio com BHT 0,1\% (P/V) seguido de uma sonicação por 5 minutos. Posteriormente, foi agregado $1 \mathrm{ml}$ de tampão Tris ( $\mathrm{pH} 7,520 \mathrm{mM}$ ) $/ \mathrm{NaCl} 1$ $\mathrm{M}$ e as amostras foram centrifugadas por $1 \mathrm{~min}$ a $3.000 \mathrm{rpm}$ por $5 \mathrm{~min}$. A fase clorofórmica foi recuperada e o pellet submetido a duas novas re-extrações com clorofórmio + BHT 0,1\% (P/V) uma primeira com $2 \mathrm{ml}$ e uma última com $1 \mathrm{ml}$ da solução. Os três extratos foram reunidos e o volume final ajustado a $4 \mathrm{ml}$ com clorofórmio. Uma alíquota de $2 \mathrm{ml}$ foi secada em nitrogênio gasoso, ressuspendidas em $0,2 \mathrm{ml}$ de solução hexano/isopropanol $(99,5: 0,5)$ e, antes da injeção, filtradas duas vezes.

O conteúdo de tocoferol foi determinado utilizando o cromatógrafo líquido Hewlett-Packard series 1100 HPLC System acoplado a um detector de fluorescência (Agilent Technologies, série 1200). A separação cromatográfica foi realizada em coluna de fase normal Metasil Si (250 mm × $4.6 \mathrm{~mm}, 5 \mu \mathrm{m}$, Varian, Metachem, Torrance, CA) operada em temperatura ambiente utilizando um sistema de eluição isocrático (fase móvel) de 99,5:0,5 hexano/isopropanol com fluxo de $1 \mathrm{ml} \mathrm{min}^{-1}$. Os compostos eluídos foram detectados por fluorescência com excitação a 296 nm e emissão a 340 nm. Os diferentes isômeros de tocoferol foram identificados e quantificados por meio da comparação do tempo de retenção e das áreas dos picos dos padrões adquiridos comercialmente (Merck, tocopherol set Calbiochem, \#613424). Uma curva de calibração foi realizada utilizando uma solução de tocoferóis com concentração variando entre 0,31 e $5 \mathrm{\mu g} / \mathrm{mL}$ para cada isômero. Desse modo, foi feita uma correlação linear entre as áreas dos picos e as concentrações injetadas de cada composto. A equação de regressão linear obtida para cada isômero foi utilizada para quantificar o conteúdo dos tocoferóis nas amostras.

\subsubsection{Análise estatística}

Os diferentes parâmetros analisados nas linhagens transgênicas foram avaliados estatisticamente de acordo com Sokal e Rohlf (1981). Quando o conjunto de dados obedeceu ao critério de homoscedasticidade, com ou sem transformação logarítmica ou de raiz quadrada, os dados foram analisados por ANOVA seguido pelo teste de Duncan e/ou Tukey $(P<0,05)$ para comparação dos parâmetros entre as linhagens 
transgênicas silenciadas e o controle. $\mathrm{Na}$ falta de homoscedasticidade, uma comparação não-paramétrica foi feita por meio do teste Kruskal Wallis $(P<0,05$ e 0,1$)$. Os testes estatísticos foram realizados utilizando o programa InfoStat v. 2009 (www.infostat.com, Grupo InfoStat, FCA, Universidad Nacional de Córdoba, Argentina). 


\section{RESULTADOS}

\subsection{A proteína SEC14 possui o domínio CRAL/TRIO e um peptídeo de direcionamento a cloroplastos}

A partir do clone de $S$. pennellii contendo o gene sec14 obtido pelo nosso grupo (Almeida et al., 2011), e da região ortóloga de S. lycopersicum identificada no banco da SGN (Solanaceae Genmics Network), contig SL2.31ct07099, foram obtidas as sequências genômicas completas do gene sec14 de ambas as espécies. Os alelos, incluindo as UTRs, possuem 2.669 e 2.624 pb para $S$. lycopersicum e $S$. pennellii, respectivamente, e apresentaram a mesma estrutura gênica com cinco éxons e quatro íntrons, variando apenas no tamanho dos íntrons (Figura 4). Em ambas sequências foi identificado o domínio CRAL/TRIO na região amino-terminal e o domínio SEC14 de ligação a lipídeos, característico da família protéica. Adicionalmente, foram preditos peptídeos de direcionamento ao cloroplasto, sendo que o do alelo de $S$. lycopersicum apresentou 59 aa e o de S. pennellii 36 aa. Não foram detectados domínios transmembrana pela análise in silico. Ao todo, foram detectados quatro polimorfismos de aminoácidos, um em cada domínio, outro no peptídeo sinal e por último um na região carboxi-terminal da proteína (Figura 5).

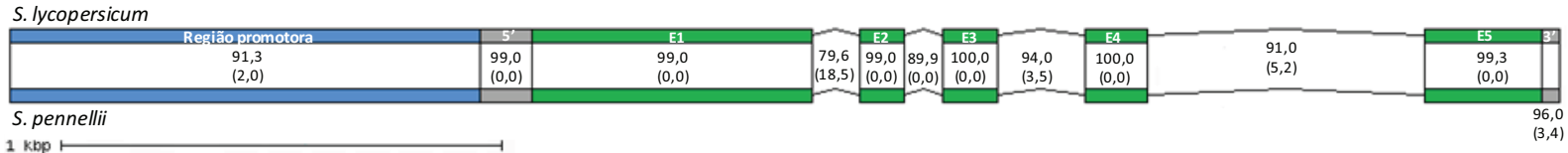

Figura 4. Análise comparativa da estrutura gênica entre os alelos de $\boldsymbol{S}$. Iycopersicum e $\boldsymbol{S}$. pennellii para o gene sec14.

Os blocos cinza e verdes correspondem às UTRs e éxons, respectivamente. A porcentagem de identidade e indels (XX) entre ambos os genótipos encontra-se indicada para cada região individualmente.

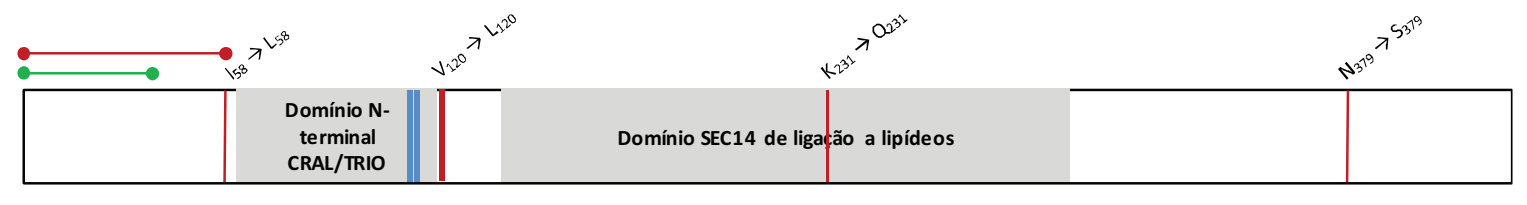

100 aa

Figura 5. Análise comparativa da sequência protéica entre os alelos de $\boldsymbol{S}$. lycopersicum e $\boldsymbol{S}$. pennellii para a proteína SEC14.

Os polimorfismos de aminoácidos entre os genótipos encontram-se indicados com linhas vermelhas. Os peptídeos de direcionamento a cloroplasto estão indicados com uma linha vermelha e verde para $S$. lycopersicum e $S$. pennellii, respectivamente. Os domínios protéicos identificados estão demarcados com blocos cinza. $O$ motivo típico de ligação a moléculas hidrofóbicas $\operatorname{LLRFL}^{R} / K A R$, encontra-se marcado em azul. 
Para avaliar a diversidade das proteínas SEC14 foi realizada uma análise filogenética contendo sequências de $A$. thaliana, Ricinus communis, $O$. sativa e $Z$. mays, homólogas às previamente caracterizadas funcionalmente, e foram incluídas as sequências obtidas neste trabalho de $S$. lycopersicum e S. pennellii. A topologia da árvore permitiu identificar dois clados, os quais podem ser diferenciados claramente pela presença dos domínios protéicos diferenciais (Figura 6). As proteínas de $S$. lycopersicum e $S$. pennellii estudadas neste trabalho, embora possuam os mesmos domínios, CRAL/TRIO e SEC14, que as descritas por Peterman et al. (2004), possuem peptídeo sinal para cloroplasto o qual não tinha sido reportado na literatura neste tipo de proteínas.

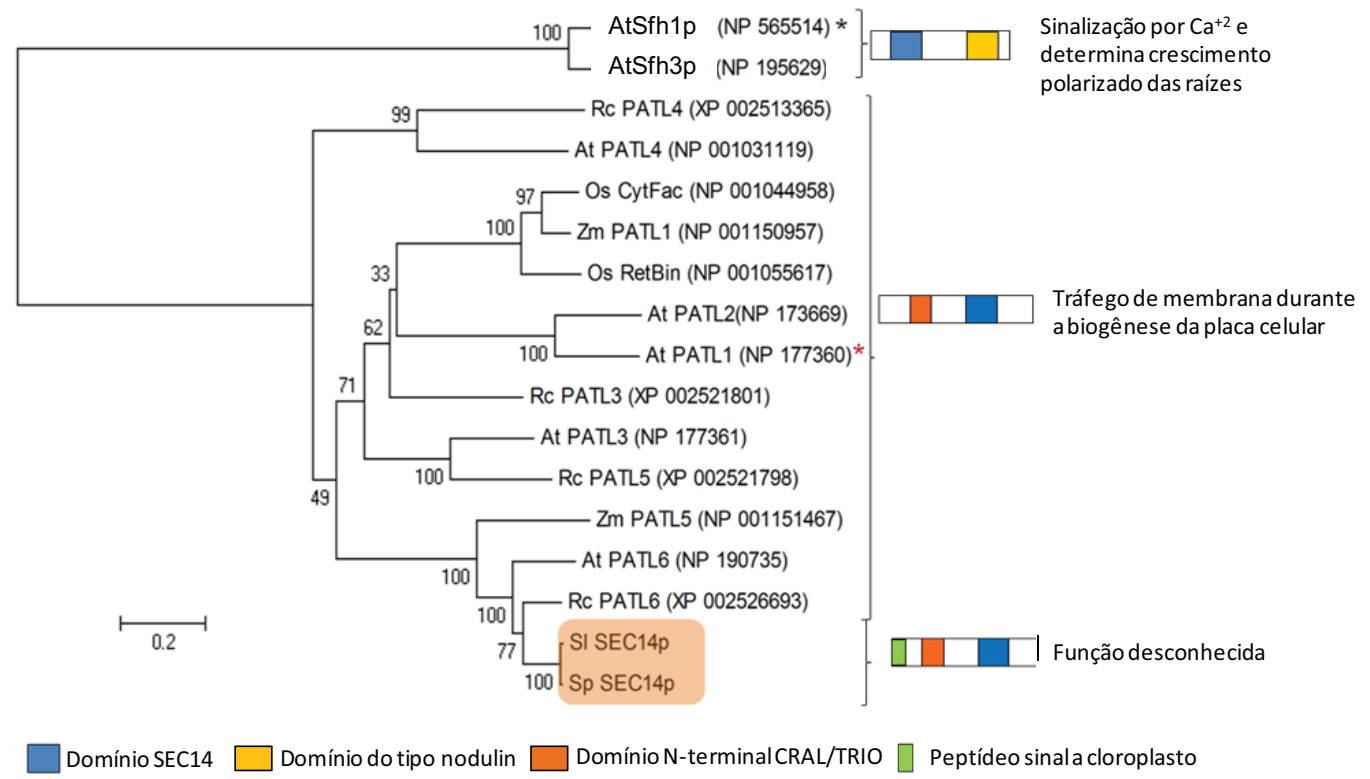

Figura 6. Análise filogenética das proteínas SEC14.

À direita da árvore estão indicadas as estruturas protéicas de cada clado, assim como as funções demonstradas para cada grupo. * Sequências extraídas de Vincent et al. (2005). * Sequências extraídas de Peterman et al. (2004). As sequências descritas neste trabalho estão destacadas na caixa laranja. At: A. thaliana; Rc: R. communis; Os: O. sativa; Zm: Z. mays; Sl: S. lycopersicum; Sp: S. pennellii. PATL: proteína patelina. CytFac: Fator citosólico. RetBin: Proteína de ligação a retinaldeido.

\subsection{A proteína SEC14 é direcionada a cloroplasto}

Para somar evidências sobre a função da proteína SEC14 foi desenhado um experimento de localização subcelular com o intuito de identificar o compartimento onde essa proteína atua. Devido ao fato de ter sido identificada uma substituição nãosinônima entre as sequências protéicas de $S$. lycopersicum e $S$. pennellii, que altera o tamanho do peptídeo sinal determinado in silico, foram analisados ambos os alelos. 
Para isso, foram obtidas as construções pK7FWG2-SEC14Lyc e pK7FWG2-SEC14Pen contendo o fragmento de 1.272 pb correspondente ao cDNA completo das proteínas SEC14, desde o ATG até o códon anterior ao de fim da tradução, fusionado à sequência codificante da proteína GFP. Cultivos de $A$. tumefaciens contendo cada uma das construções supramencionadas foram infiltrados em folhas de $N$. benthamiana. Após 48 h, foram montadas lâminas com discos de folhas infiltradas e visualizadas ao microscópio confocal. As proteínas de fusão de ambos os alelos, foram localizadas no cloroplasto das células, evidenciada pela sobreposição da emissão da proteína GFP e da clorofila, sem apresentar diferenças no padrão (Figura 7).
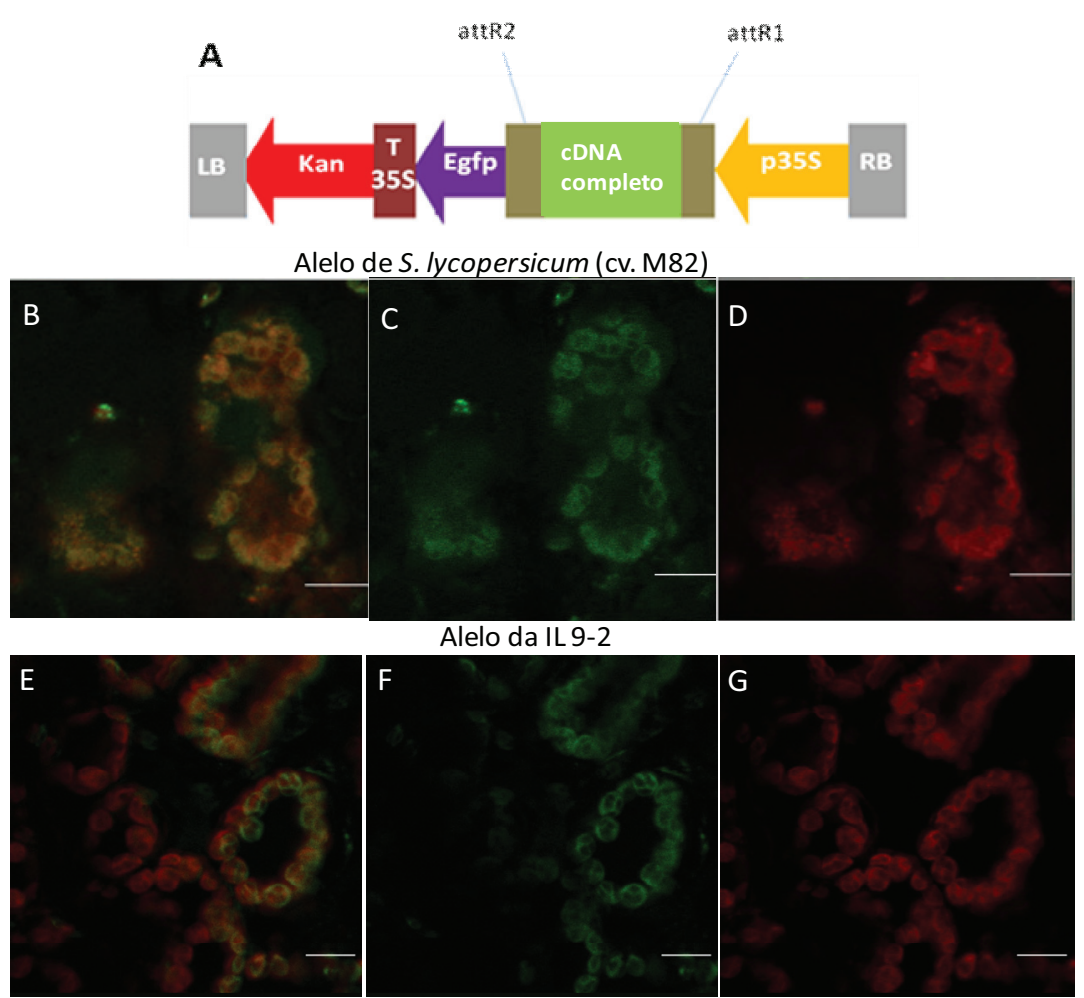

Figura 7. Localização subcelular da proteína de fusão SEC14::GFP.

Esquema da construção pK7FWG2-SEC14 (A). Células de mesófilo de folhas de $N$. benthamiana agroinfiltradas com $A$. tumefasciens (GV3101) contendo a construção pK7FWG2-SEC14Lyc (B, C, D) e pK7FWG2-SEC14Pen ( $E, F, G$ ). Sobreposição das imagens de fluorescência da clorofila e de GFP (B e E). Imagem da fluorescência de GFP (C e F). Imagem da fluorescência da clorofila (D e G). A barra da escala corresponde a $10 \mu \mathrm{m}$. LB: borde esquerdo. Kan: cassete de resistência a canamicina. T35s terminador $35 \mathrm{~s}$ do CaMV. eGFP: proteína fluorescente verde. CDNA completo: cDNA dos respectivos alelos. p35s: promotor 35s do CaMV. RB: Borde direito.

\subsection{Obtenção das plantas silenciadas para o gene sec14}

Para demonstrar o envolvimento do gene sec14 na determinação das diferencias observadas entre $S$. lycopersicum (cv. M82) e a IL 9-2 no conteúdo de tocoferol nos frutos, foi adotada a estratégia de silenciamento gênico por RNA de 
interferência. Dessa forma, foi obtida a construção pK7GWIWG2(I)Sec14 contendo um fragmento de 224 pb do quinto éxon do gene (Figura 8). A escolha desse fragmento foi determinada a partir do alinhamento utilizado para a análise filogenética, realizada no item 4.1 deste capítulo, de maneira que o silenciamento fosse específico para o gene de interesse evitando interferir na expressão de outros genes homólogos. Por meio da transformação genética mediada por $A$. tumefaciens, foram obtidas 19 linhagens independentes de tomate que enraizaram em presença do agente seletivo.

\section{RNAi LB Kan- T $224 b$ Intron $224 b->$ p35S RB}

Figura 8. Representação esquemática do vetor pK7GWIWG2(I)sec14.

Construção utilizada para a obtenção das plantas transgênicas de tomate S. lycopersicum (cv. Moneymaker) RNAi:sec14. LB: borda esquerda. Kan: cassette de resistêncvia a canamicina. T: terminador 35s do CaMV. 224b: fragmento da sequência codificante do gene sec14. p35s: promotor 35s do CaMV. RB: borda direita.

A presença do transgene nas linhagens obtidas foi verificada por meio de PCR utilizando iniciadores específicos para o promotor 35S. Assim, foram identificados três escapes e determinada uma eficiência de transformação de 84,2\% (Tabela 3). Posteriormente, nove das linhagens positivas foram sincronizadas por meio de estaquia junto aos respectivos controles, e foi avaliado o silenciamento do gene alvo utilizando qPCR. A Figura 9 apresenta os dados de expressão relativa do gene sec14 demonstrando que sete das linhagens transgênicas possuem níveis de RNAm mais baixos que o controle selvagem, resultando assim em uma eficiência de silenciamento do $77,8 \%$ (Tabela 3).

Tabela 3. Eficiência da transformação de tomate com a construção para silenciamento do gene sec14.

\begin{tabular}{ccccccc}
\hline Gene & $\begin{array}{c}\text { Linhagens } \\
\text { regeneradas }\end{array}$ & $\begin{array}{c}\text { Linhagens } \\
\text { positivas por } \\
\text { PCR }\end{array}$ & $\begin{array}{c}\text { Eficiência de } \\
\text { transformação } \\
\%\end{array}$ & $\begin{array}{c}\text { Linhagens } \\
\text { avaliadas por } \\
\text { qPCR }\end{array}$ & $\begin{array}{c}\text { Linhagens } \\
\text { silenciadas }\end{array}$ & $\begin{array}{c}\text { \% Plantas } \\
\text { silenciadas }\end{array}$ \\
\hline \multirow{2}{*}{$\sec 14$} & 19 & 16 & 84,2 & 9 & 8 & 88,8 \\
\hline
\end{tabular}




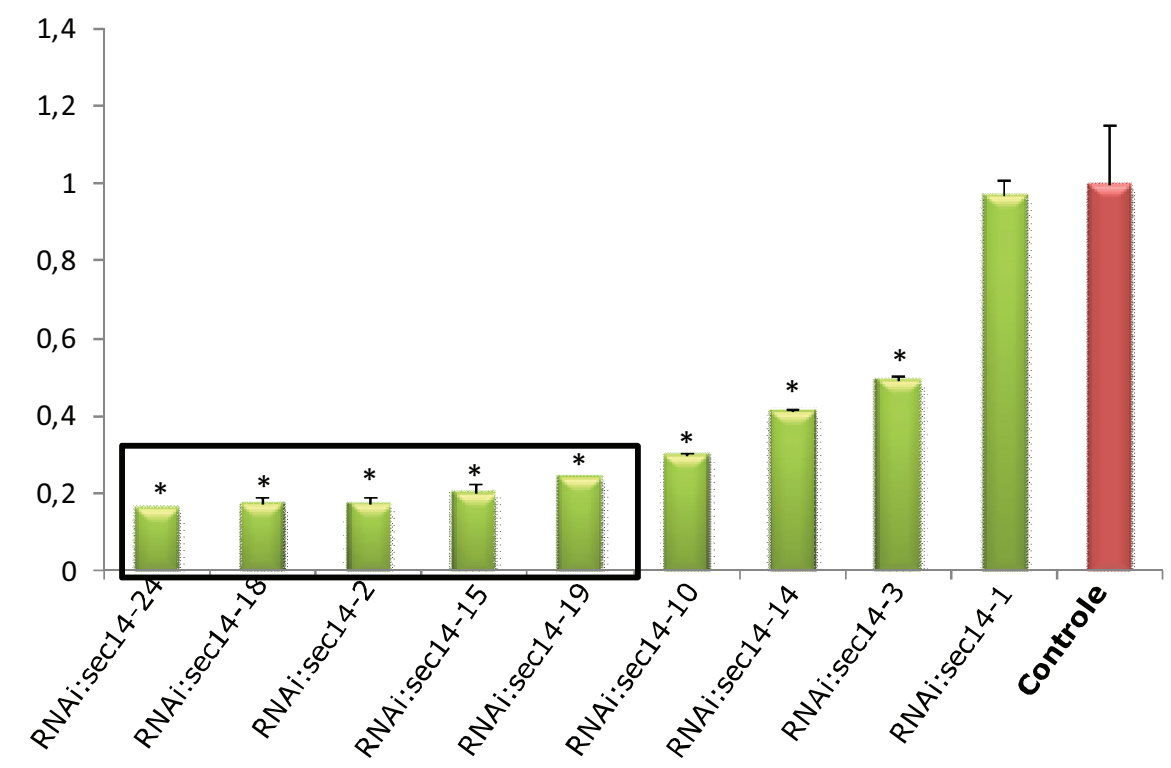

Figura 9. Análise de expressão do gene sec14 nas linhagens transgênicas.

Os resultados representam a média de três réplicas técnicas. Os valores estão expressos como a abundância relativa do RNAm comparado ao controle S. lycopersicum (cv. Moneymaker). Na caixa preta destacam-se as linhagens selecionadas para avaliação fenotípica. *Diferenças estatisticamente significativas pelo teste de Kruskal-Wallis $(P<0,005)$.

\subsection{Caracterização fenotípica das linhagens transgênicas}

Para a avaliação fenotípica foram selecionadas cinco linhagens (RNAi:sec14-2, RNAi:sec1415, RNAi:sec1418, RNAi:sec1419 e RNAi:sec1424) que apresentaram a maior redução dos níveis de RNAm do gene sec14 (Figura 9). As linhagens selecionadas foram propagadas vegetativamente por meio de estaquia gerando seis réplicas de cada uma para caracterização fenotípica. Ao longo do experimento foi descartada a linhagem RNAi:sec142 já que quatro dos seis clones morreram, ficando assim quatro linhagens a serem caracterizadas.

\subsubsection{Verificação do nível de silenciamento nas linhagens transgênicas.}

Para verificar o silenciamento nas réplicas biológicas obtidas, os níveis de RNAm do gene sec14 foram verificados novamente em folhas fonte e frutos maduros por qPCR. As quatro linhagens selecionadas mostraram a redução na expressão inicialmente verificada, para ambos os tecidos avaliados (Figura 10). Unicamente, a linhagem RNAi:sec1424 não apresentou uma redução significativa nos níveis de RNAm em fruto maduro, porém, o fenótipo mostrou-se conservado ao longo da caracterização. 


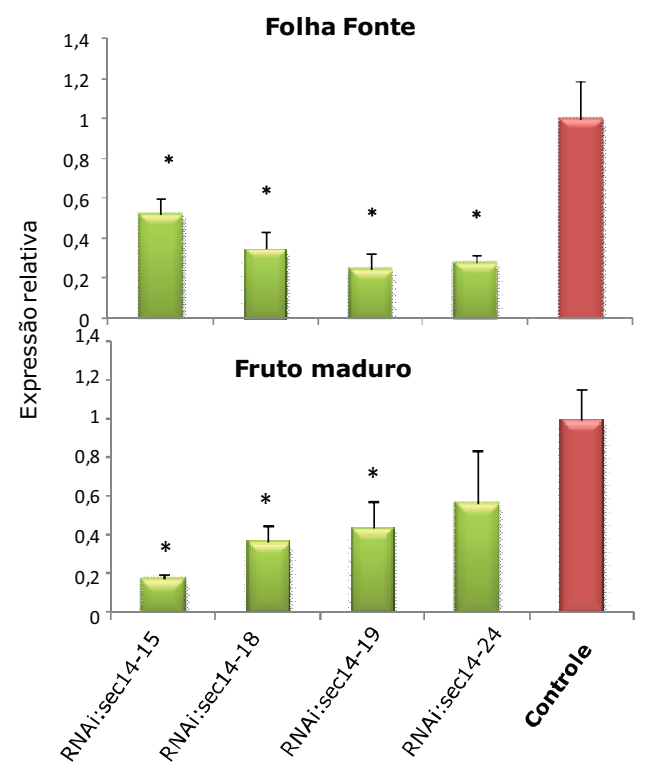

Figura 10. Análise de expressão do gene sec14 nas linhagens transgênicas selecionadas.

Os resultados representam a média de seis réplicas biológicas com três réplicas técnicas cada uma. Os valores estão expressos como a abundância relativa do RNAm comparado ao controle $S$. lycopersicum (cv. Moneymaker). *Diferenças estatisticamente significativas $(P<0,05)$.

4.4.2. O silenciamento do gene sec14 altera o funcionamento da maquinaria fotossintética

Para avaliar o possível efeito do silenciamento do gene sec14 na fotossíntese foram realizadas medições de intercâmbio gasoso e fluorescência da clorofila a diferentes densidades de fluxo de fótons. Não foram observadas alterações na taxa de assimilação de $\mathrm{CO}_{2}$, condutância estomática e transpiração (Figura 11). De forma contrastante, a redução da expressão do gene sec14 provocou uma alteração clara na taxa de transporte de elétrons, no quenching fotoquímico e não-fotoquímico, eficiência do fotossístema II e no acúmulo de quinona reduzida (Figura 11 e 12). 

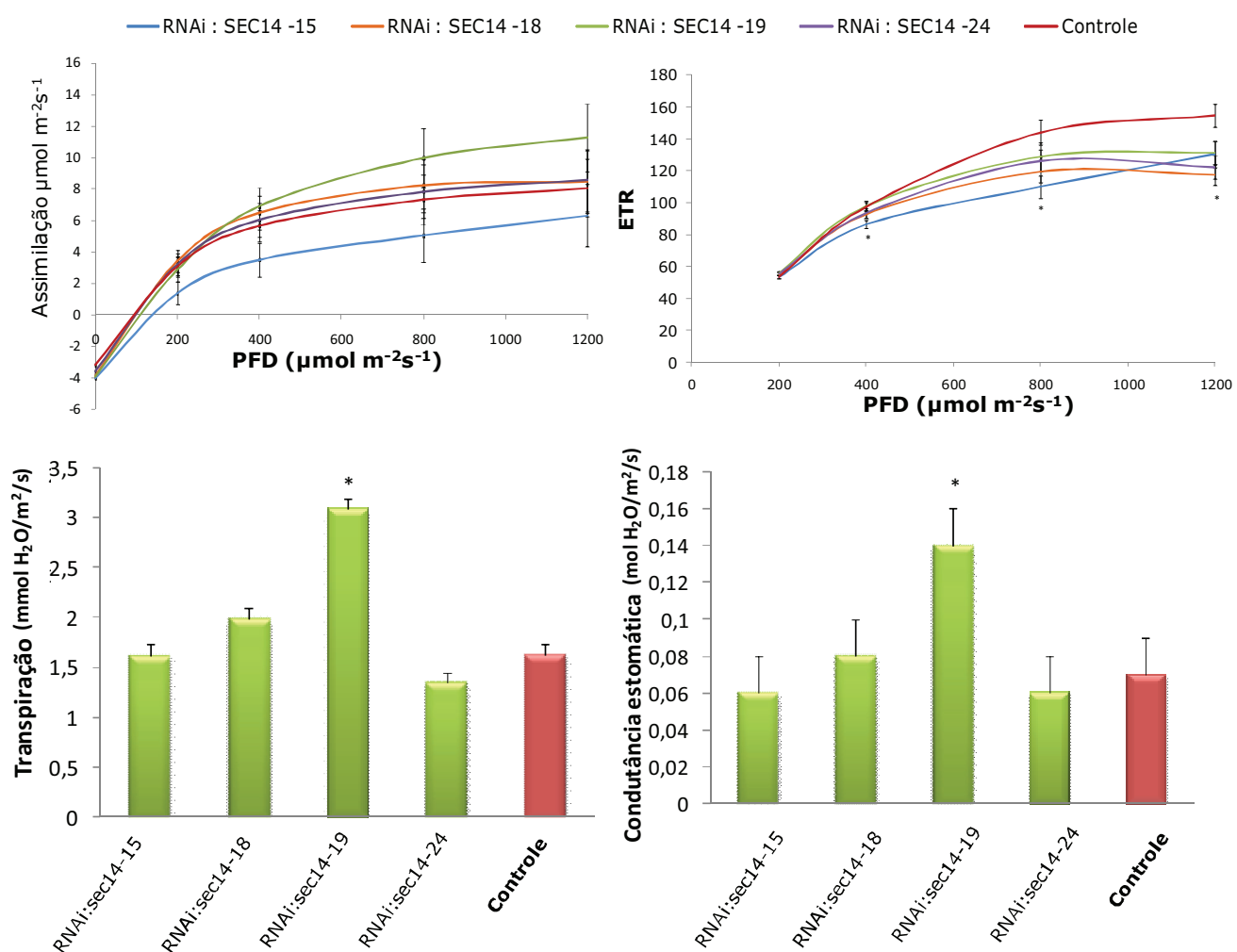

Figura 11. Parâmetros fotossintéticos e de trocas gasosas nas linhagens transgênicas.

ETR: taxa relativa de transporte de elétrons. Transpiração e condutância estomática a $1.200 \mu \mathrm{mol}$ de fótons $\mathrm{m}^{-2} \mathrm{~s}^{-1}$. Os valores apresentam a média obtida em seis réplicas biológicas. *Diferenças estatisticamente significativas $(P<0,05)$.
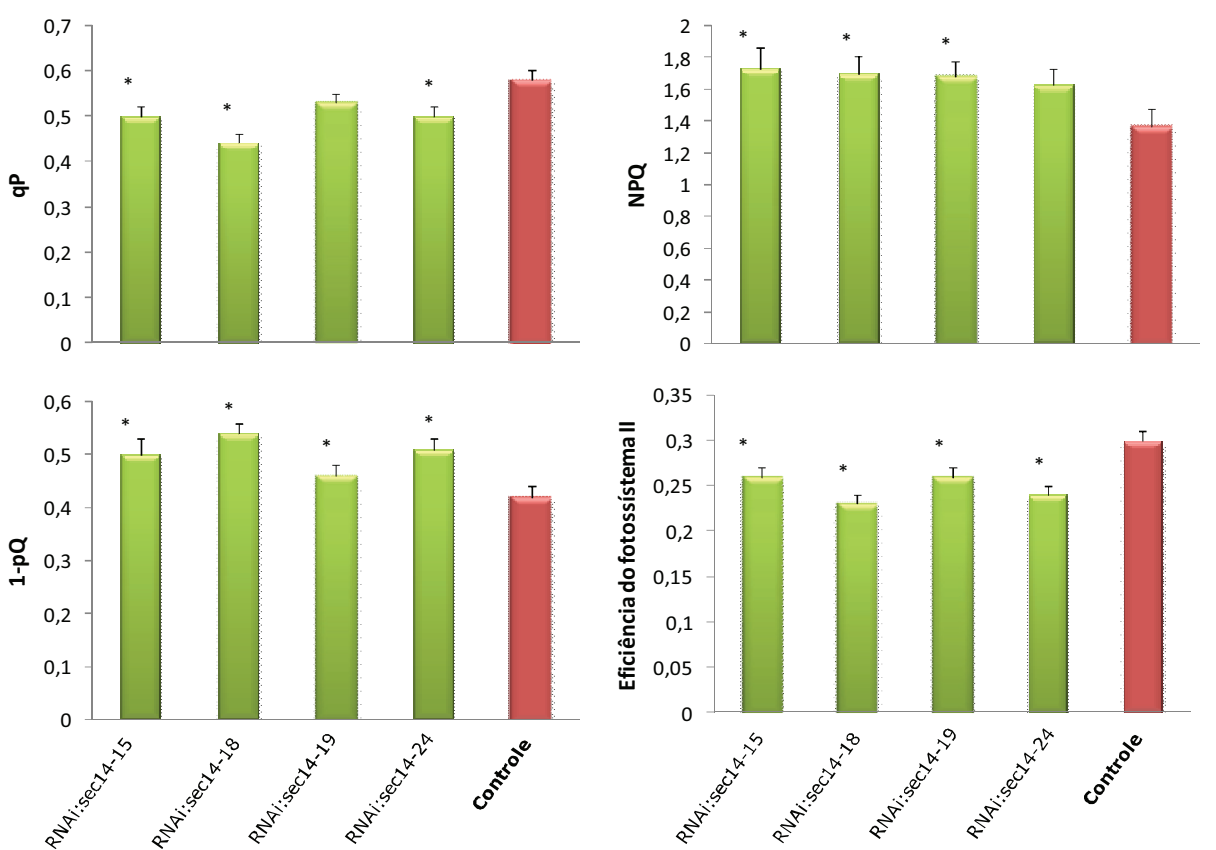

Figura 12: Parâmetros da fluorescência da clorofila nas linhagens transgênicas.

qP: quenching fotoquímico. NPQ: quenching não-fotoquímico. 1-pQ: acúmulo do aceptor quinona reduzida. Os dados representam a média obtida em seis réplicas biológicas. *Diferenças estatisticamente significativas $(P<0,05)$. 


\subsubsection{O silenciamento do gene sec14 não altera o conteúdo de pigmentos}

De forma geral, o conteúdo de pigmentos em folha fonte, frutos verdes e maduros, não apresentou diferenças significativas quando comparado ao controle $S$. lycopersicum (cv. Moneymaker) (Figura 13). Mesmo que algumas linhagens (RNAi:sec14-15 e 18) mostrassem alterações nos pigmentos para fruto verde e maduro, respectivamente, não foi um perfil conservado no restante das linhagens.

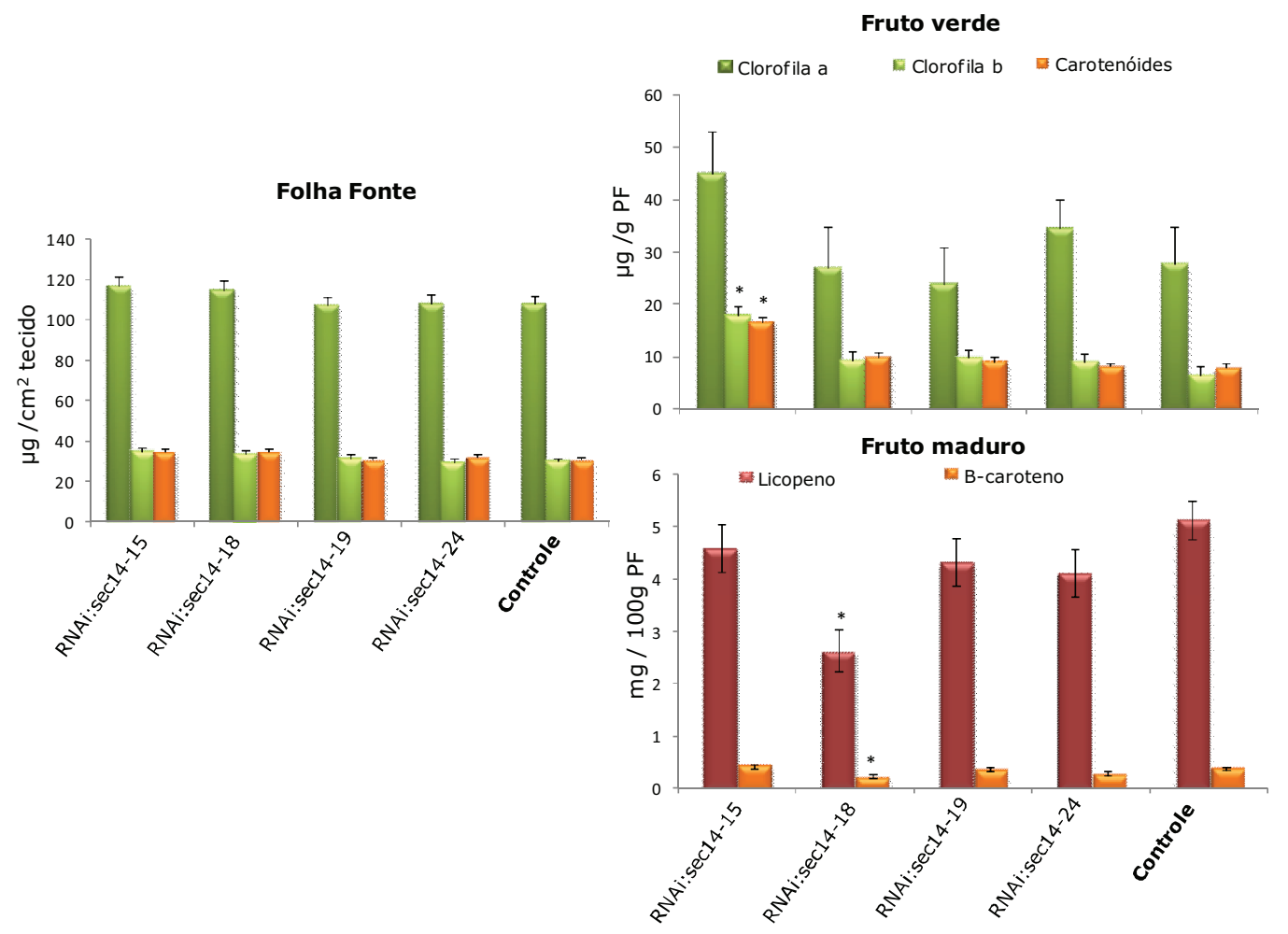

Figura 13. Conteúdo de pigmentos nos diferentes tecidos nas linhagens trangênicas.

As barras indicam a média obtida em no mínimo três e quatro réplicas biológicas para frutos e folha fonte, respectivamente. * Diferenças estatisticamente significativas $(P<0,05)$. PF: peso fresco.

4.4.4. O silenciamento do gene sec14 altera parcialmente o conteúdo de açúcares e amido

A determinação do conteúdo de açúcares solúveis e amido revelou uma alteração parcial no perfil desses metabólitos nas linhagens transgênicas. Em folha fonte é observada uma queda conteúdo dos fotoassimilados avaliados. No fruto maduro não foi possível observar uma tendência homogênea para todas as linhagens, sendo que para duas linhagens foi observado menor conteúdo de frutose e maior de amido (Figura 14). 


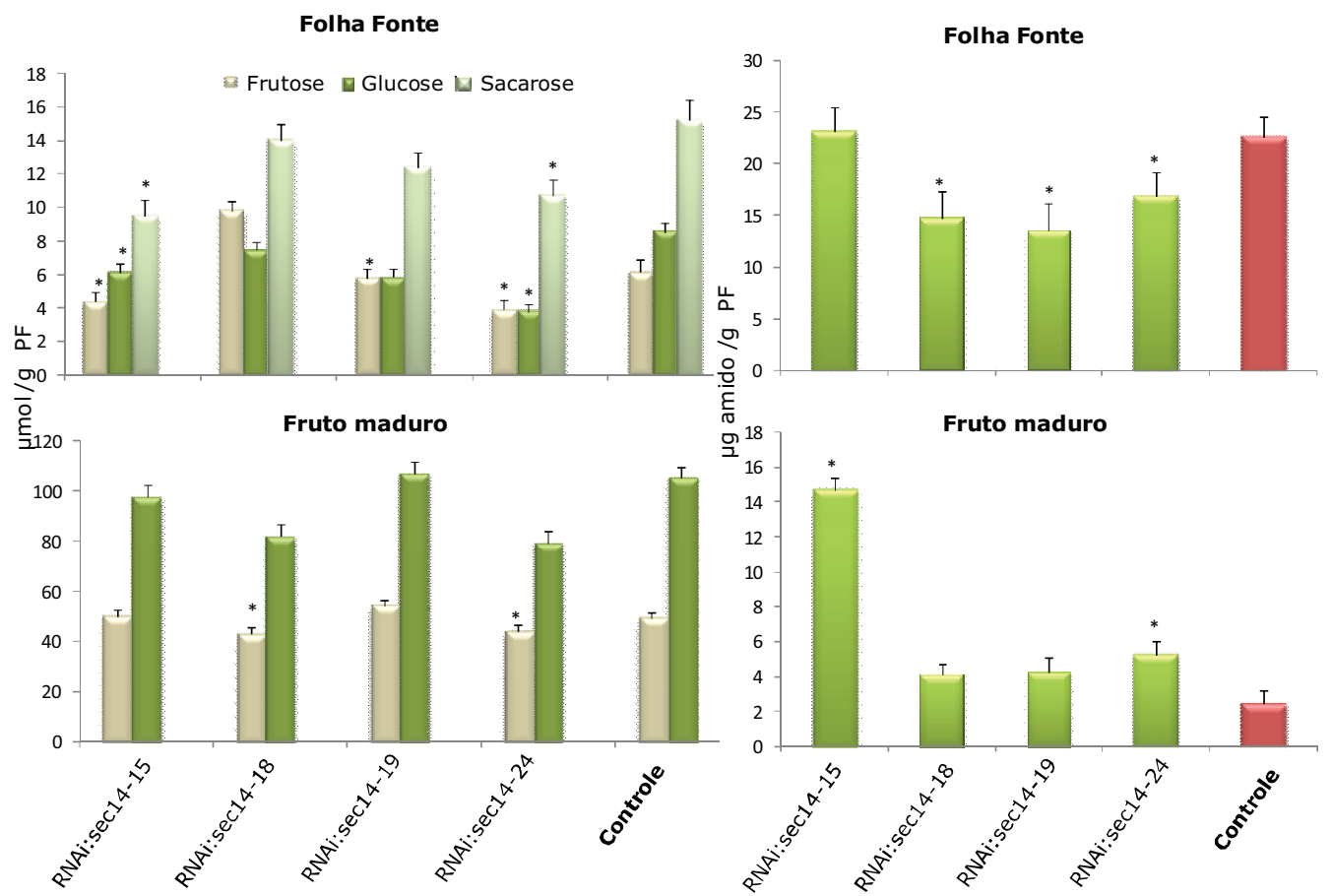

Figura 14. Conteúdo de açúcares e amido nas linhagens transgênicas.

As barras indicam a média obtida em no mínimo quatro e cinco réplicas biológicas para fruto maduro e folha fonte, respectivamente. *Diferenças estatisticamente significativas $(P<0,05)$.

\subsubsection{O silenciamento do gene sec14 não altera o conteúdo de aminoácidos totais}

Foram quantificados os aminoácidos totais em folha fonte e fruto maduro das plantas transgênicas, para assim, avaliar o possível efeito do silenciamento do gene sec14 no metabolismo de nitrogênio. Não foram detectadas alterações nos conteúdos dos aminoácidos para nenhuma das linhagens (Figura 15).

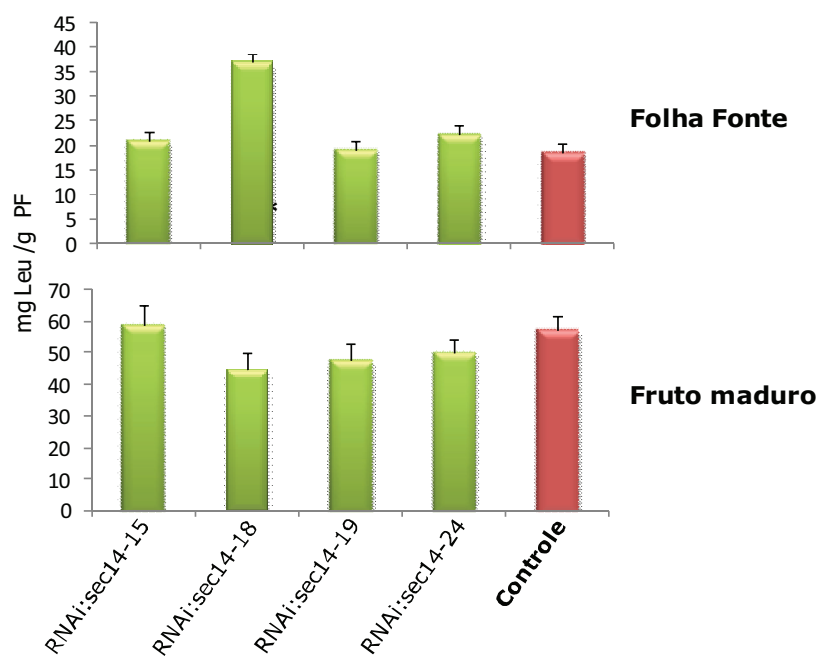

Figura 15. Conteúdo de aminoácidos totais nas linhagens transgênicas.

As barras indicam a média obtida em no mínimo três e cinco réplicas biológicas para fruto maduro e folha fonte, respectivamente. Não foram encontradas diferenças estatisticamente significativas $(P<0,05)$. 
4.4.6. O silenciamento do gene sec14 altera os conteúdos de tocoferóis em folha fonte e fruto maduro

Com o objetivo de testar a hipótese do envolvimento do gene sec14 no metabolismo de vitamina $E$, foram quantificados os quatro isômeros de tocoferol ( $a, \beta$, $\gamma$, e $\delta$ ) em folha fonte e dreno e, fruto verde e maduro. Foi possível detectar os isômeros a e $\gamma$ para todos os tecidos, porém $\beta$ e $\delta$ só foram observados em folha dreno e fruto maduro. Em folha dreno e fruto verde não foram detectadas alterações no conteúdo dos diferentes isômeros analisados nem no tocoferol total (Figura 16 e 18). Já em folha fonte houve uma queda no conteúdo de ambos isômeros identificados, a e $\gamma$, e consequentemente no tocoferol total (Figura 17). Por último, no fruto maduro, três das linhagens transgênicas apresentaram baixos níveis de a-tocoferol quando comparados ao genótipo controle, que se refletiu numa queda no conteúdo de tocoferol total (Figura 19).
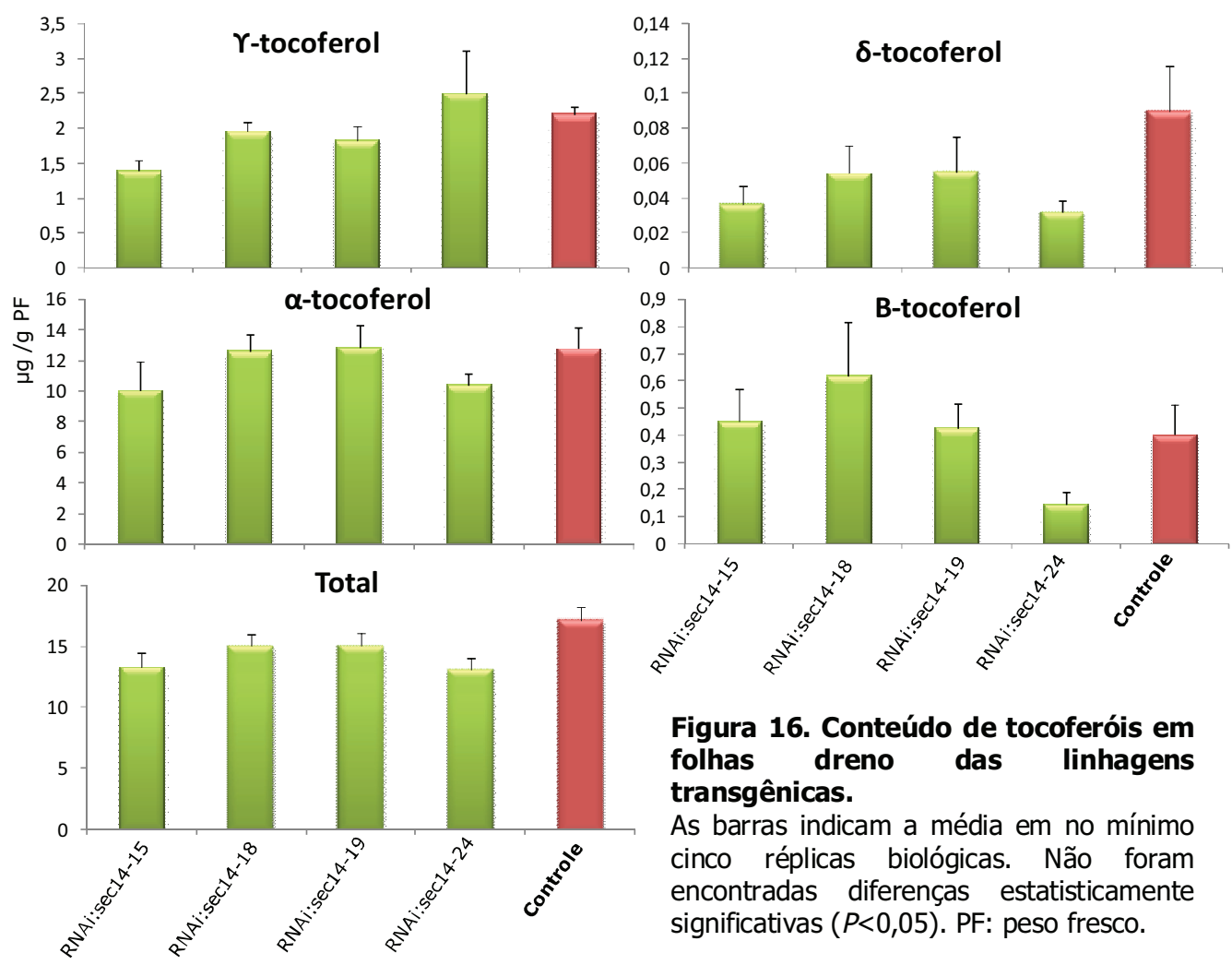

Figura 16. Conteúdo de tocoferóis em folhas dreno das linhagens transgênicas.

As barras indicam a média em no mínimo cinco réplicas biológicas. Não foram encontradas diferenças estatisticamente significativas $(P<0,05)$. PF: peso fresco. 

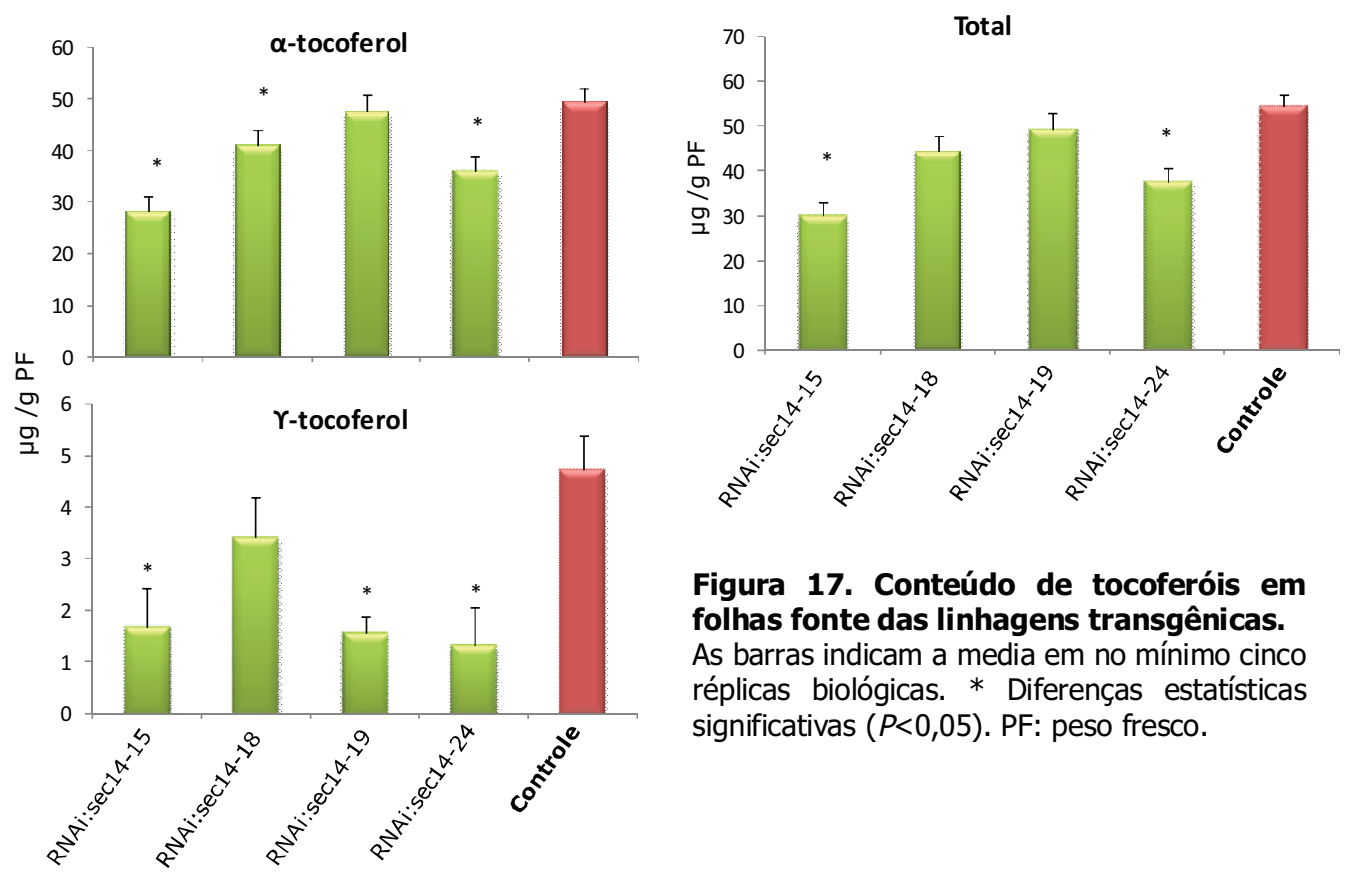

Figura 17. Conteúdo de tocoferóis em folhas fonte das linhagens transgênicas.

As barras indicam a media em no mínimo cinco réplicas biológicas. * Diferenças estatísticas significativas $(P<0,05)$. PF: peso fresco.
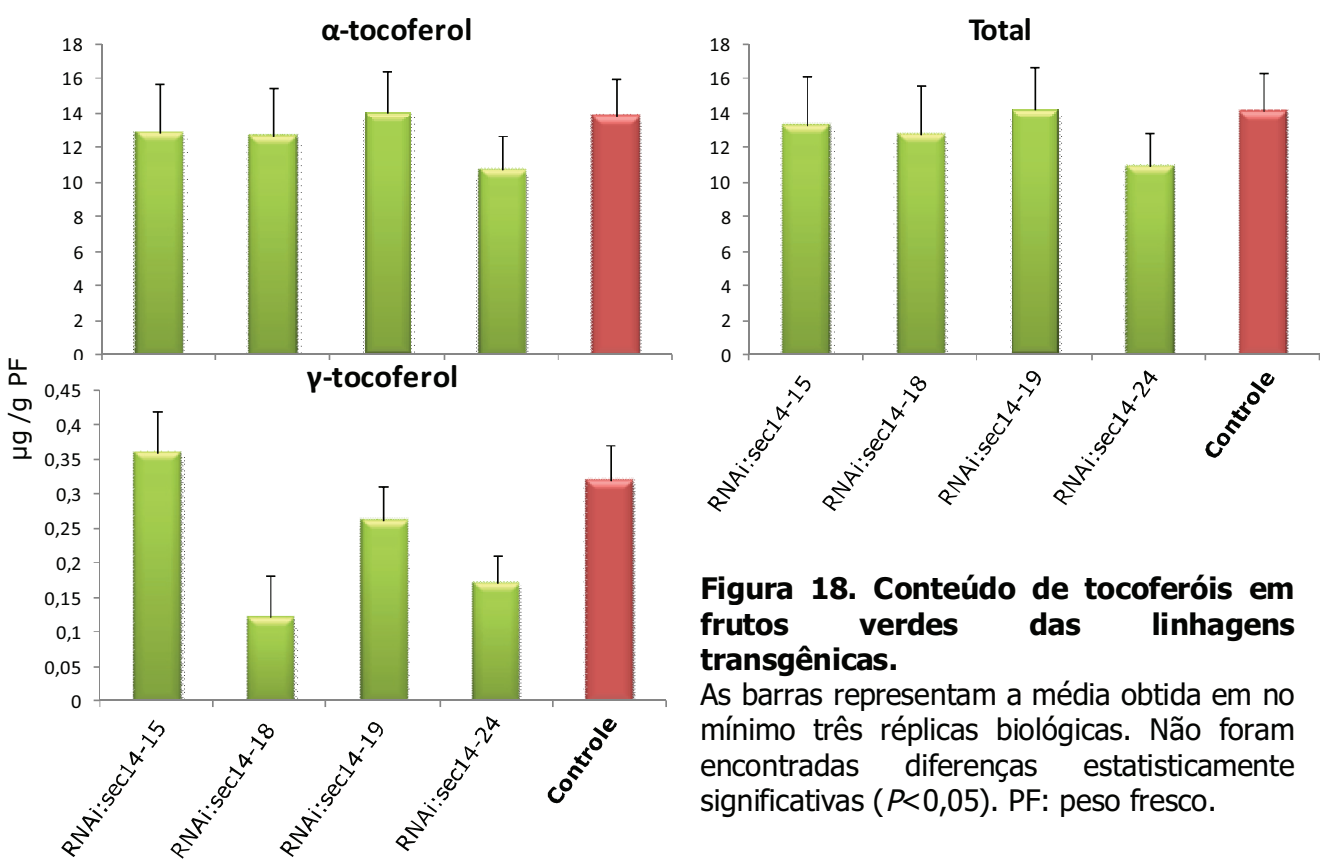

Figura 18. Conteúdo de tocoferóis em frutos verdes das linhagens transgênicas.

As barras representam a média obtida em no mínimo três réplicas biológicas. Não foram encontradas diferenças estatisticamente significativas $(P<0,05)$. PF: peso fresco. 


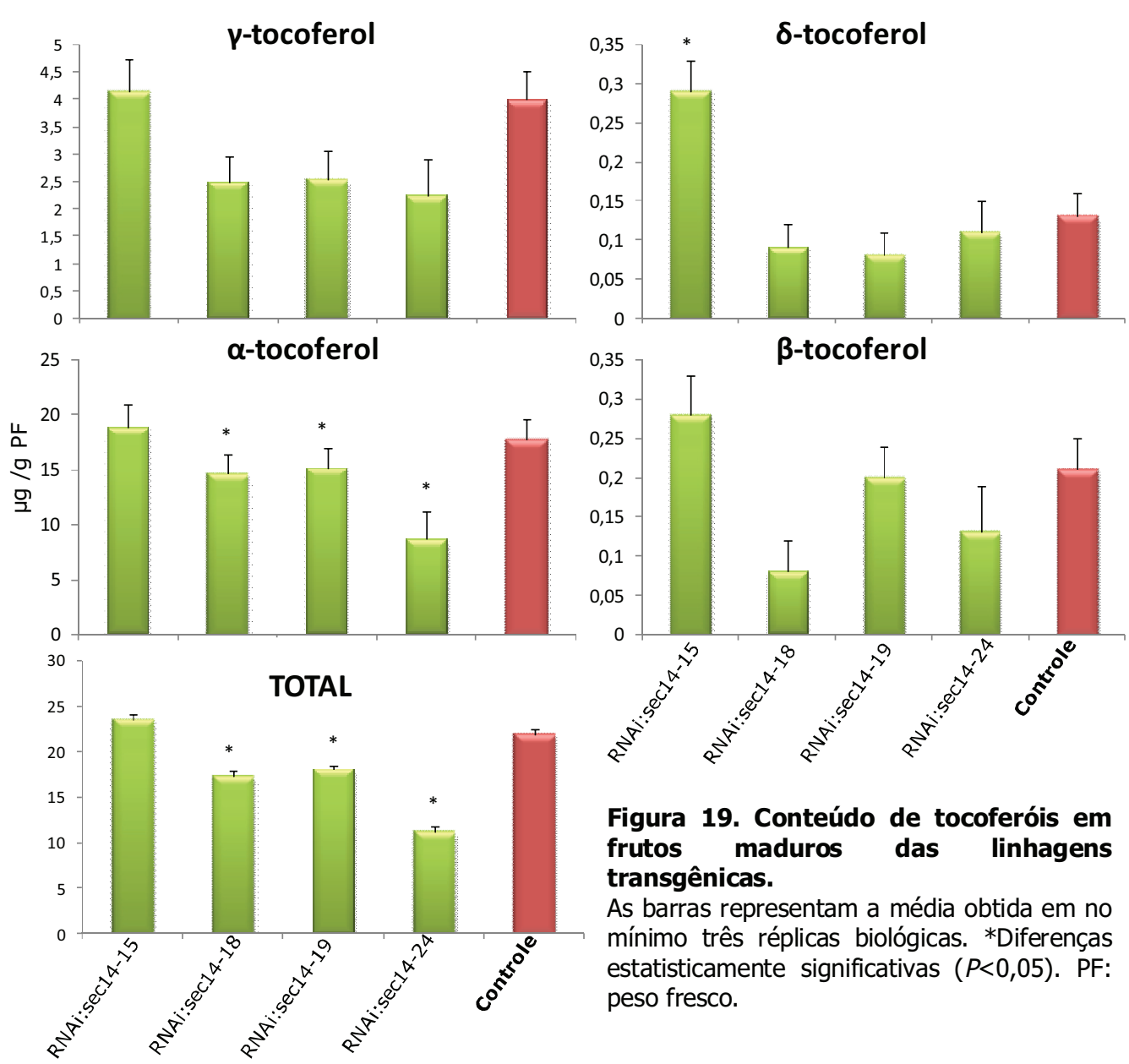

4.4.7. A expressão dos genes que codificam para as enzimas da rota central de VTE não foi alterada

Com o intuito de avaliar o papel da proteína SEC14 na regulação da biossíntese de tocoferol, foram verificados os níveis de RNAm das enzimas da rota central (Figura 2). De forma geral, não foram encontradas variações nos níveis de RNAm dos genes avaliados, mas no caso da enzima $\mathrm{Y}$-tocoferol C-metil transferase (VTE4) foi observada uma alteração da sua expressão unicamente nas linhagens RNAi:sec14-19 e RNAi:sec14:24, não sendo representativo quando comparado com o restante das linhagens (Figura 20). 


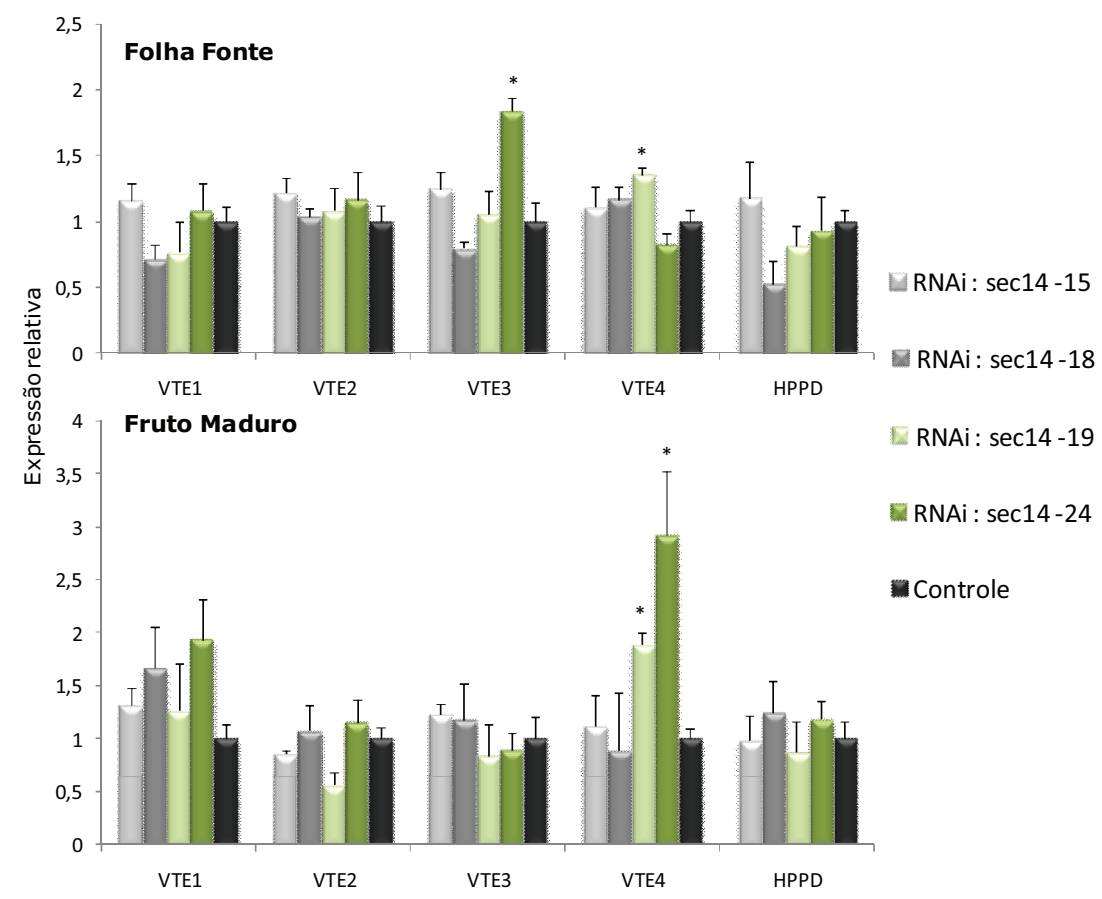

Figura 20. Análise de expressão das enzimas da rota central de biossíntese de tocoferol nas plantas transgênicas.

Os resultados representam a média de três réplicas técnicas de, no mínimo, quatro e cinco réplicas biológicas para fruto maduro e folha fonte, respectivamente. Os valores estão expressos como abundância relativa do RNAm comparado ao controle S. lycopersicum (cv. Moneymaker). *Diferenças estatisticamente significativas $(P<0,05)$.

4.4.8. O silenciamento do gene sec14 não altera os indicadores de produção das linhagens transgênicas

Para avaliar a produção das linhagens transgênicas foi medido o peso médio de frutos verdes e maduros, a biomassa fresca da planta e posteriormente o índice de colheita. Para nenhum dos parâmetros foram encontradas diferenças significativas (Tabela 4). Estes resultados indicam que a redução dos níveis da proteína SEC14 não tem efeito direto na produção da planta assim como na repartição de fotoassimilados.

Tabela 4. Indicadores de produção das linhagens transgênicas RNAi:sec14

\begin{tabular}{c|cccc}
\hline Linhagem & $\begin{array}{c}\text { FRUTO VERDE } \\
\text { (g/fruto) }\end{array}$ & $\begin{array}{c}\text { FRUTO MADURO } \\
\text { (g/fruto) }\end{array}$ & $\begin{array}{c}\text { BIOMASSA } \\
\text { (g/planta sem raiz) }\end{array}$ & $\begin{array}{c}\text { ÍNDICE DE } \\
\text { COLHEITA* }\end{array}$ \\
\hline RNAi : SEC14 -15 & $15,67 \pm 5,44$ & $49 \pm 5,89$ & $806 \pm 182,66$ & $31,52 \pm 5,06$ \\
RNAi : SEC14 -18 & $24,44 \pm 3,85$ & $37,02 \pm 2,31$ & $1013 \pm 116,21$ & $37,24 \pm 9,08$ \\
RNAi : SEC14 -19 & $22,6 \pm 4,71$ & $35,34 \pm 1,88$ & $855,5 \pm 104,40$ & $39,06 \pm 15,24$ \\
RNAi : SEC14 -24 & $21,07 \pm 4,21$ & $39,94 \pm 3,92$ & $980,2 \pm 72,84$ & $31,58 \pm 6,21$ \\
& & & & \\
Controle & $\mathbf{2 0 , 6 3} \pm \mathbf{3 , 3 3}$ & $\mathbf{3 8 , 2 8} \pm \mathbf{1 , 6 0}$ & $\mathbf{8 4 3 , 3 8} \pm \mathbf{9 7 , 4 9}$ & $\mathbf{4 2 , 1} \pm \mathbf{1 1 , 5 5}$ \\
\hline
\end{tabular}

Dados correspondentes à colheita das plantas após quatro meses em casa de vegetação. Não foram encontradas diferenças estatisticamente significativas $(P<0,05)$. 


\section{DISCUSSÃO}

As proteínas SEC14, de S. lycopersicum e $S$. pennellii, associadas a um QTL de a-tocoferol no cromossomo 9 (Almeida et al., 2011) possuem uma estrutura relativamente conservada com as previamente descritas. Na sua estrutura foram preditos domínios de ligação a moléculas hidrofóbicas como o SEC14, característico da família, e o CRAL-TRIO, descrito em mamíferos como de ligação a a-tocoferol (Figura 5). Mais ainda, as proteínas apresentaram o motivo $\operatorname{LLRFL}^{R} / \mathrm{k} A R$, conservado nas espécies mais distantes e que parece ser determinante na especificidade da ligação a moléculas hidrofóbicas (Joaunicc et al., 1998). Uma característica diferencial encontrada foi a presença de um peptídeo de direcionamento a cloroplasto para ambos os alelos, o qual não tinha sido identificado previamente nessa família e que sugere uma função inédita. As proteínas $S$. pennellii SEC14 e S. lycopersicum SEC14, apresentaram polimorfismos de aminoácidos nos domínios funcionais identificados que poderiam determinar, eventualmente, diferenças na atividade. A presença de um polimorfismo no extremo $\mathrm{N}$-terminal da proteína determina a variação no comprimento do peptídeo sinal dos alelos, no entanto não foi observada nenhuma alteração no padrão de localização plastidial em ambas as espécies (Figura 7). É oportuno ressaltar que o estudo do perfil transcricional dos alelos, realizado pelo nosso grupo (de Godoy et al., comunicação pessoal), não apresentou diferenças significativas para nenhum dos tecidos avaliados.

A biossíntese da VTE ocorre no cloroplasto e as enzimas da rota central encontram-se localizadas em diferentes compartimentos suborganelares. A VTE2, VTE3 e VTE4 encontram-se associadas à membrana interna do envelope (Ferro et al., 2003; Froehlich et al., 2003; Brink et al., 1995; Zbierzak et al., 2010). Por sua vez, a VTE1 encontra-se localizada nos plastoglóbulos (Kessler et al., 1999, Austin et al., 2006), partículas fundamentais na biossíntese e acúmulo de tocoferóis. A localização plastidial da proteína SEC14 somado ao fato da biossíntese de VTE ocorrer nesta mesma organela reforça a hipótese do envolvimento desta proteína na alteração dos conteúdos de a-tocoferol identificado na IL 9-2 que levaram a identificação desse QTL no bin $9 \mathrm{E}$.

Com o intuito de demonstrar o envolvimento da proteína SEC14 no metabolismo de tocoferol foi adotada a estratégia de silenciamento estável por RNAi. Foram obtidas plantas transgênicas de tomate expressando uma molécula dupla fita de RNA correspondente a um fragmento de região codificante do gene. Foram 
selecionadas cinco linhagens que apresentaram uma redução nos níveis de RNAm de $50-80 \%$ em folha e $40-80 \%$ em frutos maduros.

As linhagens transgênicas revelaram uma queda no conteúdo de tocoferol total e do isômero a tanto em folha fonte quanto em fruto maduro; o isômero y também apresentou queda em folha fonte (Figura 17 e 19). Por outro lado, foi observada uma drástica alteração da maquinaria fotossintética.

A VTE está distribuída entre as membranas do tilacóide (89\%), envelope (8\%), e plastoglóbulos (3\%) (Lichtenthaler, 1968, 2007; Matringe et al., 2008; Vidi et al., 2006), protegendo, sinergicamente com xantofilas (Havaux et al., 2005) e outros sistemas antioxidantes (Kanwischer et al., 2005), a fase lipídica da membrana de danos fotoxidativos (Matringe et al., 2008). Por outro lado, oxigênios singletes induzem perdas na atividade do fotossístema II (PSII), diminuindo os níveis das proteínas D1 e levando a uma degradação dos pigmentos durante a fotoinibição do PSII (KriegerLiszkay e Trebst, 2006). Desta maneira, diversos estudos têm mostrado a VTE como protetora do PSII, atuando na eliminação (quenching) dos oxigênios singletes, já que uma molécula de a-tocoferol é capaz de desativar centenas de oxigênios singletes por meio de processos físicos e químicos (Falk e Munné-Bosch, 2010). Assim, a diminuição no transporte de elétrons, evidenciado pela baixa eficiência do fotossistema II e no acúmulo de plastoquinonas reduzidas (Figura 11 e 12), pode ser explicado pela queda nos conteúdos de tocoferol e consequente redução da eficiência do sistema antioxidante. $\mathrm{O}$ aumento dos níveis de espécies reativas de oxigênio (ROS), produzidas pelo sistema de transporte de elétrons e fotossistemas (Foyer e Nocter, 2003, 2005), levaria ao acúmulo de plastoquinonas reduzidas e, finalmente, à saturação do fluxo de transporte de elétrons. Para verificar essa hipótese, é desejável realizar uma quantificação de ROS nas plantas transgênicas a fim de verificar a existência do estresse oxidativo proposto.

Quando as folhas passam do escuro à luz, os centros de reação do PSII são fechados progressivamente. Isso desencadeia em um aumento na fluorescência da clorofila explicado principalmente por dois processos: i) o quenching fotoquímico que é o aumento na taxa de transporte de elétrons a partir do PSII e ii) o quenching nãofotoquímico, que é o aumento na conversão da energia luminosa em calor (Maxwell e Johnson, 2000). Quando a cadeia de transporte de elétrons se encontra saturada é observado um aumento do quenching não-fotoquímico e uma diminuição do quenching fotoquímico, o qual foi verificado nas linhagens transgênicas (Figura 12). Ainda mais, a 
redução observada no teor de açúcares solúveis e amido, nas folhas fonte, confirma a queda na eficiência fotossintética de forma geral (Figura 14).

A análise da expressão dos genes que codificam para as enzimas da rota central de VTE não apresentou alterações nas plantas silenciadas (Figura 20), sendo assim, como explicar o baixo conteúdo de tocoferol observado? O potencial antioxidativo do tocoferol não depende apenas das suas propriedades químicas, mas também da mobilidade e acessibilidade dentro da membrana (Serbinova et al., 1991). Nesse sentido, os tocoferóis estão associados à eliminação de radicais peroxil dos lipídeos, que são responsáveis pela propagação da peroxidação lipídica nas membranas (Liebler, 1993). Assim, é proposto que a proteína SEC14 atue no transporte e distribuição de tocoferóis nos diferentes compartimentos dos plastídios. Desta maneira, a instabilidade das membranas levaria à posterior desorganização da estrutura do cloroplasto, incluindo eventualmente os plastoglóbulos, comprometendo o posicionamento da maquinaria biossintética de tococromanóis resultando assim, na queda nos conteúdos de VTE (Figura 21). Por outro lado, não pode ser descartada uma possível função da proteína SEC14 na reciclagem de tocoferóis oxidados, um sistema que foi recentemente caracterizado em plantas (Kobayashi e DellaPenna, 2008). Neste sentido, para demonstrar o efeito da queda dos conteúdos da VTE na desestabilização das membranas, seria interessante quantificar lipídeos e tocoferóis oxidados e realizar análises ultra-estruturais dos cloroplastos nas linhagens transgênicas.

Da mesma maneira que em folhas, os resultados obtidos da caracterização fenotípica dos frutos demonstram que o silenciamento do gene sec14 levou também a uma queda no conteúdo de tocoferol (Figura 19). No entanto, pelo heterotrofismo do fruto maduro, não foi possível evidenciar um impacto drástico no conteúdo de açúcares, sugerindo que o possível estresse oxidativo, eventualmente produzido pelo metabolismo respiratório, possa ser neutralizado por sistemas antioxidantes alternativos (Falk e Munné-Bosch, 2010).

Concluindo, o aumento expressivo no conteúdo de VTE observado na IL 9-2, poderia ser ocasionado pela maior eficiência do alelo selvagem no sistema de reciclagem de tocoferóis oxidados, embora pouco se conheça acerca da taxa de restituição de tocoferóis em plantas. Considerando a hipótese da SEC14 atuar na distribuição do tocoferol e, por tanto, contribuir para a estabilidade das membranas; é pouco provável que sejam as diferenças alélicas pontuais as determinantes do alto conteúdo de VTE na IL. Nesse caso, a própria rota biossintética poderia atuar como 
fator limitante, seja pelo suprimento de intermediários ou pela atividade de suas enzimas. Como mencionado na introdução, no mesmo fragmento do cromossomo 9, foram identificados os genes que codificam para as enzimas VTE3(1) e VTE5. Assim, a atividade dos três alelos selvagens, de forma integrada, poderia explicar o incremento de VTE observado na IL. Nesse sentido, o nosso grupo encontra-se desenvolvendo paralelamente estudos funcionais para esses outros dois genes candidatos. Adicionalmente, pretende-se aprofundar a caracterização funcional da proteína SEC14 por meio de caracterização de mutantes, expressão da proteína em sistemas heterólogos ( $E$. coli) e experimentos de interação da proteína com a-tocoferol.

Os resultados obtidos neste trabalho contribuem para a compreensão dos mecanismos de biossíntese e acúmulo de um composto antioxidante de alto interesse na nutrição humana. Além disso, soma evidências para o melhor entendimento de processos vitais da fisiologia vegetal. Desta forma, o conhecimento gerado abre perspectivas para futuras aplicações biotecnológicas, que permitam cobrir a crescente demanda por alimentos nutracêuticos. 


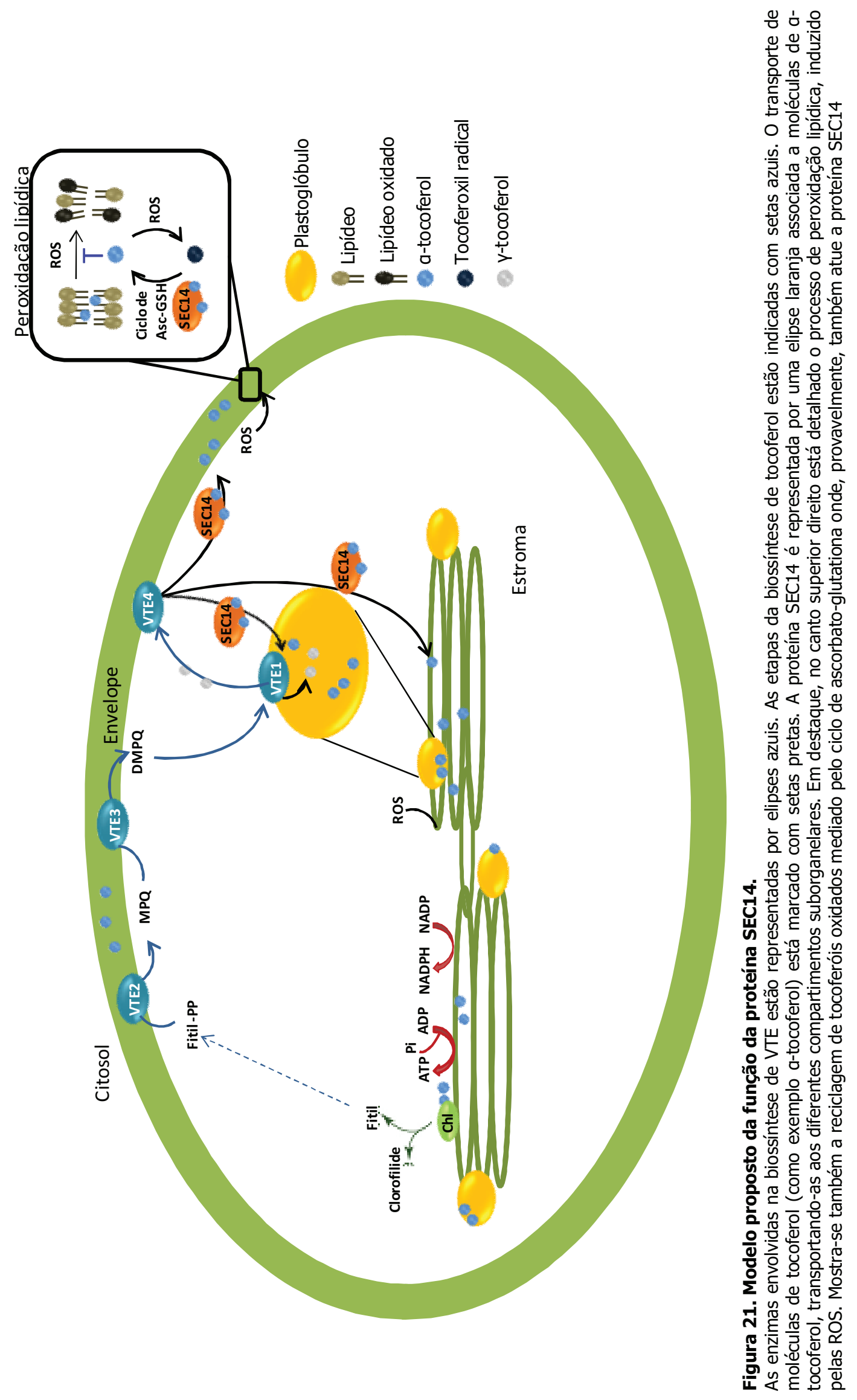




\section{CONCLUSÕES}

Com a caracterização funcional do gene sec14 que abrange a análise da estrutura gênica e protéica, determinação da localização subcelular e, análise fenotípica de plantas silenciadas é possível estabelecer as seguintes conclusões:

1) A proteína SEC14 participa do sistema antioxidante mediado por tocoferol;

2) A deficiência em SEC14 leva a estresse oxidativo alterando a eficiência fotossintética;

3) O impacto do silenciamento da proteína SEC14 sobre o conteúdo de VTE estaría determinado pela desorganização espacial das enzimas da rota biossintética e/ou pela sua participação no reciclado desses compostos;

4) A deficiência de proteína SEC14 não perturba o metabolismo de açúcares em fruto pela sua condição heterotrófica;

5) As evidências coletadas reforçam o postulado que a funçao da VTE como antioxidante não esta só determinada pelas suas propriedades químicas, mas também pela mobilidade e accesibilidade dentro da membrana, e;

6) Os resultados obtidos permitem propôr à SEC14 como uma proteína com estrutura e função inéditas em plantas. 


\section{REFERÊNCIAS}

Abbasi AR, Saur A, Hennig P, Tschiersch H, Hajirezaei M, Hofius D, Sonnewald U, Voll LM. 2008. Tocopherol deficiency in transgenic tobacco (Nicotiana tabacum L.) plants leads to accelerated senescence. Plant Cell and Environment 32, 144-57.

Abbasi AR, Hajirezaei M, Hofius D, Sonnewald U, Voll LM. 2009. Specific roles of alphaand gamma-tocopherol in abiotic stress responses of transgenic tobacco. Plant Physiology 143, 1720-38.

Abushita AA, Hebshi EA, Daood HG, Biacs, PA. 1997. Determination of antioxidant vitamins in tomatoes. Food Chemistry 60, 207-212.

Almeida J, Quadrana L, Asís R, Setta N, de Godoy F, Bermúdez L, Otaiza SN, Corrêa da Silva JV, Fernie AR, Carrari F, Rossi M. 2011. Genetic dissection of vitamin E biosynthesis in tomato. Journal of Experimental Botany (no prelo).

Altschul SF, Gish W, Miller W, Myers EW, Lipman DJ. 1990. Basic local alignment search tool. Journal of Molecular Biology 215, 403-410.

Austin JR 2nd, Frost E, Vidi PA, Kessler F, Staehelin LA. 2006. Plastoglobules are lipoprotein subcompartments of the chloroplast that are permanently coupled to thylakoid membranes and contain biosynthetic enzymes. The Plant Cell 18, 1693-1703.

Bankaitis VA, Malehorn DE, Emr SD, Greene R. 1989. The Sacharomyces cerevisiae SEC14 gene encodes a cytosolic factor that is required for transport of secretory proteins from the yeast Golgi complex. The Journal of cell biology 108, 1271128.

Bankaitis VA, Aitken JR, Cleves AE, Dowhan W. 1990. An essential role for a phospholipid transfer protein in yeast Golgi function. Nature 347, 561-562.

Bankaitis VA, Mousley CJ, Schaaf G. 2009. The Sec14 superfamily and mechanisms for crosstalk between lipid metabolism and lipid signaling. Trends in Biochemical Sciences 35, 150-60.

Bankaitis VA, Mousley CJ, Schaaf G. 2010. The Sec14 superfamily and mechanisms for crosstalk between lipid metabolism and lipid signaling. Trends Biochemical Sciences 35, 150-60.

Bell SJ, Grochoski GT. 2008. How safe is vitamin E supplementation? Critical reviews in food science and nutrition 48, 760-74.

Bréhélin C, Kessler F, Van Wijk KJ. 2007. Plastoglobules: versatile lipoprotein particles in plastids. TRENDS in Plant Science 12, 260-265.

Brink S, Fischer K, Klösgen RB, Flügge UI. 1995. Sorting of nuclear-encoded chloroplastmembrane proteins to the envelope and the thylakoid membrane. The Journal of Biological Chemistry 270, 20808-20815.

Corpet, F. 1988. Multiple sequence alignment with hierarchical clustering. Nucleic Acids Research 16, 10881-10890.

Corrêa da Silva JV, Fernie AR, Carrari F, Rossi M. 2011. Genetic dissection of vitamin E biosynthesis in tomato. Journal of experimental botany (no prelo).

Das S, Gautam N, Dey SK, Maiti T, Roy S. 2009. Oxidative stress in the brain of nicotine-induced toxicity: protective role of Andrographis paniculata Nees and vitamin E. Applied Physiology, Nutrition, and Metabolism 34,124-135.

DellaPenna D. 2005a. A decade of progress in understanding vitamin $E$ synthesis in plants. Journal of plant physiology 162, 729-37.

DellaPenna D. 2005b. Progress in the dissection and manipulation of vitamin E synthesis. Trends in plant science 10, 574-9.

DellaPenna D, Last R.L. 2006a. Progress in the dissection and manipulation of plant vitamin E biosynthesis. Physiologia Plantarum 126, 356-368. 
DellaPenna D, Pogson BJ. 2006b. Vitamin synthesis in plants: tocopherols and carotenoids. Annual review of plant biology 57, 711-38.

Di Rienzo JA. 2009. Statistical software for the analysis of experiments of functional genomics. RDNDA. Argentina. 756587.http://sites.google.com/site/fgStatistics/

Falk J, Munné-Bosch S. 2010. Tocochromanol functions in plants: antioxidation and beyond. Journal of Experimental Botany 61, 1549-1566.

Fernie AR, Roscher A, Ratcliffe G, Kruger NJ. 2001. Fructose 2,6-biphosphate actiates pyrophosphate: fructose-6-phosphate 1-phosphotransferase and increases triose phosphate to hexose phosphate cycling in heterotrophic cells. Plantta 212, 250-263.

Ferro M, Salvi D, Brugière S, Miras S, Kowalski S, Louwagie M, Garin J, Joyard J, Rolland N. 2003. Proteomics of the chloroplast envelope membranes from Arabidopsis thaliana. Molecular and Cellular Proteomics 2, 325-345.

Foyer CH, Noctor G. 2003. Redox sensing and signaling associated with reactive oxygen in chloroplasts, peroxisomes and mitochondria. Physiologica Plantarum 119, 355-364.

Foyer $\mathrm{CH}$, Nocter G. 2005. Redox homeostasis and antioxidant signalling: a metabolic interface between stress perception and physiological resonses. The Plant Cell 17, 1866-1875.

Fraser PD, Pinto ME, Holloway DE, Bramley PM. 2000. Application of high-performance liquid chromatography with photodiode array detection to the metabolite profiling of plant isoprenoids. The Plant Journal 24, 551-558.

Froehlich JE, Wilkerson CG, Ray WK, McAndrew RS, Osteryoung KW, Gage DA, Phinney BS. 2003. Proteomic study of the Arabidopsis thaliana chloroplastic envelope membrane utilizing alternatives to traditional two-dimensional electrophoresis. Journal of Proteome Research 2, 413-425.

Frusciante L, Carli P, Ercolano MR, Pernice R, Di Matteo A, Fogliano V, Pellegrini N.2007.Antioxidant nutritional quality of tomato. Molecular nutrition \& food research 51, 609-17.

Havaux M, Eymery F, Porfirova S, Rey P, Dörman P. 2005. Vitamin E protects against photoinhibition and photooxidative stress in Arabidopsis thaliana. The Plant Cell 17, 3451-3469.

Heredia A, Peinado I, Barrera C, Grau AA. 2009. Influence of process variables on colour changes, carotenoids retention and cellular tissue alteration of cherry tomato during osmotic dehydration. Journal of Food Composition and Analysis 22, 285-294.

Hoeckema A, Hirsch PR, Hooykas PJ, Schilperoot RA. 1983. A binay plant vector strategy based on separation of vir and T-region of the Agrobacterium tumefaciens Ti-plasmid. Nature 303, 179-180.

Jouannic N, Lepetit M, Vergnolle C, Cantrel C, Gardies AM, Kader JC, Arondel V. 1998. Isolation of a CDNA from Arabidopsis thaliana that complements the sec14 mutant of yeast. European journal of biochemistry 258, 402-410.

Kamal-Eldin A, Appelqvist LA. 1996.The chemistry and antioxidant properties of tocopherols and tocotrienols. Lipids 31, 671-701.

Kanwischer M, Porfirova S, Bergmüller E, Dörmann P. 2005. Alterations in tocopherol cyclase activity in transgenic and mutant plants of Arabidopsis affect tocopherol content, tocopherol composition, and oxidative stress. Plant Physiology 137, 713-723.

Kapranov P, Routt SM, Bankaitis VA, de Bruijn FJ, Szczyglowski K. 2001. Nodulespecific regulation of phosphatidylinositol transfer protein expression in Lotus japonicus. Plant Cell 13, 1369-1382. 
Karimi M, Inzé D, Depicker A. 2002. GATEWAY ${ }^{\mathrm{TM}}$ vectors for Agrobacterium-mediated plant transformation. Trends in Plant Science 7, 193-195.

Kearns MA, Monks DE, Fang M, Rivas MP, Courtney PD, Chen J, Prestwich GD, Theibert $A B$, Dewey RE, Bankaitis VA. 1998. Novel developmentally regulated phosphoinositide binding proteins from soybean whose expression bypasses the requirement for an essential phosphatidylinositol transfer protein in yeast. The EMBO Journal 17, 4004-4017.

Kessler F, Schnell D, Blobel G. 1999. Identification of proteins associated with plastoglobules isolated from pea (Pisum sativum L.) chloroplasts. Planta 208, 107-113.

Kobayashi N, DellaPenna D. 2008. Tocopherol metabolism, oxidation and recycling under high light stress in Arabidopsis. Plant Journal 55, 607-618.

Krieger-Liszkay A, Trebst A. 2006.Tocopherol is the scavenger of singlet oxygen produced by the triplet states of chlorophyll in the PSII reaction centre. Journal of Experimental Botany 57, 1677-1684.

Kruk J, Holländer-Czytko H, Oettmeier W, Trebst A. 2005. Tocopherol as singlet oxygen scavenger in photosystem II. Journal of plant physiology 162, 749-57.

Li X, Routt SM, Xie Z, Cui X, Fang M, Kearns MA, Bard M, Kirsch DR, Bankaitis VA. 2002. Identification of a novel family of nonclassic yeast phosphatidylinositol transfer proteins whose function modulates phospholipase D activity and Sec14p-independent cell growth. Molecular biology of the cell 11, 1989-2005.

Li Y, Wang Z, Sun X, Tang K. 2008. The current opinions on the functions of tocopherol based on the genetic manipulation of tocopherol biosynthesis in plants. Journal of Integrative Plant Biology 50, 1057-1069.

Lichtenthaler HK. 1968. Plastoglobuli and the fine structure of plastids. Endeavor 27, 144-149.

Lichtenthaler HK. 2007. Biosynthesis, accumulation and emission of carotenoids, alphatocopherol, plastoquinone, and isoprene in leaves under high photosynthetic irradiance. Photosynthesis Research 92, 163-179.

Liebler DC. 1993. The role of metabolism in the antioxidant function of vitamin E. Critical Reviews in Toxicology 23, 147-169.

Matringe M, Ksas B, Rey P, Havaux M. 2008.Tocotrienols, the unsaturated forms of vitamin $\mathrm{E}$, can function as antioxidants and lipid protectors in tobacco leaves. Plant Physiology 147, 764-778.

Mène-Saffrané L, DellaPenna D. 2009. Biosynthesis, regulation and functions of tocochromanols in plants. Plant Physiology and Biochemistry 48, 301-309.

Mueller LA, Solow TH, Taylor N, Skwarecki B, Buels R, Bins J, Lin C, Wright MH, Ahrens R, Wang Y, Herbst EV, Keyder ER, Menda N, Zamir D, Tanksley SD. 2005. The SOL Genomics Network. A Comparative Resource for Solanaceae Biology and Beyond. Plant Physiology 138, 1310-1317.

Mueller L, Mills A, Skwarecki B, Buels R, Menda N, Tanksley S. 2008. The SGN comparative map viewer. Bioinformatics 24, 422-423.

Mueller, L. et al. 2009. A snapshot of the emerging tomato genome sequence. The Plant Genome 2, 78-92.

Munné-Bosch S, Alegre L. 2002. The function of tocopherols and tocotrienols in plants. Critical Reviews in Plant Sciences 21, 31-57.

Munné-Bosch S, Shikanai T, Asada K. 2005. Enhanced ferredoxin-dependent cyclic electron flow around photosystem I and alpha-tocopherol quinone accumulation in water-stressed ndhB-inactivated tobacco mutants. Planta 222, 502-11.

Ogbonna JC. 2009. Microbiological production of tocopherols: current state and prospects. Applied microbiology and biotechnology 84, 217-25. 
Peterman TK, Ohol YM, McReynolds LJ, Luna EJ. 2004. Patellin1, a novel Sec14-like protein, localizes to the cell plate and binds phosphoinositides. Plant Physiology 136, 3080-3094.

Peterman TK, Sequeira A, Samia S, Lunde EE. 2006. Molecular cloning and characterization of patellin1, a novel sec14-related protein, from zucchini (Cucurbita pepo). Journal of Plant Physiology 163, 1150-1158.

Pfaffl MW, Horgan GW, Dempfle L. 2002. Relative expression software tool (RESTC) for group-wise comparison and statistical analysis of relative expression results in real-time PCR. Nucleic Acids Research 39, 9 -36.

Pryor WA. 2000. Oxidative stress status-the fifth set. Free radical biology \& medicine 1 , 1063.

Ricciarelli R, Zingg JM, Azzi A. 2002. The 80th Anniversary of Vitamin E: Beyond Its Antioxidant Properties. Biological Chemistry 383, 457-465.

Ros E. 2009. Nuts and novel biomarkers of cardiovascular disease. The American Journal of Clinical Nutrition 89, 1649-1656.

Ruijter JM, Ramakers C, Hoogaars WM, Karlen Y, Bakker O, van den Hoff MJ, Moorman AF. 2009. Amplification efficiency: linking baseline and bias in the analysis of quantitative PCR data. Nucleic Acids Research 37, 45.

Saito K, Tautz L, Mustelin T. 2007. The lipid-binding SEC14 domain. Biochimica et Biophysica Acta 1771, 719-726.

Saitou N \& Nei M. 1987. The neighbor-joining method: A new method for reconstructing phylogenetic trees. Molecular Biology and Evolution 4, 406-425.

Sambrook J, Fritsch EF, Maniatis T. 1989. Molecular Cloning, a laboratory manual. Second Edition, Cold Spring Harbor Laboratory Press.

Schauer N, Semel Y, Roessner U, Gur A, Balbo I, Carrari F, Pleban T, Perez- Melis A, Bruedigam C, Kopka J, Willmitzer L, Zamir D, Fernie AR. 2006. Comprehensive metabolic profiling and phenotyping of interspecific introgression lines for tomato improvement. Nature Biotechnology 24, 447-454.

Semchuk NM, Lushchak OV, Falk J, Krupinska K, Lushchak VI. 2009. Inactivation of genes, encoding tocopherol biosynthetic pathway enzymes, results in oxidative stress in outdoor grown Arabidopsis thaliana. Plant Physiology and Biochemistry 47, 384-390.

Serbinova E, Kagan V, Han D, Packer L. 1991. Free radical recycling and intramembrane mobility in the antioxidant properties of alpha-tocopherol and alpha-tocotrienol. Free Radicals in Biology and Medicine 10, 263-275.

Sienkiewicz-Porzuceka A, Sulpice R, Osorio S, Krahnert I, Leisse A, UrbanczykWochniak E, Hodges. M, Fernie AR, Nunes-Nesi A. 2010. Mild reductions in mitochondrial NAD-dependent isocitrate dehydrogenase activity result in altered nitrate assimilation and pigmentation but do not impact growth. Molecular Plant 3, 156-173.

Sokal RR, Rohlf FJ. 1981. Biometry. Freeman Secon Edition, New York.

Soll J, Schultz G. 1979. Comparison of geranylgeranyl and phytyl substituted methylquinols in the tocopherol synthesis of spinach chloroplasts. Biochemical and Biophysical Research Communications 91, 715-720.

Stocker A, Zimmer S, Spycher SE, Azzi A. 1999. Identification of a Novel Cytosolic Tocopherol-Binding Protein: Structure, Specificity, and Tissue Distribution. IUBMB Life 48, 49-55.

Stocker A e Baumann U. 2003. Supernatant protein factor in complex with RRR-alphatocopherylquinone: a link between oxidized Vitamin $\mathrm{E}$ and cholesterol biosynthesis. Journal of molecular biology 332, 759-765.

Sun Q, Zybailov B, Majeran W, Friso G, Olinares, PDB, van Wijk KJ. 2009. PPDB, the Plant Proteomics Database at Cornell. Nucleic Acids Research 37, 969-974. 
Tamura K, Dudley J, Nei M, Kumar S. 2007. MEGA4: Molecular Evolutionary Genetics Analysis (MEGA) software version 4.0. Molecular Biology and Evolution 24, 1596-1599.

Thompson J, Higgins D, Gibson T.1994. CLUSTAL W: improving the sensitivity of progressive multiple sequence alignment through sequence weighting positionspecific gap penalties and weight matrix choice. Nucleic Acids Research 22, 4673-4680.

Vidi PA, Kanwischer M, Baginsky S, Austin JR, Csucs G, Dörmann P, Kessler F, Bréhélin C. 2006. Tocopherol cyclase (VTE1) localization and vitamin E accumulation in chloroplast plastoglobule lipoprotein particles. The Journal of Biological Chemistry 281, 11225-11234.

Vincent M, Chua F, Nogue A, Fairbrother H, Mekeel Y. 2005. A Sec14p-nodulin domain phosphatidylinositol transfer protein polarizes membrane growth of Arabidopsis thaliana root hairs. The Journal of cell biology 168, 801-812.

Wang X, Quinn PJ. 2000. The location and function of vitamin E in membranes (review). Molecular membrane biology 17, 143-56.

Wen-Jun S e Forde B. 1989. Efficient transformation of Agrobacterium spp. by high electroporation. Nucleic Acids Research 17, 8385.

Zbierzak AM, Kanwischer M, Wille C, Vidi PA, Giavalisco P, Lohmann A, Briesen I, Porfirova S, Bréhélin C, Kessler F, Dörmann P. 2009. Intersection of the tocopherol and plastoquinol metabolic pathways at the plastoglobule. The Biochemical journal 425, 389-99.

Zhang CX, Ho SC, Chen YM, Fu JH, Cheng SZ, Lin FY. 2009. Greater vegetable and fruit intake is associated with a lower risk of breast cancer among Chinese women. International Journal of Cancer 125,181-188.

Zscheille F e Porter J. 1947. Analytical methods for carotenes of Lycopersicon species and strains. Analytical Chemistry 19, 47-51. 
CONSIDERAÇÕES GERAIS 

O ponto de partida desta tese foi uma análise metabólica e genética, entre $S$. lycopersicum e $S$. pennellii, que permitiu descrever diversos QTL que afetam o metabolismo central dos frutos de tomate. Assim, foram propostas diferentes abordagem, utilizando ferramentas de genômica e genética reversa, com o intuito de identificar e caracterizar molecular e fisiológicamente alguns dos mecanismos, que explicam as variações bioquímicas observadas.

Em primeiro lugar (Capítulo I), foi realizada uma busca no genoma por possíveis genes candidatos que pudessem explicar as diferenças metabólicas mencionadas (Bermudez et al., 2008). A identificação de diversos genes candidatos que apresentaram polimorfismos entre os genótipos analisados e correlação da expressão com o conteúdo de metabólitos foi um primeiro indício da eficiência da estratégia para o estudo de caracteres complexos.

Posteriormente (Capítulo II), para avaliar de forma geral a diversidade presente nas regiões genômicas associadas aos caracteres metabólicos, foi realizada uma análise de microssintenia, como complementação à construção de um mapa físico. Neste trabalho, foram utilizadas ferramentas de genômica comparativa e análises evolutivas. Desta forma, foi demonstrado alto grau de conservação na estrutura gênica, mas com polimorfismo nas regiões regulatórias e no padrão de inserção de elementos de transposição. Adicionalmente, este estudo permitiu uma estimativa com alto nível de precisão do tempo de divergência entre essas duas espécies (Kamenetzky et al., 2010), o qual constituiu uma das bases para a elaboração do projeto genoma de S. pennellii que se encontra atualmente em andamento pelo nosso grupo na Argentina.

Por fim (Capítulo III e IV), as hipóteses geradas a partir dos dois primeiros capítulos levaram à análise funcional do gene chaperona DnaJ e do sec14. Esta última parte representou um grande desafio tanto conceitual como metodológico já que, além do risco de apostar nas candidaturas, foi necessário estandardizar protocolos para o estudo funcional de promotores, localização subcelular de proteínas in vivo, obtenção de plantas de tomate estavelmente transformadas, quantificação de transcritos por qPCR, quantificação de diversos metabolitos e tocoferois. Os resultados obtidos permitiram um melhor entendimento dos mecanismos que regulam o metaboloma nos frutos de tomate; em particular, aqueles envolvidos no conteúdo de açúcares solúveis, de fundamental importância para a qualidade industrial, e de tocoferol que representa um metabólito de alto interesse nutricional. 

ANEXO 1 



\title{
Genomic Analysis of Wild Tomato Introgressions Determining Metabolism- and Yield-Associated Traits ${ }^{1[C][W]}$
}

\author{
Laura Kamenetzky², Ramón Asís ${ }^{2,3}$, Sebastián Bassi, Fabiana de Godoy, Luisa Bermúdez, Alisdair R. Fernie, \\ Marie-Anne Van Sluys, Julia Vrebalov, James J. Giovannoni, Magdalena Rossi, and Fernando Carrari* \\ Instituto de Biotecnología, Instituto Nacional de Tecnología Agropecuaría, and Consejo Nacional de \\ Investigaciones Científicas y Técnicas, B1712WAA Castelar, Argentina (L.K., R.A., S.B., F.C.); Departamento \\ de Botânica, Instituto de Biociências, Universidade de São Paulo, Sao Paulo 05508-900, Brazil (F.d.G., L.B., \\ M.-A.V.S., M.R.); Max Planck Institute for Molecular Plant Physiology, D-14 476 Potsdam-Golm, Germany \\ (A.R.F.); and Boyce Thompson Institute for Plant Research and United States Department of Agriculture- \\ Agricultural Research Service, Cornell University, Ithaca, New York 14853 (J.V., J.J.G.)
}

With the aim of determining the genetic basis of metabolic regulation in tomato fruit, we constructed a detailed physical map of genomic regions spanning previously described metabolic quantitative trait loci of a Solanum pennellii introgression line population. Two genomic libraries from S. pennellii were screened with 104 colocated markers from five selected genomic regions, and a total of 614 bacterial artificial chromosome (BAC)/cosmids were identified as seed clones. Integration of sequence data with the genetic and physical maps of Solanum lycopersicum facilitated the anchoring of 374 of these BAC/ cosmid clones. The analysis of this information resulted in a genome-wide map of a nondomesticated plant species and covers $10 \%$ of the physical distance of the selected regions corresponding to approximately $1 \%$ of the wild tomato genome. Comparative analyses revealed that S. pennellii and domesticated tomato genomes can be considered as largely colinear. A total of 1,238,705 bp from both BAC/cosmid ends and nine large insert clones were sequenced, annotated, and functionally categorized. The sequence data allowed the evaluation of the level of polymorphism between the wild and cultivated tomato species. An exhaustive microsynteny analysis allowed us to estimate the divergence date of S. pennellii and S. lycopersicum at 2.7 million years ago. The combined results serve as a reference for comparative studies both at the macrosyntenic and microsyntenic levels. They also provide a valuable tool for fine-mapping of quantitative trait loci in tomato. Furthermore, they will contribute to a deeper understanding of the regulatory factors underpinning metabolism and hence defining crop chemical composition.

Tomato (Solanum species) fruits constitute one of the most important sources of minerals, vitamins, fibers, and antioxidants in the human diet. Genomic approaches focused on determining the genetic basis of pathway regulation underlying quantitative variation in the production of these nutrients will likely provide information to facilitate the identification of cardinal

\footnotetext{
${ }^{1}$ This work was supported by the Instituto Nacional de Tecnología Agropecuaría and the Agencia Nacional de Promoción Científica y Tecnológica (Argentina), the Fundação de Amparo à Pesquisa do estado de São Paulo and the Conselho Nacional de Desenvolvimento Científico e Tecnológico (Brazil), the Max Planck Society (Germany), the European Solanaceae Integrated Project FOOD-CT2006-016214, and the National Science Foundation Plant Genome Program (grant no. 05-01778).

${ }^{2}$ These authors contributed equally to the article.

${ }^{3}$ Present address: Centro de Investigaciones en Bioquímica Clínica e Inmunología, Facultad de Ciencias Químicas, Universidad Nacional de Córdoba, CC 5000 Córdoba, Argentina.

* Corresponding author; e-mail fcarrari@cnia.inta.gov.ar.

The authors responsible for distribution of materials integral to the findings presented in this article in accordance with the policy described in the Instructions for Authors (www.plantphysiol.org) are: Fernando Carrari (fcarrari@cnia.inta.gov.ar) and Magdalena Rossi (mmrossi@usp.br).

${ }^{[C]}$ Some figures in this article are displayed in color online but in black and white in the print edition.

${ }^{[W]}$ The online version of this article contains Web-only data.

www.plantphysiol.org/cgi/doi/10.1104/pp.109.150532
}

genes. The cumulative body of data concerning developmental and metabolic shifts coupled with those recently acquired using postgenomic tools has prompted the adoption of this species as a model system for plants bearing fleshy fruits (Mueller et al., 2005). Such a model is required, because although many of these processes might be shared by many different plant species, this should not be straightly assumed, since remarkable metabolic differences have been observed even between closely related species (Fernie and Willmitzer, 2001).

The facts that the domesticated species Solanum lycopersicum can be crossed with a number of its wild relatives and that these species have shown tremendous variation in metabolite content both in leaves and fruits (Schauer et al., 2006) render wild germplasm as an important source for metabolic gene discovery (Zamir, 2001). For this reason, extensive germplasm collections, including numerous natural and induced mutants and interspecific populations, have been made publicly available by the Tomato Genetics Resource Center (http:/ /tgrc.ucdavis.edu/). An example of this is the collection of 76 introgression lines (ILs; Eshed and Zamir, 1995) comprising single overlapping introgressions of the Solanum pennellii (accession no. LA716) genome within the S. lycopersicum genome (cv M82). These lines are an excellent source of the stable genetic variation used worldwide by different re- 
searchers to map 2,795 quantitative trait loci (QTLs) to date, including those affecting plant biomass, yield, drought tolerance, morphology, gene expression, and metabolism (Lippman et al., 2007). The success of the $S$. pennellii ILs in establishing new principles for plant breeding and for resolving the molecular basis of complex traits has been demonstrated by the cloning of the first QTLs in this species: FW2.2 (a fruit size gene; Frary et al., 2000) and Brix9-2-5 (a sugar yield gene; Fridman et al., 2000, 2004). The broad phenotypic diversity inherent in this population alongside its simple mapping framework has also led to the identification of heterotic QTLs for biomass production, a major step toward isolating heterosis genes (Lippman et al., 2007). A clone-based physical map of S. pennellii, however, is necessary to fully exploit this population and to produce a unique resource for Solanaceae genomics. Such a map would also provide previous information for comparative analyses, mapbased cloning, and validation of the sequence assemblies of the tomato whole genome (Solanaceae Genome Network [SGN]; www.sgn.cornell.edu).

The aim of our current research was to perform a large-scale comparative genome analysis of the $S$. pennellii wild tomato and S. lycopersicum. Five genomic regions (BINs) comprising more than 100 recently identified QTLs associated with fruit carbon primary metabolism (Schauer et al., 2006, 2008) were chosen. These QTLs include fruit color (Liu et al., 2003), volatile content (Tieman et al., 2006), and yield traits linked to metabolite variations found in the fruits (Eshed and Zamir, 1995; Schauer et al., 2006; Semel et al., 2006). The physical map, built by anchoring 374 clones from bacterial artificial chromosome (BAC) and cosmid $S$. pennellii genomic libraries to the tomato genetic map, revealed a consistent pattern of coaligning regions, thus suggesting that the two genomes can largely be considered as colinear. Targeted sequencing of $1,238,705 \mathrm{bp}$ allowed the annotation of 407 genes and uncovered a high degree of microsynteny between the two species. To a lesser extent, microsynteny was also observed with the Arabidopsis genome. However, this colinearity was somewhat perturbed by differential transposable element (TE) insertion patterns, different intergenic region lengths, and extensive single nucleotide polymorphism (SNP) and insertion-deletion (InDel) polymorphism. The time of divergence between species was estimated to be 2.7 million years ago (MYA). Furthermore, the large data set presented here would constitute a useful tool for QTL fine-mapping and relatively easy screening of target clones in map-based cloning approaches.

\section{RESULTS}

Integration of Genetic and Physical Maps of S. pennellii and S. lycopersicum Genomic Regions Spanning QTLs

The S. pennellii IL population has allowed the association of more than 2,700 QTLs (for review, see
Lippman et al., 2007), including many related to fruit compositional quality (Schauer et al., 2006, 2008). Based on this data set repository and with the intention of resolving the genetic determinants responsible for the observed phenotypic variations, five genomic regions were selected: BINs $1 \mathrm{C}, 2 \mathrm{~B}, 4 \mathrm{I}, 7 \mathrm{H}$, and $11 \mathrm{C}$. These regions are associated with a total of 104 QTLs comprising traits related to fruit primary metabolite content, yield, and fruit volatile content (Eshed and Zamir, 1995; Schauer et al., 2006; Tieman et al., 2006; Table I). In order to reach the goal proposed above, an integration of the genetic and physical maps of $S$. pennellii and S. lycopersicum was performed. By screening two $S$. pennellii genomic libraries, 614 seed clones were identified using pooled overgo probes for the five selected BINs. Over 70\% of the overgo probes hit at least one BAC or cosmid clone, and no major differences were observed between libraries (Supplemental Table S1). Two-dimensional pooling hybridization allowed the anchoring of 374 clones to their corresponding map positions (Table I). In addition, the map positions of $24 \%$ of these clones were confirmed by independent hybridizations to closely linked or cosegregating markers (Supplemental Table S2A).

The average insert size of anchored clones, as estimated by pulsed-field gel electrophoresis, was 108.3 $\mathrm{kb}(125.8$ and $90.8 \mathrm{~kb}$ for BAC and cosmid, respectively). Since the $S$. pennellii genome has been estimated to be approximately 1.2 Gb (Arumuganathan and Earle, 1991) and considering the total number of clones of each library (see "Materials and Methods"), we estimate that genome coverage is 5.5 and 3.8 for the $\mathrm{BAC}$ and cosmid libraries, respectively, with an average of $4.7 \times$. Thus, the anchored $374 \mathrm{BAC} /$ cosmid clones represent around $1 \%$ of the wild tomato genome and approximately $10 \%$ of the physical distance of the selected regions. However, these values should be taken with caution, since they rely on a genetic map constructed with less than 100 individuals (TomatoEXPEN 2000, S. lycopersicum LA925 $\times$ S. pennellii LA716; http:/ /www.sgn.cornell.edu/).

To support the integration of the wild species clones with both the $S$. lycopersicum genomic sequence and the available genetic map, the 374 anchored BAC and cosmid clones were end sequenced. Both end sequences were obtained for 233 clones, only one end sequence reached a suitable quality criteria in 53 of the clones, and no high-quality sequence was produced for 88 clones. Thus, after quality and vector trimming, a total of 519 end sequences, representing $76 \%$ of all anchored clones, were obtained and subjected to further analyses. After masking repetitive elements, the sequences from clones anchored with the same marker were assembled into 54 contigs (Table I; Supplemental Table S2B). These analyses rendered a total of 436 nonredundant end sequences $(312,095 \mathrm{bp})$.

To support the above analysis, $S$. pennellii clones were selected for full-length sequencing using the following criteria: (1) PCR confirmation for the presence of candidate genes previously identified by our 
Table I. S. pennellii BAC and cosmid clones anchored onto five genomic regions spanning fruit quantitative metabolic loci (QML) and yield-associated loci (YAL)

Metabolite QTLs and YALs listed here were previously reported by Eshed and Zamir (1995), Liu et al. (2003), Schauer et al. (2006), Semel et al. (2006), and Tieman et al. (2006).

\begin{tabular}{|c|c|c|c|c|c|c|c|c|c|c|c|}
\hline $\begin{array}{l}\text { Genomic } \\
\text { Region } \\
\text { (BIN) }\end{array}$ & $\begin{array}{c}\text { No. of } \\
\text { Markers }\end{array}$ & Seed Clones & $\begin{array}{c}\text { Clones } \\
\text { Anchored } \\
\text { by Individual } \\
\text { Hybridization }\end{array}$ & $\begin{array}{l}\text { Average } \\
\text { Clone } \\
\text { No. per } \\
\text { Marker }\end{array}$ & $\begin{array}{l}\text { Average } \\
\text { Clone No. } \\
\text { per cM }\end{array}$ & $\begin{array}{l}\text { No. of End } \\
\text { Sequences }\end{array}$ & $\begin{array}{l}\text { No. of } \\
\text { Contigs }\end{array}$ & $\begin{array}{l}\text { Total Length of } \\
\text { Nonredundant } \\
\text { End Sequences }\end{array}$ & $\begin{array}{l}\text { Clones with } \\
\text { Confirmed } \\
\text { Position } \\
\text { by End } \\
\text { Sequencing }\end{array}$ & $\begin{array}{c}\text { Clones } \\
\text { with Single } \\
\text { Map } \\
\text { Positions }\end{array}$ & $\begin{array}{c}\text { Associated } \\
\text { QML/YAL }\end{array}$ \\
\hline & & & & \multicolumn{8}{|c|}{$b p$} \\
\hline 1C (19.4 cM) & 19 & 323 (for $1 \mathrm{C}$ and $2 \mathrm{~B}$ ) & 49 & 2.6 & 2.5 & 78 & 7 & 51,372 & 19 & 8 & $13^{\mathrm{a}}$ \\
\hline 2B (13.0 cM) & 25 & & 132 & 5.3 & 10.1 & 173 & 21 & 91,196 & 51 & 23 & $10^{\mathrm{b}} / 5^{\mathrm{c}}$ \\
\hline $7 \mathrm{H}(36.0 \mathrm{cM})$ & 18 & 100 & 68 & 3.8 & 1.8 & 105 & 13 & 65,200 & 41 & 31 & $7^{f} / 2^{g}$ \\
\hline $11 \mathrm{C}(19.0 \mathrm{cM})$ & 23 & 110 & 70 & 3.0 & 3.7 & 92 & 7 & 60,966 & 19 & 17 & $12^{\mathrm{h}} / 8^{\mathrm{i}}$ \\
\hline Total & 104 & 614 & 374 & & & 519 & 54 & 312,095 & 161 & 100 & 104 \\
\hline Average & & & & 3.5 & 4.6 & & & & & & \\
\hline
\end{tabular}

${ }^{a}$ Ala, Asp, Cys, Met, oxoproline-5, S-methyl-Cys, isomaltose, phosphate, Glc-6-P, sorbitol, quinate, succinate, threonate. ${ }^{b}$ Glu, $S$-methyl-Cys, Fru, Gal, Glc, Man, glycerol-3-phosphate, dehydroascorbate, gluconate, isocitrate. ${ }^{\mathrm{c}}$ Flowers per plant, pericarp, seed number per fruit, seed number per plant, leaf morphology. $\quad{ }^{\mathrm{d}}$ Asn, Asp, $\beta$-Ala, $\gamma$-aminobutyric acid, Glu, Gln, Ile, Leu, Lys, Met, Pro, Fru, Fuc, Glc, Suc, phosphate, Fru-6-P, Glc-6-P, glycerol-3-phosphate, inositol-1-phosphate, stearate, palmitate, citrate, dehydroascorbate, gluconate, glycerate, isocitrate, 3-methylbutanal, 3-methylbutanol, 2-methylbutanal, 2-methylbutanol, isovaleronitrile, isobutyl acetate, pentanal, trans-2-pentenal, 1-penten-3one, cis-2-penten-1-ol. eplant weight, Brix, fruit color, fruit length per width, fruit width, harvest index, pericarp, seed width, style length, green fruit at harvest time. $\quad{ }^{\mathrm{f}} \gamma$-Aminobutyric acid, homoserine, Ile, Leu, Met, Ser, Glc-6-P. $\quad{ }^{\mathrm{g}}$ Fruit length, fruit weight. $\quad{ }^{\mathrm{h}}$ Asp, $\gamma$-aminobutyric acid, Leu, Glc, dehydroascorbate, fumarate, pentanal, 3-methylbutanal, 3-methylbutanol, 2-methylbutanal, 2-methylbutanol, isovaleronitrile. length, Brix yield, flowers per plant, fruit number, inflorescence number, pericarp per width, seed number per plant, seed weight per plant.

group (Bermúdez et al., 2008); (2) confirmation of physical map position by end sequence anchoring; and (3) availability of information from orthologous $S$. lycopersicum genomic regions. On the basis of these criteria, nine clones were sequenced: one clone anchored to BIN 1C, two to BIN 2B, one to BIN 4I, four to BIN $7 \mathrm{H}$, and one to BIN 11C. Insert lengths ranged from 50,564 to $148,978 \mathrm{bp}$. Map positions and clone identifiers are available in Supplemental Table S2A.

The full-length sequencing of these clones resulted in a total of $926,691 \mathrm{bp}$ of sequence, which, together with the end sequences described above, encompasses a total of $1,238,786 \mathrm{bp}$. This sequence volume represents $1.5 \%$ of the five genomic regions under study and about $0.1 \%$ of the entire $S$. pennellii genome. The complete data set, including hybridization anchored clones, masked nonredundant end sequences, and large insert clone sequences, was used to build a physical map. Figure 1 shows a graphical representation of the relationships found between the S. lycopersicum genetic map and the anchored clones of the wild species. The identity of $S$. pennellii sequences to mapped markers (blue lines) and to S. lycopersicum genomic sequence (red lines) allowed the determination of orthologous regions between the two species for $43 \%$ of the anchored clones.

At first glance, the topology of the maps of these five genomic regions showed that the $S$. pennellii genome can be considered colinear with that of the domesticated tomato. This can clearly be observed in Figure 1 by the density of the lines linking $S$. pennellii with $S$. lycopersicum clones and their positions on the map. However, it is possible to identify a few regions where red lines connect distant $S$. pennellii clones to a single $S$. lycopersicum one and vice versa (i.e. the interval 93-108 centimorgan [cM] in BIN 7H; Fig. 1D). These features suggest the occurrence of rearrangements such as chromosomal inversions and/or InDels. Another interesting feature of the map topology is apparent in the junction of the red lines linking several distant $S$. pennellii clones to narrower intervals within the $S$. lycopersicum genome. The S. pennellii clones anchored to a 10.7-cM interval (T1606-TG498 markers) on BIN 4I matched S. lycopersicum BACs $(\mathrm{A}-\mathrm{H})$ that were anchored with markers covering 5.5 cM (C2_At2g45730cLPT-2-K6) according to the Tomato-EXPEN 2000 map (Fig. 1C). Similarly, on BIN 11C, several S. pennellii BAC clones anchored within an interval of $3.0 \mathrm{cM}$ (SSR76-C2_At1g44790) matched a single S. lycopersicum BAC (A) anchored with the T1161 marker at 38.0 $\mathrm{cM}$ (Fig. 1E). Although this result is suggestive of a genome expansion event in S. pennellii, as reflected by the relative genome sizes of these species, it is not possible to formally exclude that this colinearity break reflects the low resolution of the map and/or the current relative paucity of information concerning the S. lycopersicum genomic clones in the regions studied here.

The number of anchored clones per marker (3.5; Table I) is in general agreement with the libraries' redundancy $(4.7 \times)$. However, the cLER-14H18 marker anchored 76 S. pennellii clones (BIN 2B; Fig. 1B), while only eight $S$. lycopersicum clones were identified (Supplemental Table S1). End sequence analyses and contig assemblies of $S$. pennellii clones revealed that most of them span the anchoring marker or a cosegregating one, thus confirming their map positions. Furthermore, 


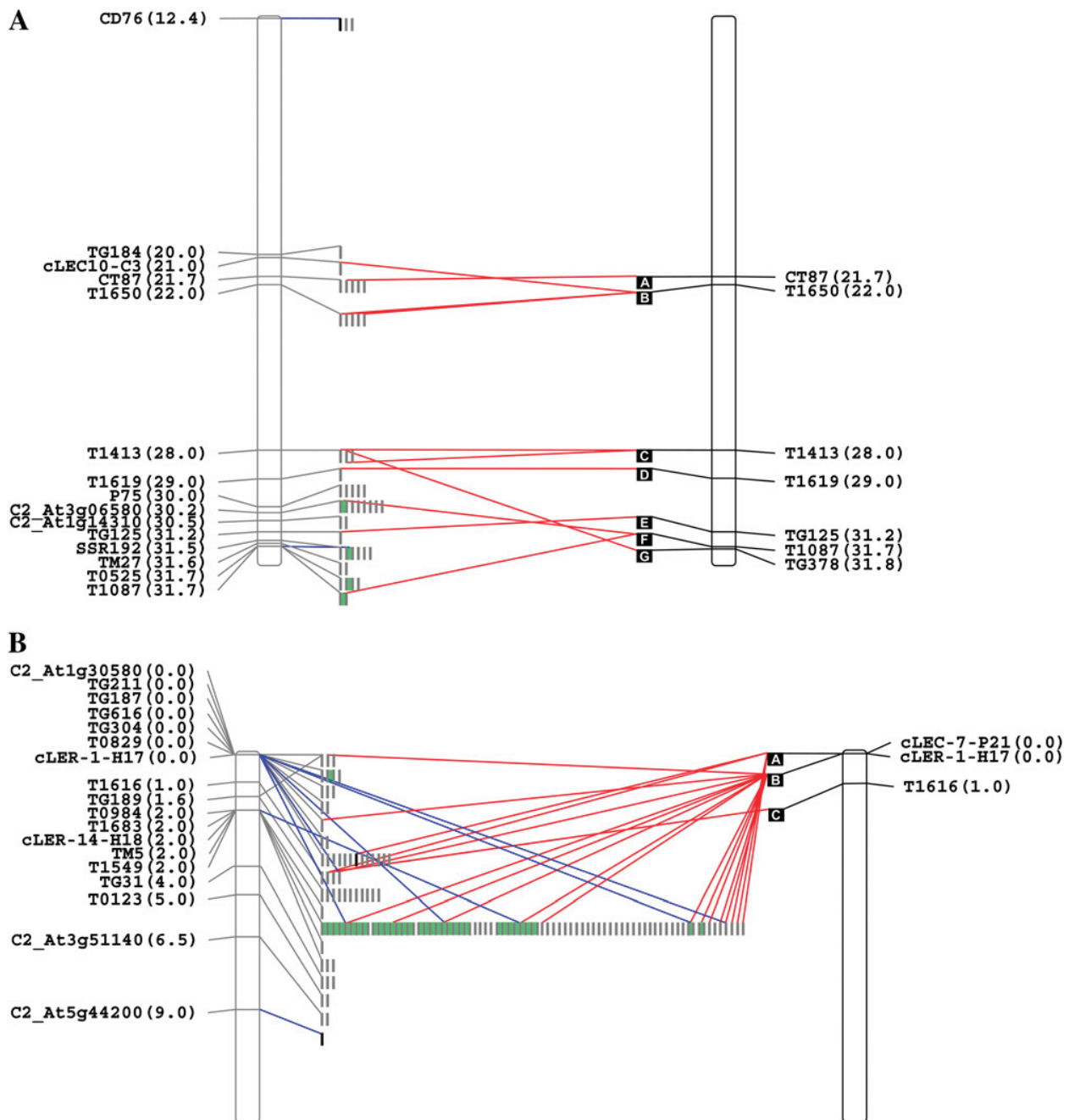

Figure 1. Integrated genetic and physical maps of selected genomic regions of $S$. pennellii and $S$. Iycopersicum. Genetic markers and their corresponding map positions (according to the Tomato-EXPEN 2000 map) are shown on the left and right sides of the $S$. pennellii and $S$. lycopersicum chromosome fragment representations, respectively. S. pennellii anchored BAC/ cosmid clones are represented by gray bars. Clones belonging to the same contig are grouped into green boxes. Full-length sequenced clones are represented by black bars. S. lycopersicum clones are represented as black squares ordered alphabetically. Gray lines link $S$. pennellii BAC/cosmid clones with their corresponding hybridizing genetic markers. Blue lines indicate the $S$. pennellii $\mathrm{BAC} / \mathrm{cosmid}$ end sequences containing the corresponding marker sequences. Red lines link $S$. pennellii BAC/cosmid end sequences matching $S$. lycopersicum BAC clone sequences. Black lines link S. lycopersicum BAC clones to their corresponding markers. The entire data set is available at the SGN Web site in the Tomato Physical Map interface (http://www.sgn. cornell.edu/cview/). A, BIN 1C. B, BIN 2B. C, BIN 4I. D, BIN 7H. E, BIN 11C. [See online article for color version of this figure.]

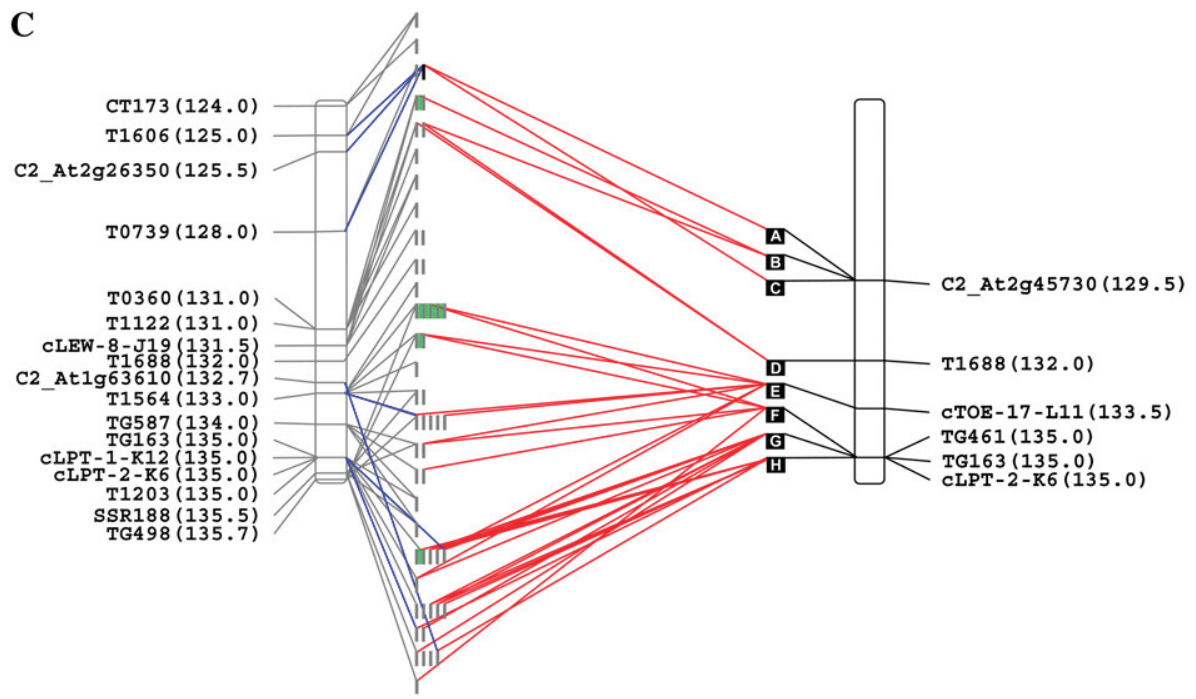

these clones hit only two contiguous S. lycopersicum BACs and harbor ribosomal genes and TEs. Taken together, these results suggest that a local amplification may well have occurred in the $S$. pennellii genome.
Annotation and Functional Categorization of S. pennellii Coding Sequences

The significant number of sequences generated, together with the fact that they are linked to physio- 

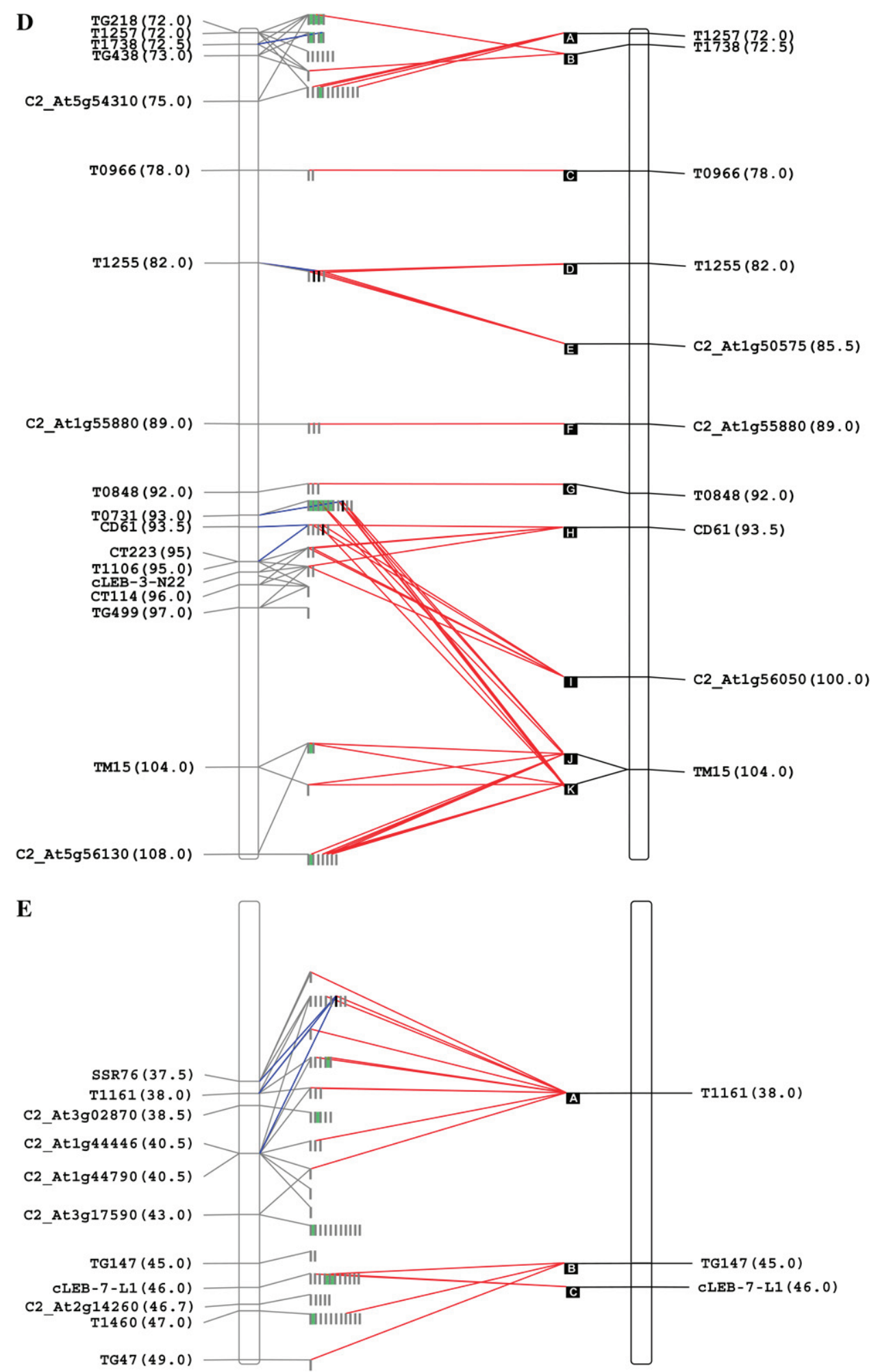

Figure 1. (Continued.)

logically relevant QTLs, renders this information an untapped resource for exposing known and novel genes that could be involved in controlling these traits. For this reason, an exhaustive annotation was attempted for the 436 nonredundant end sequences and the nine BAC/cosmid clones. From the nonredundant end sequences, a total of 298 putative genes were identified and assigned to functional categories (Supplemental 
Table S3). From the fully sequenced BAC/cosmid clones, 109 complete open reading frames were identified by two approaches: (1) utilizing the FGENESH (Salamov and Solovyev, 2000) and Augustus (Stanke et al., 2004) prediction softwares, and (2) manual confirmation by the cross-match interface of the phrap program and BLAST comparison (Supplemental Table S4). A detailed analysis of the large-insert sequence annotation revealed comparable gene density values of 0.1 genes $\mathrm{kb}^{-1}$ in BINs $1 \mathrm{C}, 2 \mathrm{~B}, 7 \mathrm{H}$, and $11 \mathrm{C}$. However, BIN 4I displayed 0.2 genes $\mathrm{kb}^{-1}$ and the lowest density of TEs (Supplemental Tables S4 and S5). The annotated sequences are representative of unigenes derived from cDNA libraries from a broad spectrum of tomato tissues and physiological conditions. Moreover, 103 of the 109 predicted open reading frames through the five genomic regions matched Arabidopsis genes, revealing a high degree of conservation in the gene repertories of the two species. Furthermore, with the exception of the BAC analyzed from chromosome 1, in all other clones, 13 microsyntenic segments were identified between the wild tomato species and Arabidopsis (Arabidopsis thaliana), which are highlighted in color in Supplemental Table S4. These regions encompass 54 genes that span 218,060 nucleotides representing about $25 \%$ of the annotated large-insert clone sequences.

The 407 annotated genes were further subjected to functional categorization using the MapMan ontology adapted for solanaceous species by UrbanczykWochniak et al. (2006). These genes fell into 23 of the 35 gene categories, and their distribution along the five genomic regions is shown in Figure 2. Total sequence percentage per BIN that fell into any functional category varied between $51 \%$ and $84 \%$ for BINs $11 \mathrm{C}$ and $4 \mathrm{I}$, respectively. The number of gene classes per BIN ranged from nine in BIN $11 \mathrm{C}$ to 19 in BIN 7H, revealing differences in gene diversity among BINs (Fig. 2). With the exception of region B on chromosome 2, "unknown function" (category 35) was the most represented category for all BINs. The second two most abundant categories, "DNA modifiers" (category 28) and "protein modification" (category 29), are those comprising ribosomal proteins and TEs, respectively. In all the BINs analyzed, a significant percentage of predicted coding regions fell into the "RNA regulation" category (category 27), which includes regulatory proteins such as $M Y B, W R K Y$, and zinc finger transcription factors. Several MapMan functional classes were found exclusively in certain genomic regions. For example, genes falling into the "major carbohydrates" category (category 2) were found only in regions of chromosomes 2 and 4. "TCA [tricarboxylic acid] cycle/organic acid transformations" and "cofactor and vitamin synthesis" categories (categories 8 and 18) were found only in BIN 1C, while "redox regulation" (category 21) was found exclusively in BINs $4 \mathrm{I}$ and $7 \mathrm{H}$. Genes related to "transport" (category 34) were found only in BINs 4I, $7 \mathrm{H}$, and $11 \mathrm{C}$. The same was found for genes related to "lipid metabolism" (category 11) and "tetrapyrrole synthesis" (category 19), which were present only in BIN $7 \mathrm{H}$ and $11 \mathrm{C}$, respectively.

\section{SNP and InDel Discovery}

Due to the importance of SNP and InDel discovery in genetic mapping, the number and density of these differences were evaluated within the 436 nonredundant end sequences and their corresponding S. lycopersicum orthologous regions (Supplemental Table

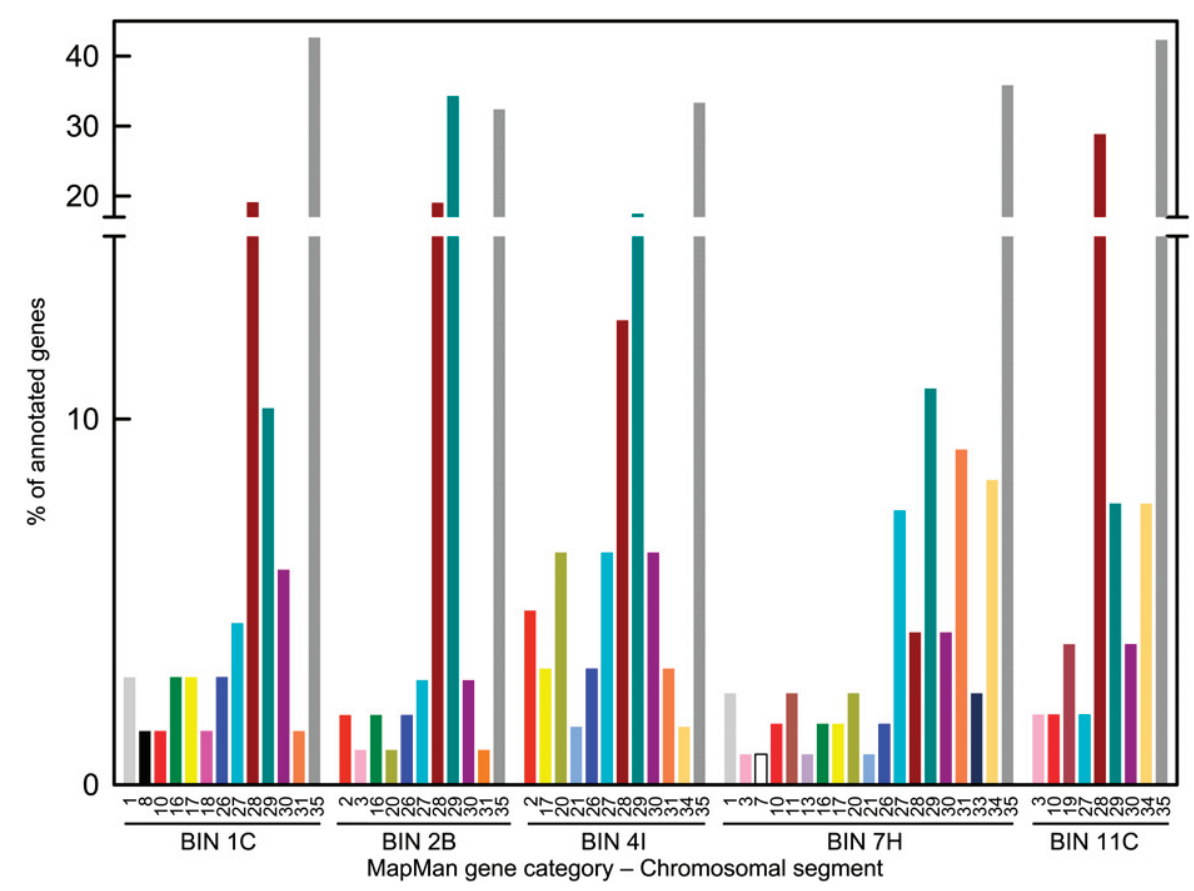

Figure 2. Functional categorization of S. pennellii genomic sequences. BAC/ cosmid end (singletons and contigs) and full-length sequences were categorized according to MapMan software (http:// mapman.mpimp-golm.mpg.de). Categories are as follows: 1 , photosynthesis; 2 , major carbohydrates; 3, minor carbohydrates; 7, oxidative pentose phosphate pathway; 8, tricarboxylic acid cycle/organic acid transformations; 10 , cell wall; 11 , lipid metabolism; 13, amino acid metabolism; 16 , secondary metabolism; 17 , hormones; 18, cofactor and vitamin synthesis; 19, tetrapyrrole synthesis; 20 , stress; 21 , redox regulation; 26, miscellaneous enzyme families; 27, RNA regulation; 28, DNA modifiers; 29, protein modifications; 30 , signaling; 31, cell; 33, development; 34, transport; 35, unknown function. [See online article for color version of this figure.] 
A

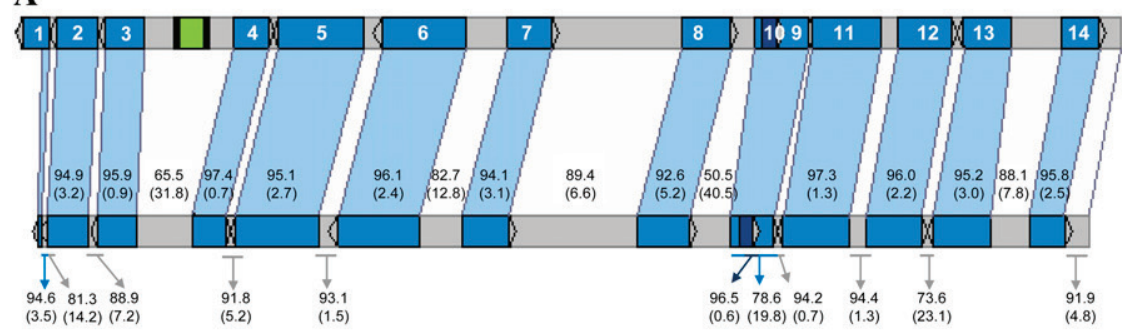

S. pennellii clone C04SpBP093E005.P4C04

S. lycopersicum clone C04HBa0331L22

S. pennellii clone C07SpCP066B007.P5C04

B

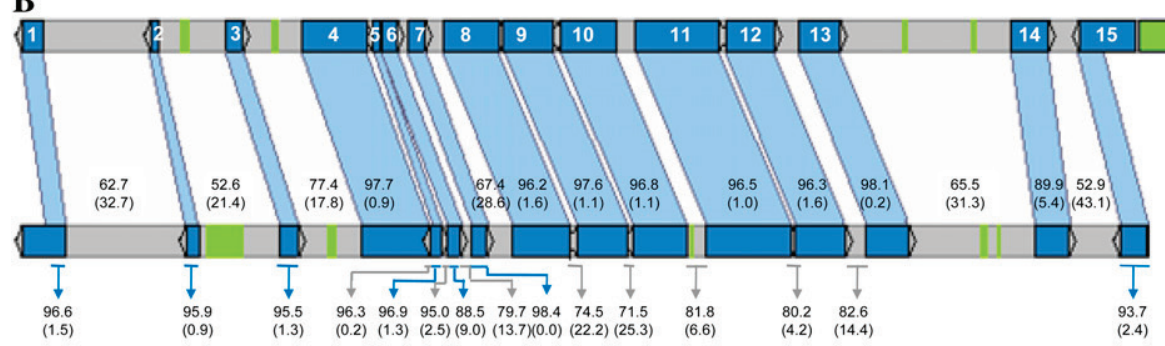

\begin{tabular}{ll|l|l|l|l|l|l|l|}
\hline 16 & 18 & 19 & 20 \\
\hline
\end{tabular}

C

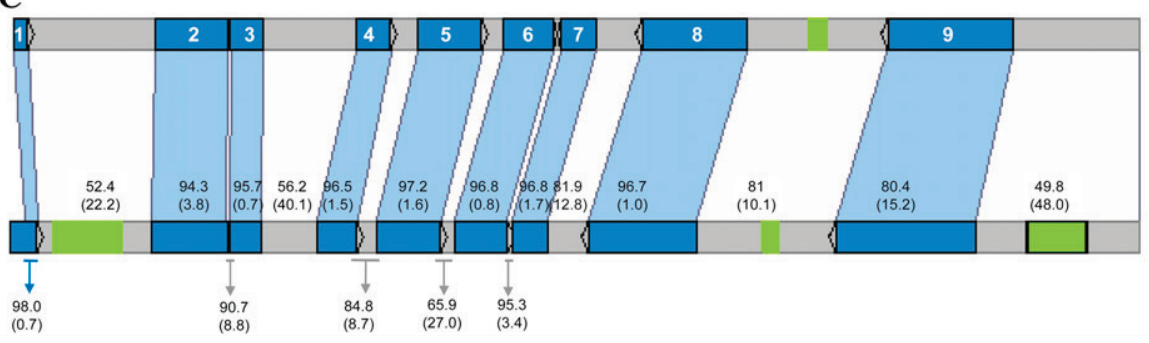

S. pennellii clone C11SpBP029K005.P4E08

S. Iycopersicum clone $\mathrm{C} 11 \mathrm{HBa} 0062 \mathrm{I} 24$

Figure 3. Comparative analysis between $S$. lycopersicum and $S$. pennellii orthologous genomic regions. Genes are indicated as blue arrows and coded according to Table II. Green blocks depict transposable elements. Green blocks squared in black correspond to retrotransposons, and their LTRs are indicated as black bars at the ends of the elements. The percentage identity and InDels (in parentheses) between genotypes along genic (including untranslated regions) and intergenic regions are indicated. Compared orthologous genomic regions of BIN $4 \mathrm{I}(\mathrm{A}), 7 \mathrm{H}(\mathrm{B})$, and $11 \mathrm{C}(\mathrm{C})$ are presented. [See online article for color version of this figure.]

S2C). Polymorphisms along each identified alignment were analyzed following stringent criteria: (1) nucleotide variations were regarded as reliable SNPs only if the quality of the base call achieved a quality value $(\mathrm{Qv}) \geq 20$; and (2) end sequences with only one $S$. lycopersicum matching region were used. This allowed the comparison of 59,510 bp between both species. SNPs varied among genomic regions, ranging from 2.1 per $100 \mathrm{bp}$ in BIN I of chromosome 4 to 9.7 per $100 \mathrm{bp}$ in BIN B of chromosome 2, with an average of 4.3 (Supplemental Table S2C), according to the values expected for these plant species (L. Mueller, personal communication). In the same regions, the distribution of InDels also varied between 0.37 per $100 \mathrm{bp}$ in BIN 4I and 0.5 per $100 \mathrm{bp}$ in BIN 1C. A graphical overview of SNP and InDel mapping revealed that there were no particular patterns of polymorphism within the analyzed chromosomal regions (Supplemental Fig. S1). A high proportion of the SNPs and InDels identified were detected within predicted coding regions (Supplemental Table S3). In the case of the analyzed region of chromosome 2 (which showed the highest percent- age of polymorphisms), all the SNPs and InDels detected fell within three gene categories: 29 (protein modification), 35 (unknown function), and 28 (DNA modifiers).

\section{Microsynteny and Evolutionary Analyses of S. pennellii and S. lycopersicum Orthologous Regions}

Large-insert clones from S. pennellii were compared with the corresponding conserved syntenic segments of $S$. lycopersicum in order to explore both the differences in genome structure and the sequence divergence between these closely related species. Although this work embraces the study of five genomic regions, the following analyses were focused solely on BINs 4I, $7 \mathrm{H}$, and $11 \mathrm{C}$ because they are the only ones that do not span repetitive sequences and for which unambiguous orthologous sequences from S. lycopersicum were available.

We observed that the syntenic regions contain 38 distinct genes showing conserved genomic ordering, orientation, and gene structure (exon/intron) between 
Table II. Comparative analysis between S. lycopersicum and S. pennellii orthologous genomic regions

SI, S. lycopersicum; Sp, S. pennellii; At, Arabidopsis; CB, total of compared bases; ND, not determined; UD, undetermined because $d n=0$.

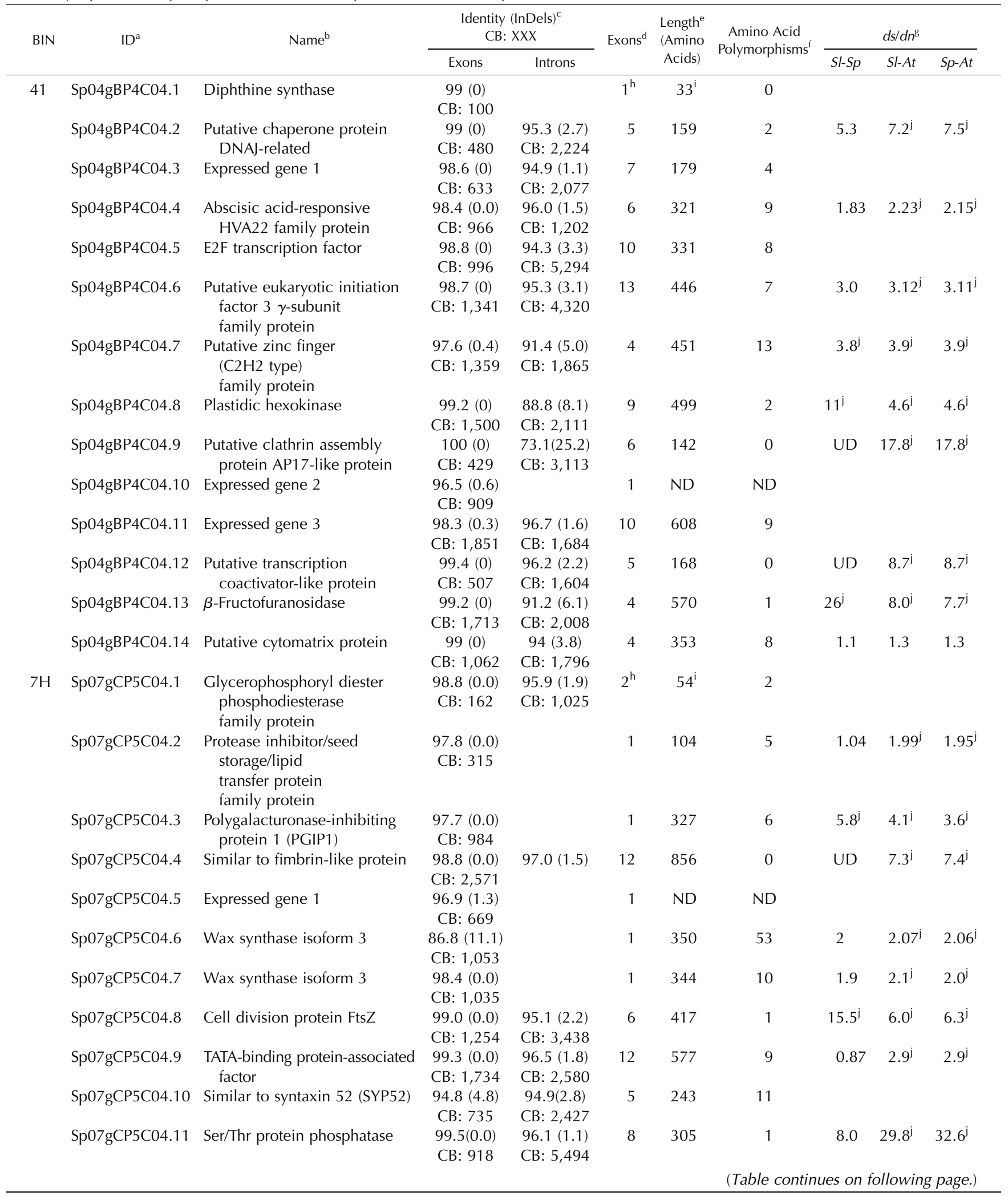




\begin{tabular}{|c|c|c|c|c|c|c|c|c|c|c|}
\hline \multirow[t]{2}{*}{$\mathrm{BIN}$} & \multirow[t]{2}{*}{$I D^{\mathrm{a}}$} & \multirow[t]{2}{*}{ Name $^{b}$} & \multicolumn{2}{|c|}{$\begin{array}{c}\text { Identity }(\text { InDels) } \\
\text { CB: XXX }\end{array}$} & \multirow[t]{2}{*}{ Exons $^{\mathrm{d}}$} & \multirow{2}{*}{$\begin{array}{l}\text { Length }^{\mathrm{e}} \\
\text { (Amino } \\
\text { Acids) }\end{array}$} & \multirow{2}{*}{$\begin{array}{c}\text { Amino Acid } \\
\text { Polymorphisms }\end{array}$} & \multicolumn{3}{|c|}{$d s / d n^{g}$} \\
\hline & & & Exons & Introns & & & & $S I-S p$ & $S I-A t$ & $S p-A t$ \\
\hline \multirow{10}{*}{$11 \mathrm{C}$} & Sp07gCP5C04.12 & $\begin{array}{l}\text { Lipid-binding serum } \\
\text { glycoprotein } \\
\text { family protein }\end{array}$ & $\begin{array}{l}98.8(0.0) \\
\text { CB: } 1,302\end{array}$ & $\begin{array}{l}95.1(2.3) \\
\text { CB: } 2,731\end{array}$ & 5 & 433 & 8 & 1.9 & $2.1^{\mathrm{j}}$ & $2.2^{\mathrm{j}}$ \\
\hline & Sp07gCP5C04.14 & $\begin{array}{l}\text { S-Adenosyl-L-Met:carboxyl } \\
\text { methyltransferase family } \\
\text { protein }\end{array}$ & $\begin{array}{l}99.1(0.0) \\
\text { CB: } 1,155\end{array}$ & $\begin{array}{l}80.1(11.7) \\
\text { CB: } 1,222\end{array}$ & 4 & 384 & 3 & 5.5 & $7.0^{j}$ & $6.6^{\mathrm{j}}$ \\
\hline & Sp07gCP5C04.15 & $\begin{array}{l}\text { Hyp-rich glycoprotein } \\
\text { family protein }\end{array}$ & $\begin{array}{c}96.5(1.2) \\
\text { CB: } 964\end{array}$ & $\begin{array}{l}91.8(3.1) \\
\text { CB: } 1,397\end{array}$ & $3^{\mathrm{h}}$ & $295^{\mathrm{i}}$ & 23 & & & \\
\hline & Sp11gBP4E08.1 & $\begin{array}{l}\text { Tetratricopeptide } \\
\text { repeat-containing protein }\end{array}$ & $\begin{array}{c}98.7(0.0) \\
\text { CB: } 476\end{array}$ & $\begin{array}{c}97.0(1.6) \\
\text { CB: } 507\end{array}$ & $3^{h}$ & $158^{i}$ & 3 & & & \\
\hline & Sp11gBP4E08.3 & $\begin{array}{l}\text { Glc-6-P/phosphate } \\
\text { translocator-related }\end{array}$ & $\begin{array}{l}98.2(0.0) \\
\text { CB: } 1,014\end{array}$ & $\begin{array}{l}93.8(1.2) \\
\text { CB: } 1,376\end{array}$ & 5 & 337 & 9 & 2.6 & $7.03^{j}$ & $7.04^{j}$ \\
\hline & Sp11gBP4E08.4 & $\begin{array}{l}\text { Peptidoglycan-binding LysM } \\
\text { domain-containing protein }\end{array}$ & $\begin{array}{l}98.9(0.0) \\
\text { CB: } 1,237\end{array}$ & $\begin{array}{l}94.7(2.2) \\
\text { CB: } 1,692\end{array}$ & 5 & 413 & 11 & 1.2 & $4.1^{\mathrm{j}}$ & $4.2^{\mathrm{j}}$ \\
\hline & Sp11gBP4E08.5 & Coiled-coil protein & $\begin{array}{l}98.8(0.0) \\
\text { CB: } 2,013\end{array}$ & $\begin{array}{l}96.0(2.8) \\
\text { CB: } 2,106\end{array}$ & 4 & 670 & 11 & $3.8^{\mathrm{j}}$ & $1.5^{j}$ & $1.5^{\mathrm{j}}$ \\
\hline & Sp11gBP4E08.6 & $\begin{array}{l}\mathrm{CH} 1 \text { (chlorophyll } b \\
\text { biosynthesis); } \\
\text { chlorophyllide a } \\
\text { oxygenase }\end{array}$ & $\begin{array}{l}98.9(0.0) \\
\text { CB: } 1,612\end{array}$ & $\begin{array}{l}95.4(1.5) \\
\text { CB: } 2,203\end{array}$ & 9 & 536 & 2 & $16.5^{\mathrm{j}}$ & $6.6^{j}$ & $6.8^{\mathrm{j}}$ \\
\hline & Sp11gBP4E08.7 & $\begin{array}{l}\text { BTB/POZ domain-containing } \\
\text { protein }\end{array}$ & $\begin{array}{l}99.8(0.0) \\
\text { CB: } 987\end{array}$ & $\begin{array}{l}95.1(2.7) \\
\text { CB: } 1,812\end{array}$ & 4 & 329 & 1 & 4.0 & $6.5^{j}$ & $6.3^{\mathrm{j}}$ \\
\hline & Sp11gBP4E08.8 & F-box family protein & $\begin{array}{c}99.3(0.0) \\
\text { CB: } 990\end{array}$ & $\begin{array}{l}96.5(1.1) \\
\text { CB: } 7,288\end{array}$ & 11 & 330 & 3 & 3.9 & $6.1^{\mathrm{j}}$ & $6.1^{\mathrm{j}}$ \\
\hline
\end{tabular}

${ }^{\mathrm{a}}$ Gene identification. $\quad{ }^{\mathrm{b}}$ Gene functional identity. $\quad{ }^{\mathrm{c}}$ Percentage of identity and InDels between the S. lycopersicum and S. pennellii regions analyzed. $\quad{ }^{\mathrm{d}}$ Number of exons compared between both genotypes. ${ }^{\mathrm{N}}$ Number of amino acids compared between both genotypes. ${ }^{\mathrm{f}}$ Polymorphic amino acids on the predicted protein sequence. $\quad{ }^{g}$ Synonymous distance/nonsynonymous distance. hexons not included in the comparative evolutionary analysis of $S$. pennellii and $S$. lycopersicum orthologous regions. ínly partial sequences were compared because genes were located at the end of the clones for any of the genotypes. $\quad$ 'Statistically significant purifying selection $(P<0.05)$.

both species and that this nearly perfect colinearity is slightly altered by intergenic regions of variable size and a differential pattern of TE insertions (Fig. 3; Supplemental Table S5). An analysis of the distribution of polymorphisms revealed, as expected, a higher percentage of InDels in intergenic regions than in genic ones (Fig. 3) and in introns as opposed to exons (Table II). The degree of conservation for each gene was evaluated by estimating the rate of synonymous and nonsynonymous substitution distances $(d s / d n)$. This analysis was carried out for all genes that fulfilled the following criteria: (1) they displayed full-length coding sequences (thus, uncompleted genes located on the BAC/cosmid ends were excluded); (2) they exhibited no frameshifts or stop codons (gene Sp07gCP5C04.8 was excluded); (3) they had Arabidopsis orthologs; and (4) they showed homogeneous relative substitution rates between S. pennellii and S. lycopersicum, considering Arabidopsis as an outgroup. For all 27 analyzed genes, the ratio $d s / d n$ was greater than 1 , thus indicating the absence of positive selection (Table II). A test of selection was performed in order to assess whether genes were undergoing neutral $(d s=d n)$ or purifying $(d s>d n)$ selection, revealing that both cases were present. Interestingly, all the genes that displayed nonstatistically significant purifying selection between $S$. pennellii and $S$. lycopersicum also displayed amino acid polymorphisms. It is important to note that the $d s / d n$ ratio may be subject to misinterpretation if the codon usage is restricted; however, for the data set used in this work, no codon bias was observed for any gene in all three species analyzed.

Since in this work, 27 loci belonging to three different chromosomes of $S$. pennellii were sequenced and the corresponding orthologs from $S$. lycopersicum were identified, these data represent a unique source to investigate the divergence time between these closely related tomato species. Using the fossil record estimation of 120 MYA for the divergence between Arabidopsis and Solanaceae 
(Bell et al., 2005; Magallon and Sanderson, 2005) and the $d s$ of the concatenated coding sequences, the genomic region-specific substitution rates and the species divergence time were estimated. Analysis of the substitution rate revealed no significant differences between BINs, suggesting that the three regions analyzed may code for important conserved proteins (Table III). When all three regions are considered together, the species divergence time was estimated at 2.7 MYA (Fig. 4).

Two Copia-like long terminal repeat (LTR) retrotransposons with perfect tandem duplication sites were found among the genomic regions analyzed in this work. A SHACOP_I_MT in BIN 4I was present only in S. pennellii (Supplemental Table S5), and a TOPSCOTCH_ LP_I in BIN 11C was found only in S. lycopersicum. Based on the molecular clock, their insertion times were estimated and, as expected, both elements appeared after the species split (Fig. 4), in agreement with the species divergence time estimated above.

\section{DISCUSSION}

In the study described herein, we performed a largescale analysis of the $S$. pennellii genome and compared it with that of its cultivated tomato counterpart $S$. lycopersicum. To achieve this goal, different approaches were taken: (1) a macrosynteny analysis via the construction of a physical map; (2) sequencing, annotation, and functional categorization of a portion of the wild tomato genome; (3) polymorphism evaluation between these species; and (4) a microsynteny analysis aimed at exposing the variation that has driven the evolutionary change between these two species. Data compilation was focused on five genomic regions: BINs 1C, 2B, 4I, 7H, and 11C, spanning 104 QTLs associated with fruit carbon primary metabolism (Schauer et al., 2006, 2008), fruit color (Liu et al., 2003), volatile content (Tieman et al., 2006), and yield traits linked to metabolite variations found in the fruits (Eshed and Zamir, 1995; Schauer et al., 2006; Semel et al., 2006). Although the high number of QTLs in the studied regions may merely reflect the effect of a few QTLs on several related traits, rather than the existence of multiple independent QTLs, the analyses of the generated data set will serve as a bridge for linking the genome to phenotypes for basic and applied studies.

\section{Comparative Physical Map between S. pennellii and S. lycopersicum}

Due to its versatility and low cost, physical mapping has become a natural component of large genomesequencing endeavors (Gregory et al., 2002; Wallis et al., 2004). In fact, this strategy was originally adopted for the tomato genome-sequencing project (Mueller et al., 2009). Here, a comparative physical map was built anchoring 374 S. pennellii BAC/cosmid clones, which resulted in approximately $10 \%$ of the physical distance coverage of the five selected regions and $1 \%$ of the total wild tomato genome. Across the five regions studied, $58 \mathrm{~S}$. lycopersicum BAC clones were fully sequenced and available on the SGN Web site. The physical map presented here anchored 31 of these clones to $S$. pennellii sequences, representing reliable coverage of $53 \%$ of the sequence information available for the reference genome.

Overall, the topology of the physical map built here reveals a high level of colinearity between $S$. pennelli and the cultivated tomato genomes. However, this colinearity is based on the quality of the S. lycopersicum physical map and on the genetic distances between the markers of the $S$. lycopersicum $\times S$. pennellii reference map, which are far from perfect, especially considering that the latter was constructed with fewer than 100 individuals. However, two independent results support the accuracy of the $S$. pennelli physical map. First, $24 \%$ of the initially anchored clones were further localized at the same position by hybridization with another closely linked or cosegregating marker. Second, the positions of $43 \%$ of the anchored clones were confirmed by sequence identity to both mapped markers and to $S$. lycopersicum genomic sequences.

The hypothesis of Solanaceae genome colinearity has been proposed several times based on comparative genetic mapping experiments, which yielded evidence for the conservation of gene repertoire and colinear chromosome segments for related species (Wang et al., 2008). Particular features of the physical map presented here suggest the presence of local breaks in the colinearity of the regions analyzed. For example, the instances wherein $S$. pennelli and $S$. lycopersicum clones are distant from each other are suggestive of chromosomal inversion and/or InDels. Moreover, some $S$. pennellii genomic intervals seem to

\begin{tabular}{|c|c|c|c|c|}
\hline $\mathrm{BIN}$ & S. lycopersicum BAC & S. pennellii BAC/Cosmid ${ }^{b}$ & Substitution Rate ${ }^{c}$ & Divergence Time $^{d}$ \\
\hline $4 \mathrm{I}^{\mathrm{e}}$ & C04HBa0331L22 & C04SpBP093E005.P4C04 & $4.26 \times 10^{-09}$ & $2,936,857( \pm 690,736)$ \\
\hline $11 C^{g}$ & $\mathrm{C} 1 \mathrm{HBa0062I24}$ & C11SpBP029K005.P4E08 & $4.40 \times 10^{-09}$ & $2,838, .221( \pm 667,537)$ \\
\hline $4 \mathrm{l} / 7 \mathrm{H} / 11 \mathrm{C}$ & All $S$ lycopersicum genes & All S. pennellii genes & $4.37 \times 10^{-09}$ & $2,744,163( \pm 448,205)$ \\
\hline
\end{tabular}

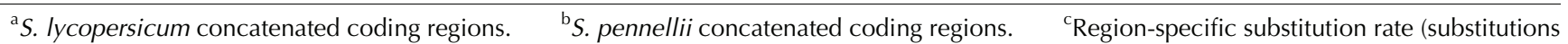
per site per year) calculated according to the fossil record estimation of 120 MYA for the divergence between Arabidopsis and Solanaceae (Bell et al., 2005; Magallon and Sanderson, 2005). ${ }^{\mathrm{d}}$ Species divergence time in MYA ( \pm confidence interval). ${ }^{\mathrm{e}}$ Concatenated coding regions of genes $2,4,6,7,8,9,12,13$, and $14 . \quad{ }^{f}$ Concatenated coding regions of genes $2,3,4,6,7,8,9,11,12$, and 14 . ${ }^{\mathrm{g}}$ Concatenated coding regions of genes 2 to 9 . 


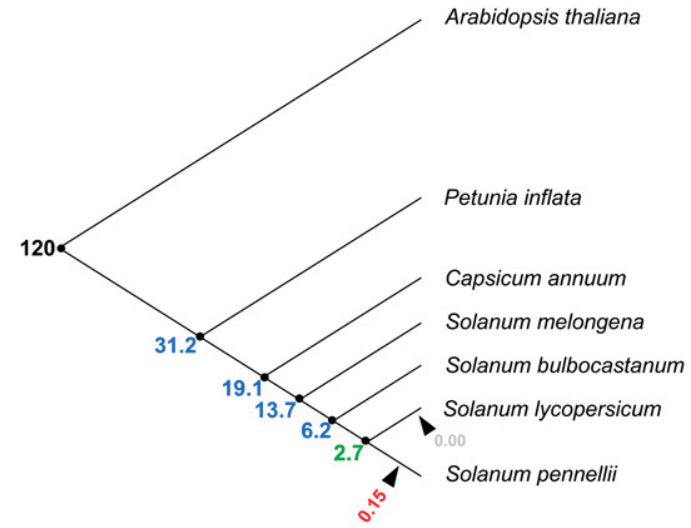

Figure 4. Species divergence time in MYA according to Bell et al. (2005; black), Magallon and Sanderson (2005; black), and Wang et al. (2008; blue). S. pennellii and S. lycopersicum divergence (green) was estimated using a molecular clock. SHACOP_I_MT (red) and TOPSCOTCH_LP_I (gray) retrotransposon insertions are indicated by arrows. [See online article for color version of this figure.]

be compressed in S. lycopersicum, hinting at the expansion of specific $S$. pennellii regions, which is in agreement with the larger genome size estimation for this species (Arumuganathan and Earle, 1991). The results of microsynteny analysis, which revealed larger intergenic regions in $S$. pennellii than in $S$. lycopersicum, reinforce this statement. These rearranged regions, together with the screening for SNPs and InDels, will likely facilitate the identification of polymorphic markers.

As reported by Zhao et al. (2002), the sequence of 114 $\mathrm{BAC}$ clones from the taxonomically related rice subspecies Oryza sativa indica 'Guangluai 4' was particularly useful for gap closing of sequence gaps of rice chromosome 4. Although a significant number of InDels were detected between the two tomato species, the S. pennellii BAC/cosmid clones anchored in this work allowed the detection of 64 extension clones (those matching the S. lycopersicum genome at only one end) and another 21 clones filling in gaps between two $S$. lycopersicum clones (those matching two nonoverlapping $S$. lycopersicum clones of the same region). Together with the information obtained from the anchoring results described above, all these sequences provide useful tools for comparative genome analyses, map-based cloning, validation of genome sequence assemblies, and an easier access to the regulatory sequences surrounding important genes.

\section{Annotation of S. pennellii Coding Sequences}

After annotation of the 436 nonredundant end sequences and the nine BAC/cosmid clones, 407 genes were identified. In agreement with all large-scale plant genome analyses, our results for large-insert sequences display an inverse distribution between genes and TE-containing regions (Arabidopsis Genome Initiative, 2000; Paterson et al., 2009). In particular, the gene density along BIN 4I $\left(0.2\right.$ genes $\left.\mathrm{kb}^{-1}\right)$ doubles that of the rest of the genomic regions analyzed $(0.1$ genes $\mathrm{kb}^{-1}$ ), while it displays the lowest density of TEs. Gene identification by end sequence data analysis also revealed BINs $4 \mathrm{I}$ and $7 \mathrm{H}$ as the most gene-enriched regions. These gene density values are higher than those previously estimated for S. lycopersicum heterochromatin (Van der Hoeven et al., 2002; Wang et al., 2008; Mueller et al., 2009), although it should be noted that they may reflect a bias considering the high abundance of QTLs in these genomic regions.

Focusing on a region of tomato chromosome 7 of about $57 \mathrm{~kb}$, Rossberg et al. (2001) found the same arrangement of five predicted genes as that found in a region of Arabidopsis chromosome 1. This kind of colinearity with Arabidopsis has also been reported for a region of tomato chromosome 2 harboring the major fruit-shape locus ovate with Arabidopsis chromosome 4 (Ku et al., 2001) and between a tomato centromeric BAC of chromosome 6 harboring the FER locus and three distinct regions on Arabidopsis chromosomes 2, 3, and 5 (Guyot et al., 2005). With the exception of the case of BIN 1C, our results from BAC/ cosmid full-length sequencing revealed several examples of microsynteny between the $S$. pennellii and Arabidopsis genomes. These results, together with those recently published from genome-wide approaches in Arabidopsis detecting a few genetic "hot spots" exhibiting major effects on hundreds of QTLs (Lisec et al., 2008; Fu et al., 2009), open new routes to explore further relations between common pathways regulating metabolism in these two species.

Concerning gene categorization, the number of gene classes per BIN ranges between nine for BIN 11C and 19 for BIN 7H, suggesting a functional compartmentalization of the genome, at least for the analyzed regions. Among all the identified genes, several plausible candidates that could directly underlie previously reported metabolic QTLs can be identified. However, the analyzed sequences represent only $10 \%$ of these regions, and the participation of these genes defining the metabolic QTLs remain to be functionally proven. A combination of the generation of recombinant lines harboring smaller introgressions of the $S$. pennellii genome and reverse genetic approaches is under way at present to assess the candidature of these genes.

\section{Microsynteny and Evolutionary Analysis of Orthologous Regions}

Domestication of crops is arguably the most dramatic recent event in plant evolution. Evidence indicates that most of the anatomical changes selected during domestication are determined by the modification of gene expression patterns of a few regulatory loci (Doebley et al., 1997). This is the case, for example, of the fw2.2 locus, responsible for the fruit weight variation between wild and cultivated tomato (Frary et al., 2000). Moreover, the large- and small-fruit alleles 
do not differ in protein sequence but in transcription levels due to promoter polymorphisms (Nesbitt and Tanksley, 2002). With the putative fruit-related loci analyzed in this work, a slightly different panorama is observed when comparing S. pennellii and S. lycopersicum. A total of 277,534 bases were compared between both species. A total of 32 out of the 38 completed genes identified displayed amino acid polymorphisms, and 16 out of the 27 genes with estimated $d s / d n$ displayed neutral selection. Even the eight genes with significant purifying selection showed amino acid polymorphisms. These results indicate that coding regions have accumulated polymorphisms since both species diverged. With the exception of a cytomatrix-encoding protein (Sp04gBP4C04.14), all the coding regions displayed significant purifying selection between tomato and Arabidopsis, thus indicating that the analyzed genes have a conserved function.

Using an estimated substitution rate of $6.03 \times 10^{-9}$ and four loci, Nesbitt and Tanksley (2002) reported that S. pennellii and S. lycopersicum diverged 7.0 MYA. More recently, Wang et al. (2008) reported the analysis of sequences for an unduplicated conserved syntenic segment in the genomes of five Solanaceae species (petunia [Petunia hybrida], pepper [Capsicum annuum], eggplant [Solanum melongena], potato [Solanum tuberosum], and tomato). The results indicated that the last common ancestor of these species lived approximately 31.2 MYA and that the divergence of tomato and potato had occurred approximately 6.2 MYA. In this study, a more precise calculation using specific substitution rates and genetic distances of 27 different loci along three different chromosomes allows us to estimate the divergence between $S$. pennellii and S. lycopersicum at 2.7 MYA. Since $S$. pennellii is one of $S$. lycopersicum's most distantly related wild species, our results indicate that the lycopersicum species of the genus Solanum began its radiation more recently than previously estimated. Two different Copia-like LTR retrotransposons were found through the analyzed regions. Their corresponding insertion dates were estimated, and they were shown to have occurred after both tomato species diverged. Recently, several reports have demonstrated the impact of TEs on important agronomical traits. As illustrative examples, we can mention the effects of the insertion of retrotransposons in $\beta$-carotene accumulation in cauliflower (Brassica oleracea) plastids (Lu et al., 2006) and in gene duplication causing morphological variations of tomato fruit (Xiao et al., 2008). In this direction, work is in progress to further investigate whether the recently inserted retrotransposons identified here could be involved in differential gene expression patterns between S. pennellii and S. lycopersicum.

\section{CONCLUSION}

In this work, we integrated physical and genetic maps of selected regions of two tomato species, $S$. lycopersicum and S. pennellii. Together with BAC/ cosmid end sequencing, we detected a number of putative SNPs and InDels that could be particularly useful as a screening tool in fine-mapping approaches and that, following experimental validation, could be of considerable practical relevance in breeding programs. Moreover, they will aid in filling marker-poor segments of the genome and in understanding the relationship between levels of crossing over per physical distance and levels of polymorphism in Solanaceae species. Targeted sequencing of BAC/cosmid clones, gene annotation, and comparative analyses suggest that changes in both coding and noncoding sequences could be implicated in the phenotypic diversity within the genus. In addition, a precise estimation of $S$. pennellii and $S$. lycopersicum divergence time indicates that tomato radiation occurred 2.7 MYA.

The framework of the physical map, sequence assembly, and novel candidate genes presented here provides a considerable collection of resources for tomato research, especially considering the 104 QTLs that have previously been mapped to the genomic regions analyzed. Together with previous genomic sequences of $S$. pennellii candidate genes (Bermúdez et al., 2008), these resources constitute a valuable data set repository of genomic information for this Solanaceae species. Work is in progress to further characterize the functions of several of the novel candidate genes described here.

\section{Note}

While this paper was under revision, a draft of the tomato genome sequence was released (December 1, 2009, International Tomato Genome Sequencing Consortium; http://solgenomics.net/tomato/). Thus, the analyses performed in this work were rerun and 82 further $S$. pennellii BAC/cosmid clones were putatively anchored to S. lycopersicum scaffolds. However, it is important to point out that these scaffolds are not yet physically ordered and, consequently, the expected map positions of these $S$. pennellii sequences are not confirmed. Although the $S$. pennellii sequences reported here were compared with a considerable number of BAC sequences and with a draft version of the cultivated tomato genome, $35 \%$ of the $S$. pennellii $\mathrm{BAC} /$ cosmid clones remained unanchored. This could be indicative of either a discontinued synteny between the species and/or a lack of corresponding S. lycopersicum genomic sequence information and thus requires further analyses.

\section{MATERIALS AND METHODS}

\section{Screening and Anchoring of Solanum pennellii Genomic Clones}

The five genomic regions selected for analysis were BINs 1C, 2B, 4I, 7H, and $11 \mathrm{C}$, which were determined by the overlapping of Solanum pennelli IL introgressed fragments according to the Tomato-EXPEN 1992 map (Solanum 
lycopersicum LA925 × S. pennellii LA716; http:/ / www.sgn.cornell.edu/; Eshed and Zamir, 1995). In order to select markers spanning the regions of interest, Southern-blot hybridizations were performed using the BIN flanking markers as probes (Sambrook et al., 1989). This analysis allowed us to delimit the five selected BINs between markers TG24 and TG80, TG31 and CT106, CT173 and TG464, TG199 and TG499, and TG523 and TG384 for the 1C, 2B, 4I, 7H, and $11 \mathrm{C}$ chromosomal segments, respectively (data not shown). The selected regions carry a total of 277 molecular markers mapped on the publicly available Tomato-EXPEN 2000 and Tomato-EXPEN 1992 maps spanning 99.1 cM (BIN 1C, 19.4 cM; BIN 2B, 13.0 cM; BIN 4I, 11.7 cM; BIN 7H, 36.0 cM; BIN $11 \mathrm{C}, 19.0 \mathrm{cM})$. A total of 104 markers that map to single loci in S. lycopersicum were used for library screening (Table I). Ninety overgo-derived markers were selected from the collection available at the SGN site. The other 14 were inhouse designed with the OligoSpawn software (Zheng et al., 2006). The complete list of the 104 overgoes used in this study is given in Supplemental Table S1.

The S. pennellii (accession LA716, the donor parent of the IL population) genomic libraries were built in pBeloBACII (52,992 clones) and pCLD04541 (50,304 clones) vectors for BAC and cosmid, respectively (Chen et al., 2007) Both libraries were the result of genomic DNA partially digested with HindIII endonuclease. High-density membranes were screened with 15 to 20 pooled overgo probes (first hybridization). A two-dimensional pooling strategy was performed in order to anchor each clone to its corresponding hybridizing marker (second hybridization). Hybridizations were performed according to Sambrook et al. (1989) with minor modifications. BAC/cosmid filters were prehybridized in a solution containing $2 \times$ SSC, $0.1 \%$ SDS, and $10 \mathrm{mg} \mathrm{mL}^{-1}$ salmon sperm DNA for $3 \mathrm{~h}$ at $65^{\circ} \mathrm{C}$. Probes were denatured with $0.4 \mathrm{~N} \mathrm{NaOH}$ added to each hybridization recipient and hybridized at $65^{\circ} \mathrm{C}$ overnight. Filters were washed in $2 \times$ SSC and $0.1 \%$ SDS at $65^{\circ} \mathrm{C}$ for $5 \mathrm{~min}$ and then in $1.0 \times$ SSC and $0.1 \%$ SDS at $65^{\circ} \mathrm{C}$ for $30 \mathrm{~min}$.

\section{BAC/Cosmid Clone Insert Size Estimation and Sequencing}

DNA was purified using the R.E.A.L Prep 96 Plasmid Kit (Qiagen). Clone insert sizes were estimated by pulsed-field gel electrophoresis by digesting 0.5 to $2 \mu \mathrm{g}$ of purified DNA with NotI endonuclease in order to release the insert. Insert size was calculated with ImageQuant TL 7.0 software (G\&E).

For BAC/cosmid end sequencing, 0.2 to $0.5 \mu \mathrm{g}$ of purified DNA was used, and sequencing reactions were performed with ABI Big Dye Terminator version 3.1. Samples were read in an ABI 3730 sequencer. Vector and lowquality sequences $(\mathrm{Qv}<20)$ were trimmed out, and only reads above 300 nucleotides were considered.

$\mathrm{BAC} /$ cosmid full-length sequencing was performed either by shotgun (Macrogen) or pyrosequencing (454 Life Sciences, through a partnership with Roche). Reads were assembled using the Phred+Phrap+Consed software package (Ewing and Green, 1998; Gordon et al., 1998).

\section{Map Building}

All the generated sequences were masked using the Repeat Masker program (http://www.repeatmasker.org) before analysis in order to avoid further associations with nonorthologous regions. End reads from BAC/ cosmid clones, anchored to the same marker, were subjected to contig assembly with the DNA Baser version 2.60 .90 software with default parameters. A Python script (Chapman and Chang, 2000) was used to analyze the nonrepetitive sequences, either from contigs or singletons by BLASTN (Altschul et al., 1990). The databases used were (1) all currently available $S$. lycopersicum genomic clone sequences and (2) the marker sequence database. Both databases are accessible at the ftp site of http://www.sgn.cornell.edu/. For comparison against $S$. lycopersicum BAC sequences (version 441, October 5, 2009 , containing 1,188 sequences and encompassing 127,592,092 bp), a hit criterion of above $80 \%$ identity was considered. For comparison against marker sequences (database containing 9,625 sequences and encompassing $3,947,844 \mathrm{bp}$ ), only hits with at least $96 \%$ identity across more than $150 \mathrm{bp}$ were considered. Furthermore, the associations between S. lycopersicum genomic clone sequences and marker sequences were identified using the Marker search feature from the SGN Web site with the parameters mentioned above. The complete set of established relationships is presented in Supplemental Table S2A. Anchored clones and end sequences are available at the SGN Web site in the Tomato Physical Map interface (http://www.sgn.cornell. edu/cview/).

\section{Annotation of BAC/Cosmid End Sequences and Polymorphism Analyses}

Nonrepetitive singletons and contigs were annotated by comparison against the following databases: nonredundant proteins at the National Center for Biotechnology Information (November 2008 version, 9,487,554 sequences and $3,243,454,420 \mathrm{bp}$ ), the unigenes database at SGN (February 2009 version, 123,550 sequences and 92,327,235 bp), and the Arabidopsis (Arabidopsis thaliana) protein database (The Arabidopsis Information Resource $8,38,963$ sequences and 85,192,362 bp) using BLASTN and BLASTX with e-values $\leq 10^{-6}$, above $80 \%$ identity along $\geq 300 \mathrm{bp}$. Repetitive sequences were annotated by comparison against The Institute for Genomic Research (TIGR) plant repeat databases (ftp://ftp.tigr. org/pub/data/TIGR_Plant_Repeats/) using BLASTN with e-values $\leq 10^{-5}$ (Altschul et al., 1990). All annotated sequences (including large-insert sequences; see below) were organized in functional classes according to the MapMan ontology software (http:// mapman.mpimp-golm.mpg.de).

SNP and InDel analyses were performed with the SeqScape version 2.5 software using a base call value of 20 or greater as true nucleotides, removing bases from the ends until fewer than four bases out of 20 had $Q v<20$ and filtering settings by default. Graphical output was performed by a bespoke Python script, which parses the formatted SeqScape output and reads both the position and the kind of polymorphism (SNP or InDel). An arbitrary value of 1 was used for SNPs, while InDels could take a value of 2 or 3 depending of the InDel size. Positive values were used for SNPs and insertions and negative values were used for deletions.

\section{Large-Insert Sequence Annotation}

S. pennellii BAC/cosmid full-length sequences as well as three S. lycopersicum BAC clones, C04HBa0331L22, C07HBa0061J13, and C11HBa0062I24, were annotated using two different gene prediction programs: FGENESH (www. softberry.com; Salamov and Solovyev, 2000) and Augustus (http:/ /augustus. gobics.de; Stanke et al., 2004). Each BAC/cosmid was screened independently against the SGN unigene database (http://www.sgn.cornell.edu/; September 2009 version, 123,550 sequences and 92,327,235 bp) using the sequence comparison programs cross-match (www.phrap.org). Predicted genes were hand curated by comparison with the corresponding identified unigene by BLAST (Altschul et al., 1990). When no unigene hit was found at the SGN database, TIGR Plant Transcript Assemblies database was used (http:// plantta.tigr.org/). Only genes predicted both by gene prediction programs and matching an mRNA sequence were annotated. The criteria for gene annotation were (1) at least $95 \%$ identity and above $90 \%$ coverage of the unigene length or (2) at least $70 \%$ identity over $85 \%$ of sequence length when only Arabidopsis mRNAs were found.

Repetitive sequences were identified using RepeatMasker (http://www. repeatmasker.org) software, and only elements covering at least $70 \%$ of the matching repeat sequence were considered. LTR retrotransposons were also identified using LTR finder (http://tlife.fudan.edu.cn/ltr_finder/). Element class and family name, as well as the matching repeat sequence available at Repbase (www.girinst.org), are indicated in Supplemental Table S5.

A new nomenclature to name $S$. pennellii genes is proposed: $\mathrm{SpXXgB}$ (or C) XXXXX.\#, where Sp stands for $S$. pennellii, the two digits indicate the chromosome number, $\mathrm{g}$ represents the genomic sequence, $\mathrm{B}$ stands for BAC or $\mathrm{C}$ for cosmid vectors, the five digits address library coordinates, and \# stands for consecutive numbers indicating gene order within the clone.

For comparative analysis between S. lycopersicum and S. pennellii orthologous genomic regions, the $S$. lycopersicum BAC clone sequence that better spanned the $S$. pennellii sequence was selected. Sequence comparisons between genotypes for InDel and SNP identification were calculated using the Needleman-Wunsch global alignment algorithm available at http:/ / www.ebi. ac.uk/Tools/emboss/align/.

\section{Evolutionary Analyses}

Alignments of coding regions were performed with ClustalW multiple alignment software (version 1.5; Thompson et al., 1994) and hand curated with reference to amino acid alignment. Synonymous ( $d s)$ and nonsynonymous $(d n)$ distances and their SE values were estimated with MEGA 3.1 (Kumar et al., 2004) using the corrected Nei-Gojobori method (JukesCantor). Codon bias was determined by the effective number of codons value computed using DNAsp version 4.10.9 (Rozas et al., 2003). Test of 
selection was also performed with MEGA 3.1 (Kumar et al., 2004) using the corrected Nei-Gojobori method. To reject the null hypothesis of neutral selection $(d s=d n), P<0.05$ was considered in the $Z$ test. Relative rate tests were performed utilizing HYPHY (http://www.hyphy.org) using the codon model proposed by Muse and Gaut (1994). To reject the homogeneity null hypothesis, $P<0.05$ was considered in the $\chi^{2}$ test. Genomic region-specific substitution rates $(K)$ and species divergence time were estimated using $K=d s / 2 T$, where $d s$ is the estimated number of synonymous substitutions per site between homologous sequences (synonymous distance) and $T$ is the divergence time. $K$ was estimated using the fossilsupported Arabidopsis/Solanaceae divergence time (120 MYA; Bell et al., 2005; Magallon and Sanderson, 2005), and ds was estimated based on concatenated coding regions per chromosome.

For retrotransposon dating, both LTRs of copies with target site duplications were aligned using the ClustalW multiple alignment software (version 1.5; Thompson et al., 1994). The distance $(D)$ between LTRs and its SE were estimated with MEGA 3.1 (Kumar et al., 2004) using Kimura 2-parameter, which corrects for homoplasy and differences in the rates of transition and transversion. The retrotransposon insertion date was estimated using $T=D / 2 K$, where $K$ represents the $1.3 \times 10^{-8}$ substitutions per site per year as proposed by Ma and Bennetzen (2004). Confidence intervals were calculated using the SE of the mean distance $(D)$ as estimated with MEGA 3.1.

Sequence data from this article have been deposited within the GenBank data libraries under accession numbers FI277973 to FI278499, FJ809740 to FJ809747, and FJ812349.

\section{Supplemental Data}

The following materials are available in the online version of this article. Supplemental Figure S1. SNP and InDel mapping.

Supplemental Table S1. Markers used for S. pennellii BAC/cosmid genomic library screening.

Supplemental Table S2. S. pennellii physical map data, S. pennellii contig sequences, and SNPs and InDels between S. pennellii end sequences and S. lycopersicum BAC clones.

Supplemental Table S3. BAC/cosmid end sequence annotation.

Supplemental Table S4. Annotation of S. pennellii fully sequenced BAC/ cosmid clones from BINs 1C, 2B, 4I, 7H, and 11C.

Supplemental Table S5. S. pennellii transposable elements identified in full-length sequenced clones.

\section{ACKNOWLEDGMENTS}

We thank Mariana Conte for technical assistance and Agustín Montenegro and Ignacio Tevez for taking care of the tomato plants. L.K., R.A., and F.C. are members of Consejo Nacional de Investigaciones Científicas y Técnicas.

Received November 6, 2009; accepted January 26, 2010; published January 29, 2010.

\section{LITERATURE CITED}

Altschul SF, Gish W, Miller W, Myers EW, Lipman DJ (1990) Basic local alignment search tool. J Mol Biol 215: 403-410

Arabidopsis Genome Initiative (2000) Analysis of the genome sequence of the flowering plant Arabidopsis thaliana. Nature 408: 796-815

Arumuganathan K, Earle E (1991) Estimation of nuclear DNA content of plants by flow cytometry. Plant Mol Biol Rep 9: 208-218

Bell CD, Soltis DE, Soltis PE (2005) The age of the angiosperms: a molecular timescale without a clock. Evolution 59: 1245-1258

Bermúdez L, Urias U, Milstein D, Kamenetzky L, Asis R, Fernie AR, Van Sluys MA, Carrari F, Rossi M (2008) A candidate gene survey of quantitative trait loci affecting chemical composition in tomato fruit. J Exp Bot 59: 2875-2890
Chapman BA, Chang JT (2000) Biopython: Python tools for computational biology. ACM SIGBIO Newsletter 20: 15-19

Chen KY, Cong B, Wing R, Vrebalov J, Tanksley SD (2007) Changes in regulation of a transcription factor lead to autogamy in cultivated tomatoes. Science 318: 643-645

Doebley J, Stec A, Hubbard L (1997) The evolution of apical dominance in maize. Nature 386: 485-488

Eshed Y, Zamir D (1995) An introgression line population of Lycopersicon pennellii in the cultivated tomato enables the identification and fine mapping of yield-associated QTL. Genetics 141: 1147-1162

Ewing B, Green P (1998) Basecalling of automated sequencer traces using phred II: error probabilities. Genome Res 8: 186-194

Fernie AR, Willmitzer L (2001) Molecular and biochemical triggers of potato tuber development. Plant Physiol 127: 1459-1465

Frary A, Nesbitt TC, Grandillo S, Knaap E, Cong B, Liu J, Meller J, Elber R, Alpert KB, Tanksley SD (2000) fw2.2: a quantitative trait locus key to the evolution of tomato fruit size. Science 289: 85-88

Fridman E, Carrari F, Liu YS, Fernie A, Zamir D (2004) Zooming in on a quantitative trait for tomato yield using interspecific introgressions. Science 305: 1786-1789

Fridman E, Pleban T, Zamir D (2000) A recombination hotspot delimits a wild-species quantitative trait locus for tomato sugar content to $484 \mathrm{bp}$ within an invertase gene. Proc Natl Acad Sci USA 97: 4718-4723

Fu J, Keurentjes JJB, Bouwmeester H, America R, Verstappen FWA, Ward JL, Beale MH, de Vos RCH, Dijkstra M, Scheltema RA, et al (2009) System-wide molecular evidence for phenotypic buffering in Arabidopsis. Nat Genet 41: 166-167

Gordon D, Abajian C, Green P (1998) Consed: a graphical tool for sequence finishing. Genome Res 8: 195-202

Gregory SG, Sekhon M, Schein J, Zhao S, Osoegawa K, Scott CE, Evans RS, Burridge PW, Cox TV, Fox CA, et al (2002) A physical map of the mouse genome. Nature 418: 743-750

Guyot R, Cheng X, Su Y, Cheng Z, Schlagenhauf E, Keller B, Ling HQ (2005) Complex organization and evolution of the tomato pericentromeric region at the FER gene locus. Plant Physiol 138: 1205-1215

Ku HM, Liu J, Doganlar S, Tanksley SD (2001) Exploitation of Arabidopsistomato synteny to construct a high-resolution map of the ovate-containing region in tomato chromosome 2. Genome 44: 470-475

Kumar S, Tamura K, Nei M (2004) MEGA3: integrated software for molecular evolutionary genetics analysis and sequence alignment. Brief Bioinform 5: 150-163

Lippman ZB, Semel Y, Zamir D (2007) An integrated view of quantitative trait variation using tomato interspecific introgression lines. Curr Opin Genet Dev 17: 545-552

Lisec J, Meyer RC, Steinfath M, Redestig H, Becher M, Witucka-Wall H, Fiehn O, Törjék O, Selbig J, Altmann T, et al (2008) Identification of metabolic and biomass QTL in Arabidopsis thaliana in a parallel analysis of RIL and IL populations. Plant J 53: 960-972

Liu YS, Gur A, Ronen G, Causse M, Damidaux R, Buret M, Hirschberg J, Zamir D (2003) There is more to tomato fruit colour than candidate carotenoid genes. Plant Biotechnol J 1: 195-207

Lu S, Van Eck J, Zhou X, Lopez AB, O'Halloran DM, Cosman KM, Conlin BJ, Paolillo DJ, Garvin DF, Vrebalov J, et al (2006) The cauliflower Or gene encodes a DnaJ cysteine-rich domain-containing protein that mediates high levels of $\beta$-carotene accumulation. Plant Cell 18: 3594-3605

Ma J, Bennetzen JL (2004) Rapid recent growth and divergence of rice nuclear genomes. Proc Natl Acad Sci USA 101: 12404-12410

Magallon SA, Sanderson MJ (2005) Angiosperm divergence times: the effect of genes, codon positions, and time constraints. Evolution 59: 1653-1670

Mueller L, Tanksley S, Giovannoni JJ, Vaneck J, Stack S, Buels R (2009) A snapshot of the emerging tomato genome sequence. Plant Genome 2: 78-92

Mueller LA, Solow TH, Taylor N, Skwarecki B, Buels R, Binns J, Lin C, Wright MH, Ahrens R, Wang Y, et al (2005) The SOL Genomics Network: a comparative resource for Solanaceae biology and beyond. Plant Physiol 138: 1310-1317

Muse SV, Gaut BS (1994) A likelihood approach for comparing synonymous and nonsynonymous nucleotide substitution rates, with application to the chloroplast genome. Mol Biol Evol 11: 715-724

Nesbitt TC, Tanksley SD (2002) Comparative sequencing in the genus Lycopersicon: implications for the evolution of fruit size in the domestication of cultivated tomatoes. Genetics 162: 365-379

Paterson AH, Bowers JE, Bruggmann R, Dubchak I, Grimwood J, 
Gundlach H, Haberer G, Hellsten U, Mitros T, Poliakov A, et al (2009) The Sorghum bicolor genome and the diversification of grasses. Nature 457: 551-556

Rossberg M, Theres K, Acarkan A, Herrero R, Schmitt T, Schumacher K, Schmitz G, Schmidt R (2001) Comparative sequence analysis reveals extensive microcolinearity in the lateral suppressor regions of the tomato, Arabidopsis, and Capsella genomes. Plant Cell 13: 979-988

Rozas J, Sánchez-DelBarrio JC, Messeguer X, Rozas R (2003) DnaSP, DNA polymorphism analyses by the coalescent and other methods. Bioinformatics 19: 2496-2497

Salamov AA, Solovyev VV (2000) Ab initio gene finding in Drosophila genomic DNA. Genome Res 10: 516-522

Sambrook J, Fritsch T, Maniatis T (1989) Molecular Cloning: A Laboratory Manual. Cold Spring Harbor Laboratory Press, Cold Spring Harbor, NY

Schauer N, Semel Y, Balbo I, Steinfath M, Repsilber D, Selbig J, Pleban T, Zamir D, Fernie AR (2008) Mode of inheritance of primary metabolic traits in tomato. Plant Cell 20: 509-523

Schauer N, Semel Y, Roessner U, Gur A, Balbo I, Carrari F, Pleban T, Perez-Melis A, Bruedigam C, Kopka J, et al (2006) Comprehensive metabolic profiling and phenotyping of interspecific introgression lines for tomato improvement. Nat Biotechnol 24: 447-454

Semel Y, Nissenbaum J, Menda N, Zinder M, Krieger U, Issman N, Pleban T, Lippman Z, Gur A, Zamir D (2006) Overdominant quantitative trait loci for yield and fitness in tomato. Proc Natl Acad Sci USA 103: 12981-12986

Stanke M, Steinkamp R, Waack S, Morgenstern B (2004) AUGUSTUS: a Web server for gene finding in eukaryotes. Nucleic Acids Res 32: 309-312

Thompson J, Higgins D, Gibson T (1994) CLUSTAL W: improving the sensitivity of progressive multiple sequence alignment through sequence weighting, position-specific gap penalties and weight matrix choice. Nucleic Acids Res 22: 4673-4680
Tieman DM, Zeigler M, Schmelz EA, Taylor MG, Bliss P, Kirst M, Klee HJ (2006) Identification of loci affecting flavour volatile emissions in tomato fruits. J Exp Bot 57: 887-896

Urbanczyk-Wochniak E, Usadel B, Thimm O, Nunes-Nesi A, Carrari F, Davy M, Bläsing O, Kowalczyk M, Weicht D, Polinceusz A, et al (2006) Conversion of MapMan to allow the analysis of transcript data from solanaceous species: effects of genetic and environmental alterations in energy metabolism in the leaf. Plant Mol Biol 60: 773-792

Van der Hoeven R, Ronning C, Giovannoni J, Martin G, Tanksley S (2002) Deductions about the number, organization, and evolution of genes in the tomato genome based on analysis of a large expressed sequence tag collection and selective genomic sequencing. Plant Cell 14: 1441-1456

Wallis JW, Aerts J, Groenen MA, Crooijmans RP, Layman D, Graves TA, Scheer DE, Kremitzki C, Fedele MJ, Mudd NK, et al (2004) A physical map of the chicken genome. Nature 432: 761-764

Wang Y, Diehl A, Wu F, Vrebalov J, Giovannoni J, Siepel A, Tanksley SD (2008) Sequencing and comparative analysis of a conserved syntenic segment in the Solanaceae. Genetics 180: 391-408

Xiao H, Jiang N, Schaffner E, Stockinger EJ, Van der Knaap E (2008) A retrotransposon-mediated gene duplication underlies morphological variation of tomato fruit. Science 319: 1527-1530

Zamir D (2001) Improving plant breeding with exotic genetic libraries. Nat Rev Genet 2: 983-990

Zhao Q, Zhang Y, Cheng Z, Chen M, Wang S, Feng Q, Huang Y, Li Y, Tang $\mathbf{Y}$, Zhou B, et al (2002) A fine physical map of the rice chromosome 4 . Genome Res 12: 817-823

Zheng J, Svensson JT, Madishetty K, Close TJ, Jiang T, Lonardi S (2006) OligoSpawn: a software tool for the design of overgo probes from large unigene datasets. BMC Bioinformatics 7: 7 

ANEXO 2 



\title{
Genetic dissection of vitamin E biosynthesis in tomato
}

\author{
Juliana Almeida ${ }^{1}$, Leandro Quadrana ${ }^{2}$, Ramón Asís ${ }^{3}$, Nathalia Setta ${ }^{1}$, Fabiana de Godoy ${ }^{1}$, Luisa Bermúdez ${ }^{1}$, \\ Santiago N. Otaiza ${ }^{3}$, Junia V. Corrêa da Silva ${ }^{1}$, Alisdair R. Fernie ${ }^{4}$, Fernando Carrari ${ }^{2,5}$ and \\ Magdalena Rossi ${ }^{1,5},{ }^{*}$ \\ 1 Departamento de Botânica-IB-USP, 277, 05508-900, São Paulo, SP, Brazil \\ 2 Instituto de Biotecnología, Instituto Nacional de Tecnología Agropecuaría (IB-INTA), and Consejo Nacional de Investigaciones \\ Científicas y Técnicas (CONICET), PO Box 25, B1712WAA Castelar, Argentina (partner group of the Max Planck Institute for Molecular \\ Plant Physiology, Potsdam-Golm, Germany) \\ 3 CIBICI, Facultad de Ciencias Químicas Universidad Nacional de Córdoba, CC 5000, Córdoba, Argentina \\ 4 Max Planck Institute for Molecular Plant Physiology, Wissenschaftspark Golm, Am Mühlenberg 1, Potsdam-Golm, D-14476, Germany \\ 5 These authors contributed equally to this work \\ *To whom correspondence should be addressed. E-mail: fcarrari@cnia.inta.gov.ar; E-mail: mmrossi@usp.br
}

Received 25 October 2010; Revised 7 February 2011; Accepted 8 February 2011

\begin{abstract}
Vegetables are critical for human health as they are a source of multiple vitamins including vitamin E (VTE). In plants, the synthesis of VTE compounds, tocopherol and tocotrienol, derives from precursors of the shikimate and methylerythritol phosphate pathways. Quantitative trait loci (QTL) for $\alpha$-tocopherol content in ripe fruit have previously been determined in an Solanum pennellii tomato introgression line population. In this work, variations of tocopherol isoforms $(\alpha, \beta, \gamma$, and $\delta)$ in ripe fruits of these lines were studied. In parallel all tomato genes structurally associated with VTE biosynthesis were identified and mapped. Previously identified VTE QTL on chromosomes 6 and 9 were confirmed whilst novel ones were identified on chromosomes 7 and 8 . Integrated analysis at the metabolic, genetic and genomic levels allowed us to propose 16 candidate loci putatively affecting tocopherol content in tomato. A comparative analysis revealed polymorphisms at nucleotide and amino acid levels between Solanum lycopersicum and S. pennellii candidate alleles. Moreover, evolutionary analyses showed the presence of codons evolving under both neutral and positive selection, which may explain the phenotypic differences between species. These data represent an important step in understanding the genetic determinants of VTE natural variation in tomato fruit and as such in the ability to improve the content of this important nutriceutical.
\end{abstract}

Key words: Fruit metabolism, Solanum pennellii, tocopherol, tomato, vitamin E.

\section{Introduction}

Vegetables are critical for human health as they are a source of multiple vitamins and other essential compounds. In particular, tomato fruits are an important dietary source of antioxidants for humans due both to the fact that have a high intrinsic content of these compounds and the elevated consumption of this crop by the western population. The main non-enzymatic antioxidants found in tomato fruits are ascorbic acid (VTC), lycopene and carotenoids, phenolics, and vitamin E (VTE) (Abushita et al., 1997; Frusciante et al., 2007). Recent studies have reinforced the hypothesis of beneficial effects of VTE on human health, mainly in the prevention of coronary heart disease, breast cancer, and protection against nicotineinduced oxidative stress in the brain (Das et al., 2009; Ros 2009; Zhang et al., 2009). Although its function in plants remains somewhat undefined, several reports link VTE to the protection of pigments, proteins, and polyunsaturated fatty acids of the photosynthetic apparatus against reactive

Abbreviations: IL, introgression line; LRT, likelihood ratio test; MEP, methylerythritol phosphate; QTL, quantitative trait loci; ROS, reactive oxygen species; SK, shikimate; VTC, vitamin C; VTE, vitamin E.

(c) 2011 The Author(s).

This is an Open Access article distributed under the terms of the Creative Commons Attribution Non-Commercial License (http://creativecommons.org/licenses/by$\mathrm{nc} / 2.5)$, which permits unrestricted non-commercial use, distribution, and reproduction in any medium, provided the original work is properly cited. 
oxygen species (ROS) generated during photosynthesis (Semchuk et al., 2009). It has additionally been proposed that VTE interacts with other antioxidant mechanisms in order to maintain cellular redox homeostasis (Foyer and Noctor, 2005).

The synthesis of VTE occurs in photosynthetic organisms and its major constituents are a group of amphipathic molecules containing a polar chromanol head group derived from homogentisate and a polyprenyl lipophilic side chain, products of the shikimate (SK) and methylerythritol phosphate (MEP) pathways, respectively. VTE compounds, collectively termed tocochromanols, can be classified into two groups on the basis of the degree of saturation of their hydrophilic tails. Tocopherols, which are the most abundant in plants, have saturated tails derived from phytyl $2 \mathrm{P}$, whereas tocotrienols have an unsaturated tail derived from geranylgeranyl 2P. The VTE biosynthesis pathway proceeding from the reduction of hydroxyphenylpyruvate to homogentisate is considered the 'VTE core pathway' and comprises seven enzymes: 4-hydroxyphenylpyruvate dioxygenase (HPPD, EC 1.13.11.27), homogentisic acid geranylgeranyl transferase (HGGT/HST, EC 2.5.1.-), homogentisate phytyl transferase (VTE2, EC 2.5.1.-), dimethyl-phytylquinol methyl transferase (VTE3, EC 2.1.1.-), tocopherol cyclase (VTE1, EC 5.3.-.-), $\gamma$-tocopherol Cmethyl transferase (VTE4, EC 2.1.1.95), and phytol kinase (VTE5, EC 2.7.-.-). There are four naturally occurring forms of tocopherols and tocotrienols $(\alpha, \beta, \gamma$, and $\delta)$, which differ in the position and number of methyl groups on the chromanol ring (Munné-Bosch and Alegre, 2002). Although all VTE isoforms are potent antioxidants in vitro, $\alpha$-tocopherol is the most active in terms of vitamin activity, partly because it is retained in the human body in preference to other tocopherols and tocotrienols (Traber and Sies, 1996). In plants, tocochromanol has been found exclusively in plastids. Since it has not been proved thus far that any isoform can be transported within the plant, and the enzymes of the core pathway have been found in plastids (Sun et al., 2009), it is assumed that the biosynthesis also occurs in this compartment.

Although the VTE biosynthetic pathway was elucidated in 1979 (Soll and Schultz, 1979), the identification of the genes involved is much more recent. In the last decade, via the use of genetic and genomics-based methods, the genes encoding the enzymes for most of the steps of the VTE core biosynthesis pathway have been identified and cloned. However, as yet, this is confined to the model organisms Arabidopsis thaliana and Synechocystis sp. PCC6803 (Li et al., 2008). Indeed, the characterization of VTE mutants and transgenic lines has provided considerable insight into the regulatory network of tocochromanol biosynthesis (for review see Mène-Saffrané and DellaPenna, 2009; Falk and Munné-Bosch, 2010). These combined studies have additionally suggested roles for VTE compounds beyond their antioxidant function including their participation in diverse physiological processes including germination, photoassimilate partitioning, growth, leaf senescence, and plant responses to abiotic stress (Falk and Munné-Bosch, 2010).
Moreover, several studies have demonstrated a close interaction between VTE and other metabolic pathways. Tomato fruits overexpressing phytoene synthase (PSY), a key enzyme in carotenoid biosynthesis, displayed increased levels of tocopherol (Fraser et al., 2007). Moreover, tocochromanol content is additionally affected when the post-chorismate pathway is manipulated. Arabidopsis transgenic plants overexpressing the bacterial bi-functional chorismate mutase (CM)/prephenate dehydratase (PDT), displayed significantly higher levels of phenylalanine, as well as $\gamma$-tocopherol and $\gamma$-tocotrienol, besides other secondary metabolites (Tzin et al., 2009). Plant tocochromanol biosynthesis is furthermore subjected to control by both environmental and endogenous signals. In agreement with this statement, the silencing of the light response factor DEETIOLATED1 resulted in tomato fruits with enhanced levels of antioxidants, including carotenoids, flavonoids, and tocopherol (Davuluri et al., 2005; Enfissi et al., 2010).

Cultivated tomato (Solanum lycopersicum) is the most consumed vegetable globally. The fact that its wild relatives display tremendous variation in metabolite content in both leaves and fruits (Schauer et al., 2005), renders wild germplasm an important source for metabolic gene discovery focused on aiding efforts to improve the nutritional and industrial quality of crop species (Zamir, 2001; Fernie et al., 2006; Tohge and Fernie, 2010). Utilizing this approach, Schauer et al. (2006) reported a detailed metabolite profile of 76 tomato introgression lines (ILs) containing chromosome segments of the wild species Solanum pennellii in the genetic background of the cultivated $S$. lycopersicum (cv M82; Eshed and Zamir, 1995). Following the quantification of 74 metabolites of known chemical structure, they were able to identify 889 quantitative fruit metabolic loci for variations in the content of amino and organic acids, sugars, alcohols, fatty acids, VTC, and VTE. Two of these quantitative trait loci (QTL), explaining variation in the $\alpha$-tocopherol fruit content, were located on chromosomes 6 and 9. Independent experiments available at the Tomato Functional Genomics Database (Fei et al., 2006; http:// ted.bti.cornell.edu/) have also revealed differences in tocopherol content associated with the exact same genomic regions. However, the mechanisms explaining these variations are currently not understood, partially due to a lack of knowledge of the complete VTE biosynthetic pathway in tomato.

The aim of the current report is to provide a framework for associating gene sequence with fruit tocopherol content phenotypes by (i) characterizing and mapping all genes involved in the VTE biosynthesis pathway in tomato, (ii) identifying QTL for the content of the vitamers of VTE and their candidate genes, (iii) cloning and sequencing these genes from $S$. pennellii, and (iv) examining evolutionary patterns of candidates genes by comparing orthologues from $S$. pennelli, $S$. lycopersicum, and $A$. thaliana. The combined results of this study will be discussed in the context of the fundamental understanding of the accumulation of VTE opening further stages for functional analyses. 


\section{Materials and methods}

\section{Plant material}

Tomato seeds from S. lycopersicum L. (cv M82) and S. pennellii introgressed lines were obtained from Tomato Genetic Resource Center (http://tgrc.ucdavis.edu). Tomato plants were grown in $20-1$ pots under greenhouse conditions: $16 / 8 \mathrm{~h}$ photoperiod, $24 \pm 3{ }^{\circ} \mathrm{C}$, $60 \%$ humidity, and $140 \pm 40 \mu \mathrm{mol} \mathrm{m} \mathrm{m}^{-2} \mathrm{~s}^{-1}$ incident photoirradiance. Cloning was carried out from fully expanded source leaves and mature fruits (60 d after flowering). For tocopherol quantification six ripe fruits were taken from six individual plants of ILs 6-1, 6-2, 7-4, 7-4-1, 7-5, 8-2, 8-2-1, 9-1, 9-2-6. Tissue was collected, immediately frozen into liquid nitrogen, and stored at $-80{ }^{\circ} \mathrm{C}$ until use.

\section{Survey of tocopherol biosynthesis enzymes, genome mapping, and expression analyses}

The VTE pathway presented in Fig. 1 was outlined by combining data reported for enzymatic steps involved in SK, MEP, and VTE biosynthesis available on KEGG (Kyoto Encyclopedia of Genes and Genomes, http://www.genome.jp/kegg/) and related scientific literature. Arabidopsis loci were obtained from the KEGG database and these sequences were used to perform TBLASTN (Altschul et al., 1990) searches against tomato expressed sequences from the Lycopersicon Combined Build \# 3 unigene database housed by the Solanaceae Genomics Network (http://solgenomic.net). The criteria used to determine orthology were $\geqslant 40 \%$ identity at the amino acid level and $\geqslant 65 \%$ coverage of the Arabidopsis protein. For uncompleted unigenes, the coverage cut-off was set at $\geqslant 30 \%$. Based on BLASTN results, all unigene sequences were used as queries to identify the corresponding genomic sequences from the $S$. lycopersicum genome assembly-version 2.31 (3,230 sequences; 781,381,961 total letters) - The International Tomato Genome Sequencing Project at the Solanaceae Genomics Network (http:// solgenomic.net). In silico prediction of the subcellular localization of tomato unigenes was performed using TargetP (http:// www.cbs.dtu.dk/services/TargetP) and ChloroP program (http:// www.cbs.dtu.dk/services/ChloroP) based on their deduced amino acid sequences.

The identified tomato genes were mapped onto the TomatoEXPEN 2000 genetic map available at the Solanaceae Genomics Network. The genetic positions were obtained by BLASTN (Altschul et al., 1990) searches of the identified unigenes and/or their corresponding genomic sequences against the entire Tomato-EXPEN 2000 map marker sequences database (http:// solgenomics.net/index.pl). Map Chart software 2.2 (Voorrips, 2000) was used to construct the graphical representation of the genetic map.

Expression data for the set of genes analysed here were extracted from a TOM1 microarray experiment previously published (Carrari et al., 2006). This experiment comprises transcript analyses from tomato fruits harvested along development and ripening stages $(10,15,20,21,35,49,56$, and $70 \mathrm{~d}$ after anthesis).

\section{Tocopherol quantification by HPLC and QTL mapping}

Tocopherol extraction was performed as described by Fraser et al. (2000) with the following modifications: tomato fruit were ground to a fine powder in liquid nitrogen and $500 \mathrm{mg}$ of material was extracted with $1.5 \mathrm{ml}$ of methanol and, after vortexmixing, $1 \mathrm{ml}$ of chloroform was added. Following $5 \mathrm{~min}$ of sonication, $1 \mathrm{ml}$ of Tris buffer $(50 \mathrm{mM}$ Tris $\mathrm{pH} 7.5 / 1 \mathrm{M} \mathrm{NaCl})$ was added. The chloroform phase was recovered and the methanol phase (remaining pellet) was re-extracted with chloroform $(2 \mathrm{ml})$. Chloroform extracts were pooled and adjusted to a final volume of $4 \mathrm{ml}$. Two millilitres were dried under nitrogen gas and re-suspended in $0.2 \mathrm{ml}$ of 99.5:0.5 hexane/isopropanol. The tocopherol content was determined using a Hewlett-Packard series 1100 HPLC system coupled with a fluorescence detector (Agilent Technologies series 1200). Separation was carried out on a normal-phase column Metasil Si $(250 \mathrm{~mm} \times 4.6 \mathrm{~mm}, 5 \mu \mathrm{m}$, Varian; Metachem, Torrance, CA, USA) maintained at room temperature using an isocratic solvent system (mobile phase) consisting of 99.5:0.5 hexane/isopropanol with a flow rate of $1 \mathrm{ml}$ $\mathrm{min}^{-1}$. Eluting compounds were detected and quantified by fluorescence with excitation at $296 \mathrm{~nm}$ and emission at $340 \mathrm{~nm}$. Identification and quantification of tocopherol compounds was achieved by comparison with the retention times and peak areas of standards purchased from Merck (tocopherol set; Calbiochem \#613424). A daily calibration curve was carried out using a tocopherol solution with a concentration range between 0.31 $\mu \mathrm{g} \mathrm{ml} l^{-1}$ and $5 \mu \mathrm{g} \mathrm{ml}^{-1}$ for each isoform. Data of tocopherol isoforms or total tocopherol content were statistically analysed according to Sokal and Rohlf (1981). When the data pull presented homoscedasticity, with or without data transformation using ln or square root, an ANOVA followed by a Dunnett test $(P<0.05)$ was used to compare tocopherol content between ILs and M82 control. Due to lack of homoscedasticity, a nonparametric comparison was also performed by Kruskal-Wallis test $(P<0.05$ and $P<0.1)$. Statistical tests were performed with Bioestat 5.0 (Ayres et al., 2007) and InfoStat v. 2009 (Grupo InfoStat, FCA, Universidad Nacional de Córdoba, Argentina).

The position of tocopherol QTL on the Tomato-EXPEN 2000 map was determined according to the flanking markers of the $S$. pennellii introgression fragments in the analysed ILs (Eshed and Zamir, 1995) and mapping of unigenes performed as described in Kamenetzky et al. (2010).

\section{Identification of VTE-related pathway candidate genes}

Candidate genes were surveyed along the genomic regions spanned by the identified VTE QTL as described in Bermúdez et al. (2008). All molecular markers mapped onto the selected genomic regions were identified in the comparison merging the Tomato-EXPEN 2000, the Tomato-EXPEN 1992, and the Tomato IL maps by using the comparative map web interface of the Solanaceae Genomics Network (Mueller et al., 2008). All marker sequences were used as query to identify the corresponding unigenes in the Solanaceae Genomics Network database. Gene product functions were determined according to homology to a previously characterized protein, whose function had been experimentally demonstrated in other related plant species, by using the BLASTX algorithm (Altschul et al., 1990) against the NCBI non-redundant (nr) protein database (http://blast.ncbi.nlm.nih.gov/Blast.cgi). The cut-off criteria were: $\geqslant 40 \%$ identity at amino acid level and $\geqslant 65 \%$ coverage of the orthologous Arabidopsis protein. For uncompleted unigenes the coverage cut-off was set at $\geqslant 30 \%$.

\section{Amplification, cloning, and sequencing}

Total RNA from $100 \mathrm{mg}$ of source leaf or fruit tissue was isolated using Trizol reagent (Invitrogen, \#15596-026) and $1 \mu \mathrm{g}$ from each sample was treated with amplification grade DNase I (Invitrogen, \#18068-015) to remove potential contamination of genomic DNA. The treated RNA was reverse-transcribed to first-strand cDNA and primed with oligo(dT) using Superscript First-Strand (Invitrogen, \#18080-044) following the manufacturer's protocol.

Primers were designed using the software Oligo Analyzer 3.1 (http://www.idtdna.com) on the basis of unigene sequences including the sequence surrounding the putative ATG start and stop codons. The primer sequences are available in Table S1 in Supplementary data available at $J X B$ online.

Full-length cDNA fragments were generated by PCR using Taq Platinum pfx DNA polymerase (Invitrogen, \#11708-013). The PCR reactions were conducted in a total volume of $50 \mu \mathrm{l}$ containing $0.3 \mathrm{mM}$ each dNTPs, $0.4 \mu \mathrm{M}$ each primer, $1.5 \times$ reaction buffer, $1 \mathrm{mM} \mathrm{MgSO} 4, \sim 150 \mathrm{ng}$ of cDNA, and $2.5 \mathrm{IU}$ of enzyme. The amplification conditions were: $94{ }^{\circ} \mathrm{C}$ for $3 \mathrm{~min} ; 35$ 
4 of 18 Almeida et al.

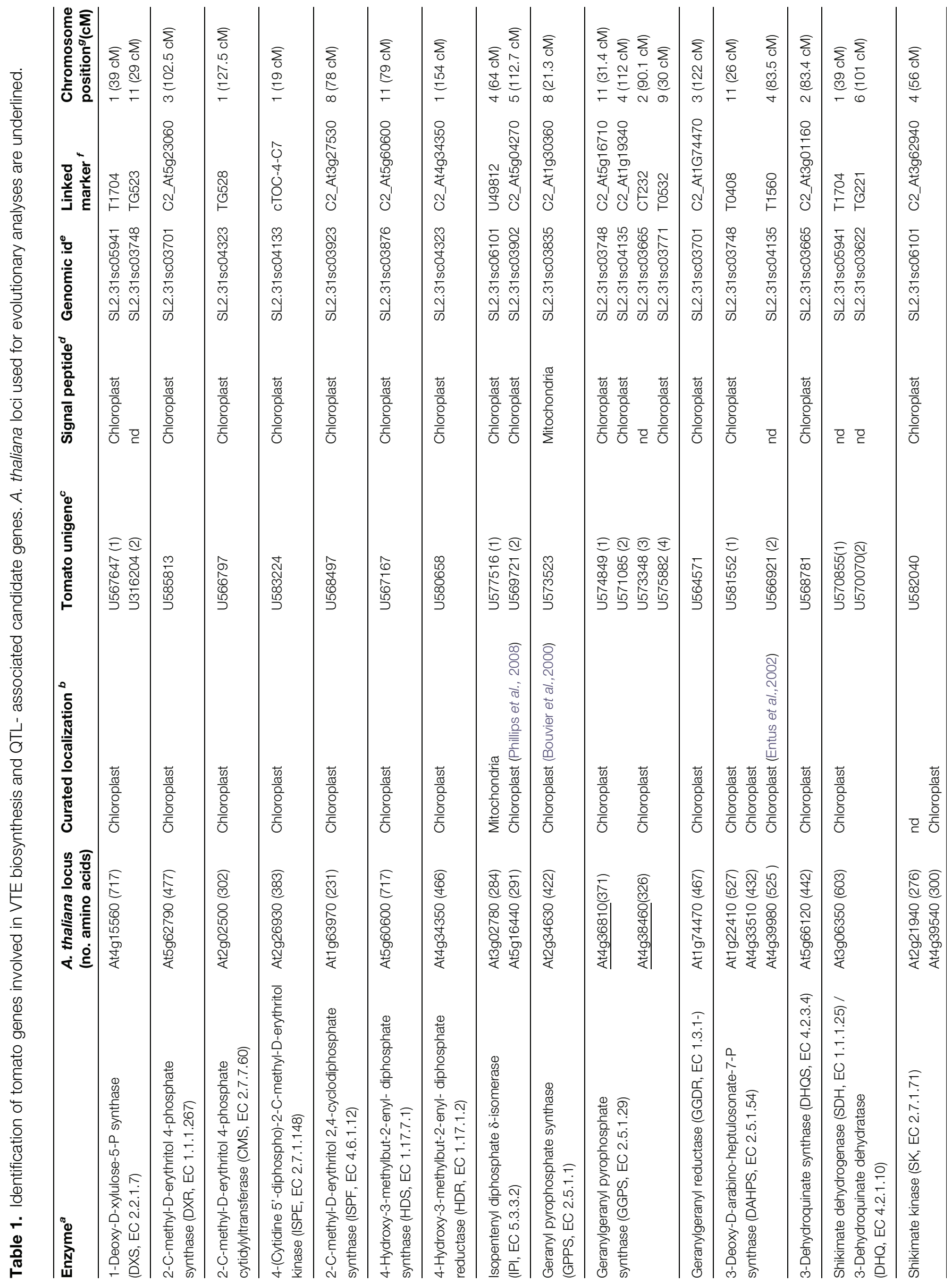




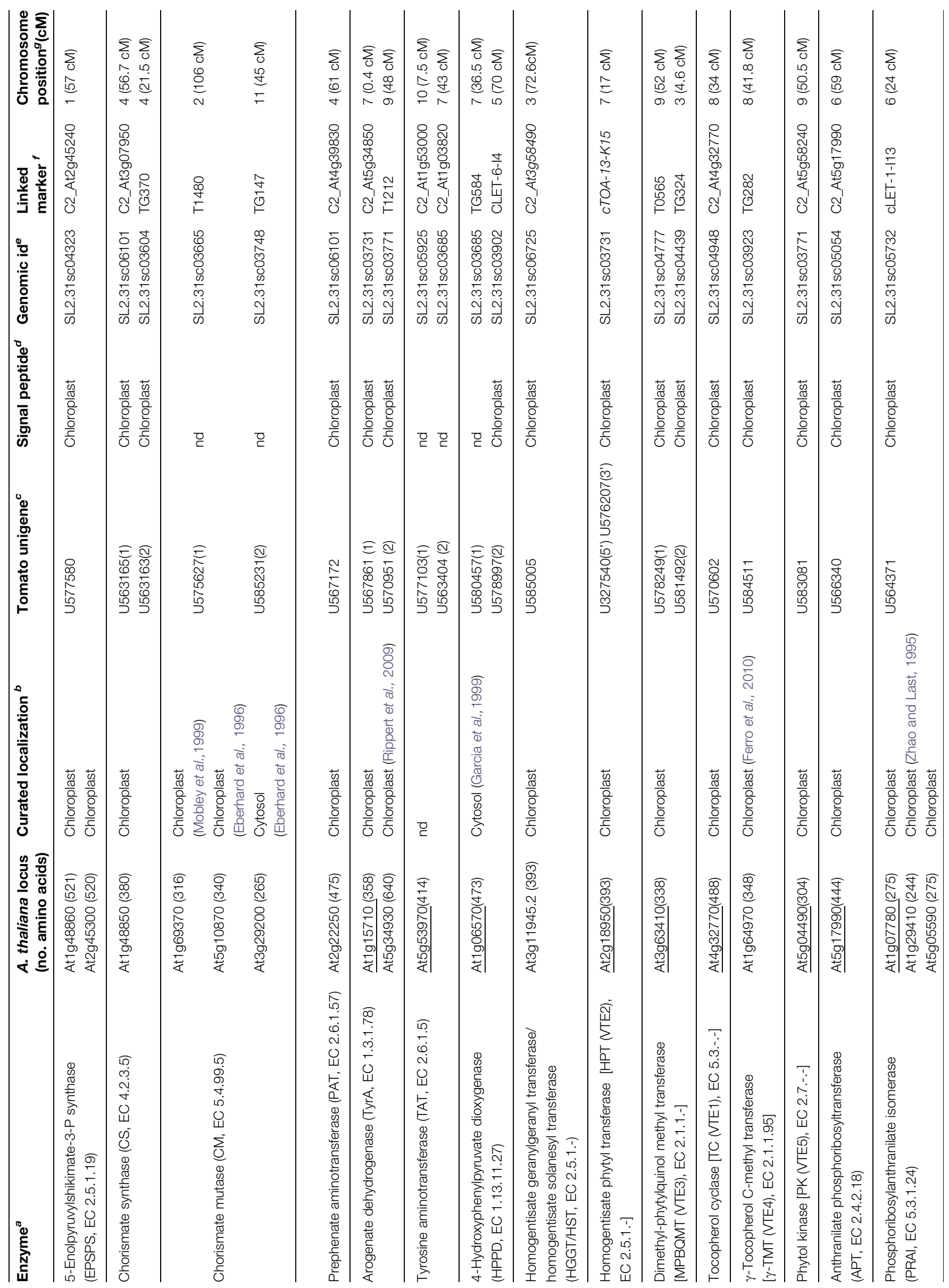


cycles of $94{ }^{\circ} \mathrm{C}$ for $15 \mathrm{~s}$; primer-specific annealing temperature for $30 \mathrm{~s}$; and then $68{ }^{\circ} \mathrm{C}$ for $2 \mathrm{~min}$. Amplification products were purified with GFX purification Kit (Amersham Biosciences, \#289034-70) and cloned into a pCR-Blunt II TOPO vector using a TOPO-Zero Blunt cloning kit (Invitrogen, \#45-0245). Plasmid DNA was isolated using a Qiagen Miniprep Kit (\#27106) and inserts were sequenced with BigDye Terminator (Applied Biosystems, \#4336919) on an ABI3700 automated sequencer (Applied Biosystems). Sequence data from this article have been deposited in the GenBank Data Libraries under accession number HQ014366-HQ014383 and HQ219713-HQ219716. Polymorphisms were detected at nucleotide and amino acid levels by aligning $S$. pennellii and $S$. lycopersicum sequenced alleles (excluding primer regions) using the MULTALIN program (http://wwwarchbac.u-psud.fr/genomics/multalin.html; Corpet, 1988).

\section{Evolutionary analyses}

The coding region alignments of A. thaliana, S. lycopersicum, and $S$. pennellii were performed with BioEdit Sequence Alignment Editor (Hall, 1999) using the ClustalW package (v1.81 Thompson et al., 1994) and were manually curated according to amino acid alignment. Non-synonymous $\left(d_{\mathrm{N}}\right)$ and synonymous $\left(d_{\mathrm{S}}\right)$ distances and their SE values were estimated with MEGA 4.1 software (Tamura et al., 2007) using the Nei-Gojobori method (p-distance). In order to preserve the reading frames, the alignment gaps were deleted prior to estimation of $d_{\mathrm{S}}$ and $d_{\mathrm{N}}$. Codon bias was determined by the effective number of codons $\left(N_{\mathrm{c}}\right)$ value computed in the CodonW program (mobyle.pasteur.fr/cgi-bin/portal.py?form=codonw). $N_{\mathrm{c}}$ varies between 21 for maximum codon bias, when only one codon is used per amino acid, and 61 for minimum codon bias, when synonymous codons for each amino acid are used at similar frequencies. One-way ANOVA with Tukey's posthoc test in the InfoStat software was performed to evaluate significant differences in codon usage.

In order to compare codon evolution models to determine selective constraint, three models were fitted using the CODEML program of the PAML suite (Yang, 2007). The first model, M0, assumes that all codons across the sequences have the same level of $d_{\mathrm{N}}$ and $d_{\mathrm{S}}$ and estimates these values and the $d_{\mathrm{N}} / d_{\mathrm{S}}$ ratio $(\omega)$. $\omega$ is a signal of the selection at protein level thus, $0<\omega<1$ indicates purifying selection, $\omega=1$ neutral selection, and $\omega>1$ points to the presence of positive selection. The model M1a proposes the existence of two classes of codon, a proportion with $0<\omega<1$ and the remainder of codons with $\omega=1$. Finally, model M2a divides codons into three classes: those with $0<\omega<1, \omega=1$, and $\omega \geqslant 1$. The fit of model M0 versus M1a or M1a versus M2a is evaluated by a likelihood ratio test comparing twice the difference in $\log$ likelihoods with a $\chi^{2}$ distribution (Yang, 2007).

\section{Results}

\section{Identification, mapping, and expression analyses of tomato genes involved in VTE biosynthesis}

VTE compounds, tocopherols, and tocotrienols, are products of the convergence of the plastidial MEP and SK pathways. With the aim of identifying every metabolic step in tocochromanol biosynthesis in tomato, the two routes from their primary metabolism precursors were linked to the VTE core pathway (Fig. 1) based on data available in the KEGG database. After an in-depth search of the unigene database deposited in the Solanaceae Genomics Network (http://solgenomics.net), using Arabidopsis loci as reference sequences, all the putative tomato enzyme encoding genes were identified (Table 1). Twenty-nine biochemical reactions constitute the 


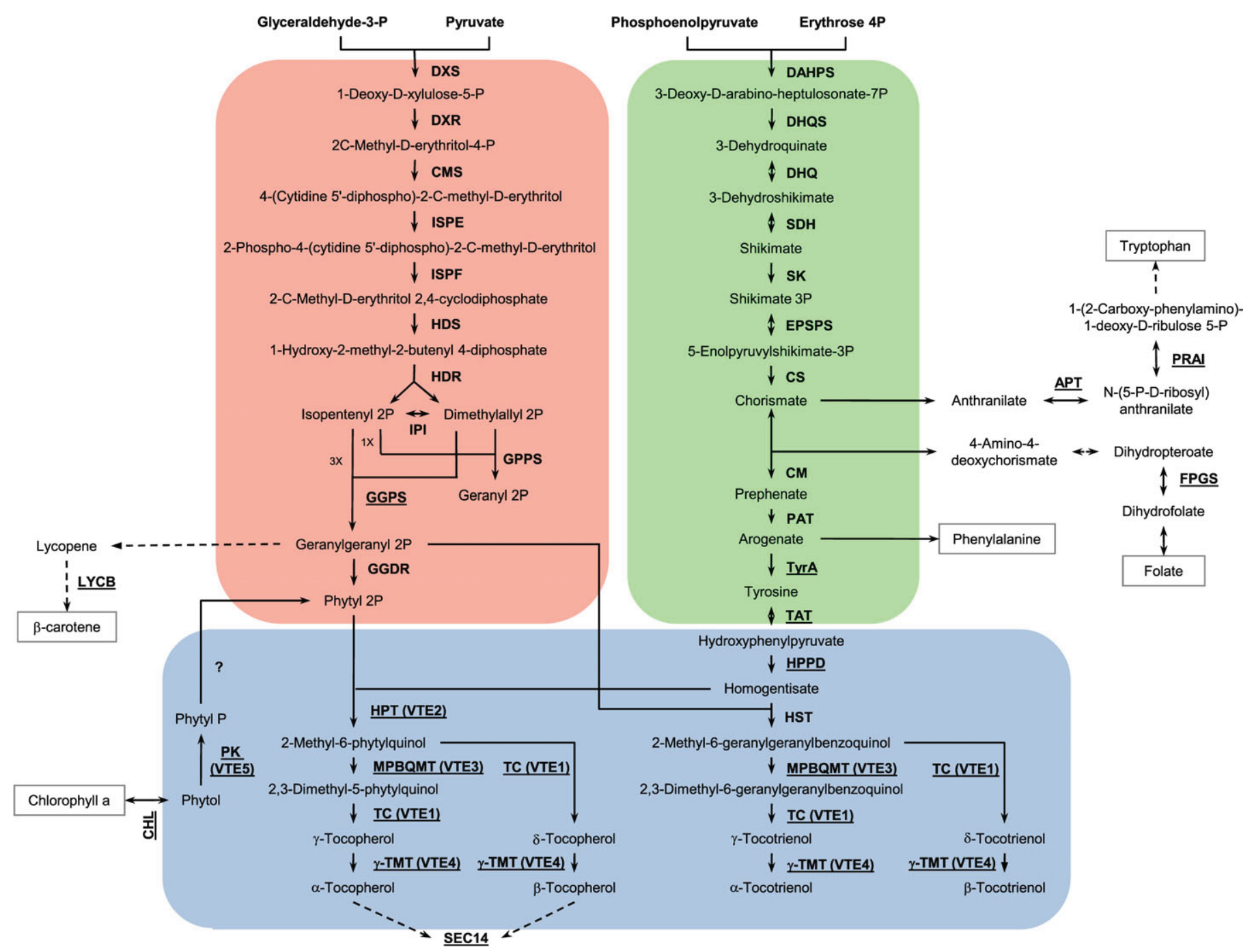

Fig. 1. VTE biosysnthesis pathway. The MEP, SK, and tocopherol core pathways are highlighted in red, green, and blue, respectively. Candidate genes of the VTE-related pathways (carotenoid, chlorophyll, tryptophan and folate metabolism, and the SEC14 protein) are not highlighted. Enzymes are named according to their abbreviations in Table 1. Genes for which wild alleles were cloned, sequenced, and analysed are underlined.

VTE biosynthesis pathway and these are catalyzed by 28 enzymes, for which a total of 41 different tomato encoding loci were described. For eleven of the enzymes, the number of surveyed tomato genes differs from those described for Arabidopsis, according to the criteria adopted here. Only one point in the pathway shown in Fig. 1 remains obscure in plant metabolism, which is the phosphorylation of phytyl $\mathrm{P}$ to provide phytyl 2P from phytol via VTE5, as an alternative to the MEP pathway (Valentin et al., 2006).

The subcellular localization of the protein products of previously identified $S$. lycopersicum loci were predicted by the TargetP and ChloroP softwares. Enzymes that did not contain a predicted targeting peptide were considered cytosolic. This in silico prediction was in general agreement with the experimental evidence reported for the Arabidopsis orthologues (Table 1). For two proteins, however, predictions revealed unexpected results. The tomato geranyl pyrophosphate synthase (GPPS) enzyme was predicted to be targeted to the mitochondria, while for the bi-functional shikimate dehydrogenase/3-dehydroquinate dehydratase (SDH/DHQ) no signal peptides were detected for any of the identified loci. Moreover, none of the tomato CMs presented a predicted plastid signal peptide. The fact that the last enzyme of the post-chorismate portion of the SK pathway, tyrosine aminotransferase (TAT), and HPPD appeared to be localized in the cytosol in Arabidopsis cells provides intrigue regarding the transport of homogentisate across the chloroplast envelope (Joyard et al., 2009). These predictions, with regard to the tomato proteins, also failed to propose a subcellular localization for TAT, even though one of the HPPD unigenes exhibited a chloroplast signal peptide prediction.

As a second step in the characterization of the genetic basis of tocochromanol biosynthesis, the 41 tomato loci involved in MEP, SK, and VTE core pathways were localized onto the tomato genetic map (Tomato-EXPEN 2000) (Figs 1, 2, Table 1). Mapping was based on physical linkage between mapped markers and the unigenes and/or 


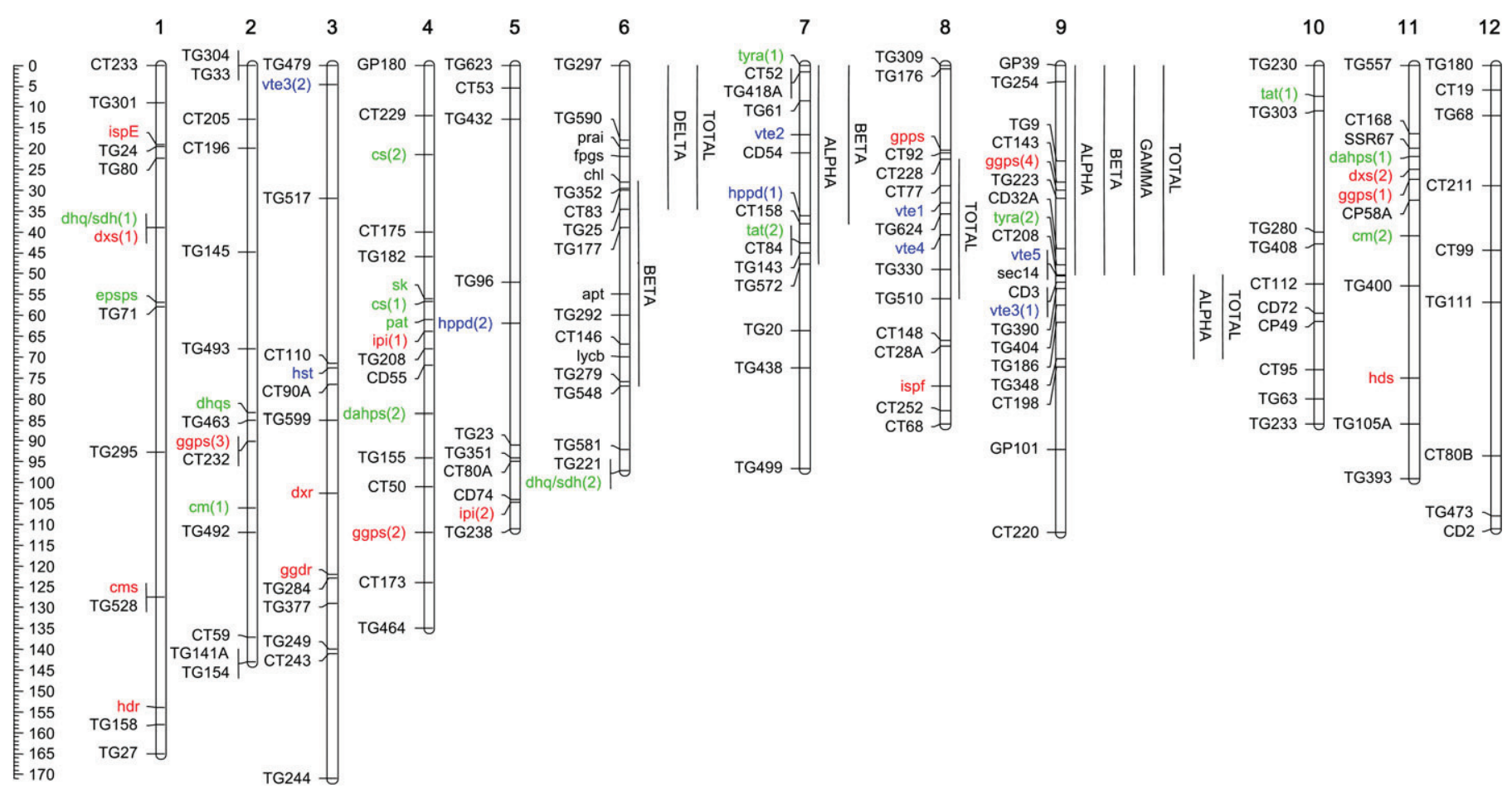

Fig. 2. Genomic localization of tocopherol biosynthesis and candidate genes. All genes were localized in the Tomato-EXPEN 2000 genetic map available at the Solanaceae Genomics Network (http://solgenomics.net/index.pl). Markers and genes are indicated on the left side of the chromosomes. Tocopherol QTL are indicated on the right side of the chromosomes. Gene colour code is in accordance with Fig. 1.

their corresponding genomic sequences. With the exception of chromosome 12 , all other tomato chromosomes harbour at least one of the identified loci. Interestingly, most of the tocochromanol core pathway enzymeencoding loci were localized on chromosomes 7, 8, and 9, except for hst and vte3(2), mapping to chromosome 3, and $h p p d(2)$, mapping to chromosome 5. Remarkably, the four genes mapped on chromosome 9, vte3(1), vte5, arogenate dehydrogenase [tyra(2)], and geranylgeranyl pyrophosphate synthase [ggps(4)] all co-localize with a previously reported QTL for $\alpha$-tocopherol content described by Schauer et al. (2006).

Of the 41 identified genes, the expression patterns of 27 of them could be evaluated across fruit development and ripening, by retrieving data from a previously published microarray experiment (Carrari et al., 2006). This analysis revealed that all 27 genes were expressed in tomato fruits in at least one time point. The ${ }^{*}$ omeSOM model of neural clustering recently developed (Milone et al., 2010) revealed six groups. Whilst these clusters grouped genes from all three evaluated pathways, no specific pathway patterns were identified (data not shown).

\section{QTL for fruit tocopherol content and identification of candidate genes}

As mentioned above, these mapping results revealed that the majority of the VTE core pathway enzyme-encoding genes are grouped within chromosomes 7, 8, and 9. Previously, using GC-MS analysis, Schauer et al. (2006) reported two QTL for fruit $\alpha$-tocopherol content localized to chromosomes 6 and 9. In order to investigate further the presence of other QTL associated with the genomic regions that harbour the tocopherol core biosynthesis genes, and as such to obtain a precise and detailed quantification, an HPLC protocol for measuring all four tocopherol isoforms was applied.

The content of $\alpha-, \beta-, \gamma-, \delta$, and total tocopherol was determined from ripe tomato fruits from the ILs 6-1, 6-2, 7 $4,7-4-1,7-5,8-2,8-2-1,9-1,9-2-6$ as well as fruits from the corresponding $S$. lycopersicum control (cv M82). The amount of each isoform and their ratios are presented in Fig. 3, whereas the identified QTL are positioned on the genetic map presented in Fig. 2. On chromosome 9, two QTL were identified for $\alpha$ - and total tocopherol (ILs 9-1 and 9-2-6), one for $\beta$-tocopherol (IL 9-1), and one for $\gamma$-tocopherol (IL 9-1). Both QTL for total tocopherol are in agreement with the results reported in Schauer et al. (2006). The QTL on IL 9-2-6 co-localize with two VTE core pathway encoding genes: vte3(1) and vte5 (Fig. 2), whilst the QTL on IL 9-1 spans the genomic region containing tyra (2) and ggps(4). Measurements performed in fruits from ILs with $S$. pennellii introgressions on chromosome 6 showed significant differences from M82 fruits in the levels of $\beta$-tocopherol (IL 6-2), $\delta$-, and total tocopherol (IL 6-1). Moreover, QTL were also identified on chromosome 7 (ILs 7-4 and 7-4-1 for $\alpha$ - and $\beta$-tocopherol, respectively) and 8 (IL 8-2-1 for total tocopherol) also co-localizing with the genes encoding the VTE core pathway enzymes: vte 2 and 
hppd(1) on chromosome 7 and vtel and vte 4 on chromosome 8 (Fig. 2). Besides the mentioned genes, the presence of tyra(1) at $0.4 \mathrm{cM}$ and tat(2) at $43 \mathrm{cM}$ on chromosome 7 could also be responsible for the $\alpha$ - and $\beta$-tocopherol QTL mapped onto these regions.

By surveying the genomic regions spanning the identified QTL, six novel candidate genes belonging to VTE-related pathways were found. On chromosome 6, at $32 \mathrm{cM}$, a chlorophyllase encoding gene (CHL, EC 3.1.1.14) was identified. It has been proposed that the first step in the degradation of chlorophyll during senescence and fruit ripening is catalysed by this enzyme (Hörtensteiner, 2006) through the synthesis of phytol, providing phytyl $2 \mathrm{P}$ to the VTE pathway via VTE5. Moreover, three enzyme-encoding genes for the two branching pathways from chorismate to tryptophan and folate were also identified: a phosphoribosylanthranilate isomerase (PRAI, EC 5.3.1.24), a folylpolyglutamate synthase (FPGS, EC 6.3.2.17), and an anthranilate phosphoribosyltransferase (APT, EC 2.4.2.18) mapping at 24, 26, and $59 \mathrm{cM}$, respectively. Finally, the lycopene $\beta$-cyclase (LYCB) encoding gene was found at $74 \mathrm{cM}$ of chromosome 6 . This enzyme, which catalyses the last step in $\beta$-carotene biosynthesis, has been deeply characterized after a positional cloning strategy by Ronen et al. (2000) and constitutes a strong candidate for tocopherol content due to the common precursor geranylgeranyl 2P. Another putative candidate, the SEC14 protein-encoding gene, was found on chromosome 9. Several studies have demonstrated the involvement of this protein in tocopherol transport in mammalian cells and lipid traffic in plants (Saito et al., 2007; Bankaitis et al., 2009). With the exception of the chl these novel candidates are expressed in tomato fruits at least one time point of the developmental analysis performed by Carrari et al. (2006).

Taken together the results obtained from tomato gene identification, mapping, tocopherol quantification, and QTL localization, 16 candidate loci putatively affecting tocopherol content in tomato can be proposed: prai, fpgs, chl, apt, and lycb on chromosome 6; tyra(1), vte2, hppd(1), and tat(2) located on chromosome 7; vtel and vte4 on chromosome 8; and ggps(4), tyra(2), vte5, sec14, and vte3(1) on chromosome 9 (Figs 1-3).

\section{Allele characterization of QTL-associated candidates}

The identification of 16 QTL-associated candidate genes prompted us to unearth the allelic differences between S. lycopersicum and S. pennellii (underlined genes in Fig. 1). The coding regions of wild alleles were thus subsequently cloned from the corresponding ILs using primers annealing to the initial and stop codons. Although only minor size differences were observed between the two alleles for most of the genes, TyrA(2)-, VTE4-, PRAI-, and CHL-encoding genes exhibited different amplicon length. These results indicated that neither vast allelic polymorphisms, nor large genomic rearrangements, span the chromosomal region encompassing the analysed genes. This comparison revealed
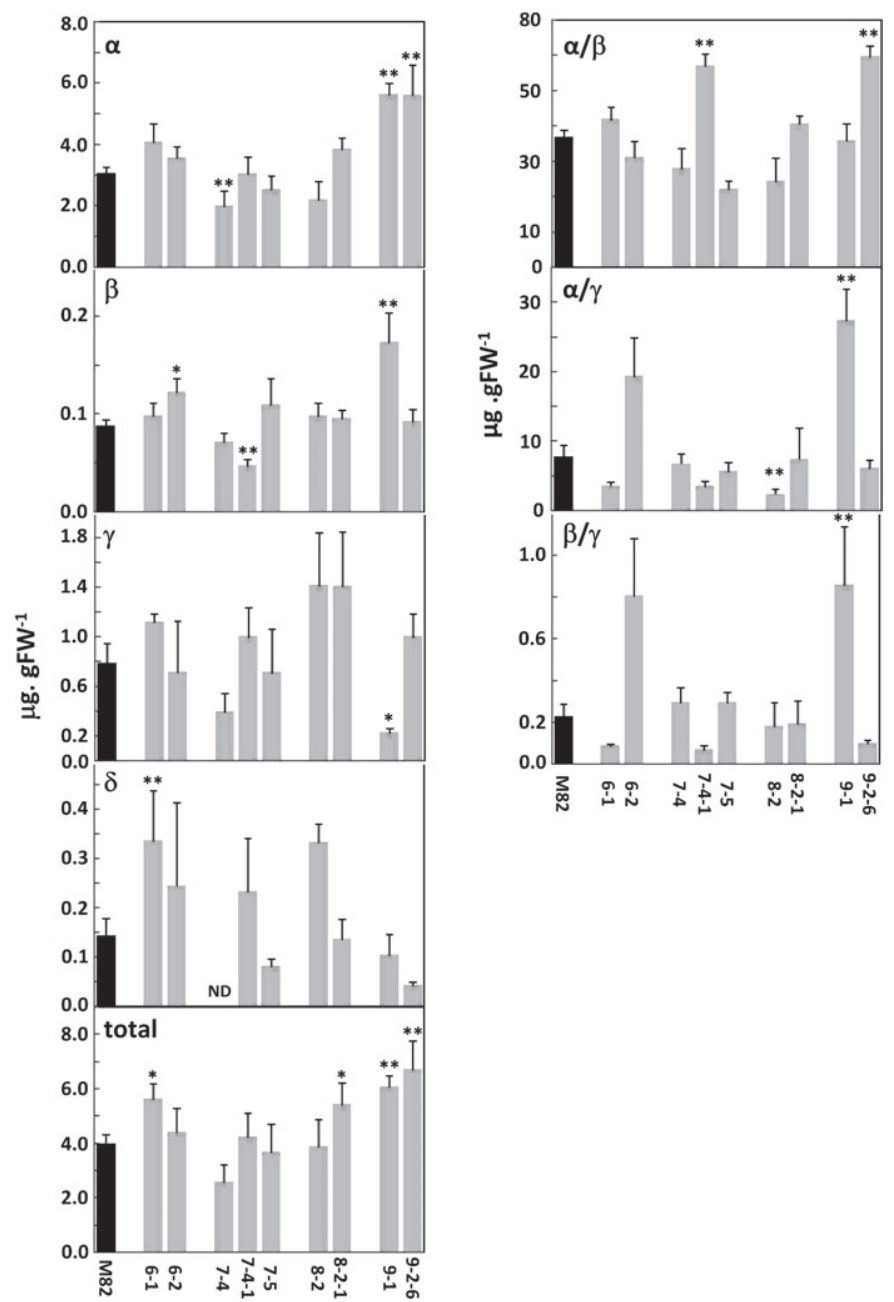

Fig. 3. Tocopherol content. Tocopherol content was determined by HPLC. Grey bars indicate means of six biological replicates. Significant differences compared with the M82 control cultivar (black bars) according to Dunnett test $(P<0.05)$ and/or KruskalWallis test $\left(P<0.05^{* \star}\right.$ and $\left.P<0.1^{\star}\right)$ are indicated.

that all analysed candidate genes present at least one nonsynonymous polymorphism (Table 2). The most divergent alleles are those encoding the PRAI enzyme for which the $S$. pennelli allele encodes a protein 26 amino acids shorter in comparison with the $S$. lycopersicum allele.

\section{VTE biosynthesis genes: evolutionary analyses of cultivated and wild tomato alleles}

The fate of cellular metabolic networks generally depends on the products of many loci. The inter-relationships between loci at the phenotypic level raise the question of whether they evolved independently. In this work QTL for tocopherol content using $S$. pennelli ILs were mapped, and 16 candidate loci linked to those QTL were identified and the wild species alleles cloned. Furthermore, in order to study how the structure of the VTE metabolic pathway could have influenced protein evolution rates, the evolutionary pattern among the candidate genes and their 
Table 2. Comparison of S. lycopersicumand S. pennellii alleles of cDNA encoding VTE candidate genes. LYC, S. Iycopersicum; PEN, S. pennellii.

\begin{tabular}{|c|c|c|c|c|c|c|c|}
\hline \multirow[t]{2}{*}{ Gene } & \multirow[t]{2}{*}{ Unigene } & \multicolumn{2}{|c|}{$\begin{array}{l}\text { Coding sequence } \\
\text { (nt) }\end{array}$} & \multicolumn{2}{|c|}{$\begin{array}{l}\text { Predicted } \\
\text { protein } \\
\text { (no. amino } \\
\text { acids) }\end{array}$} & \multirow[t]{2}{*}{$\begin{array}{l}\text { No. of polymorphic } \\
\text { nucleotides }^{a}\end{array}$} & \multirow[t]{2}{*}{$\begin{array}{l}\text { No. of polymorphic } \\
\text { amino acids }^{a}\end{array}$} \\
\hline & & LYC & PEN & LYC & PEN & & \\
\hline ggps(4) & U575882 & 1005 & 1005 & 334 & 334 & 11 & 3 \\
\hline $\operatorname{tat}(2)$ & U563404 & 1269 & 1269 & 422 & 422 & 10 & 6 \\
\hline tyra(1) & U567861 & 1134 & 1134 & 377 & 377 & 7 & 1 \\
\hline tyra(2) & U570951 & 1173 & 1182 & 390 & 393 & 24+9insertions & $9+3$ insertions \\
\hline vte4 & U584511 & 1089 & 1086 & 362 & 361 & 9+3deletions & 2+1deletion \\
\hline vte1 & U570602 & 1497 & 1497 & 498 & 498 & 12 & 5 \\
\hline vte3(1) & U578249 & 1020 & 1020 & 339 & 339 & 7 & 1 \\
\hline \multirow[t]{2}{*}{ vte2 } & U327540 (covers 5' end) & 1209 & 1209 & 402 & 402 & 8 & 3 \\
\hline & U576207 (covers 3' end) & & & & & & \\
\hline vte5 & U583081 & 882 & 882 & 293 & 293 & 10 & 4 \\
\hline$h p p d(1)$ & U580457 & 1263 & $1263^{b}$ & 420 & $420^{b}$ & 16 & 7 \\
\hline apt & U566340 ${ }^{c}$ & $1097^{c}$ & $1097^{c}$ & 365 & 365 & 8 & 4 \\
\hline prai & U564371 & 906 & 828 & 301 & 275 & 12+78deletions & $3+26$ deletions \\
\hline fpgs & U581922 ${ }^{c}$ & $1457^{c}$ & $1457^{c}$ & 485 & 485 & 13 & 4 \\
\hline$c h l$ & U574853 & 939 & 948 & 312 & 315 & $22+9$ insertions & $9+3$ insertions \\
\hline $\sec 14$ & U583419 & 1275 & 1275 & 424 & 424 & 11 & 4 \\
\hline$l y c b$ & U570109 & 1497 & 1497 & 498 & 498 & 19 & 9 \\
\hline
\end{tabular}

${ }^{a}$ Nucleotide or amino acid insertions or deletions in S. pennellii sequences.

b $S$. pennellii does not present a stop codon along the analysed region.

c Probably lacking 3' end.

paralogues was also investigated, estimating the pairwise synonymous $\left(d_{\mathrm{S}}\right)$, non-synonymous $\left(d_{\mathrm{N}}\right)$, and $d_{\mathrm{N}} / d_{\mathrm{S}}$ divergence between $S$. lycopersicum and $S$. pennellii (Fig. 4). The $d_{\mathrm{S}}$ and $d_{\mathrm{N}}$ values varied greatly between genes, ranging from 4.8 to 16 times for $d_{\mathrm{S}}$ and $d_{\mathrm{N}}$, respectively. Four genes, ggps(2), tyra(2), chl, and lycb, displayed particularly high values of $d_{\mathrm{N}}$, above the mean. The $d_{\mathrm{N}} / d_{\mathrm{S}}$ also varied remarkably among the 22 loci analysed with the highest value being 17.4 times the lowest. The genes of MEP, post-chorismate SK, and tocopherol biosynthesis core pathways displayed values similar to or lower than the average with the exception of those presenting more than one locus. Among candidate genes of related pathways apt, chl, and $l y c b$ displayed higher $d_{\mathrm{N}} / d_{\mathrm{S}}$ values than the mean. Interestingly, the five genes for which more than one locus was identified displayed variations of $d_{\mathrm{N}} / d_{\mathrm{S}}$ values between paralogues. The $d_{\mathrm{N}} / d_{\mathrm{S}}$ values for the different ggps, tat, tyra, vte3 and hppd varied by 3.5, 2.1, 7.6, 3.4, and 1.9 times, respectively. Differences in $d_{\mathrm{N}} / d_{\mathrm{S}}$ values between the paralogues might be due to high $d_{\mathrm{N}}$ caused by a weak selection at non-synonymous sites, or related to the intensity of natural selection on synonymous codon usage. To investigate the existence of codon usage bias, the effective number of codons $\left(N_{\mathrm{c}}\right)$ was calculated for each gene and species ( $S$. pennellii and S. lycopersicum). No statistically significant differences (ANOVA, $P>0.01$ ) in $N_{\mathrm{c}}$ were observed between ggps, tat, tyra, and vte3 paralogues, suggesting that the $d_{\mathrm{N}} / d_{\mathrm{S}}$ differences are most probably due to a constraint relaxation for one of the gene copies rather than codon bias. In contrast, for the hppd pair a significant $N_{\mathrm{c}}$ bias was observed (ANOVA, $P<0.01$ ). This can be also visualized in Fig. 4 comparing $d_{\mathrm{N}}$ and $d_{\mathrm{S}}$ values, suggesting that the $d_{\mathrm{N}} / d_{\mathrm{S}}$ rate differences between hppd paralogues might not be explained by constraint relaxation.

Although $d_{\mathrm{N}} / d_{\mathrm{S}}$ is a useful indicator of selective pressure, there is some oversimplification in its application since it may be that only certain codons in a gene can change in a way that enhances fitness whereas all others cannot accept substitutions without cost to fitness. Thus, to better explore patterns of sequence variation, the orthologous sequences from A. thaliana, S. lycopersicum, and S. pennellii for all 22 genes under study were aligned and a Likelihood Ratio Test (LRT) with three models of molecular evolution was applied. The first, M0, assumes that all positions across the sequences have the same level of $d_{\mathrm{N}}$ and $d_{\mathrm{S}}$. The second, M1a, proposes that a proportion of codons is under purifying selection while the remainder have neutral evolution. Finally, M2a divides codons into three classes, those with purifying selection, those with neutral evolution pattern, and the remainder with positive selection. In order to avoid data misinterpretation, the $N_{\mathrm{c}}$ was estimated and the comparison between species did not show statistically significant differences $(P>0.01)$, indicating that there is no codon bias usage. Comparison of the three models showed that for 19 genes M1a displayed the best fit, indicating that, 


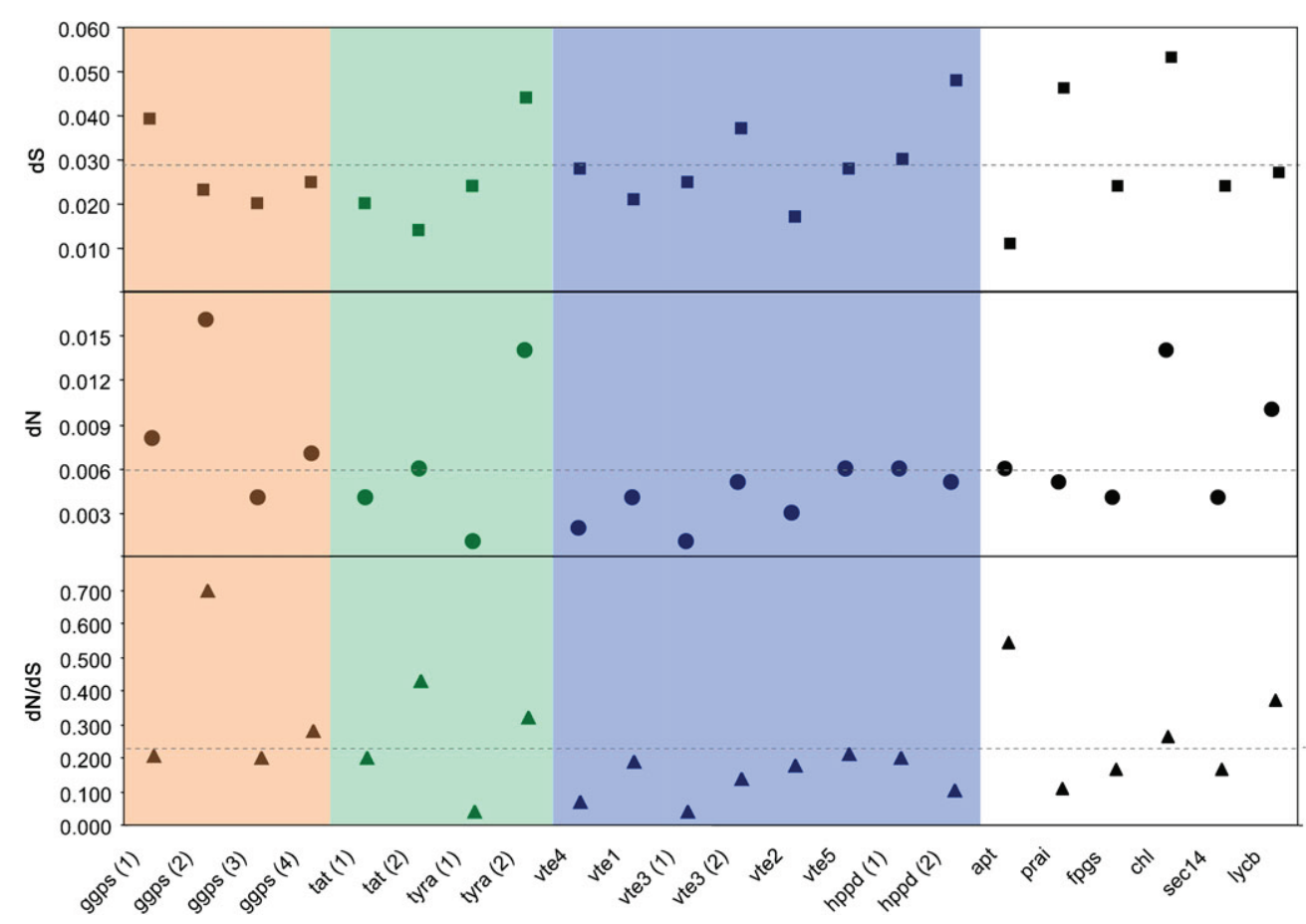

Fig. 4. Evolutionary rates at synonymous (dS) and non-synonymous (dN) sites of candidate genes linked to tocopherol QTL. Genes belonging to MEP, SK, and tocopherol core pathways are highlighted in red, green, and blue, respectively. VTE-related pathway candidates are not highlighted. Lines indicated estimated means.

even when a proportion of the codons for every gene are evolving neutrally, there is no support for positive selection. Nevertheless, for $\operatorname{ggps}(2), \operatorname{ggps}(4)$, and vte1, M2a presented a better fit than M1a, with different levels of significance, showing that these genes exhibited signs of positive selection. Interestingly, while $\operatorname{ggps}(2)$ and vte1 showed a higher proportion of codons evolving under positive selection $(\sim 25 \%)$ than ggps $(4)(0.8 \%)$, they displayed lower significance levels. This can be explained by the high $\omega$ value of ggps(4) indicating that there is no variation in the synonymous sites along the codons under positive natural selection (Table 3 ).

\section{Discussion}

The two pathways feeding the main precursors of VTE biosynthesis, MEP and SK, as well as the tocopherol core route, were surveyed across the tomato genome with the aim of identifying regulatory steps of the VTE fruit biosynthesis. The metabolic reconstruction of VTE metabolism resulted in the identification of 29 reactions catalysed by the protein products of 28 genes, for which 41 different S. lycopersicum loci were identified (Fig. 1, Table 1). In the course of reconstructing these routes, certain assumptions concerning the presence or absence of reactions involved in VTE metabolism had to be made. First, in the MEP pathway, GPPS is the enzyme leading to monoterpene biosynthesis, while GGPS is responsible for the production of geranylgeranyl $2 \mathrm{P}$ by the sequential coupling of three isopentenyl $2 \mathrm{P}$ (IPP) molecules to dimethylallyl $2 \mathrm{P}$
(DMAPP). Geranylgeranyl 2P serves as a precursor for carotenoid, tocochromanol, gibberelin, and chlorophyll biosynthesis (Aharoni et al., 2005; Joyard et al., 2009). Hence, the classical trend is to assume that GPPS would not be involved in tocochromanol production. Tomato plants silenced for GPPS even displayed a dwarfed phenotype and reduced gibberellin levels, and did not alter carotenoid and chlorophyll content (Van Schie et al., 2007). These results thus indicated that pigments are originated from a geranyl $2 \mathrm{P}$-independent geranylgeranyl $2 \mathrm{P}$ pool and suggested that GPPS might not influence VTE biosynthesis. However, further functional experiments that validate this hypothesis are clearly needed. Secondly, HGGT, which condenses homogentisate with geranylgeranyl $2 \mathrm{P}$ during tocotrienol synthesis, was identified in grass species in which tocotrienols are the most abundant tocochromanol forms (Cahoon et al., 2003). Neither in Arabidopsis nor in tomato was HGGT identified. However, tocotrienol traces have been detected in both tomato and tobacco (Chun et al., 2006). This might be explained by the promiscuous activity in substrate acceptance of other prenyl transferases such as homogentisate solanesyl transferase (HST) and/or the homogentisate phytyl transferase (VTE2). Flux changes through the SK, MEP, and/or tocopherol pathway could conceivably shift the substrate preference of both these enzymes (Herbers, 2003; Falk and Munné-Bosch, 2010). This hypothesis is supported by the fact that under certain conditions tobacco plants, which do not have a canonical HGGT, and co-express the Arabidopsis HPPD and the yeast prephenate dehydrogenase, exhibit higher levels of tocotrienols (Rippert et al., 2004). Therefore, the 
Table 3. Parameter estimates and tests of selection.

\begin{tabular}{|c|c|c|c|c|c|c|c|c|c|c|}
\hline Gene & $\begin{array}{c}\text { Mo } \\
\ln L^{a}\end{array}$ & $\omega^{b}$ & $\begin{array}{l}\text { M1a } \\
\ln ^{a}\end{array}$ & $\omega 0^{c}$ & $\rho 0 \mathrm{~d},{ }^{e}$ & $\begin{array}{l}\text { M2a } \\
\ln ^{a}\end{array}$ & $\omega 0^{f}$ & $\rho 0^{g}$ & $\omega 2^{h}$ & $\rho 2^{i j}$ \\
\hline ggps(1) & -2640.1 & 0.041 & -2598.9 & 0.015 & $0.734^{\star \star}$ & -2598.9 & 0.012 & 0.743 & - & 0.000 \\
\hline ggps(2) & -2594.4 & 0.096 & -2551.5 & 0.028 & $0.730^{\star \star}$ & -2549.9 & 0.032 & 0.746 & 2.474 & $0.254^{*}$ \\
\hline ggps(3) & -2444.5 & 0.014 & -2411.5 & 0.018 & $0.812^{\star \star}$ & -2411.5 & 0.018 & 0.813 & 1.134 & 0.187 \\
\hline ggps(4) & -2233.7 & 0.061 & -2200.8 & 0.019 & $0.811^{\star *}$ & -2196.7 & 0.020 & 0.811 & 999.000 & $0.008^{\star *}$ \\
\hline $\operatorname{tat}(1)$ & -2718.5 & 0.101 & -2690.3 & 0.045 & $0.792^{\star \star}$ & -2690.3 & 0.045 & 0.792 & - & 0.000 \\
\hline $\operatorname{tat}(2)$ & -2857.8 & 0.077 & -2841.7 & 0.046 & $0.817^{\star \star}$ & -2841.7 & 0.046 & 0.817 & - & 0.000 \\
\hline tyra(1) & -2487.3 & 0.002 & -2460.9 & 0.024 & $0.741^{\star \star}$ & -2460.9 & 0.024 & 0.741 & - & 0.000 \\
\hline tyra(2) & -2657.4 & 0.108 & -2615.1 & 0.024 & $0.612^{\star \star}$ & -2615.1 & 0.024 & 0.612 & - & 0.000 \\
\hline vte4 & -2425.8 & 0.063 & -2391.8 & 0.028 & $0.765^{\star \star}$ & -2391.8 & 0.028 & 0.765 & - & 0.000 \\
\hline vte1 & -3430.5 & 0.075 & -3373.5 & 0.029 & $0.730^{\star \star}$ & -3371.9 & 0.039 & 0.743 & 2.165 & $0.257^{\star}$ \\
\hline vte3(1) & -2138.5 & 0.051 & -2124.3 & 0.031 & $0.900^{\star *}$ & -2124.3 & 0.031 & 0.900 & - & 0.000 \\
\hline vte3(2) & -2256.5 & 0.057 & -2231.6 & 0.022 & $0.842^{\star \star}$ & -2231.6 & 0.022 & 0.842 & - & 0.000 \\
\hline vte2 & -2693.8 & 0.096 & -2653.3 & 0.030 & $0.739^{\star \star}$ & -2653.3 & 0.030 & 0.739 & - & 0.000 \\
\hline vte5 & -2302.1 & 0.079 & -2287.6 & 0.023 & $0.541^{\star \star}$ & -2287.6 & 0.023 & 0.541 & - & 0.000 \\
\hline hppd(1) & -2586.5 & 0.064 & -2552.8 & 0.024 & $0.818^{\star \star}$ & -2552.8 & 0.024 & 0.820 & 2.258 & 0.016 \\
\hline hppd(2) & -2617.9 & 0.037 & -2579.5 & 0.020 & $0.805^{\star \star}$ & -2579.5 & 0.020 & 0.805 & - & 0.000 \\
\hline apt & -2447.7 & 0.099 & -2400.6 & 0.024 & $0.771^{\star \star}$ & -2399.3 & 0.033 & 0.799 & 2.629 & 0.201 \\
\hline prai & -1556.9 & 0.144 & -1551.3 & 0.104 & $0.732^{\star \star}$ & -1551.9 & 0.104 & 0.732 & - & 0.000 \\
\hline fpgs & -3435.8 & 0.100 & -3410.5 & 0.055 & $0.742^{\star \star}$ & -3410.5 & 0.055 & 0.742 & - & 0.000 \\
\hline$c h l$ & -2198.3 & 0.127 & -2186.0 & 0.078 & $0.846^{\star \star}$ & -2185.9 & 0.080 & 0.853 & 1.124 & 0.146 \\
\hline $\sec 14$ & -2547.0 & 0.030 & -2527.3 & 0.025 & $0.894^{\star \star}$ & -2527.2 & 0.025 & 0.894 & - & 0.000 \\
\hline$l y c b$ & -2628.0 & 0.084 & -2608.2 & 0.046 & $0.772^{\star \star}$ & -2608.2 & 0.046 & 0.772 & - & 0.000 \\
\hline
\end{tabular}

${ }^{a}$ Log likehood of model.

b Parameter estimate assuming a single $d_{N} d_{S}$ ratio per gene.

${ }^{c}$ Estimated $d_{N} d_{S}$ for proportion of codons $\left(\rho_{0}\right)$ under purifying selection; the rest of codons assumed to be evolving neutrally.

${ }^{d}$ Estimated proportion of codons under purifying selection.

e Test of M1a versus M0. ${ }^{\star *} \chi^{2}$ test using $P<0.01$.

${ }^{f}$ Estimated $d_{N} d_{S}$ for proportion of codons $\left(\rho_{0}\right)$ under purifying selection.

$g$ Estimated proportion of codons under purifying selection.

${ }^{h}$ Estimated $d_{N} / d_{S}$ for proportion of codons $\left(\rho_{2}\right)$ under positive selection.

${ }^{i}$ Estimated proportion of codons under positive selection.

$j$ Test of M2a versus M1a. ${ }^{*} \chi^{2}$ test using $P<0.10$; ${ }^{\star *} \chi^{2}$ test using $P<0.01$.

-, not available.

enhanced supply of homogentisate may affect the substrate specificity of prenyl transferases leaking through tocotrienol synthesis (Falk and Munné-Bosch, 2010). In addition, A. thaliana HST, which is essential for plastoquinone-9 biosynthesis - catalysing the condensation of solanesyl 2P (SDP) and HGA - also accepts farnesyl 2P and geranylgeranyl 2P as prenyl donors (Sadre et al., 2006; Tian et al., 2007), providing further evidence in support of tocotrienol production in the absence of a specific HGGT.

Prephenate aminotransferase (PAT, EC 2.6.1.57), which converts prephenate intermediate into arogenate, has been characterized in bacteria. Although its activity had also been detected in plants, no associated loci were identified with this enzymatic function (Tzin et al., 2009). Recently, two independent reports performed biochemical and functional characterization of this plant enzyme thus, completing the identification of the genes involved in phenylalanine and tyrosine biosynthesis (Graindorge et al., 2010; Maeda et al., 2010).

One missing links still remains within the metabolic network under study, which is the absence of a phytol-P kinase that could provide phytyl $2 \mathrm{P}$ as an alternative to the MEP pathway (Ischebeck et al., 2006; Valentin et al., 2006).
All the MEP enzyme-encoding genes surveyed here are in accordance with sequences previously reported for tomato (Lois et al., 2000; Rohdich et al., 2000; Rodríguez-Concepción et al., 2001, 2003; Botella-Pavía et al., 2004; Ament et al., 2006; Paetzold et al., 2010; and GenBank database direct submission for IPI -GQ169536 and EU253957-), with the exception of the 2-C-methyl-Derythritol 4-phosphate cytidylyltransferase (CMS)- and geranylgeranyl reductase (GGDR)-encoding genes, which have not been reported before in this species. Moreover, two additional loci for GGPS were identified here. For the SK pathway, enzyme-encoding genes involved in reactions upstream of the prephenate intermediate have already been reported in tomato (Gasser et al., 1988; Schmid et al., 1992; Görlach et al., 1993, 1995; Eberhard et al., 1996; Bischoff et al., 1996, 2001). Moreover, novel loci for SDH/DHQ and CM were identified, whilst the loci encoding PAT, TyrA, and TAT were first described in tomato.

Protein localization data are highly valuable information in order to elucidate gene function. The MEP and SK pathways are well accepted to operate in the chloroplast (Rippert et al., 2009). Even so, the recent identification of 
some cytosolic isoforms points to the existence of an extraplastidial SK pathway (Ding et al., 2007). The results presented here for the in silico prediction of the subcellular localization of the tomato deduced protein sequences indicated that the reactions of VTE metabolism occur mostly in chloroplasts. In contrast, for the bi-functional SDH/ DHQ no signal peptide was detected, most probably due to the failure to detect true targeting, since reported analysis of subcellular fractions indicated that tomato SDH/DHQ is localized in the chloroplast (Bischoff et al., 2001). However, Ding et al. (2007) functionally characterized a cytosolic $\mathrm{SDH} / \mathrm{DHQ}$ isoform in tobacco and identified the tomato orthologue (BF096277/SGN-U578253). This locus was not included in this study due to its low identity to Arabidopsis protein according to the Pipeline criteria adopted and the absence of functional support so far. Unsuccessful subcellular prediction is not an unusual scenario, since in silico, signal peptides are occasionally misidentified. However, these predictions indicated mitochondrial targeting for the A. thaliana GPPS (data not shown), whilst experimental data revealed that this enzyme is directed to the plastid (Bouvier et al., 2000). It is important to point out the existence of some ambiguous reports on actual GPPS localization where experimental evidence supports its localization either in plastid or in the cytosol depending on the species (Nagegowda, 2010). Moreover, for the TAT and CM enzymes, the plastidial localization could not be confirmed by in silico analysis in agreement with the undetermined subcellular occurrence of the post-chorismate portion of the SK pathway.

Following the identification of the tomato genes encoding all enzymes for the tocochromanol synthesis pathway, the 41 loci were further mapped. Furthermore, a detailed profile for all tocopherol isoforms was performed in fruits from ILs harbouring introgressed regions spanning the VTE biosynthesis core pathway genes (ILs 7-4, 7-4-1, 8-2, 8-2-1, 9-1, and 9-2-6) along with those in chromosome 6 (ILs 6-1 and 62) for which $\alpha$-tocopherol QTL have been previously reported (Schauer et al., 2006). Although VTE content has been demonstrated to be a highly environmentally affected trait (Schauer et al., 2008), the results reported here indicate that at least those QTL mapped on chromosomes 6 and 9 show a relatively high heritability level as they are in accordance with previous experiments reported by Schauer et al. (2006). Moreover it is worth noting that, as opposed to the previous study, which was carried out on field-grown plants, the data reported here were obtained from greenhouse plants.

Integrated analysis at metabolic, genomic, and genetic levels allowed us to propose 16 candidate loci putatively affecting tocopherol content in tomato: prai, fpgs, chl, apt, and $l y c b$ on chromosome 6 ; tyra(1), vte2, $\operatorname{hppd}(1)$, and tat(2) located on chromosome 7; vtel and vte4 on chromosome 8; and ggps(4), tyra(2), vte5, sec14, and vte3 (1) on chromosome 9. In plants, several QTL controlling tocopherol content have been identified in soybean, maize, oilseed rape, and Arabidopsis. As revealed in this report, only some of those QTL localized to areas of the genome where tocopherol core pathway genes occur
(Marwede et al., 2005; Gilliland et al., 2006; Chander et al., 2008; Li et al., 2010).

Detailed analysis of the identified QTL together with the co-localizing genes raised interesting features concerning VTE content regulation. None of chromosome 6 QTL colocalize with any of the MEP, SK, or tocopherol core pathway genes, thus suggesting that tocopherol content variation observed in ILs 6-1 and 6-2 might be determined by the effect of genes belonging to VTE-related pathways. IL 6-1 showed elevated $\delta$ - and total tocopherol content in comparison with $S$. lycopersicum (M82) control. This line harbours the $S$. pennellii alleles of the prai, fpgs, and chl genes. The first two could be regulating hydroxyphenylpyruvate fluxes into the tocopherol pathway by the deviation of chorismate from tryptophan and folate biosynthetic routes. On the other point of the pathway drawn in Fig. 1, the hypothesis that chlorophyll degradation-derived phytol serves as an important intermediate for tocopherol synthesis has been demonstrated by characterization of the Arabidopsis vte5 mutant (Valentin et al., 2006). In this sense, the presence of $S$. pennellii chl allele in IL 6-1 might be raising the phytyl $2 \mathrm{P}$ input into tocopherol synthesis. On the same chromosome, IL 6-2 displayed significantly higher levels of $\beta$-tocopherol than the control. This IL carries $S$. pennellii alleles of $c h l$, apt, and $l y c b$. Even when these genes are linked to intermediate metabolites of the tocopherol pathway (chorismate and geranylgeranyl 2P) no evident links can be specifically associated with the $\beta$-isoform. The candidature of genes not directly involved in the VTE structural pathway is supported by the regulatory network acting on branching points. The CM acting on the SK pathway is allosterically feedback-inhibited in plants by phenylalanine and tyrosine and induced by tryptophan (Tzin and Galili, 2010). Allelic variation in prai and apt could be modifying tryptophan synthesis, altering influx through the SK pathway and then, increasing homogentisate precursor, finally resulting in the tocopherol content variation observed in ILs 6-1 and 6-2.

Two QTL have been detected on chromosome 7; while IL 7-4 displayed lower levels of $\alpha$-tocopherol, IL 7-4-1 showed reduced amounts of the $\beta$-isoform. The introgressed wild genome fragments in these ILs harbour $S$. pennellii alleles of tyra(1), vte2, and hppd(1). IL 7-4 also spans the wild allele of tat(2). These four candidates can alter total precursor influx to tocopherol biosynthesis. Nevertheless, the way that these genes could differentially modify the amounts of tocopherol isoforms is currently unclear.

On chromosome 8, the IL 8-2 displayed a significantly lower $\alpha / \gamma$-tocopherol ratio when compared with control (Fig. 3). Interestingly, this IL bears $S$. pennellii alleles of vtel and vte4 genes whose protein product activities synthesize these two tocopherol isoforms. Therefore, the low $\alpha / \gamma$-tocopherol ratio could be caused by lower VTE1 and/or higher VTE4 activity of wild alleles. Intriguingly, IL 8-2-1 also harbours the wild alleles of vtel and vte4. Even though no significant alteration in $\alpha / \gamma$-tocopherol ratio was observed, a significant increase in total tocopherol was detected in the fruits. 
IL 9-1 exhibits increased levels of $\alpha-, \beta-$, and total tocopherol most probably due to differential activity levels of the enzymes encoded by the $S$. pennellii allele of the tyra(2) and ggps(4) loci that could lead to higher input of hydroxyphenylpyruvate and phytyl $2 \mathrm{P}$ to the tocopherol core pathway. Elevated $\alpha / \gamma$ and $\beta / \gamma$ ratios support this hypothesis (Fig. 3). Interesting to note is the fact that tyra(2) shows one of the highest $d_{\mathrm{N}}$ values, indicating protein divergences between $S$. pennellii and $S$. lycopersicum (Fig. 4). In this sense, the results presented here reinforce the hypothesis of Rippert et al. (2004) that hydroxyphenylpyruvate is a key step in the accumulation of VTE in plants. IL 9-2-6 exhibits increased levels of $\alpha$ - and total tocopherol and harbours the $S$. pennellii allele of the vte5 gene, which could improve the input of phytyl $2 \mathrm{P}$ via the phytol alternative pathway (Valentin et al., 2006). However, levels of $\beta$-tocopherol are not increased in IL 9-2-6, which could be explained by the more efficient activity of the $S$. pennellii vte 3 allele. This is also reflected in the significant differences found in the $\alpha / \beta$ ratio (Fig. 3).

Although there is a reliable link between the identified candidate genes and fruit tocopherol content, the effect of unidentified loci within the QTL cannot be discarded and, due to the considerable size of the $S$. pennellii fragments in the ILs, the differences observed in tocopherol accumulation could also be caused by undetected genes located within them.

Candidate gene approach has proved to be extremely powerful for studying the genetic architecture of complex traits (Zhu and Zao, 2007). By revealing the pattern of molecular genetic variation, the evolutionary analyses offer complementary data for strengthening gene candidature (Moyle and Muir, 2010). In this sense, the pattern of selection of different genes within a metabolic pathway allows the determination of whether they are subject to equivalent evolutionary forces underlying trait phenotypic variation. Comparing S. lycopersicum and $S$. pennellii alleles, out of the 22 genes studied, those encoding MEP, post-chorismate SK, and VTE core pathway enzymes presented $d_{\mathrm{N}} / d_{\mathrm{S}}$ ratios below the mean, excluding those with more than one loci. In contrast, out of the six analysed candidate genes of related pathways, apt, chl, and lycb displayed $d_{\mathrm{N}} / d_{\mathrm{S}}$ ratios values above the mean (Fig. 4). This constraint relaxation cannot be related to a higher regionspecific mutation rate on chromosome 6 because two other genes mapped also on chromosome 6, prai and fpgs, presented low $d_{N} / d_{S}$ ratios. Therefore, these results suggest a strong purifying selection for tocopherol central biosynthesis genes while there is a more relaxed constraint for those genes of related pathways. When the selection constraint is evaluated codon by codon applying a likelihood ratio test, new insights about the evolutionary history of the genes are revealed. Nineteen genes exhibit purifying selection associated with neutral evolving codons (Table 3) in agreement with the $d_{\mathrm{N}} / d_{\mathrm{S}}$ analysis and previous reports that concluded that significant heterogeneity of evolutionary rates in metabolic pathway genes is mainly ascribed to differential constraint relaxation rather than to positive selection (Livingston and Anderson, 2009; Yang et al., 2009). Even so, three loci exhibited patterns consistent with positive selection evolving codons. In tomato, loci showing positive selection have been identified associated with biotic and abiotic stresses (Jiménez-Gomez and Maloof, 2009). It would be unexpected to envisage signs of positive selection in loci of major biosynthetic pathways that feed multiple metabolic routes such as MEP and SK. However, the signs of diversifying selection found for ggps(2) and ggps(4) could be explained by the existence of two other paralogues evolving under a more conservative evolutionary pattern. In the case of vtel, the reduction in protein negative selective pressure might indicate that this is not a committed step in tocopherol production.

Studies of evolutionary rates of genes in the plant anthocyanin ( $\mathrm{Lu}$ and Rausher, 2003) and carotenoid (Livingstone and Anderson, 2009) pathways have demonstrated that upstream genes in the pathway evolved more slowly than downstream genes. However, this seems not to be a constant trend. Downstream genes in the gibberellin pathway did not exhibit elevated substitution rates and instead, genes encoding either the branch point enzyme or those catalysing multiple steps in the pathway showed the lowest evolutionary rates due to strong purifying selection (Yang et al., 2009). This observation is in close agreement with the theory of pathway fluxes, which indicates that natural selection would target enzymes controlling metabolic fluxes between converging pathways. Consequently, these branch points are usually targets of selection, experiencing higher evolutionary constraints (Flowers et al., 2007). In this sense, the lowest value of $d_{\mathrm{N}} / d_{\mathrm{S}}$ was observed for the tyra(1) gene whose protein product shares its substrate with phenylalanine/tyrosine biosynthesis resulting in branching points, whilst the tyra(2) paralogue displays a relaxed evolutionary constraint, indicative of a functional divergence.

Genes responsible for adaptive morphological and physiological differences between species carry signatures of positive selection (Aguileta et al., 2010). In this sense, regarding the variation in VTE content observed in the $S$. pennellii introgressed lines in comparison with that of $S$. lycopersicum, the presence of neutral and/or positive evolving codons could result in novel protein features being a source of new functional profiles. Even when coding sequences are relevant to phenotype, they might not be the location at which key evolutionary changes occur. Analyses across coding sequences do not reveal allelic differences in regulatory sequences that could also be determining the observed phenotypic variations. In fact, a co-response analysis of 32 of the genes identified here revealed an intricate network suggesting these pathways to be finely regulated at the level of gene expression (data not shown).

This report describes a comprehensive survey of the genes encoding VTE biosynthesis pathway enzymes in tomato, and the methods adopted allowed the identification of novel tocopherol QTL. By an integrated analysis of the genome sequence data together with a well-characterized biosynthetic pathway, like that for VTE in Arabidopsis model 
species, this genetic/genomic approach described loci and allelic variations that probably impact antioxidant content in tomato fruit. The identified candidate genes support cross-talk between the MEP, SK, and tocopherol core pathways through the control of VTE accumulation in tomato fruit. In addition, the VTE-related pathway genes might contribute to regulation of the supply of intermediates for plastid tocopherol biosynthesis. The data produced provide a platform for functional studies that will contribute to elucidation of the biosynthesis and catabolism of tocochromanols, and their role in plant physiology.

\section{Supplementary data}

Supplementary data are available at $J X B$ online.

Supplementary Table S1 lists the gene primers used.

\section{Acknowledgements}

The authors thank Gregorio Ceccantini for assistance with statistical analyses. This work was partially supported by grants from FAPESP, CNPq, and USP (Brazil); Max Planck Society (Germany); INTA, CONICET, and ANPCyT (Argentina); and under the auspices of the EU SOL Integrated Project FOOD-CT-2006-016214. J.A. was a recipient of a CAPES (Brazil). L.B., F.G., and N.S. were recipients of a FAPESP (Brazil) fellowships. L.Q. was a recipient of an ANPCyT (Argentina) fellowship. R.A. and F.C. are members of CONICET (Argentina). This work was carried out in compliance with current laws governing genetic experimentation in Brazil and in Argentina.

\section{References}

Abushita AA, Hebshi EA, Daood HG, Biacs PA. 1997.

Determination of antioxidant vitamins in tomatoes. Food Chemistry 60, 207-212.

Aguileta G, Lengelle J, Marthey S, et al. 2010. Finding candidate genes under positive selection in non-model species: examples of genes involved in host specialization in pathogens. Molecular Ecology 19, 292-306.

Aharoni A, Jongsma MA, Bouwmeester HJ. 2005. Volatile science? Metabolic engineering of terpenoids in plants. Trends in Plant Science 10, 594-602.

Altschul SF, Gish W, Miller W, Myers EW, Lipman DJ. 1990. Basic local alignment search tool. Journal of Molecular Biology 215, 403-410.

\section{Ament K, Van Schie CC, Bouwmeester HJ, Haring MA,}

Schuurink RC. 2006. Induction of a leaf specific geranylgeranyl pyrophosphate synthase and emission of (E, E)-4,8,12-trimethyltrideca1,3,7,11-tetraene in tomato are dependent on both jasmonic acid and salicylic acid signaling pathways. Planta 224, 1197-1208.

Ayres M, Ayres Júnior M, Ayres DL, Santos AA. 2007. Bioestat aplicações estatísticas nas áreas das ciências bio-médicas. Sociedade Civil Mamirauá/MCT CNPq, Belém, PA, Brasil.
Bankaitis VA, Mousley CJ, Schaaf G. 2009. The Sec14 superfamily and mechanisms for crosstalk between lipid metabolism and lipid signaling. Trends in Biochemical Sciences 35, 150-160.

Bermúdez L, Urias U, Milstein D, Kamenetzky L, Asis R, Fernie AR, Van Sluys MA, Carrari F, Rossi M. 2008. A candidate gene survey of quantitative trait loci affecting chemical composition in tomato fruit. Journal of Experimental Botany 59, 2875-2890.

Bischoff M, Rösler J, Raesecke HR, Görlach J, Amrhein N, Schmid J. 1996. Cloning of a cDNA encoding 3-dehydroquinate synthase from a higher plant, and analysis of the organ-specific and elicitor-induced expression of the corresponding gene. Plant Molecular Biology 31, 69-76.

Bischoff M, Schaller A, Bieri F, Kessler F, Amrhein N, Schmid J. 2001. Molecular characterization of tomato 3-dehydroquinate dehydratase-shikimate:NADP oxidoreductase. Plant Physiology 125, 1891-1900.

Botella-Pavía P, Besumbes O, Phillips MA, Carretero-Paulet L, Boronat A, Rodriguez-Concepcion M. 2004. Regulation of carotenoid biosynthesis in plants: evidence for a key role of hydroxymethylbutenyl diphosphate reductase in controlling the supply of plastidial isoprenoid precursors. The Plant Journal 40, 188-199.

Bouvier F, Suire C, d'Harlingue A, Backhaus RA, Camara B. 2000. Molecular cloning of geranyl diphosphate synthase and compartmentation of monoterpene synthesis in plant cells. The Plant Journal 24, 241-252.

\section{Cahoon EB, Hall SE, Ripp KG, Ganzke TS, Hitz WD,}

Coughlan SJ. 2003. Metabolic redesign of vitamin E biosynthesis in plants for tocotrienol production and increased antioxidant content. Nature Biotechnology 21, 1082-1087.

Carrari F, Baxter C, Usadel B, et al. 2006. Integrated analysis of metabolite and transcript levels reveals the metabolic shifts that underlie tomato fruit development and highlight regulatory aspects of metabolic network behaviour. Plant Physiology 142, 1380-1396.

Chander S, Guo YQ, Yang XH, Yan JB, Zhang YR, Song TM, Li JS. 2008. Genetic dissection of tocopherol content and composition in maize grain using quantitative trait loci analysis and the candidate gene approach. Molecular Breeding 22, 353-365.

Chun J, Lee J, Ye L, Exler J, Eitenmiller RR. 2006. Tocopherol and tocotrienol contents of raw and processed fruits and vegetables in the United States diet. Journal of Food Composition and Analysis 19, 196-204.

Corpet, F. 1988. Multiple sequence alignment with hierarchical clustering. Nucleic Acids Research 16, 10881-10890.

Das S, Gautam N, Dey SK, Maiti T, Roy S. 2009. Oxidative stress in the brain of nicotine-induced toxicity: protective role of Andrographis paniculata Nees and vitamin E. Applied Physiology, Nutrition, and Metabolism 34, 124-135.

Davuluri GR, van Tuinen A, Fraser PD, et al. 2005. Fruit-specific RNAi-mediated suppression of DET1 enhances tomato nutritional quality. Nature Biotechnology 23, 890-895.

Ding L, Hofius D, Hajirezaei MR, Fernie AR, Börnke F, Sonnewald U. 2007. Functional analysis of the essential bifunctional tobacco enzyme 3-dehydroquinate dehydratase/shikimate 
dehydrogenase in transgenic tobacco plants. Journal of Experimental Botany 58, 2053-2067.

Eberhard J, Bischoff M, Raesecke HR, Amrhein N, Schmid J. 1996. Isolation of a cDNA from tomato coding for an unregulated, cytosolic chorismate mutase. Plant Molecular Biology 31, 917-922.

Emanuelsson O, Brunak S, von Heijine G, Nielsen H. 2007. Locating proteins in the cell using TargetP, SignalP and related tools. Nature Protocols 2, 953-971.

Enfissi EM, Barneche F, Ahmed I, et al. 2010. Integrative transcript and metabolite analysis of nutritionally enhanced DE-ETIOLATED1 downregulated tomato fruit. The Plant Cell 22, 1190-1215.

Entus R, Poling M, Herrmann KM. 2002. Redox regulation of Arabidopsis 3-deoxy-D-arabino-heptulosonate 7-phosphate synthase. Plant Physiology 129, 1866-1871.

Eshed Y, Zamir D. 1995. An introgression line population of Lycopersicon pennellii in the cultivated tomato enables the identification and fine mapping of yield-associated QTL. Genetics 141, 1147-1162.

Falk J, Munné-Bosch S. 2010. Tocochromanol functions in plants: antioxidation and beyond. Journal of Experimental Botany 61, 1549-1566.

Fei Z, Tang X, Alba R, Giovannoni J. 2006. Tomato Expression Database (TED): a suite of data presentation and analysis tools. Nucleic Acids Research 34, D766-D770.

Fernie AR, Yaakov T, Zamir D. 2006. Natural genetic variation for improving crop quality. Current Opinion in Plant Biology 9, 196-202.

Ferro M, Brugiere S, Salvi D, et al. 2010. AT_CHLORO:

a comprehensive chloroplast proteome database with sub-plastidial localization and information for functional genomics using quantitative label-free analyses. Molecular and Celllular Proteomics 9, 1063-1084.

Flowers JM, Sezgin E, Kumagai S, Duvernell DD, Matzkin LM, Schmidt, PS, Eanes WF. 2007. Adaptive evolution of metabolic pathways in. Drosophila. Molecular Biology and Evolution 24, 1347-1354.

Foyer CH, Noctor G. 2005. Redox homeostasis and antioxidant signaling: a metabolic interface between stress perception and physiological responses. The Plant Cell 17, 1866-1875.

Fraser PD, Enfissi EM, Halket JH, Truesdale MR, Yu DM, Gerrish C, Bramley PM. 2007. Manipulation of phytoene levels in tomato fruit: effects on isoprenoids, plastids and intermediary metabolism. The Plant Cell 19, 3194-3211.

Fraser PD, Pinto ME, Holloway DE, Bramley PM. 2000. Application of high-performance liquid chromatography with photodiode array detection to the metabolite profiling of plant isoprenoids. The Plant Journal 24, 551-558.

Frusciante L, Carli P, Ercolano MR, Pernice R, Di Matteo A, Fogliano V, Pellegrini N. 2007. Antioxidant nutritional quality of tomato. Molecular Nutrition and Food Research 51, 609-617.

Garcia I, Rodgers M, Pepin R, Hssich T, Matringe M. 1999. Characterization and subcellular compartmentation of recombinant 4hydroxyphenylpyruvate dioxygenase from Arabidopsis in transgenic tobacco. Plant Physiology 119, 1507-1516.
Gasser CS, Winter JA, Hironaka CM, Shah DM. 1988. Structure, expression, and evolution of the 5-enolpyruvylshikimate-3-phosphate synthase genes of petunia and tomato. Journal of Biological Chemistry 263, 4280-4287.

Gilliland LU, Magallanes-Lundback M, Hemming C, Supplee A, Koornneef M, Bentsink L, Dellapenna D. 2006. Genetic basis for natural variation in seed vitamin E levels in. Arabidopsis thaliana. Proceedings of the National Academy of Sciences, USA 103, 18834-18841.

Görlach J, Beck A, Henstrand JM, Handa AK, Herrmann KM, Schmid J, Amrhein N. 1993. Differential expression of tomato (Lycopersicon esculentum L.) genes encoding shikimate pathway isoenzymes: I. 3-deoxy-D-arabino-heptulosonate 7-phosphate synthase. Plant Molecular Biology 23, 697-706.

Görlach J, Raesecke HR, Abel G, Wehrli R, Amrhein N, Schmid J. 1995. Organ-specific differences in the ratio of alternatively spliced chorismate synthase (LeCS2) transcripts in tomato. The Plant Journal 8, 451-456.

Graindorge M, Giustini C, Jacomin AC, Kraut A, Curien G, Matringe M. 2010. Identification of a plant gene encoding glutamate/ aspartate-prephenate aminotransferase: the last homeless enzyme of aromatic amino acids biosynthesis. FEBS Letters 584, 4357-4360.

Hall TA. 1999. BioEdit: a user-friendly biological sequence alignment editor and analysis program for Windows 95/98/NT. Nucleic Acids Symposium Series 41, 95-98.

Herbers K. 2003. Vitamin production in transgenic plants. Journal of Plant Physiology 160, 821-829.

Hörtensteiner S. 2006. Chlorophyll degradation during senescence. Annual Review of Plant Biology 57, 55-77.

Ischebeck T, Zbierzak AM, Kanwischer M, Dormann P. 2006. A salvage pathway for phytol metabolism in Arabidopsis. Journal of Biological Chemistry 281, 2470-2477.

Joyard J, Ferro M, Masselon C, Seigneurin-Berny D, Salvi D, Garin J, Rolland N. 2009. Chloroplast proteomics and the compartmentation of plastidial isoprenoid biosynthetic pathways. Molecular Plant 2, 1154-1180.

Jiménez-Gomez JM, Maloof JN. 2009. Sequence diversity in three tomato species: SNPs, markers, and molecular evolution. BMC Plant Biology 9, 85.

Kamenetzky L, Asís R, Bassi S, et al. 2010. Genomic analysis of wild tomato introgressions determining metabolic- and yieldassociated traits. Plant Physiology 152, 1772-1786.

Li Y, Wang Z, Sun X, Tang K. 2008. The current opinions on the functions of tocopherol based on the genetic manipulation of tocopherol biosynthesis in plants. Journal of Integrative Plant Biology 50, 1057-1069.

Li H, Liu H, Han Y, Wu X, Teng W, Liu G, Li W. 2010. Identification of QTL underlying vitamin E contents in soybean seed among multiple environments. TAG Theoretical and Applied Genetics 120, 1405-1413.

Livingstone K, Anderson S. 2009. Patterns of variation in the evolution of carotenoid biosynthetic pathway enzymes of higher plants. Journal of Heredity 100, 754-761. 
Lois LM, Rodríguez-Concepción M, Gallego F, Campos N, Boronat A. 2000. Carotenoid biosynthesis during tomato fruit development: regulatory role of 1-deoxy-d-xylulose 5-phosphate synthase. The Plant Journal 22, 503-513.

Lu Y, Rausher MD. 2003. Evolutionary rate variation in anthocyanin pathway genes. Molecular Biology and Evolution 20, 1844-1853.

Maeda H, Yoo H, Dudareva N. 2010. Prephenate aminotransferase directs plant phenylalanine biosynthesis via arogenate. Nature Chemical Biology 7, 19-21.

Marwede V, Gul MK, Becker HC, Ecke W. 2005. Mapping of QTL controlling tocopherol content in winter oilseed rape. Plant Breeding 124, 20-26.

Mène-Saffrané L, DellaPenna D. 2009. Biosynthesis, regulation and functions of tocochromanols in plants. Plant Physiology and Biochemistry 48, 301-309.

Milone D, Stegmayer G, Kamenetzky L, Lopez M, Lee J-M, Giovannoni JJ, Carrari F. 2010. *omeSOM: a software for clustering and visualization of transcriptional and metabolite data mined from interspecific crosses of crop plants. BMC Bioinformatics 11, 438-447.

Mobley EM, Kunkel BN, Keith B. 1999. Identification, characterization and comparative analysis of a novel chorismate mutase gene in. Arabidopsis thaliana. Gene 240, 115-123.

Moyle L, Muir CD. 2010. Reciprocal insights into adaptation from agricultural and evolutionary studies in tomato. Evolutionary Applications 3, 409-421.

Mueller LA, Mills A, Skwarecki B, Buels R, Menda N, Tanksley SD. 2008. The SGN Comparative Map Viewer. Bioinformatics 24, 422-423.

Munné-Bosch S, Alegre L. 2002. The function of tocopherols and tocotrienols in plants. Critical Reviews in Plant Sciences 21, 31-57.

Nagegowda DA. 2010. Plant volatile terpenoid metabolism: biosynthetic genes, transcriptional regulation and subcellular compartmentation. FEBS Letters 584, 2965-2973.

Paetzold H, Garms S, Bartram S, Wieczorek J, UrosGracia EM, Rodriguez-Concepción M, Boland W, Strack D, Hause B, Walter MH. 2010. The isogene 1-deoxy-D-xylulose 5phosphate synthase II controls isoprenoid profiles, precursor pathway allocation and density of tomato trichomes. Molecular Plant 3, 904-916.

Peterman TK, Ohol YM, McReynolds LJ, Luna EJ. 2004. Patellin1, a novel Sec14-like protein, localizes to the cell plate and binds phosphoinositides. Plant Physiology 136, 3080-3094.

Phillips MA, D’Auria JC, Gershenzon J, Pichersky E. 2008. The Arabidopsis thaliana type I isopentenyl diphosphate isomerases are targeted to multiple subcellular compartments and have overlapping functions in isoprenoid biosynthesis. The Plant Cell 20, 677-696.

Ravanel S, Cherest H, Jabrin S, Grunwald D, Surdin-Kerjan Y, Douce R, Rebeille F. 2001. Tetrahydrofolate biosynthesis in plants: molecular and functional characterization of dihydrofolate synthetase and three isoforms of folylpolyglutamate synthetase in Arabidopsis thaliana. Proceedings of the National Academy of Sciences, USA 98, 1523-1535.

Rippert P, Scimemi C, Dubald M, Matringe M. 2004. Engineering plant shikimate pathway for production of tocotrienol and improving herbicide resistance. Plant Physiology 134, 92-100.

Rippert P, Puyaubert J, Grisollet D, Derrier L, Matringe M. 2009. Tyrosine and phenylalanine are synthesized within the plastids in. Arabidopsis. Plant Physiology 149, 1251-1260.

Rodríguez-Concepción M, Ahumada I, Diez-Juez E, SauretGüeto S, Lois LM, Gallego F, Carretero-Paulet L, Campos N, Boronat A. 2001. 1-Deoxy-D-xylulose 5-phosphate reductoisomerase and plastid isoprenoid biosynthesis during tomato fruit ripening. The Plant Journal 27, 213-222.

Rodríguez-Concepción M, Querol J, Lois LM, Imperial S, Boronat A. 2003. Bioinformatic and molecular analysis of hydroxymethylbutenyl diphosphate synthase (GCPE) gene expression during carotenoid accumulation in ripening tomato fruit. Planta 217, 476-482.

Rohdich F, Wungsintaweekul J, Lüttgen $\mathrm{H}$, Fischer M, Eisenreich W, Schuhr CA, Fellermeier M, Schramek N, Zenk MH, Bacher A. 2000. Biosynthesis of terpenoids: 4-diphosphocytidyl-2-Cmethyl-d-erythritol kinase from tomato. Proceedings of the National Academy of Sciences, USA 97, 8251-8256.

Ronen G, Carmel-Goren L, Zamir D, Hirschberg J. 2000. An alternative pathway to $\beta$-carotene formation in plant chromoplasts discovered by map-based cloning of Beta and old-gold color mutations in tomato. Proceedings of the National Academy of Sciences, USA 97, 11102-11107.

Ros E. 2009. Nuts and novel biomarkers of cardiovascular disease. American Journal of Clinical Nutrition 89, 1649S-1656S.

Sadre R, Gruber J, Frentzen M. 2006. Characterization of homogentisate prenyltransferases involved in plastoquinone-9 and tocochromanol biosynthesis. FEBS Letters 580, 5357-5362.

Saito K, Tautz L, Mustelin T. 2007. The lipid-binding SEC14 domain. Biochimica et Biophysica Acta 1771, 719-726.

Schauer N, Semel Y, Balbo I, Steinfath M, Repsilber D, Selbig J, Pleban T, Zamir D, Fernie AR. 2008. Mode of inheritance of primary metabolic traits in tomato. The Plant Cell 20, 509-523.

Schauer N, Semel Y, Roessner U, et al. 2006. Comprehensive metabolic profiling and phenotyping of interspecific introgression lines for tomato improvement. Nature Biotechnology 24, 447-454.

Schauer N, Zamir D, Fernie AR. 2005. Metabolic profiling of leaves and fruit of wild species tomato: a survey of the Solanum lycopersicon complex. Journal of Experimental Botany 56, 297-307.

Schmid J, Schaller A, Leibinger U, Boll W, Amrhein N. 1992. The in-vitro synthesized tomato shikimate kinase precursor is enzymatically active and is imported and processed to the mature enzyme by chloroplasts. The Plant Journal 2, 375-383.

Schenk N, Schelbert S, Kanwischer M, Goldschmidt EE, Dörmann P, Hörtensteiner S. 2007. The chlorophyllases At $\mathrm{CLH} 1$ and AtCLH2 are not essential for senescence-related chlorophyll breakdown in. Arabidopsis thaliana. FEBS Letters 581, 5517-5525. 
Semchuk NM, Lushchak OV, Falk J, Krupinska K, Lushchak VI. 2009. Inactivation of genes, encoding tocopherol biosynthetic pathway enzymes, results in oxidative stress in outdoor grown Arabidopsis thaliana. Plant Physiology and Biochemistry 47, 384-390.

Sokal RR, Rohlf FJ. 1981. Biometry. Second Edition. Freeman, New York.

Soll J, Schultz G. 1979. Comparison of geranylgeranyl and phytyl substituted methylquinols in the tocopherol synthesis of spinach chloroplasts. Biochemical and Biophysical Research Communications 91, 715-720.

Sun Q, Zybailov B, Majeran W, Friso G, Olinares PDB, van Wijk KJ. 2009. PPDB, the Plant Proteomics Database at Cornell. Nucleic Acids Research 37, 969-974.

Tamura K, Dudley J, Nei M, Kumar S. 2007. MEGA4: Molecular Evolutionary Genetics Analysis (MEGA) software version 4.0. Molecular Biology and Evolution 24, 1596-1599.

Thompson J, Higgins D, Gibson T. 1994. CLUSTAL W: improving the sensitivity of progressive multiple sequence alignment through sequence weighting position-specific gap penalties and weight matrix choice. Nucleic Acids Research 22, 4673-4680.

Tian L, DellaPenna D, Dixon RA. 2007. The pds2 mutation is a lesion in the Arabidopsis homogentisate solanesyltransferase gene involved in plastoquinone biosynthesis. Planta 226, 1067-1073.

Tohge T, Fernie AR. 2010. Combining genetic diversity, informatics and metabolomics to facilitate annotation of plant gene function. Nature Protocols 5, 1210-1227.

Traber MG, Sies H. 1996. Vitamin E in humans: demand and delivery. Annual Review of Nutrition 16, 321-347.

Tzin V, Malitsky S, Aharoni A, Galili G. 2009. Expression of a bacterial bi-functional chorismate mutase/prephenate dehydratase modulates primary and secondary metabolism associated with aromatic amino acids in. Arabidopsis. The Plant Journal 60, 156-167.

Tzin V, Galili G. 2010. New insights into the shikimate and aromatic amino acids biosynthesis pathways in plants. Molecular Plant $\mathbf{3}$, 956-972.

Valentin HE, Lincoln K, Moshiri F, et al. 2006. The Arabidopsis vitamin E pathway gene5-1 mutant reveals a critical role for phytol kinase in seed tocopherol biosynthesis. The Plant Cell 18, 212-224.

Van Schie CCN, Ament K, Schmidt A, Lange T, Haring MA, Schuurink RC. 2007. Geranyl diphosphate synthase is required for biosynthesis of gibberellins. The Plant Journal 52, 752-762.

Voorrips RE. 2002. MapChart: software for the graphical presentation of linkage maps and QTLs. Journal of Heredity $\mathbf{9 3}, \mathbf{7 7 - 7 8 .}$

Yang Z. 2007. PAML 4: a program package for phylogenetic analysis by maximum likelihood. Molecular Biology and Evolution 24, 1586-1591.

Yang Y, Zhang F, Ge S. 2009. Evolutionary rate patterns of the gibberellin pathway genes. BMC Evolutionary Biology 9, 206-217.

Zamir D. 2001. Improving plant breeding with exotic genetic libraries. Nature Reviews Genetics 2, 983-989.

Zhang CX, Ho SC, Chen YM, Fu JH, Cheng SZ, Lin FY. 2009. Greater vegetable and fruit intake is associated with a lower risk of breast cancer among Chinese women. International Journal of Cancer 125, 181-188.

Zhao J, Last RL. 1995. Immunological characterization and chloroplast localization of the tryptophan biosynthetic enzymes of the flowering plant Arabidopsis thaliana. Journal of Biological Chemistry 270, 6081-6087.

Zhu M, Zhao S. 2007. Candidate gene identification approach: progress and challenges. International Journal of Biological Sciences 3, 420-427. 